Arquitetura para cidades na América Latina contemporânea:

distâncias e aproximações entre São Paulo e Medellín 



\title{
Arquitetura para cidades na América Latina contemporânea: distâncias e aproximações entre São Paulo e Medellín
}

\author{
Mariana Martinez Wilderom Chagas \\ Tese apresentada à Faculdade de Arquitetura e Urbanismo da Universidade de São Paulo \\ (FAUUSP) para a obtenção do título de Doutor em Arquitetura e Urbanismo \\ Área de concentração de História e Fundamentos da Arquitetura e do Urbanismo
}

Orientador: Luiz Recamán

São Paulo, 2019 
Autorizo a reprodução e divulgação total ou parcial deste trabalho, por qualquer meio convencional ou eletrônico, para fins de estudo e pesquisa, desde que citada a fonte.

e-mail: mariana.wilderom@usp.br

Exemplar revisado e alterado em relação à versão original, sob responsabilidade da autora e anuência do orientador. A versão original, em formato digital, ficará arquivada na biblioteca da faculdade.

São Paulo, o5 de agosto de 2019.

Catalogação na Publicação

Serviço Técnico de Biblioteca

Faculdade de Arquitetura e Urbanismo da Universidade de São Paulo

Wilderom-Chagas, Mariana M.

Arquitetura para cidades na América Latina Contemporânea: distâncias e aproximações entre São Paulo e Medellín / Mariana M. Wilderom-Chagas; orientador Luiz Recamán - São Paulo, 2018. 386 páginas.

386 páginas

ədo) - Faculdade de Arquitetura

e Urbanismo da Universidade de São Paulo.

Área de concentração: História e Fundamentos da Arquitetura e do Urbanismo.

1. Arquitetura Contemporânea. 2. Desenho Urbano. 3. São Paulo. 4. Medellín. I. Recamán, Luiz, orientador II. Título. 
Wilderom, Mariana. Arquitetura para cidades na América Latina contemporânea: distâncias e aproximações entre São Paulo e

Medellín. Tese apresentada à Faculdade de Arquitetura e Urbanismo para a obtenção do título de Doutor em Arquitetura e Urbanismo.

Aprovado em:

Banca Examinadora

Prof. Dr. Luiz Recamán

Instituição FAUUSP

Julgamento

Assinatura

Prof. Dr.

Instituição

Julgamento

Assinatura

Prof. Dr.

Instituição

Julgamento

Assinatura

Prof. Dr.

Instituição

Julgamento

Assinatura

Prof. Dr.

Instituição

Julgamento

Assinatura 

Dedicatória

À Rosemary e Bastiaan Wilderom, 



\section{Agradecimentos}

Ao Luiz Recamán, pela orientação e interlocução que possibilitaram esse trabalho.

Ao Leandro Medrano pelas contribuições no exame de qualificação e que junto aos membros do $\mathrm{PC}_{3}$, propiciou debates que ampliaram minha visão.

Ao Tom Avermaete, que iluminou pontos cegos em meus discursos.

À Monica Junqueira, que me orientou no Mestrado, inaugurando indagações que continuam me movendo.

À Regina Meyer cujas contribuições à época da dissertação ainda ressoam no presente trabalho.

Ao Alessandro Muzi e Marlon Longo, amigos indispensáveis para a vida, fundamentais para essa tese: nossas conversas impactaram em muitas linhas aqui escritas.

A Jorge Perez Jaramillo, Carlos Pardo Botero, Juan Lopera Perez, John Octavio Ortiz, Juan Pablo López Cortés, Carlos Montoya Correa, Giovanna Spera, Miguel Mesa, Juan David Diez, Felipe Mesa, pelo gentil e esclarecedor diálogo sobre arquitetura e urbanismo em Medellín.

A Tereza Herling, Carlos Leite e Marcos Boldarini, que generosamente me ajudaram a estabelecer relações entre política urbana e A\&U, nesse diálogo entre São Paulo e Medellín.

À Medellín, que em meio a seus problemas e perseveranças, relevouse uma cidade gentil e elucidativa, abrindo tantas reflexões que espero poder ainda desbravar.

A Isabel Vieira, Claudia Kim, Denise Teixeira, Fabiana Paiva pelas aventuras compartilhadas na arquitetura e no cotidiano.

Aos amigos da TU Delft, Maria Novas, Dorina Pllumbi, Fatma Tanis, Sitong Luo, Kaiyi Zhu, Armina Pilav e a todos com quem compartilhei incursões acadêmicas no território holandês.

Jorge Mejía, Klaske Havik, Pelin Tan, Camilo Boano, professores que, na TU Delft, contribuíram para minha pesquisa.

A Gabriella Radoll, Marina Malagolini e Paula Noia, uma família construída na faculdade e uma rede de afeto e compreensão indispensável nesse processo.

A todos amigos e interlocutores que eventualmente me esqueci, por perdoarem a memória curta em virtude do cansaço.

A minha família, por tudo aquilo que somos e construímos juntos.

Ao Paulo André Chagas, por todos os dias felizes de minha vida.

À Fundação de Amparo à Pesquisa do Estado de São Paulo (FAPESP), processos $n^{0} 2015 / 19847-9$ e $n^{0} 2017 / 26688$-o, que financiou a pesquisa e o estágio na TUDelft, sem os quais essa tese não seria possível. 



\section{Resumo}

Este trabalho desenvolve um estudo comparativo entre Medellín e São Paulo, por meio de um panorama da produção recente da arquitetura e do urbanismo (A\&U) nessas duas cidades. Para tanto foram selecionados projetos que propõem intervenções nas dinâmicas socioespaciais do território. Eles são mobilizados visando uma reflexão que contribua para ampliar os termos pelos quais a disciplina entende o universo material, social e conceitual com os quais interage. São analisados os processos de metropolização das duas cidades e os projetos que enfrentam essa condição. Constata-se que a $A \& U$ se depara com a necessidade de recobrar uma paisagem urbana que compreenda uma equidade socioespacial. Isso demanda a reconexão entre planos e projetos urbanos e a reconciliação entre infraestrutura e território, o que passa pelo reconhecimento da matriz urbana real. Também são analisados projetos que enfrentam a segregação socioespacial, perscrutando sua capacidade de não reproduzirem as desestruturações, diferenciações e afastamentos implícitos nesse processo, a partir do lote de intervenção. Nesse percurso também se extraem reflexões sobre a fragmentação dos espaços e a funcionalização da vida cotidiana. As contínuas atualizações do nosso descompasso social, que se agravam no capitalismo globalizado, exigem da arquitetura uma posição de resistência e de reação por meio de impulsos contra-hegemônicos. Isso se faz necessário diante dos processos disruptivos que atingem a produção do espaço (social) urbano. Essa proposição ressalta a dimensão sociourbana da A\&U e recobra a relevância da disciplina enquanto ferramenta de grande potência crítica.

Palavras-chave: arquitetura; urbanismo; arquitetura latino-americana contemporânea; urbanismo social; desenho urbano; Medellín; São Paulo. 



\section{Abstract}

This work develops a comparative study between Medellín and São Paulo, through a panorama of the recent production of architecture and urbanism (A\&U) in these two cities. For this purpose, the projects were selected as they proposed interventions in the socio-spatial dynamics of the territory. In this sense, we search for a reflection that contributes to broadening the terms by which the discipline understands the material, social and conceptual universe with which it interacts. For this, the processes of metropolisation of the two cities and the projects that face this condition were analyzed. It was noted that $A \& U$ are faced with the need to recover an urban landscape that includes socio-spatial equity. This calls for the reconnection between urban planning and urban design and the reconciliation of infrastructure and territory, which involves recognizing the real urban matrix. We also analyzed projects that deal with socio-spatial segregation, looking at their capacity not to reproduce the destructuring, differentiation and distancing implicit in this process from the intervention lot. This proposal also draws reflections on the fragmentation of spaces and the functionalisation of everyday life. Because of the continual updating of our social debts, which worsens in globalized capitalism, this demands of A\&U a position of resistance and reaction by counter-hegemonic impulses. This is necessary in the face of the disruptive processes that affect the production of urban (social) space. This proposition underscores A\&U's sociourban dimension and regains the relevance of the discipline as a tool for critical thinking.

Keywords: architecture; urbanism; contemporary Latin American architecture; social urbanism; Urban design; Medellín; Sao Paulo. 


\section{Sumário}

Introdução

A origem do diálogo entre São Paulo e Medellín

Condições de partida

1. Um problema disciplinar: a antiurbanidade

1.1 O impasse da Arquitetura e do Urbanismo

Brasil

Colômbia

1.2 As "condições de possibilidade"

$1.3 \mathrm{O}$ espaço

1.4 A cidade e a arquitetura

1.5 A urbanidade do cotidiano

1.6 O espaço social segregado na América Latina

1.7 Caminhos interpretativos

2. A urbanização produtora de não lugares $\quad 69$

2.1 Medellín

2.1.1 A evolução urbana de Medellín

2.1.2 Arquitetura urbana em Medellín

Metrocables, 2003

Unidades de Vida Articulada, 2014

Jardín Circunvalar, 2014

Parques del Rio, $2016 \quad 101$

2.2 São Paulo

128

2.2.1 A evolução urbana de São Paulo $\quad 129$

2.2.2 Arquitetura urbana em São Paulo 138

CEUs, 2000-2004 141

Territórios CEUs, 2013 $\quad 145$

Cantinho do Céu, 2008-2011 147

Centro de Formação Cultural Cidade Tiradentes, 2012

Parque da Juventude,2003-2010 $\quad 156$

$\begin{array}{lr}2.3 \text { Recobrando uma paisagem urbana } & 170\end{array}$

$\begin{array}{ll}\text { 2.3.1 Reconhecendo a matriz urbana real } & 171\end{array}$

2.3.2 Reconectando planos e projetos urbanos $\quad 173$

$\begin{array}{ll}2.3 .3 \text { Reconciliando infraestrutura e território } & 175\end{array}$ 
3. A segregação reafirmada no lote

Colégio Antonio Derka, 2008

Jardínes Infantiles, 2009-2011

Parques Biblioteca, 2007-2011

Centro Cultural Moravia, 2004-2007

MIB Quebrada Juan Bobo, 2007-2011

Parque Ciudad del Rio, 2007-2011

UVAs, 2015-2018

3.2 Segregação em São Paulo

CEUs, 2001

Projeto Viver, 2004

Jardim Edite, 2008-2013

Parque Novo Santo Amaro V, 2009-2012

SESC 24 de maio, 2017

Parque Jardim das Perdizes, 201 1-2017

4. A fragmentação dos espaços cotidianos

A arquitetura como modo de imaginação

Entre espaços vazios e vastas indeterminações

O Parque de los pies descalzos, 1999

Parque de los Deseos, 2004

4.2 Arquitetura em São Paulo

Praça das Artes, 2012

4.3 Arquitetura para cidades

A dimensão sociourbana da arquitetura 

"No theory can develop without eventually encountering a wall, and practice is necessary for piercing this wall."

Gilles Deleuze

Buscando uma reflexão crítica acerca da agenda contemporânea da arquitetura e de sua relação com o urbano - em seus temas, atribuições e crises - a tese propõe um estudo comparativo entre a arquitetura pública recentemente produzida nas cidades de São Paulo, no Brasil, e Medellín, na Colômbia. Isso porque ambas apresentam casos notáveis em que a arquitetura foi mobilizada como estratégia de intervenção nas dinâmicas socioespaciais da cidade, apresentando diferentes ganhos e dificuldades.

Em São Paulo, entre os anos de 2001-2004, 21 equipamentos públicos chamados Centros Educacionais Unificados (CEUs) foram construídos nos bairros periféricos. Nesse mesmo momento em que se buscava a equidade de oportunidades educativas e culturais na cidade, foram também implantados terminais e corredores de ônibus tipo BRT (Bus Rapid Transit), assim como um novo sistema de bilhetagem com tarifas unificadas, liberando baldeações livres e gratuitas limitadas pelo período de duas horas. Nos anos que se seguiram, entre 2005-2012, houve um momento especial de desenvolvimento econômico brasileiro, que favoreceu a construção de mais $24 \mathrm{CEUs,} \mathrm{bem} \mathrm{como} \mathrm{a} \mathrm{proposição}$ de experiências inovadoras que avançaram sobre a urbanização de favelas e a qualificação de seus espaços livres. Foram realizados concursos permitindo que diversos arquitetos participassem junto ao poder público no desenvolvimento de novas tipologias habitacionais de interesse social. Em 2014, sob maiores dificuldades políticas e econômicas no país, deu-se a revisão do Plano Diretor Estratégico de 2002, (Lei n1․ 430 de 13 de Setembro de 2002), que, ademais, trouxe uma série de instrumentos e dispositivos que visavam garantir padrões mais qualificados de urbanização. Dentre as várias frentes de ação previstas no plano, destaca-se o esforço em mediar a produção dos espaços coletivos também realizados pela iniciativa privada. As experiências anteriormente descritas se somaram na mesma direção, mas foram marcadas por descontinuidades e contradições: de governo, de arranjos da administração pública e de concepções projetuais.

Nesse mesmo período, Medellín se tornaria conhecida pelo Urbanismo Social. Este é um termo que surgiu com o governo municipal de Sergio Fajardo (2004-2007), definindo um conjunto de políticas e projetos urbanos associados à implantação de equipamentos públicos e reurbanização de assentamentos precários, concentrando esforços em áreas de alta vulnerabilidade social ${ }^{2}$. Também, por meio de

\footnotetext{
${ }^{1}$ Foucault, Michel, and Gilles Deleuze. 1977. "Intellectuals and Power." In Language, CounterMemory, Practice: Selected Essays and Interviews, edited by D. F. Bouchard. Ithaca: Cornell University Press, p.261

${ }^{2}$ Ao longo da pesquisa de doutorado foram desenvolvidos alguns artigos que exploram o contexto histórico, as condicionantes socioespaciais e a evolução das políticas urbanas nos últimos 15 anos em Medellín, para a melhor compreensão dos projetos analisados. A tese
} 
investimentos expressivos na mobilidade e no espaço construído, contextualizando a implantação de infraestrutura e dos equipamentos públicos com o auxílio de projetos urbanísticos de maior envergadura, buscou-se, assim como em São Paulo, alinhavar problemas da cidade informal e dos bairros mais carentes à agenda do planejamento e das políticas urbanas da cidade como um todo.

As análises sobre esse processo político e urbanístico têm provocado juízos de condenação ou sucesso irrestrito. Passados 15 anos dessa experiência, faz-se necessária uma avaliação mais circunstanciada da realidade urbana de Medellín. Particularmente, porque essas experiências pareceram fomentar uma nova urbanidade. Ela teria se tornado ferramenta essencial ao poder público na construção urgente de um pacto social de caráter abrangente, que buscava a reversão do quadro de violência urbana. Essa estratégia, bem acolhida por parte significativa da população, foi continuada por seus sucessores, ainda que sob outros lemas e orientações políticas (com algumas notas dissonantes às diretrizes originárias do governo de Fajardo). Ainda assim, a agenda do Urbanismo Social permaneceu reconhecível na maior parte dos programas desses diferentes governos que o sucederam.

Um olhar mais cuidadoso sobre essas duas experiências também percebe que os instrumentos da arquitetura foram chamados a responder outros problemas da cidade contemporânea em contextos que contrastam com as intenções de incidir sobre as carências e precariedades do território informal. Uma vez que, nas duas cidades, pode-se observar o desafio crescente da interação da arquitetura com o espaço público também em eixos de investimento de capital privado.

Prefigurava-se um horizonte de pesquisa sobre o cenário contemporâneo dessas duas cidades, por terem acionado as ferramentas da Arquitetura e Urbanismo (A\&U) para o enfrentamento dos problemas urbanos. Entretanto, constatavam-se impasses comuns a muitas cidades latino-americanas, o que apontava para dificuldades especificamente disciplinares da A\&U. Suas estratégias exigem constante problematização e atualização de conceitos, assim como de categorias de análise para compreensão da produção do espaço e das estratégias projetuais formuladas em nosso tempo. É válido notar que essas questões colocadas demandavam, de antemão, especial atenção ao universo empírico das experiências realizadas, base imprescindível para o exercício crítico e as necessárias reformulações no campo do pensamento.

\section{A origem do diálogo entre São Paulo e Medellín}

O olhar sobre essas duas realidades trouxe algumas questões iniciais, verificadas preliminarmente na pesquisa de mestrado Espaço Educacional Contemporâneo: reflexões sobre os rumos da arquitetura

sintetiza as aproximações e conclusões parciais desses artigos. Cf.WILDEROM, 2013; WILDEROM-CHAGAS, 2016; WILDEROM, 2018a; e WILDEROM, 2018b. 
escolar na cidade de São Paulo (1935-2013). Nesse trabalho, a história do espaço educacional na cidade foi problematizada segundo questões contemporâneas suscitadas pelos CEUs, um complexo de equipamentos educacionais, culturais e recreativos implantados em bairros com alto índice de vulnerabilidade social. Em meio às demais leituras realizadas pela pesquisa, percebia-se que a tipologia que resultou dos primeiros projetos desse equipamento foi carregada de expectativas em relação à sua capacidade de transformar o espaço urbano no qual se inseria. O projeto foi aclamado por seus idealizadores e pela crítica especializada como uma estratégia indutora de urbanidade, uma vez que a multiplicidade de suas funções se organizava na criação de um espaço público que seria capaz de trazer qualidades da cidade formal a regiões desprovidas desses atributos. O procedimento projetual que lograria construir essas novas relações com os territórios existentes, foi também vinculado a um legado da chamada escola paulista, conforme descreve Renato Anelli (2004):

\footnotetext{
Os CEUs querem inaugurar uma nova urbanidade para seus bairros. Mas não se trata de fazer uma "tábula rasa" do local. Esses partidos não se limitam a uma ação no campo do objeto e buscam identificar e transformar a situação territorial da área onde eles se instalam. Dialogam diretamente com as características geomorfológicas, tais como morros, várzeas e os cursos d'água que constituem o que resta de natureza nos terrenos escolhidos. Alguns exemplos podem ilustrar essa atitude tão cara aos expoentes da "escola paulista" de Vilanova Artigas e Paulo Mendes da Rocha.
}

Essa leitura descreve os pressupostos projetuais dos CEUs como uma postura crítica à visão modernista de intervenção no território e a um renovado cuidado às preexistências. As percepções colhidas em campo se depararam, no entanto, com a condominialização desses equipamentos (WILDEROM, 2014, p. 183). Com efeito, se tratava de um programa educacional e social paradigmático para a cidade, porque alcançava sistematicamente bairros em que o Estado se fazia pouco presente. E eram edificações de alta qualidade programática e construtiva, que ofertavam uma ampla gama de serviços culturais, esportivos e educacionais de grande potência na socialização dessa população. Mas esses equipamentos, como intervenções urbanas que inauguravam um procedimento novo do poder público em relação aos bairros periféricos da cidade, se apresentavam, afinal, como grandes conjuntos arquitetônicos encerrados por grades. Essas contradições indicavam a necessidade de um debate que extrapolava a questão especificamente educacional prevista naquele trabalho. Elas delineavam a inevitabilidade de se reinterpretar a relação entre urbanidade e arquitetura contextualizadas nas clivagens de nosso espaço social, atravessando a amplitude de desafios que vêm sendo lançados à produção do espaço público, conforme aponta Camargo (2009, p. 331):

(...) o descompasso entre as políticas públicas e as reais necessidades da população tem levado à inevitável ocupação informal, que tem aumentado mais do que a própria cidade formal, criando outro problema de intervenção em uma situação consolidada, tornando 
necessário, portanto, que se revejam as relações, tanto teóricas quanto

práticas, entre a arquitetura e a cultura do nosso tempo.

Com isso, entendeu-se que a discussão teria de se mover em direção ao desafio imposto à disciplina da $A \& U$, quando esta se lançava a produzir intervenções projetuais que buscavam uma relação com questões urbanas de extrema complexidade, dada a realidade segregada e fragmentada das metrópoles latino-americanas.

Assim, reconheceu-se que os projetos e os discursos traziam aspectos que precisavam ser cotejados com o espaço construído por essas ideias, considerando suas condicionantes, conquistas e impasses, hoje plenamente verificáveis. Esse procedimento foi considerado mais prolífico se problematizado por meio de referências externas, que trazem elementos de renovação para a equação da análise, evitando um sistema autorreferente entre produção e validação por meio da crítica local.

Nesse sentido, as recentes experiências em Medellín sinalizaram possibilidades de aproximação. Uma vez que boa parte dos projetos construídos também mobilizavam equipamentos voltados à educação $\mathrm{e}$ à cultura para enfrentar problemas urbanos em áreas marcadas pela informalidade. O resultado, nessas duas cidades, no entanto, denotava diferenças na maneira como, estruturalmente, o poder público se organizou para criar territórios de projeto, na multiplicidade de programas e equipamentos, mas, principalmente, como as respostas eram formuladas pelos arquitetos. Esse panorama de aproximações e particularidades perante a mesma problemática requeria maiores aprofundamentos e tornou-se o campo de investigação para esta tese.

\section{Condições de partida}

Prosseguimos com a necessidade de reinterpretação da relação entre urbanidade e arquitetura dentro de cidades marcadas por vastas áreas de ocupação informal que contrastam com a estrutura urbana dos eixos de investimento de capital privado, fato que aproxima São Paulo a Medellín. Mas constatou-se também, de partida, uma antiurbanidade do ponto de vista das estratégias da $A \& U$ - em parte nos projetos de São Paulo, que poderia ser atribuída a um ideário formalista da arquitetura sedimentado pelos principais exemplos da vanguarda moderna brasileira, que ainda estruturam de modo expressivo a cultura arquitetônica paulista. E seria uma influência ainda determinante na maneira como esses projetos recentes pensam o espaço em que atuam. Essa é uma hipótese que se apoia na pesquisa preliminar do mestrado, mas toma corpo por meio do debate realizado por Luiz Recamán (1996; 2000; 2002; 2004; 2012; 2013; 2015) e Leandro Medrano (2013; 2015; 2018). Os autores, em seus trabalhos mais recentes, dedicam especial atenção à reviravolta crítica que a crise do neoliberalismo provocou, visto que ela colocou o espaço - e em especial o espaço urbano - no centro das 
estratégias e táticas de transformação social, o que justifica ainda mais as questões trazidas pela presente pesquisa ${ }^{3}$.

A hipótese desse trabalho partiu da premissa de que essa antiurbanidade interna ao projeto de arquitetura constrange as potencialidades de transformação socioespacial intrínsecas às relações que se estabelecem entre edifício e cidade. A verificação comparativa e crítica dos estudos de caso em Medellín, em um momento que essa cidade recebe atenção pela sua transformação social respaldada por projetos de arquitetura e intervenções urbanas, pareceram-nos um caminho instigante para iluminar os problemas de nossa própria realidade.

Para a análise proposta, a pesquisa estabeleceu a articulação de duas frentes de trabalho concomitantes que nortearam o estudo de base comparativa: a pesquisa teórica, com os marcos conceituais que orientam a leitura disciplinar, e a pesquisa empírica, com análise de estudos de caso nas duas cidades. Os marcos teóricos consideram, além de obras circunscritas ao campo da $A \& U$, referências de áreas como a geografia crítica e a sociologia urbana, dentre outras que complementam a compreensão do processo de urbanização e das relações da produção do espaço social, atendendo a necessária interdisciplinaridade dessa análise. $\mathrm{O}$ espectro de referências utilizadas acaba por delinear uma contribuição para a perspectiva latino americana do debate, ainda que este não seja o objetivo primordial da pesquisa. Isso decorreu da necessidade de se estabelecer as aproximações entre as diferentes arquiteturas contemporâneas produzidas em dois países desse subcontinente. Por consequência, tivemos que enfrentar as problemáticas específicas das suas dinâmicas sociais. Reiterou-se, nesse processo, a necessidade de criar novos procedimentos analíticos, identificar noções e terminologias, a fim de precisar a grande categoria de afinidades compartilhadas vinculada às problemáticas enfrentadas pela disciplina arquitetônica na América Latina. Mesmo assim, cuidou-se de não recorrer a uma relação reducionista de identidade entre as diferentes obras, conforme adverte Jorge Liernur (2015, p.8):

\begin{abstract}
Não se trata de um código programático ou formal, muito menos um conjunto de traços de caráter ou alguma identidade essencial em comum, mas sim o pertencimento a uma dinâmica particular da história e um conjunto de problemas em aberto, como resultado de condições comuns de existência. Algumas dessas questões estão relacionadas a transformações metropolitanas e arquitetônicas, processos de produção, posturas referentes a um contexto natural, ou da história da arquitetura local e de sua sensibilidade social. ${ }^{4}$
\end{abstract}

Transitando sobre essas possibilidades de aproximação entre os casos nas duas cidades, particularmente interessada sobre a sensibilidade social dessas arquiteturas, a estratégia de comparação entre essas duas cidades trabalhou com uma seleção inicial de 22 estudos de caso

\footnotetext{
3 Esse argumento sintetiza a perspectiva das discussões desenvolvidas junto ao grupo de pesquisa $\mathrm{PC}_{3}$ : Pensamento Crítico e Cidade contemporânea coordenado por Luiz Recamán e Leandro Medrano (FAUUSP).

${ }^{4}$ Tradução da autora.
} 
recentes distribuídos entre São Paulo e Medellín, buscando projetos em que a arquitetura se colocava como intervenção urbana. Do universo de projetos que atendiam a esse requisito mais geral, foram escolhidos aqueles que permitiam emparelhar experiências nas duas cidades em cinco temas derivados da análise de Luiz Recamán, em seu texto Os Impasses da Arquitetura Paulista Recente (2017). Nesse texto, o autor sintetizava na virada do século os principais dilemas da produção contemporânea da arquitetura paulista dentro da realidade de uma cidade submetida aos interesses econômicos globalizados. São temas comuns também a Medellín e abrangem de tal maneira a problemática da arquitetura e sua relação com a produção do espaço urbano, que serviram como base de seleção e reflexão cruzada sobre os estudos de caso, a saber: (1) A periferia da cidade como fruto do crescimento acelerado das últimas décadas; (2) A questão da moradia em projetos de habitação popular ; (3) Núcleo urbano central enquanto espaço em transformação e crise; (4) Eixos privilegiados de investimentos de capital privado. Além desses quatro eixos que constam no texto original, propusemos (5) Infraestrutura Urbana e sua inserção na cidade.

A análise combinada dessas experiências, que se aproximam nos padrões de urbanização e se distanciam em seu sistema cultural arquitetônico, permitiram iluminar e discernir os constrangimentos das relações entre forma social e forma urbana, quando mediadas por essas diferentes tradições/orientações disciplinares. Nas experiências analisadas, percebemos que essas podem ou idealizar, sublimar e relegar o universo social ao rol de conteúdos extra-arquitetônicos ${ }^{5}$, ou reinterpretar e incorporar essas dinâmicas a uma estratégia projetual, dialogando assim com processos de produção do espaço social na formulação de seus paradigmas espaciais.

Nesse sentido, ao admitir como objeto de estudo, primordialmente, projetos que se colocam como intervenções socioespaciais, fica possibilitado que o debate se realize na intersecção entre os subcampos da disciplina da Arquitetura e Urbanismo. Uma tarefa que desafia os quadros teóricos e metodológicos, ainda mais quando nos lançamos a entender a antiurbanidade como um limite disciplinar que acomete o pensamento e a ação na "matriz arquitetônica" local. Por esse motivo, o primeiro capítulo 1. Um problema disciplinar: a antiurbanidade se dedica a posicionar essa questão que permeia a tese, esclarecendo as referências e o método que orientam as leituras críticas sobre os projetos. Os demais três capítulos organizam a fricção entre o campo teórico e o empírico, enquanto realizam a leitura comparativa entre os projetos nas duas cidades. A orientação desse trabalho analítico, por meio do rebatimento de questões entre os casos, se dá por temas que emergem da tese como desafios que demandam proposições da disciplina, sendo: 2. A urbanização produtora de não lugares; 3. A

\footnotetext{
${ }^{5}$ Esse termo é utilizado no sentido proposto por Luiz Recamán, particularmente em dois textos "Oscar Niemeyer e o Brasil - anotações“ e "Álvaro Siza e o Brasil”, presentes em sua tese de livre docência (FAUUSP, 2018).
} 
segregação reafirmada no lote; 4. A fragmentação dos espaços cotidianos.

Essa estrutura temática ${ }^{6}$ torna mais evidente a intenção de se cotejar as relações entre as características socioespaciais do processo de urbanização e respectivas respostas arquitetônicas estudadas nos dois países. Essas relações já se sobressaíam e eram transversais à comparação pautada pela organização original dos eixos analíticos, mas quando da organização preliminar do trabalho, permaneciam confinadas a um certo paralelismo, porque divididas entre problemas tipológicos, funcionais e, também, urbanos em diferentes acepções.

Ao final, os três temas resultantes também permitem passar por essas questões de modo integrado, sob uma gradação escalar mais apropriada ao problema transversal que é a urbanidade: partindo da estrutura urbana metropolitana (do planejamento urbano) no capítulo 2, passando pela escala do lote (do projeto de arquitetura) no capítulo 3, em direção ao espaço imediato do indivíduo na cidade (que tenciona de modo trans-escalar a disciplina da A\&U) no capítulo 4. Essas transições pretendem também conferir patamares de compreensão que ganham progressivamente maior nitidez. Desse modo, a abordagem temáticaescalar orienta o percurso analítico que percorre comparativamente os projetos, regidos pelos principais atributos espaciais e pela fricção com o mundo social que estes ativam. Evita-se assim a estratégia que emparelha repetida e inadvertidamente critérios fixos entre todos os projetos. Para essa pesquisa, a parametrização quantitativa das análises não pareceu ser prolífica nem conferir maior rigor científico às mesmas $^{7}$. No entanto, ao final do trabalho foram anexadas fichas que pretendem equalizar as informações de base e o contexto de implantação e produção dos projetos. Estas deram suporte às reflexões quando da redação da tese e servem de apoio ao leitor.

Em cada capítulo temático se realizam três momentos de análise:

1) Compreensão da condição urbana e suas especificidades subordinadas à dinâmica socioespacial subdesenvolvida;

2) Identificação, nas ocorrências recentes da produção das duas cidades, respostas ou impulsos arquitetônicos que refletem sobre desafios dessa urbanização com contribuições para uma reflexão disciplinar;

3) Análise crítica de um conjunto de atitudes que apontam para um pensamento e estratégias projetuais promissoras acerca desses desafios.

A pesquisa se apoiou também em registros fotográficos, que permitiram uma leitura prolongada sobre o contexto dos projetos. No

\footnotetext{
${ }^{6}$ Essa estrutura temática deriva do trabalho junto ao Prof. Dr. Tom Avermaete, orientador e supervisor da autora durante estágio realizado como pesquisadora visitante na TUDelft por 3 meses com Bolsa de Estágio de Pesquisa no Exterior da Fundação de Amparo à Pesquisa do Estado de São Paulo (processo FAPESP n. 2017/26688-o).

7 No memorial de qualificação se apresentou um estudo preliminar de uma matriz classificatória e comparativa de todos os projetos que tinha se propunha a estabelecer parâmetros quantitativos para as análises realizadas. No entanto, esse procedimento não obteve resultados satisfatórios para a problematização da pesquisa, conforme debatido na banca examinadora.
} 
sentido de verificar sua fricção com a morfologia e as dinâmicas socioespaciais que interagem com o "campo de forças" da qual a intervenção arquitetônica ${ }^{8}$ passa a fazer parte. Essas imagens são utilizadas ao longo da tese para avaliar a relação que o projeto estabelece com seu entorno, para exemplificar como se dá o acesso ao conjunto/volume arquitetônico, o que se depreende da cidade a partir das relações visuais proporcionadas pelo projeto, dentre outros detalhes dificilmente verificáveis, se não pela relação presencial com o objeto analisado. Essa opção denota um esforço de tornar essas urbanidades comparáveis, evitando recorrer ao discurso dos arquitetos cristalizados em ensaios fotográficos oficiais, que acabam por reiterar visualmente sínteses argumentativas.

Da mesma forma, os diagramas comparativos das implantações desenvolvidos para a pesquisa ${ }^{9}$ buscam identificar relações entre percepções de campo e instrumentos projetuais, que pareciam adquirir diferenças expressivas entre os casos colombianos e brasileiros. Elas complementam o movimento, caso a caso, de enfrentamento do objeto empírico de modo mais preciso e sistemático.

A dimensão exploratória dessa pesquisa, verificada nessa estrutura, se justifica na urgência em buscar entradas e contornos para a absorção dos debates sobre a crise social e urbana, para a Arquitetura e Urbanismo. Como uma disciplina da área de ciências sociais aplicadas, sua dimensão propositiva é inescapável e sua contínua atualização imprescindível. Por meio dessa estratégia, pretende-se que o trabalho identifique as potencialidades expressas em urbanidade, que surgem do diálogo entre intervenções arquitetônicas/urbanísticas - configurando a dimensão prático-sensível (LEFEBVRE, 1991) - e a práxis social - da vida cotidiana -, evidenciando as variáveis que operam nessa relação e que contribuem para o pensamento da Arquitetura e Urbanismo e os instrumentos de sua ação. Por fim, as análises a seguir e suas conclusões devem ser compreendidas considerando-se as limitações de quem trabalha sobre a instabilidade do momento presente.

\footnotetext{
${ }^{8}$ No sentido proposto por Medrano e Recamán (2013, p. 9): "A dinâmica urbana da cidade de São Paulo resulta de uma multiplicidade de processos que corresponde à própria dinâmica social. O pensamento arquitetônico sobre a cidade poderia compor importante vetor que orientasse ou interferisse em seu desenvolvimento desordenado, dentro desse amplo painel de agentes transformadores do espaço urbano. Se essa realidade sociourbana puder ser considerada um "campo de forças" geral, o pensamento arquitetônico pode ser entendido como um sistema de ideias e intervenções que atua direta e parcialmente dessa configuração geral."

${ }^{9}$ Vide Capítulo 4.
} 


\section{Um problema disciplinar: a antiurbanidade}

Através e contra a hierarquização, não poderia incidir, aqui e
ali, arquitetura ou urbanisticamente, "alguma coisa" que
resulte do modo de produção existente, que nasça de suas
contradições desvendando-as, e não as cobrindo com um véu?

Henri Lefebvre $e^{\text {10 }}$

A pergunta que a tese se propôs a responder implica um problema metodológico do trabalho, mas também espelha uma crise interna da disciplina: como estabelecer relações - críticas - entre a arquitetura e o contraditório tecido urbano em que ela opera? Como reconhecer nessa interação com a realidade, algum impulso transformador das dinâmicas sociais advindo de uma intervenção no espaço? Isso se transfigurou no exame dos insuperados impasses da modernidade, a que se refere Lefebvre na epígrafe: repensar a hierarquização, segregação e funcionalização do espaço a serviço da lógica de produção capitalista. Então, motivados por estas ponderações e por um enfoque disciplinar da $A \& U$, prosseguimos na verificação de um quadro referencial para a crítica entre arquitetura e cidade na modernidade e seus rebatimentos locais. O motivo do desdobramento das complexidades conceituais como condição de partida - se dá pelo enfrentamento da cidade existente como problema inerente aos estudos de caso. Também a manifestação de um caráter antiurbano na formulação de estratégias projetuais em São Paulo é a mola fundamental da hipótese e é uma indagação que perpassa as análises desenvolvidas na pesquisa. Esses questionamentos são conceitualmente percorridos com o auxílio das principais referências que apoiam a discussão proposta. Desse modo, o capítulo pretende sintetizar e introduzir os problemas que mobilizam e estruturam as linhas desta tese.

\subsection{O impasse da Arquitetura e do Urbanismo}

Como apresentamos anteriormente, a presente pesquisa parte da análise comparativa entre as cidades de São Paulo (Brasil) e Medellín (Colômbia) para compreender como a Arquitetura e Urbanismo (A\&U) respondem, em cada contexto, a questões similares. As aproximações possíveis entre essas duas cidades da América Latina foram propostas, pois as duas cidades enfrentam problemáticas referentes à modernização tardia e ao crescimento urbano explosivo segregacionista e excludente, peculiares aos países na periferia do capitalismo ${ }^{\text {II }}$. No entanto, se prefiguravam distâncias entre os dois casos, ao se estabelecer a questão disciplinar da $\mathrm{A} \& \mathrm{U}$ como o campo de formulação da hipótese. Isto porque a herança da arquitetura moderna, o contexto de formação do meio profissional e as condições de produção da

\footnotetext{
${ }^{10}$ LEFEBVRE, H. Prefácio: a produção do espaço. Estudos avançados, v. 27, n. 79, 2013, p.120

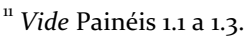


arquitetura teriam determinado a constituição de gerações de arquitetos e de escolas distintas em cada cidade, cujas práticas resultariam das disparidades nas estruturas disciplinares, nas abordagens projetuais por elas informadas e, consequentemente, na possibilidade de interação dos projetos resultantes com as dinâmicas socioespaciais diferentes em São Paulo e em Medellín.

Tendo duas cidades no centro da análise, também se tornou fundamental incorporar à discussão as dimensões histórica e social do espaço urbano, notadamente marcadas pelas particularidades do fenômeno da urbanização no contexto do subdesenvolvimento. As contradições oriundas desse processo são agravadas no atual estágio do capitalismo avançado. A contextualização da urbanização em cada caso é aqui retomada, não como pano de fundo da análise a ser empreendida, mas algo a ser enfrentado metodologicamente por essa pesquisa, porque é algo intrinsecamente problemático para a A\&U. Ela teria, no século 20, deixado claro seus limites de interação com as dinâmicas socioespaciais justamente devido a uma visão parcelar da questão urbana (LEFEBVRE, 1991). Essa dificuldade foi continuamente reafirmada tanto pela dificuldade em que a disciplina sistematiza e apreende os fenômenos sobre os quais ela opera quanto pela evolução da própria teoria e prática da arquitetura ao longo do século passado. Sobre esta última, se faz referência aos desvios enfrentados pela $A \& U$ modernos que, operando por meio de um determinismo físico em resposta aos mais complexos problemas sociais, acabou se enredando em contradições intransponíveis. Nisso, é válido lembrar que os grandes fracassos do urbanismo moderno, que se apresentam como maior exemplo desse processo, se deram, particularmente, por meio dos edifícios residenciais de alta densidade, demonstrando que esses desastres situados na cidade concernem fundamentalmente a respostas formuladas pela arquitetura, conforme lembra Cuthbert (2003, p. 2). Essa ponderação se torna importante na medida em que sublinha a noção de um desequilíbrio sistêmico da disciplina, independentemente da escala em que ela atua. Esses questionamentos acerca dos limites da tradição moderna que podem aflorar sobre as estratégias projetuais contemporâneas puseram sob avaliação tanto os exemplos brasileiros, quanto os colombianos.

A referência fundamental desse debate é a obra de Manfredo Tafuri. Em Projeto e Utopia (1985), o autor constata e sistematiza a derrocada da arquitetura moderna e de seu projeto utópico, condenando a ineficiência de sua ideologia, diante da gestão capitalista direta do território e conclamando os arquitetos a reconhecerem a "inação de seus instrumentos inofensivos" (1985). Ao elucidar de maneira tão contundente o comprometimento da disciplina, enraizando-o na dinâmica do capitalismo tardio, Tafuri condenou o crítico a uma posição implacável de acusações negativas e demolidoras e o arquiteto ao completo impedimento de exercer sua profissão - ao menos não antes de uma revolução social completa. Para muitos, isso representou o descarte de qualquer possibilidade de mudança da realidade por meio da arquitetura, conforme pondera Nesbitt (2006, p. 42). Mas, ainda assim, precisamos seguir produzindo cidades e fazendo a crítica. 
No Brasil, Otília Arantes fará a crítica da ideologia arquitetônica buscando estudar conjuntamente obras, tendências e teorias que reagem às consequências desta grande reversão do Projeto Moderno. Nesse movimento, se desvendam os pontos problemáticos do encontro entre a dimensão estética e impasse social (ARANTES, 2015, p. 14). Ao perscrutar o formalismo que dá corpo à ideologia arquitetônica, desde o período heroico modernista, se estendendo à exacerbação na chave fachadista pós-moderna, a autora constata, a partir dos anos 1990, o fim da linha: a espetacularização arquitetônica (a arquitetura simulada) amparada por programas culturais, que terminaria por condenar a arquitetura e o urbanismo a um papel de mero instrumento do capitalismo que consome a cidade:

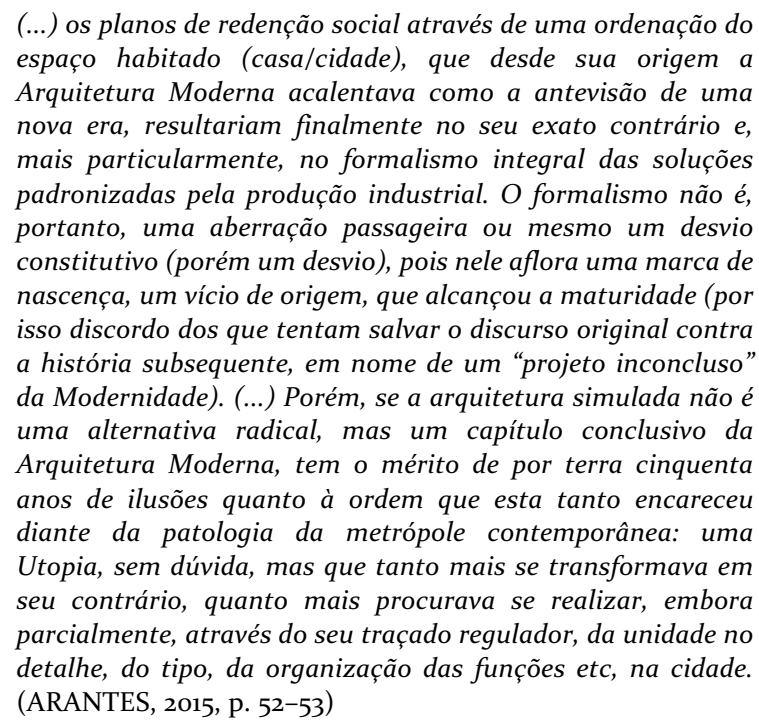

Compartilhando dessa orientação crítica, Recamán (2002) olharia para o projeto moderno brasileiro buscando posicioná-lo nesse embate. Segundo o autor, o desejo apressado de modernização, no Brasil, abraçaria, a partir dos anos 1930, com desenvoltura formal única, a "ideologia do plano". Ao se transformar, na experiência local, "na realidade do plano", o ideário moderno se viu liberto, cada vez mais, de sua função social. A análise da formulação dos paradigmas espaciais de Oscar Niemeyer permitiu ao autor localizar os pontos de descolamento entre a matriz de pensamento hegemônico da arquitetura brasileira e a sua realidade social. Por meio das obras principais do arquiteto, percebe-se o caminho da desterritorialização da arquitetura moderna brasileira, que se desprende dos seus compromissos com a as dinâmicas socioespaciais. Esse processo é simbolizado pela arquitetura que se desvincula do plano urbanístico, se afastando do ideal da "extroversão universalizadora do módulo", que caracterizaria o processo de modernização europeu, e tomando seu rumo definitivo em direção à singularidade autossuficiente da unidade. Alguns arranjos de composição arquitetônica foram desenvolvidos por Niemeyer justamente para resolver as contradições entre a realidade circundante de um Brasil arcaico e o desejo projetado nessas obras de mostrar-se 
modernizado, no entanto, acabaram por aprofundá-las. De modo que se verifica do MESP à Pampulha "a equação estética das energias expansíveis em choque com os limites socioespaciais intransponíveis. Extroversão sem enfrentamento do real gera grande conjunto mas não espaço social e urbano" (RECAMÁN, 2015a, p. 55)

Brasília parece ser a epítome dessa equação: o último nível de formalização em resposta às desigualdades sociais do Brasil dos anos 1950. A única conciliação entre arquitetura e urbanismo modernos se deu a partir da tabula rasa máxima de uma forma cidade-plano, condizente com a forma cidade-nação. Assim, por não conseguir conviver com a realidade urbana que vai se consolidando, a solução encontrada pela arquitetura moderna brasileira é de uma abstração formal sem precedentes (RECAMÂN, 2002, p. 146).

Esse processo marcou definitivamente a formação da cultura arquitetônica brasileira e o caráter ideológico da sua vertente hegemônica. Recamán, ao constatar inegáveis espelhamentos entre um projeto político - aporético em sua ideação social, autoritário e centralizador em sua realização - e a correspondente formulação arquitetônica, deixa pouco espaço para uma apreciação despreocupada da beleza plástica das obras de mestres. Sua leitura também permite ver que a produção da arquitetura que sucedeu esse paradigma também não pareceu romper com o argumento formal da arquitetura. Ela encontrou, no entanto, novas ancoragens estéticas e discursivas para enfrentar contextos muito exíguos de expressão:

\begin{abstract}
Com a construção de Brasília e com o golpe militar de 64 encerra-se essa fase da ideologia arquitetônica brasileira. As soluções encontradas (que estavam aglutinadas na unidade e que se dissiparam na composição do conjunto-cidade) vão continuar a fornecer subsídios para novas radicalidades, que vão retirar de sua origem e desenvolvimento antiurbano uma possibilidade estética para contrapor-se à nova realidade social do país, nos anos mais autoritários do regime militar. Após a experiência limite de Brasília, a arquitetura moderna brasileira, titubeante, limita-se a "desempenhar tarefas de retaguarda e apoio marginal (simetria local da derrocada ideológica da arquitetura moderna no centro, como anuncia Tafuri). (RECAMÁN, 2002, p. 147)
\end{abstract}

Resulta desse procedimento analítico do autor, um método que se faz necessário diante da urbanização brasileira funcionalmente excludente. Então, partindo dessa referência, ao se submeter às mesmas perguntas às pesquisas espaciais da arquitetura paulista, que a partir dos anos 1950 no contexto de expansão da potência industrial irão enfrentar o processo de metropolização, são também reveladas, em outras chaves, dificuldades similares de ajuste entre dinâmicas sociais implícitas nos projetos e a realidade urbana na qual se realizam. As obras de Vilanova Artigas, tomado como objeto de estudo, dada sua importância para a formação da escola paulista, são depoimentos claros sobre essa contradição, indicando que ele foi capaz de desenvolver

(...) não só um vocabulário de soluções, todas muito conhecidas e replicadas, mas principalmente desenvolveu uma sintaxe construtivo-espacial que só tem sentido se

\footnotetext{
${ }^{12}$ Vide Painel 1.4.
} 
considerada a busca de uma nova espacialidade urbanomoderno-brasileira, um novo paradigma espacial. À ousadia da tarefa corresponde a construção do país moderno, e são as mesmas as suas vicissitudes. (RECAMÁN, 2015a, p. 58)

Entre o projeto, a sua realização e, afinal, a sua existência, há desacordos estruturais e não colaterais de menor importância, como poderíamos supor. Isso porque ressoam, dessa produção, notas de um projeto frustrado, uma alternativa que não se concretizou, que resulta no seu avesso: a antiurbanidade ${ }^{13}$, algo verificável na formulação espacial de microcosmos urbano dentro de suas casas e na interpretação da dimensão urbana funcionalizada, no conjunto de blocos habitacionais populares (MEDRANO; RECAMÁN, 2013). Esses pressupostos se desdobram também em sua produção voltada para o Estado, como nas escolas ${ }^{14}$ e equipamentos públicos, manifestando-se como uma introversão espacial radical, que traz para dentro da grande cobertura do volume único, a funcionalidade de arquiteturas que antes estavam espalhadas pelo bairro:

$$
\begin{aligned}
& \text { A escola de Artigas reuniu, então, sob um mesmo teto, o } \\
& \text { programa abrangente que a Convênio Escolar havia } \\
& \text { distribuído no conjunto e nos conjuntos. Toda a complexidade } \\
& \text { da formação integral e universal dos pequenos cidadãos passa } \\
& \text { a ser organizada sob uma grande cobertura que inclui, e aí um } \\
& \text { ponto a ser destacado, os espaços livres. Esses mesmos que } \\
& \text { não são mais encontráveis na cidade que se privatizara. Toda } \\
& \text { a experiência educacional, e social, poderia ser realizada nesse } \\
& \text { grande espaço acolhedor que se torna, se considerarmos seu } \\
& \text { momento histórico, espaço de proteção e } \\
& \text { recolhimento. (RECAMAN; WILDEROM, 2018) }
\end{aligned}
$$

Assim, o paradigma espacial preponderante nessas formulações arquitetônicas só se realiza se distanciada ou devidamente protegida da realidade urbana. Um problema fundamentalmente vinculado à leitura que se fez sobre a cidade: "A cidade é uma casa. A casa é uma cidade" 15 não é só um aforismo. Mas é uma síntese de um ideário continuamente atualizado, que pressupõe que as unidades arquitetônicas conteriam nelas mesmas a invenção de um "urbano", não importando a sua escala. E, a cidade na condição de conjunto dessas unidades-cidade, misturadas a outros fragmentos desordenados, criaria um espaço geral não determinado pela lógica dessas unidades. Mas esse espaço, ou não tem possibilidades de ordenação geral ou aguarda um movimento de mudança externo que o altere, para que, afinal, com essa lógica "comunal" consiga entrar em fase e concordância (MEDRANO; RECAMÁN, 2013, p. 13). Por meio dessa postura projetual, as interações com a cidade como ela é, ficam impossibilitadas. Inevitavelmente se protege por muros ou grades essa existência alternativa inconclusa, essa arquitetura à espera, reafirmando a impossibilidade de conectá-la a sociedade real.

\footnotetext{
${ }^{13}$ Cf. RECAMÁN, 2018.

${ }^{14}$ Vide Painel 1.5 As figuras 1.5.1 a 1.5.3 representam a transição entre os paradigmas espaciais de unidades espalhadas pela cidade, conforme discutido no artigo "Escola (des)fazendo cidade" (RECAMAN; WILDEROM, 2018). Essas imagens são aqui mobilizadas para ilustrar a mudança entre as estratégias projetuais que se vinculam também à questão contemporânea dos CEUs que nos serviu de ponto de partida para esta tese.

${ }^{15}$ Cf. ARTIGAS, 2004.
} 
O saldo desse processo aparentemente irreconciliável, é menos percebido pela investigação e crítica projetual, do que pelo contexto da prática profissional (RECAMÁN, 2015b). Os impasses identificados por essa análise estética têm claros rebatimentos no presente. Ao buscar evidências desse problema com um olhar desprovido do método crítico, o diagnóstico pode perder-se em conjunturas específicas que dispersam a carga crítica, deixando as problematizações relegadas a um plano extra-arquitetônico. Assim, os problemas da arquitetura contemporânea se dissipam entre diversos ofensores: o enfraquecimento do campo profissional, a economia em crise, a queda de braço entre as pautas urbanas e os interesses imobiliários, as conjunturas políticas desfavoráveis ou até mesmo a falta de cultura cívica dos gestores que gradeiam as obras a posteriori. Esse movimento defensivo está protegido sob o esmaecimento de contradições reveladoras e, também, pela relativização da importância da crítica. Muito porque essas dificultavam a profissão em retomar seu rumo, no devastado campo de atuação que saía das trincheiras de uma crise ideológica, rumo ao período de redemocratização.

Mas, ao adentrar o século 21, os debates interrompidos ou os problemas acomodados no extracampo da arquitetura, ainda se fazem presentes. Inclusive, o aceleramento das dinâmicas capitalistas parece ter exacerbado ainda mais a tendência da arquitetura em se refugiar nas suas estratégias idealizadoras, pois a "promiscuidade entre cultura e capital financeiro - e seus desdobramentos territoriais especulativos levaram a intensificação formal do objeto icônico e à paralisia de sua almejada dinâmica urbana ou relacional", conforme observa Recamán (2015b, p. 16).

A clivagem social continua a aumentar na cidade em sua condição pós-industrial, renovando esse processo em compasso acelerado. Ao adentramos a era do capitalismo financeiro carregando alguns desacertos, se torna premente retirar da inércia alguns conflitos apaziguados. Um olhar sobre a recente produção arquitetônica, orientado pelo método anteriormente descrito é, de certo modo, uma necessidade que se impõe e um caminho que se abre. Método este, que deve ser capaz de compreender a produção do espaço social em todas as suas implicações e potencialidades:

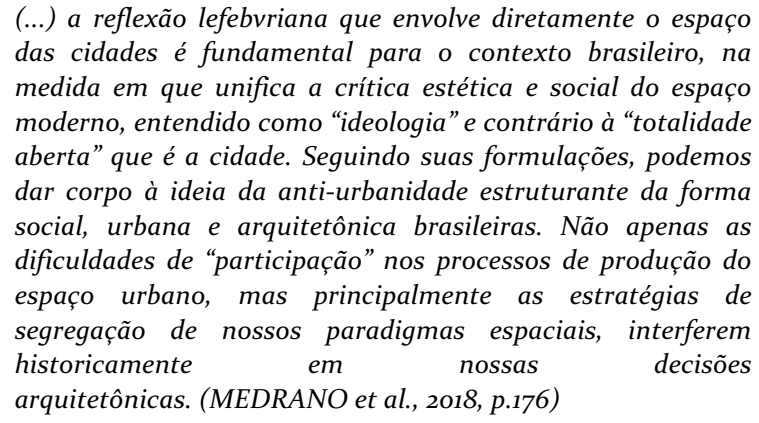
das cidades é fundamental para o contexto brasileiro, na medida em que unifica a crítica estética e social do espaço moderno, entendido como "ideologia" e contrário à "totalidade aberta" que é a cidade. Seguindo suas formulações, podemos dar corpo à ideia da anti-urbanidade estruturante da forma social, urbana e arquitetônica brasileiras. Não apenas as dificuldades de "participação" nos processos de produção do espaço urbano, mas principalmente as estratégias de segregação de nossos paradigmas espaciais, interferem historicamente em nossas decisões arquitetônicas. (MEDRANO et al., 2018, p.176)

A necessidade desse movimento crítico, apoiado no instrumental de autores como Henri Lefebvre que permitem estabelecer as relações de mediação que a disciplina da A\&U realiza entre $a$ forma social e a forma urbana, refletem uma necessária recuperação do sentido metodológico 
e crítico da arquitetura. E também a cidade, como representação coletiva e individual, parece demandar novamente essa participação da disciplina na construção de novas formas de vida urbana. Isso se verifica na forma como a cidade ressurge com força total após 2008, por meio dos movimentos sociais urbanos. Isso porque a conformação de bens comuns urbanos e as relações de comunalização observados nesse momento por David Harvey (2014) denotam impulsos de resistência a essa condição espacialmente segregada e determinada pelos interesses de acúmulo de capital que condicionam a vida nas cidades.

Essa força advinda de uma organização social talvez não aconteça de uma forma consciente ou plenamente organizada, mas surge com uma disposição a ocupar os espaços da cidade, como os movimentos de 2013 no Brasil demonstraram. Nessa crise e no ativamento crítico do social, o urbano se apresenta como uma possiblidade (ou uma virtualidade no sentido de Lefebvre) ${ }^{16}$ e isso implica uma aposta na urbanidade não como uma conjuntura, mas como uma estrutura, até mesmo na cidade de São Paulo:

Em relação às demandas na cidade, tanto especialistas quanto cidadãos podem observar o surgimento de um tipo de unidade no sentido negativo, que pode ser resumido como o "urbano" que havia desaparecido. Um desejo de urbanidade que se manifesta de maneira separada e setorial, mas que aponta para uma nova forma de concepção ou um novo horizonte de direitos que amalgama as objetividades e subjetividades, a infraestrutura e a representação, o espaço e a produção, a liberdade e o trabalho. Essa virtualidade urbana apresenta uma possibilidade dentro da atual conjuntura que não foi captada pelas ferramentas críticas ou práticas disponíveis dentro da tradição arquitetônica e de planejamento urbano local, apesar do progresso considerável que se acumulou nas últimas décadas. É essa reconstrução no negativo de uma urbanidade necessária, capaz de definir a cidade de São Paulo e seus atuais conflitos. ${ }^{17}$ (MEDRANO; RECAMAN, 2018b, p. 70)

\footnotetext{
${ }^{16}$ Conforme defendem Medrano e Recamán (2018, p.72): "Hoje parece que é a virtualidade lefebvriana (...) - ao invés de um imaginário comum - aponta para uma cidade possível. Essa virtualidade lefebvriana engloba mais do que suas partes, seja em termos de nossa compreensão da cidade, da separação de classes ou de sua geografia produtiva" (tradução nossa). O termo virtualidade perpassa a obra de Lefebvre, aparecendo fundamentalmente no debate proposto pelo autor em "O direito à cidade".

${ }^{17}$ Do texto original: "Regarding the demands in the city, both specialists and citizens can observe the emergence of a type of unity in the negative sense, which can be summarized as the missing 'urban'. A desire for urbanity which manifests itself in a separate and sectorial manner but which points toward a new form of conception or a new horizon of rights amalgamating objectivities and subjectivities, infrastructure and representation, space and production, and freedom and work. This urban virtuality presents a possibility within the current conjuncture that has not been captured by the critical or practical tools available within the local architectural and urban planning tradition, despite the considerable progress which has gathered pace during the last decades. It is this reconstruction in the negative of a necessary urbanity that is capable of defining the city of São Paulo and its present conflicts". Tradução nossa.
} 


\section{Colômbia}

Tendo constatado nossos impasses e tendências projetuais predominantes, fazendo a crítica a partir das impossibilidades verificadas localmente, a necessidade de expandir os termos da análise para enfrentar a realidade contemporânea traz ao campo de debate o caso de Medellín. Isso porque, em período recente, a prolífica produção nessa cidade coloca novas estratégias projetuais, conjunturas e agentes da produção do urbano em pauta, contribuindo para a expansão ou reavaliação da equação inicial de nossa constatada antiurbanidade. Algumas ponderações preliminares sobre a tradição da arquitetura moderna colombiana confirmaram a condição de contraponto ao caso brasileiro. A começar pela percepção de Silvia Arango (1990, p. 187):

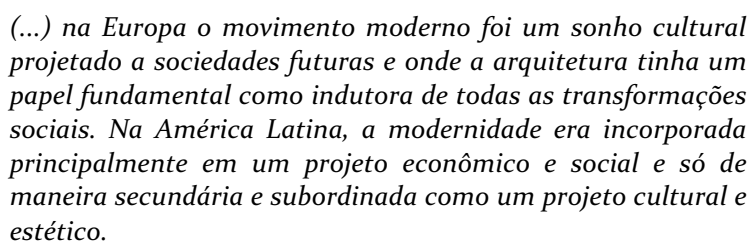
projetado a sociedades futuras e onde a arquitetura tinha um papel fundamental como indutora de todas as transformações sociais. Na América Latina, a modernidade era incorporada principalmente em um projeto econômico e social e só de maneira secundária e subordinada como um projeto cultural e estético.

Essa posição da arquitetura em segundo plano, ainda que funcionalizada no projeto político da nação, parece mais válido para a Colômbia do que para o Brasil, uma vez que ao final dos anos 1930 o moderno chega a esse país dentro de um desejo difuso de atualização que se espelhava nas sociedades mais avançadas para por em dia a economia, as cidades, o Estado e a infraestrutura do país. Isso ocorria de modo que a arquitetura parecia ser mais um dos assuntos na pauta e não encontraria maior sincronismo com os movimentos culturais que "marchavam em outro ritmo", visto que a arte abstrata e uma narrativa experimental na poesia, por exemplo, só iriam aparecer na Colômbia nos anos 1950, como exemplifica a autora.

Em contrapartida, a arquitetura moderna brasileira, junto à literatura e às demais artes, formou um sistema ${ }^{18}$ e teve tamanha força e protagonismo na criação dos emblemas nacionais, que relegá-la a um papel acessório nas formulações políticas, seria insuficiente. Para nosso olhar disciplinar, isso é central, pois a formação da arquitetura moderna por aqui, nessa chave, implicou a sedimentação de estratégias formalistas resilientes, que ainda operam nas concepções estéticas e argumentativas de tantos projetos contemporâneos.

Outras exceções, em que a arquitetura passa ao primeiro plano em uma relação direta e produtiva junto aos projetos dos Estados nacionais, são delineadas na visão das vanguardas latino-americanas de Adrian Gorelik. Segundo o autor, México e Argentina apresentarão, de maneiras muito diversas, mas também selando um pacto junto aos projetos estatais de modernização conservadora, suas formulações da modernidade. Em todo caso, como bem notaria Ramírez Nieto (2009), nos interessa perceber que os anos entre 1929-1939 foram decisivos para que a arquitetura moderna se vinculasse a projetos nacionais na

\footnotetext{
${ }^{18}$ Cf. RECAMÁN, 2018.
} 
América Latina, ainda que para grande parte dos países, isso tenha se dado sob âmbitos restritos de atuação profissional. Esses anos de reestruturação do mercado mundial, pós-crise de 1929, foram aqueles que impulsionam projetos políticos nacionalistas de fomento às nascentes indústrias latino-americanas, e vê-se a arquitetura ser funcionalizada na aparição de governos autoritários - como o governo Vargas no Brasil - ou de alternativas para impor a nova ordem que se instituía. Esse é um momento decisivo cujos acertos e frustrações ainda se fazem sentir claramente nos espaços urbanos contemporâneos, por isso o necessário retorno a esse ciclo.

No âmbito colombiano, o período consistiu em uma virada política após quase 50 anos de hegemonia do partido conservador. Os anos 1930 inauguraram uma nova etapa com a ascensão do partido liberal e o desejo coletivo de modernização. Mas a assimilação lenta da modernidade arquitetônica no país, a fez figurar sem maiores destaques dentre outros estilos da época, algo também dificultado por determinações construtivas. Pois muito dos primeiros edifícios modernos colombianos foram construídos em tijolo, dependendo de paredes estruturais feitas desse material, uma vez que concreto era importado, o que o tornava caro. A substituição das importações desse material só ocorreria na década de 1950, sendo que a produção nacional massiva de ferro para a construção civil ocorreria ainda mais tarde, o que contribui para um uso moderado dessa tecnologia construtiva. Assim, conforme aponta Vélez-White (200o) a modernização das grandes cidades colombianas, como Medellín, ocorreu primeiramente por meio de uma visão muito superficial do pensamento que produz a arquitetura do movimento moderno, pois se fazia por métodos artesanais e compreendendo esse "estilo" como mera simplificação de formas, "construindo edifícios colossais a mão". Essa arquitetura vacilante não foi capturada e nem estaria apta a maiores empreitadas simbólicas dessa nação, em seu breve respiro liberal.

Na segunda metade do século 20, no entanto, quando da aceleração do crescimento das cidades e da criação dos cursos de arquitetura, percebe-se uma adequada sincronia dos preceitos modernos a essas demandas. Além da expansão das infraestruturas, o progressivo aumento de automóveis e as novas dinâmicas urbanas demandaram a renovação dos centros urbanos tradicionais, a espacialização das funções da cidade em usos comerciais, financeiros e administrativos, a aparição de novas centralidades. Isso também incluiu a segregação socioespacial e o crônico déficit habitacional, ou seja, as tendências típicas do acelerado crescimento físico de um país de economia atrasada que mudaram definitivamente a imagem urbana tradicional (ARANGO, 1990, p. 209). Essa assimilação da modernidade foi marcada por uma primeira geração que aderiu às tendências do estilo internacional com a ênfase construtiva. Nessa propagação de uma homogeneidade formal, acabou-se diminuindo as diferenças regionais e foi do mesmo modo expressivo a adesão ao urbanismo Corbusiano. Nesse momento, um despontar de uma tendência ao alarde formal é também creditada à influência que a arquitetura brasileira exerceu na produção local, ainda segundo Silvia Arango. Mas também é notável o 
fato de que, em 1947, Le Corbusier visitou Bogotá e Medellín. Isso deu origem à sua colaboração com Wiener e Sert para o desenvolvimento de planos para estas cidades colombianas, bem como para Tumaco e Cali.

Os planos reguladores de Bogotá e Medellín, entregues em 1952, foram reveladores dos limites do pensamento moderno formulado à distância sob a "ideologia do plano" extemporânea. Representaram também grandes polêmicas: denotavam o desconhecimento das realidades físicas, sociais e inclusive topográficas das cidades a que se propunham intervir. A repercussão dessa incoerência na Colômbia, no entanto, atenuou-se, evitando a crítica ao ideário do mestre, de modo que os problemas encontraram paz na culpabilização das limitadas capacidades técnicas e administrativas dos governos locais em implantar na totalidade essas grandes ideias. Já se percebia aqui o movimento ideológico no qual a realidade parecia falhar ao plano. Assim, sustentou-se a crença nesse urbanismo científico de ordem pura e abstrata, de grandes escalas e de unidades arquitetônicas pontuais que mostravam que "os arquitetos modernos não possuíam óculos conceituais para ver e projetar a escala do espaço público" conforme descreve Arango (1990, p. 215).

A segunda fase desse processo de assimilação dos preceitos modernistas se deu somente no final dos anos 1960, e adotou uma outra postura, mais consciente e crítica. Esse processo foi reforçado também pelo esgotamento conceitual dessa primeira fase da arquitetura moderna que, com o afastamento do purismo essencialista dos anos 1940, derivou para um formalismo gratuito sem grandes futuros. A chamada corrente topológica (ARANGO, 119o, p. 237) de Fernando Martínez Sanabria e Rogelio Salmona assinalaria uma posição contrastante de suma importância nesse momento.

A consciência da geografia e dos materiais locais de Aalto e Wright e a corrente organicista são algumas referências possíveis para compreender a genealogia desse pensamento, que vai buscar um "sentido de lugar" em suas formulações arquitetônicas. Mas, para além das singularidades da produção desses arquitetos, a postura projetual deles traz uma importante contribuição ao se contrapor à modernidade da abstração formalista de matriz corbusiana. Esse posicionamento tem como possibilidades interpretativas uma leitura afeita a uma particularidade local, de sensibilidade ao território colombiano. Essa guinada também se ancora em evidências de uma contraposição mais direta - e de real confrontação - entre o mestre franco-suíço e o mais importante expoente da escola colombiana: Rogelio Salmona.

Conforme demonstra Quintana Guerrero (2016, p. 322-346) os anos de 1948 a 1954 que Salmona trabalhou no escritório de Le Corbusier o levariam de uma imersão dedicada ao ideário do mestre, a frustrações com seus caprichos formais e abstrações refratárias à realidade técnica e social que seus projetos confrontavam. Por outro lado, o subsequente contato com os arquitetos Alvar Aalto e Jean Prouvé, com as aulas do sociólogo e historiador Pierre Francastel ${ }^{19}$, ou as viagens pelas históricas

${ }^{19}$ Cf. URREA UYABÁN, 2014. 
cidades europeias e ao norte da África foram alguns contrapontos fundamentais. Essas experiências conformariam um novo referencial para pensar arquitetura, revelando a força das tipologias históricas, a integração da arte e da técnica, abrindo novos rumos diante dos descaminhos encontrados no ateliê do renomado arquiteto. As idiossincrasias corbusianas pareceram levar Salmona a uma desmistificação do mestre e a um processo crítico formativo. Talvez um dos momentos mais relevantes desse amadurecimento do arquiteto nesse período seja registrado em seu depoimento, sobre sua participação do Plano Diretor para Bogotá (1950), a cargo do escritório de Corbusier junto à Wiener e Sert:

Sobre o Plano Piloto para Bogotá: (...) não podia nem aceitar
ideologicamente, nem afetivamente que a arquitetura
moderna não expressava as características da região, o o mais
importante, que o fio da história se cortava (...) Desenhar
propostas que destroem $90 \%$ da cidade da infância, da cidade
das memórias, não era fácil, não entendia o que estava
acontecendo. E também não podia dizer à Le Corbusier o quão
incongruente eram suas propostas, que não eram novas, está
claro, mas Bogotá era uma realidade tangivel pra mim, não
era uma abstração, vivia em uma dicotomia bastante
desconfortável. (URREA UYABÁN, 2014, p.76 - tradução
nossa)

Assim, o contraste e afastamento entre as tradições modernas brasileiras e colombianas parece encontrar respostas nessa negação veemente da filiação corbusiana em busca de novos referenciais, por parte da segunda, bem como também por meio da tecnologia construtiva que dá corpo e significado às suas espacialidades $\mathrm{e}$ abordagens projetuais. Enquanto o tijolo, pequena unidade que pode compor um sistema estrutural ou simplesmente pavimentar e proteger superfícies, marcará a produção colombiana, o concreto predominará na produção brasileira, se designando como forma-estrutura de grande porte e contundência. $\mathrm{O}$ concreto parece assim, pressupor gestos e intenções totalizadoras, enquanto a unidade diminuta e repetitiva do material cerâmico faz aceitar toda a forma e circunstância. Essas opções projetuais e argumentativas foram percebidas em sua oposição por Ramón Gutierrez (1998, p. 39). O autor descreve o caminho buscado pela arquitetura de Rogelio Salmona como a alternativa à tragédia formalista de Oscar Niemeyer e Vilanova Artigas. Isso porque Salmona, ao optar por materiais e técnicas tradicionais, lograva trazer suas formulações arquitetônicas ao pé dos graves e complexos problemas do tempo e do espaço em sua dura concretude.

Essas definições tão contrastadas são o testemunho de uma época e, contraditoriamente, têm contribuído para pôr sob suspeita as aproximações entre os casos latino-americanos. Esses posicionamentos revelam um entusiasmo latino-americano que se testemunhou no início dos Seminários de Arquitetura Latinoamericana $(\mathrm{SAL})^{20}$. Pondera-se

\footnotetext{
${ }^{20}$ Os Seminários de Arquitectura Latinoamericana são reuniões promovidas por um grupo de arquitetos, críticos e historiadores de vários países que vêm permitindo uma interlocução do subcontinente sobre o assunto. Os primeiros encontros articularam um debate original em torno de questões como identidade, alinhamentos e regionalismo, com o rechaço unânime do "regionalismo crítico" (SEGAWA, 2005, p. 5o). Foram realizados 17 SAL entre os anos de 1985 e 2018.
} 
que esse desejo por uma identidade comum, impulsionado pelas ideologizações em torno do ladrillo, como marca de um "latinoamericanismo" construtivo, também poderia desembocar para uma visão um tanto quanto doutrinária. Mas essas aspirações morreram com a globalização (SEGAWA, 2005, p. 51). Assim, independentemente dos discursos de uma época, essa "arquitetura do tijolo" e sua ética projetual seguem aqui como um importante elemento problematizador das estratégias projetuais adotadas em território brasileiro.

Nos interessa aqui pontuar que esse foi o ponto de partida da tese, a marcante diferença entre as duas escolas principais de cada país. No entanto era necessário verificar, particularmente no caso de Medellín, as especificidades da absorção desse debate e dessa postura projetual na produção local, debate transversal à tese e que se fará presente nos próximos capítulos. Ainda que se vislumbrasse um certo isolamento dessa cidade e suas prováveis singularidades, em relação à capital do país, se verificava de antemão que os projetos de Medellín se aproximavam da principal corrente colombiana naquilo que Segawa (2005, p. 74) havia destacado como traço definidor da abordagem projetual de Salmona: a busca pela realidade do problemático universo socioespacial latino-americano. Segundo o autor, Salmona o fez por meio de uma abordagem localista atenta ao passado recente, e que se vai fazendo mais complexa ao intensificar a estratégia de projeto sobre princípios e relações geométricas e tipos arquitetônicos ${ }^{21}$.Essa formulação tipológica e de ousadas formas geométricas associativas, também parecia um traço forte verificado nos casos preliminarmente verificados em Medellín.

\subsection{As "condições de possibilidade"}

As relações entre edifício e cidade perscrutadas neste trabalho, por meio da leitura comparativa, buscam, afinal encontrar nexos para a construção de uma nova urbanidade que fomente a socialização e seus diferentes graus de interações intersubjetivas. Essa mesma fresta de possibilidades pode ser resgatada em Tafuri. No capítulo Problemas à maneira de conclusão, Tafuri (1985, p. 115-122) aborda as caracterizações dessas questões que, no limiar do impedimento, deixariam a porta entreaberta para possíveis estratégias da arquitetura. Ele enumera os problemas supostamente intransponíveis, naquele momento, a serem enfrentados pela disciplina. Para o crítico, seria necessário desenvolver uma cultura arquitetônica que aceitasse o terreno de operações pautado pela realidade do domínio capitalista do espaço, e que, ao fazêlo, tivesse a capacidade de reconhecer as tendências ocultas, os objetivos reais de estratégias contraditórias, os laços que unem entre si setores econômicos aparentemente independentes, ou seja, uma leitura ampla da realidade da produção do espaço e todos seus agentes que enfrentasse as ambiguidades e os contrassensos do real. Além disso, a disciplina deveria desistir da ineficaz noção de equilíbrio, uma vez que

\footnotetext{
${ }^{21}$ Vide Painel 1.6.
} 
as forças econômicas encontram na crise, o desenvolvimento, de modo que basear-se na pacificação do ordenamento territorial não seria uma alternativa, mas sim, uma postura anacrônica. Também não seria mais possível agir com base em modelos eminentemente estáticos, devendo então seguir uma estratégia baseada na remoção de desequilíbrios. Sobre a situação profissional do arquiteto, Tafuri foi implacável em suas constatações. Sob a égide do capitalismo avançado, o arquiteto assistia

* Ao envelhecimento do método de projetar, antes mesmo de poder verificar suas hipóteses na realidade;

* Ao declínio do profissionalismo e da sua inserção em programas onde o papel ideológico da arquitetura é mínimo;

* À necessidade de resolver desequilíbrios, contradições e atrasos da reorganização contínua capitalista e do desenvolvimento produtivo;

* À frustração de suas ilusões intelectuais, tais como a impossibilidade de produzir uma arquitetura de classe que tende a antecipar, apenas com o valor da imagem, as condições de uma arquitetura para uma sociedade libertada (o que seria um manifesto utopismo).

Tafuri conclui que o enfrentamento dessas condições de atuação da arquitetura demandaria, de saída, uma revolução linguística, metodológica e estrutural. Seria um desafio muito além da simples vontade de subjetivar ou da atualização de uma sintaxe. Se, por um lado, essa longa demonstração da complexidade das relações entre as formulações estéticas e o mundo real - e a consequente demolição da estrutura tradicional da nossa disciplina - tende a ser paralisante, por outro lado, o autor deixa escapar de sua equação a importância do espaço como mediador das relações sociais. Isto é, o espaço teria um potencial latente que demanda à disciplina descobrir meios de interpretar e interagir (e não mais determinar, a partir de abstrações totalizadoras). À arquitetura se demandava uma nova tarefa de mediação, como um sistema aberto que compreende a totalidade da vida e da forma urbana, mas atua em imbricações e circunstâncias instáveis e difusas, em que o espaço não é mais a tabula rasa a dar suporte a ideias cristalizadas, mas é matéria social, base que demanda uma complexa mediação.

É nesse sentido, de reposicionar o espaço nessa discussão, que se mostra fundamental mobilizar a discussão de Jameson (1985). Esse autor concorda com Tafuri no fato de que nenhuma mudança fundamental e inédita se apresenta, diante da reprodução social massiva do capitalismo tardio. Mas ele também identificará no discurso tafuriano um método: a "história dialética" que, assim como na teoria de Adorno e de Barthes, seria um gênero textual que permite o pensamento dialético, mas que também depende da determinação de uma contradição insolúvel e da impossibilidade de um futuro para se estruturar. Em sendo uma construção teórica, hipotética (embora extremamente aderida à realidade), o tom pessimista e a falta de 
alternativas devem ser relativizados. A saída, para Jameson, estaria em um aprofundamento da discussão mobilizando os elementos fundamentais marxistas, sobre os quais a obra de Gramsci fornece instrumentos apropriados para desatar alguns nós.

Segundo Jameson (1985, p.72), as noções de Gramsci em torno das ideias de "hegemonia" e "contra hegemonia", sugerem que pequenos movimentos também fornecem a possibilidade de transformação social, e isso pode ser visto como uma alternativa à versão excessivamente redutora e defensivamente materialista adotada por Tafuri, frente às políticas do espaço.

\begin{abstract}
(...) a noção de Gramsci de "hegemonia" (juntamente com a ideia posterior e relacionada de "revolução cultural") tenta substituir toda a distinção de materialismo versus idealismo (e, juntamente com ela, o conceito tradicional de base e superestrutura). Portanto, não seria mais "idealista" no mau sentido antigo que sugere que a "contra hegemonia" significa produzir e manter certa "ideia" alternativa do espaço, da vida urbana, cotidiana e coisas do gênero. (tradução nossa) ${ }^{22}$
\end{abstract}

Prosseguindo, o autor faz uma defesa das ideias e da utopia, e suas respectivas capacidades de gerarem - ainda que como um ato reflexo e não previsível - a consciência de possibilidades alternativas, em uma espécie de defesa da desalienação do cotidiano. Isso se daria até mesmo por meio de projetos que não o conseguissem fazer através de uma concepção estética e, analogamente social, totalmente revolucionária (JAMESON, 1985, p.72):

\begin{abstract}
O essencial é que sejam capazes [os arquitetos] de formar concepções e imagens utópicas a partir de tais projetos, contra as quais se desenvolva uma autoconsciência de suas atividades concretas nesta sociedade (ao ser entendido, no espírito de Tafuri, que tais projetos coletivos só seriam praticamente e materialmente possíveis após uma transformação sistêmica da sociedade). Mas essas "ideias" utópicas são tão "objetivas" quanto os edifícios materiais: as possibilidades - a possibilidade de conceber esse novo espaço têm condições de possibilidade tão rigorosas quanto qualquer artefato material.
\end{abstract}

Por fim, Jameson ressalta que existem locais mais propícios para que “condições de possibilidade" emerjam, enquanto experiências no espaço propiciando ideias contra hegemônicas. Particularmente, isso se daria nos países subdesenvolvidos, em que o capital não parece estar estabelecido em sua forma tradicional:

Essas condições de possibilidade devem ser encontradas, antes de tudo, no desenvolvimento desigual da história mundial e na existência, em outros lugares, no segundo e terceiro mundos, de projetos e construções que não são possíveis no primeiro. Diferentes espaços em qualquer outro lugar (de qualquer

\footnotetext{
${ }^{22}$ Do texto original 'Gramsci's notion of 'hegemony' (along with the later and related idea of 'cultural revolution') attempts rather to displace the whole distinction of materialism versus idealism (and, along with it, of the traditional concept of base and superstructure). It would therefore no longer be 'idealist' in the bad old sense to suggest that 'counterhegemony' means producing and keeping alive a certain alternate 'idea' of space, the urban, daily life, and the like". Tradução nossa.
} 
Nesse longo ensaio, Jameson sugere um novo ângulo interpretativo para Tafuri, e ressalta a necessidade de uma arquitetura Gramsciana, consciente de seu potencial de transformação e atenta a dimensão estratégica de sua ação, algo por se construir. Para tanto, o autor aponta, como um passo necessário e definitivo, um exame da obra de Henri Lefebvre. Por meio do aprofundamento das noções contidas na obra do filósofo francês, seria então possível encontrar um prolífico campo de pesquisa e uma alternativa ao niilismo tafuriano. Ainda que não seja possível anular as condições inescapáveis do capitalismo, a obra de Lefebvre permitiria entrever, no espaço, a possibilidade de encontrar a resistência aos efeitos mais nefastos da modernidade na sociedade e no indivíduo. Entretanto,

a concepção de espaço de Henri Lefebvre como a categoria fundamental da política e da própria dialética - a grande visão profética destes últimos anos de desânimo e renúncia - ainda não foi compreendida em todas as suas implicações pioneiras, muito menos exploradas e implementadas: Embora o papel influente de Lefebvre como um ideólogo e um crítico da arquitetura francesa hoje seja notável, este requisita maior reflexão. $(J A M E S O N, 1985,51)^{24}$

\section{$1.3 \mathrm{O}$ espaço}

Podemos depreender que necessitamos, afinal, de uma refinada capacidade interpretativa das disputas e dos atores que incidem no espaço, das relações entre forma social e forma urbana, para então conseguir reconhecer e dialogar com o que Jameson (1985) nomeou de "condições de possibilidade". Um dos pontos centrais da teoria do espaço de Lefebvre, mobilizada por Jameson para essa tarefa, é aquela que coincide com a leitura de Milton Santos, no sentido de constatar que o espaço é um fato social que também define os fenômenos sociais, da mesma maneira é produtor e produto, possuindo a capacidade de ser determinante e determinado. Essas relações dialéticas, que se estabelecem entre a sociedade e o espaço, são o eixo da leitura de Lefebvre e dão origem à densa teoria que o autor desenvolverá, particularmente, em A produção do espaço (1974). Como o título do livro indica, torna-se fundamental entender como o espaço é produzido, para que essas relações possam ser incorporadas nas

\footnotetext{
${ }^{23}$ Do texto original: "Those conditions of possibility are to be found, first and foremost, in the uneven development of world history and in the existence, elsewhere, in the second and ThirdWorlds, of projects and constructions that are not possible in the First; this concrete existence of radically different spaces elsewhere (of whatever unequal realization) is what objectively opens the possibility for the coming into being and development of 'counterhegemonic values' here”. Tradução nossa.

${ }^{24}$ Do texto original: "Meanwhile, Henri Lefebvre's conception of 'space' as the fundamental category of politics and of the dialectic itself-the one great prophetic vision of these last years of discouragement and renunciation-has yet to be grasped in all its pathbreaking implications, let alone to be explored and implemented; while Lefebvre's influential role as an ideologist and a critic of French architecture today must be noted and meditated upon”. Tradução nossa.
} 
análises das disciplinas que trabalham com o espaço, em toda sua complexidade:

\begin{abstract}
O espaço não pode mais se conceber como passivo, vazio, ou como de fato não tendo outro sentido, tal como os "produtos", senão o de ser trocado, de ser consumido, de desaparecer. Enquanto produto, por interação ou retroação, o espaço intervém na própria produção: organização do trabalho produtivo, transportes, fluxo das matérias-primas e das energias, redes de distribuição dos produtos. À sua maneira produtivo e produtor, o espaço entra nas relações de produção $e$ nas forças produtivas (mal ou bem organizado). Seu conceito não pode, portanto, isolar-se e permanecer estático (LEFEBVRE, 2013 [1985], 125)
\end{abstract}

A demanda por uma teoria "unitária" e transdisciplinar do espaço, isto é, que construiria uma unidade entre os campos que o apreendem separadamente, sendo capaz de fazer confluir todos os espaços possíveis incluindo o espaço, o real, mental ou social é o horizonte do debate de Lefebvre (STANEK, 2011, p. 153). Mas, dentro daquilo que nos cabe abarcar neste trabalho, reafirma-se, por meio de sua leitura, a importância do espaço como mediador e potencial transformador das relações sociais e a consequente possibilidade de a A\&U de incidir sobre o mesmo. David Harvey, um atento leitor de Lefebvre, indica a potência crítica de seus conceitos sobre o espaço, sobretudo por meio da noção de direito à cidade. Ele se tornou um mote consolidado tanto nas pautas reivindicatórias dos movimentos sociais, quanto nas políticas públicas no início do século 21 (HARVEY, 2014). Mas a integralidade desse conceito supera a ideia de acesso amplo aos direitos cidadãos, componentes básicos da vida urbana, sendo muito mais um necessário processo social, que reivindica a participação plena no desenvolvimento do urbano, como descreve Harvey (2012, p. 74):

\begin{abstract}
A questão de que tipo de cidade queremos não pode ser divorciada do tipo de laços sociais, relação com a natureza, estilos de vida, tecnologias e valores estéticos que desejamos. $O$ direito à cidade está muito longe da liberdade individual de acesso a recursos urbanos: é o direito de mudar a nós mesmos pela mudança da cidade. Além disso, é um direito comum antes de individual já que esta transformação depende inevitavelmente do exercício de um poder coletivo de moldar o processo de urbanização. A liberdade de construir e reconstruir a cidade e a nós mesmos é, como procuro argumentar, um dos mais preciosos e negligenciados direitos humanos.
\end{abstract}

Esse quadro referencial teve como objetivo posicionar, primeiramente os impasses e, posteriormente as possíveis saídas interpretativas tendo o espaço no sentido lefebvriano como potente categoria - para retomar um debate disciplinar diante dos entraves que Tafuri apontou. Buscamos a seguir, nessa incursão teórica preliminar, algumas noções para ampliar a capacidade de avaliar a dimensão histórica e social da forma urbana. Isso é necessário para que se estabeleça uma leitura mais ampla do sentido prospectivo da $A \& U$, entendendo-a com ferramenta que cria possibilidades que passam a existir por meio das interações sociais fomentadas, no momento em que se intervém no território, nas condições do presente. Pressupõe-se assim, na ação da arquitetura, o conhecimento da realidade urbana, que permite incidir sobre o possível 
(ou sobre as possibilidades) e não apenas sobre o acabado ou sobre o passado (LEFEBVRE, 1991[1968], p.37).

Essas possibilidades que emergem de uma intervenção no espaço, são suas virtualidades. Para analisar as arquiteturas e interpretar essas virtualidades, se faz útil lançar mão do método da transdução, isto é "transformar o objeto teórico em objeto possível" e checar como ele responde a essa projeção hipotética, buscando suas potencialidades:

\begin{abstract}
A transdução elabora e constrói um objeto teórico, um objeto possível, a partir de informações sobre a realidade. A transdução supõe um feed-back entre o marco conceitual utilizado e as observações empíricas. Sua teoria (metodologia) conforma as operações mentais espontâneas do urbanista, do arquiteto, do sociólogo, do político, do filósofo. Introduz o rigor na invenção, e o conhecimento na utopia ${ }^{25}$ (LEFEBVRE, 1971,p.150)
\end{abstract}

Entende-se que cada projeto de arquitetura elabora e constrói um espaço e suas relações sociais hipotéticas, teóricas. Para depreender essas projeções e analisá-las criticamente, é preciso conhecer o presente a que elas se reportam, em todas as suas contradições, no mesmo sentido que Tafuri sugeria a identificação das forças e disputas ocultas com as quais a arquitetura precisaria interagir. Isso passa pelo conhecimento da coexistência de diferentes tempos históricos e estruturas que trazem contradições do passado ao presente. Essa análise do presente, do passado e que se projeta ao futuro é o que Lefebvre chamará de método regressivo-progressivo:

Resumamos esse desenho, inerente ao método perseguido: um
estudo "retrô" do espaço social em sua história e sua gênese, a
partir do presente remontando a essa gênese - depois retorno
ao atual, o que permite entrever, se não prever, o possível e o
futuro. Esse procedimento dá lugar a estudos locais, em
diversas escalas, inserindo-os na análise geral, na teoria
global. As implicações e imbricações lógicas são
compreendidas como tais, mas sabendo-se que tal
compreensão não exclui (ao contrário) os conflitos, as lutas,
as contradições. Nem, inversamente, os acordos,
entendimentos, alianças. Se o local, o regional, o nacional, o
mundial se implicam e se imbricam, aquilo que se incorpora
no espaço, os conflitos atuais ou virtuais não estão dele nem
ausentes nem eliminados. Implicações e contradições, no
espaço e nos outros domínios, têm mais amplitude hoje do que
quando este livro foi escrito. As relações de implicação não
interditam as estratégias adversas, nem sobre os mercados,
nem nos armamentos. Portanto, no espaço. (LEFEBVRE, 2013
[1985], p.:126-128)

Assim, considerando a potência transformadora e resistente do espaço e as possibilidades interpretativas dessas aproximações metodológicas, a análise da forma e do espaço da A\&U se coloca como uma confrontação entre os paradigmas espaciais produzidos pelas ferramentas disciplinares e suas virtualidades sociais prefiguradas. Ela deve cotejar as problemáticas urbanas, historicamente constituídas, e

\footnotetext{
${ }^{25}$ Do texto original: "La transducción elabora y construye un objeto teórico. un objeto posible, a partir de informaciones sobre la realidad, así como a partir de una problemática planteada por esta realidad. La transducción supone un feed-back entre el marco conceptual utilizado y las observaciones empíricas. Su teoría (metodología) conforma las operaciones mentales espontáneas del urbanista, del arquitecto, del sociólogo, del político, del filósofo. Introduce el rigor en la invención, y el conocimiento en la utopía”. Tradução nossa.
} 
que deverão ser propriamente enfrentadas, de maneira que a arquitetura surja como um modo de imaginação, como sugere Lefebvre (2014).

Então, a avaliação crítica combinada dos estudos de caso a que esse estudo se propõe realizar passa pelo reconhecimento de contrastes e afinidades, quando da identificação e síntese analítica das principais concepções e estratégias disciplinares mobilizadas. E estas são avaliadas pela realidade em que atuam, e pelas possibilidades de interação com essa condição de existência que as referentes arquiteturas criam.

Ao cotejar as implantações, estratégias formais e argumentos projetuais aos seus contextos em variadas escalas, se considera as particularidades do processo histórico e da formação socioeconômicas de cada cidade e as particularidades advindas de seu processo de modernização. As especificidades do campo profissional, a formação das matrizes disciplinares, as filiações e influências da prática arquitetônica são também fatores centrais que contribuem para uma acuidade na verificação das diferenças das estratégias mobilizadas. Assim como as escolhas interpretativas do programa de necessidades encomendados e seu desdobramento reflexivo no partido projetual. Essa análise dos projetos de arquitetura busca, assim, se acercar da relação dialética que se estabelece entre a forma construída e a interação com esses contextos, como intérpretes e mediadores da forma social que lançam hipóteses sobre essa realidade. O espaço, nessa análise, também não é um conceito estático, como intentamos ponderar, que se descreve exclusivamente pelos atributos físicos evidentes. Mas sim o espaço dinâmico, determinado e determinante.

Nesse sentido, a observação em campo se torna fundamental para situar a leitura do programa, da forma, da estrutura, do espaço que se cria, em relação às demandas surgidas na cotidianidade. Essa experiência, ainda que parcial, permite deslocar a discussão do objeto arquitetônico para àquilo que o condiciona e como ele também acomoda e propicia interações com o local e com o social.

\subsection{A cidade e a arquitetura}

Podemos ver a cidade, com o auxílio dessas aproximações lefebvrianas, como uma circunstância prático-sensível, isto é, que tem uma dimensão morfológica que decorre de uma dinâmica social e é dialeticamente construída a partir dela. A cidade representa a simultaneidade e a integração (não segregação) do espaço, que são valores fundamentais a essa estrutura social.

No entanto, no processo histórico, essas características vão sendo tensionadas e assistimos a cidade - obra coletivamente construída, que privilegia o valor de uso - se tornar urbanização - efeito da industrialização, em que a organização do espaço passa a ser regida prioritariamente pelo valor de troca (LEFEBVRE, 1991[1968]).

Desse modo, se vai paulatinamente separando o individual do coletivo, e de suas representações no espaço. Analogamente ocorre a desconstrução da cidade e de seu valor de obra, em direção aos 
produtos espaciais da urbanização, que representam o imperativo do valor da troca.

A emergência da cidade moderna, seus edifícios e conformações urbanísticas (que são indissociáveis e representam um sistema de conhecimento) permitiu que Lefebvre visualizasse o extremo oposto da relação entre forma social e forma urbana da polis:

\begin{abstract}
O espaço da "modernidade" tem características precisas: homogeneidade-fragmentação-hierarquização. Ele tende ao homogêneo, por diversas razões: fabricação dos elementos e materiais; exigências análogas dos intervenientes; métodos de gestão e de controle, de vigilância e de comunicação. Homogeneidade, mas sem plano nem projetos. Falsos "conjuntos"; de fato, trata-se de isolados. Pois paradoxalmente (ainda) esse espaço homogêneo se fragmenta: lotes, parcelas. Em migalhas! O que produz guetos, isolados, grupos de lotes unifamiliares e pseudoconjuntos mal ligados aos arredores e aos centros. Com uma hierarquização estrita: espaços residenciais, espaços comerciais, espaços de lazer, espaços para os marginais etc. Reina uma curiosa lógica desse espaço, que se atribui ilusoriamente à informatização. E que oculta, sob sua homogeneidade, as relações "reais" e os conflitos. Aliás, parece que essa lei ou esse esquema do espaço com sua lógica (homogeneidade-fragmentação-hierarquização) teve um alcance maior e atingiu uma espécie de generalidade, com efeitos análogos, no saber e na cultura, no funcionamento da sociedade inteira. (LEFEBVRE, 2013 [1985], :126)
\end{abstract}

Os duplos processos de industrialização e urbanização, crescimento e desenvolvimento, produção econômica e vida social, são inseparáveis e conflitantes. O espaço da modernidade, como o avesso do ideal da cidade e de sua dimensão coletiva, dá subsídios para compreender os atributos socializantes do espaço que precisam ser ativados pelas disciplinas que nele intervêm: tais como simultaneidade, heterogeneidade, recomposição (contra a fragmentação).

É valido ressaltar que as formulações de Henri Lefebvre, que contribuiria para deflagrar o spatial turn $^{26}$ nas ciências sociais, tem ainda pouca expressão no modo como sua obra é recebida no debate nacional, em sua relação com temas arquitetônicos, no âmbito da literatura especializada (MEDRANO et al., 2018). Portanto, não se pretende aqui resolver essa demanda. No entanto, algumas noções desse autor são necessariamente mobilizadas, visto que representam contribuições singulares à elucidação das significações do espaço como produto social, chave interpretativa essencial para esse trabalho. Ainda que esse autor tenha sido mais sistematicamente estudado nas áreas da geografia $^{27}$ e da sociologia urbana ${ }^{28}$, pesquisadores como Lukasz Stanek (2011; 2014) vem sinalizando um prolífico caminho entre os

\footnotetext{
${ }^{26}$ Para Edward Soja (2009:12), foram justamente Lefebvre e Foucault, os responsáveis por deflagrarem o Spatial Turn, porque permitiram um pensamento radical ontológico, epistemológico, sobre as relações teóricas entre espaço e tempo, fornecendo uma série de argumentos que reconfiguravam a disciplina. O geógrafo interpreta esse processo como inevitável e fundamental a todos os campos das humanidades: "O Spatial Turn ainda está em andamento e não alcançou o significativamente todas as disciplinas acadêmicas. Sua expansão futura, entretanto, tem potencial para ser um dos desenvolvimentos intelectuais e políticos mais significativos do século 21." (tradução nossa). Cf. SOJA, 2009.

${ }^{27}$ Cf. CARLOS; SIMONI-SANTOS; ALVAREZ, 2018.

${ }^{28} \mathrm{Cf}$. FREHSE, 2013.
} 
fundamentos filosóficos e empíricos da obra de Lefebvre e seu envolvimento direto na $\mathrm{A} \& \mathrm{U}$.

\subsection{A urbanidade do cotidiano}

Algumas das contribuições importantes para a compreensão dos atributos dessa desejável urbanidade nova, que deverá resistir aos processos nocivos que a modernização impõe ao social, estão no livro Introdução à modernidade de Lefebvre (1969 [1962]). Nele, o autor reflete sobre os processos espaciais, sociais e culturais que se imbricam na modernidade. No sétimo prelúdio (como Lefebvre denomina os capítulos do livro), "Notas sobre a cidade nova", o autor se propõe a comparar diferentes relações entre vida cotidiana, em duas cidades: Navarrenx e Mourenx. A primeira cidade era um pequeno burgo medieval $^{29}$, já a segunda, Mourrenx, era uma cidade moderna, construída em 1958 para fornecer alojamento para os trabalhadores necessários à usina de gás. Essa cidade foi projetada pelos arquitetos e urbanistas Coulon, Douillet e Maneval, e demonstrava a total funcionalização modernista da forma urbana. De tal forma que a cidade poderia ser lida a partir de seus três grupos de habitação coletiva, três grupos de habitação familiar, todos reunidos em torno de uma área central onde se concentraram as instalações institucionais e os equipamentos públicos.

Sobre Navarrenx - um burgo do século XIV reconstruído dois séculos mais tarde, sem traços marcadamente medievais - Lefebvre diz: "conheço cada pedra. Sobre essas pedras, eu leio os séculos, um pouco como os forasteiros nos círculos dos troncos cortados leem as idades das árvores" (1969, p. 137-147). O autor prolonga sua análise da forma física, histórica e social de Navarrenx, comparando-a a um molusco. Isso porque, ao separar o ser vivo de sua casca, pode-se percebê-lo disforme, pegajoso, sem nenhuma relação mais direta com as estrias, simetrias e ranhuras da sua concha. A analogia tenta aproximar a impossibilidade de separar a forma física (concha) e a forma social (o ser vivo), ao mesmo tempo em que descreve a dificuldade de estabelecer correspondências entre uma e outra. Se a dimensão física do burgo - concha - indica as formas e ações de uma comunidade milenar, ela própria inscrita numa sociedade e numa cultura cada vez mais largas e mais distantes, é preciso entender, ao mesmo tempo, que a comunidade (viva) trabalhou, organizou e reorganizou, modificandoa sucessivamente segundo suas necessidades, sua estrutura espacial (concha). Ao mesmo tempo em que cada casa contém um pouco desse animal pegajoso, cada casa tem seu aspecto próprio.

Para melhor exemplificar a relação entre a forma individual e coletiva, social e urbana da cidade medieval, o autor usaria outra aproximação analógica:

\footnotetext{
${ }^{29}$ É também a cidade que Lefebvre frequentara a vida inteira e onde faleceu.
} 
Nessas velhas casas e sobre elas, o funcional, o apropriado à vida, o ornamental e o supérfluo encontram-se sem brilho, de uma maneira às vezes agradável (nem sempre), encantadora tanto como discreta. A palavra "ornamento" convém mais do que a palavra "beleza" e do que a palavra "estilo", ainda que exista aqui uma espécie de estilo de vida e um gosto incontestável. (LEFEBVRE, 1969, p. 138)

O caráter fragmentário do ornamento, sua manifestação do gosto individual - que se reporta ao coletivo - é uma importante chave para contrapor Navarrenx à Mourrenx. A unidade problemática de um ornamento seria o oposto da beleza totalizadora e homogeneizante da estética moderna. E, ainda assim, os ornamentos, as casas, as edificações oficiais exprimem suas funções específicas, sendo pequenas expressões individuais que também criam, ao mesmo tempo, uma experiência de totalidade em Navarrenx. Para entender uma arquitetura que se pretende ancorar num sentido coletivo, na formação de um urbano, ao mesmo tempo se integrar a um universo físico de preexistências, essas ponderações ampliam a leitura dos nexos formais que podem ser ativados: da linguagem individual dos elementos mínimos das edificações ao reconhecimento da formação de tipologias que se repetem. Também a mistura de usos e as gradações escalares são descritas em seus pormenores, nos seus aspectos transicionais de usos inclassificáveis, como parte fundamental de um espaço sensível aos ritmos da vida:

Cada cidade é uma obra e também cada casa. Tudo nela se
mistura e se une: objetivos, funções, formas, prazeres e
atividades. Se bem que haja em N., esboços de bairros
distintos (em volta dos locais de feira, em volta da igreja e da
prefeitura e fora dos muros, nos subúrbios) nenhum desses
bairros se separa dos outros; o residencial não se isola dos
lugares de trabalho ou onde nos divertimos (às vezes). Entre o
campo, as ruas e as casas, não há corte nem confusão; passa-
se dos campos ao coração do burgo e as habitações por uma
sucessão ininterrupta: árvores, jardins, pórticos e pátios,
animais. A rua, no burgo, não é nem um deserto nem o único
lugar de encontro da felicidade e da infelicidade, o único lugar
humano. Transição espontânea, ela não é um simples lugar de
passagem e também não procura prender as pessoas com
iluminações e objetos expostos. Nela se passeia, se conversa,
se vive. Nada do que se passa na rua escapa ao olhar das casas
e as pessoas olham sem se privarem desse prazer. Mas os
passantes também estendem seu olhar até o fundo dos
corredores e dos pátios. Nada de privilégio abusivo para o
meio de comunicação, mas nada de má sorte atingindo-o com
esterilidade. A rua integra-se. Escutam os artesãos cantarem,
e baterem os martelos, e ranger a plaina e chorarem as
crianças e as mães ralharem. (LEFEBVRE, 1969, p. 139)

Já em Mourenx, Lefebvre irá identificar, na estética moderna (reconhecendo sua beleza e intenção primordial), a abstração e a separação desses conteúdos sociais. Isso se dá por meio da redução dos edifícios a objetos técnicos monofuncionais, que organizam e fragmentam a vida cotidiana. Esse fenômeno é indissociável, para Lefebvre, à razão analítica e tecnocrática, tão úteis à burocracia do Estado socialista quanto ao sistema capitalista mais avançado.

Chego a Mourenx e horrorizo-me. No entanto a cidade nova não se apresenta mal. O Plano conjunto (o plano-massa) não carece de porte: blocos e torres alternam as linhas do 
horizontais e verticais. O corte entre a paisagem- colinas arborizadas, landas, vinhedos - e a cidade, por mais brusco que seja, tolera-se; ele não brutaliza demais os olhos. Os prédios parecem bem concebidos e bem construídos; sabe-se que eles oferecem aos habitantes- pelo menor custo, parecebanheiros e quartos com água, secadores, peças bem iluminadas onde as pessoas podem instalar seu aparelho de rádio e sua televisão a contemplar o mundo à domicílio... $O$ capitalismo de Estado, no nosso país, não faz mal as coisas. Técnicos e tecnocratas não carecem de boa vontade, ainda que esta vontade seja imperiosa. Não se vê muito bem em que e como o socialismo de Estado faria de outra maneira e melhor. (LEFEBVRE, 1969, p. 139)

Nessa cidade moderna, o tempo e a história social não tem representação espacial. $\mathrm{O}$ que se encontrava unido e mesclado em Navarrenx, encontra-se agora funcionalizado. A construção coletiva, social e espacial, se encontra mediada por códigos alheios à coletividade que não nos permitem visualizar a forma futura, as ideias e relações que se poderiam criar a partir dessa mediação:

\begin{abstract}
No entanto, toda vez eu me horrorizo diante dessas "máquinas de habitar". (...) Em Mourenx que tenho eu sob os olhos? Os prédios, eles também, são objetos técnicos e máquinas. Darão eles ou dão já em um humanismo novo? São eles mediadores entre a natureza e o homem, entre os humanos? Ligam ele entre si os indivíduos, as famílias, os grupos, ou os separam? As pessoas irão docemente, com quer o plano, comprar no centro comercial, pedir um conselho no centro social, brincar no centro de lazeres, cumprir pontualmente os atos do cidadão no centro administrativo? (sem omitir o fato de que esses centros não existem ainda, apenas no papel, e que eles serão já um progresso!). A espontaneidade consegue aqui se restituir, e uma comunidade se criar? O funcional integrar-se numa realidade orgânicauma vida-que recebe dela uma estrutura, mas a modifica adaptando-a? Eu não respondo ainda nem sim nem não. $\hat{E}$ uma hipótese aceitável e uma nova série de interrogações. Aqui, em Mourenx, onde entramos? No socialismo ou no supercapitalismo? Na cidade radiosa ou no mundo do tédio sem recurso? (LEFEBVRE, 1969, p. 140)
\end{abstract}

A perda da surpresa, das sensibilidades do cotidiano, em nome de uma organização funcional não pode ser lida com neutralidade. A homogeneidade, a repetição, as permissões e proibições, o controle que deriva desse conjunto de formulações espaciais, apontam para uma organização social específica e esvaziada de sensibilidades. Da mesma maneira, a concepção estética que reforça esta leitura da sociedade, não pode se isentar das interações e possibilidades que cria ou impede. As descrições de Lefebvre reintegram esses fatores, em uma leitura de grande fortuna crítica, ainda que em tom literário - o mais apropriado para captar a totalidade da experiência do real:

Mourenx me ensinou muita coisa. Aqui, os objetos têm o
título de sua existência social: sua função. Cada objeto serve e
o diz. Sua função é bem distinta e bem própria. No melhor
caso, quando a cidade nova for acabada e bem-sucedida, tudo
nela será funcional, e cada objeto terá uma função própria, a
sua. Esta função, cada objeto a indica, significa-a, grita-a a
sua volta. Ele se repete infinitamente. O objeto reduzido a sua
função é também reduzido a sua significação, aproxima-se
indefinidamente do sinal e o conjunto desses objetos de um
conjunto de sinais. Em Mourenx, não há ainda muitos sinais
verdes ou vermelhos. Tudo é apenas sinais verdes ou
vermelhos: isto exigido, isto proibido. O objeto reduzido a uma
simples significação confunde-se com a coisa nua, despojada, 
desprovida de sentido. (...) Aqui nada acontece (em aparência pelo menos) de maneira sensível. Não há acontecimento possível senão único: que tudo vá pelos ares, ou que tudo desmorone. Para falar em termos de teoria informacionista: a redundância é enorme. Ela se aproxima a 100\%. Tudo é claro e inteligível, tudo é banal. Tudo é fechadura e sistema materializado. O texto que oferece a cidade aos nossos olhos é perfeitamente legível, tão pobre quanto claro apesar dos esforços dos arquitetos para variar a linhas, A surpresa? $O$ possível? Desvanecidos desse lugar que deveria ser o das possibilidades? (LEFEBVRE, 1969, p. 141)

A fragmentação do espaço, a espacialização monofuncional das atividades urbanas geram, por fim, o tédio. Os indícios colhidos em campo, pelo autor, constatam o esmigalhamento do que se entendia por cotidianidade. E reforçam, ainda mais, a alienação do trabalho e a perda da subjetividade do indivíduo. O que Lefebvre via como a "a unificação pelo alto e a supressão das diferenças originais" de certo modo antecipava a sociedade de massas e a urbanização segregadora que enfrentamos no século 21:

\begin{abstract}
Tudo que era separável foi distinguido e separado: não somente os domínios e os gestos, mas os lugares e as pessoas. $O$ que, desde as idades neolíticas, era quase confundido nos lugares espontâneos da vida social foi separadamente jogado no tempo e no espaço. De maneira que os intermediários entre esses elementos separados (quando eles existem, o que é um bem: meios de comunicação, ruas e estradas, sinais e códigos, agentes de câmbio e de comércio, etc.) recebem uma importância exagerada. O que liga, torna-se mais importante do que os "seres" ligados. Mas esta importância não confere em nada vida e atividade a esses intermediários. A rua e a estrada tornam-se essenciais, mas desérticas na mesma circulação incessante e sempre repetida. A venda torna-se mais importante do que a produção, a troca mais do que a atividade, os intermediários mais do que os criadores, os meios mais do que os fins. E tudo cai no tédio. (LEFEBVRE, 1969, p. 142)
\end{abstract}

Por fim, podemos entender que Lefebvre aponta para um único meio de superação: a retomada do espaço do cotidiano, e a superação da dualidade entre objeto técnico e objeto estético. A mistura, a surpresa, a espontaneidade se opõem duramente à homogeneidade $\mathrm{e}$ previsibilidade dos objetos técnicos. A concepção estética, formulada pela arquitetura, não poderá fugir dessas tensões ao pretender um diálogo com as forças sociais que se encontram latentes na cidade e no dia a dia, algo de nosso interesse.

\title{
1.6 O espaço social segregado na América Latina
}

O mal-estar sentido nas cidades europeias, diante das pressões e fraturas da urbanização resolvida na chave modernista, são percebidas claramente ao final dos anos 196o, conforme nos mostra Lefebvre. Os seus estudos sociológicos são realizados em campo, por meio de sucessivos trabalhos em torno de pesquisas empíricas, como na análise 
da política habitacional dos grands ensembles ${ }^{30}$. O autor nos fornece subsídios para localizar e reconhecer o desenraizamento entre as formulações espaciais e a vida cotidiana, ao serem atravessadas pelos paradigmas espaciais modernizantes.

A critica à espacialidade funcional moderna também foi realizada, em outros contextos. Dentro dos interesses dessa pesquisa, podemos buscar na reação de Rogelio Salmona (1977, p. 66) alguns indícios importantes sobre esse processo Ele descreverá, com importantes nuances, o que se observava na Colômbia na produção de habitação de interesse social, em uma entrevista realizada em 1969. As complicações e particularidades da modernidade nas cidades de "terceiro mundo", agudizavam os impactos sobre a dimensão humana, dado seu crescimento explosivo de proporções exponenciais. Essa especificidade também se define pela facilidade com que a intensificação dessa violência socioespacial se propagava, por meio da segregação e da exclusão. Isso não era uma novidade advinda da modernidade e, sim, uma condição de origem, do processo de modernização tardia alicerçado em relações sociais desiguais que remontam a especificidades do passado colonial em cada país do subcontinente. Assim como as cidades colombianas, muitas outras na América Latina apresentaram dificuldades em produzir espaços coletivos com inércia para resistir a esse fenômeno disruptivo que se impunha. Isto se torna claro pelo fato de que o aumento da migração do campo para a cidade é funcionalizado pelo modelo de desenvolvimento econômico, que se aproveita da decorrente oferta de força de trabalho a preço baixo, algo notável na configuração socioespacial dessas cidades, onde o capitalismo se desenvolve pela produção de periferias ${ }^{31}$.

Nesse sentido, Salmona dirá que as cidades colombianas "não existiam" previamente, no sentido de que, historicamente nunca propiciaram a integração social pelo espaço urbano - o que pressupõe o ideal da cidade também para Lefebvre. Observando sua realidade, Salmona demonstrava que nessa contínua atualização de relações sociais tão desiguais, não parecia haver qualquer chance dos enclaves urbanos, que se reafirmam com o fluxo migratório, se comunicarem entre si e de se vincularem uns aos outros para formar uma nova ordem social e a arquitetura tampouco contribuía para solucionar tal problema:

$$
\begin{aligned}
& \text { (...) não há nem uma cultura urbana, nem uma cultura no } \\
& \text { campo, o que se está formando neste momento é uma série de } \\
& \text { “conglomerados" completamente anárquicos, produto de uma } \\
& \text { série de necessidades, de uma busca maior de liberdade pela } \\
& \text { qual se busca a cidade como uma grande "ilusão". Mas a } \\
& \text { cidade latino-americana não está respondendo, nem em sua } \\
& \text { historicidade, nem em sua especificidade, nem em seu espaço } \\
& \text { físico, que poderia ser um espaço muito coerente para } \\
& \text { radicalizar todos os problemas culturais, sociais e humanos }
\end{aligned}
$$

\footnotetext{
$3^{\circ}$ Os grands ensembles (grandes complexos habitacionais de alta densidade) assim como as casas tipo pavillon (casas suburbanas) constituem formas espaciais sintomáticas da urbanização francesa após a Segunda Guerra Mundial a que Lefebvre se dedicará a estudar no Institut de sociologie urbaine (ISU), co-fundado por ele em 1962 e por ele presidido até 1973.

${ }^{31}$ Como podemos inferir da leitura realizada sobre processo de desenvolvimento brasileiro por Francisco de Oliveira (2013) de espoliação urbana por Kowarick (1993) e do fenômeno da urbanização da América Latina por Paul Singer (1973).
} 
das pessoas, não está respondendo as necessidades que a gente busca nela. Quero dizer, há uma ilusão da cidade - e não no sentido que poderia ter para as pessoas nos países mais desenvolvidos - a cidade para eles é algo muito concreto, tem um atributo muito preciso, muito real, inclusive um atributo criativo (...) Quero dizer, algumas tradições que existiam no campo estão se perdendo diante da atração que a cidade exerce para eles, entretanto a cidade não está respondendo - e portanto nem a arquitetura nem o urbanismo - a essas necessidades fundamentais dos grupos sociais que chegam a ela.(...) Na América Latina a cidade não existia e não existe como um feito novo que responda, precisamente, a essas necessidades.” (SALMONA, 1977, p. 68- tradução nossa)

Diante desse quadro, o crítico argentino Damián Bayón perguntaria a Salmona, o que fazer, como arquiteto, e como reagir diante da hipótese que se formulou em Brasília $^{32}$ : uma resposta colossal ao problema. Salmona criticaria o afastamento que essa experiência guardou da realidade em que ela foi implantada, algo como um plano sem dimensão social, mas que não negava a necessidade de se colocar a arquitetura à frente do problema da criação de um espaço social:

(...) Brasília me parece uma belle vue de l'esprit, é um plano tipo Le Corbusier - que corresponde às necessidades de um homem universal, enquanto que o brasileiro, o que vai a Brasília, tem umas características muito específicas que não foram estudadas, que não foram analisadas. Agora, para responder à pergunta desde o começo: é obvio que na América Latina o problema é social, econômico e político; como em todas as partes do mundo, mas especialmente aqui, dado que as necessidades são muito mais radicais. Quero dizer, creio que se deve fazer cidades novas porque são necessárias, mas há que fazê-las de uma maneira planificada. Segundo: há que revitalizar as cidades velhas. Existem núcleos urbanos que tem, mesmo assim, uma grande importância histórica e que podem, dentro de um plano geral de desenvolvimento, desempenhar o papel que deveriam ter. Agora, é necessário transformar naturalmente as cidades atuais que não correspondem já as necessidades não só do processo lento de industrialização que se deu na América Latina, mas também ao processo de coletivização, dado o enorme incremento demográfico que tem as cidades latino-americanas. O seja, um problema com o qual não se encontram os países mais desenvolvidos. (...) Hoje se segue pensando a arquitetura como no século XIX, e as cidades seguem sendo, em certo modo, planos abstratos. Ou seja, um pouco feito como fazem os pintores, compondo algo com algo. Mas não estão respondendo realmente, não estão criando "um espaço social". E o espaço social é uma coisa que há desse averiguar a que corresponde, para poder conquista-lo. Conquistá-lo com que? Por meio da arquitetura. (SALMONA, 1977, p. 69- tradução nossa)

Assim, vemos por meio desse diálogo que o espaço social de que fala Salmona, não estava reconhecidamente formulado pela disciplina da

\footnotetext{
${ }^{32}$ A pergunta original de Bayón à Salmona: “Todo és crítica, pero yo quiero uma crítica constructiva: ¿ qué outra cosa se podría hacer?, porqué todo está em el argumento de esta encuesta; yo tengo outra pregunta - que por tu manera de hablar no hace falta casi - para obligar al dialoguista a responder. Es el caso de Brasilia, que me parece típico. Yo vengo de Brasília, nunca había estado, y me impressiona la obra realizada porque em trece años han hecho algo colossal, pero estoy lleno de dudas al respecto. ¿Cuál es tu idea encuanto a las ciudades? ¿Hay que hacerlas nuevas, hay que pensarlas como Brasilia, o de outra manera completamente distinta? ¿Hay que salvar, tratar de hacer vivir a las ciudades antíguas? ¿Qué hay que hacerles, inyectarles qué?". Vide BAYÓN; GASPARINI, 1977, p. 68)
} 
A\&U e nem pelas políticas urbanas, para o arquiteto colombiano. Como ele bem observaria, os feitos até o momento se davam no sentido de resolver problemas de circulação, de transporte, mas isso não havia sido capaz de "radicalizar os problemas sociais para que as pessoas possam dentro desse espaço social - buscar a integração com o meio físico da cidade". Salmona destacará, nessa mesma entrevista, a necessidade de olhar os tugúrios (assentamentos subnormais ou favelas). Ainda que tivessem seu aspecto mais humano advindo da solidariedade da necessidade, elas denotavam certa vivacidade que faltava às urbanizações formais. E, para o arquiteto, esse era um assunto que estava fora da estrutura de ensino da maior parte das escolas de arquitetura. Ele notará que o jogo abstrato de volumes bem distribuídos da arquitetura moderna não seria capaz de entender a questão da habitação social, porque estaria longe de ler as distintas categorias sociais e econômicas que precisavam ser integradas entre si.

É interessante notar que, para além da fala individual do arquiteto, nesse momento, parece se generalizar uma postura mais crítica dos preceitos modernistas da primeira geração, no cenário colombiano que incorpora diversas dimensões instáveis da realidade. Ainda que o processo de organização do espaço urbano, como uma disputa de diversos agentes, tenha se encaminhado para a uma segregação dos grupos sociais, similar ao caso brasileiro, a difusão desse esforço crítico, ainda propositivo, é algo que não ocorreu do mesmo modo no debate brasileiro. Isso pode ser verificado até mesmo na produção estatal do Instituto de Crédito Territorial da Colômbia, órgão do governo responsável pela produção de habitação social no país desde 1939. Em 1961, se construiria Ciudad Kennedy, um conjunto habitacional que de dez mil unidades habitacionais, que incorporaria diversas modalidades e tipologias de experimentação em habitação, incluindo até mesmo projetos incrementais e autoconstrução assessorada (ARAVECCHIA BOTAS, 2018).

Em um outro território que, assim como a Colômbia, não estava impedido de mover-se por outros caminhos, que não aqueles trilhados pelos emblemas da arquitetura moderna nacional, também se desenvolvia uma importante experiência de pesquisa e produção de habitação de interesse social. Isso se deu em Lima e reuniu arquitetos interessados na dimensão comunitária da arquitetura, tão presente nas argumentações de Salmona. O Projeto Experimental de Habitação (PREVI) ${ }^{33}$ se deu entre 1965-1973 como programa desenvolvido com a assessoria técnica provida pela Organização das Nações Unidas (ONU) e seu Programa para o Desenvolvimento das Nações Unidas (PNUD) junto ao Banco da Habitação do Peru ${ }^{34}$. Foram quatro projetos piloto de bairros com unidades habitacionais construídos em Lima, entre um governo democrático e um Golpe de Estado que empossou uma junta militar. Mas é notável que o concurso internacional realizado para esse projeto, buscando ampliar a experimentação de novas tipologias em habitação, em 1969 reuniu 13 arquitetos de nacionalidades distintas, de modo a tentar cobrir uma maior representatividade mundial, e o

\footnotetext{
${ }^{33}$ Do original em espanhol, Proyecto Experimental de Vivienda (PREVI) de Lima.

${ }^{34}$ Do original em espanhol Banco de la Vivienda de Perú.
} 
mesmo número de arquitetos locais. Era um momento de contato entre o debate latino-americano que encontrava certas equivalências em preocupações que arquitetos europeus que desenvolviam uma potente crítica da arquitetura dos CIAM, no contexto do pós-guerra, como Aldo Van Eyck do Team 10. As propostas esquematizadas no concurso implantavam 1500 casas, mas também incluíam a localização dos equipamentos educacionais, sociais, comerciais e o projeto dos sistemas construtivos das casas, comprometendo-se com a estimativa de custos. Em vista da alta qualidade dos projetos foram, afinal, contratados 26 arquitetos para realizar clusters de 20 unidades, para construir um bairro com 500 unidades (GARCÍA-HUIDOBRO; TORRES TORRITI; TUGAS, 2008). Essa experiência é notável pela incorporação de novos temas à questão habitacional, desde a dimensão da apropriação, que poderia interagir com a forma da unidade habitacional de modo evolutivo e incremental, a variabilidade e as configurações associativas das unidades, para a constituição de um tecido urbano, os sistemas de espaços livres, etc.

No Brasil, as experiências do Estado entre 1940 e 1964 na produção viabilizada pelos IAPs (Instituto de Aposentadorias e Pensões) são destacadas principalmente pela sua importância na difusão da arquitetura e do urbanismo modernos. Esses projetos experimentaram novas tipologias habitacionais mobilizando variadas referências: das siedlungen alemãs, dos Höfe vienenses, das soluções Gropius para as residências da Bauhaus, das unités d'habitación de Le Corbusier, dentre outras $^{35}$. Nesse sentido, muitos projetos também incorporaram equipamentos sociais e se propuseram a desenhar complexos habitacionais de grande porte. Fizeram isso na esteira dos preceitos do urbanismo moderno.

Apesar da sua relevância para a cultura arquitetônica brasileira e como política habitacional de impacto, em comparação com o que havia sido feito até então no país, pondera-se que essa pesquisa não avançou muito sobre técnicas construtivas. No sentido de favorecer a racionalização e ampliação da experiência, de modo compatível com o déficit habitacional em ascensão.

O ciclo subsequente da produção de habitação de interesse social não fez uso das formulações precedentes, visto que na chave tecnocrática que se adotou para a expansão massiva da produção de unidades, lançou-se mão de simplificados esquemas modernistas - fordistas desenvolvendo grandes complexos habitacionais nas periferias das cidades.

${ }^{35}$ Cf. BONDUKI, 2017, p.170-184. 


\subsection{Caminhos interpretativos}

Os descaminhos da arquitetura e do urbanismo modernos demonstraram quão facilmente uma compreensão socialmente engajada desse projeto ideológico encontrou contradições intransponíveis. Nesse deslocamento, houve um comprometimento drástico no papel que o arquiteto desempenha perante a sociedade, conforme denotaram Avermaete e Teerds (2015). Para os autores, essa fissura na estabilidade da função social do arquiteto, no entanto, nunca irá ser plenamente reparada. Isso porque o campo é constantemente instado a repensar suas próprias premissas, solicitado a não perder a profundidade de sua atuação e a manter uma perspectiva clara de sua relevância, objetivos e ferramentas dentro da sociedade.

Aproximamo-nos dessa análise, no sentido de buscar nas experiências construídas, em seus impulsos e em suas limitações, aportes para reflexão crítica disciplinar. Essa postura nos leva a olhar para o universo empírico de projetos nas duas cidades, movendo-nos pelas leituras e temas que propomos a seguir. 
Painel 1.1 Medellín e São Paulo Visão geral

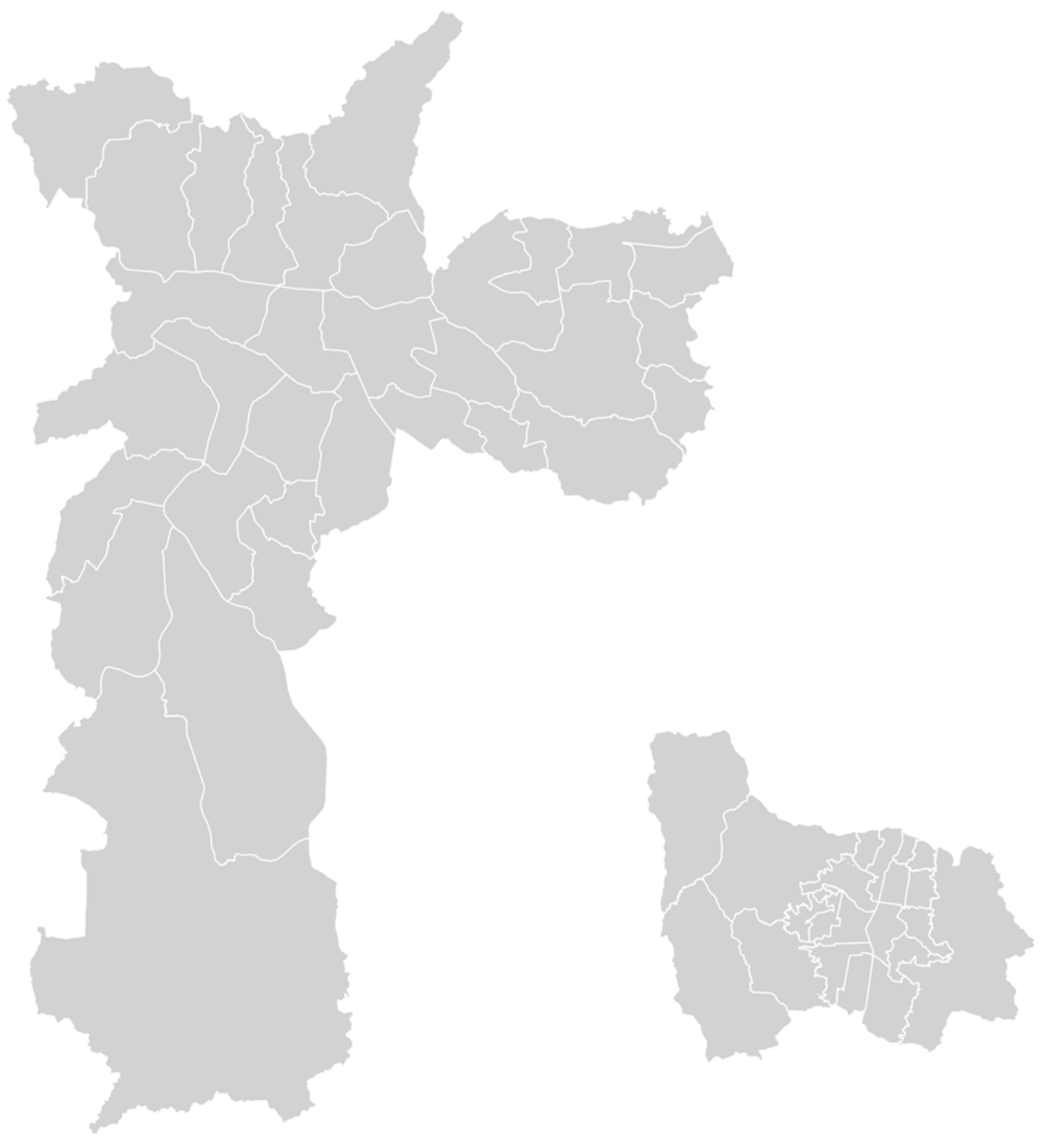

Mapa comparativo São Paulo e Medellín

$\begin{array}{llll}0 & 5 & 10 & 15 \mathrm{~km}\end{array}$

Figura 1.1.1 

Painel 1.1 Medellín e São Paulo Visão geral

\begin{tabular}{r|r|r|} 
& Medellín & São Paulo \\
\cline { 2 - 3 } $\mathbf{1 8 2 5}$ & $\mathbf{1 2 . 5 9 2}$ & \\
$\mathbf{1 8 3 5}$ & $\mathbf{1 4 . 8 0 0}$ & $\mathbf{2 1 . 9 4 0}$ \\
$\mathbf{1 8 7 0}$ & $\mathbf{2 9 . 7 6 5}$ & 26.663 \\
$\mathbf{1 8 7 2}$ & 34.488 & 31.385 \\
$\mathbf{1 8 8 3}$ & 37.237 & 48.160 \\
$\mathbf{1 8 9 0}$ & 41.960 & 64.934 \\
$\mathbf{1 9 0 0}$ & 46.682 & $\mathbf{2 3 9 . 8 2 0}$ \\
$\mathbf{1 9 0 5}$ & 58.815 & 395.026 \\
$\mathbf{1 9 1 2}$ & 70.547 & 652.607 \\
$\mathbf{1 9 1 8}$ & 79.146 & 787.338 \\
$\mathbf{1 9 2 0}$ & 83.869 & 922.069 \\
$\mathbf{1 9 2 8}$ & $\mathbf{1 2 0 . 0 4 4}$ & 1.056 .800 \\
$\mathbf{1 9 3 8}$ & $\mathbf{1 6 8 . 2 6 6}$ & 1.191 .530 \\
$\mathbf{1 9 4 0}$ & 172.989 & $\mathbf{1 . 3 2 6 . 2 6 1}$ \\
$\mathbf{1 9 5 0}$ & 177.711 & $\mathbf{2 . 1 9 8 . 0 9 6}$ \\
$\mathbf{1 9 5 1}$ & 358.189 & 2.989 .771 \\
$\mathbf{1 9 6 0}$ & 362.912 & 3.781 .446 \\
$\mathbf{1 9 6 4}$ & 772.887 & 4.853 .031 \\
$\mathbf{1 9 7 0}$ & 777.610 & 5.924 .615 \\
$\mathbf{1 9 7 3}$ & $\mathbf{1 . 1 0 0 . 0 8 2}$ & 7.208 .921 \\
$\mathbf{1 9 8 0}$ & 1.104 .805 & 8.493 .226 \\
$\mathbf{1 9 9 1}$ & 1.109 .527 & 9.646 .185 \\
$\mathbf{1 9 9 3}$ & $\mathbf{1 . 8 3 4 . 8 8 1}$ & 10.040 .219 \\
$\mathbf{2 0 0 0}$ & $\mathbf{2 . 1 5 9 . 2 4 3}$ & $\mathbf{1 0 . 4 3 4 . 2 5 2}$ \\
$\mathbf{2 0 0 5}$ & $\mathbf{2 . 4 9 9 . 0 8 0}$ & 10.843 .878 \\
$\mathbf{2 0 1 0}$ & $\mathbf{2 . 6 3 6 . 1 0 1}$ & $\mathbf{1 1 . 2 5 3 . 5 0 3}$ \\
$\mathbf{2 0 1 8}$ & $\mathbf{2 . 8 7 1 . 1 3 3}$ & $\mathbf{1 2 . 1 7 6 . 8 6 6}$ \\
& & \\
\hline
\end{tabular}

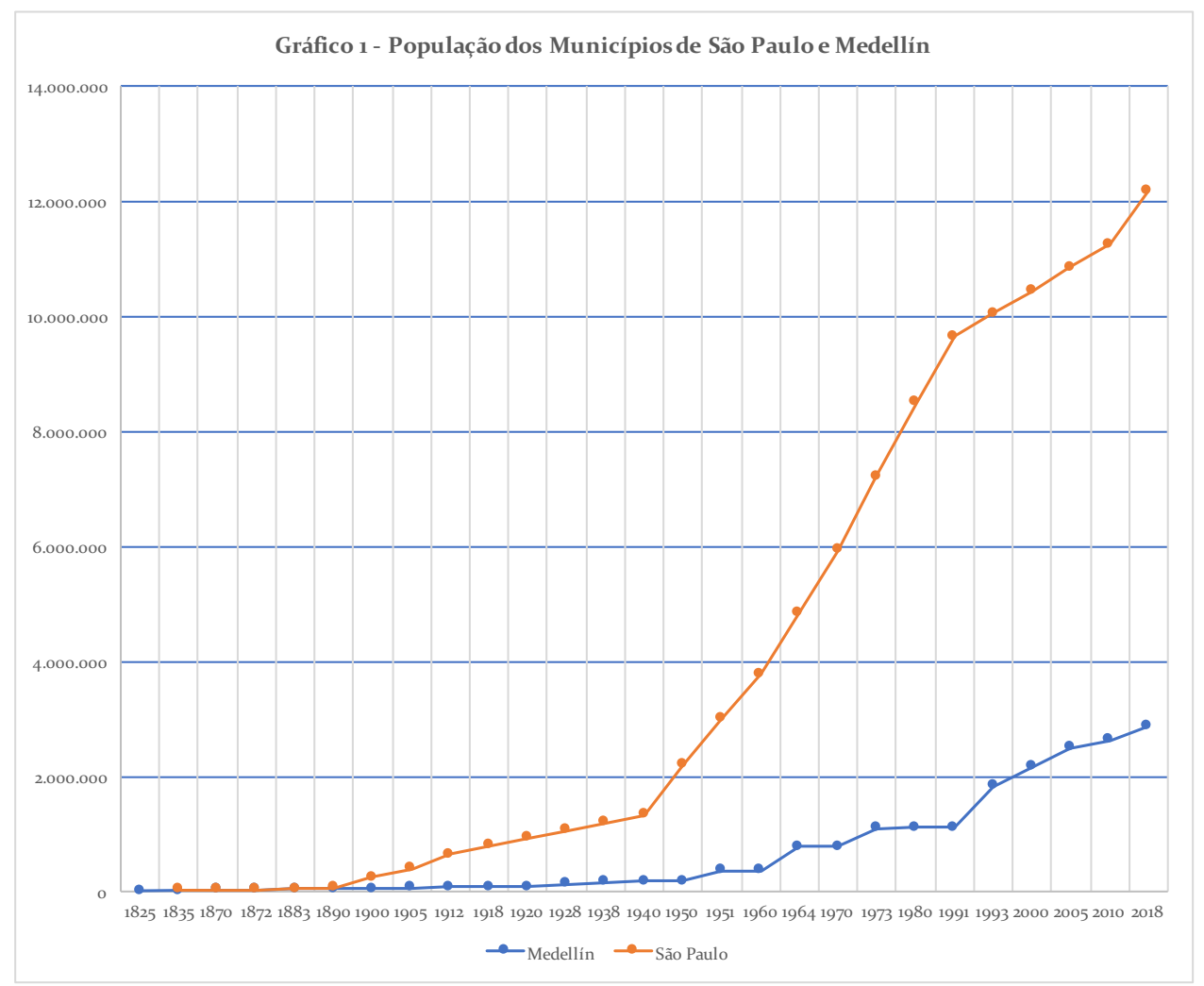

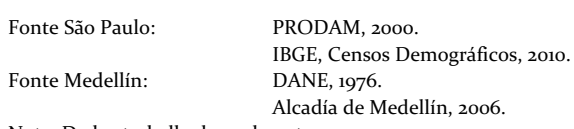

Nota: Dados trabalhados pelo autor.

Legenda: Dados interpolados pelo autor.
Figura 1.1.2 Medellín e São Paulo: duas cidades que sofreram explosões demográficas ao longo do século XX 


\section{Painel 1.2 Mapa geral Medellín}

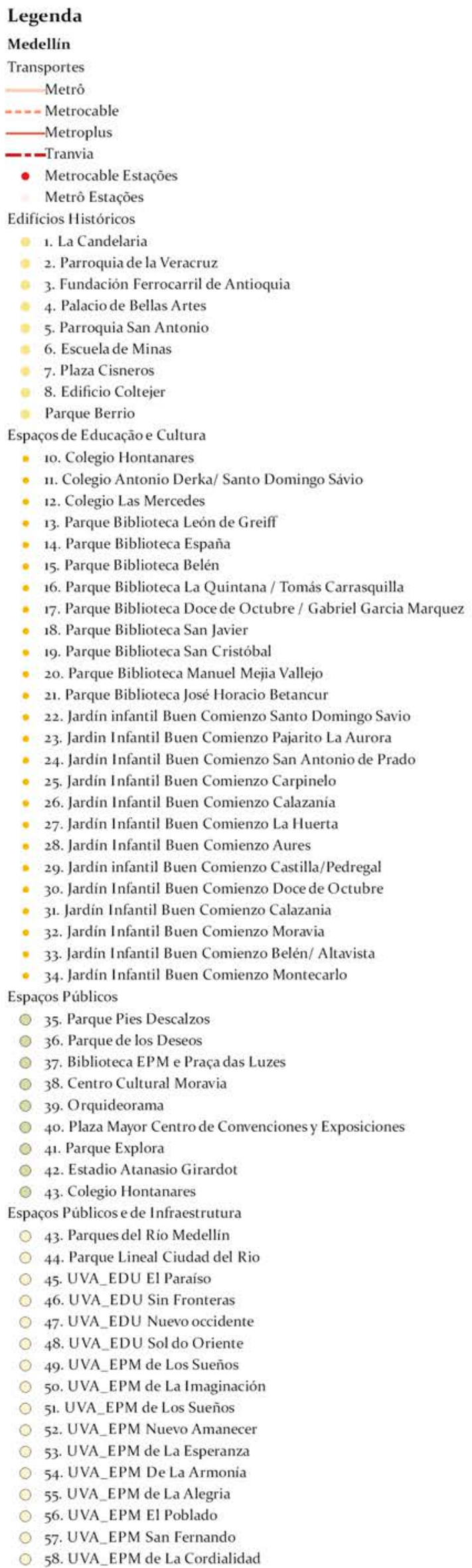




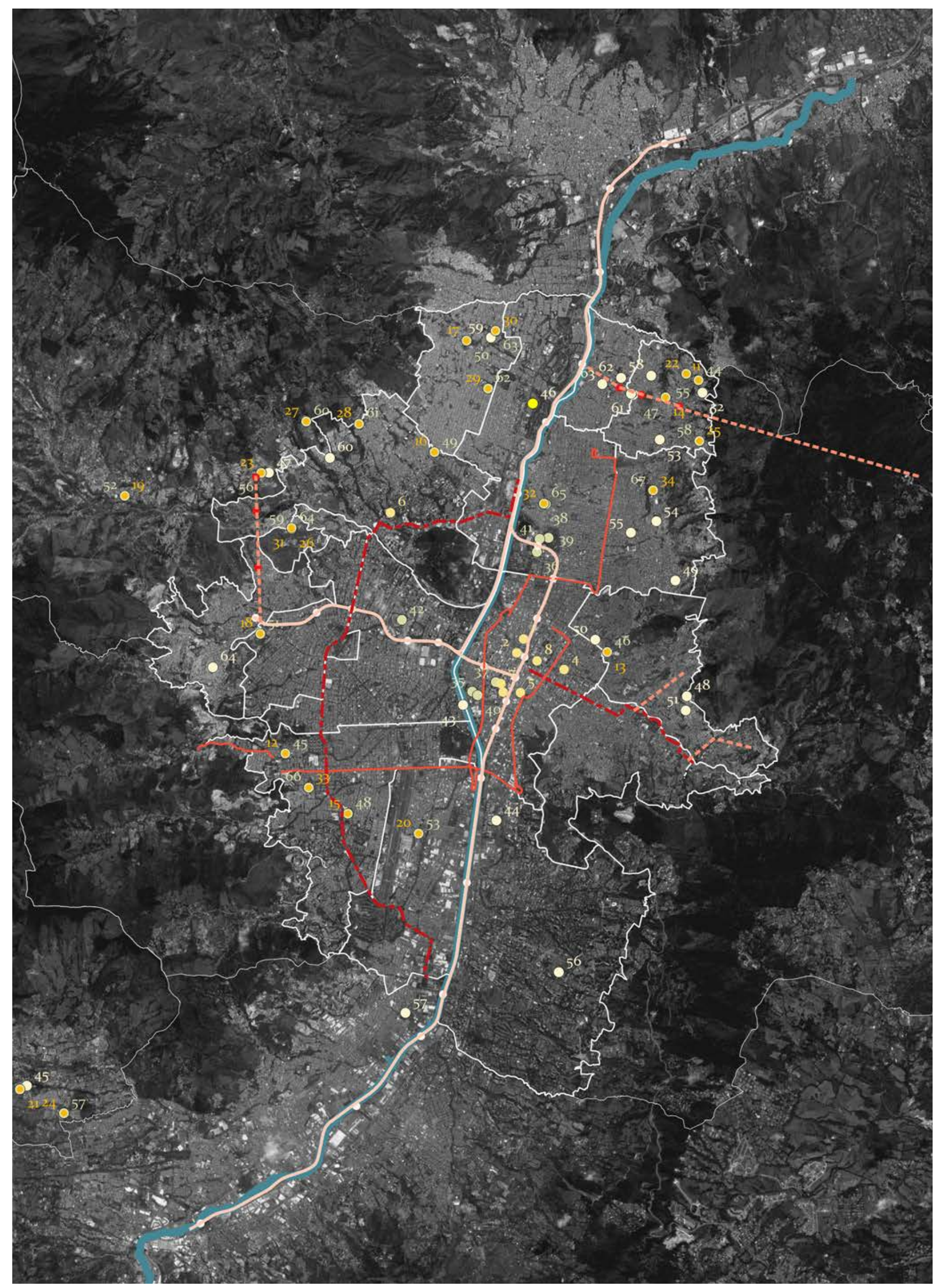


Painel 1.2.2 Mapa geral São Paulo

\section{Legenda}

SÃO PAULO

CEUs

Estudos de Caso

1. Praça das Artes

2. Parque da Juventude

3. Centro de Formação Cultural Cidade Tiradentes

4. Cantinho do Céu

5. Jardim Edite

6. Projeto Viver

7. Sesc 24 de Maio

8. Paraue Novo Santo Amaro V

Linha de trem

Estação de trem

Linha de metrô

- Estação de metrô

Monotrilho

— Corredor de ônibus

_ Corredor de ônibus intermunicipal

Hidrografia

Hidrografia - Bacias 


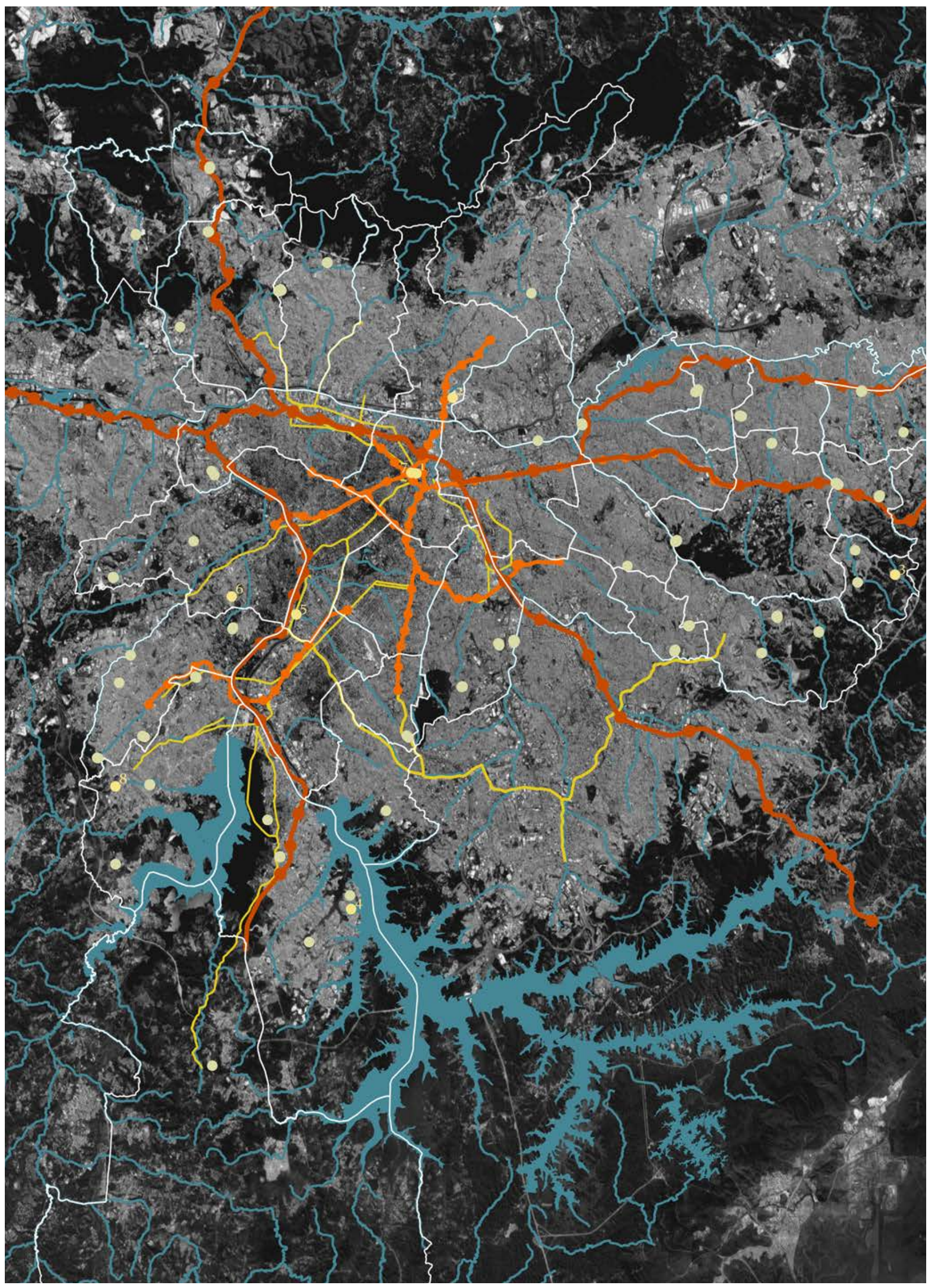


Painel 1.2.4 Dados básicos socioeconômicos Medellín

MAPA DE ESTRATIFICAÇÃO SOCIO ECONÔMICA

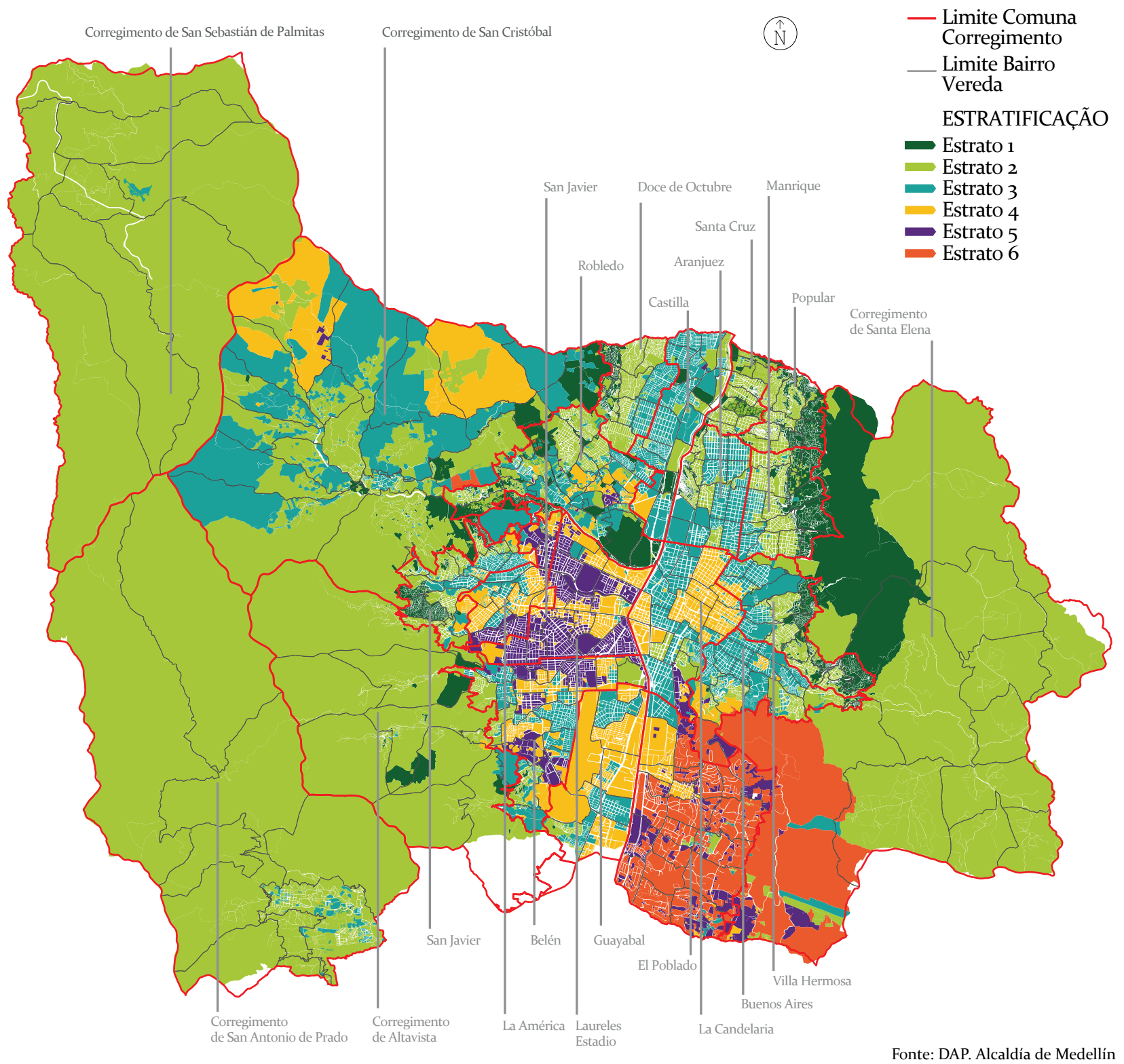

Figura 1.2.5 


\section{Dados básicos socioeconômicos São Paulo}

Domicílios com renda domiciliar

de até 3 salários mínimos

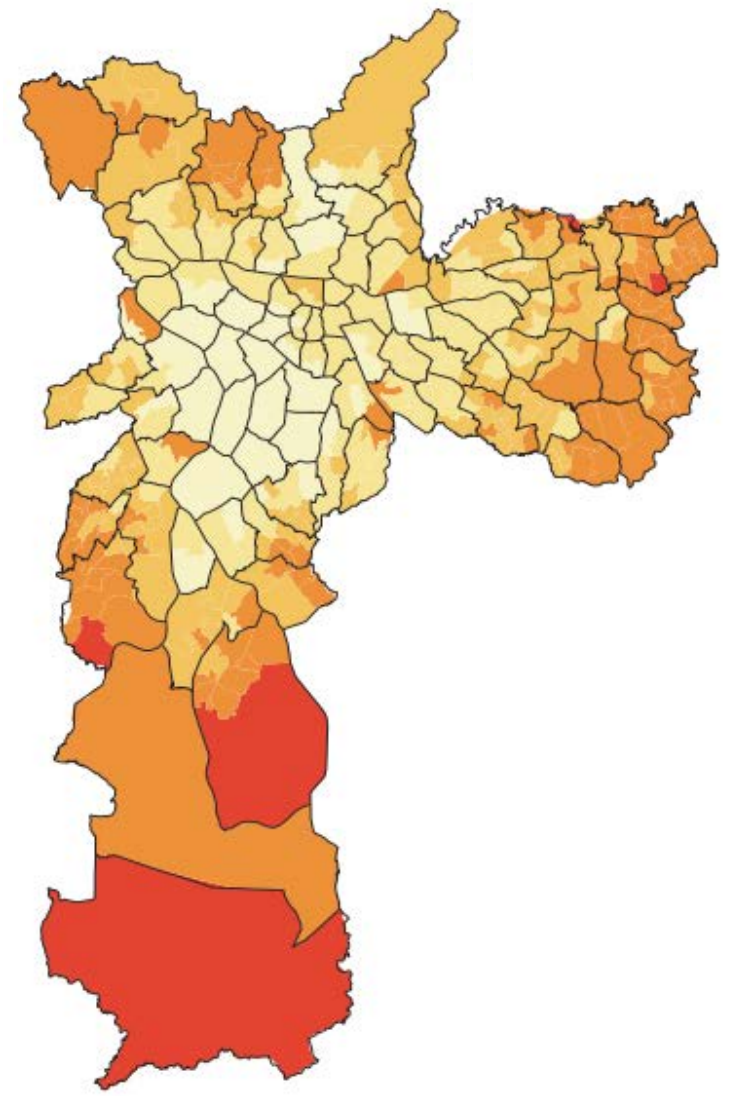

Domicílios com renda domiciliar

de até 20 ou mais salários mínimos

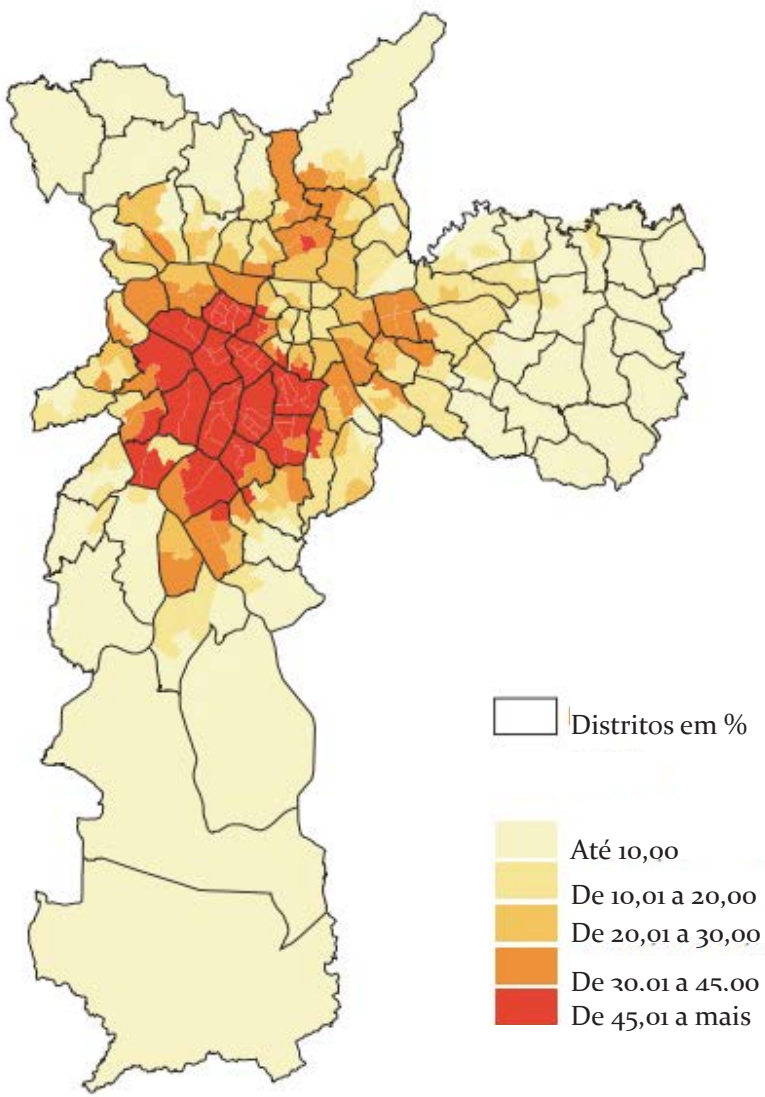

Nota As porcentagens indicam a relação entre domicílios de determinada faixa de renda e o número total de domicílios permanentes, ambas variáveis referentes a cada uma das 456 Áreas de Ponderação da Amostra do Censo IBGE/200o definidas para o Município de São Paulo.

Figura 1.2.6 
Painel 1.3 Continuidades e descontinuidades

Paisagem urbana São Paulo

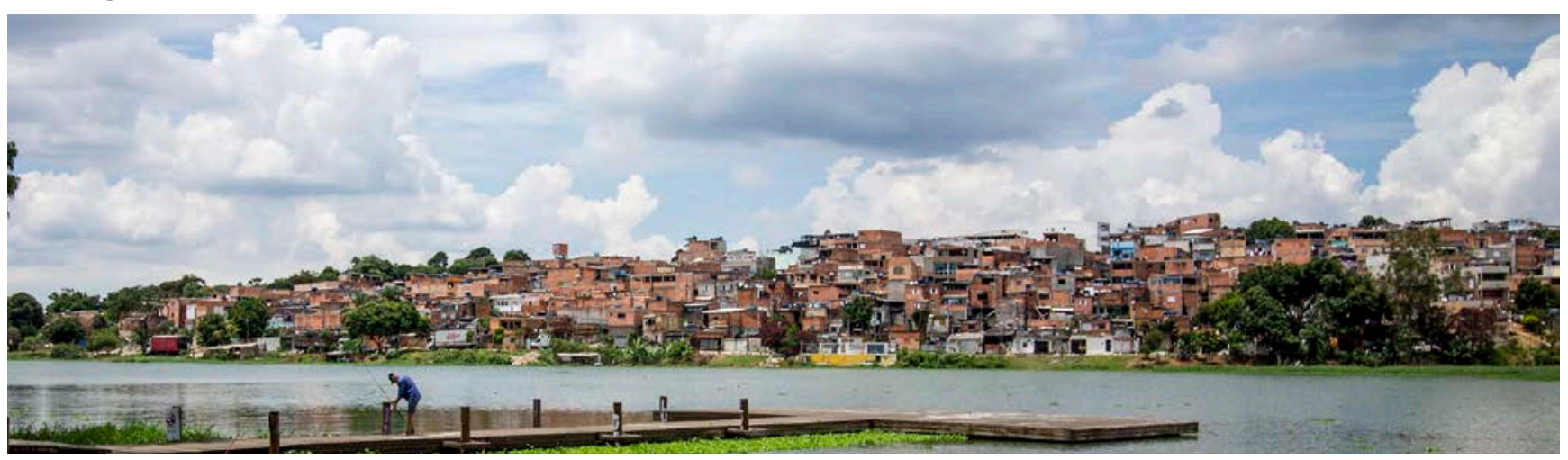

Figura 1.3.1

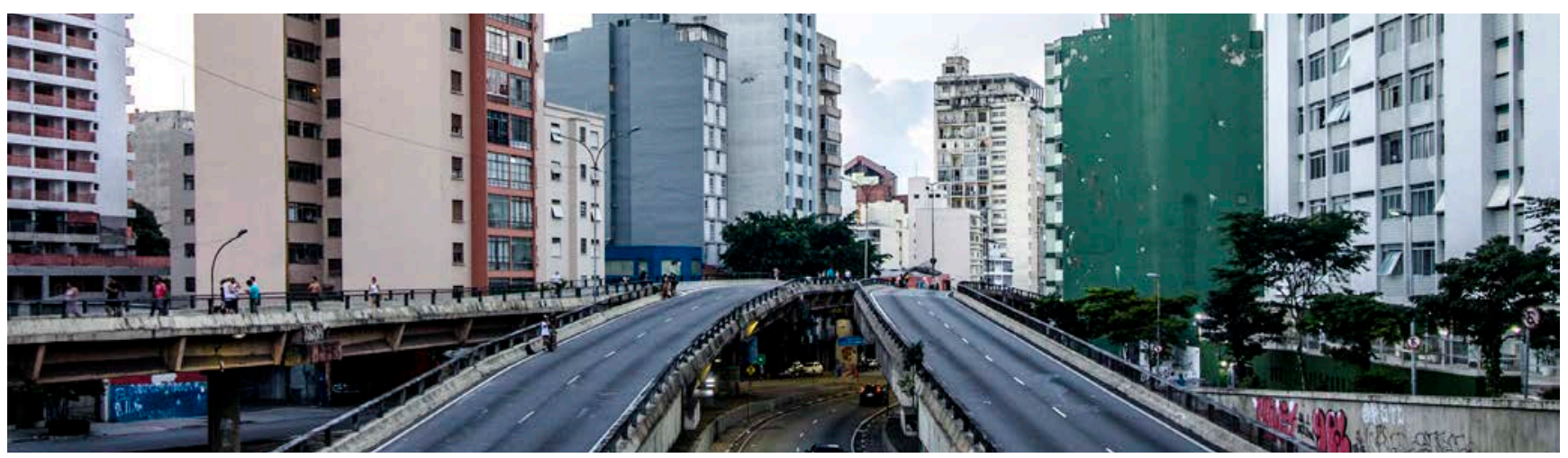

Figura 1.3.2

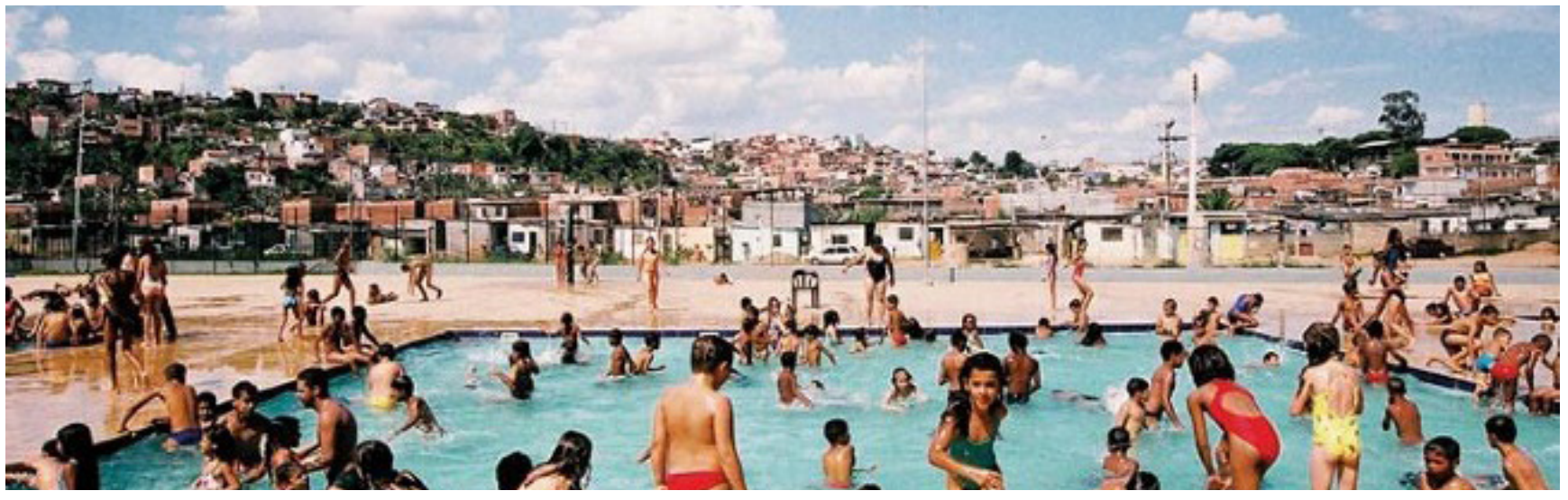

Figura 1.3.3

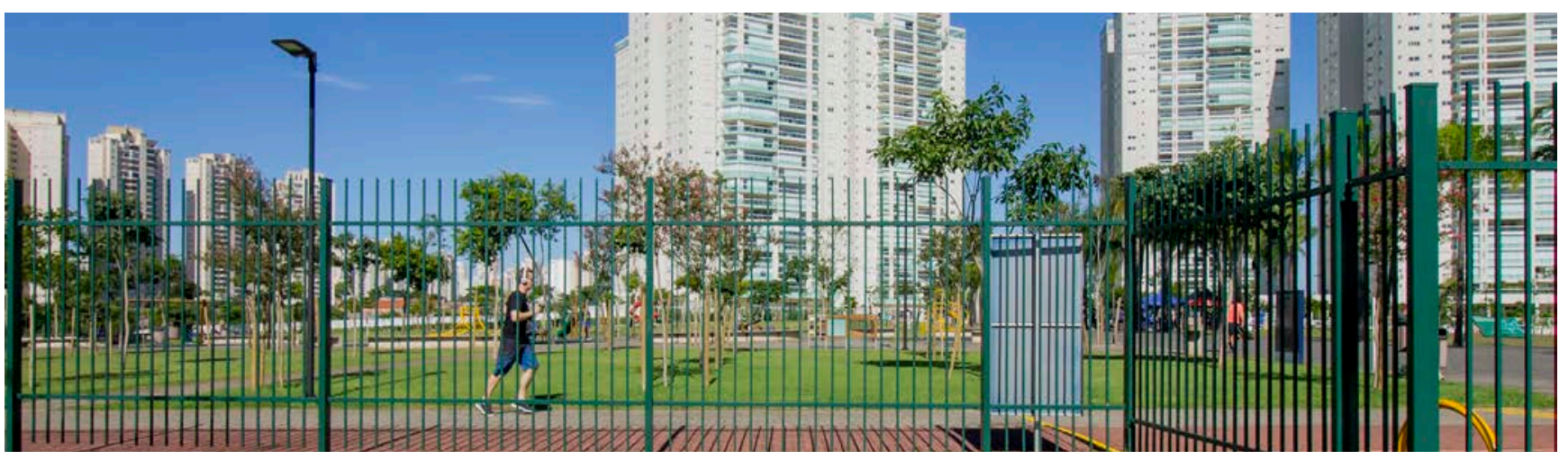

Figura 1.3.4 
Paisagem urbana Medellín

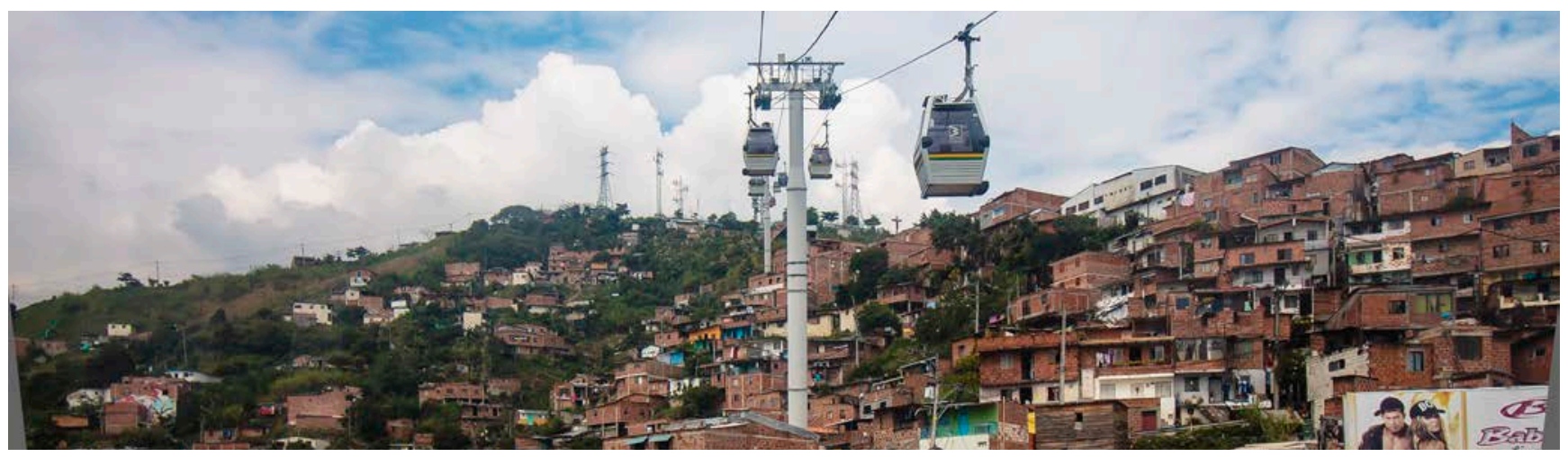

Figura 1.3.5

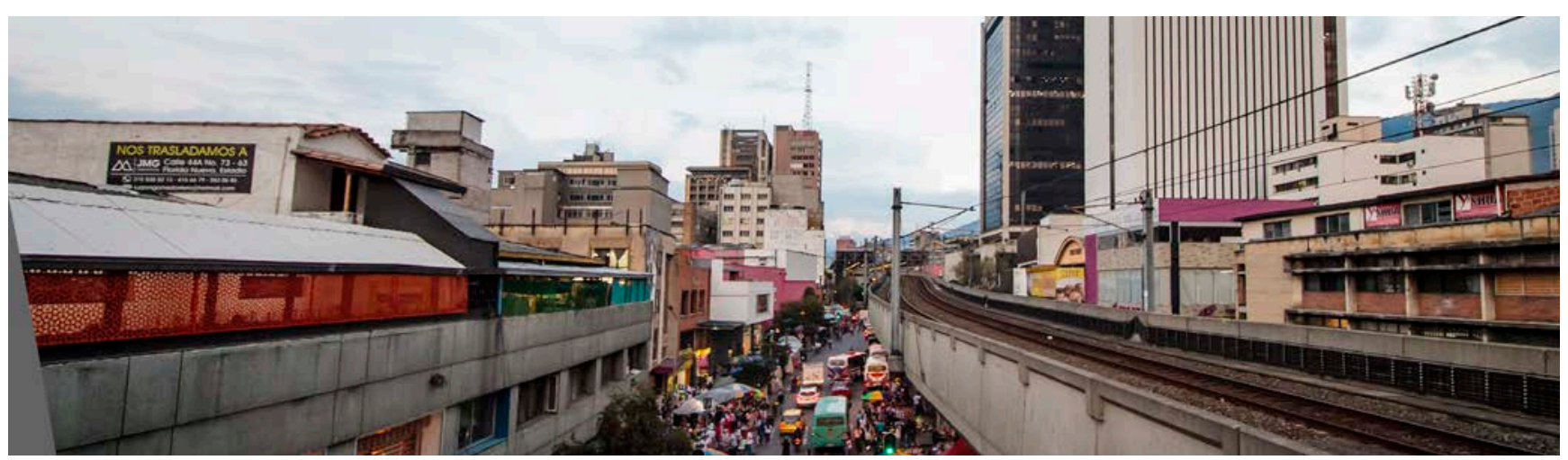

Figura 1.3.6

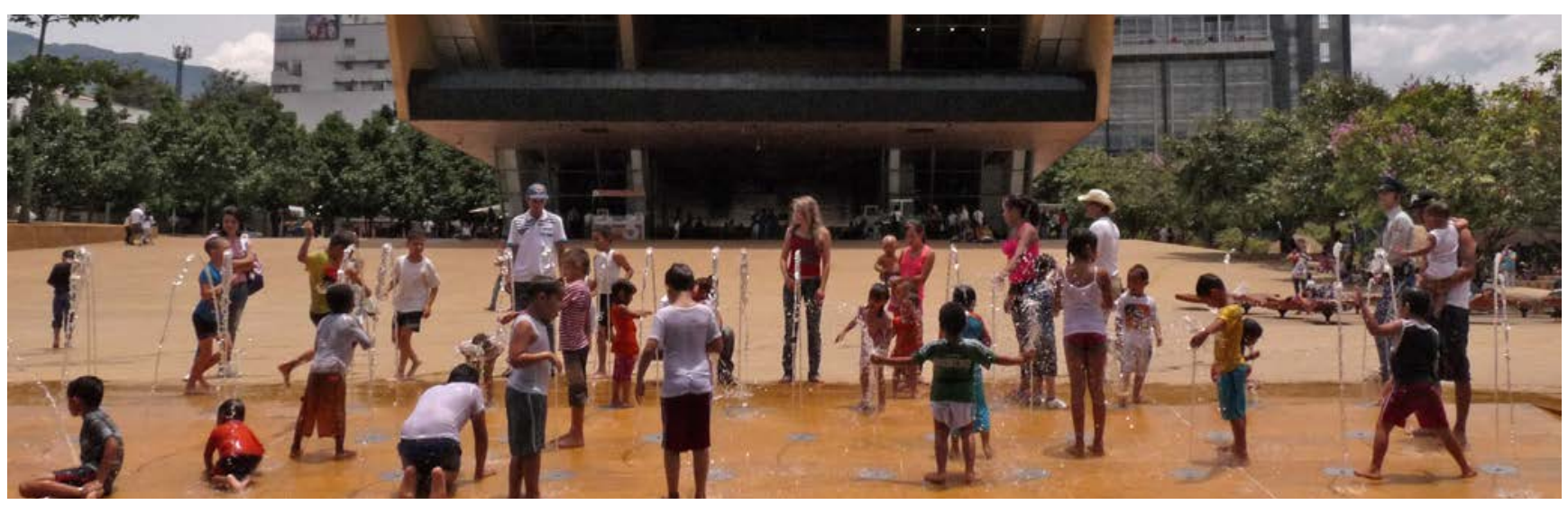

Figura 1.3.7

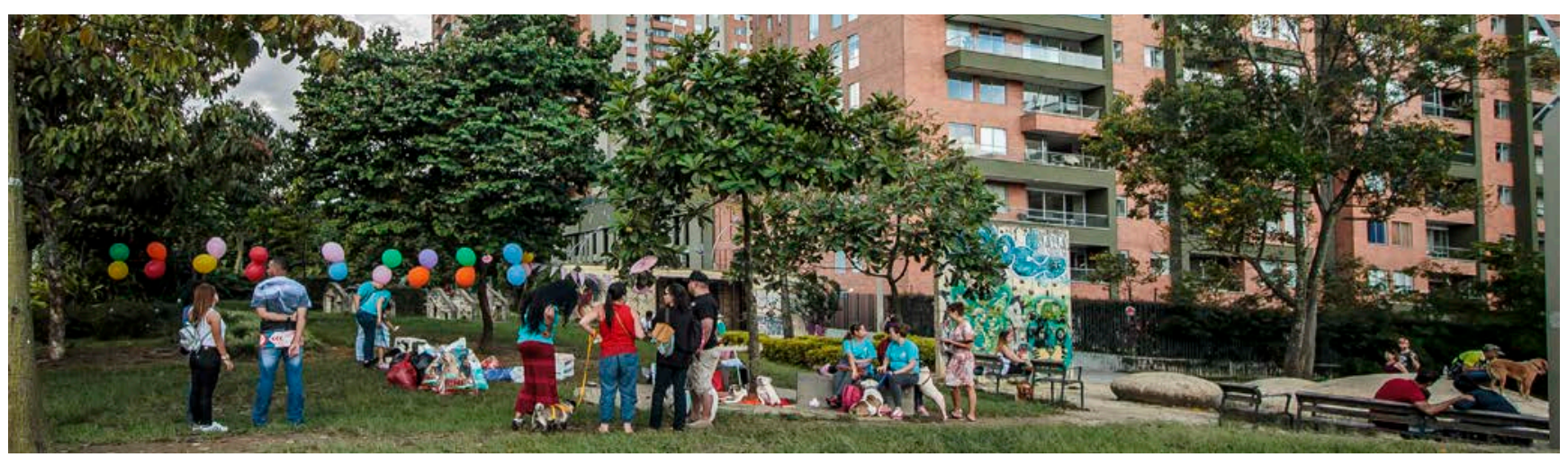

Figura 1.3.8 
Painel 1.4 Paradigmas espaciais Oscar Niemeyer

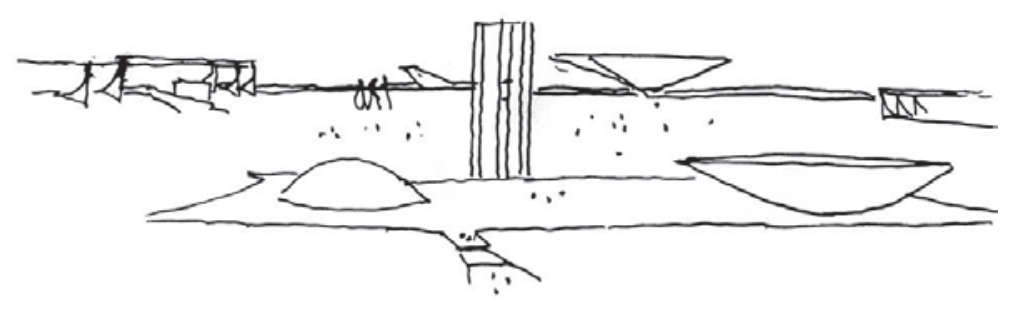

Figura 1.4.1 Brasília

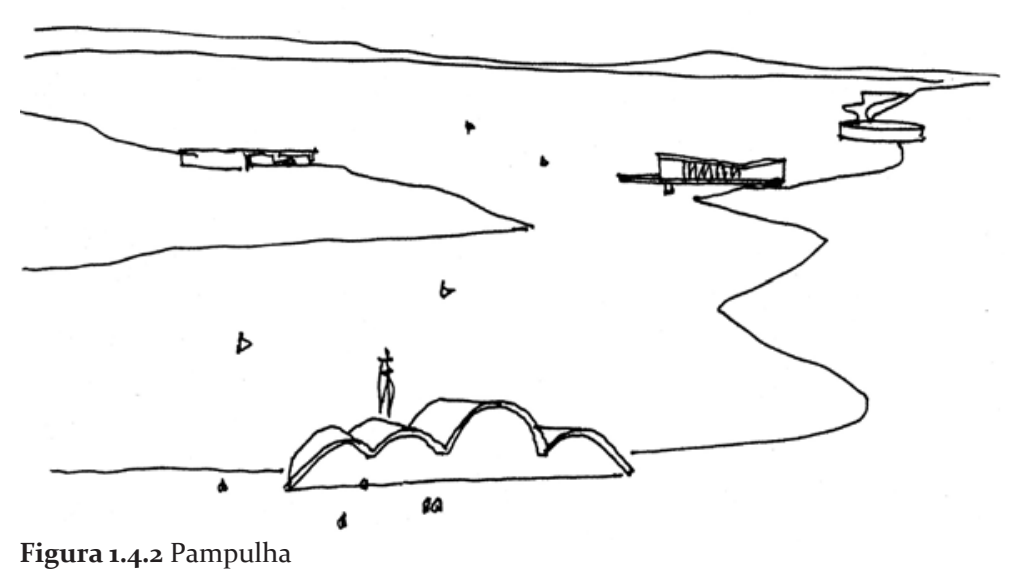

Figura 1.4.2 Pampulha

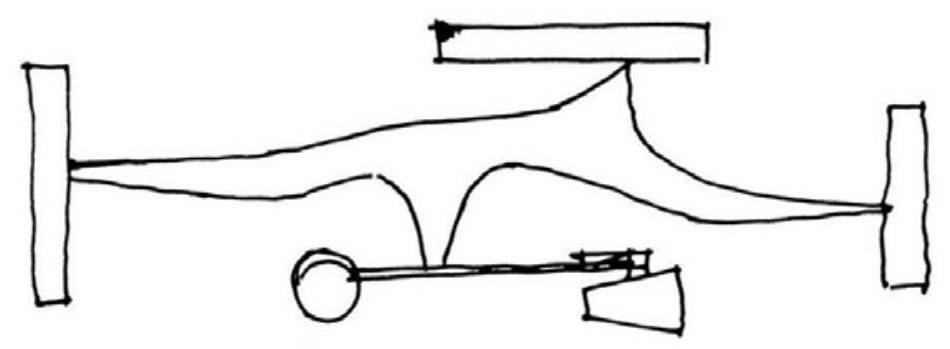

Figura 1.4.3 Ibirapuera

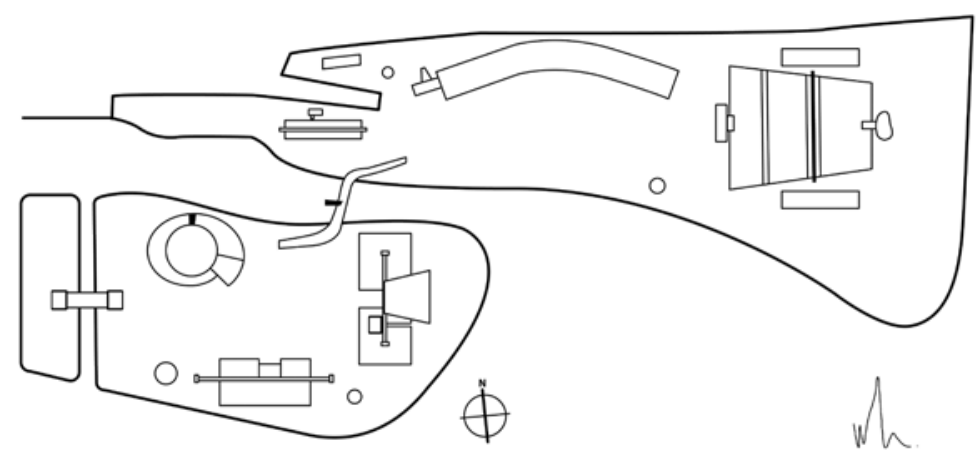

Figura 1.4.4 Memorial da América Latina

64 


\section{Painel 1.5 Paradigmas espaciais Vilanova Artigas}

A evolução da tipologia escolar (1.5.1) edifício implantando diretamente nas praças da república das cidades brasileiras, (1.5.2) conjunto arquitetônico implantado na praça com blocos funcionais (educacionais e recreativos) soltos na praça / posteriormente encerrado por muros quando transformado em escola infantil nos anos 1970; (1.5.3) o paradigma espacial das escolas de Vilanova Artigas em que os blocos funcionais se transformam em células-funcionais articulam em níveis, no entorno da praça central e abrigadas sob uma grande cobertura; (1.5.4) a retomada dos blocos funcionais soltos no lote pelos CEUs, obrigatoriamente encerrados por grades para o controle de acesso à escola.
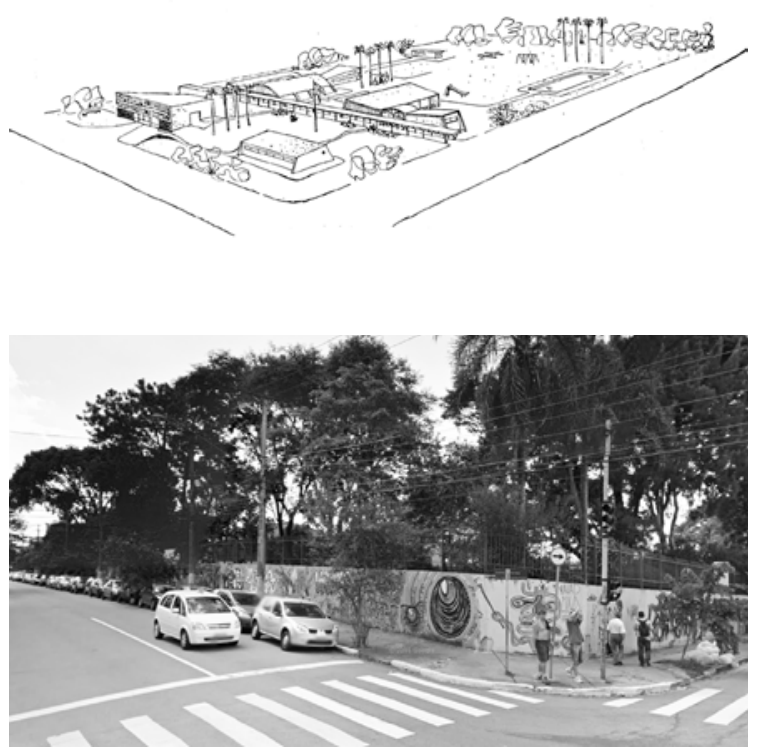

Figura 1.5.2 Parque infantil da Vila Pompeia Projeto de Eduardo Corona e foto da esquina da Rua Diana com Rua Padre Chico nos dias de hoje (o parque hoje é uma EMEI)

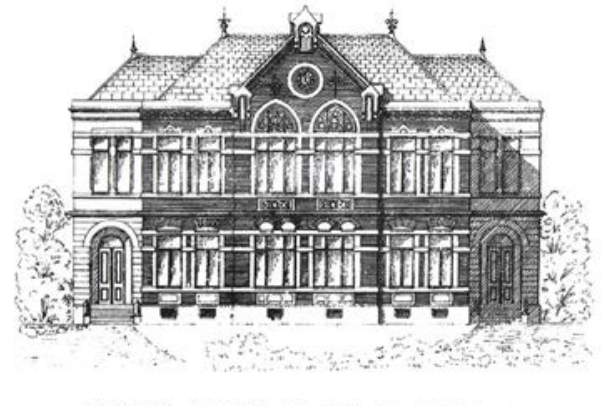

GRUPO ESCOLAR DE CAMPINAS
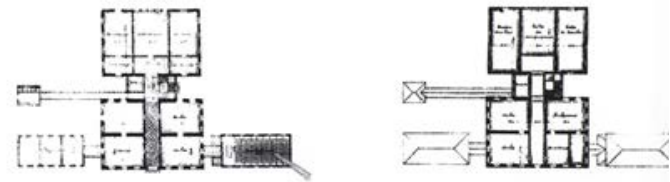

Figura 1.5.1 Grupo Escolar de Campinas, Ramos de Azevedo, 1897.

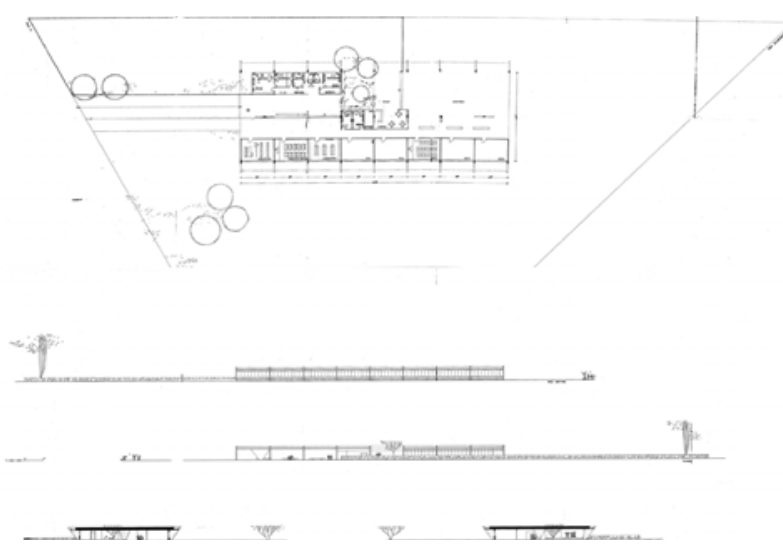

Figura 1.5.3 Ginásio de Itanhaém. Vilanova Artigas, 1959

$$
\text { CEU }
$$$$
\text { CEU ros }
$$

\section{(1)}

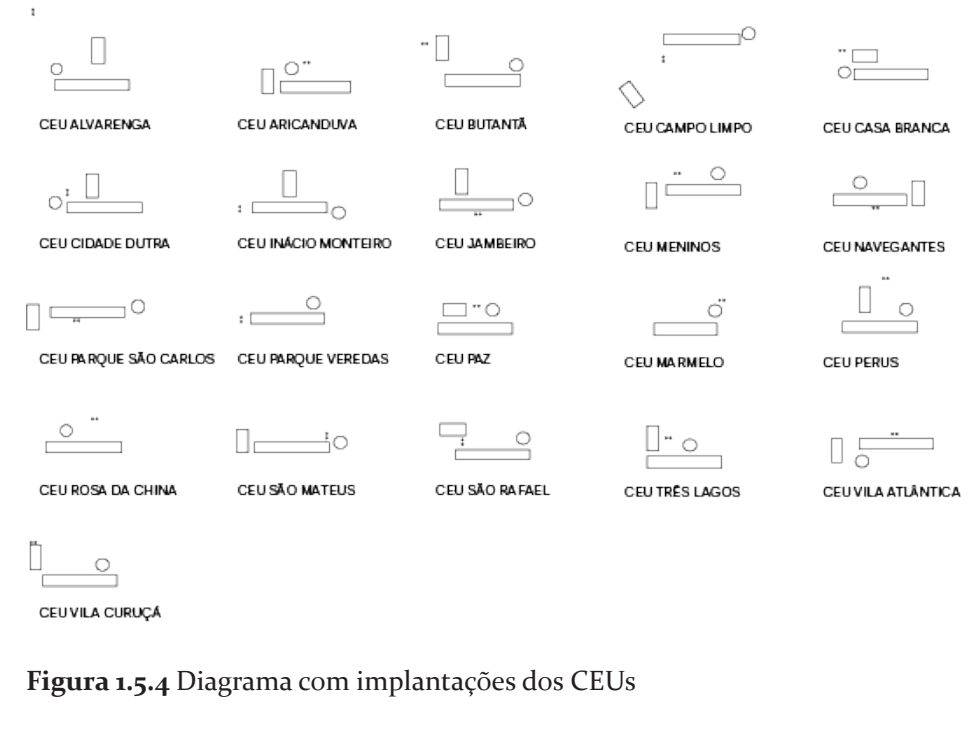

Figura 1.5.4 Diagrama com implantações dos CEUs

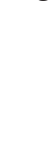


Painel 1.6 Paradigmas espaciais Rogelio Salmona

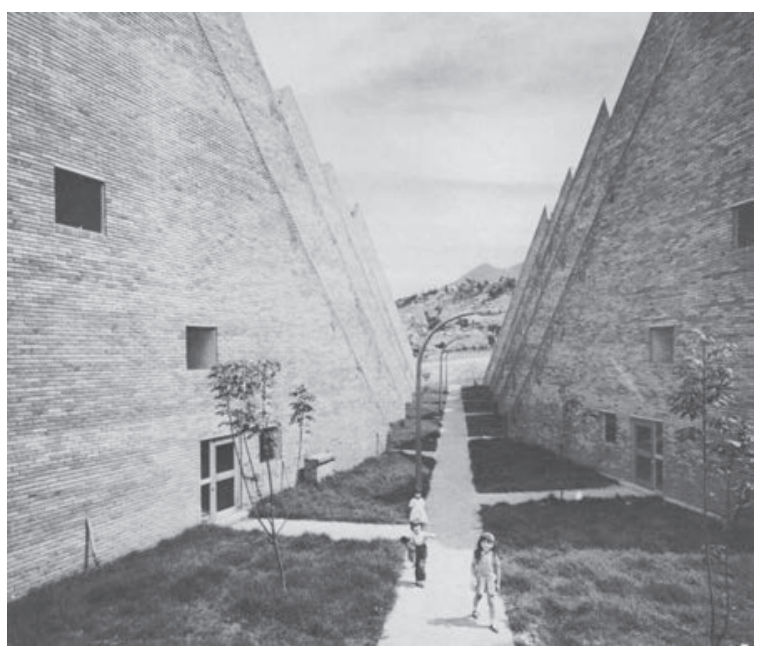

Figura 1.6.1

Complexo de Habitação Social em São Cristóbal de Rogélio Salmona e Hernán Vieco (1963-1966). A proposta de um conjunto residencial é também a necessidade de criar um tecido urbano. $\mathrm{O}$ projeto constrói áreas livres variadas que fazem a transição entre o espaço interno ao conjunto e a cidade. Isso se dá por meio da interação entre os vazios e o arranjo geométrico das edificações.

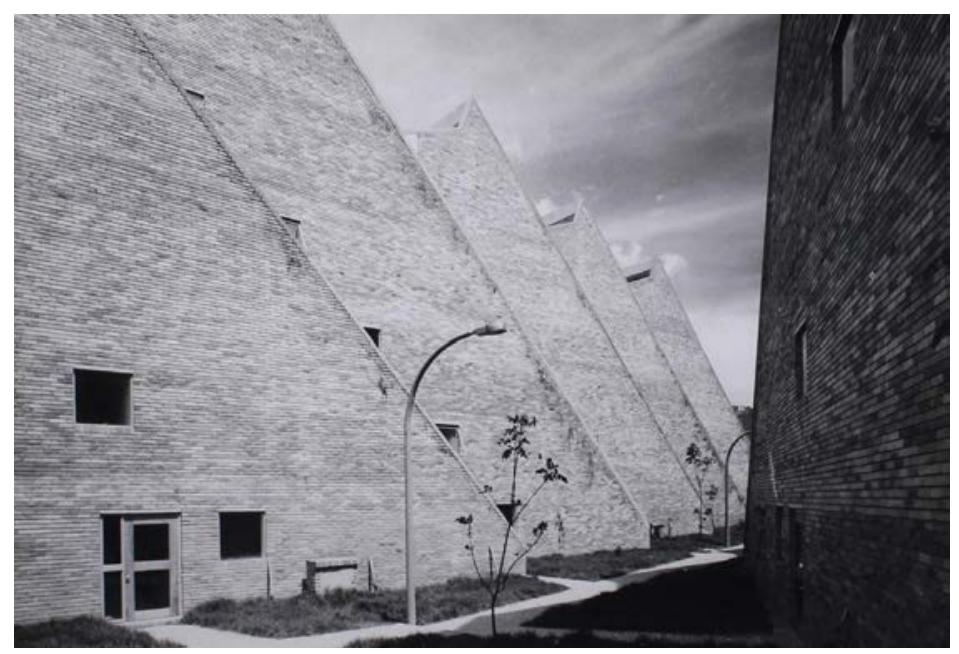

Figura 1.6.2

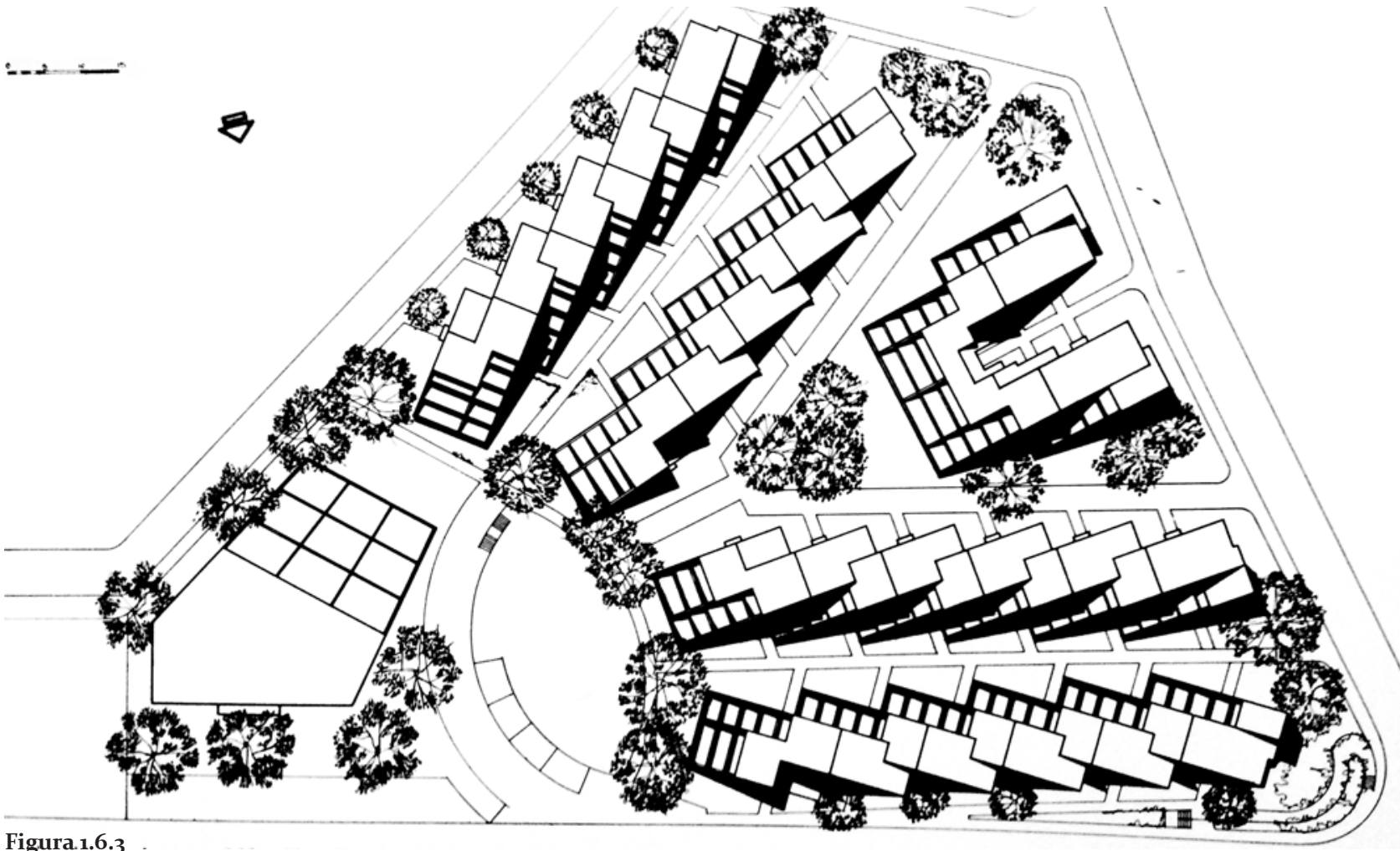

Figura.1.6.3 


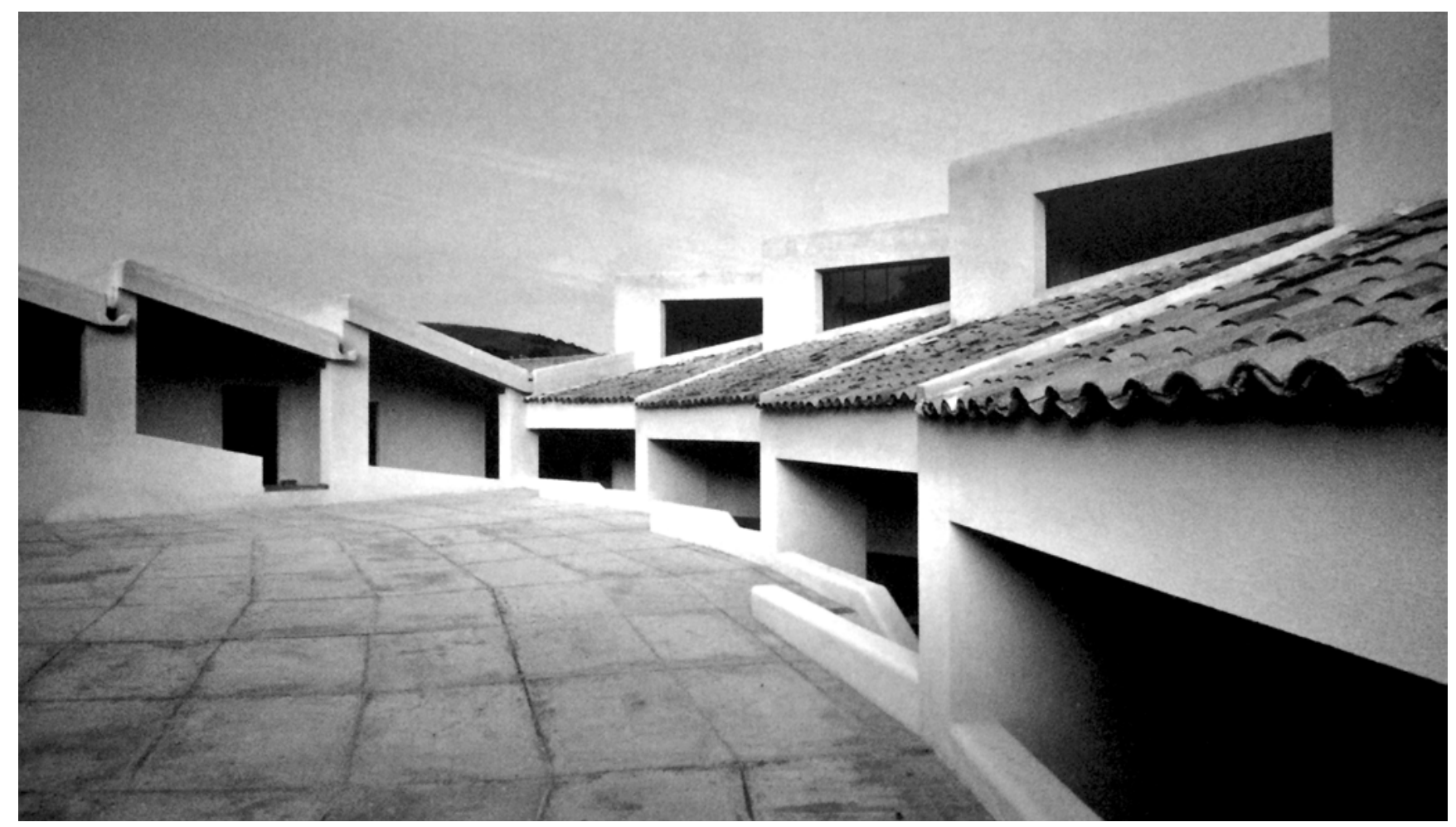

Figura 1.6.4

Centro de Reabilitação Infantil em Sesquilé, 1960. Projeto de Fernando Martinez Sanabria. O projeto cria formas que, com a repetição, permitem ao edifício crescer e criar espacialidades internas.

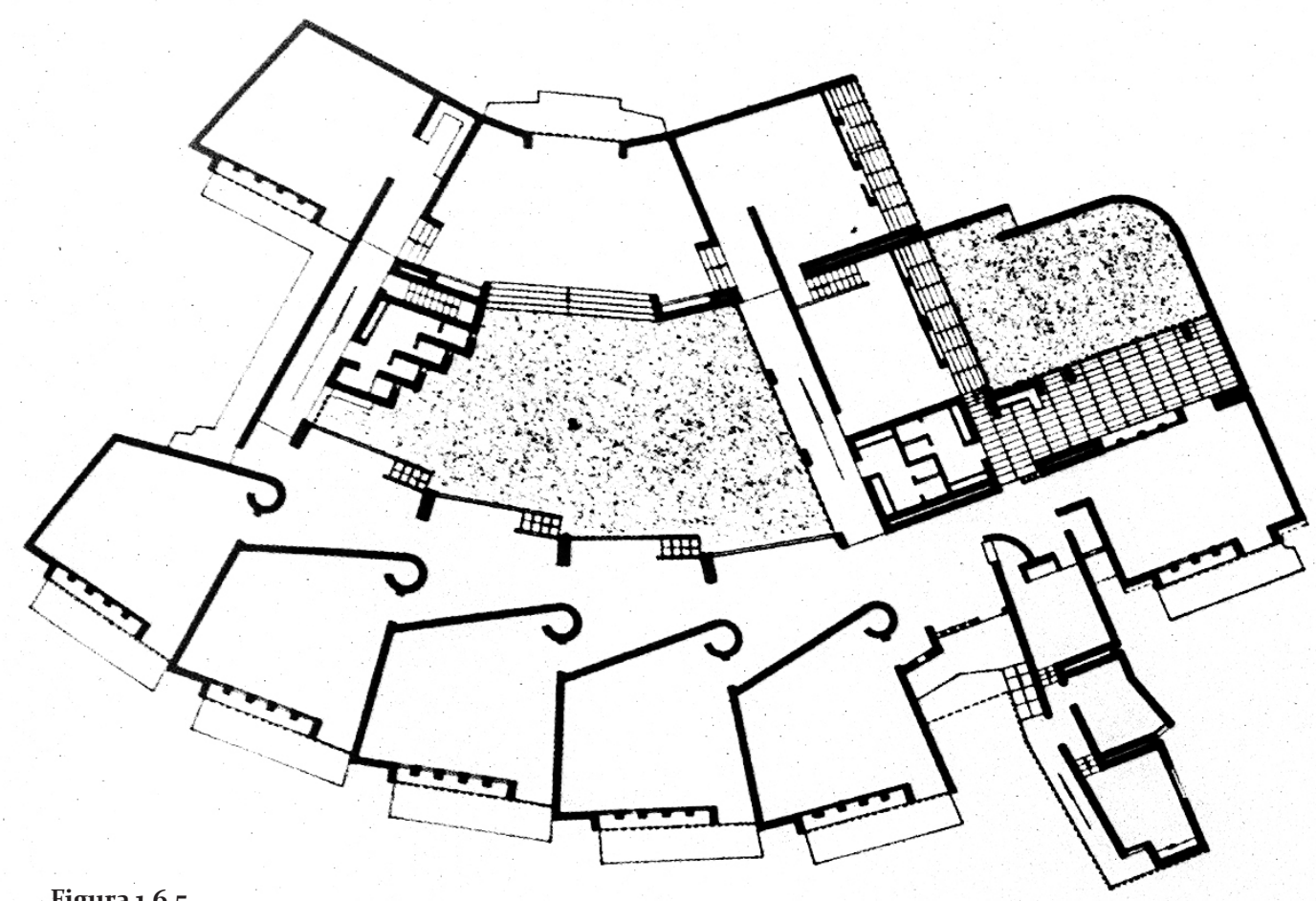

Figura 1.6.5 



\section{A urbanização produtora de não lugares}

Basta um olhar superficial às paisagens biofísicas, econômicas e culturais da maior parte do terceiro mundo para se dar conta de que o desenvolvimento está em crise, e que a violência, a pobreza e a deterioração social e ambiental crescente são o resultado de 50 anos de receitas de crescimento econômico, "ajustes estruturais", macroprojetos sem avaliação de impacto, endividamento perpétuo, e marginalização da maioria da população dos processos de pensamento e decisão sobre a prática social.

Arturo Escobar ${ }^{36}$

O olhar de Arturo Escobar, diante do cenário estarrecedor que resulta da segregação e pobreza no terceiro mundo, clama por uma problematização dos processos de modernização e desenvolvimento, utilizando a paisagem como prova real de seu argumento. $\mathrm{O}$ pensamento desse autor nos convida a olhar para a estrutura e a morfologia urbana do mesmo modo, buscando-as como síntese das condições históricas encapsuladas no presente, das temporalidades sobrepostas no espaço, da relação do local com o mundial, atentando às particularidades de duas cidades na periferia do capitalismo.

Esse potencial revelador do urbano faz saltar aos olhos inúmeros impactos socioespaciais que refletem e operacionalizam dimensões de projetos políticos e econômicos conflituosos, colocando os instrumentos de mediação dos processos de urbanização - o plano e o projeto - a favor dessas pautas socialmente disfuncionais. Mas, nessa perspectiva niilista que parece se impor, lembramos que o espaço é determinado e determinante (SANTOS, 2004, p. 163). Isto é, esse urbano não se resume ao espelho de um problema maior e nem à origem de todos os males, como se fez crer no debate antiurbano dos anos $1970^{37}$.

O presente capítulo não busca discursos históricos alternativos, nem se lança a exaurir os problemas que afligem São Paulo e Medellín. Mas ao olhar de modo combinado para essas paisagens urbanas em transformação, entende-se que estas são chaves fundamentais para o enfrentamento do problema, se buscarmos uma abordagem dialética e metodológica do espaço, como condição privilegiada para a reformulação do pensamento e da ação sobre o mesmo. E, retomando o subtexto da argumentação de Escobar, isso se faz considerando a internacionalização da economia, uma condição que não pode mais ser negada. Mas, por meio de uma posição crítica, pode-se contribuir para repensar as condições de participação nesse sistema e nesses espaços, agora transnacionais. Esse passo é fundamental para reformular o lugar histórico e cultural que nos foi atribuído e que, por vezes, impõem limites ao nosso campo de visão (sobre nós mesmos). Por esse motivo, se mostra tão necessário buscar caminhos, ainda que exploratórios e parciais, dentro do enfoque deste trabalho, para renová-lo e ampliá-lo.

À luz desses argumentos, perscrutamos o processo de urbanização de São Paulo e Medellín, considerando os agentes, planos e projetos que interagem na produção desse espaço. Adotamos, neste capítulo, maior

${ }^{36}$ ESCOBAR, ARTURO. La invención del tercer mundo. Construcción y deconstrucción del desarrollo. Caracas: Fundación Editorial el perro y la rana, 2007, p.11.

${ }^{37}$ Cf. SINGER,1973; e GORELIK,2005. 
ênfase na sua dimensão infraestrutural e nos sistemas técnicos que deram suporte à modernização das cidades, tendendo a uma discussão da urbanidade em uma escala metropolitana. O percurso proposto pretendeu, em meio a contextualizações e análises centradas em problemas específicos, retornar sistematicamente ao desenvolvimento de questões disciplinares da $\mathrm{A} \& \mathrm{U}$ em sua integração com aspectos dos mecanismos econômicos e sociológicos historicamente constituídos. Nos atentamos às dimensões morfológicas desse processo, visto que os projetos analisados reafirmam ou transformam um relevo socioespacial. Isto é, estes projetos interagem, constroem e ativam relações entre a forma social e forma urbana, de espectros e escalas muito variadas. Ao enfrentarmos essas possibilidades de discussão disciplinar, aproximando duas cidades latino-americanas em suas recentes experiências, o fazemos com o mesmo sentido de urgência de Escobar, pressionados por um processo de urbanização explosivo e excludente, inscrito no fenômeno do subdesenvolvimento ${ }^{38}$. Partimos também da percepção de que a reversão ou redução dos impactos da estruturação territorial dessas cidades, passa também por ressignificar essa paisagem urbana, por ora um triste testemunho de processos de exclusão social. Assim, adentramos o presente capítulo com esse horizonte reflexivo e com essa escala mais abrangente de análise, mobilizando primeiro o exemplo de Medellín, para que a realidade mais distante problematize os debates previamente sondados e a experiência cotidiana que acomodam nossa relação com São Paulo.

\footnotetext{
${ }^{38} \mathrm{O}$ que Jorge Liernur (2015) aponta como as "condições comuns de existência” que as cidades latino-americanas compartilham são entendidas e analisadas, nesse trabalho, como as problemáticas de um processo urbano inscrito no subdesenvolvimento. Isso, baseando-se no que Milton Santos (2010) entende enquanto categoria possível para analisar as cidades latinoamericanas e que ele também irá explorar em diversas obras dedicadas ao tema. Pondera-se que essa categoria de pensamento sobre a condição brasileira foi consistentemente relativizada por Francisco de Oliveira (2013) em O Ornitorrinco. Mas o autor não descarta a possibilidade de mobilizar o subdesenvolvimento, e sim, ativa-o junto à dependência externa, dentre outras categorias explicativas que se atualizam para o entendimento dessa híbrida conformação socioeconômica brasileira, que se apresenta como uma das sociedades capitalistas mais desigualitárias da contemporaneidade.
} 
Painel 2.1 As duas cidades
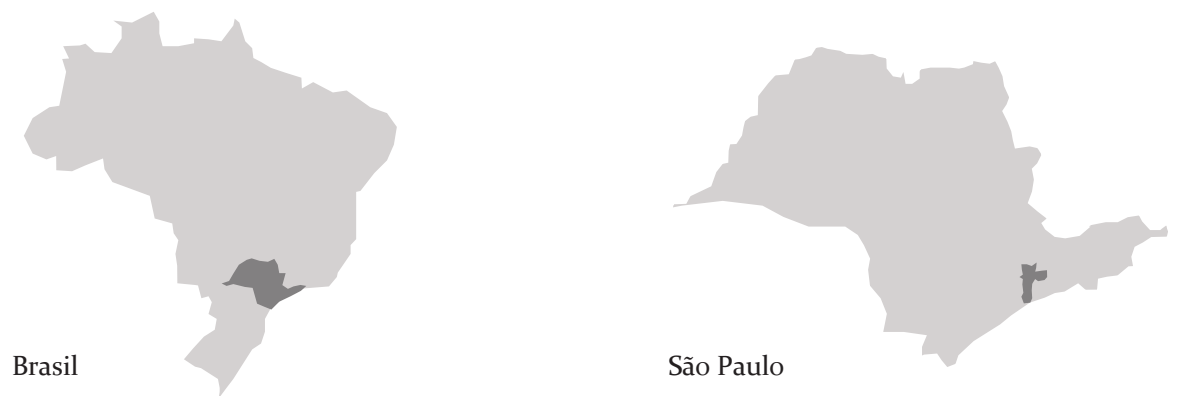

São Paulo

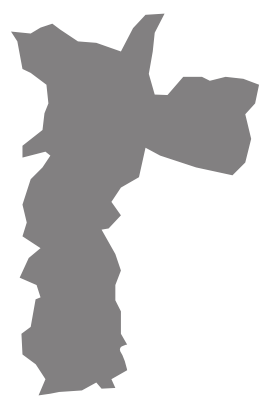

Figura 2.1.1 Contextualização: São Paulo

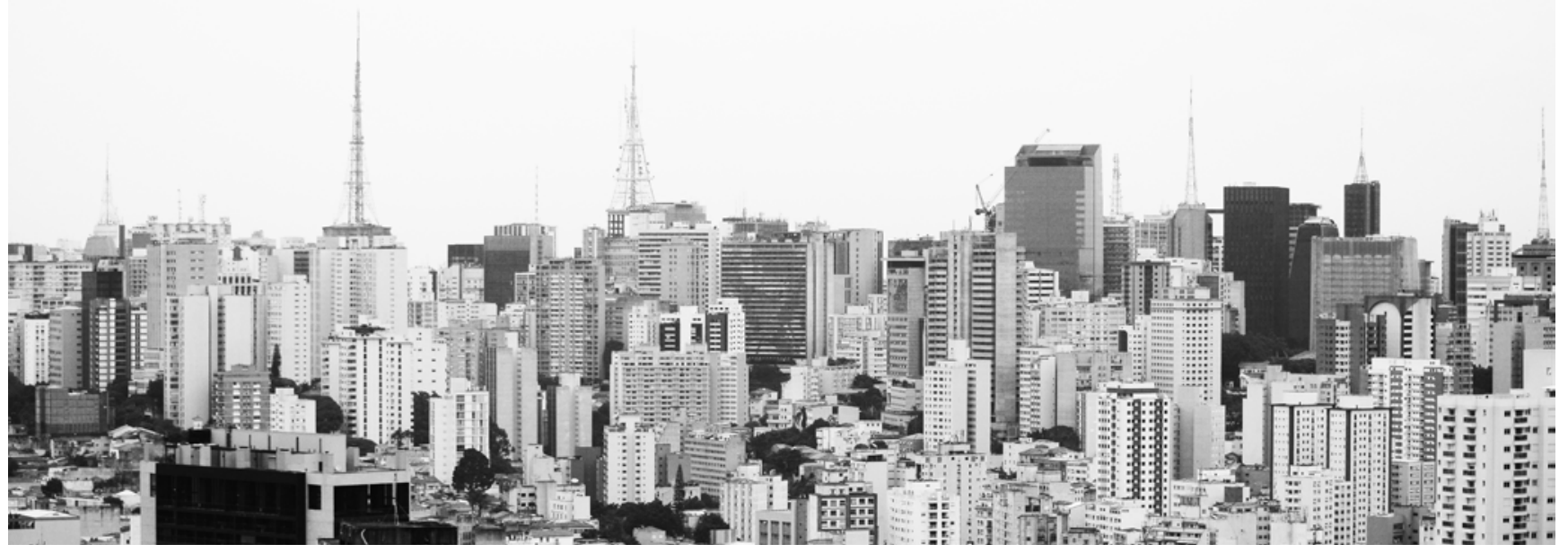

Figura 2.1.2 Centro de São Paulo
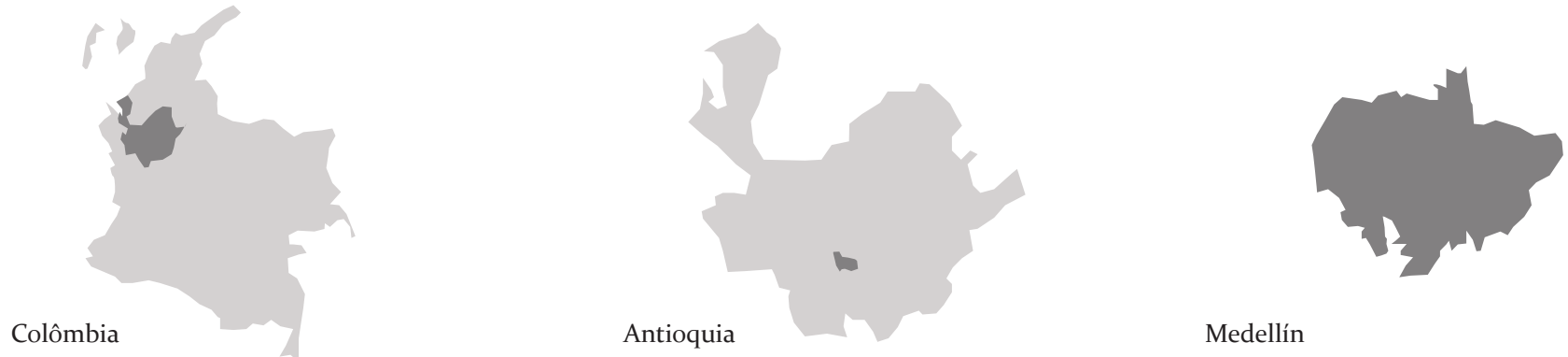

Medellín

Figura 2.1.3 Contextualização: Medellín

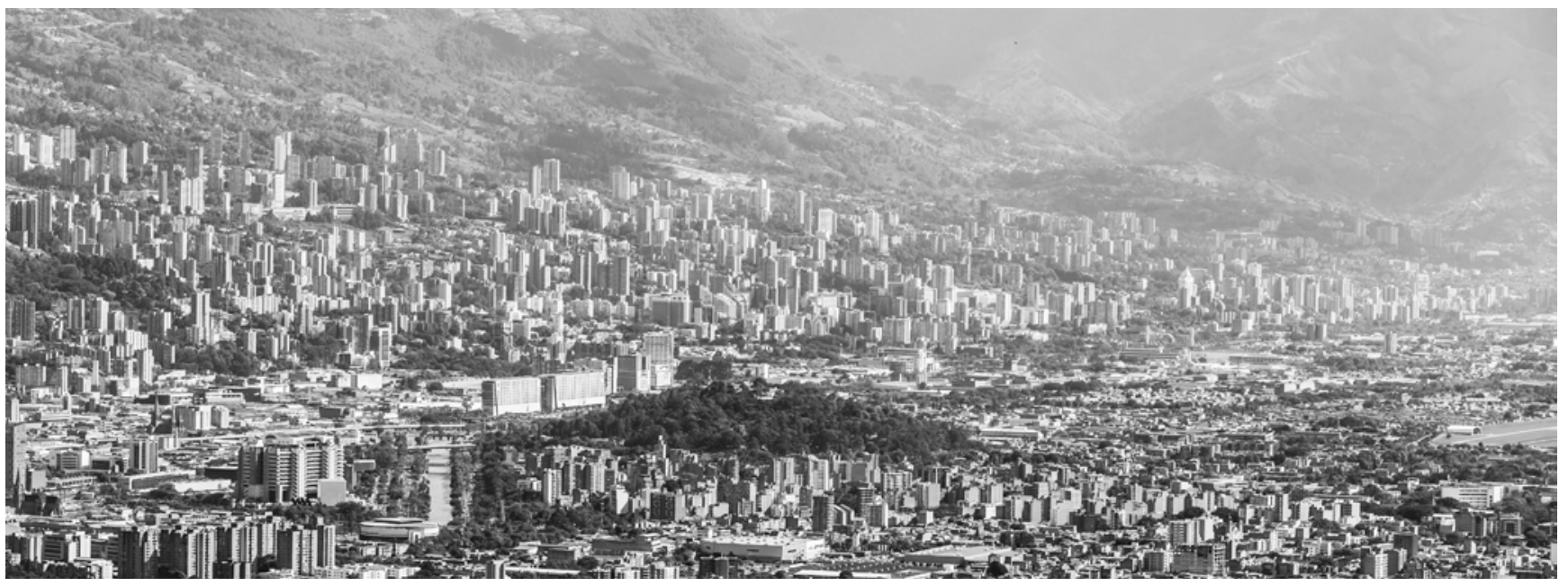

Figura 2.1.4 Medellín 
Painel 2.1 As duas cidades

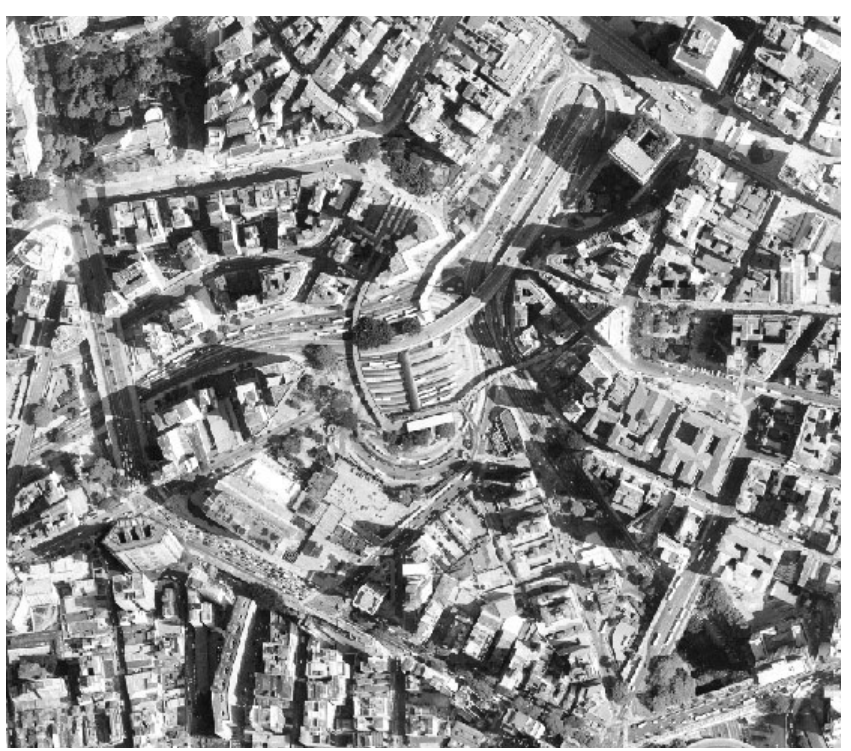

Figura 2.1.5 Centro de São Paulo

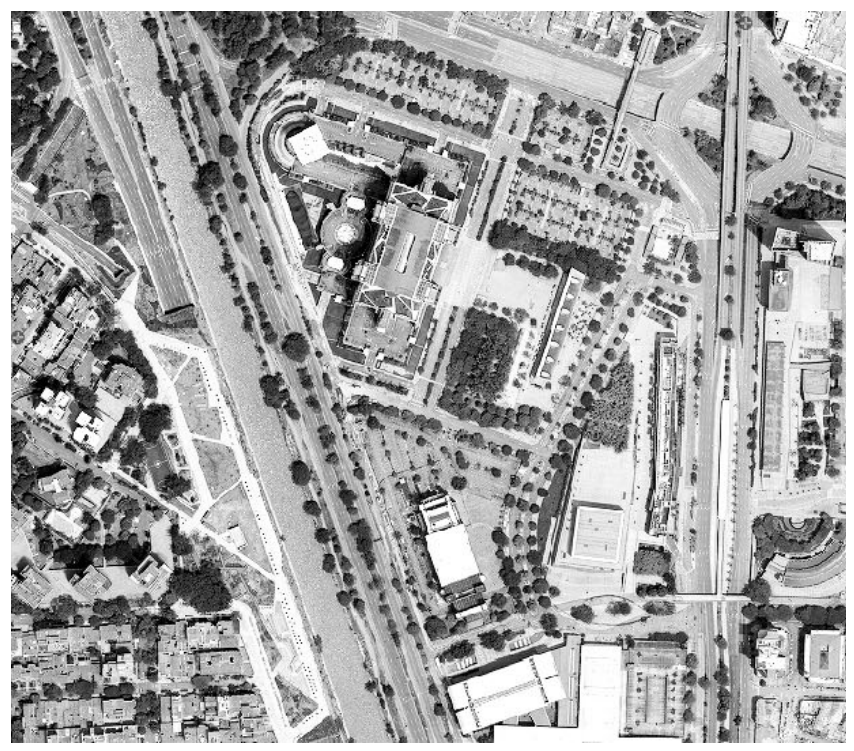

Figura 2.1.7 Alpujarra - Centro administrativo de Medellín

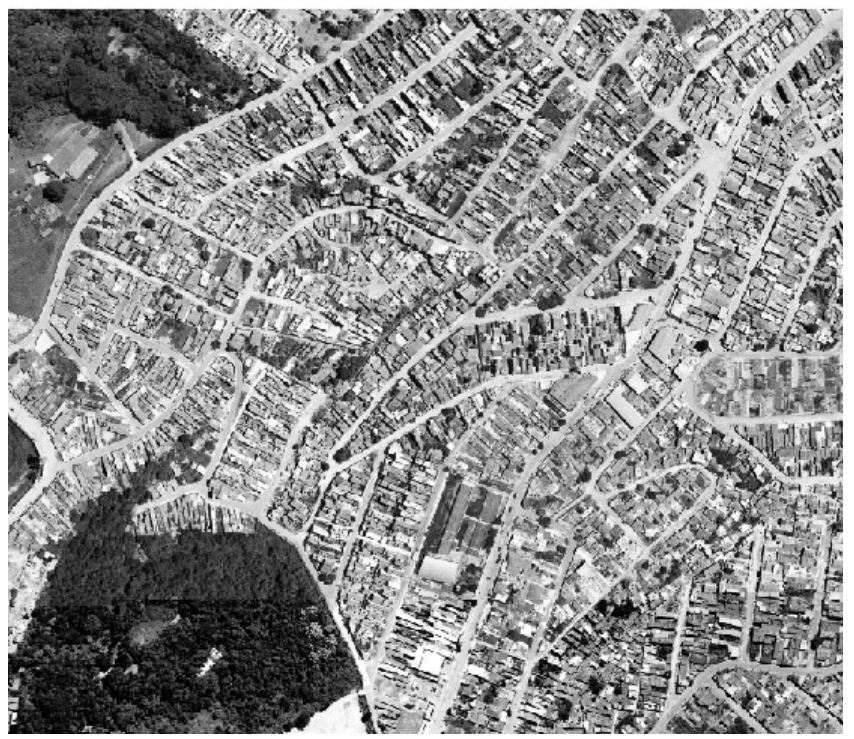

Figura 2.1.6 Grajaú

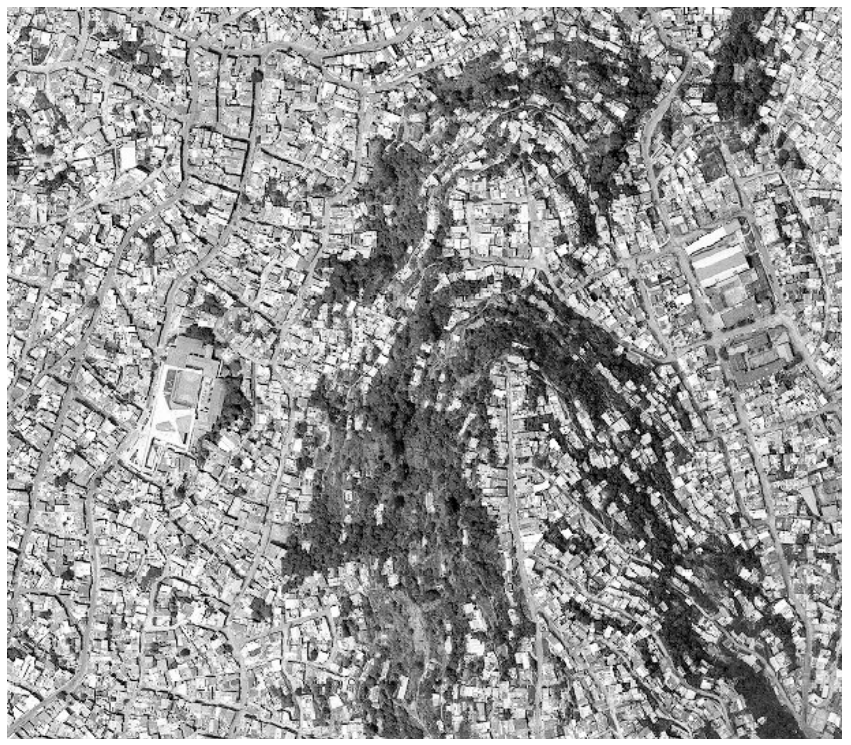

Figura 2.1.8 Santo Domingo Savio

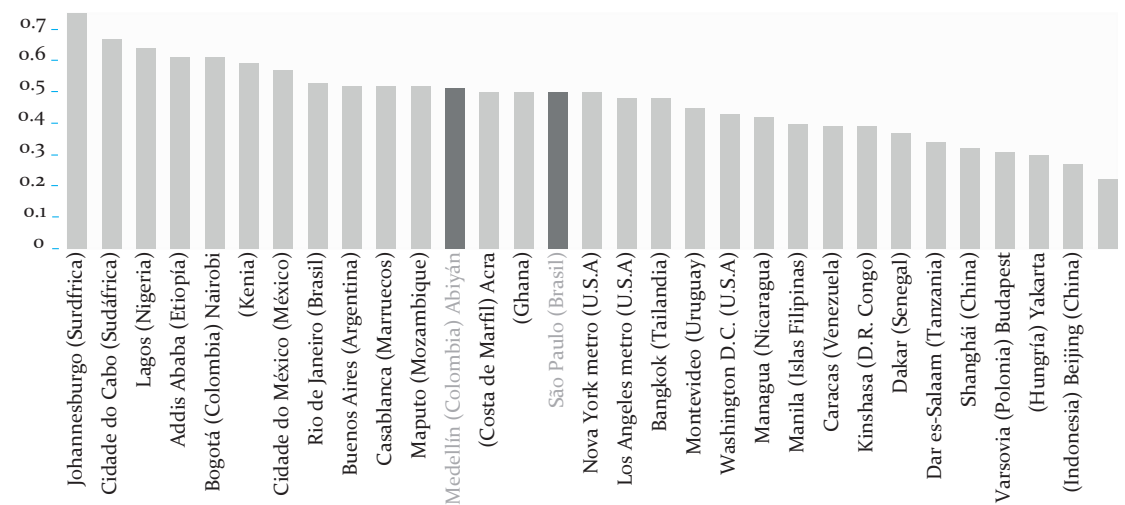

Fonte: ONU-Habitat, Global Urban Observatory, 2009. UN-ECLAC, UN-ESCAP, UNU e outras fontes other sou
Figura 2.1.9 Índice GINI

Desigualdade Populacional em uma mostra de cidades: Coeficientes GINI 2000-2009 (o,4=linha de alerta internacional) 
Painel 2.2 As Cidades e seus rios São Paulo

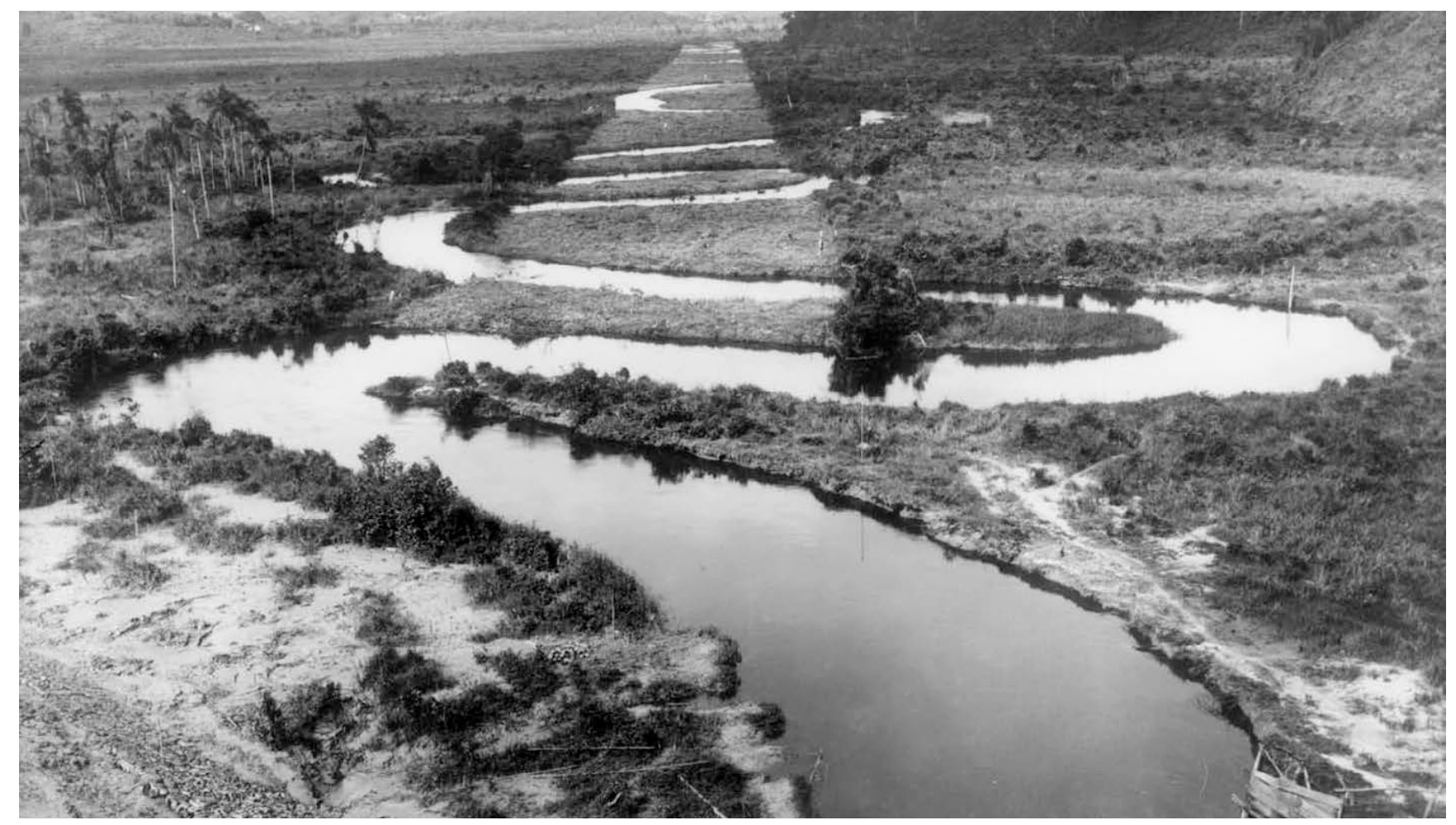

Figura 2.2.1 Desmatamento do traçado do canal do Pinheiros

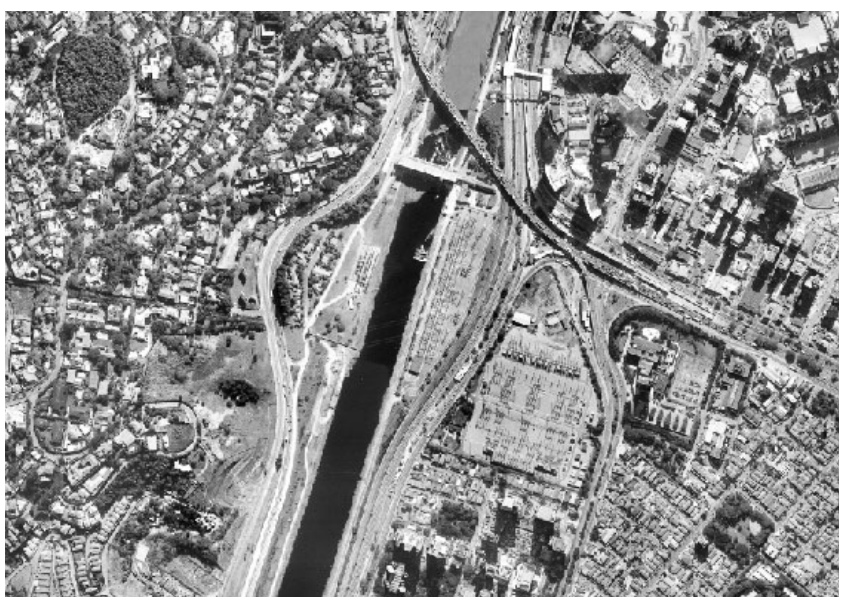

Figura 2.2.2 Rio Pinheiros

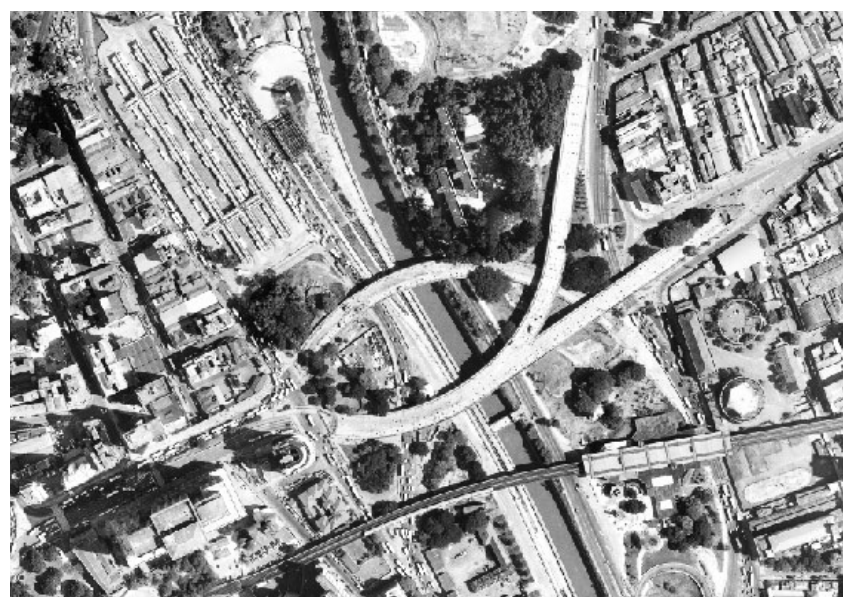

Figura 2.2.3 Rio Tamanduateí

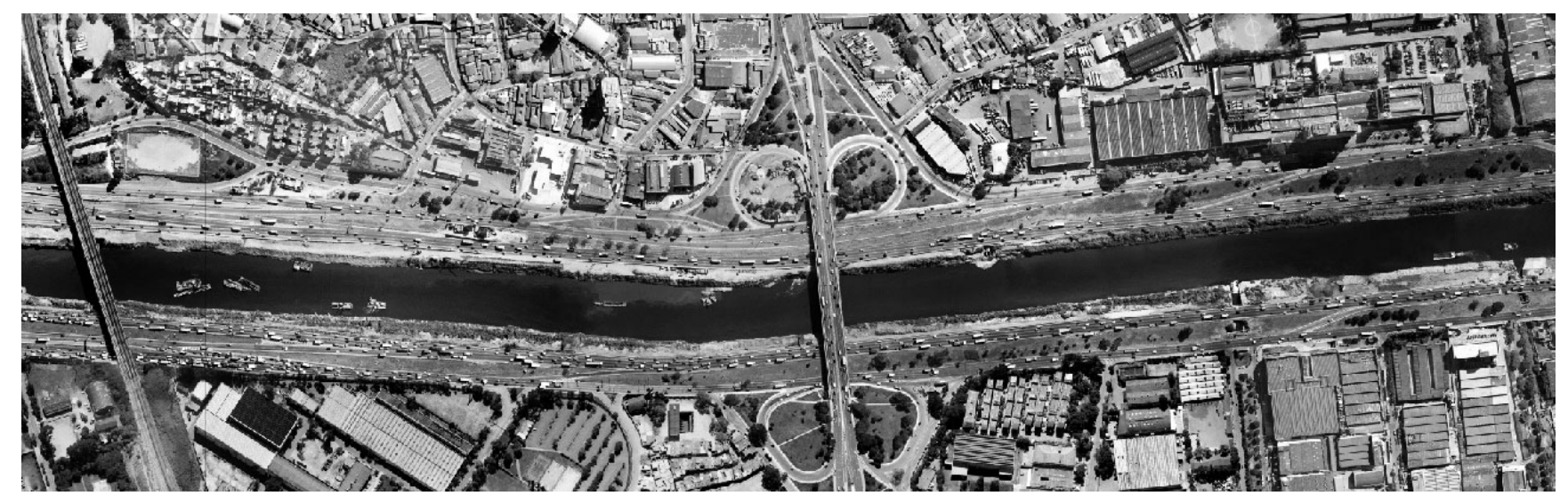

Figura 2.2.4 Rio Tietê 
Painel 2.2 As Cidades e seus rios Medellín

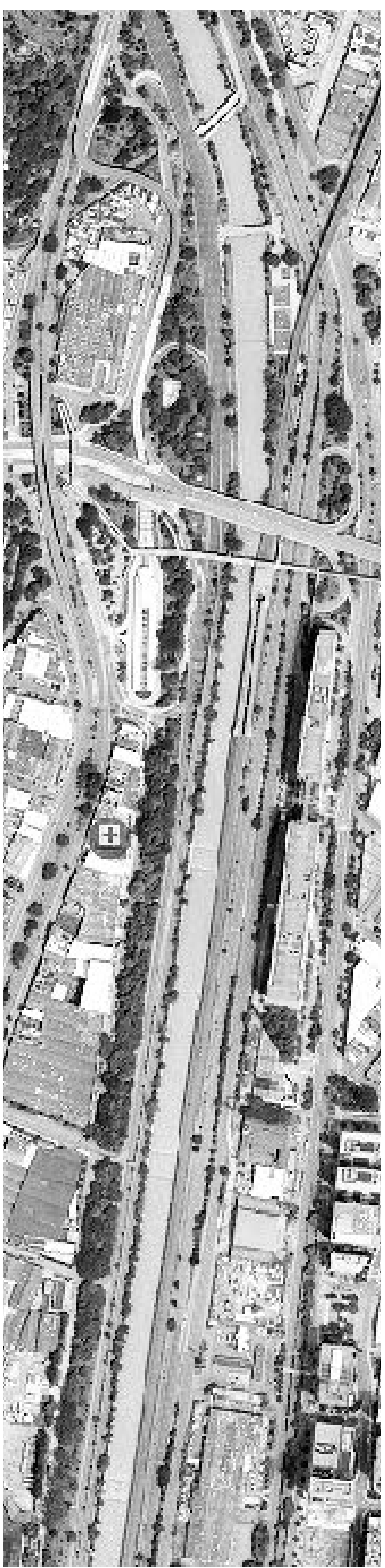

Figura 2.2.5 Rio Medellín

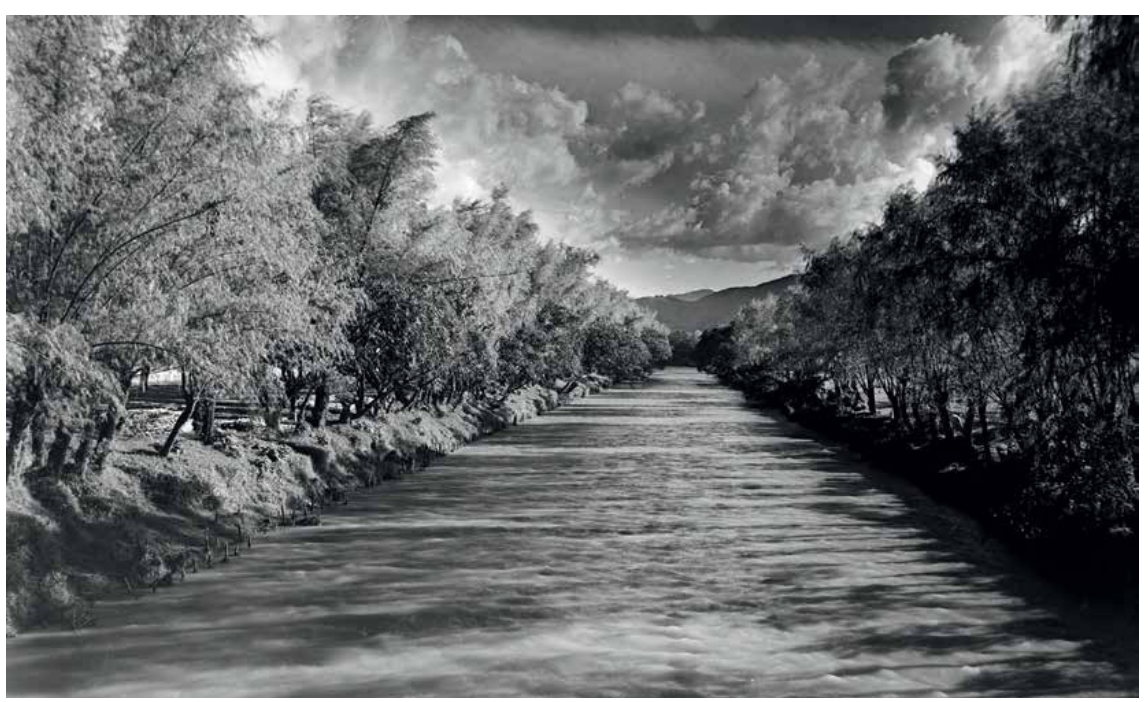

Figura 2.2.6 Río Medellín. 1928

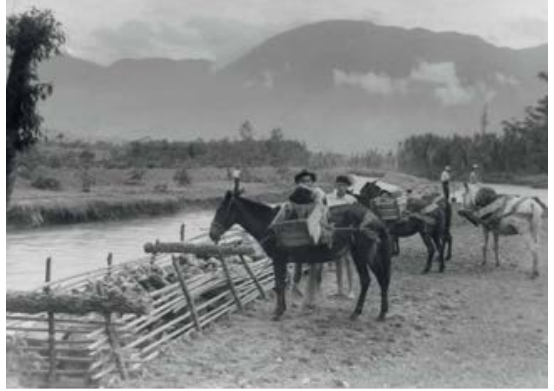

Figura 2.2.7 Mulas e trabalhadores no rio Medellín. 1942.

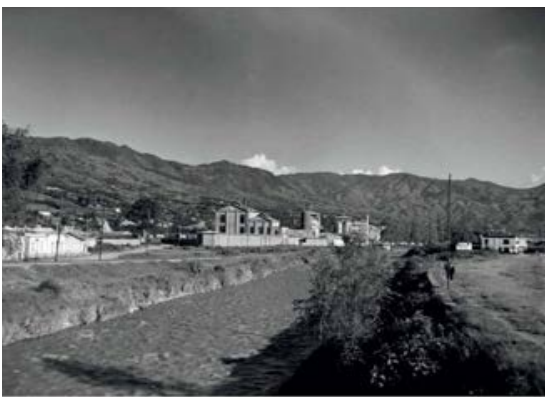

Figura 2.2.8 Río Medellín.

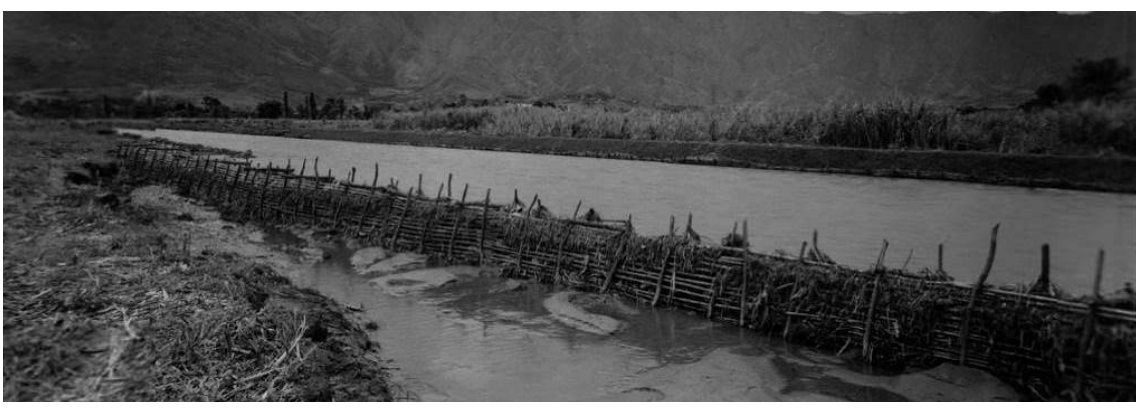

Figura 2.2.9 Trabalhos de canalização em 1941

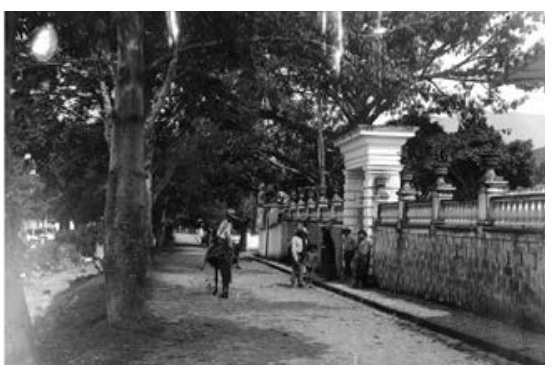

Figura 2.2.10 Quebrada Santa Helena, 1912 Bairro Quebrada Arriba

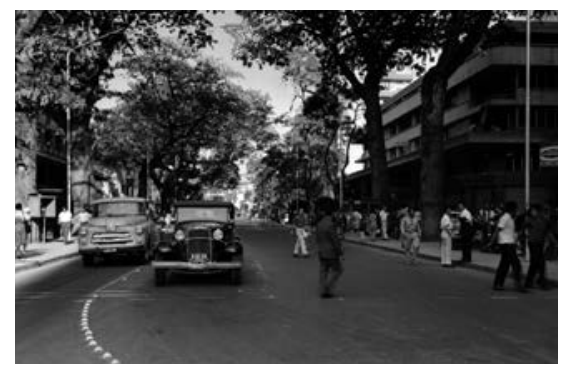

Figura 2.2.11 Quebrada Santa Helena, 1967 Avenida La Playa sobre a quebrada canalizada 

Medellín é a capital do departamento de Antioquia, localizada na região noroeste da Colômbia. A cidade se assenta sobre o ramo central da cordilheira dos Andes ${ }^{39}$, a 1538 metros de altitude, na porção central do Vale do Aburrá, que tem cerca de $90 \mathrm{~km}$ de extensão. Ela é a segunda cidade mais populosa e rica do país, com cerca de 2,5 milhões de habitantes ${ }^{40}$, ocupando uma área total de $380,64 \mathrm{~km}^{2}$, ou seja, $1 / 4 \mathrm{da}$ área da cidade de São Paulo. E, desse total, somente $110,22 \mathrm{~km}^{2}$ são de solo urbano, que se organizam em 6 zonas compostas por 16 comunas, agrupando 249 bairros. Já a área rural de $270,42 \mathrm{~km}^{2}$, concentrada nas bordas laterais da cidade, divide-se em 5 corregimientos: San Sebastián de Palmitas, San Cristóbal, Alta Vista, San Antonio de Prado, Santa Elena.

A cidade é o núcleo da Área Metropolitana do Vale de Aburrá ${ }^{41}$, que é composta por outros nove municípios: Barbosa, Girardota, Copacabana, Bello, Itagüí, La Estrella, Envigado, Sabaneta e Caldas ${ }^{42}$, somando 3,5 milhões de habitantes ${ }^{43}$. Todas elas cortadas longitudinalmente pelo rio Medellín (ou Aburrá), na direção norte-sul. Essa divisão entre vertentes oriental e ocidental impacta a ocupação e integração total do tecido urbano de Medellín, conferindo características bem distintas entre os dois lados, bem como entre os bairros localizados na planície e aqueles que sobem as encostas.

Esse relevo acidentado e a decorrente fragmentação do território foi o que dificultou a consolidação de um pacto político estável na Colômbia. Isso porque o isolamento das diferentes regiões se provou um entrave ao controle militar, fundamental à hegemonia de um poder centralizado. Desse modo, conformaram-se fortes grupos de dirigentes locais, com grande participação da igreja e de associações civis. Na ausência de um governo nacional forte, a cidadania na Colômbia (uma república desde 1819) se estruturou por meio da afiliação desses grupos a um dos partidos políticos dominantes. Isso resulta na excludente divisão oligárquica do poder entre conservadores e liberais, característica comum aos novos Estados independentes latinoamericanos, sendo responsável pela configuração de um emaranhado de rivalidades locais em todos os níveis (HYLTON, 2010, p. 46-48).

\footnotetext{
${ }^{39}$ A cordilheira se divide em três ao adentrar o território colombiano.

$4^{\circ}$ População prevista em 2018, segundo projeções realizadas pela Alcaldía de Medellín, Perfil Demográfico 2016-2020 disponível em: <https://www.medellin.gov.co/irj/go/km/docs/wpccontent/Sites/Subportal\%2odel\%2oCiudada no/Plan\%2ode\%2oDesarrollo/Secciones/Informaci\%C3\%b3n\%2oGeneral/Documentos/POT/m edellinpoblacion.pdf $>$ Acesso em 16 de agosto de 2018.

${ }^{41}$ A Região Metropolitana do Vale do Aburrá é uma entidade administrativa de direito público que associa os 10 municípios que compõem o Vale do Aburrá. Foi criada por meio da Portaria Departamental no 34 , de 27 de novembro de 1980, para a promoção, planejamento e coordenação do desenvolvimento conjunto e da prestação de serviços dos municípios que a formaram. Atualmente cumpre funções de: Planejamento do território sob sua jurisdição; autoridade ambiental na área urbana dos municípios que a compõem; autoridade metropolitana no transporte de massa; executora de obras de interesse metropolitano.

${ }^{42}$ Trata-se da primeira área metropolitana criada na Colômbia, em 198o. Os municípios são integrados geograficamente, mas também em sua economia e na prestação de serviços de energia, água, esgoto e telefonia (ALCALDIA DE MEDELLÍN, 2014).

43 Conforme dados do censo oficial DANE (Departamento Administrativo Nacional de Estadística), 2005 .
} 
Desse modo, se estabeleceram as bases do conflito armado e da grande violência que se alastraria pela Colômbia: um problema histórico, político, econômico e fundamentalmente espacial.

Condicionada também por essas disputas políticas, Medellín irá se desenvolver na base de uma economia agrário-exportadora, sofrendo um processo de industrialização rápido, demandando medidas intensas para adaptar seu território de modo a acompanhar o compasso acelerado da modernização tardia. Interagindo com esse processo, se deu a migração populacional massiva do campo para a cidade, que buscava trabalho ou fugia do conflito armado nas áreas rurais. Isso deflagraria o aumento exponencial de demanda por moradia e serviços sociais para esses migrantes, algo negligenciado pelo poder público por sucessivas décadas.

Assim, ao analisarmos a estrutura urbana de Medellín, vemos como resultado desse processo, segundo Perfetti del Corral (1995, p. 11), a sobreposição de projetos e visões urbanísticas em fragmentos de três cidades diferentes: o centro, que herdou o traçado de grade da cidade colonial (1675-1710); o ensanche (1890-1935) que estendeu para as encostas do nordeste as perspectivas das ruas contínuas impostas à topografia, na chave racionalista do Plan Medellín Futuro; e a margem ocidental do rio, que delineia o projeto da cidade moderna do plano regulador, definida conforme os parâmetros do CIAM.

Mas, na periferia dessa urbanização formal, visualiza-se outra cidade. Nas encostas circundantes, onipresentes na paisagem, se avolumam os tugúrios, nome dado às favelas de Medellín. Quando do início da ocupação, eles configuraram territórios ignorados pelas políticas urbanas, depois passaram a ser alvo de medidas que previam sua erradicação ${ }^{44}$. A superação desse paradigma se daria somente com o agravamento do conflito armado e de seus imensos impactos socioespaciais, que não se restringiram ao território marginalizado. A expansão da crise de violência para a cidade formal se consolidaria como uma pressão, exigindo a ressignificação dessa problemática urbana aos olhos do poder público. Somente assim, a cidade informal passaria ao centro das preocupações, invertendo a lógica e as prioridades do planejamento corrente. Isso implicou a necessária renovação de instrumentos urbanísticos, arranjos institucionais e metodologias de projeto especiais para enfrentar essa realidade, saindo da condição de rejeição da existência das áreas informais, para a estratégia de integração destas à cidade.

Esse processo se deu a partir do final dos anos 1980, quando a cidade mergulhou em uma crise de violência urbana levando ao esfacelamento da dimensão pública, ou seja, a impossibilidade da vivência coletiva do espaço urbano em uma cidade sitiada por fronteiras invisíveis ${ }^{45}$. Essa

\footnotetext{
44 Conforme aponta Sánchez Mazo (2014), os assentamentos precários em Medellín são registrados desde 1840 , quando um grupo de escravos emancipados se organiza no bairro $\mathrm{O}$ Salado, na zona centro-ocidental da cidade. Mas é a partir de 1930 que a cidade se torna atrativa para a população externa por conta da atividade industrial, gerando grandes ondas de migração. Esse processo sofre nova intensificação na década de 1970.

45 Termo cunhado em Medellín para apontar os limites entre localidades dominadas por gangues ilegais, criminosos ou grupos armados de esquerda ou direita. Isso significava que, se uma pessoa ou grupo de pessoas excedesse o limite de seu local de residência, sem aviso prévio,
} 
cidade sob tensão permanente exigiu medidas transversais de combate ao conflito, pois as estratégias de guerra, quase sempre apoiadas pelos $\mathrm{EUA}^{46}$, que abatem o inimigo de cima e com força maior, não se provaram efetivas. O problema se multiplicou e contaminou os espaços cotidianos, demandando soluções de todas políticas sociais e estratégias de desenho urbano que pudessem dar suporte a transformação dessa ordem social. Nesse sentido, é preciso sublinhar que a dimensão espacial e urbana emergiu como principal característica das saídas formuladas em torno dessa crise, ainda que provenientes das diferentes esferas administrativas. Isso fez de Medellín um laboratório de experiências, que já datam de mais de 15 anos e que permitem pensar sobre os impasses da dimensão produtiva e social do processo de modernização e desenvolvimento da forma urbana de São Paulo. E, consequentemente, nas ferramentas de ação da A\&U sob essa inescapável condição. É válido observar que as análises sobre esse processo político e urbanístico têm provocado juízos de condenação ou sucesso irrestrito. Mas tentando nos afastar de polarizações pouco produtivas, mobilizamos esse caso porque permite pôr em perspectiva as contradições que surgem do enfrentamento das particularidades da matriz urbana real das cidades latino-americanas. Menos em um sentido exemplar, de modelo a ser seguido, e mais como experiência que permite a reflexão crítica sobre os limites e possibilidades dos ganhos sociais, e também nos faz pensar sobre as novas questões que surgem na produção desse complexo espaço urbano.

Ainda que essa experiência tenha as tonalidades específicas do processo colombiano, adquire contornos muito similares aos fenômenos verificados em cidades como São Paulo. Se o problema do narcotráfico e da violência urbana por aqui, aparentemente, se manifestam de modo mais brando, as demandas sociais em nossa imensa periferia, no entanto, não parecem menos urgentes. Elas, talvez, estejam somente mais abafadas pela confortável distância que diminui a visibilidade e separa os centros de decisão de nossos bairros mais carentes e oprimidos pelo crime organizado. Afinal, se Medellín vem formulando novas hipóteses no sentido de reduzir o impacto da urbanização explosiva e segregadora, arriscando na espacialização de um novo pacto social em meio a crise urbana, isso demanda o entendimento dos agentes, das estratégias e dos resultados em torno desse projeto. É o que propomos a seguir.

elas poderiam ser vítimas de um grupo que exerce o controle desse território (Guitérrez Tamayo \& Sánchez Mazo, 2017, p. 102)

${ }^{46}$ A operação Marquetália, em 1964, no contexto do Plan LASO (Latin American Security Operation) foi uma das primeiras grandes investidas militares contra guerrilheiros das Farc (Forças Armadas Revolucionárias da Colômbia) apoiada pelos EUA, no contexto do combate do país ao comunismo no subcontinente. E também é o caso do Plan Colombia I, ou o "Plano para a paz, a prosperidade e o fortalecimento do Estado" (Presidência da República, 200o), o PCI estabeleceu originalmente que as negociações com a guerrilha eram a resposta mais adequada por parte do Estado para o problema do conflito armado. No entanto, dada a necessidade de garantir o apoio do Plano dos EUA, ele foi se tornando um programa de combate ao narcotráfico intensificado. Uma vez que as negociações fracassaram no início de 2002, o PCI sofreu outra mutação, sendo que na administração Uribe se sobressaiu com o endurecimento do confronto militar com grupos guerrilheiros. Cf. OLAVE ARIAS, 2013 e ROJAS, 2007. 
Fundada em 1616, Medellín se origina de uma vila voltada à mineração do ouro. Mas caracterizou-se, desde o princípio, como um importante entreposto comercial e, ao final do século XVIII passou a articular a economia regional tornando-se a capital da Antioquia, em 1826. O terreno de sua fundação se situa entre o rio Medellín (margem oriental) e a quebrada ${ }^{47}$ Santa Elena, que nele deságua. Tratava-se de um sítio privilegiado pelos seus recursos naturais, como a água abundante para o povoado. O Parque Berrio ${ }^{48}$, originalmente a Plaza Principal, foi o centro fundacional de Medellín, obedecendo a típica quadrícula espanhola. Dessa cidade colonial, além do traçado, resta somente a Igreja Candelária (1776), situada ao lado dessa grande praça onde, em 1649, se construiu um primeiro edifício em madeira e palha que atendia a todo o vale, e a paróquia La Veracruz (1809) onde originalmente havia uma ermida, em 1682 (VÉLEZ WHITE, 20oo). Isso denota o traço marcante de uma urbanização acelerada que não hesitará em remodelar sucessivamente seu território para acomodar as etapas do processo de modernização econômico.

Nesse sentido, assim como em São Paulo, o ciclo do café foi de extrema importância para alavancar o primeiro momento de desenvolvimento mais expressivo da cidade, visto que ela passou a centralizar as atividades econômicas da importante produção cafeicultora antioqueña. Além disso, esse capital financiaria o arranque das atividades industriais, processo que se dá entre 1890 e 1913. Nesses anos se instalam grandes indústrias têxteis e, ao mesmo tempo em que elas fortaleciam e expandiam a economia local, impulsionavam profundas transformações urbanas. Para tanto, buscou-se a institucionalização de atividades ligadas ao planejamento da cidade e à estruturação dos serviços públicos para atender a essa pressão, por meio de duas instituições: Consejo Municipal (pública) e a do Serviço de Mejorias Públicas (privada), conforme aponta Aristizábal (2016). Ambas eram dirigidas e influenciadas por membros da elite local, de modo que as primeiras experiências urbanísticas da cidade refletem suas necessidades, relativas à expansão do setor produtivo e aos seus interesses imobiliários.

A SMP será a grande responsável por promover contratos municipais para parques, estradas e bairros e organizar a canalização de córregos e rios. Essa modernização se dava a passos rápidos: uma usina de eletricidade foi construída em 1897 e a iluminação de rua foi instalada em 1898; em 1889, uma escola de engenharia complementou a primeira universidade da cidade, fundada em 1871 (HYLTON, 2007, p. 73). Esses acontecimentos refletem a racionalidade e lógica empreendedora de "gerentes técnicos" formados na Escola de Minas (fundada em 1887). Essa geração terá grande importância na direção e a administração de

\footnotetext{
${ }^{47}$ As quebradas são riachos ou córregos. Em Medellín tem a característica de correrem das montanhas para o Rio Aburrá.

${ }^{48} \mathrm{O}$ parque recebeu esse nome somente em 1895
} 
empresas públicas, com a municipalização, entre 1917 e 1921, dos principais serviços domiciliares (água, esgoto, energia e telefone) ${ }^{49}$.

A inserção de Medellín no mercado mundial, primeiro com a comercialização do café e depois com o processo de industrialização, se dará mediante a implantação da infraestrutura ferroviária e da retificação e canalização de seu principal rio. As duas vias férreas que passaram pela cidade ao sul e ao norte, respectivamente a de Amagá (1911) e a Ferrocarril de Antioquia (1914), conectaram-na com as áreas produtivas e com os dois importantes portos do país: Barranquilla (Mar do Caribe) e Buenaventura (Oceano Pacífico). A cidade passou a se integrar na escala regional antioqueña, facilitando a chegada de ouro, carvão e da produção de alimentos provenientes da região sudoeste. $\mathrm{O}$ café que chegava à cidade era escoado aos portos que também viabilizam a importação de mercadorias e maquinários para indústria em crescimento (PRECIADO ZAPATA, 2015, p. 31)..$^{50}$

No esteio dessas transformações da ferrovia, aumentou a pressão para que fossem solucionados diversos problemas em torno do Rio Medellín. Desde 1883 a canalização do rio suscitava muitos interesses de toda a classe dirigente da cidade, como a possibilidade de melhorar as condições higiênicas e de salubridade, mas também pela possibilidade de drenar os terrenos e incorporá-los às dinâmicas do solo urbano, expandindo a malha urbana entre a antiga Villa e as margens do rio (GONZÁLEZ ESCOBAR, 2007, p. 83). Entre 1890 e 1910 foram feitos diversos estudos para obras de engenharia visando a solução das inundações e dos terrenos pantanosos. As práticas populares de banho e recreação nos rios também já pareciam incompatíveis com o desejo de modernização de suas elites, de modo que essas obras deveriam corresponder também a sobreposição desses novos ideários em relação a antigos hábitos. Assim, entre 1910 e 1914 se retifica e se canaliza o primeiro trecho, beneficiando a região do importante mercado de Guayaquil e da estação Central de Ferrocarril da Antioquia, principal porta de entrada comercial da cidade. A partir de 1936 começou o processo de retificação de trechos ao norte e ao sul, em boa parte financiados por essa companhia ferroviária, mas também por outras indústrias que tinham interesses em sanar seus terrenos nas várzeas do rio. Em 1941, as obras no rio passaram a ser atribuições do governo central, pois integrariam todos os municípios do Valle do Aburrá, o que faz desse projeto de canalização e retificação do rio o mais importante projeto urbano para o que seria a futura área metropolitana, conforme percebe Preciado Zapata. Ao longo do rio também se construíram vias conectando os núcleos industriais das cidades do vale e que hoje, se constituem um vetor de importância nacional por conectarem os departamentos do norte e do sul da Colômbia. Com isso percebemos

\footnotetext{
${ }^{49}$ Em 1955, as empresas municipais públicas (água, esgoto, energia e telefone) foram unificadas e se converteriam nas Empresas Públicas de Medellín (EPM), conforme a conhecemos hoje.

${ }^{50}$ A demora na construção da ferrovia da Antioquia exemplifica os problemas enfrentados na Colômbia. Teve de superar dificuldades técnicas, mudanças de contratos e as variadas guerras civis que paralisaram o avanço da linha férrea. A primeira locomotiva chegou à Medellín em 1914, mas a linha só ficou pronta quando se construiu o túnel de La Quiebra em 1929. Cf. GONZÁLEZ ESCOBAR, 2007.
} 
que a domesticação do rio e a concentração de infraestruturas ao longo de seu eixo constituem as marcas no território desse processo de viragem entre a cidade comercial e a cidade industrial.

E as linhas férreas não só transportavam carga, mas funcionavam também como uma linha de transporte massivo entre as cidades da região. A construção das linhas de bonde, iniciadas em 1919, chegavam já em 1923 a mobilizar mais de 9000 passageiros diários, incrementando a mobilidade na cidade. Isso facilitou a expansão urbana no sentido nordeste, possibilitando a localização da população trabalhadora e a classe média em novos bairros (CORREA RESTREPO, 2012, p. 161).

O sentido do crescimento também era reforçado por projetos urbanos como a criação do Parque Bolívar (1888-1892) e a contígua construção da catedral da cidade (1875-1931). Note-se que os terrenos para essas obras foram doados por membros da elite local com a finalidade de valorizar suas terras, que foram urbanizadas tão logo da construção desses marcos urbanos. Ao final do século 19, junto ao passeio de La Playa (ao longo da Quebrada Santa Elena) essa região se converte na área residencial mais elegante da cidade (BOTERO, 1993, p. 19). Medellín cresceria recebendo levas migratórias, particularmente nas primeiras décadas do século 20 , atraídas pela oferta de emprego na atividade industrial, mas também para o estudo dos jovens da elite regional, além daqueles que a procuravam pela importância política, o que fornecia maiores oportunidades do que as demais cidades do departamento (RAMÍREZ PATIÑO, 2011).

Entre 1890 e 1937 a cidade sofrerá transformações de maior significado em sua estrutura urbana orientadas pelo projeto chamado de "Medellín Futuro". Derivado de um amálgama de ideários ${ }^{51}$, mas com forte apelo urbanístico parisiense promovido pelos membros da SMP, não configurava uma proposta original com a legitimidade e a aderência à realidade do território que permitisse orientar continuamente uma proposta de planejamento urbano. No entanto, o projeto controlou o crescimento da cidade, iniciou práticas urbanísticas, introduziu reflexões e realidades da modernização, como a ampliação das ruas, o caminho para o bonde, a projeção e a realização de parques, a construção de infraestrutura e equipamentos comunitários (o aqueduto, o telégrafo, a praça para a feira, o Parque da Independência, a construção de bairros afins), conforme aponta Perfetti del Corral (1995, p. 17).

O desenvolvimento da cidade demandou, a partir da década de 1930 uma série de obras infraestruturais como, por exemplo, esgotamento sanitário. Estas já serão realizadas de forma pragmática, pressionadas pelo problema de enchentes e insalubridade. As propostas para esse problema não terão qualquer leitura urbanística mais qualificada. É de se observar que, assim como se fez com o Rio Medellín, seus principais afluentes (como a Quebrada Santa Elena), que haviam se tornado receptores de águas servidas, serão paulatinamente retificados e

\footnotetext{
${ }^{51}$ A multiplicidade de aportes técnicos que incidiram sobre o tecido urbano nesses anos carregam pressupostos desenvolvidos pelo movimento higienista francês e inglês, o urbanismo científico de Cerdá, o pragmatismo técnico alemão, os desenvolvimentos do City Planning norte americano, segundo González Escobar (2007, p. 132)
} 
canalizados (ÁLVAREZ ARBOLEDA; CHICANGANA BAYONA, 2015). Esse destino do rio Medellín e de diversas quebradas será, a partir de então, o avesso de sua origem. Deixam de ser elementos fundacionais do povoado, estruturantes da paisagem e do lazer urbano, para se tornarem entraves a seu desenvolvimento, reduzidos a problemas sanitários ${ }^{52}$.

Ao final dos anos 1940, o urbanismo pautado pelo ideário de embelezamento e melhoramentos atingia seu limite na orientação de diretrizes de planejamento da cidade. A atualização do plano se fazia necessária e foi facilitada pela lei 88 de 1947, que incluía, pela primeira vez na legislação urbanística colombiana, a obrigação de se desenvolver planos regulatórios para cidades com mais de 20 mil habitantes.

Em 1948, os arquitetos Josep Luis Sert e Paul Lester Wiener, parceiros na empresa TPA (Town Planning Associates), foram contratados para fazer um Plano Piloto para Medellín. Isso porque entre 1942 e 1959 eles fizeram planos urbanísticos para diversos países latino-americanos como o Brasil, Peru, Venezuela, Cuba. Na Colômbia, também elaboraram os planos para as cidades de Tumaco (1947), Cali e Bogotá (ambos em 1949, junto a Le Corbusier). Os planos refletiam os conceitos da Carta de Atenas (1933) e organizavam a cidade de acordo com as quatro funções básicas: habitação, trabalho, lazer (cultivo do corpo e do espírito) e circulação. (SCHNITTER CASTELLANOS, 2003) 53 .

Esse modelo urbano exigia uma série de vontades políticas, além da disponibilidade de recursos econômicos, técnicos e humanos que, no caso de Medellín, não estavam disponíveis, resultando em uma aplicação parcial do plano, carecendo do senso de totalidade que estava implícito nele (PERFETTI DEL CORRAL, 1995, p. 19). Restaram alguns impactos isolados, como o centro cívico complementar, que acabou sendo executado somente na década de 1980 (La Alpujarra). A criação da Oficina de Planeación Municipal, criada naquele momento, reforçou a consolidação institucional do planejamento na cidade. $O$ macrozoneamento também deriva de leituras do Plano Piloto, como a localização da Zona Industrial ao sul do Vale, o terminal de transportes ao norte, a consolidação de um corredor multimodal paralelo ao rio, assim como a orientação da expansão do setor ocidental da cidade, também seguiu princípios gerais indicados. Atribui-se também, como um efeito tardio do Plano Piloto, a incorporação da noção de Área Metropolitana, como um modelo territorial específico de planejamento, pensado para a situação do Vale do Aburrá. Visto que anos 1970 ocorreria a formulação de um Plano Metropolitano por parte da Oficina de Planeacion del Municipio de Medellín e, posteriormente, no início dos anos 1980, consolidou-se a Área Metropolitana do Valle de Aburrá. A leitura do território proposta pelo plano também incluía o reconhecimento do rio e das quebradas como um potencial sistema de espaços públicos.

\footnotetext{
${ }^{52}$ Vide Painel 2.2.

${ }^{53}$ Vide Painel 2.3.
} 
O caso da construção do bairro La Floresta, previsto no Plano Piloto, no entanto, parece reiterar a problemática relação entre as propostas de Wiener e Sert e a realidade de Medellín. Pensado como um primeiro exemplo de habitação econômica para os trabalhadores, ele seria construído pelo Instituto de Crédito Territorial da Colômbia (ICT). O bairro previa casas econômicas em abóbada de tijolos cerâmicos organizadas segundo o urbanismo moderno. No entanto, das 140 casas inicialmente projetadas, apenas 40 foram construídas desse modo, cobrindo-se o restante com telhas de cimento-amianto devido a problemas de custo. Os serviços sociais projetados tais como igreja, centro de saúde, escola e playground não foram construídos. E o posterior desenvolvimento de obras viárias contribuiu para fazer desaparecer a unidade de vizinhança inicialmente proposta (SCHNITTER CASTELLANOS, 2003).

Esses são indícios daquilo que se percebe como um legado negativo do ideário modernista, no seu descolamento da realidade socioespacial a que se lança a transformar. Também se somam a esse problema consequências advindas da sua compreensão e implantação parcial, como a difusão de uma ideologia de renovação urbana (BOTERO, 1993; VÉLEZ WHITE, 200o; GONZÁLEZ ESCOBAR, 2014). Isso implicaria uma obsessiva destruição do passado; a ênfase nas diretrizes na adequação do sistema viário ao crescente fluxo de carros particulares e a localização do habitat dos diferentes setores sociais de acordo com uma clara estratificação socioeconômica (NARANJO GIRALDO; VILLA MARTÍNEZ, 1997, p. 48-53).

A subsequente formulação do Plano Diretor de 1959, acabou por reafirmar e complementar a experiência anterior. Na década seguinte, no entanto, realizou-se uma série de estudos inovadores que tentaram dar conta dos problemas cruciais da cidade que crescia com os fluxos migratórios. Esses estudos notavelmente abrangiam importantes problemas como o déficit habitacional, os tugúrios (favelas) e a regulamentação da urbanização (NARANJO GIRALDO; VILLA MARTÍNEZ, 1997, p. 41). Mas, se representavam um avanço ao realizarem diagnósticos mais acurados, careciam, no entanto, de políticas que dessem conta de gerenciar e operacionalizar estratégias integradas de ação, baseadas nessas leituras da realidade. Assim, a cidade seguiu crescendo sem instrumentos ordenadores aderidos à problemática realidade.

Nesse ínterim, o crescimento explosivo da cidade foi reduzido a um problema de expansão da mancha urbanizada e seria "resolvido" com a revisões do perímetro urbano estabelecido desde 1945, pelo Acordo 52 de 1963. A medida incorporava bairros que tinham sido invadidos ou loteados ilegalmente e também que receberam unidades habitacionais do Instituto de Crédito Territorial (ICT). No entanto, parte significativa dos bairros na fronteira com a zona rural ficaram fora do recorte legal. Com a lei 66 de 1968, que proíbe os governos locais de dotarem de infraestrutura os assentamentos irregulares ou invadidos fora do perímetro definido anteriormente, gerou-se uma situação incompatível entre a realidade e os instrumentos de planejamento. Conforme apontam Naranjo Giraldo e Villa Martinez (1997, p. 48-53), essas 
medidas se afastaram dos processos socioespaciais que conformavam o território, de modo que não atenderam às demandas da população e pouco contribuíram para o nível administrativo. Esse processo se agravou no transcurso das décadas de 1960-1970, fazendo com que cerca de $50 \%$ dos habitantes de Medellín fossem residentes de bairros considerados ilegais. Contraditoriamente, esse foi o momento de difusão das políticas de erradicação dos tugúrios, ou seja, na rejeição da condição de metade da cidade.

Medellín parecia chegar ao final do século 20 tendo sua malha viária como único fator estruturante da totalidade do seu espaço urbano (CASTRILLÓN ALDANA; CARDONA OSORIO, 2014). Essa tendência fora sistematicamente reforçada não só pelos planos viários, mas por diretrizes de urbanização regidas pelos interesses privados, que se orientavam segundo os mais atualizados hábitos urbanos de consumo. O símbolo desse momento foi a inauguração do centro comercial San Diego, o primeiro shopping mall do país na cidade de Medellín, em 1972 (GONZÁLEZ ESCOBAR, 2010, p. 180).

Enquanto isso, os problemas resultantes do conflito armado se agravaram e deixaram de ser uma adversidade contida nos perímetros dos bairros informais. Medellín adentrou os anos 1980 sob uma grave crise urbana e social e, consequentemente, de governabilidade. Esse problema histórico encontrava seu ponto crítico, tornando a cidade, que outrora se orgulhava pelos seus avanços econômicos e modernizantes, um símbolo da falência do Estado colombiano.

\subsubsection{Arquitetura urbana em Medellín}

Os planos e projetos urbanos contemporâneos a serem analisados derivam de uma inevitável reflexão coletiva sobre a dura década de 1990. Medellín foi consagrada como a cidade mais violenta do mundo em 1991, registrando uma taxa de homicídios de 381 por 100.000 pessoas, índice que a equiparava a um território em guerra. Para efeito de comparação, o pico da taxa de homicídios da Região Metropolitana de São Paulo, considerando o período entre 1992 e 2005, se deu no ano de 1999 com 52 mortes para 100.000 pessoas (MELLO; SCHNEIDER, 2007), menos de um sétimo da verificada em Medellín.

O narcotráfico, a guerrilha, o paramilitarismo e a repressão praticada pelo próprio Estado resultaram nesse cenário e marcaram definitivamente a história da cidade. Mas essa violência deve ser compreendida a partir de um quadro mais abrangente, em uma cidade que cresceu em ritmo galopante no processo de industrialização ${ }^{54}$. Assim, as demandas por serviços públicos aumentaram na mesma medida em que se assistiu à precarização da vida urbana, e esse contexto socioespacial excludente alimentaria a guerra originada no jogo político entre conservadores e liberais, que seguia empurrando civis excluídos do sistema político ou econômico para o conflito armado.

${ }^{54} \mathrm{Cf}$. SANTOS, ANO, p.76. 
A cidade, que havia se tornado palco do famoso Cartel de Pablo Escobar, era também o lugar onde um Estado desacreditado vacilava. $\mathrm{O}$ caminho buscado para a superação desse impasse se deu, primeiramente, por meio de políticas nacionais de desmilitarização, com a prisão e extradição de líderes do narcotráfico e em operações militares apoiadas pelos EUA. Essas medidas se mostraram de eficácia limitada, diante das cicatrizes do conflito refletidas no cotidiano da cidade, que demandavam outra escala de ação, mais arraigada no presente e na localidade - e tão importante quanto - para a ruptura do que se configurava como um ciclo. É a esse contexto que o projeto do Urbanismo Social buscou reagir, como um método de intervenção urbana que se apoia em uma complexa articulação institucional do poder público e que depende intrinsecamente de ferramentas da Arquitetura e do Urbanismo.

Esse processo de transformação urbana e social vem sendo atribuído ao governo de Sergio Fajardo (2004-2007) que cunha o termo, mas se estende a Alonso Salazar (2008-2011) e Aníbal Gaviria (2012-2015), visto que eles dão continuidade a parte significativa dessas políticas urbanas, ainda que adotando outros slogans que denotam a alternância partidária. O atual prefeito Federico Gutierrez (2016-2019) segue valorizando tópicos reconhecíveis da agenda do Urbanismo Social, embora sinalize discordâncias significativas e descontinuidades de projetos do governo anterior.

Esse momento político, circunscrito nas duas últimas décadas, se apoia em importantes avanços conquistados alguns anos antes. A começar pelas eleições diretas de prefeitos de 1988, em uma tentativa do governo nacional de fortalecer a democracia. Isso acontecia ao mesmo tempo em que se negociava a paz com as Forças Armadas Revolucionárias da Colômbia (FARC), e que, contraditoriamente, a violência e a impunidade sofriam uma escalada vertiginosa. Houve também o aumento do mandato, que passou de 2 anos (1988), para três (1991) e por fim quatro anos (2004). Esses são passos significativos para o fortalecimento do governo local, levando em conta que entre 1948 e 1988, a cidade teve 49 prefeitos com uma média de 9 meses para cada mandato, justamente em um momento de crescimento explosivo e de necessária estruturação e liderança política (MARTIN; MARTIN, 2015, p. 52).

Mas foi com a promulgação da Constituição Política da Colômbia de 1991, que se consolidou uma grande evolução do discurso e da prática da cidadania e dos direitos civis, políticos e sociais, elevando a participação ao mais alto nível na história da política nacional, conforme apontam Lopera Perez et al (2017, p. 22). Ela efetivou a descentralização política, administrativa e fiscal do planejamento urbano, favorecendo certa inovação das políticas públicas locais relativas à organização do território.

Igualmente relevante são as diversas leis que dão corpo à Reforma Urbana proposta pela lei 9 de 1989, que delineou conceitos como o planejamento do desenvolvimento municipal, o espaço público, a expropriação, a proteção aos moradores nos projetos de renovação urbana, a legalização de títulos para a habitação de interesse social, as 
licenças e sanções urbanísticas, os bancos de terra, a integração imobiliária e o ajuste de terras (ARBOUIN-GÓMEZ, 2012, p. 31-32). Essa lei foi revisada pela Lei de Desenvolvimento Territorial 388 de 1997, que introduziu a função social e ecológica da propriedade ${ }^{55}$, a função pública do urbanismo, a distribuição equitativa de encargos e benefícios, com prevalência do interesse geral sobre o particular (ZUQUIM, 2017, p.8). Essa lei teria grande impacto nos municípios colombianos, ao permitir a estruturação dos primeiros Planos Diretores, ou os chamados Planes de Ordenamiento Territorial (POT), definindo este como um instrumento técnico e normativo com uma validade 3 mandatos. Como um plano indicativo, ele depende de outras ferramentas de gestão para a implementação de suas diretrizes. Estes instrumentos também foram regulamentados, como os Planos Parciais (Planes Parciales, PP) e as Unidades de Ação Urbana (Unidades de Acción Urbana, UAU).

A lei 388 contribuiu para o desenvolvimento desses dispositivos urbanísticos que criaram novas possibilidades de articulação entre os atores que incidem na produção do espaço, como a regulação do financiamento dos projetos urbanísticos por meio de instrumentos de recuperação dos incrementos de valor da terra (plusvalías ou maisvalias fundiárias). Isso contribui para que o poder público recupere parte da valorização imobiliária originada pelas suas ações urbanísticas, e permite que ele possa reinvesti-las em outros projetos públicos ${ }^{56}$. Essas medidas são fundamentais para uma política urbana redistributiva.

O referido conjunto de leis se somou à abertura econômica do governo colombiano em resposta ao processo de globalização. Nota-se a transição do papel do Estado que, de provedor, torna-se promotor e facilitador de acesso aos serviços públicos e que para isso passou a dispor de uma série de instrumentos de mediação da produção do espaço urbano, em termos políticos e econômicos. Também, a Constituição de 1991 contribuiu para consolidar a descentralização política, administrativa e fiscal. Essa conquista de autonomia implicou um grande desafio para os governos municipais buscarem solvência

\footnotetext{
${ }^{55}$ Autores como Tirado Mejía (1986) indicam que a Constituição Colombiana de 1936 já teria trazido importantes avanços sobre a função social da propriedade. Essa reforma constitucional foi um marco importante de um constitucionalismo social que incorporava debates renovados de outros contextos similares. Porque ela reflete o impacto da Constituição Mexicana de 1917 que falava da propriedade privada com obrigações sociais, da propriedade comunitária e da propriedade estatal. Esse fato nos interessa na medida em que boa parte do debate sobre os avanços nas reformas urbanas dos países latino-americanos se mostra beneficiado quando do conhecimento aprofundado de realidades compartilhadas por outros países do subcontinente. E também porque, para averiguar a efetividade dos marcos regulatórios, o que depende de questões conjunturais relativas a vontade política e de instrumentos executivos, é também preciso constatar a dimensão temporal, fundamental para o amadurecimento, a estabilização e institucionalização dessas pautas.

${ }^{56}$ Para tanto, são especificadas três fontes desses benefícios: a conversão de solo rural em solo urbano; o estabelecimento ou alterações de zoneamento de usos urbanos; e a autorização de um maior aproveitamento do solo em edificação, elevando sua densidade construtiva. A lei também incluiu a permissão de leilão público de terras sem uso para que sejam destinadas à habitação de interesse social; o direito de preferência na compra de terras pelo poder público (preempção); a aquisição pública de terras a preços estabelecidos anteriormente ao anúncio de projetos urbanos; e a possibilidade de usar reajustes de terras em planos parciais de desenvolvimento (SMOLKA, 2014, p. 14-15).
} 
financeira e capacidade de gerenciamento institucional frente a uma série de atribuições adquiridas nesse processo.

Por isso, a transformação de Medellín também se justifica por certas particularidades de um município cujo porte resulta numa significativa captação de impostos territoriais e que detém empresas públicas intersetoriais lucrativas, fundamentais para o financiamento de seus projetos urbanos. Esse é o caso das Empresas Públicas de Medellín (EPM), um grupo empresarial criado em 1955, por meio de um acordo com o Conselho Administrativo de Medellín, que se tornou uma empresa autônoma resultante da fusão de quatro entidades até então independentes, para o fornecimento dos serviços de energia, água, saneamento, telefonia. Desde 1998, a EPM é uma Empresa Industrial e Comercial do Estado, tendo uma relação sui generis com o município de Medellín, que é ao mesmo tempo proprietária da empresa e cliente. Como um potente grupo empresarial, ela se expandiu adquirindo empresas de energia no Panamá e Guatemala. Entre 2001 e 2011, a EPM contribuiu com US\$ 877 milhões, uma média de $50 \%$ de seus lucros para o município, que por sua vez representam $27 \%$ dos recursos de investimento do município. Para se ter uma ideia, em 2010 os ativos da empresa foram avaliados em cerca de 10 bilhões de dólares (DÂVILA; COUPÉ; BRAND, 2012, p. 57-58).

Da mesma forma, o poder municipal construiu sua autonomia amparado por um contexto peculiar de experiências na relação entre o planejamento urbano e a problemática realidade social. Isso porque o estado de emergência em que a cidade se encontrava nos anos 1990, em decorrência do conflito armado, levou o governo nacional a criar uma Consejeria Presidencial para Medellín e sua área Metropolitana (Decreto 1875 de agosto de 1990). Esse inovador arranjo institucional terá contribuições na formação de quadros técnicos e na instituição de metodologias de trabalho fundamentais que conectam a dimensão espacial e social do urbano.

Esse legado será verificado particularmente pela ação do Programa Integral de Mejoramiento de Barrios Subnormales en Medellín (PRIMED). Esse programa derivou da elaboração, por parte da Consejeria, de um plano para o fortalecimento e o desenvolvimento produtivo e social, dividindo-o em 6 frentes de ação: geração de emprego, educação, saúde e nutrição, instrumentos de participação cidadã, fortalecimento da justiça e da segurança pública e o programa para a melhoria do espaço urbano em áreas marginalizadas. O PRIMED surgiu dessa última linha e serviu de referência às políticas urbanas subsequentes, pois inaugurou um novo patamar na capacidade de diagnóstico e ação nas áreas de assentamentos precários. Isso se apoiou na sistematização de bases de dados especializadas sobre essas áreas urbanizadas, o que seria um passo fundamental para a integração das políticas setoriais que atuariam posteriormente nessas áreas.

A cultura institucional e a capacidade técnica que deriva dessa experiência será a base da Empresa de Desarrollo Urbano (EDU), o mais importante espaço institucional intersetorial da municipalidade. Seu surgimento remete a um problema administrativo enfrentado em 1993 para a construção de um parque. A solução encontrada, na chave 
do empreendedorismo local, resultou na criação da Empresa Comercial e Industrial del Orden Municipal Parque de San Antonio, com status legal, autonomia administrativa e patrimônio independente para viabilizar a obra do parque. Três anos depois, a empresa foi transformada na Promotora Imobiliária de Medellín, com o objetivo de desenvolver projetos urbanos, imobiliários, espaços públicos e em áreas de renovação urbana. Em fevereiro de 2002, com a finalidade de executar os Projetos Urbanos Integrais (PUI), os estatutos foram modificados e passou a se chamar EDU, como entidade jurídica da ordem municipal, com patrimônio próprio e dotada de autonomia administrativa e financeira, conforme esclarece Julián Carvajal (2013, p. 11).

A EDU passou a mobilizar diferentes órgãos conforme a competência necessária para a intervenção que coordenava: como os órgãos de planejamento, as Empresas Públicas de Medellín (EPM), Instituto de Habitação Social e Habitat de Medellín (ISVIMED), Secretaria de Mobilidade, a Companhia de Transporte em Massa do Vale do Aburra (Metro), as Empresas Várias de Medellín (EVM), etc. Essa capacidade de articulação, planificação, formulação, gestão e monitoramento dos resultados desenvolvida pela EDU foi fundamental para a metodologia dos programas $\mathrm{MIB}^{57}$ (Melhoramentos Integrais de Bairros) e os Projetos Urbanos Integrais (PUI).

Assim, contando com a legitimidade institucionalizada dos POT, com referências e instrumentos de ação, fontes seguras de financiamento e gestão das políticas urbanas, Sergio Fajardo teve sólida base para construir seu ousado plano de governo. Ademais, é possível ver alguma influência dos governos municipais de Bogotá de Antanas Mockus (1995-1997), com seu investimento na "cultura cidadã", bem como da ênfase em planejamento, mobilidade urbana, espaço público e equipamentos sociais encampada por Enrique Peñalosa (1998-2001).

Fajardo também encontrou uma comunidade acadêmica e profissional engajada nas problemáticas do planejamento e do desenho urbano. O Plan de Ordenamiento Territorial de 1999 já tinha desenhado instrumentos consistentes e pautas cidadãs que vinham sendo gestadas desde a lei de reforma urbana de 1989. O Parque de los Pies Descalzos (1998) havia provado a exitosa intervenção dessa arquitetura urbana, como defende Gonzáles Escobar (2010), pois foi amplamente demandada e apropriada pela população. E a linha $\mathrm{K}$ de metrocable (2003) estava em funcionamento, demonstrando potenciais na intervenção das áreas mais vulneráveis da cidade. A participação de ONGs junto à gerência social realizada pela EDU, o engajamento do setor privado e os grandes aportes financeiros das EPM nas políticas sociais empreendidas por Fajardo também fortaleceram essas condições estratégicas.

A relativa independência partidária de Fajardo favoreceu que a sua entrada na cena política, em 2004, pudesse contar com um corpo

\footnotetext{
${ }^{57}$ Instituições/ departamentos públicos responsáveis: Alcaldía de Medellín; Instituto Social de Vivienda y Hábitat de Medellín ISVIMED; Departamento Administrativo de Planeación; Secretaría de Planeación; Secretaría de Obras Públicas; Secretaría de Desarrollo Social; Empresa de Desarrollo Urbano -EDU.
} 
técnico especializado ocupando cargos estratégicos que não precisaram ser negociados em decorrência de alianças partidárias. Essa circunstância também fortaleceu a estrutura institucional da Administração Municipal, que passou a contar com uma privilegiada intersetorialidade e integração de competências dos diversos atores públicos para a ambiciosa proposta do Plan de Desarrollo Medellín Compromiso de Toda la Ciudadanía, nome desse conjunto de medidas que deram forma ao Urbanismo Social do referido prefeito. O plano tinha como premissas: a cidade, o espaço público para os cidadãos, a participação como elemento central; a melhoria dos índices de desenvolvimento humano para enfrentar as desigualdades sociais e econômicas; e o acesso à educação como motor do desenvolvimento. E isso teria uma relação direta com um método de aprendizados sucessivos com intervenções urbanas anteriores para avançar no desenvolvimento urbano, processo que traz ao Estado a responsabilidade de dar especial atenção às vítimas de violência e pobreza, bem como o acompanhamento do processo de reintegração paramilitar (LOPERA PÉREZ; GONZÁLEZ AVENDAÑO; SÁNCHEZ, 2017, p. 29).

Essa transformação pretendida demandou integração de instrumentos das políticas urbanas com a gestão institucional e a participação da comunidade. As áreas que receberam intervenções prioritárias foram justamente as periféricas, carentes de serviços públicos e que apresentavam os piores índices de violência e vulnerabilidade social. A confluência dessas premissas resultou em programas que são identificados como os pilares do Urbanismo Social:

* Projetos Urbanos Integrais - PUI;

* Projetos de Melhoramentos Integrais de Bairros - MIB;

* Habitação social para populações em áreas de risco;

* Parques bibliotecas e outros equipamentos-chave relacionados

a cultura e educação estrategicamente articulados com projetos urbanísticos.

O panorama descrito fornece o contexto geral que permite introduzir os projetos discutidos a seguir. Mas é fundamental notar, nesse relato, que as ferramentas da arquitetura e do urbanismo não foram instrumentos secundários de suporte à agenda política. Longe de figurarem como elementos de retaguarda, foram centrais na articulação e integração das diversas políticas setoriais implementadas e justamente mobilizadas sob a pressão de se criar novos imaginários sociais para a cidade.

Nesse sentido, a seleção de projetos neste capítulo pretende enfocar sua direta relação com os sistemas infraestruturais da cidade. Permite, assim, refletir sobre a relação entre arquitetura, desenho urbano, instrumentos do planejamento e arranjos institucionais que incidem sobre a estrutura ambiental e urbana da de Medellín, bem como de seus sistemas técnicos. 
As linhas de metrocable $e^{58}$ se tornaram um dos mais importantes emblemas da transformação urbana de Medellín. As recorrentes fotos desse sistema de transporte, têm como pano de fundo a massa de unidades habitacionais precárias que se acumulam nas encostas dos morros. Simbolizam assim, por contraste, um pressuposto momento de virada desse território antes desenganado, marcado pela ausência do Estado, e o novo horizonte aberto pela sua chegada, por meio desse novo aparato técnico que proporcionou o acesso à cidade formal. São essas imagens que ilustram a maior parte das reportagens e publicações que divulgam e, em sua falsa síntese, reduzem o feito a uma pragmática conexão entre as "duas cidades". Não se trata, contudo, de um problema cuja solução está apenas no âmbito de uma proposta técnica, encerrada nos atributos de uma infraestrutura de transporte. E sim, uma questão socioespacial que demandou um longo processo desde a implantação do sistema, passando pela a avaliação de seus impactos e a necessária mobilização de ferramentas de planejamento e desenho urbano necessariamente complementares, dialogando com as novas - e problemáticas - dinâmicas deflagradas. O processo de análise e projeto que adequam a inserção urbana desse sistema de transportes torna-se, assim, tão importante quanto a funcionalidade do deslocamento que ele proporciona. Isso coloca em pauta diferentes matizes da friç̧ão entre relações socioespaciais imediatas e as grandes infraestruturas urbanas.

O projeto para um sistema de metrocables começou a ser concebido ainda nos anos 1990 pelo Metrô de Medellín, para alcançar bairros longínquos principalmente para incrementar o número de usuários da rede do metrô que se encontrava subutilizada. O sistema por cabos representava uma solução rápida e econômica, o que levou o Metrô a realizar estudos técnicos e apresentar um projeto para sua implantação aos candidatos à prefeitura em 2001. O prefeito eleito Luis Pérez (20012003) o levou adiante, de modo que Sergio Fajardo encontrou a linha $\mathrm{K}$ já em funcionamento ao iniciar seu governo. Essa linha atravessou as comunas 1 (Popular) e 2 (Santa Cruz), regiões conformadas pela invasão de terrenos e loteamentos irregulares que teve início entre os anos 1950 e 1960, resultando em ocupações precárias, de alta densidade, com 400 habitantes/ha. A zona Noroeste (Nororiental) da cidade, região atendida por essa linha, concentrava, na década de 1990, 47\% da população de Medellín e era também onde residia $25 \%$ da população mais pobre da cidade, sendo assim a zona com maior concentração de problemas sociais, culturais, ambientais e habitacionais da cidade (HINCAPIÉ BALLESTEROS; GUTIÉRREZ TAMAYO, 2017, p. 81-82).

Desse modo, quando Fajardo centrou seu plano de governo em uma política de redução de dívidas sociais por meio de transformações estruturais, conjugando programas de educação, cultura e uma "mudança de pele" dos bairros localizados nas áreas mais críticas da cidade (ECHEVERRI, A; ORSINI, F., 2010, p. 139), encontrou na Zona

\footnotetext{
${ }^{58}$ Sistema de transporte por cabo aéreo, comumente conhecido como teleféricos.
} 
Nororiental e no entorno no metrocable, o território perfeito para colocar em prática seu Urbanismo Social e uma de suas principais ferramentas: o Projeto Urbano Integral (PUI). Ainda que, desde o POT de 1999, a área noroeste da cidade já fosse apontada por uma série de considerações para intervenções, é somente com as articulações e estratégias propostas pelo Proyeto Urbano Integral de la Zona Nororiental, o PUI-Nor, realizado entre 2004-2011, que o entorno físico das estações, bem como toda compreensão de suas potencialidades, foi de fato integrado.

A história do PUI-Nor é descrita por seus idealizadores como um processo de diagnóstico e planejamento estabilizado em torno de um polígono de intervenção definido a priori, que atingiria uma população aproximada de 150.000 habitantes concentrados em mais de dez bairros com condições topográficas e morfológicas muito complexas. Diante dessas questões, principiou-se em 2004 com uma análise para a reconstrução dos bairros e identificação dos elementos estruturantes da forma urbana. Na sequência, constituíram-se equipes técnicas procedentes de universidades que já haviam desenvolvido pesquisas nesses territórios, o que resultou em um plano de ação detalhado que buscava a integralidade da transformação física, a combinação de ações em diferentes escalas e a participação da população, conforme explicam Echeverri e Orsini (2010, 142).

Segundo González Escobar (2010, p. 112), no entanto, pode-se perceber um processo menos linear e mais aberto, que pressupõe uma necessária mudança de visão que se deu no decurso das intervenções. Originalmente pensada em uma dimensão exclusivamente funcional de um sistema público de transporte, a implantação da linha de metrocables havia negligenciado impactos urbanísticos, particularmente sob o corredor aéreo, nas proximidades dos grandes pilares de suporte do sistema e ao redor das estações. A mudança de visão principiou-se pela intervenção nesse corredor com a "pedonalização" das ruas sob a linha e o melhoramento do acesso desta via às habitações. Na parte alta que dava acesso à estação terminal, também foi projetado um calçadão. Mas as propostas se expandiram com a realização de sete parques nos onze bairros de área de influência. Abrangendo, posteriormente todos os bairros da comuna 1 e 2, do PUINor (GONZÁLEZ ESCOBAR, 2010, p. 112). Ainda que seja difícil precisar o nível de controle inicial do plano e os eventuais rearranjos conjunturais demandados pela realidade da implantação do projeto, essa primeira experiência do PUI representou grandes avanços para o “Modelo Medellín” 59.

59 O "Modelo de Medellín" foi assim nomeado em 2008 pela Organização dos Estados Americanos em sua 38 assembleia Geral, quando se alegou a necessidade de criar um observatório para registrar, documentar e replicar a experiência de transformação pela qual a cidade passava (BRAND, 2013, p.4). Esse fenômeno também foi registrado intensamente por jornalistas econômicos e políticos, grandes líderes mundiais, empresários, imprensa especializada em arquitetura, urbanismo e turismo. Nos últimos anos Medellín figurou em publicações relevantes internacionais como The New York Times, The Washington Post, Newsweek, Business Week; El país, El mundo, La Vanguardia; CNN, BBC, La Nación (Argentina), The Banker, Veja, The Guardian, Foreign Policy, entre outros, conforme aponta Restrepo (2014). Também, a autora destaca o reconhecimento da cidade em competições internacionais, incluindo o Prêmio Global Knowledge Partnership 2007, para bibliotecas de rede; o Prêmio Internacional Dubai Habitat 2008; o prêmio City Barcelona FAD 2009 pelo projeto "Medellin, la más educada". A cidade também foi aclamada como "a mais inovadora do 
O PUI, apoiado em uma privilegiada estrutura institucional intersetorial, com significativo investimento em trabalho de gestão social $^{60}$, implicou uma nova relação entre infraestrutura, os projetos de arquitetura urbana e o espaço público, criando gradações de urbanidade em diferentes escalas. Percebe-se o desenvolvimento de uma "metodologia PUI", para criar condições de articulação espacial entre as estações e outros destacados projetos como o do Parque Biblioteca España, as reurbanizações e projetos de habitação no entorno das quebradas Juan Bobo e La Herrera, os Novos Colégios de Qualidade de Santo Domingo Sávio e Antonio Derka. Estes projetos se tornaram referências para a cidade e, quando vinculados entre si, se propuseram a fortalecer centralidades na escala do bairro. Isso porque também se formularam novas possibilidades de dar coesão ao tecido urbano precarizado, interligando esses projetos, com calçadões, parques e diversas formas de pequenas praças. Isso, em um setor que cresceu totalmente alijado da construção oficial de espaços públicos.

Reforçou-se, assim, a vocação da rua que, conforme aponta Gonzáles Escobar (2010, p.112), era e segue sendo o maior cenário de socialização nessas regiões. Isso pode ser verificado pelas diferentes formas de apropriação do espaço público nos calçadões e nos corredores que criaram comunicações entre os bairros La Francia, Andalucía e Villa del Socorro. Estes últimos foram unidos por pontes, o que permitiu a integração geográfica e social em lugares que antes eram isolados também pela violência e a rivalidade entre gangues. Nessa topografia abrupta, por meio de estratégias de desenho, aproveitou-se o terreno das encostas para criar mirantes e áreas esportivas, jardins e brinquedos de água. Assim, nos PUI, as diferentes escalas de desenho se entrelaçam com os aspectos gerais proposta pelos projetos de grande centralidade urbana, construindo um certo sentido de unidade a partir do mobiliário urbano, das texturas e cores de piso, que falam de uma relação de projetos com processos de inclusão social (ESCOBAR, LUIS FERNANDO GONZÁLEZ, 2016, p. 113)

A dimensão temporal também foi um fator importante manejado pela EDU. Ela estabeleceu uma estratégia para entregar as pequenas obras, como playgrounds e melhorias nos edifícios públicos existentes rapidamente, e antes das maiores intervenções, visando ganhar confiança da população. Isso para comunicar a ideia maior, por detrás de grandes projetos, funcionando como uma amostra do que poderia ser feito numa escala mais ampla. Com isso ganhava-se tempo para empreender os projetos-chave como os parques biblioteca e os novos colégios (cuja construção poderia demorar três anos). Antecipar pequenas intervenções tornou-se uma tática para vencer a dificuldade de trabalhar com uma população tomada pelo ceticismo. Estes projetos

mundo", premiada em março de 2013 pelo Citi e pelo The Wall Street Journal. A cidade também foi designada como a sede oficial do Sétimo Fórum Urbano Mundial, realizado em abril de 2014 e ganhou o prêmio Lee Kuan Yew World City em 2016.

${ }^{60}$ A EDU contava com equipes interdisciplinares formadas por arquitetos e engenheiros, mas também como assistentes e comunicadores sociais designados para trabalhar com a população nos territórios prioritários. A equipe promovia oficinas com as crianças, adultos e terceira idade para que todos os projetos empreendidos pudessem ser discutidos numa tentativa de incluir todos os atores, inclusive os que tinham uma história recente de envolvimento com violência numa perspectiva de se obter a chamada coesão social. 
foram chamados de "pequenos compromissos" e "pactos sociais" com a população, para que se construísse certo grau de confiabilidade e mobilização.

O metrocable, afinal, é um sistema de transporte de cabo aéreo normalmente utilizado para fins turísticos, e que surgiu como uma novidade, por ser utilizado como transporte de média à alta capacidade. Mas, aqui torna-se menos relevante a questão técnico-funcional desse sistema, pois seu principal atributo inovador se deu pela vinculação entre essa infraestrutura e as possibilidades de ressignificação urbana que dela irradiaram, ao conectar bairros pobres à estrutura formal da cidade. Essa experiência coloca em pauta a mobilidade e a acessibilidade, também em seu potencial simbólico. Esse aspecto é essencial para um processo de integração demandado por estas comunidades que sofrem processos de exclusão socioespacial. Assim, é de especial importância a construção de um senso renovado de dignidade e inclusão nessa população, quando da revelação de novas qualidades - singulares - de um setor urbano antes marcado pela violência e pobreza.

Nesse sentido, vê-se que a linha em direção ao parque Arví, por exemplo, que sai da última estação da linha $\mathrm{K}$, reforçou a dimensão recreativa do metrocable, estabelecendo uma nova relação para toda a cidade, qualificando um bairro periférico pela sua oportunidade de lazer. Além disso, a própria paisagem vista do alto da zona noroeste adquiriu um valor de patrimônio paisagístico e se converteu em uma referência para a cidade (LEIBLER; BRAND, 2012, p. 376). São fatores como esses que contribuem para a redução da estigmatização dessa região, antes tida como uma área isolada, fadada a um destino trágico ou, pior, causadora dos problemas de que padecia Medellín, em seus piores momentos de crise. A abertura à visitação desse setor, rompendo com o isolamento e fechamento que antes caracterizava a vida nessas áreas, também passou a promover a visualização de novos horizontes para os jovens moradores, no campo da educação tecnológica e universitária. A visibilidade e materialização do orgulho de se pertencer a um bairro do setor noroeste da cidade, por conta do metrocable e do parque-biblioteca, representou a importante sensação de fazer parte do futuro da cidade (LEIBLER; BRAND, 2012, p. 382).

A percepção de maior segurança dada a presença do Estado, também foi significativa, ainda que de relativa abrangência. Esses e outros apontamentos são trazidos pela pesquisa de Leibler e Brand (2012, p. 382) por meio de entrevistas com a população local, que levanta aspectos de grande impacto social, ainda que pouco mensuráveis. Os habitantes entrevistados, por exemplo, destacavam grande apreciação por poderem se deslocar a todas as partes da cidade com facilidade e economia, ainda que utilizasse pouco o meio de transporte, visto que $70 \%$ da população entrevistada nesses bairros se deslocava prioritariamente a pé. Percebe-se, com esse argumento, que a dimensão estritamente quantitativa de uso do sistema pode ser um parâmetro limitado para mensurar seu impacto social a longo prazo.

Outra leitura importante sobre a experiência do metrocable pode ser realizada em relação ao sistema de metrô que o precedeu, pois também 
coloca em perspectiva uma mudança de paradigmas, ainda que ambos os sistemas pertençam ao Metro de Medellín ${ }^{61}$. Esse metrô é o único em funcionamento no país e corta a cidade de Norte a Sul interligando 6 municípios da Região Metropolitana do Valle de Aburrá, (Bello, Envigado, Itagüí, La Estrella, Medellín e Sabaneta). A construção começou em 1985 sendo que a Linha A, primeira a ser inaugurada, entrou em operação somente em 1995. Essa linha acompanha a margem do rio e se torna elevada, passando pelo centro da cidade, assim como a linha B, que é o segundo ramal do metrô que se estende a oeste.

Quando em nível, ao lado do rio (ver figura 2.4.2), o metrô reforça o afastamento desse corpo de água em relação ao tecido urbanizado, compondo, junto com as vias marginais, o grande eixo de circulação que divide a cidade ao meio como uma extensa cicatriz urbana. Desse modo, percebe-se que a leitura do metrô está vinculada a uma noção de infraestruturas de transporte enquanto vetor funcional, que conecta partes distantes, mas que desarticula, nas estações, o espaço de seu entorno imediato. E, quando a linha do metrô se eleva e adentra o tecido urbanizado, a segregação do tecido existente se soma ao desmonte dos sentidos simbólicos dos locais por onde essa infraestrutura passou. Percebida como um fenômeno de deterioração das áreas sob a linha elevada, há também nesse processo uma redução da importância representativa anteriormente fixada nos edifícios e áreas públicas, agora sombreados ou apartados pelo novo sistema que se impõe.

Essa decisão tomada nos anos 1990 se vincula ao largo processo de desenvolvimento da cidade que apagou ou fragmentou tecido urbano existente, em seus diferentes ciclos econômicos, tendo a infraestrutura viária e a de transporte de massa grande participação nesse processo destrutivo. Retomar a compreensão de como isso transcorreu é uma forma de expandir a compreensão do significado da nova rede que se implantou sobre a periferia, com o advento dos metrocables. Enquanto essa nova iniciativa implicou a construção física e simbólica de novas possibilidades na cidade informal, trabalhando usos e significados na interação entre as estações e o entorno circundante, o metrô representou um processo desagregador no tecido construído da cidade formal.

O ocorrido nas áreas centrais de Medellín denota algo que, para Fernando Botero (1993, p. 37) diz também respeito à importância da sobrevivência da obra arquitetônica, que entendemos aqui como aquilo que dá forma à cidade. Para o autor, a existência desse tecido de edificações se dá pela sua permanente reanimação e interação entre a arquitetura e a cidade. Enquanto isso ocorre nas cidades europeias, Botero vê o oposto em algumas cidades latino-americanas e, em particular, em Medellín. A não sobrevivência da arquitetura ocorre em um duplo sentido: o da própria obra, e o do diálogo entre ela e a cidade. Isso se verifica com a destruição permanente da forma urbana precedente. O maior exemplo é o do primeiro arranha céu da cidade, o edifício Coltejer (1972), sede de uma importante indústria de tecelagem

\footnotetext{
${ }^{61}$ É válido destacar que é uma empresa da Prefeitura de Medellín e do Departamento de Antioquia e foi criada em 1979 para a construção do metrô
} 
e símbolo de um novo ciclo industrial. A sua construção levou à demolição, sem necessidade, do hotel Europa e o Teatro Junín, prestigiosos edifícios do começo do século passado (BOTERO, 1993, p. 56). Do mesmo modo se deu o desaparecimento do bairro Guayaquil e da Praça Cisneros, marcos importantes do nascimento da cidade industrial, esta última foi também desfigurada por uma via de doze pistas $^{62}$. Essa é a consequência de um ideário de modernização que entende por progresso qualquer tipo de mudança, conforme aponta Vélez-White (2000). Segundo a autora, o Parque Berrío, berço da cidade, também "desapareceria" com a passagem do metrô pelo centro: "o mais importante é se mover rápido, e não importa às custas de que" (Vélez-White, 200o, 26).

A dimensão contraditória deste importante investimento infraestrutural realizado nos anos 1980 nos serve aqui pela expressiva clareza de seus efeitos, na vivência dos espaços pelos quais ele passou. Se, por um lado, o transporte na cidade é relativamente eficiente; por outro, reforça o já fragmentado e problemático território, na sua experiência imediata. Em contrapartida, a experiência do metrocable (construídos a partir de 2003), aponta para uma outra possibilidade. A viagem da extremidade de um dos bairros mais distantes, por meio da linha J (Estación La Aurora) até a estação San Javier do Metrô, no eixo da cidade formal, dura somente 13 minutos. A conexão visual com o entorno ao longo de todo o percurso, parece recuperar temporalmente a conexão entre a cidade forma e a informal. As cabines transitam a uma distância do solo que não isola as músicas dos bares, o som dos córregos nas quebradas, a agitação coletiva dos pátios dos colégios, nem o som entrecortado das residências, que se empilham horizontal e verticalmente nas ladeiras. Por fim, ao chegar às estações de metrocable, percebe-se que elas não se restringem a uma simplificada ideia de um aparato técnico especializado.

Além da consideração de demandas funcionais referentes aos fluxos dos usuários, outros parâmetros que norteiam os desdobramentos urbanos de sua implantação passam por uma interpretação gradativa de escalas de interação desse equipamento com seu entorno. As estações dão origem a verdadeiros sistemas de transição de níveis entre a plataforma de embarque suspensa a cerca de 15 metros e sua projeção sobre o perfil natural do terreno, criando inúmeras possibilidades de apropriação: terraços, pequenos anfiteatros, espaços para recreação (ou as raras e valiosas planícies em um território marcado por ladeiras). Essa característica faz com que a monofuncionalidade desses equipamentos seja relativizada e que tanto as estações, quanto as cabines, se tornem elementos incorporados à paisagem real e afetiva desses bairros.

É válido dizer que as contradições da produção do espaço urbano, seja ele formal ou periférico, naturalmente despontam também nessas intervenções. No entorno destes novos espaços públicos e das estações, por exemplo, pode-se verificar novas dinâmicas de precariedade urbana com ocupações irregulares, passados alguns anos de sua implantação. A

${ }^{62}$ Essa praça foi remodelada durante o governo de Sergio Fajardo e hoje é mais conhecida como Parque de las Luces em uma tentativa de revitalizar a área. 
intervenção também promoveu a valorização imobiliária e o aumento do custo de vida no bairro. Alguns caminhos foram ensaiados pelo poder público para mitigar esses efeitos. Como, por exemplo, evitar a expulsão dos moradores de seu lugar de origem, com o poder local subsidiando tarifas de serviços públicos domiciliares, adaptando-as à capacidade de pagamento da população. Esse é o caso "Programa Mínimo Vital de Água Potável" e das tarifas diferenciais de taxa predial. (SÁNCHEZ; ZUQUIM, 2017, p. 11)

Também, o desafio de conciliação entre as novas infraestruturas de transporte e a interação com as dinâmicas do tecido existente da cidade se ampliam na medida em que a rede se expande e inaugura novos modais. Os corredores de ônibus e o Veículo Leve sobre Trilhos (tranvia) são alternativas que vêm sendo incorporadas à rede de mobilidade da cidade. Enquanto o primeiro se restringe ao setor leste da cidade e repete o modelo visto em Bogotá ou até mesmo em Curitiba, que tende a reforçar o eixo viário em contraposição à circulação mais livre do pedestre, o segundo parece trazer relações mais sensíveis a preexistências. Apesar de ainda ter apenas $4.3 \mathrm{~km}$ e 9 estações, a linha representa um eixo que liga o centro ao extremo leste da cidade, equalizando a distribuição de sistemas de transporte coletivo sobre trilhos nessa região da cidade, uma vez que as linhas A e B do metrô atendiam as porções norte-sul e oeste, respectivamente. É importante perceber que, no caso do tranvia, as intervenções no tecido da cidade não parecem interromper a trama densa e a circulação peatonal já consolidada dessa região extremamente popular. Sendo que as estações se tornam pontos iluminados que fomentam a atividade e a seguridade noturna.

As escadas rolantes implantadas em 2011 no bairro Las Independencias, na Comuna 13, também representam uma reflexão importante sobre as questões de acessibilidade intrabairro. Elas substituíram 350 degraus de concreto, o que pode significar que um trajeto realizado com duro esforço físico em 25 minutos, passa a ser um deslocamento confortável, mediado por um sistema de transporte, de cerca de 10 minutos $^{63}$. Desse modo vemos que não menos importante são as pequenas locomoções diárias, que podem representar um grande empecilho para integrar o tecido urbano na escala do bairro e no cotidiano de 12.000 usuários.

\section{Unidades de Vida Articulada, 2014}

As chamadas Unidades de Vida Articulada (UVAs), espalhadas nas encostas da cidade, consistem em espaços públicos abertos, que configuram praças, mas que também articulam programas recreativos e culturais em pequenas volumetrias edificadas sob as grandes superfícies caminháveis. Essas áreas abrigam salas multiuso para cursos, brinquedotecas, auditórios, dentre outros espaços correlatos que se

\footnotetext{
${ }^{63}$ Conforme depoimento de Brandon Restrepo, estudante usuário das escadas rolantes em depoimento a Empresa de Desarrollo Urbano (2012)
} 
arranjam sempre de modo subordinado ao programa principal das áreas livres. A descrição desses equipamentos-praça está vinculada às UVAs tipo A, cujo programa deu origem, posteriormente, a uma tipologia com maior área edificada, incorporando atividades esportivas, (UVAs tipo B). Ambas, no entanto, guardam as mesmas características dos critérios de localização e contextualização topográfica do volume arquitetônico.

As UVAs são aqui mobilizadas porque elas colocam em perspectiva, assim como o metrô e os metrocables, a relação entre as grandes infraestruturas da cidade e a necessária reinterpretação de suas interações com o tecido urbano. Isso porque a origem desses equipamentos está no sistema de abastecimento de água que, ao deixar de ser interpretado estritamente pela sua atribuição técnica - típica limitação imposta pela estanqueidade institucional ou pelas regulações das políticas setoriais - acabou por revelar um novo sistema de espaços livres da cidade. Esses espaços, com o auxílio de intervenções arquitetônicas estratégicas e de baixa complexidade, passaram a compor a rede de equipamentos públicos de Medellín, contribuindo para democratizar o acesso a estes serviços, alcançando bairros marcados tradicionalmente pela pobreza e carência desses equipamentos.

A origem das UVAs vincula-se ao desenvolvimento de um plano de iluminação urbana realizado pela EPM, o Plan Maestro de Iluminación de Medellín y el Valle de Aburrá (PMIL), que, ao sobrepor as camadas da infraestrutura e iluminação pública da cidade, constatou verdadeiras ilhas escuras em meio ao tecido urbano, que coincidiam com a presença de 144 tanques de água localizados nas áreas mais altas da cidade, conforme aponta Valencia (2016).

A empresa, que é responsável pela iluminação (geração e distribuição de energia), e também pelos serviços de saneamento, coleta de resíduos, gás e telecomunicações, era a proprietária desses terrenos e, propôs a transformação desses espaços. Assim, foi criado o Departamiento de Intervenciones Urbanas Sostenibles (DIUS), uma equipe interna de projeto, sendo que a EPM selecionou 32 tanques, com base em parâmetros como: densidade populacional, necessidades das populações do entorno, restrições geológicas, potencial de expansão do serviço de fornecimento de água, dentre outros critérios técnicos. Foram então selecionados 14 tanques considerados como de intervenção prioritária, visto que estavam localizados em áreas com indicadores sociais mais críticos e, assim, teriam maior impacto para as comunidades atendidas. A intervenção nesses tanques começou a ser realizadas a partir de 2014.

Essas UVAs do tipo A tem programas mais compactos, porque são apropriados aos salões de atividades construídos, necessariamente, de maneira integrada aos tanques e outros mecanismos dessa infraestrutura de fornecimento de água. Esses espaços também incorporam a demanda de ampliar a iluminação em sua área, contribuindo para a segurança pública, de modo que esse é um aspecto explorado na concepção do espaço: fontes interativas com iluminação colorida, holofotes, a iluminação dos grandes tanques como marcos 
referenciais urbanos, são alguns dos componentes que interagem no projeto arquitetônico das UVAs.

As UVAs tipo B derivam da experiência das UVAs tanque, no sentido que também buscaram "lotes de oportunidade" ${ }^{64}$, isto é, lotes sem uso, quadras existentes, e espaços residuais já disponíveis. Para tanto, elas passaram a ser construídas pela EDU em parceria com a Secretaria de Esportes (Inder) e são chamadas de UVAs pesadas, porque resultam em equipamentos mais densos e volumosos, com maior área construída. As UVAs tipo $B$ refletem não só a necessidade de distribuição mais equitativa de equipamentos de cultura, esporte e lazer pela cidade, mas também o desafio de fazê-lo frente à escassez de lotes em áreas já consolidadas e de tecido urbano truncado como o das áreas informais.

A constituição desses equipamentos desfaz limites categóricos entre infraestrutura, paisagem e serviços de cultura e lazer, encontrando novas significações para a construção de uma urbanidade por meio da interação entre esses temas. As UVAs criam essas possibilidades não somente por meio de um arranjo institucional peculiar, que a EPM na sua multisetorialidade e capacidade de investimento pode proporcionar, mas também pelas conquistas dos instrumentos projetuais que ampliam as formas de apropriação desses aparatos técnicos. Seja pela sua capacidade de reciclar espaços existentes em desuso, como também por construir a singularidade da situação e do desenho de cada UVA. Isso se torna uma atração para o conjunto de espaços simbólicos da cidade. As vistas reveladas pelos mirantes das 18 UVAs em funcionamento fazem com que cada um desses espaços atraia visitantes de diferentes localidades. Assim, trata-se de um equipamento que se insere nas atividades cotidianas do seu bairro e que conquista também o significado de um marco relevante para a cidade.

\section{Lardín Circunvalar, 2014}

O levantamento dos tanques das UVAs revelou uma série de unidades espaciais que, nas bordas mais extremas da cidade, ofereciam um potencial de desfrute público dos recursos ambientais. Assim propomos olhar para o Jardín Circunvalar (JC) porque também tem essa atribuição, ao mesmo tempo em que está diretamente vinculado às leituras e regulações do POT. O JC é reconhecido também no âmbito do planejamento territorial regional pois, do mesmo modo que no município, ele se articula à problemática mais geral das diretrizes futuras de estruturação do tecido urbano.

"Jardín Circunvalar" é um nome dado ao primeiro trecho implementado no município de Medellín, mas que integra o projeto maior do Cinturão Verde Metropolitano do Vale do Aburrá (CVMVA). Enquanto estratégia de planificação, permite uma série de intervenções que integram os distintos municípios do vale, visto que compartilham dessa mesma unidade geográfica. Nesse sentido, essa dupla função -

\footnotetext{
${ }^{64}$ Cf. EMPRESA DE DESARROLLO URBANO, 2014.
} 
espaço público implantado e instrumento de associação entre planejamento e desenho urbano - permite elevá-lo a uma potente metodologia projetual, porque é sistêmico, passível de ser aplicado em outras áreas e ao mesmo tempo extremamente sensível às especificidades locais.

O JC é então ativado como instrumento de contenção da ocupação nas franjas da cidade. Essa orientação remete ao primeiro POT da cidade, de 1999, que propôs esse modelo de planejamento vinculado a áreas de intervenção estratégica. Mas essas intenções foram realmente reforçadas em 2006 pelas Diretrizes de Planejamento Metropolitano e pela revisão do POT do município em 2014 (Acuerdo 48 de 2014). Nos últimos dois anos, tanto a Região Metropolitana do Vale do Aburrá quanto o município de Medellín, através do "Plan Bordes Metropolitano" e do CMVA, realizaram processos de planejamento, projeto e execução dessas intervenções previstas nesse âmbito. Somente no município a escala da estratégia já é notável, visto que compreende 13 subsetores, passando por 79 bairros, com uma área total de mais de 13 mil hectares, o que corresponde a 34,5\% da área de Medellín (NAVARRETE HEREDIA; ÁNGEL BERNAL; DONOVAN, 2014).

Sobre sua dimensão de instrumento de planejamento, a estratégia JC é orientada por uma sequência de diretrizes que visam consolidar um modelo de ocupação metropolitano compacto e policêntrico. Desse modo, a ocupação do espaço urbano central, no eixo do rio, é priorizada, visando otimizar o uso da infraestrutura concentrada nessa área.

Para organizar os mecanismos de intervenção em Medellín, a cidade foi subdivida em 3 franjas partindo do perímetro externo - nos pontos mais altos - em direção à área urbanizada central, configurando: 1) franja de proteção ambiental e rural, 2) articulação entre zona urbana e rural 3) consolidação urbana integral. Embora as três tenham a função de serem tratadas como espaços de restauração ecológica com potencial recreativo e turístico, interligando parques e unidades paisagísticas importantes, as duas primeiras têm um caráter eminentemente restritivo de ocupação. Já a última franja adquire maior complexidade de intervenção, ao passar por áreas de assentamentos precários devendo conter a expansão urbana, ao mesmo tempo em que reconhece e consolida a realidade dessa ocupação irregular. É no limiar entre a franja 2 e 3 que passa o Jardim Circunvalar. Desse modo, esse trecho de intervenções se articula com outros programas e serviços sociais como projetos das UVAs, melhoramento e consolidação de áreas residenciais subnormais e projetos urbanos que envolvem também a rede de transporte público.

O JC na Comuna 8 foi o primeiro trecho entregue entre 2014-2015 pela EDU. O projeto consiste em um caminho que conecta 8 bairros situados no entorno do morro Pan de Azúcar. Ele se aproveita de trilhas rurais preexistentes que foram recuperadas e aprimoradas. O projeto desse "caminho" utiliza diferentes recursos para vencer a topografia e qualificar o ato de atravessar essa sucessão de áreas verdes - nem sempre de grande relevância e complexidade contemplativa, mas notavelmente transformando áreas, antes residuais, em qualificados 
espaços que oferecem interessantes vistas da cidade. São escadas, pontes, mirantes, ciclovias, pistas de corrida, quadras, praças, mobiliário urbano, luminárias, pérgolas que se articulam em conjunto, sem qualquer controle de acesso. Isso é importante na medida em que não se definem como um parque no sentido de recortá-lo como unidade autônoma, separada da realidade urbana por grades e horários de funcionamento.

O setor entregue foi priorizado dentre os demais porque apresentava um processo atual de crescimento informal nessa fronteira, colocando em risco as características ambientais e os sítios arqueológicos da região. Então, ao mesmo tempo em que se previu levar ao acesso do público esse patrimônio histórico e ambiental, pretendeu-se também criar meios para delimitar, através da criação de espaços públicos, o crescimento da cidade que avança sobre a área rural. De uma abstração urbanística (delimitar o perímetro urbano) e restritiva, passamos diretamente a uma dimensão sensível e compreensiva de um equipamento de lazer: um caminho pavimentado que conecta outros três parques acima do morro. Criou-se também o "Ecoparque Las Tinajas", um equipamento que contém uma quadra de esportes e que articula caminhos permeados por hortas urbanas e viveiros. O plano mais amplo, dentro da CVMVA para o setor Pan de Azúcar, inclui organizar uma série de intervenções relativas a mobilidade, espaço público e habitação.

A experiência de percorrer o Jardín Circunvalar também permite uma reflexão sobre a construção da imagem da cidade. A escala de Medellín é apreendida facilmente pela sua condição de vale, e de seus muitos pontos altos de observação, como os dois cerros que se encontram na porção central (Nutibara e Volador). As encostas, também, permitem sempre essa visualização da área urbanizada densa e verticalizada do centro, do rio como um vetor infraestruturado, das bordas densas e informais ao norte, das torres de condomínios de alto padrão isoladas ao sudeste, dos bairros pouco verticalizados e mais homogêneos à sudoeste. Assim, a leitura da morfologia urbana e da geografia interagem e possibilitam uma construção mental e potencialmente coletiva da cidade de Medellín.

\section{Parques del Rio, 2016}

O modelo de ocupação territorial compacto vislumbrado por Medellín tem o corredor do rio como a unidade ambiental, paisagística e de planejamento mais importante. Isso é compartilhado também com a Área Metropolitana do Vale do Aburrá, de modo que esse conceito foi integrado, assim como as franjas de contenção de ocupação da cidade no Jardín Circunvalar, em seus sucessivos POTs locais e regionais.

Mas ele também foi desdobrado do plano a um projeto urbano de grande envergadura, que pretende ser implantado gradativamente: o Projeto Parques del Rio. As diretrizes desse projeto se reportam ao POT pelos problemas e potencialidades constatados na estrutura urbana existente. $\mathrm{O}$ rio é visto como um elemento de conexão e transformação 
de diversos setores da cidade que, na condição pós-industrial, vem experimentando degradação, perda de densidade e altos níveis de insegurança. Essa mudança na base produtiva da cidade requer a revisão integrada entre seus sistemas de infraestruturas e o uso e parcelamento do solo. O rio, como espinha dorsal da área metropolitana, é tão estratégico como problemático, ao mesmo tempo em que concentra e organiza os massivos sistemas de infraestrutura que o margeiam, está completamente isolado do tecido urbano por eles.

A característica mais marcante do projeto proposto é o gesto contundente de enterrar parte expressiva das vias marginais, como um anúncio de que os paradigmas de planejamento e intervenção na cidade existente teriam sido drasticamente alterados. Pois com isso, se submetem as infraestruturas da cidade à lógica de integração do território urbano e não o contrário. Por meio de estratégias de desenho, as infraestruturas de transporte passam a ser subordinadas à constituição de espaços públicos potentes, integradores do tecido circundante, que devolvem o rio à cidade. Isso incluiu a realocação do futuro Sistema Férreo do Vale do Aburrá para compatibilizá-lo com o projeto urbanístico ${ }^{65}$. Contrariam a tendência reiterada por mais de um século, de intervenções infraestruturais condicionadas unicamente por atributos técnicos e interesses econômicos, com grandes impactos desagregadores do território, implicando o alijamento da cidade de suas qualidades paisagísticas mais notáveis. Isso se deu desde a implantação da ferrovia, a canalização do rio e suas quebradas, chegando ao período rodoviarista dos anos 1970. A recuperação de uma paisagem urbana é indissociável de uma negociação entre as formas produtivas e as características intrínsecas da paisagem, em que grandes investimentos são requeridos do poder público ${ }^{66}$, ao mesmo tempo em que grandes lucros imobiliários são vislumbrados. O poder local se põe a negociar com esses agentes ${ }^{67}$, tentando acalmar motoristas enfurecidos pelo trânsito decorrente das obras com o discurso da ampliação da oferta de áreas livres; ativando mecanismos de financiamento de instrumentos urbanos para implantar o projeto, intentando antecipar e intervir nos efeitos da valorização imobiliária em áreas consolidadas.

O maior e mais ambicioso projeto de Medellín tem um futuro incerto, dadas as recentes conjunturas políticas e divergências. Contra o projeto

\footnotetext{
${ }^{65}$ Isso teria sido feito com a anuência e participação das partes envolvidas. A Empresa Metro e a Alcaldía de Medellín firmaram um convênio e desenvolveram o "Plan Maestro 2006-2030), também firmaram um acordo com o Convenio Intradministrativo de Cooperação com o Instituto Nacional de Vias (Invias) e teriam compatibilizado este com o "Plan Maestro de Movilidad", segundo a Alcandía de Medellín (2015).

${ }^{66}$ Ainda que a legislação colombiana tenha uma série de instrumentos de financiamento de projetos urbanos, o projeto "Parques del Rio" demandou uma complexa modelagem econômica para seu financiamento. Isso implicou a contratação da empresa americana multinacional AECOM, para a revisão desses instrumentos e também para a estruturação da gestão do projeto. Se propôs um plano de "franjas de liquidação" de modo que as áreas no entorno do rio terão um valor mais alto de contribuição para o financiamento da obra e, gradativamente, com o distanciamento do eixo, essa contribuição cai. Essa empresa voltada a engenharia é especializada em infraestruturas complexas, esteve envolvida no plano original da Nova Luz em São Paulo (2012), assim como no Plano Estratégico do Arco Tietê (2013).

${ }^{67}$ São numerosas as articulações necessárias do ponto de vista técnico e econômico. A Sociedade Parques del Rio, por exemplo, foi criada para articular o setor privado com essa iniciativa. Envolve a Alcaldia de Medellín, a EPM, o Metrô de Medellín e a Interconexión Eletrica AS (Empresa de distribuição de Energia semi-privada). O concurso para o projeto, no entanto, foi gerenciado pela EDU.
} 
do Parques del Rio, há a concepção do corredor multimodal de transporte que reclama a si a importância maior dentre os interesses da Área Metropolitana. Esse grande corredor férreo, com vias regionais e artérias urbanas não dá maior atenção à questão do espaço público. Outro problema que vem sendo apontado é o fato de que alto consumo de recursos públicos exigidos pelo projeto do parque e a ancoragem na diretriz de planejamento de uma cidade compacta, poderia colocar em segundo plano outros projetos no formato dos PUI, visto que estes podem tender ao adensamento das áreas periféricas. Esses são alguns dos argumentos que têm pesado contra a continuidade do projeto.

Mas em meio a essas dúvidas, um primeiro trecho (etapa $1 \mathrm{~A}$ ) do lado ocidental foi entregue no final de 2016, com $145.18 \mathrm{~m}^{2}$ de espaço público. O projeto completo prevê, em 25 anos, a formação de um grande parque linear ao longo do rio, soterrando continuamente as 7 pistas da via regional. Esse parque pretende conectar Medellín aos demais municípios do Vale de Aburrá: Bello, Sabaneta, Envigado, La Estrella Caldas, Itagui, Girardota e Copacabana. Em Medellín, essa intervenção seria fundamental para conectar os dois lados do rio que dividem a cidade ao meio. $\mathrm{O}$ investimento no parque também possibilitaria o adensamento da porção central do vale e a renovação do centro da cidade. $\mathrm{O}$ trecho entregue seguiu em obras e acaba de entregar a ponte de pedestres que conecta a intervenção, o Parque de los pies descalzos, o centro cívico da Alpujarra e o teatro metropolitano de Medellín com o outro lado da cidade, historicamente conhecida como "otrabanda". Esses equipamentos, tão próximos, eram dificilmente acessados, restando ao pedestre fazer a travessia em pontes de alto tráfego de veículos, em uma calçada de pouco menos de 1 metro.

O consumo dos recursos públicos e os impactos no valor da terra urbana são um desafio inescapável de qualquer medida que pretenda reverter os vetores de urbanização que degradam a paisagem e as vidas urbanas. $\mathrm{O}$ trecho entregue e o restrito alcance da pesquisa, não permitem constatar o saldo da disputa entre agentes imobiliários e moradores locais que podem ter seu custo de vida aumentado por conta da valorização do entorno do parque.

Sem anular outras possibilidades de suspeitar da parcialidade dos ganhos e da magnitude dos impactos, afirma-se, no entanto, a surpreendente visão de um rio sob uma condição tão similar ao Tietê e ao Pinheiros, com suas margens recuperadas como uma área de lazer ${ }^{68}$, feito orquestrado sob um projeto de assegurada qualidade paisagística e cuja inserção urbana é habilidosa na transição realizada por calçadas largas e vias locais que conectam o parque ao bairro Conquistadores, ao mesmo tempo em que estendem a ponte ao outro lado, ligando-o ao centro da cidade por meio desse sistema de áreas livres, que se pretende tanto local, quanto metropolitano.

\footnotetext{
${ }^{68} \mathrm{O}$ rio recebeu instalação de plantas de tratamento de esgoto que tiveram função estratégica para torná-lo algo agradável. É o caso das plantas se San Fernando (2000), tratando $20 \%$ das águas residuais vindas dos municípios de La Sabaneta, Envigado, Itagui e La Estrella e a do município de Bello (2015). Cf. ALCALDIA DE MEDELLíN, 2015.
} 

Painel 2.3 Medellín e seus planos

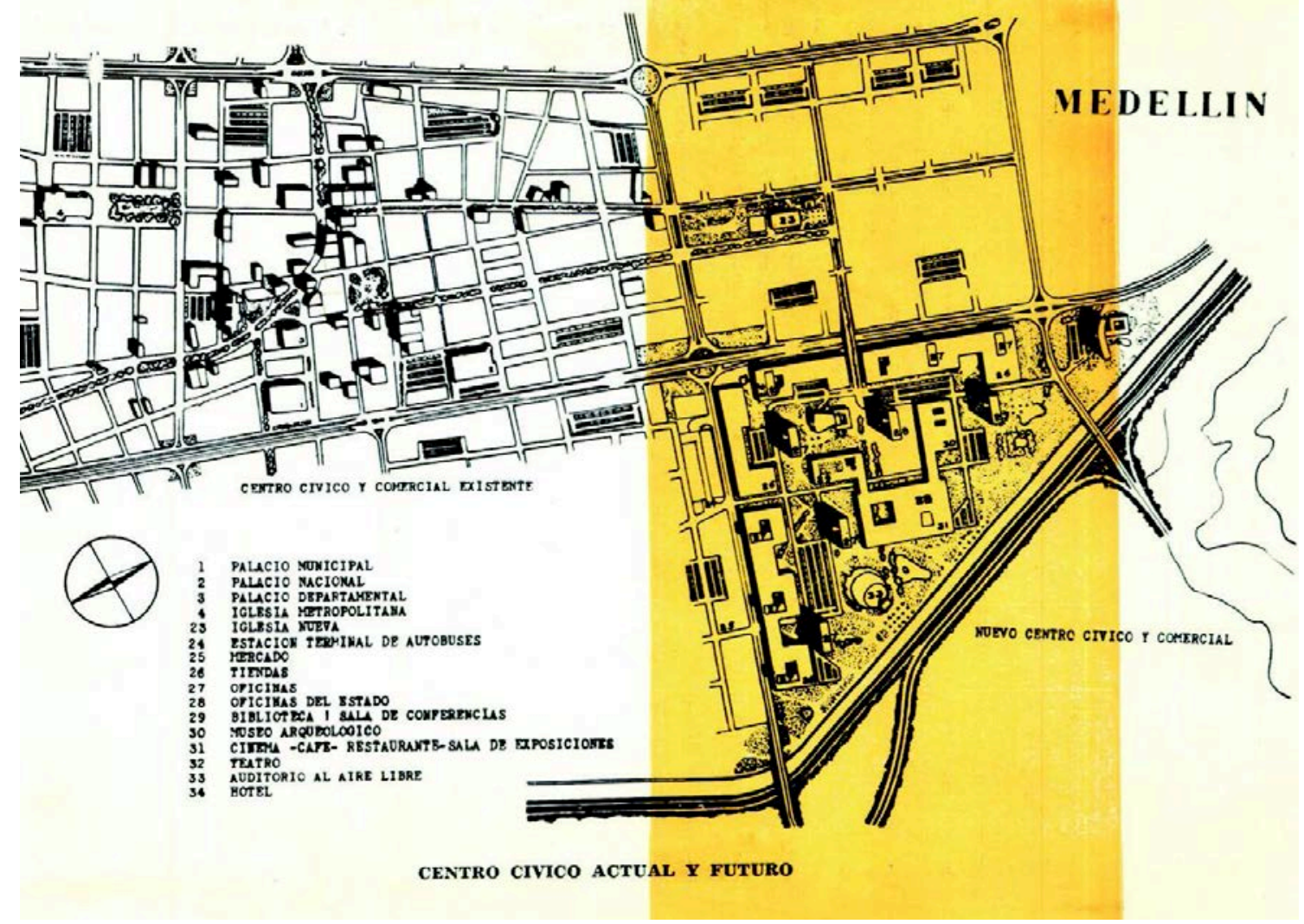

Figura 2.3.1 Plano de Wiener e Sert Para Medellín: Centro Administrativo

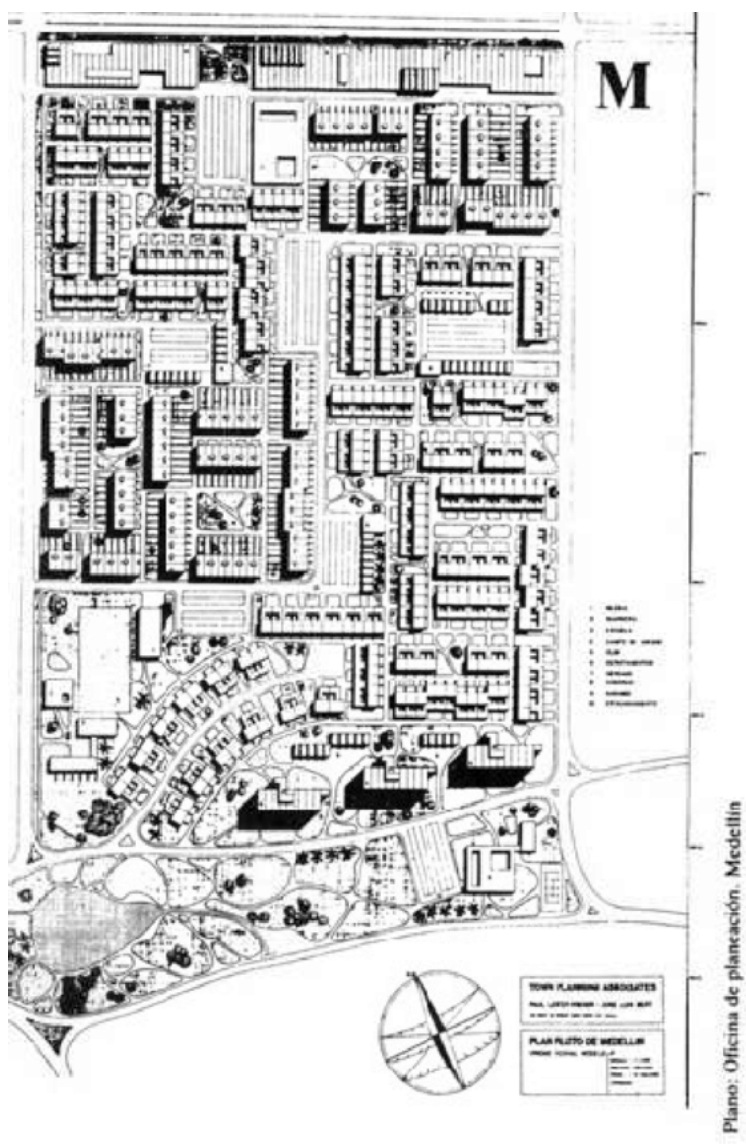

Figura 2.3.2 Proposta da Unidade de Vizinhança 
Painel 2.3 Medellín e seus planos

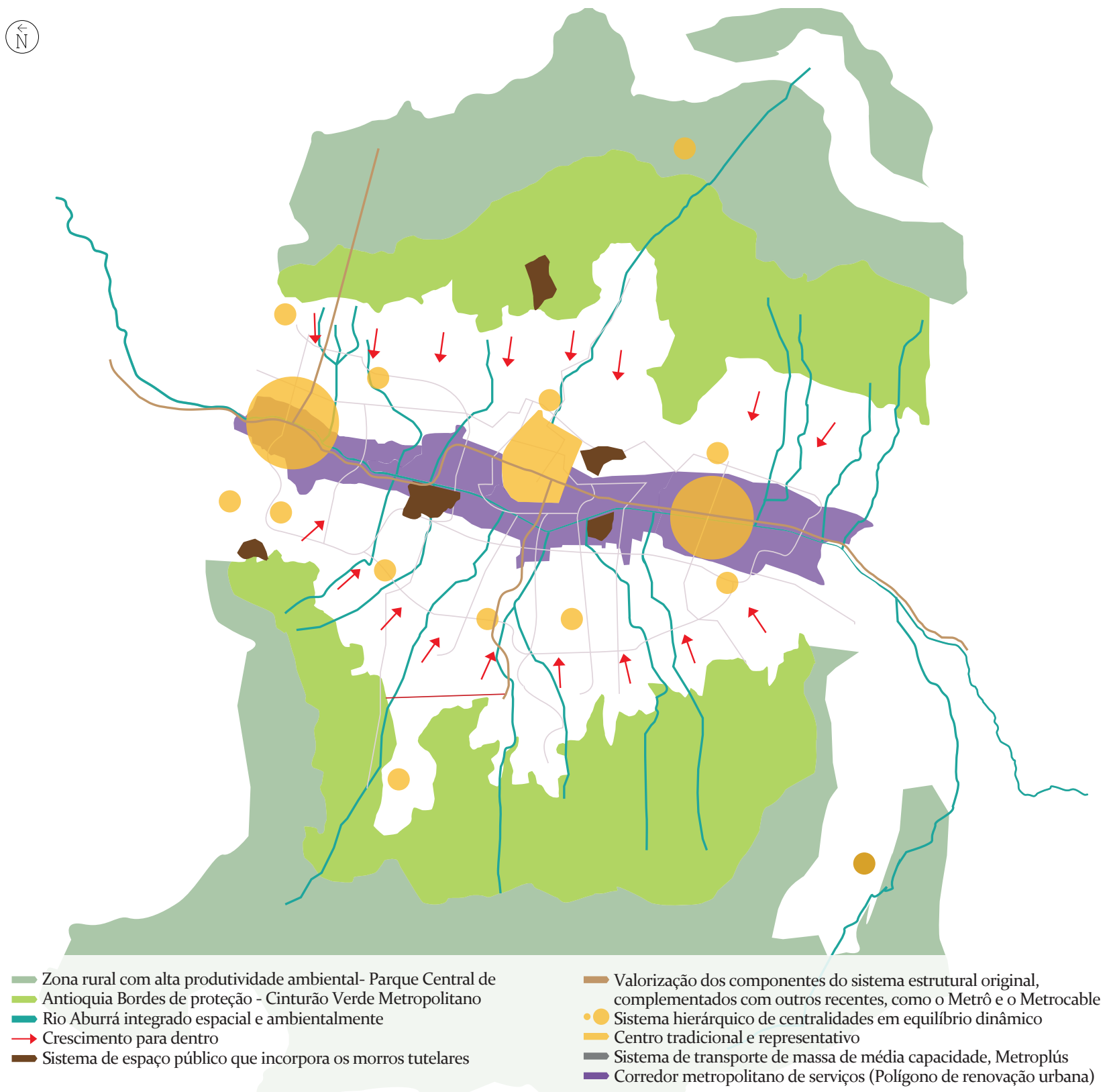

Figura 2.3.3 Modelo de ocupação do território previsto pelo Plan de Ordenamiento Territorial POT, 1999 
Centralidade metropolitana

- Centralidadades tradicionais municipais e zonas

- Centros logísticos

Limite ciudade comuna

Sistema vial metropolitano regional

- Atividade múltipla

- Corredor produtivo

- Corredores turísticos empresariais

- Principais eixos transversais

Borda associada parque central de Antioquia Sistema

de espaço público do rio

Limite urbano

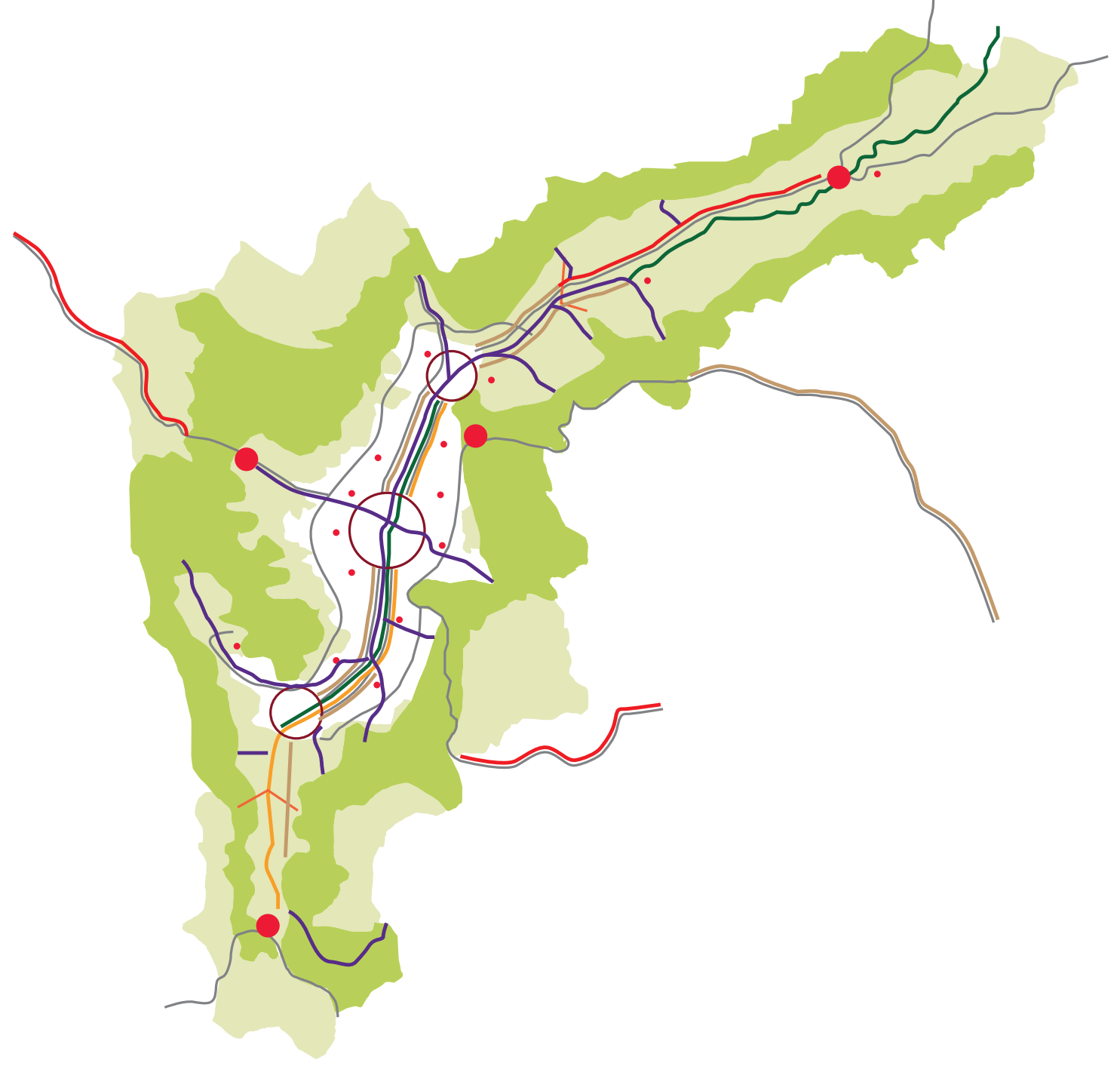

Figura 2.3.4 Modelo de ocupação do território para o Valle de Aburrá previsto pelo Plan de Ordenamiento Territorial POT, 2006 
Painel 2.4 Infraestrutura de transporte em Medellín [comparação com São Paulo]
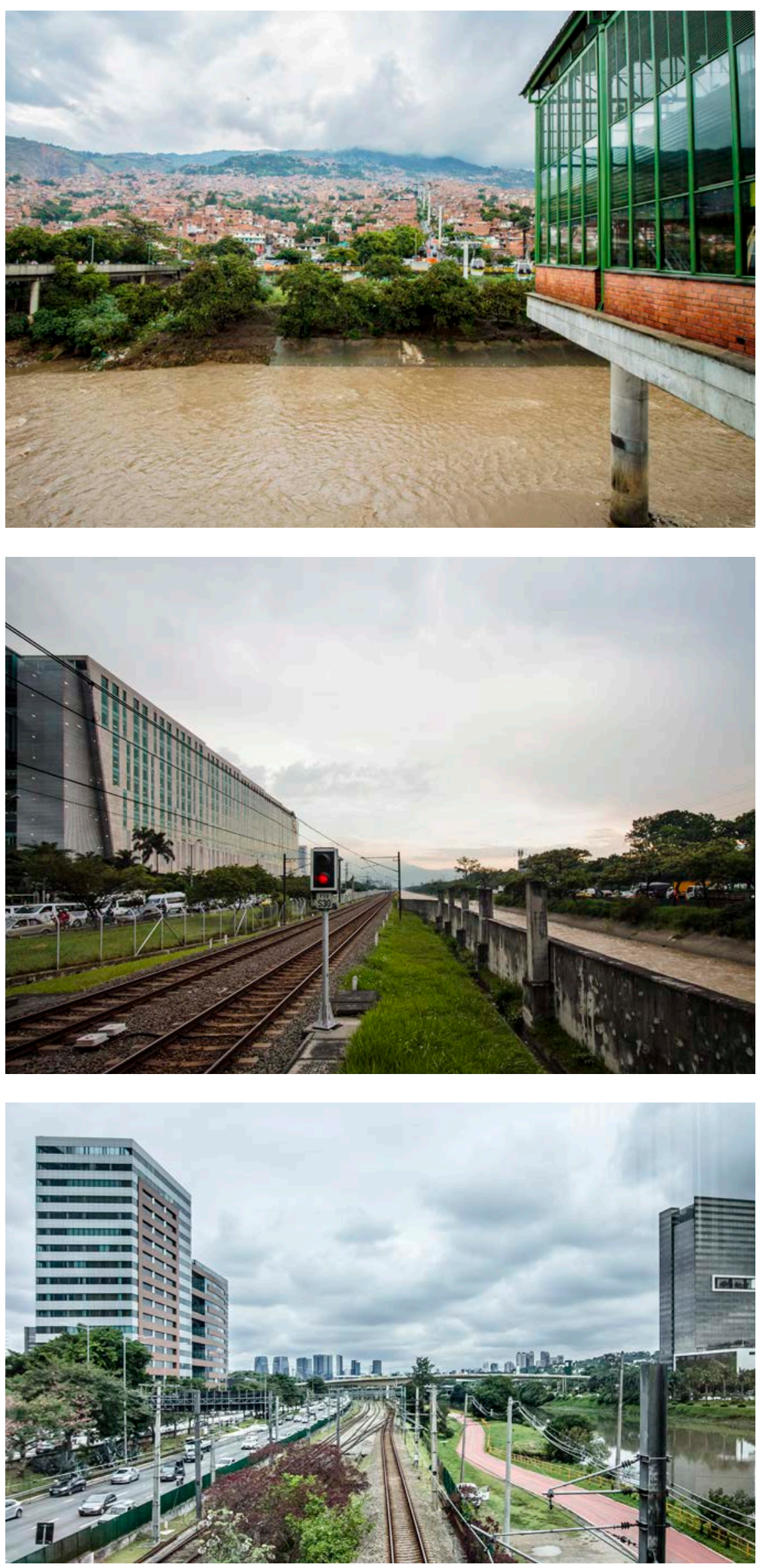

\section{Figura 2.4.1 Medellín}

Estação de Metrô Acevedo - Vista da Linha K de Metrocable subindo a Ladeira NorteOriental: em cerca 15 minutos é possível ir do extremo da linha K do Metrô, em Santo Domingo Savio até linha de metrô que corta toda a cidade oficial

Figura 2.4.2 Medellín

Estação de Metrô Industriales

A linha de metrô é intermunicipal e vindo pelo sul (passando pelos municípios de Estrella e Itagui), a linha acompanha a margem do rio. Ao lado se vêem novos edifícios que ocupam a área de antigos galpões industriais. Uma região próxima ao rico bairro do Poblado que vem sofrendo grande valorização imobiliária e consequente verticalização. $\mathrm{O}$ edifício do BanColombia à esquerda pertence à quadra do Plan Parcial Simesa

\section{Figura 2.4.2b São Paulo}

Estação de Metrô Vila Olímpia

A situação urbana é muito similar a de Medellín, seja pela infraestrutura ferroviária e rodoviária às margens do rio [retificado] quanto o adensamento e os novas operações urbanas nos antigos lotes industriais que se tornam pólos do setor financeiro na cidade 
Painel 2.4 Infraestrutura de transporte em Medellín
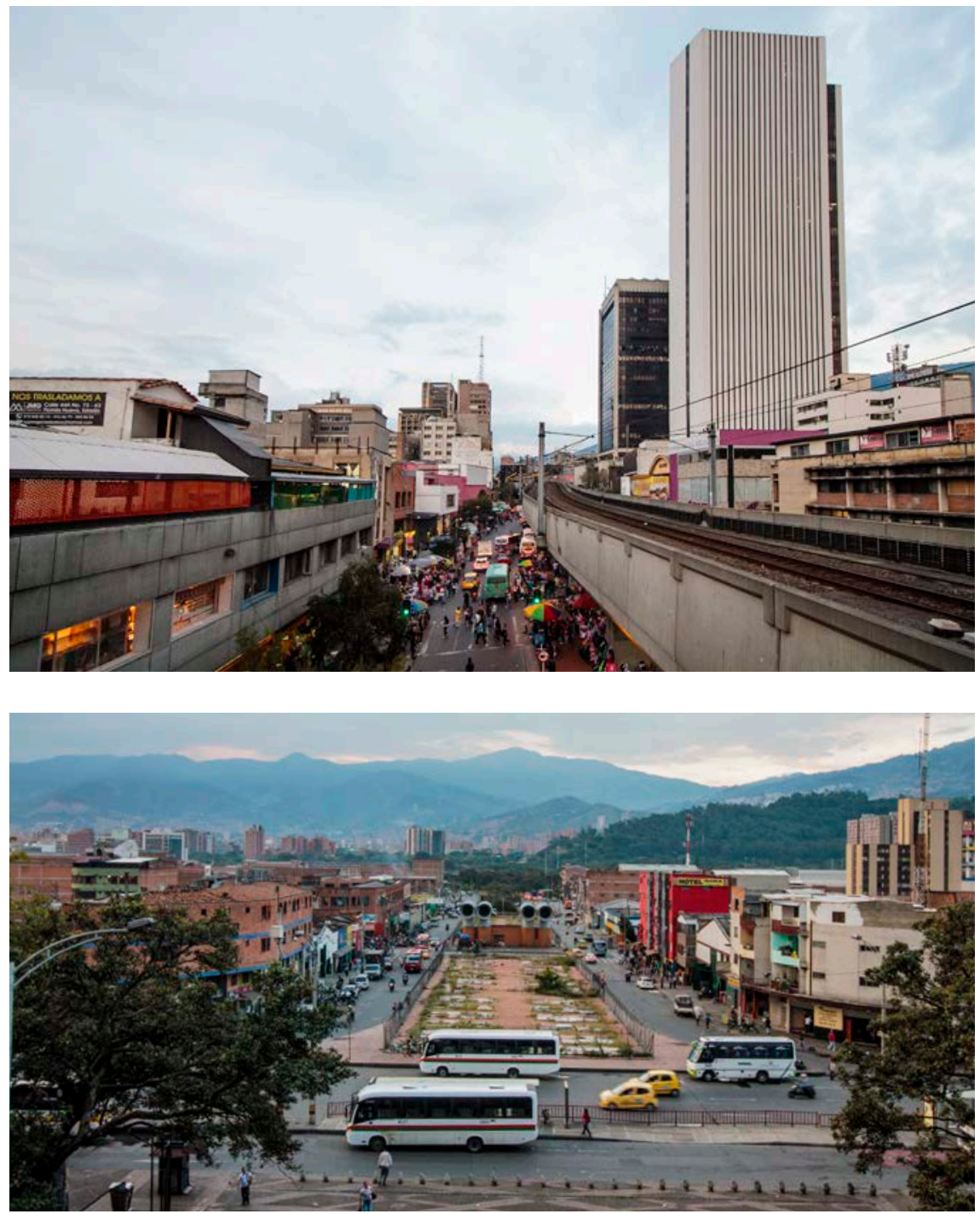

Figura 2.4.3

Estação de Metrô Prado

Pouca densidade nas imediações do centro, no eixo principal e mais bem servido de infraestrutura da cidade.

Figura 2.4.4

O vazio urbano deixado pela demolição do Bazar de los Puentes revela a parte superior de um túnel por onde passa a Avenida Oriental, uma obra dos anos 1970 que atravessou o centro da cidade causando demolições massivas e deixando grandes seqüelas no tecido urbano

Figura 2.4.6

Trajeto de metrocable Linha J de San Javier em direção à La Aurora [Occidente] pelo alto fluxo de pessoas que alimenta o comércio ambulante
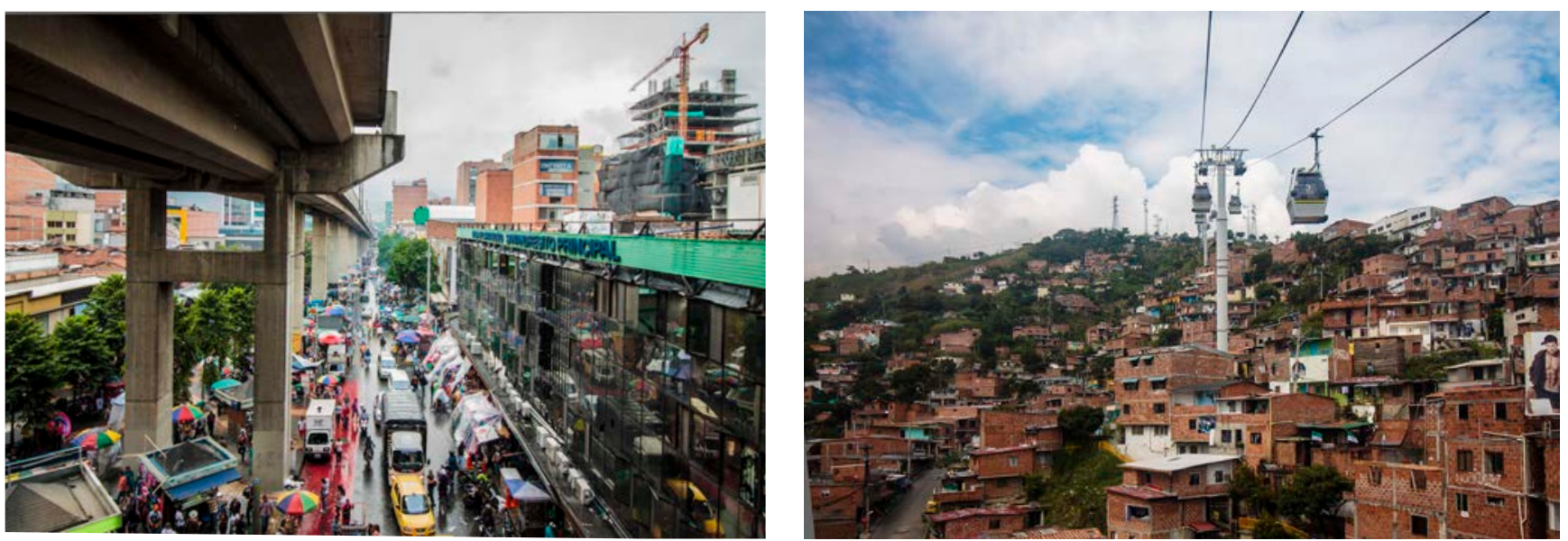
Painel 2.4 Infraestrutura de transporte em Medellín

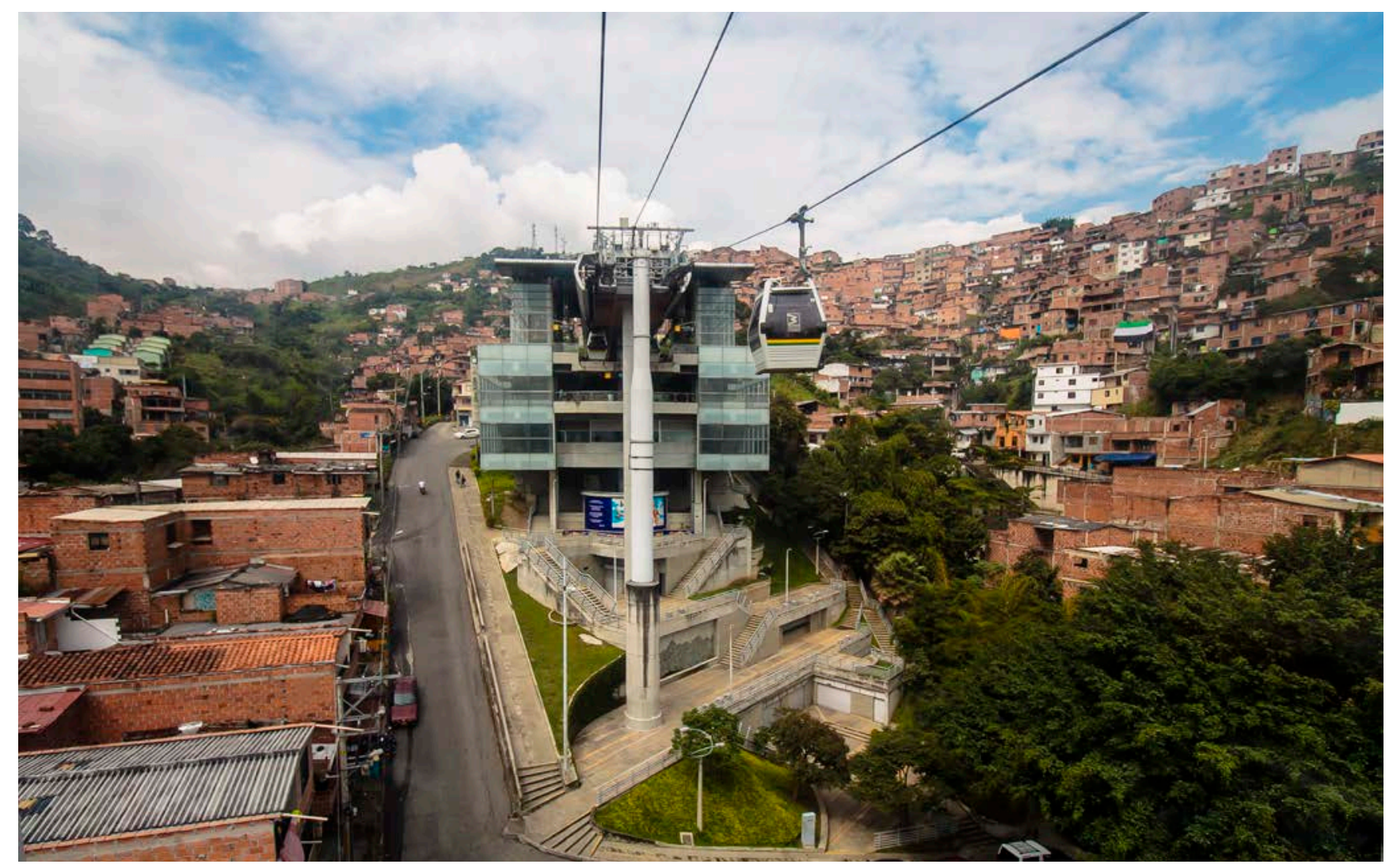

Figura 2.4.7

Estação de Metrocable

Juan XXII

vista da transição de

níveis e calçamento do

entorno

\section{Figura 2.4.8}

Estação de Metrocable

el Pinal

em construção

\section{Figura 2.4.8b}

Estação de Metrocable

La Aurora

Acesso pela cota mais

alta
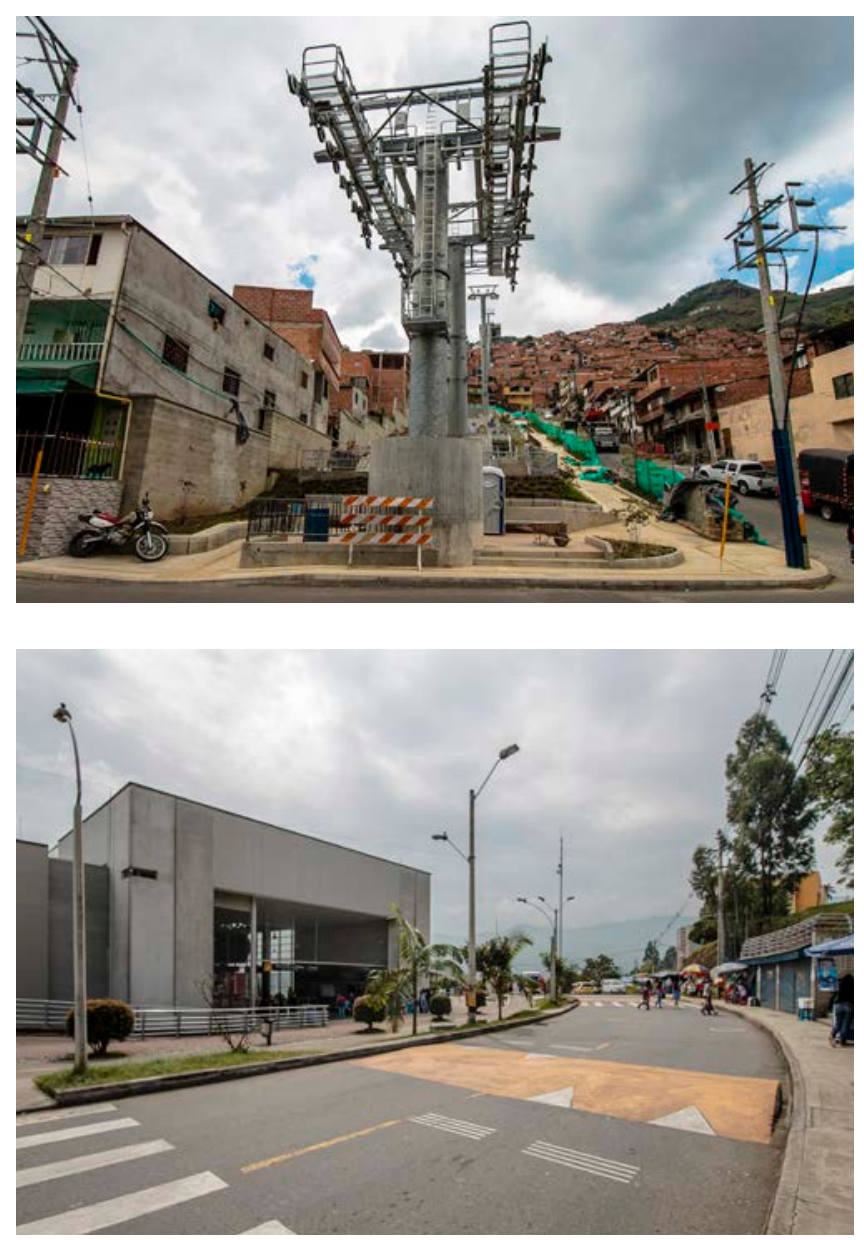


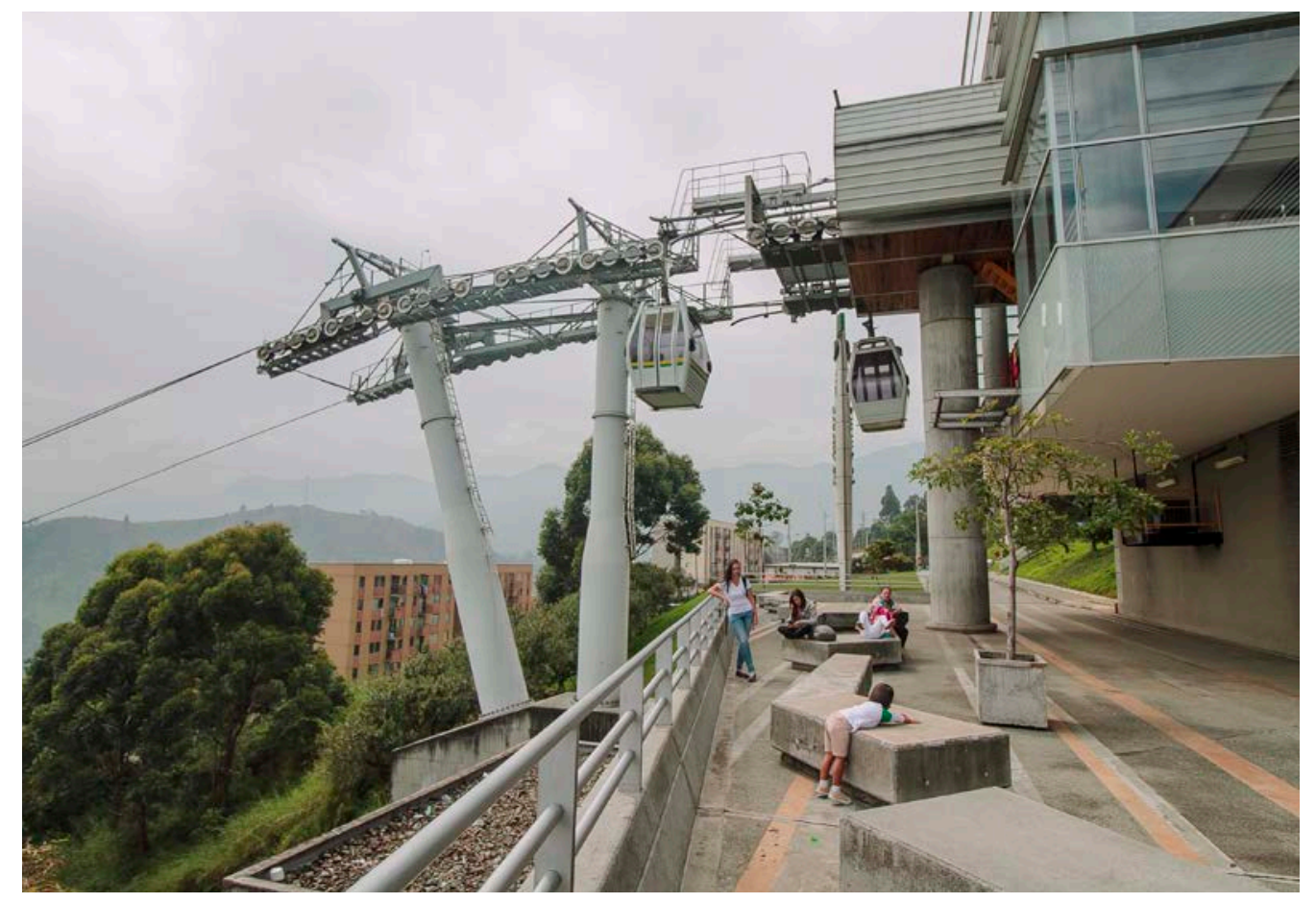

Figura 2.4.9

Estação de Metrocable

La Aurora

Praça - mirante e a rua que

da acesso à Estação

Figura 2.4.10

Figura 2.4.11

Estação de Metrocable

Santo Domingo

Cabine sobre a ladeira

Norte-Oriental e os espaços públicos na parte inferior da estação
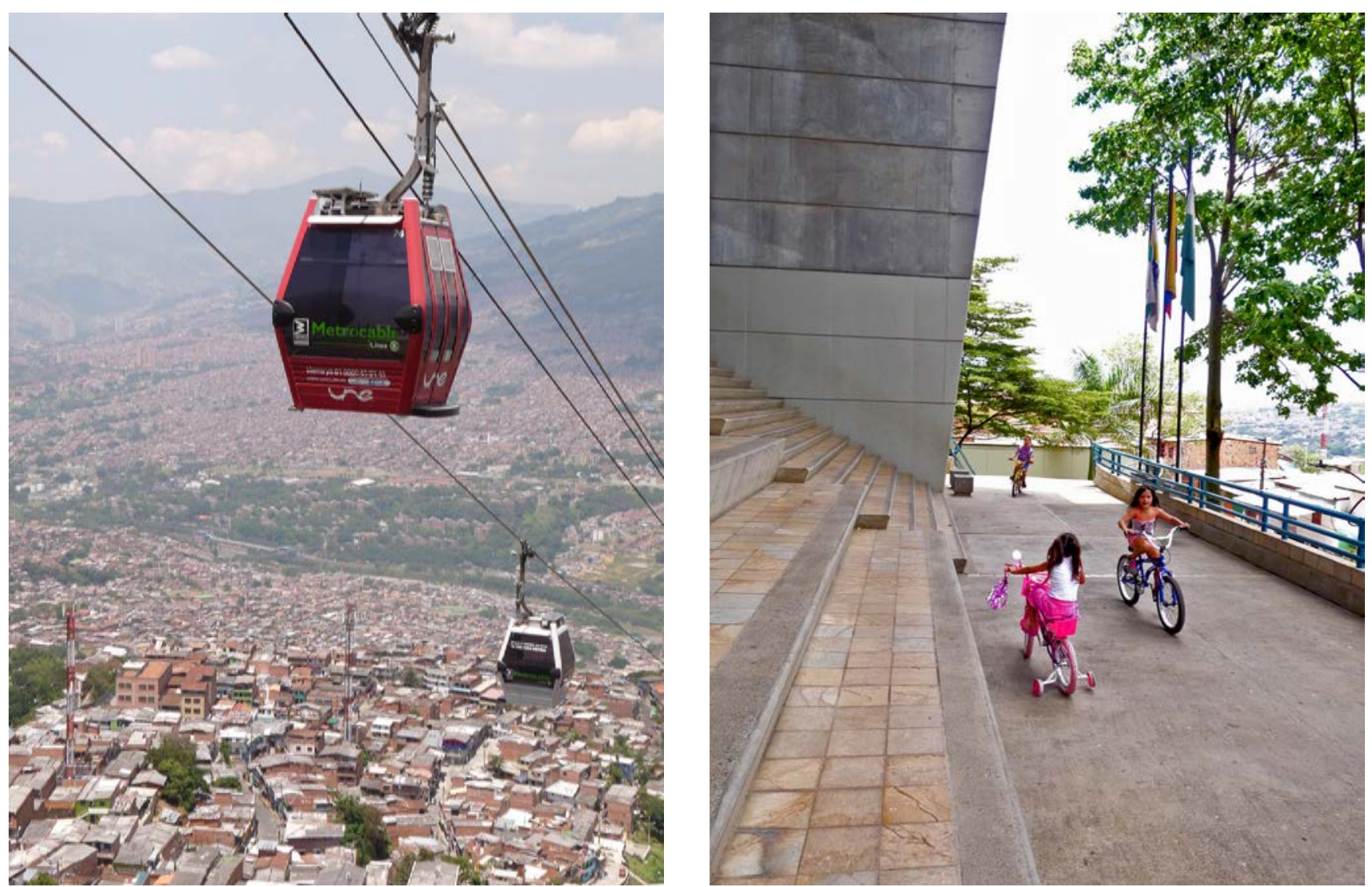
Painel 2.4 Infraestrutura de transporte em Medellín

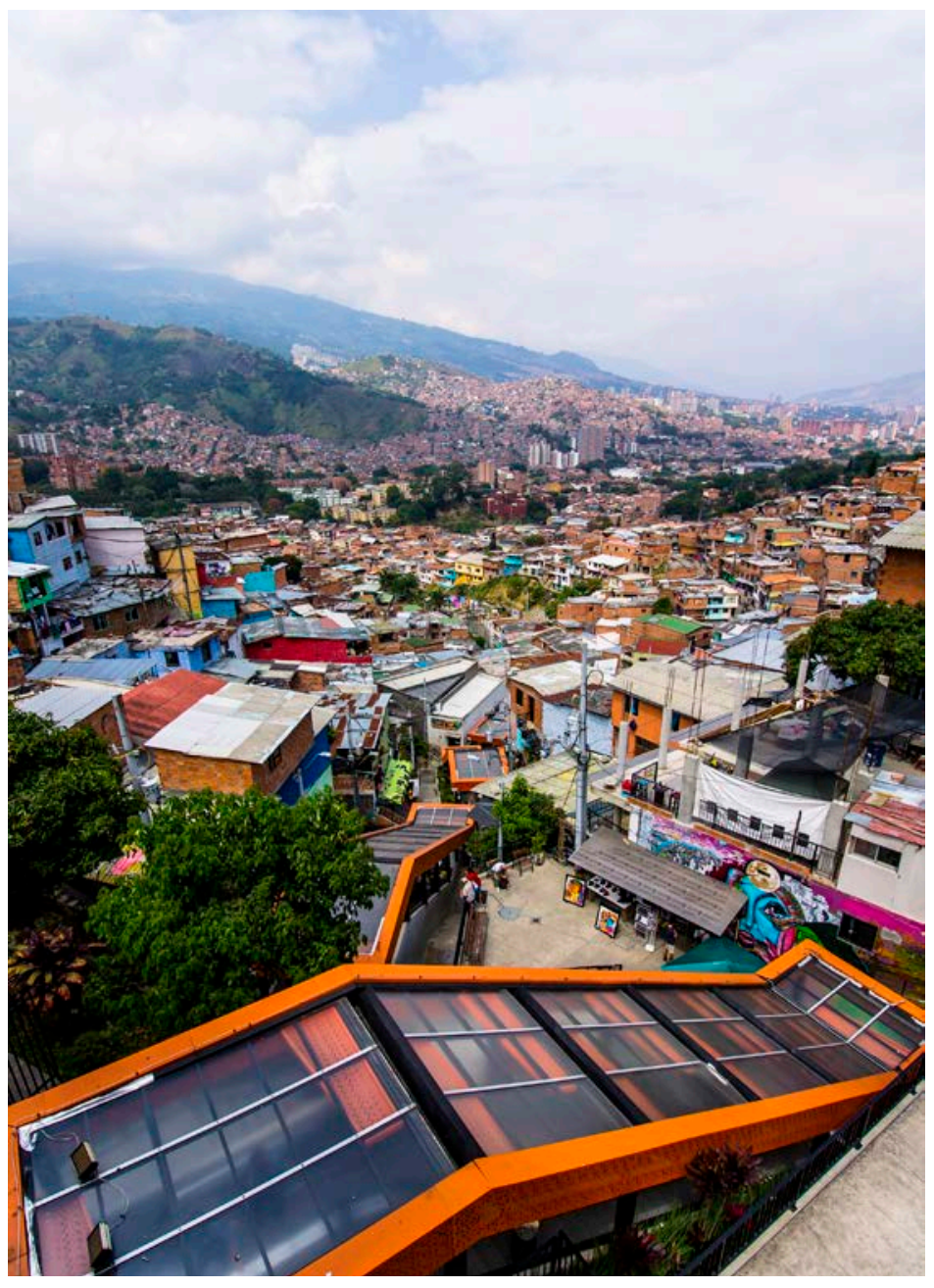

Figura 2.4.11

Figura 2.4.12

Escaleras eléctricas da

Comuna 13

Vista superior e acesso à rua

no ponto mais alto da escada

rolante
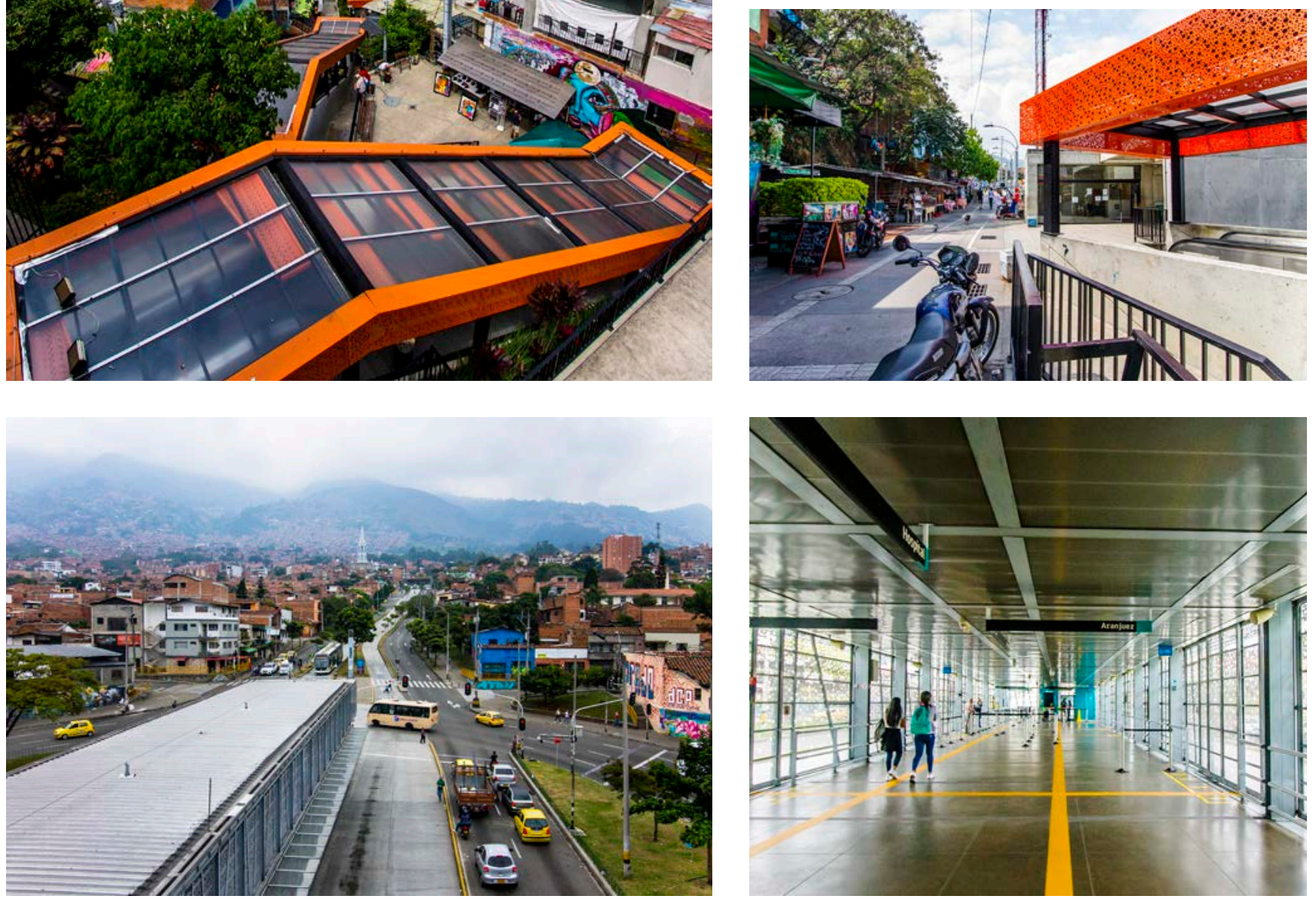

Figura 2.4.13

Figura 2.4.14

Linha de Metroplus em direção ao bairro de

Manrique e a vista interna da estação 
Figura 2.4.15

Figura 2.4.16

Vistas das imediações

da estação de Tranvía Oriente:

espaços residuais foram incorporados como

pequenas praças ou receberam tratamento

urbanístico
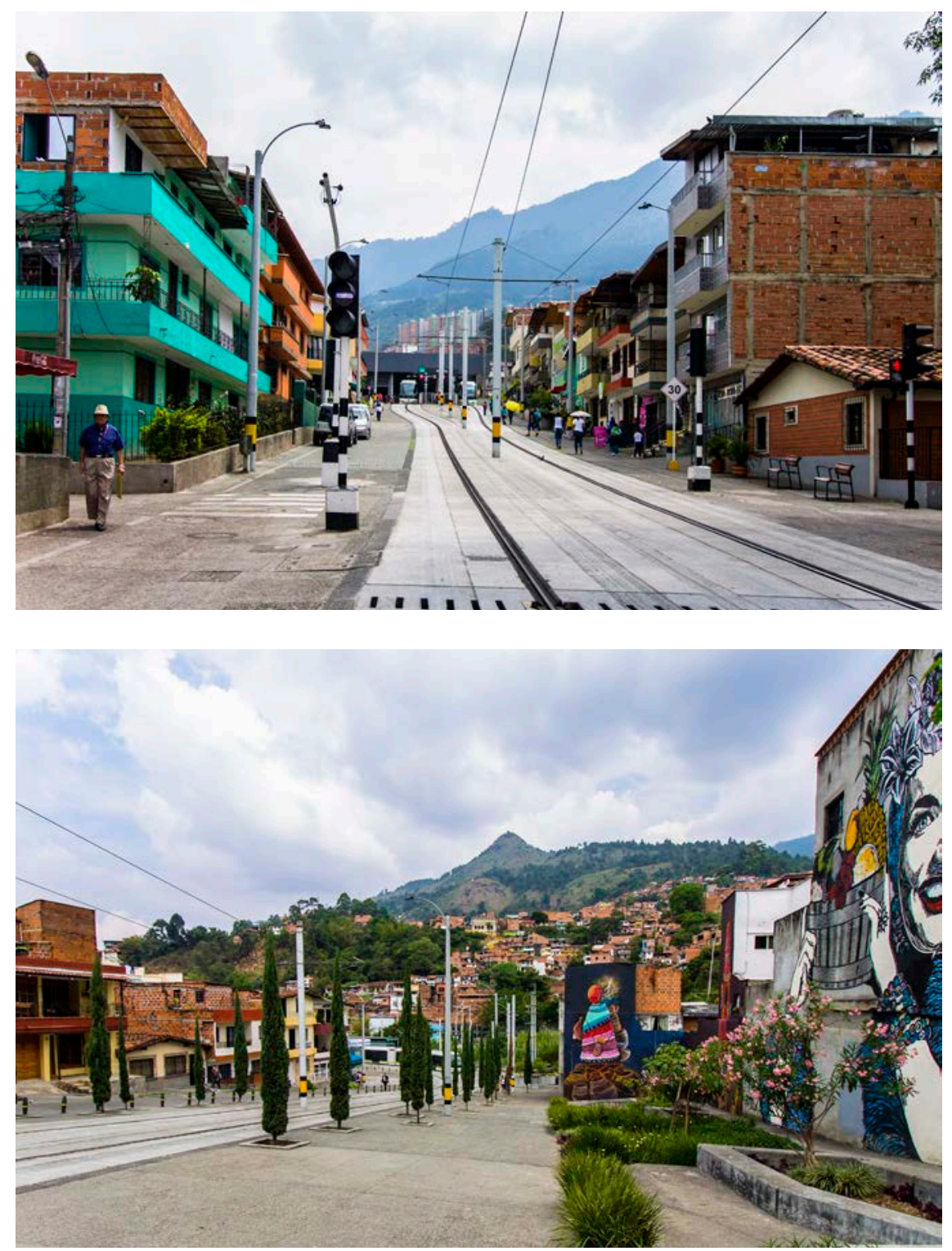

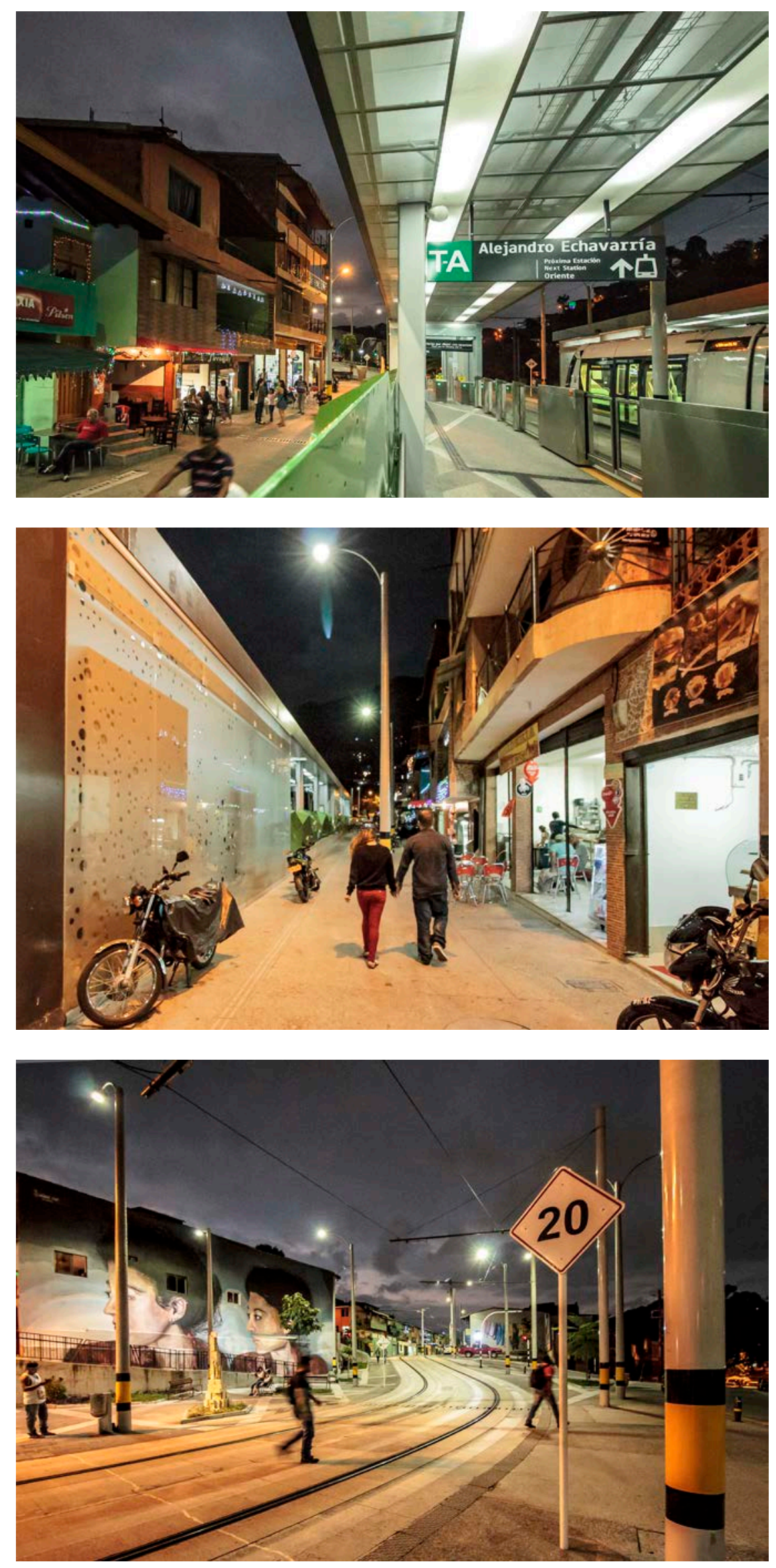

Figura 2.4.19

Figura 2.4.20

Figura 2.4.21

Estacion Tranvia

Alejandro Echevarria 
na região central da cidade

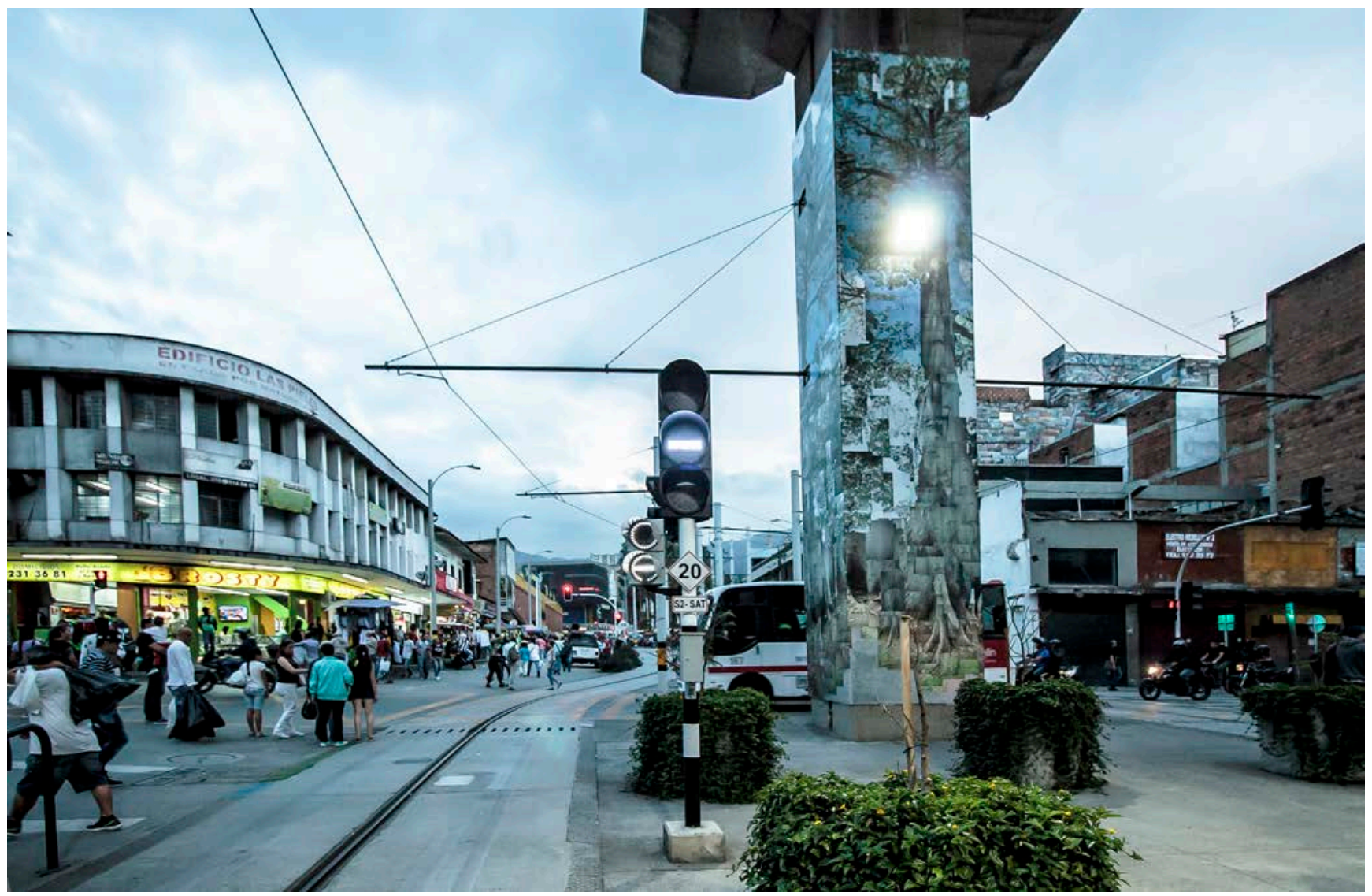


Painel 2.5 Unidades de Vida Articulada
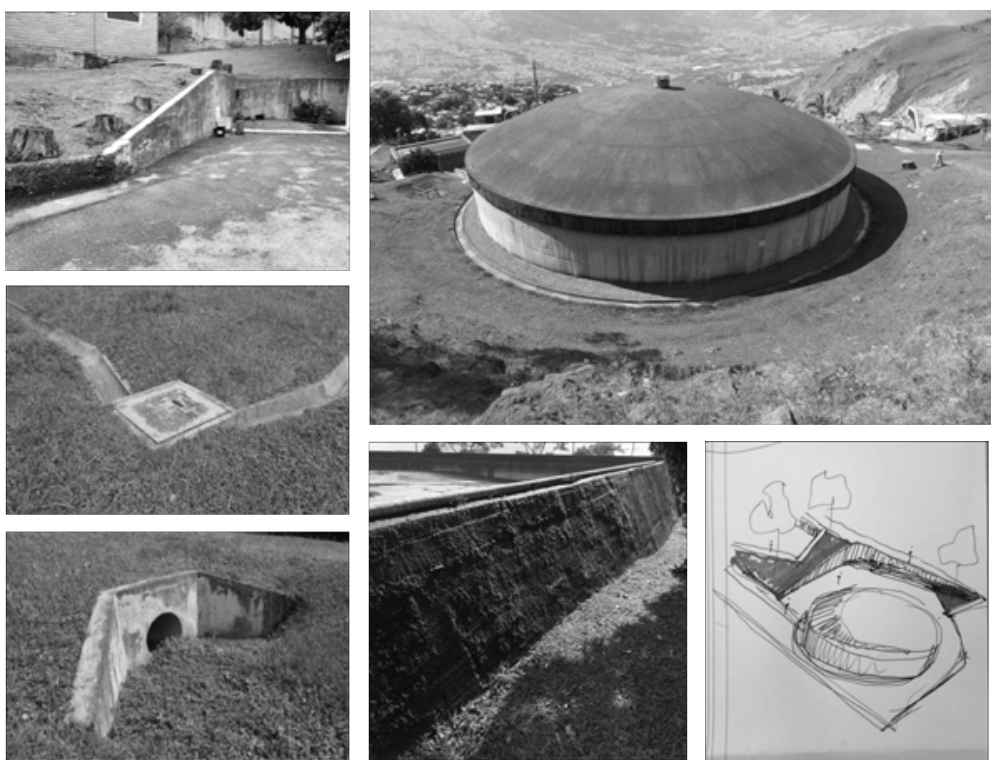

Figura 2.5.1 Infraestrutura hidráulica: elementos

foram incorporados como referências formais para o projeto das UVAs

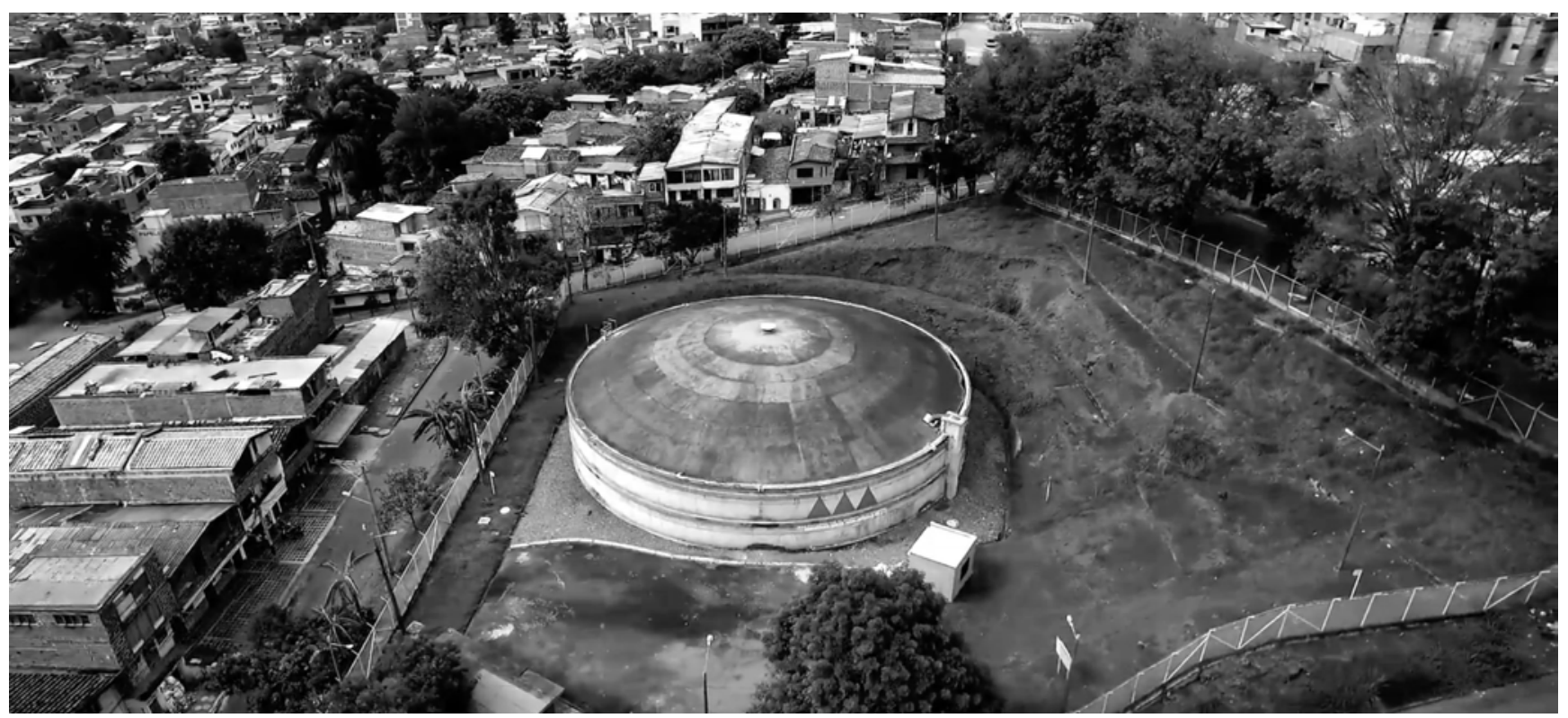

Figura 2.5.2 Situação original dos tanques antes da intervenção da EPM para transformá-los em UVAs 

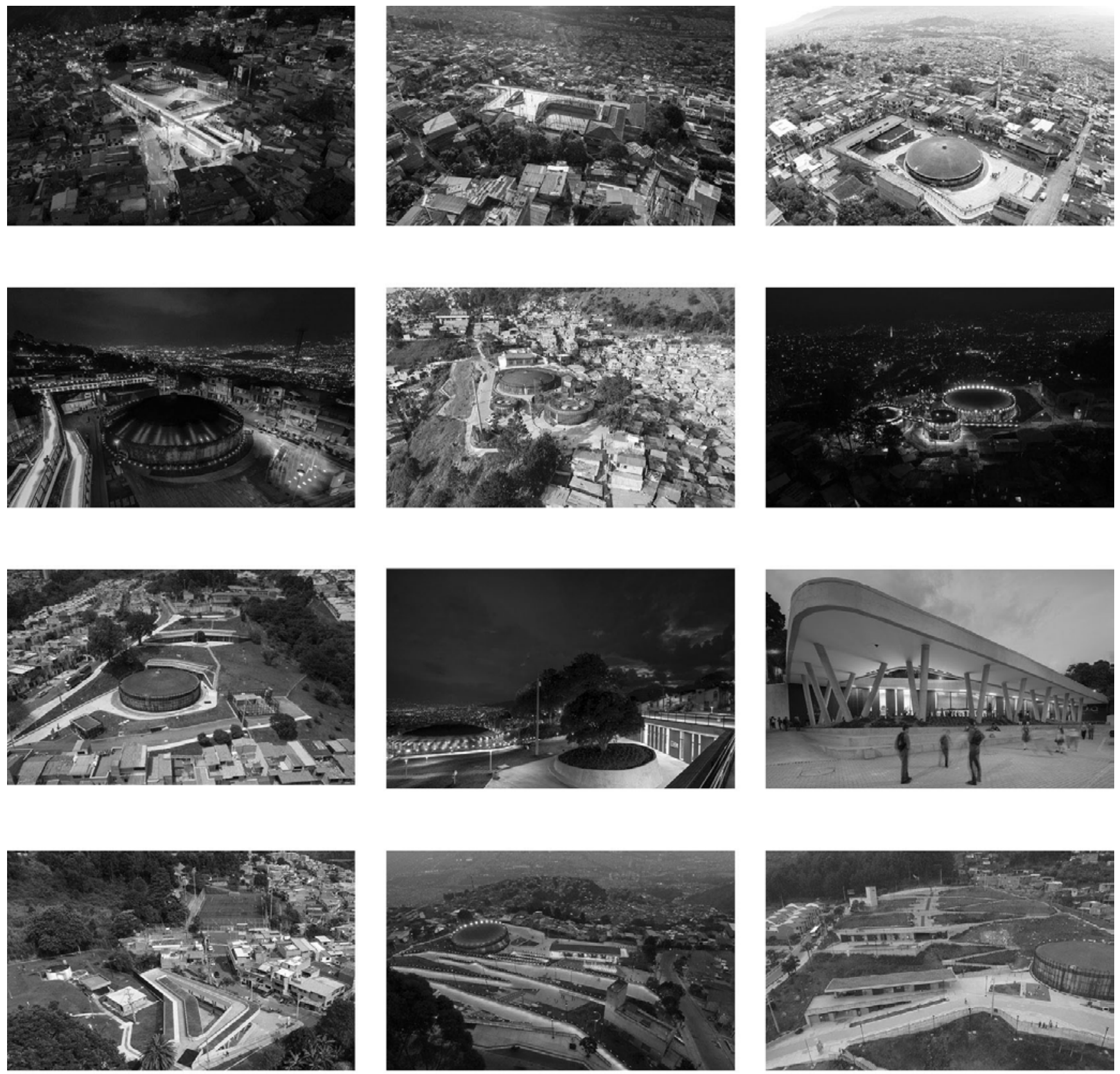

Figura 2.5.3

As 14 UVAs tanque [tipo A] que já

foram construídas pela EPM
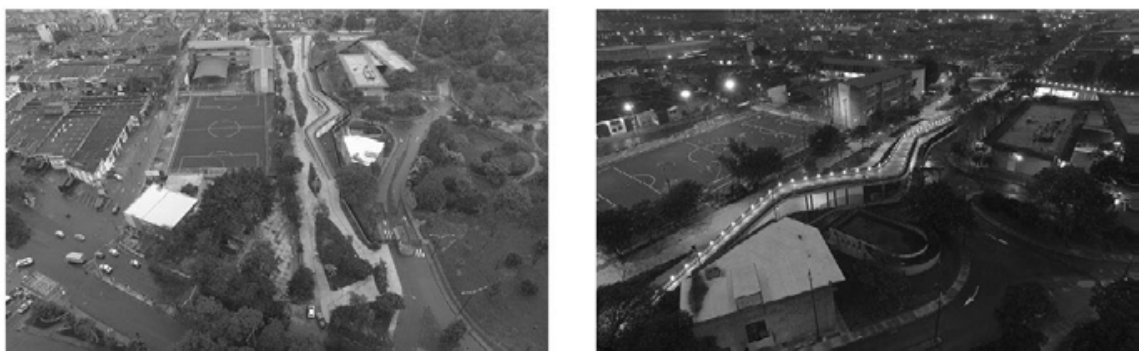
Painel 2.5 Unidades de Vida Articulada
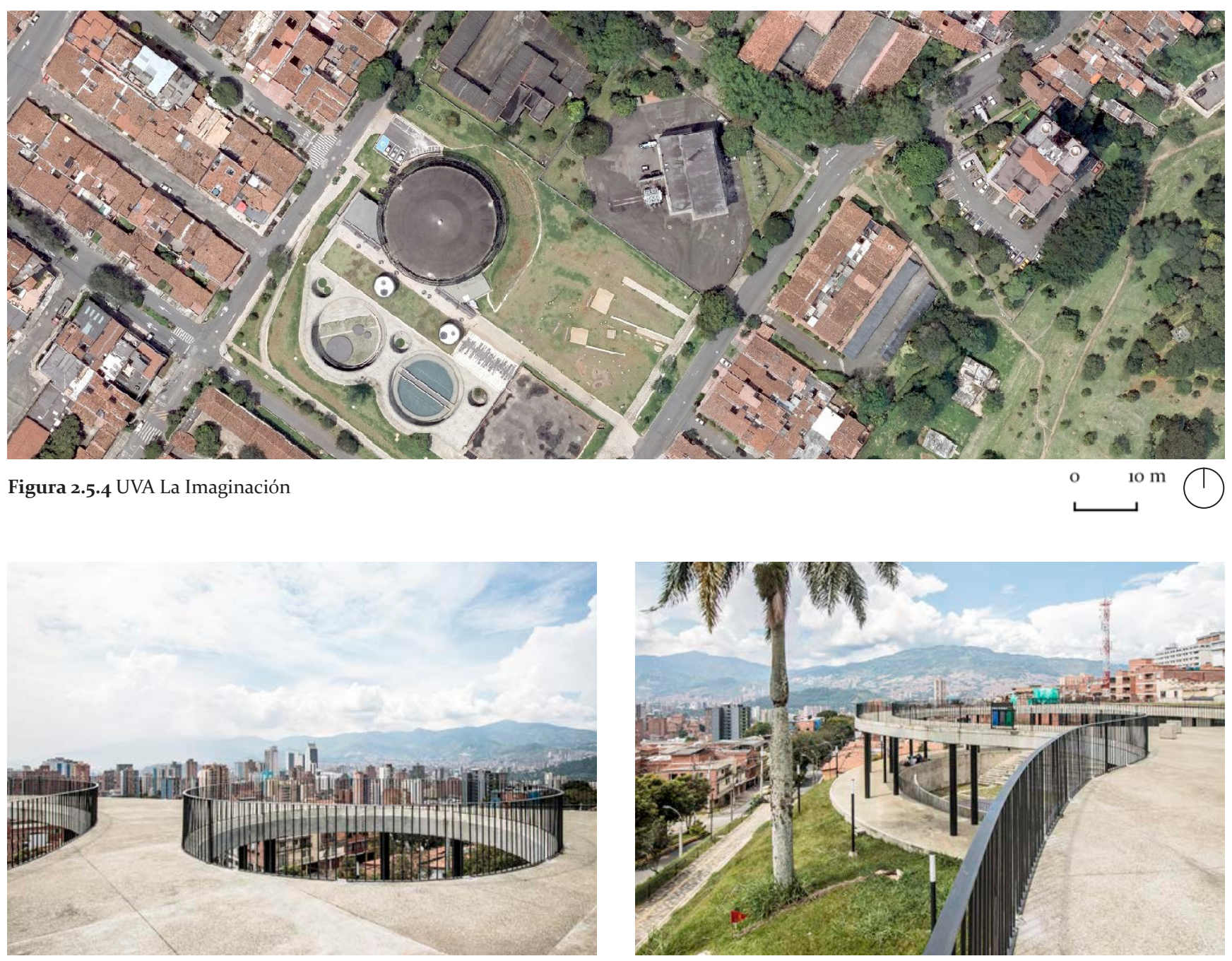

Figura 2.5.5

Vista do centro da cidade
Figura 2.5.6

Passarela e caminhos superiores no grande terraço da UVA La Imaginación

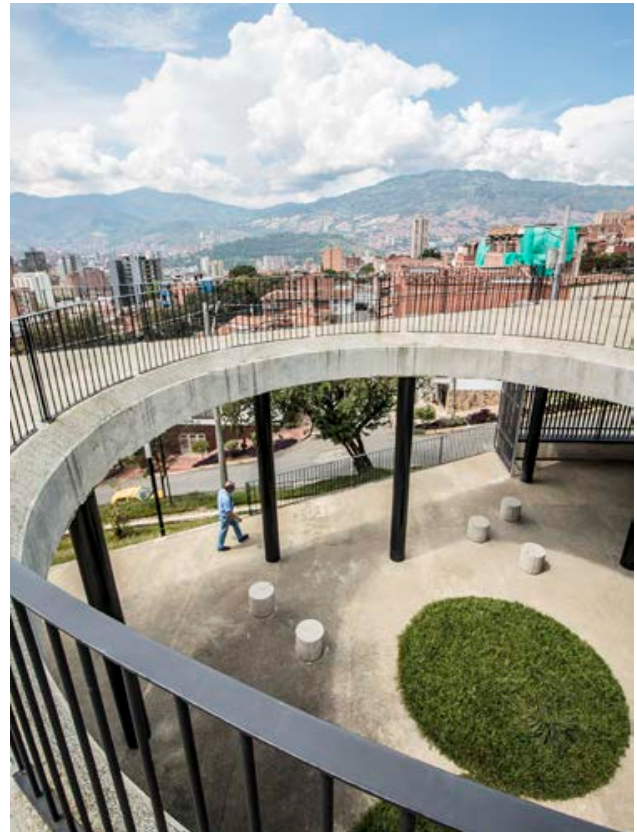

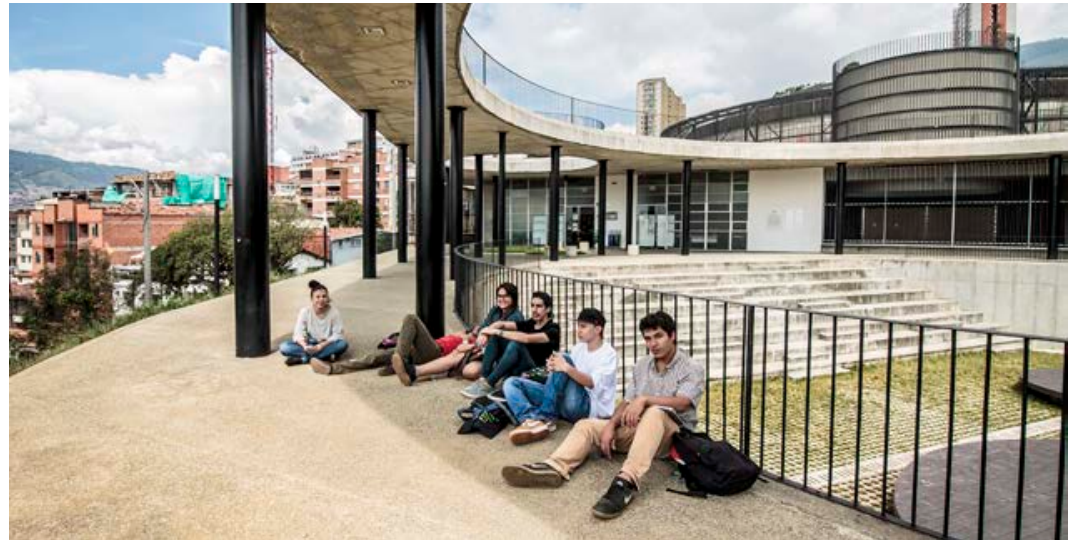

Figura 2.5.7

Camadas visuais: o terraço superior, o terraço inferior, a rua e a paisagem

Figura 2.5.8

Jovens Universitários usam a UVA La Imaginación como ponto de encontro 

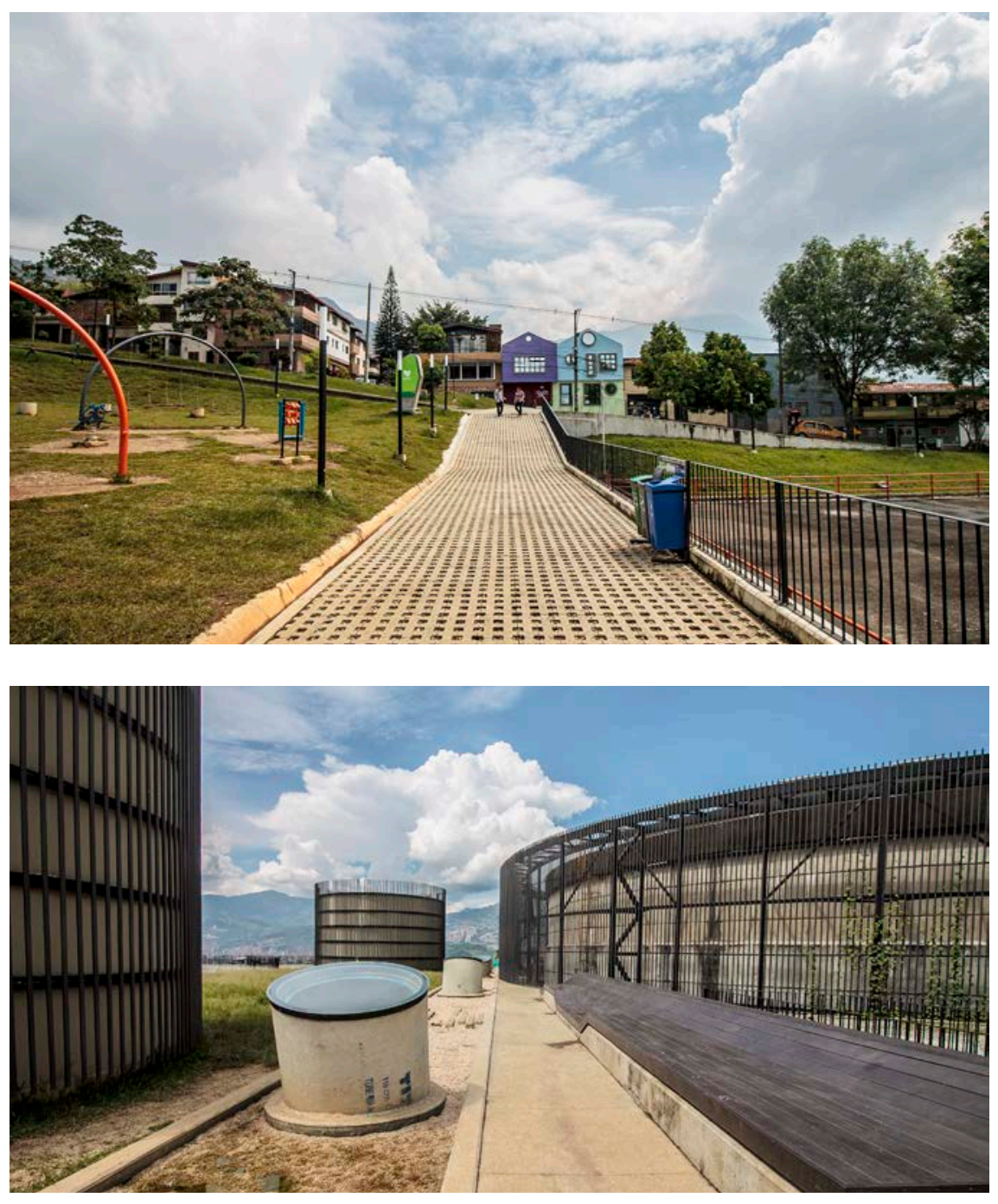

Figura 2.5.9

Figura 2.5.10 


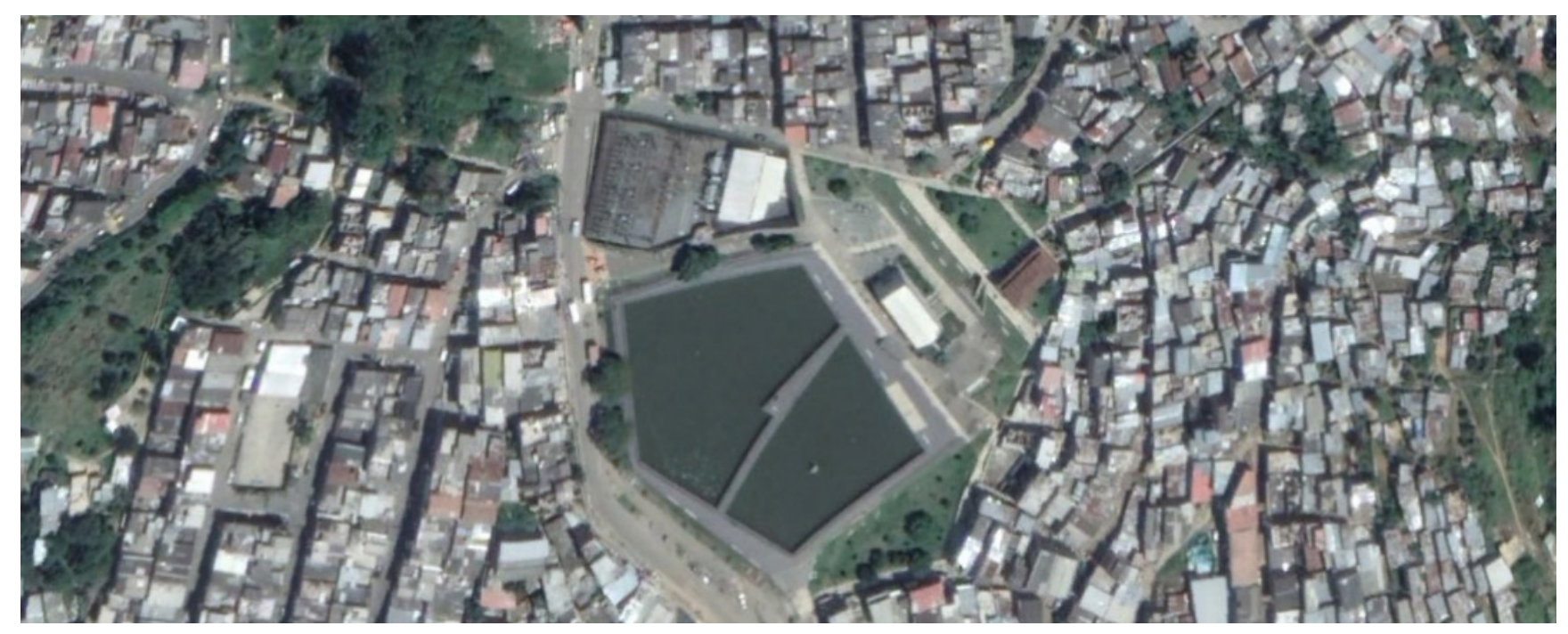

Figura 2.5.27 UVA La Armonía
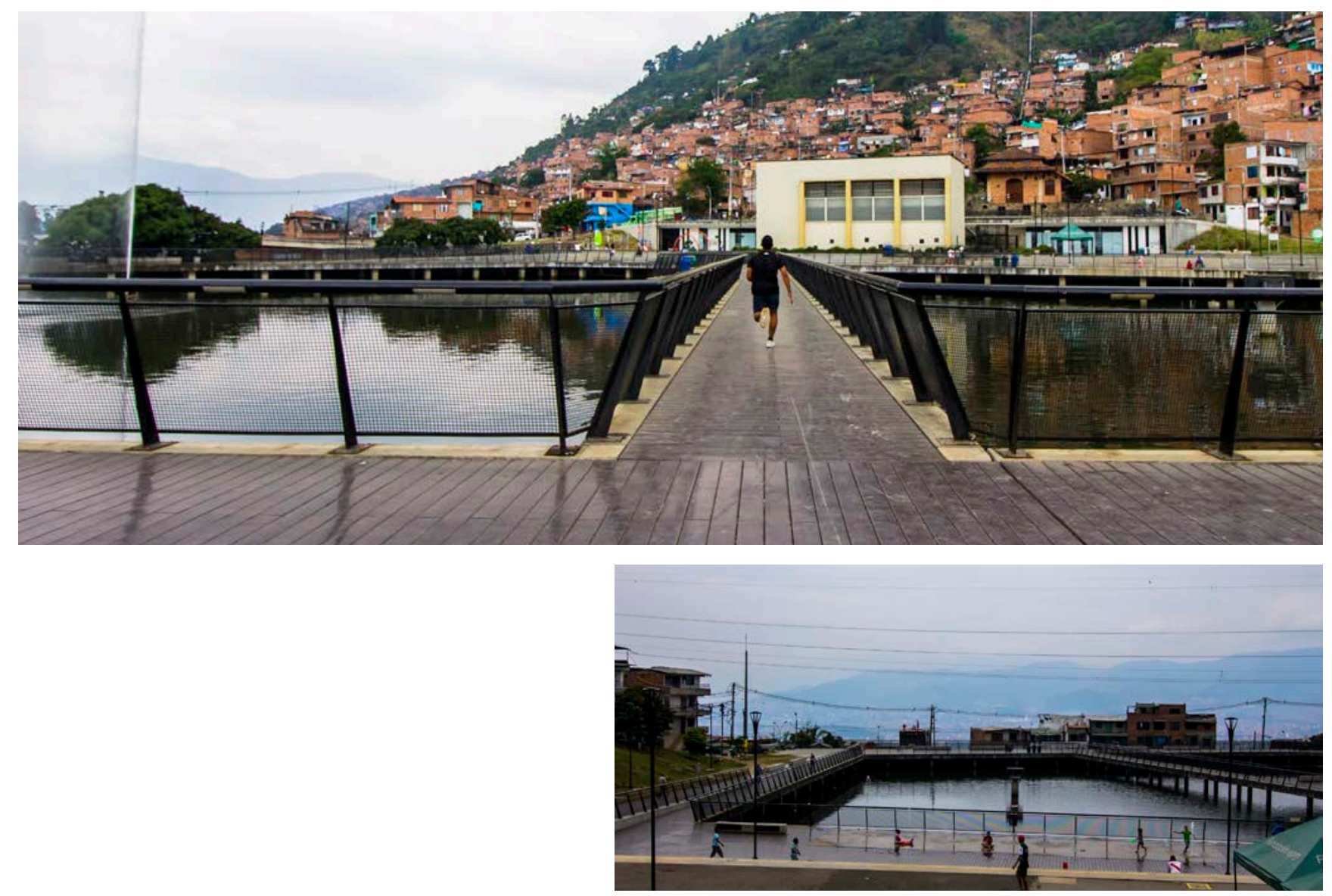

Figura 2.5.28

Figura 2.5.29

Figura 2.5.30

UVA La Armonía

O tanque dessa UVA era um dos poucos

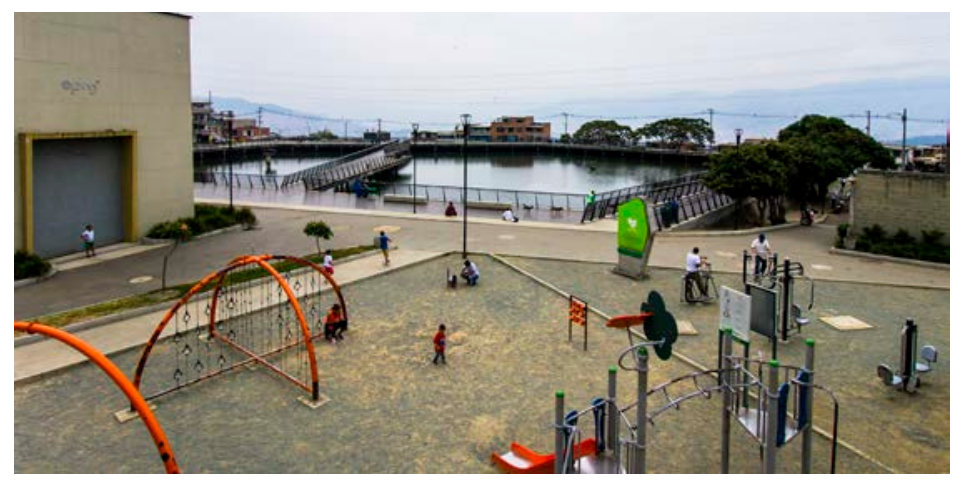

tanques abertos 

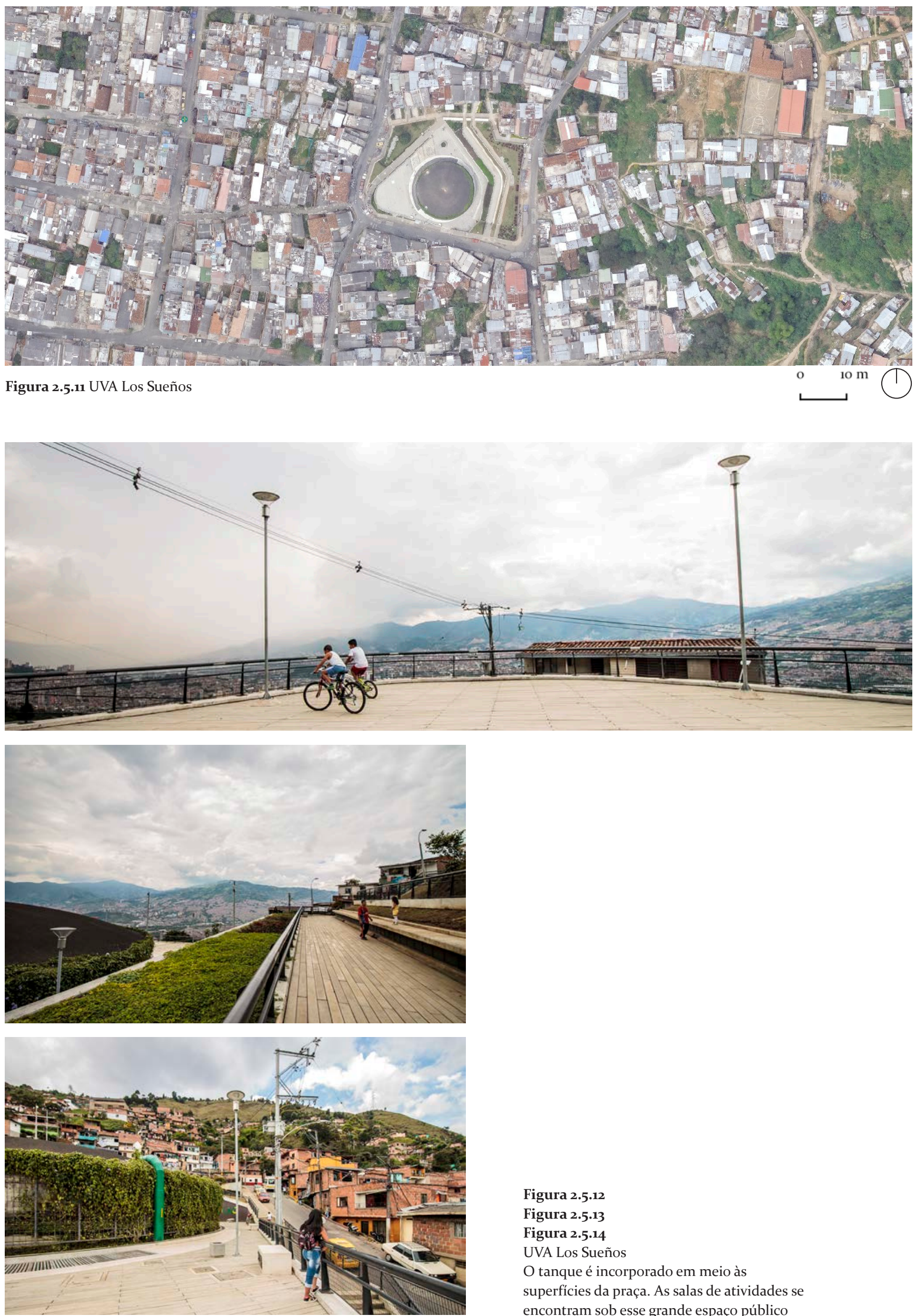

Figura 2.5.12

Figura 2.5.13

Figura 2.5.14

UVA Los Sueños

$\mathrm{O}$ tanque é incorporado em meio às superfícies da praça. As salas de atividades se encontram sob esse grande espaço público 

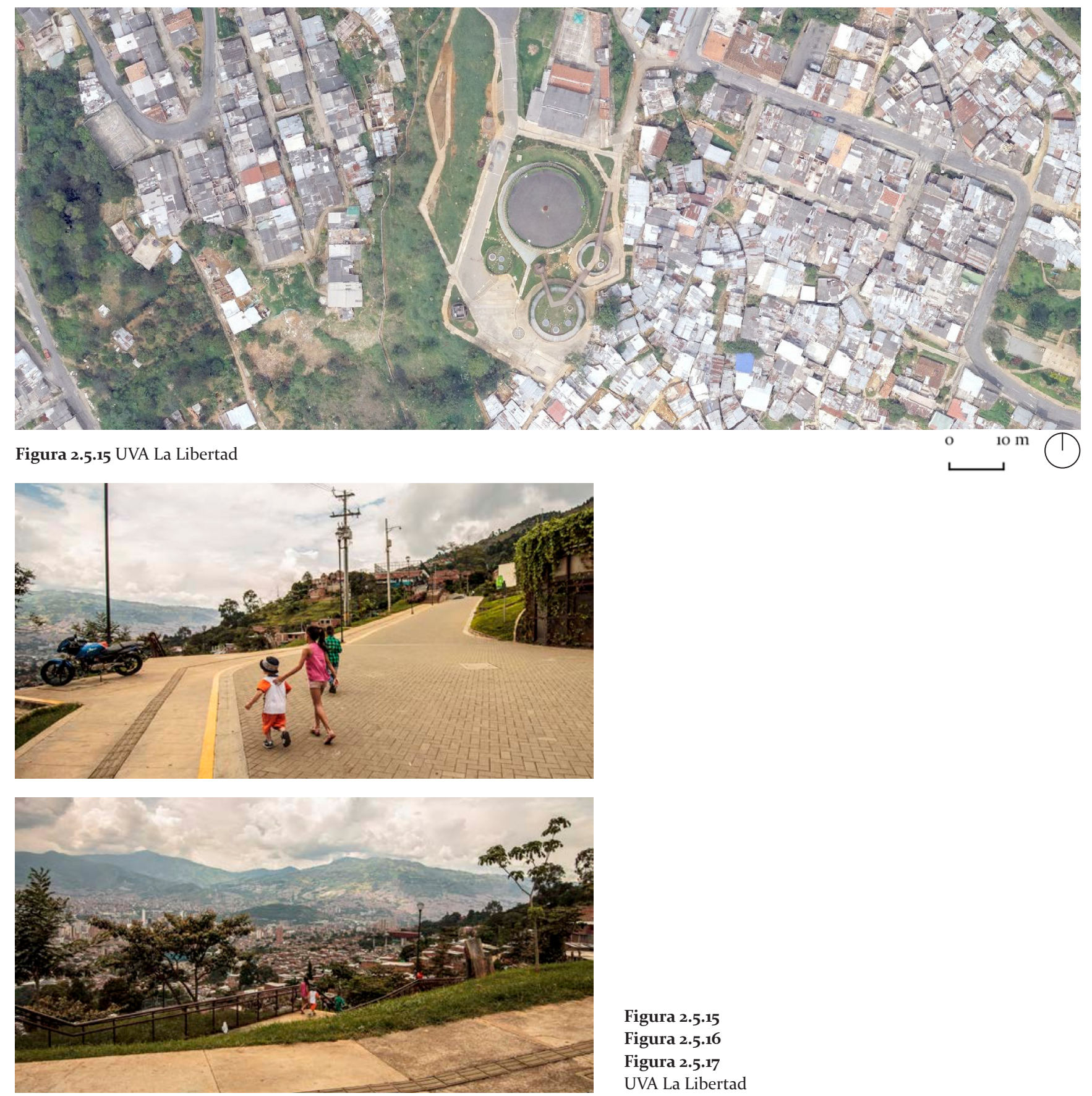

Figura 2.5.15

Figura 2.5.16

Figura 2.5.17

UVA La Libertad

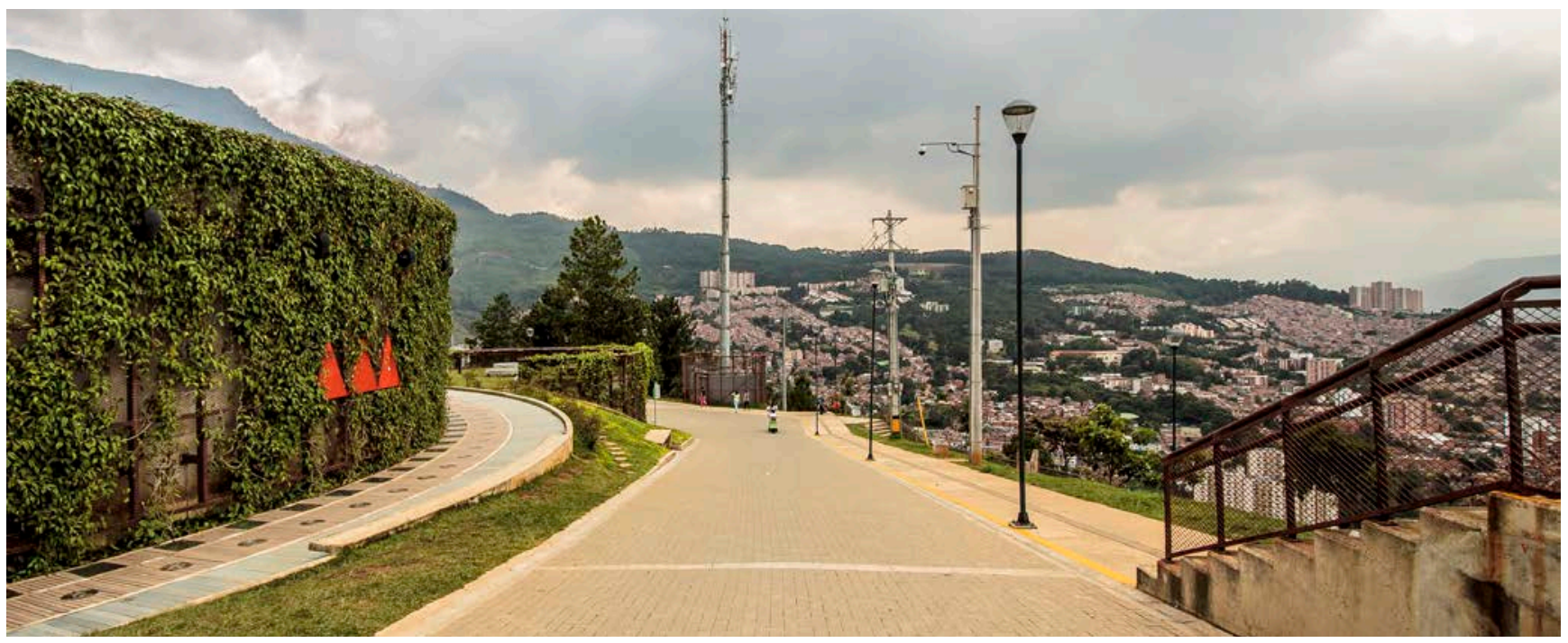




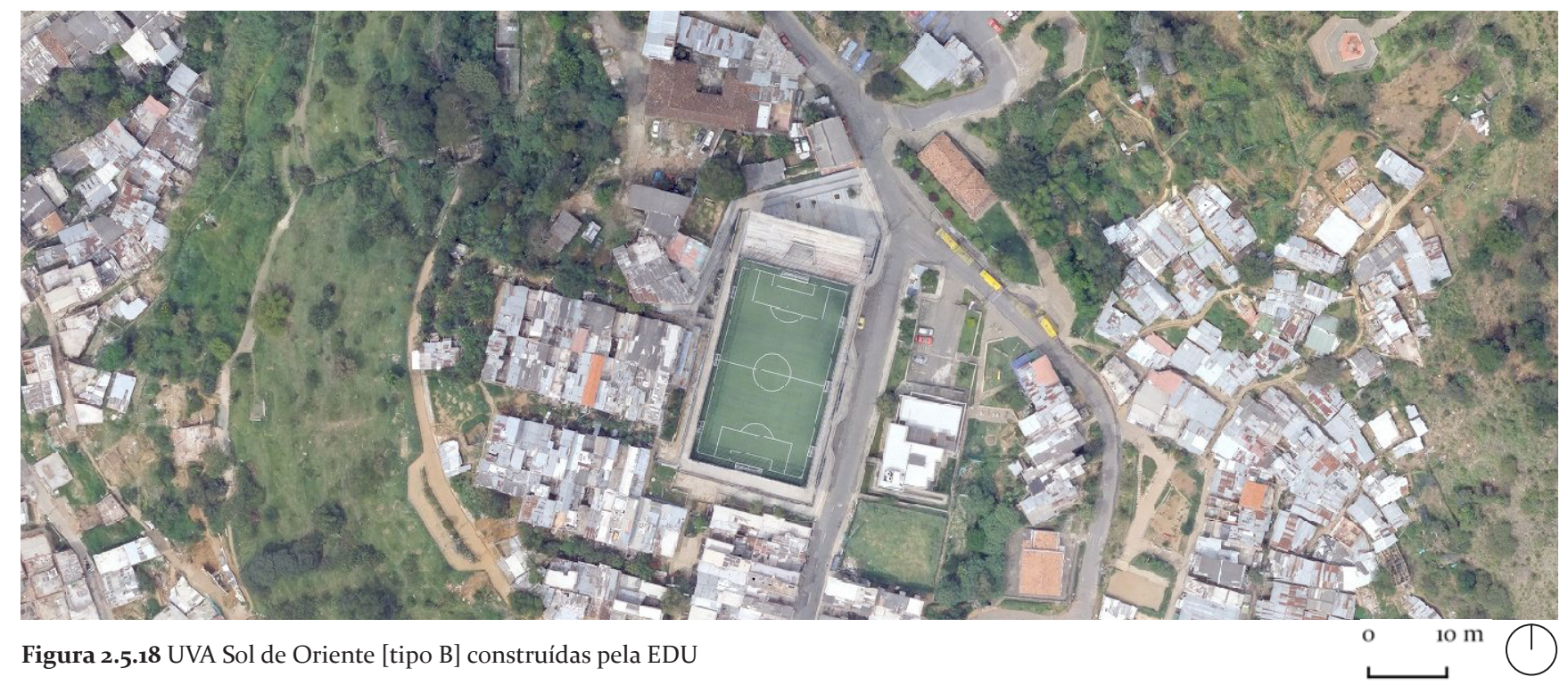

Figura 2.5.18 UVA Sol de Oriente [tipo B] construídas pela EDU

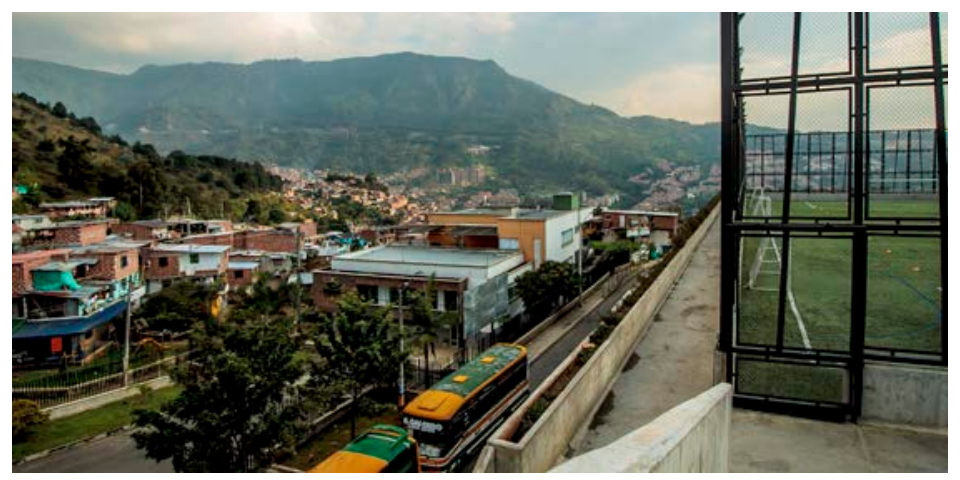

Figura 2.5.19

Do alto da UVA Sol do Oriente, vista da quadra e, abaixo, o ponto final dos ônibus conectam o bairro ao centro e demais localidades

Figura 2.5.20

Arquibancaade acesso da UVA Sol do Oriente

Figura 2.5.21

Vista superior da UVA Sol do Oriente
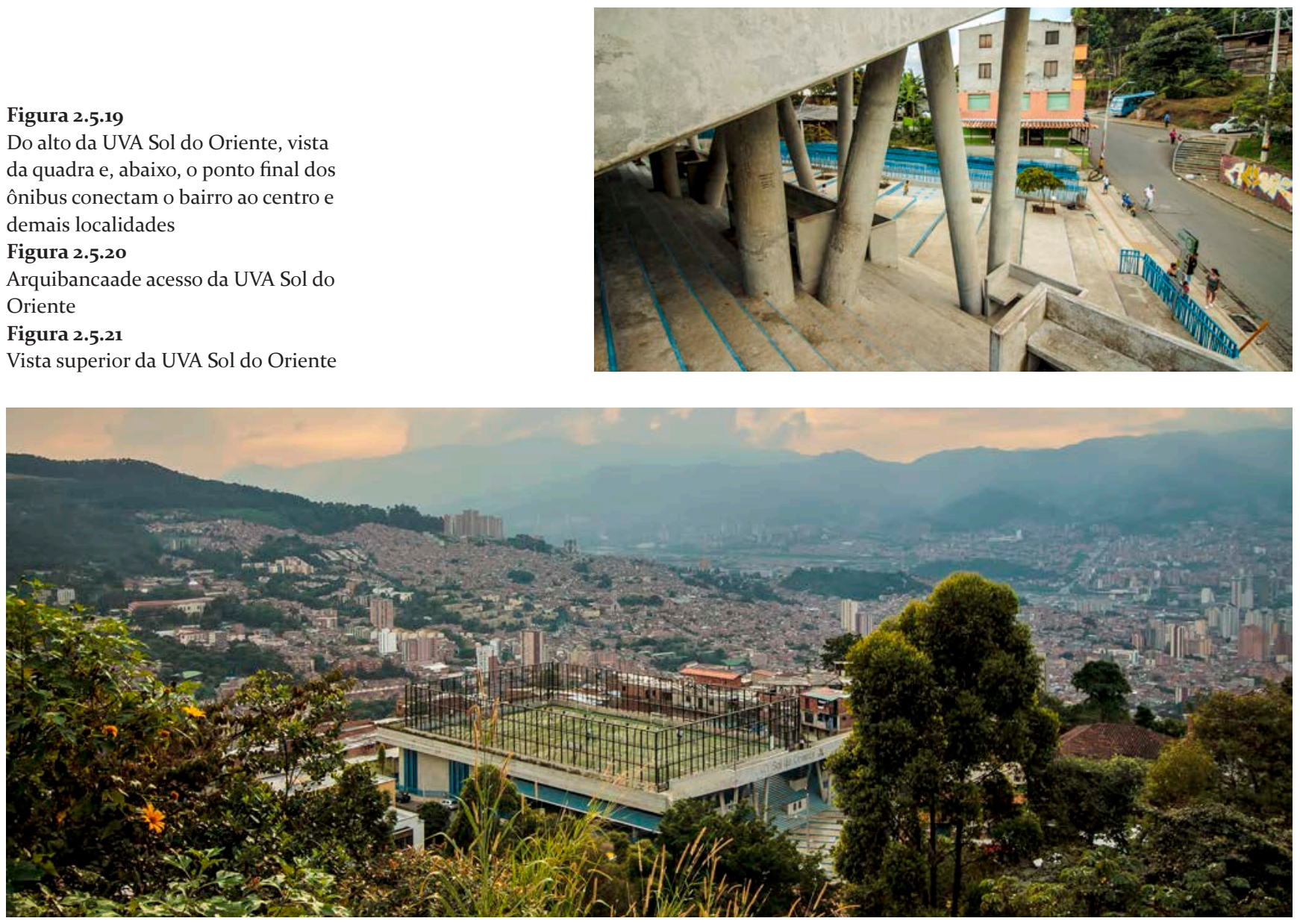
Painel 2.5 Unidades de Vida Articulada

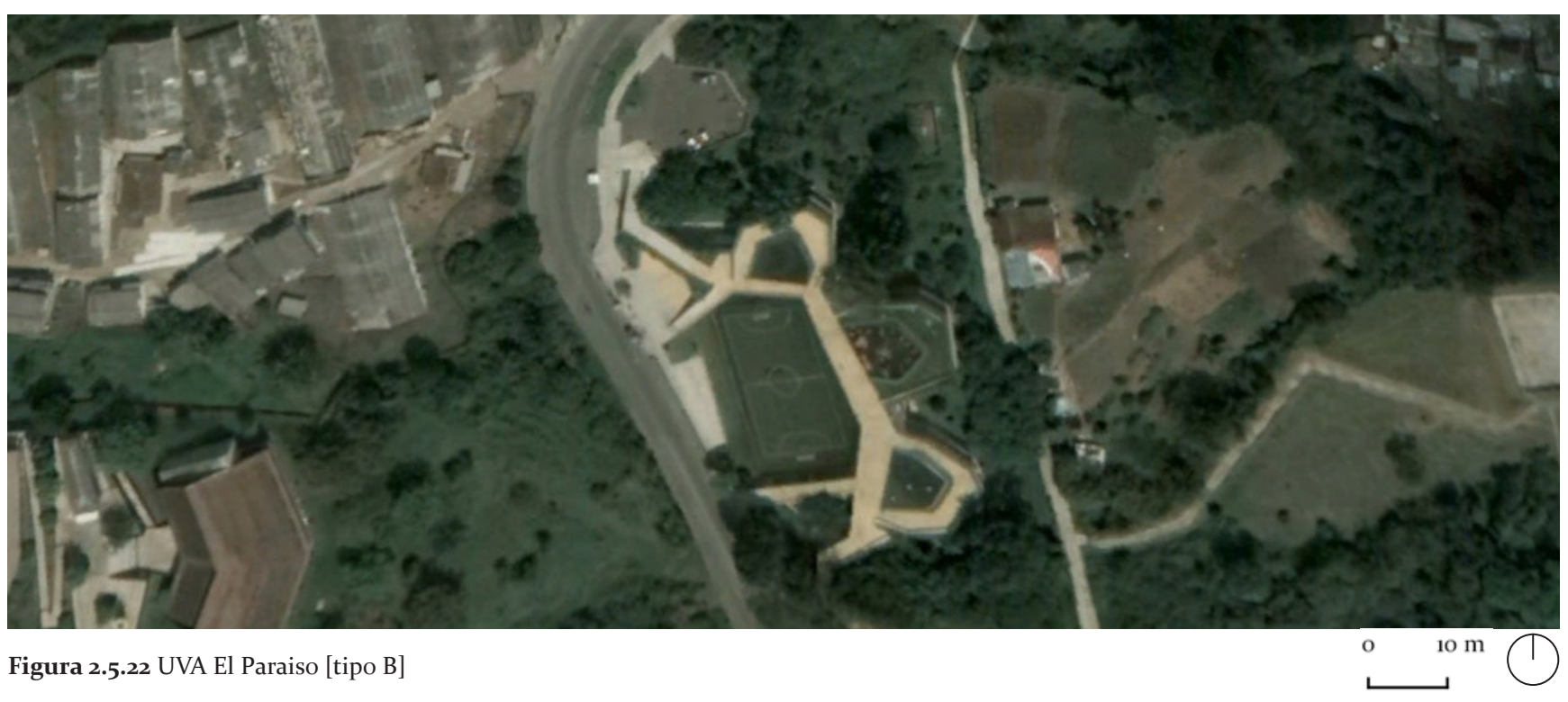

Figura 2.5.24

Campo de futebol na UVA El Paraíso

Figura 2.5.25

Arquibancada quadra interna

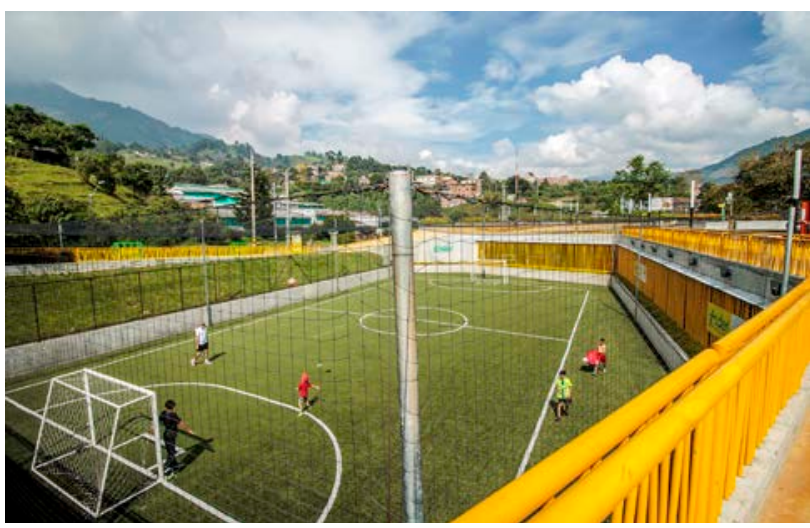

Figura 2.5.26

Vista do acesso à praça que

resulta da cobertura do

edifício que se desenvolve

no terreno em declive

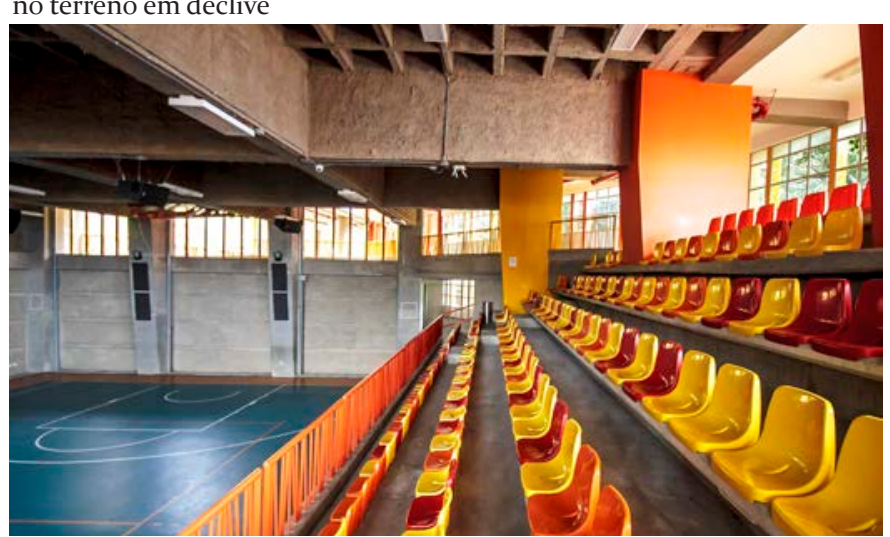

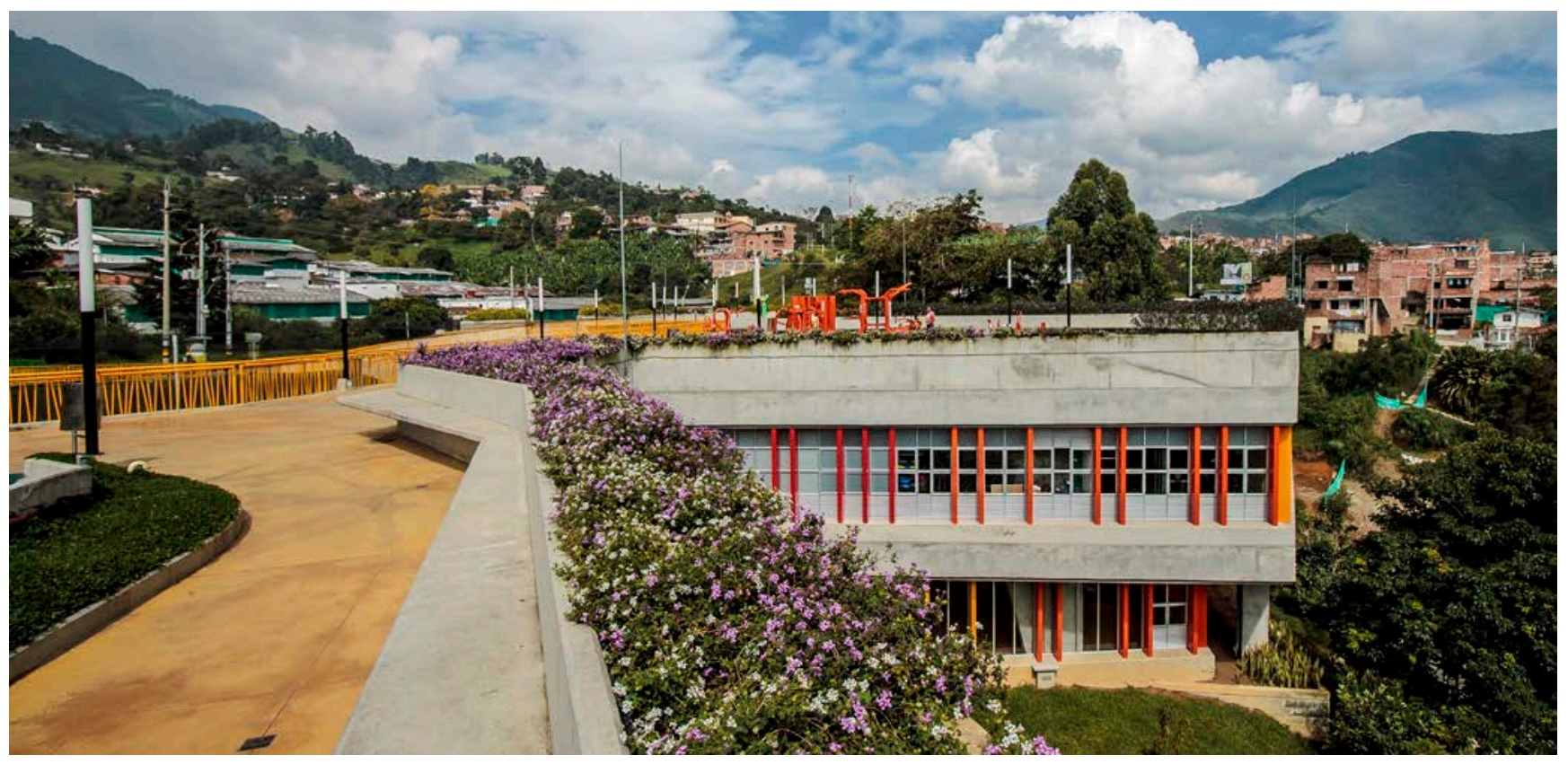


Painel 2.6 Jardín Circunvalar

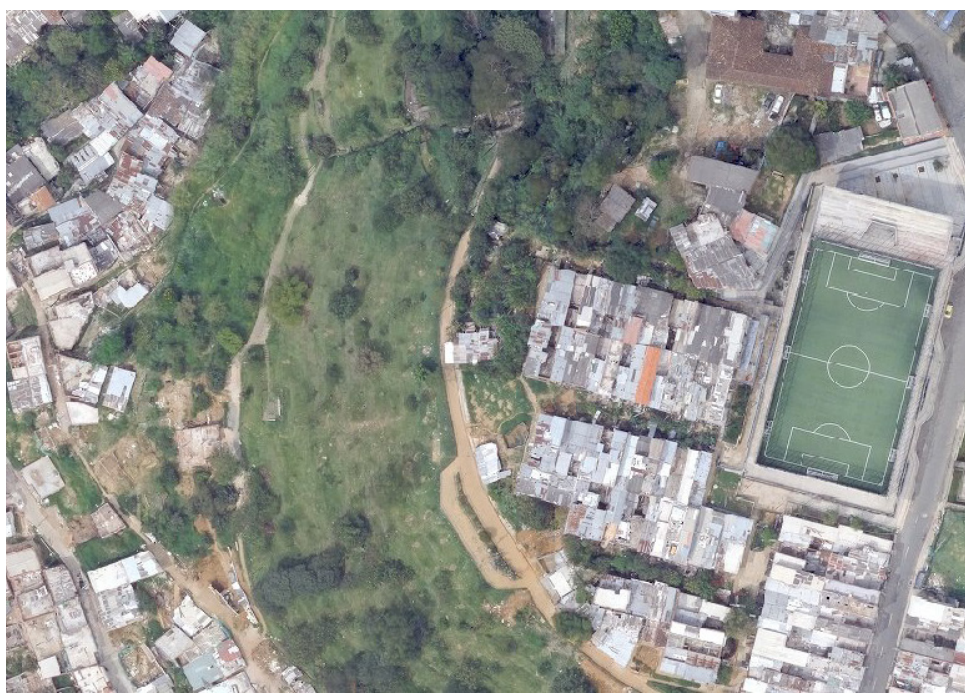

Figura 2.6.1 Ecoparque Las Tinajas
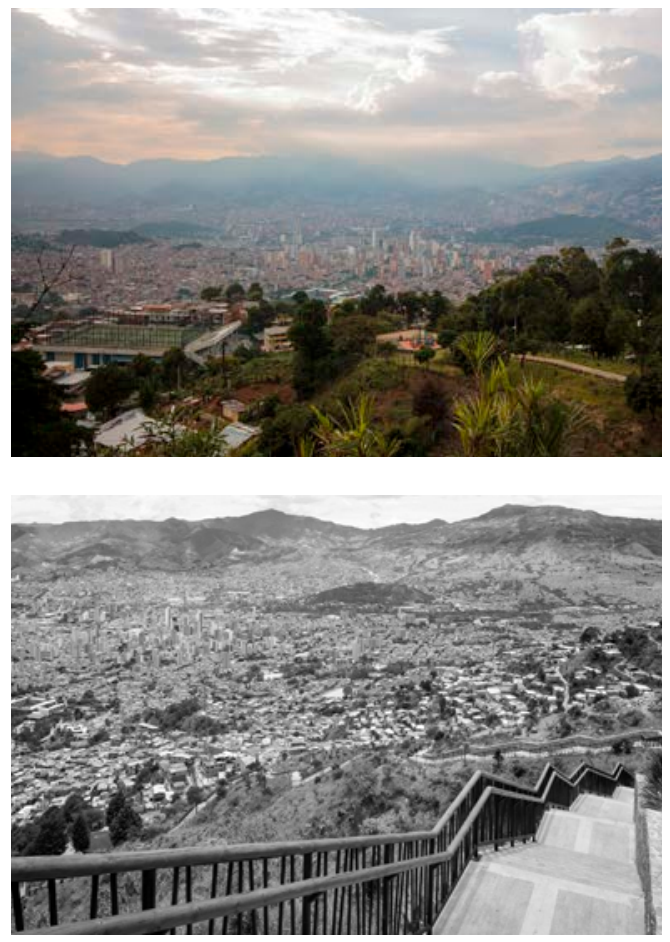

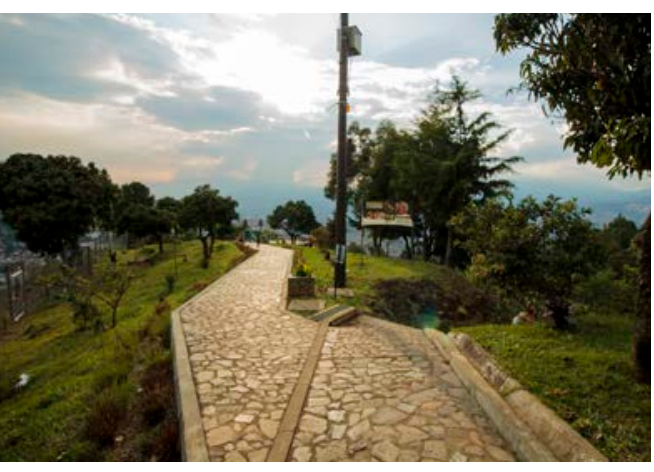

Figura 2.6.4

Figura 2.6.5

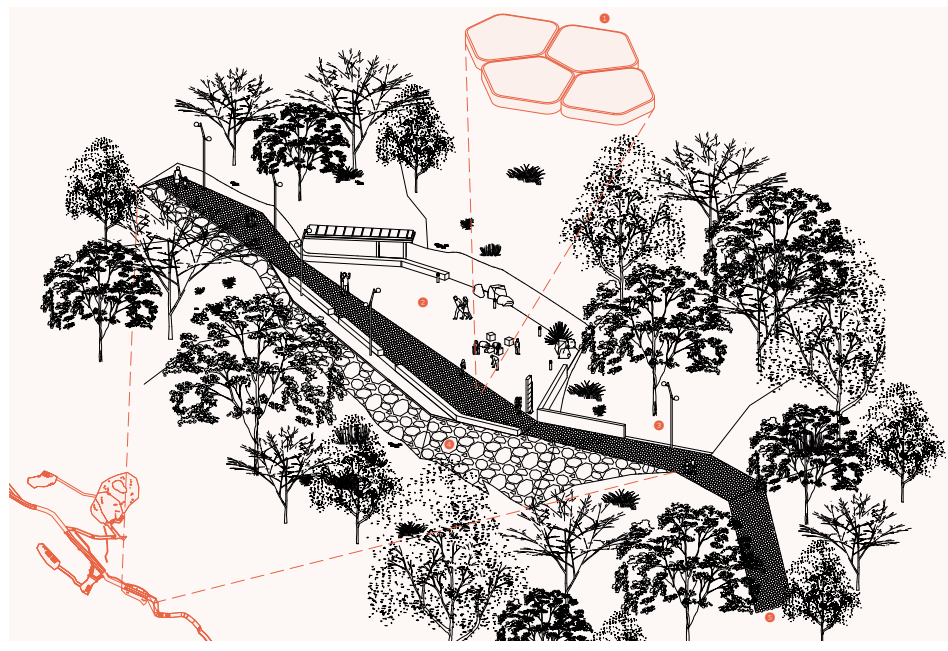

Figura 2.6.2

Vista do Jardín Circunvalar. À esquerda, a UVA Sol do Oriente. Ao fundo, o centro verticalizado da cidade e os cerros Nutibara (à esquerda) e Volador (à direita).

Figura 2.6.3

Caminhos pavimentados e drenagem do Jardín Circunvalar 
Painel 2.7 Parques Del Río

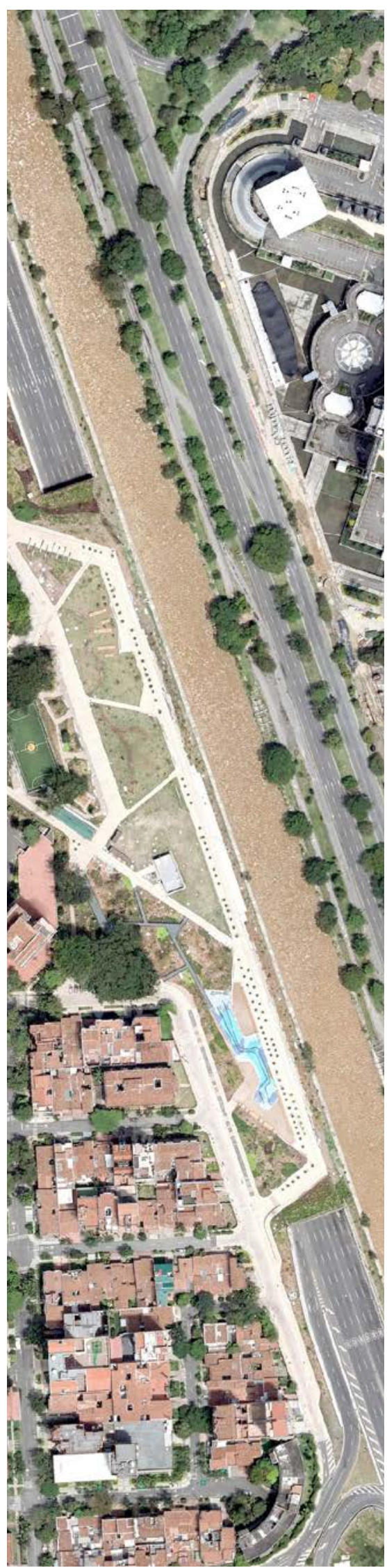

Figura 2.7.1 Parques Del Río

$010 \mathrm{~m}$
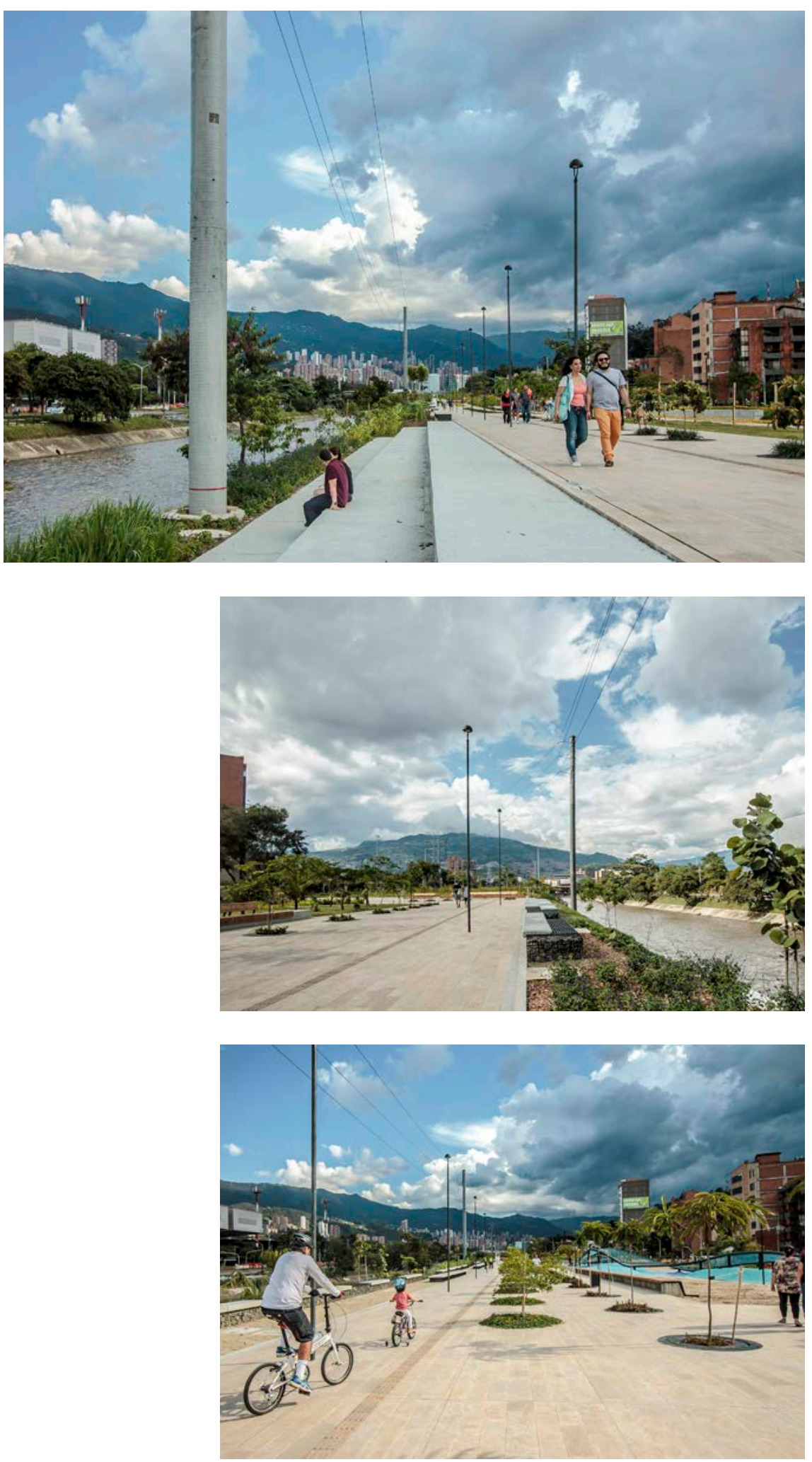

Figura 2.7.2

Figura 2.7.3

Figura 2.7.4

Parques del Rio

Acesso à margem do rio, a vista do bairro Conquistadores está ao lado direito e o centro da cidade ao lado esquerdo. 
Painel 2.7 Parques Del Río
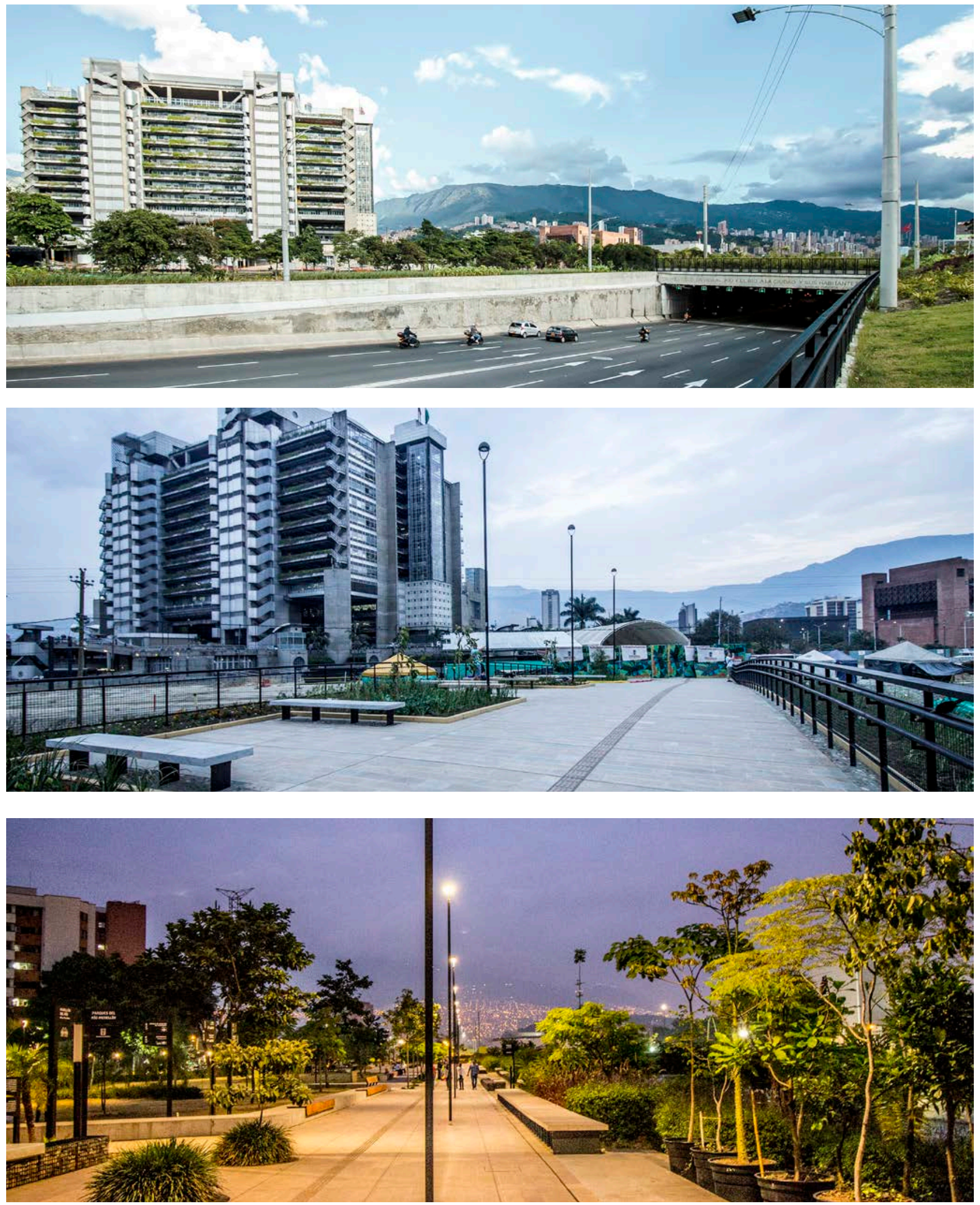

Figura 2.7.5

Vista do Túnel

Figura 2.7.6

Figura 2.7.7

Ponte para pedestres ligando o novo trecho do parque

Com essa ponte, as duas margens do rio se conectam 
A cidade de São Paulo, hoje com seus mais de 12 milhões de habitantes ${ }^{69}$, se estende por $1.874 \mathrm{~km}^{2}{ }^{70}$. A Região Metropolitana de São Paulo (RMSP) inclui mais 38 municípios, ocupando $7.923,82 \mathrm{~km} 2$ do território paulista. Em 2018, a população da região era de 21,6 milhões de habitantes, quase ou $50 \%$ do total estadual, soma-se a esses dados expressivos do ponto de vista regional, a importância econômica da RMSP para o país, visto que ela é responsável por $17,7 \%$ do PIB brasileiro $^{71}$.

O processo de crescimento expressivo, físico e econômico, que transformaria a vila de Piratininga fundada em 1554 - tornada cidade em 1711 - teria impulso somente ao cabo de mais de três séculos. No entanto, tal potencial já estava firmado pela sua localização e conformação geográfica estratégicas. São Paulo nasce de um ponto de entroncamento de rotas comerciais permitindo, ao mesmo tempo, fácil dispersão regional. Sua localização, no alto da Serra do Mar, se encontra num divisor de águas, voltado, de um lado, para os portos marítimos de Santos e São Vicente e, do outro, para o rio que avança aos sertões interiores, o Tietê, que se conecta a ampla cadeia hidrográfica, possibilitando assim, o controle de vastas extensões territoriais (SEVCENKO, 200o, p. 75).

A dinamização desse potencial de conectividade e importância regional, se daria na virada do século 19 para o 20, com a implantação da infraestrutura ferroviária e, novamente, a partir da década de 1940, com infraestrutura rodoviária. Essas competências originalmente naturais, modernizadas e infraestruturadas, acabaram por consolidar o o esquema espacial de sua origem, afinal, considerando sua localização privilegiada, São Paulo já teria nascido metropolitana (MEYER; GROSTEIN; BIDERMAN, 2004, p. 35).

À luz do exemplo colombiano, nos interessa rever algumas particularidades desse processo que conformou a paisagem urbana de São Paulo. Em ambas as cidades assistimos à submissão impassível do sítio natural à lógica das infraestruturas urbanas. Esse é um indicador importante das forças e disputas que produzem esse espaço e é algo que se confirma como tendência que perpassa os diferentes ciclos produtivos que transformaram sucessivamente o povoado, a vila, a cidade e a metrópole.

O fenômeno da urbanização, no entanto, não modela a cidade sem ser mediado por instrumentos do planejamento urbano e de ideários urbanísticos. Nesse sentido, a institucionalização do planejamento e os projetos urbanos terão dificuldades em constituir ferramentas de desenvolvimento integradas às questões socioambientais. Isso, em diferentes momentos e sob variadas orientações políticas ao longo da história, indica a alternância de projetos para uma cidade em disputa

\footnotetext{
${ }^{69}$ A população estimada em 2018 pelo IBGE (Instituto Brasileiro de Geografia e Estatística) é de 12.176.866. Sendo que, no último censo em 2010, foram contabilizados 11.253.503 habitantes.

${ }^{70}$ Em 2001 sendo que, 70 anos antes restringia-se a 18okm2. Cf. (MEYER; GROSTEIN, 2010, p. 20)

${ }^{71}$ Fonte: (EMPLASA, 2018)
} 
por forças econômicas. Ainda que sob a tutela dessas diferentes visões, o processo de urbanização permaneceu reafirmando a funcionalização do ambiente natural, vinculada a um projeto de modernização socialmente excludente e segregador, verificável em ambas as cidades aqui estudadas. Isso coincide com o descolamento entre as intenções dos planos e a realidade socioespacial produzida. Esse caminho fatal de distanciamento entre análise da realidade existente e o projeto, entrincheirados nas suas práticas isoladas, resultaram, não só em um planejamento limitado, como em obras públicas desastrosas que comprometeram o desenvolvimento urbano em São Paulo (MEYER; GROSTEIN, 2010, p. 14).

Assim, a cidade adentrou o século $21 \mathrm{sob}$ a prevalência de uma visão abstrata e funcionalista de zoneamento moldando o padrão de ocupação da cidade (FELDMAN, 2005). São Paulo pareceu se ressentir, não somente da inação decorrente dessa crise do planejamento, mas também da ausência de projetos urbanos aderidos às demandas mais amplas de sua população, incorporando e assimilando a vasta cidade informal à cidade oficial, compreendendo, dentro dessa lógica integrada, as amplas problemáticas decorrentes da expansão urbana.

Apesar de não ser possível indicar um processo linear, visto que as alternâncias partidárias da administração municipal implicaram iniciativas setoriais evidentemente díspares e fragmentárias nos primeiros 15 anos desse século, a busca por projetos que permitissem o diálogo com as experiências de Medellín contribuiu para reconhecer alguns nexos. Eles se dão entre conjunturas políticas e arranjos institucionais que deram suporte a projetos de impacto expressivo nas questões urbanas colocadas. Isso permite uma reflexão sobre as potencialidades que dependem de ingerências políticas e técnicas espaciais, mas também foram observados aspectos significativos e transformadores, que dependem da ativação de instrumentos da A\&U. Entre planos e projetos, esse arco de experiências reage a uma série de fenômenos comuns às duas cidades e sua avaliação permite aproximar essas condições urbanas construídas historicamente, não como desafios insolúveis, mas como a inescapável base de pensamento e ação de que dispomos.

\subsubsection{A evolução urbana de São Paulo}

São Paulo nasce fundamentalmente de uma tensão entre as características geográficas e a necessidade de expansão econômica e territorial. Isso porque a cidade se origina de uma ocupação que desfruta das terras férteis do espaço entre rios (Tietê, Pinheiros e Tamanduateí). Mas essa condição é também um problema para o processo de povoamento que evita, desde o início, as áreas de várzea. Ocupou-se assim, de modo lento e fragmentado, o arquipélago de terras altas (colinas), recortadas pelos vincos contínuos dos caminhos de drenagens que desaguam no rio Tietê, conforme descreve Franco (2005, p. 32) 
Somente em 1867, com a implantação da São Paulo Railway (SPR) se dará uma transformação significativa de seu território. A cidade, quando da inauguração da ferrovia possuía cerca de 26 mil habitantes, em 1890 teria 65 mil, atingindo 240 mil habitantes em 1900 (CAMPOS; ACKEL, 2002, p. 15). Isso porque a chegada da ferrovia faz de São Paulo o centro da articulação do mercado do café, entre as áreas de produção e o porto de Santos. E assim, viabiliza a potencialidade econômica e ao mesmo tempo consolida o esquema primordial de uma cidade que se origina das forças centrífugas de seus caminhos comerciais (MEYER; GROSTEIN; BIDERMAN, 2004).

E foi pela implantação dessa infraestrutura, também, que o impasse entre a ocupação das colinas, em detrimento das terras baixas e pantanosas, será definitivamente transposto. Isso transformaria decisivamente o futuro da cidade e sua relação com os rios e com sua paisagem. A SPR e a expansão das áreas industriais de correntes justificam a retificação e canalização dos rios, e começa a moldar a transformação das terras baixas, com todas as ocupações advindas do reposicionamento de São Paulo no comércio do café. Passamos a ver as várzeas e planícies fluviais de São Paulo como um espaço de concentração de sistemas infraestruturais, correspondendo a um território estruturante das inter-relações físicas, espaciais, funcionais e simbólicas da metrópole:

\begin{abstract}
Uma vez disponíveis os meios para a transformação radical do ambiente natural, a cidade começou a ser construída em larga escala por meio de projetos que propiciaram a ocupação de áreas anteriormente consideradas inviáveis, como as várzeas. Vários sistemas técnicos foram atrelados à ocupação dessas áreas, tais como o sistema de abastecimento de gás, saneamento, drenagem, geração de energia e transportes. Esse processo tornou as várzeas disponíveis para a urbanização na mesma medida em que sustentou a velocidade do crescimento de São Paulo. (FRANCO, 2005, p. 18)
\end{abstract}

O processo relatado reflete a potência da urbanização em transformar o ambiente natural em território produtivo, bem como em produto imobiliário. Essa possibilidade de crescimento da cidade se apoiou na ação técnica de empresas estrangeiras como a inglesa São Paulo Railway e a canadense São Paulo Tramway Light and Power Company. A primeira, responsável pela ferrovia do café, e a segunda, instalada na cidade em 1899, determinariam a transformação radical do sistema hídrico da bacia para geração de energia para cidade e para o sistema de bondes elétricos, conforme mostra Franco (2005). Em 1901, era inaugurada a Usina de Parnaíba ${ }^{72}$ no rio Tietê, para a geração de energia. Entre 1906 e 1909, construída uma represa no Rio Guarapiranga, afluente do Tietê, para regularizar a vazão deste último em períodos de estiagem, garantindo o aumento da capacidade de geração de energia. Essa obra propiciaria a extensão da linha de bondes elétricos para a região e a expansão de loteamentos nesse mesmo vetor. Ademais, a contínua demanda por energia com o crescimento da cidade levou a Light a propor, em 1928, também a retificação e reversão do Rio Pinheiros, permitindo assim a construção da represa Billings, que

${ }^{72}$ Localizada no município de Santana do Paranaíba, represando águas do Rio Tietê. 
alimentaria do alto da serra do mar as turbinas da usina Henry Borden em Cubatão a partir de 1926.

Assim, somava-se a essa ação especializada sobre o território a estratégia de uma liderança empresarial e urbana que articularia ou financiaria boa parte da instalação da infraestrutura, de serviços e remodelações urbanas, tomando a frente do parcelamento e a colonização das terras, com a montagem de um significativo mercado imobiliário rural e urbano, comercial e financeiro. Os investimentos desse empresariado e a pressão desses no poder público conferiam valor às terras que essa elite pretendia comercializar. Alinhado a esse desejo de modernização, ao final do século 19 percebe-se que o Estado passa a cumprir seu novo papel de agente capaz de viabilizar empreendimentos urbanos (REIS FILHO, 2004, p. 126). Assim, foram realizadas as reformas do Jardim da Luz, obras de drenagem de várzeas, iluminação pública a gás, abertura e alargamento de ruas, que esboçavam a estrutura viária criando condições para a expansão da cidade a norte e a oeste (CAMPOS; ACKEL, 2002, p. 17). Percebemos assim, que não há nenhuma novidade na estruturação do território urbano ser pautada majoritariamente pelas forças dos agentes privados em constante disputa, intermediados afinal, pelo poder público.

O crescimento e o aumento do tráfego e congestionamento no Centro, contribuiria para a saída das elites para os novos bairros que se criavam em seu entorno. A desvalorização da área central dá espaço para a ocupação pela população de baixa renda, o que contribuiu para aumentar a pressão por remodelações nessa região que, nas primeiras décadas do século XX, já se considerava, cada vez mais degradada por parte de seus proprietários da elite paulistana. É nesse contexto que o plano de "Melhoramentos para o centro da cidade de São Paulo" de 1910, foi desenvolvido dentro da Diretoria de Obras Municipais, por Victor Freire e Eugênio Guillem, como uma primeira resposta a essa problemática. Nos interessa perceber que esse plano, que incorporava a influência do pensamento de Camillo Sitte, evitava o modelo haussmaniano de bulevares retilíneos, pouco apropriados a topografia paulista. Essa alternativa foi vetada, na medida em que previa um grande número de desapropriações de imóveis particulares e, assim, enfrentou inúmeros impedimentos que iam da contestação dos altos custos ao inconveniente choque de interesses imobiliários entre figuras importantes da alta classe de proprietários. É importante notar que planos alternativos que representavam esses interesses, tentaram se sobrepor à iniciativa oficial, sendo o impasse resolvido com a contratação de paisagista francês Joseph Bouvard. Mas, ao mesmo tempo em que o plano de Bouvard (1911) se apresenta como o primeiro trabalho com visão mais abrangente da capital paulista, ele também será levado adiante por ser mais conciliador que o de Freire, ao atender aos interesses dos proprietários dos terrenos mais estratégicos e contribuir para a expansão dos negócios imobiliários ${ }^{73}$.

\footnotetext{
${ }^{73}$ Cf. D’ELBOUX, 2015. O plano também estruturava um notável conjunto de parques e praças (dentre eles o Parque do Anhangabaú e o Dom Pedro) e propunha uma estrutura viária radial com avenidas partindo do centro, algo que seria estratégico para a estrutura urbana paulistana.
} 
No encadeamento desses fatos, é possível identificar uma contradição de origem no processo de urbanização dessa cidade, que se tornaria o polo da mais importante região produtora do país, particularmente a partir da proclamação da República (1889). Conforme aponta Campos (2002, p. 188), coexistiam duas hipóteses para decidir a forma da cidade: a vertente mais submissa ao paradigma haussmaniano de padrões "dependentes" e europeizantes ou a vertente produtiva e exportadora, abrindo espaço para soluções mais "autônomas" e atualizadas. A primeira tinha como exemplo as reformas de Pereira Passos no Rio de Janeiro; já a segunda era mais visível nas referidas experiências de Vitor Freire, e também na de Saturnino de Brito e Ricardo Severo, propícias a estabelecerem relações com as dinâmicas sociais das massas emergentes, com os regimes hídricos do território tropical e as possibilidades de uma arquitetura que refletisse a cultura local, respectivamente. A primeira pareceu prevalecer, mas, acima de todas as propostas, havia entraves maiores relativos ao liberalismo e comercialismo da condição agroexportadora:

\begin{abstract}
A intenção de transformar a capital paulista numa vitrine condigna para a economia cafeeira chocava-se com intenções de aproveitamento imobiliário, indissociáveis do comercialismo vigente e, com o peso dos interesses fundiários, inerentes a uma economia de base rural. O liberalismo predominante na condição agroexportadora inviabilizava a adoção das normas reguladoras e do intervencionismo estatal requeridos pelo urbanismo moderno. Assim, embora a importação de modelos de cidade moderna fosse necessária para transformar a cidade em empório de civilização, mostruário do progresso possibilitado pelo sistema internacional de trocas, acabava comprometida pelo comércio em solo urbano. Os avanços urbanísticos eram apropriados apenas parcialmente, para assinalar os espaços dominantes, mantendo à margem a maior parte da cidade e ignorando os setores desprivilegiados. Ao mesmo tempo, a presença de projetos modernizadores concorrentes, somada ao peso dos interesses comerciais e imobiliários localizados, comprometia a continuidade das intervenções e a coerência dos resultados. (CAMPOS, 2002, p. 189)
\end{abstract}

Assim, o urbanismo na cidade de São Paulo parece surgir, tanto no afastamento de ideias mais aderidas à realidade local, quanto no condicionamento à missão de modernização de um país agrário, conservador, cujo interesse fundiário e o liberalismo dominante pautavam os limites de qualquer projeto para a cidade. Essa mediação resultará em projetos parcialmente aplicados, em qualidades estéticas e funcionais da cidade moderna restritas a espaços de maior relevância simbólica ou econômica. Esses são os sintomas da modernização que, diferentemente do caso europeu, não realizou mudanças fundamentais na base social, porque foram barradas pelos interesses das elites dominantes, conforme aponta Campos (2000).

Enquanto os intrincados interesses e debates urbanísticos se concentravam na cidade oficial, a urbanização cresceu muito além das áreas centrais e dos vetores induzidos pelas antigas estradas nos topos das colinas. Desse modo, São Paulo adentraria os anos 1930 alcançando seu primeiro milhão de habitantes, graças à paulatina extensão de 
novos bairros, sobretudo os destinados a serem ocupados pelas faixas de menor renda (REIS FILHO, 2004, p. 194).

Esses bairros ocupavam as áreas baixas, planas e baratas das várzeas do rio Tietê e Tamanduateí, por onde passavam as linhas ferroviárias e onde a oferta de energia elétrica era abundante. Esses fatores favoreciam a implantação de indústrias, atraindo a população trabalhadora. Também, as linhas de bonde, do trem e o Tramway da Cantareira, já induziam uma ocupação periférica nas zonas Norte, Leste (principal vetor) e Sul (CAMPOS; ACKEL, 2002, p. 50). Assim se reafirma a principal força de determinação do espaço urbano, construída na relação entre a expansão da infraestrutura e das forças produtivas, moldando as características principais da estrutura urbana de São Paulo.

Essa cidade diversa, dinâmica e cheia de contrastes não era feita só de atributos negativos, naturalmente, sua heterogeneidade e idiossincrasia era algo enérgico. A cidade adquiria feições variadas, conforme a experiência e o percurso de seu visitante. Como nos mostra Sevcenko (200o): para o antropólogo Levi Strauss, São Paulo nos anos 1930 lhe parecia americana, selvagem e indômita; para o poeta Blaise Cendrars, uma mistura de Nice e Londres; para o escritor Paul Adam, os altos e baixos de suas colinas centrais e os traçados das ruas lembravam-no de Verona. Esse aspecto de colcha de retalhos cosmopolita refletia, nas palavras de Sevcenko "a confusão de seu clima, a multiplicidade de culturas e suas representações na cidade de uma população era composta de ex-escravos, mestiços, imigrantes europeus, árabes e japoneses" (SEVCENKO, 200o, p. 84). Essas eram as impressões colhidas pelos diversos intelectuais estrangeiros que aqui estiveram, fazendo parte da efervescência cultural, modernista, experimentada nos ricos anos da produção do café. Mas, dentre tantas imagens possíveis para descrever a experiência na metrópole que nascia, havia uma, no entanto, que se sobressaía. Já àquela época, São Paulo se dividia em duas, em uma clara divisão social e marcadamente espacial. Havia a cidade oficial, de suas elites, e marginal, experimentada pela massa de trabalhadores:

\footnotetext{
A riqueza da cafeicultura possibilitou a emergência da metrópole pujante de São Paulo, mas o grave desequilíbrio na distribuição das riquezas e das oportunidades de participação, impediu o desenvolvimento da cidadania. A alocação topográfica da população já era reveladora dos desníveis sociais, com as elites assentadas sobre o topo seco e saudável das colinas, e o grosso da população acumulada nas planícies pantanosas, onde nenhum dinheiro público era gasto com obras de saneamento, higiene ou lazer. Dois terços das crianças nascidas na cidade morriam antes de completar dois anos de idade.(SEVCENKO, 200o, p. 97)
}

Essa dualidade se assenta nas necessidades sociais que despontaram no fazer urbano contraditório e incompleto, e passaram a ser contornadas por meio de políticas setoriais que resultaram em habitação popular, equipamentos coletivos, dentre outras demandas parcialmente atendidas. Esse padrão se instaurou particularmente a 
partir do Estado Novo (1937), mas ainda permanece como principal estratégia, no sentido de ser uma ação que pressupõe contenção desarticulada de problemas. Essas medidas foram tomadas, em princípio, para garantir a integração das classes trabalhadoras a novos patamares de vida urbana, visando assim, a reprodução da força de trabalho. Mas, conforme lembra Campos (2002), isso foi realizado sem um componente essencial do fordismo: a transformação da classe trabalhadora em classe consumidora. Isso foi amplamente debatido por Francisco de Oliveira (2013), considerando as particularidades locais da interação entre o subdesenvolvimento e a dependência, que definiram nosso papel periférico no capitalismo mundial ao longo de todo processo tardio e internamente excludente de modernização. $\mathrm{O}$ autor apontou também a falta de um projeto emancipador para o país, inclusivo e suficientemente compreensivo com as classes subordinadas, porque este não foi encampado pela nossa burguesia nacional. Assim, percebe-se também a funcionalização dessas diferenças sociais no processo de produção do espaço urbano, sob o modelo de desenvolvimento econômico, que se estrutura no que Lucio Kowarick (1993, p.62-63) reconhecerá como espoliação urbana:

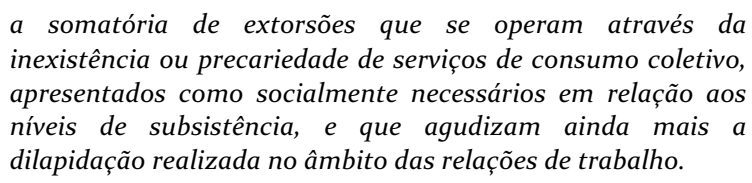

Isto é algo estrutural e fundamental no processo de acumulação de capital, que não encontrará nenhuma resposta atenuadora por parte dos agentes privados que incidem sobre o território, de modo que pesou sobre o Estado a responsabilidade para que os projetos e planos urbanos fossem compreendidos na mesma responsabilidade que as políticas setoriais, dado seu papel central e integrador que pode intensificar ou se opor ao mecanismo da espoliação urbana.

Assim, coloca-se a urbanização e seus efeitos aparentemente colaterais, em uma perspectiva mais enraizada nas decisões políticas do modelo de desenvolvimento brasileiro, traçadas ainda nos anos 1930 e, de certo modo, atualizadas nos ciclos seguintes. Mas na mesma medida é preciso frisar a importância das ingerências sobre o território, em seus diferentes mecanismos, contribuem para a reprodução e a reafirmação - até hoje -desse falido projeto nacional.

Nesse sentido, em São Paulo, as pressões do crescimento da cidade seguiram demonstrando a limitação do urbanismo seletivo e de políticas sociais fragmentárias. Faltava regulação, integração viária, provisão de equipamentos urbanos e uma visão que incorporasse as demandas da produção industrial e da população trabalhadora. Uma importante resposta a esse problema foi a elaboração do Plano de Avenidas do engenheiro Prestes Maia que, conforme Meyer e Grostein (2010, p. 22-23), propunha um sistema rádio-concêntrico de estruturação urbana que daria suporte à sua expansão, organizando e remodelando a cidade. Acabou sendo implantado somente 8 anos depois do seu desenvolvimento, quando Maia se tornou prefeito da 
cidade, entre 1938 e 1945. O Plano de Avenidas propunha espaços públicos articulados com vias grandes e arborizadas, que não foram de todo concretizadas. De modo que a leitura tecnicista da problemática urbana e a ênfase da questão viária, aspectos pelos quais o plano se tornou conhecido, resultam em grande parte da supressão da dimensão de desenho urbano prevista no plano, bem como das aplicações indevidamente fragmentárias. Essa visão parcial da questão urbana, quando da implementação e instrumentalização deste pelo poder público, contribuiu para o equívoco da cidade rumo ao paradigma rodoviarista. Isso foi reforçado, posteriormente, pelo pensamento urbanístico americano, trazido para cá por Robert Moses, que irá se consolidar a partir de 1947, de modo que as ideias, os planos, a legislação e a estrutura institucional também irão refletir essa referência (FELDMAN, 2005, p. 277).

Entre o Plano de Avenidas (1930) e o Plano Diretor de Desenvolvimento Integrado (1971), se verifica o prenúncio da passagem do planejamento que era efetivamente executado para o "planodiscurso", conforme aponta Villaça (1999) ${ }^{74}$. O segundo, em sua abrangência de diagnósticos e totalização da problemática urbana, se distancia da realidade executiva. Assim, pouco interfere na produção do espaço da cidade que se faz pela disputa de interesses dos agentes privados que nela sempre atuaram. Ao analisar as estratégias da administração municipal nesse período, Feldman (2005) também perceberá que a desconstrução da efetividade do plano, que perpassa a institucionalização do planejamento na cidade, é impulsionada pela prevalência do modelo americano de zoneamento, que tem na aprovação da Lei de 1972, um momento síntese desse processo de mais de duas décadas.

Enquanto se enfraquece a capacidade de planejamento e regulação da cidade, ela sofre os maiores efeitos da intensificação do desenvolvimento brasileiro, já que durante a Segunda Guerra, o país se torna, pela primeira vez, exportador de bens industriais. Entre 1950 e 1960 São Paulo despontou na economia brasileira com o explosivo desenvolvimento de seu parque industrial, que passava a fabricar bens de produção, além dos de consumo. Deste modo, em 196o, a cidade ultrapassava os 3 milhões e 700 mil habitantes, uma população equivalente à do Rio de Janeiro, revelando a magnitude do processo de metropolização e também da formação de suas amplas periferias. Em

\footnotetext{
${ }^{74}$ Nesse intervalo de tempo houve duas importantes experiências para o planejamento de São Paulo. A primeira foi realizada pela Sociedade para Análise Gráfica e Mecanográfica Aplicada aos Complexos Sociais (SAGMACS), foi responsável pela preparação do estudo Estrutura Urbana da Aglomeração Paulistana (1958), que, segundo Villaça (1999, p.219) teve "o mesmo destino dos planos: a gaveta”. No entanto, forneceu importantes diagnósticos através de uma metodologia diferenciada, levando em conta aspectos sociológicos, influenciou a produção subsequente do Departamento de Urbanismo de São Paulo, bem como uma geração de planejadores urbanos, que passam a adotar pesquisas baseadas na metodologia do estudo da SAGMACS. E a segunda foi o "super-plano" Plano Urbanístico Básico (1969), pois tratou-se do mais diversificado plano jamais elaborado no Brasil, abordando, além dos aspectos urbanísticos, a educação, saúde, habitação, bem-estar social. Recreação, cultura, esportes, poluição do ar, gás, limpeza pública, comunicações. Cemitérios, energia elétrica, iluminação pública, segurança pública, abastecimento, finanças e administração públicas. Muito menos "básico", pois aborda todas essas questões detalhadamente, em seis grossos volumes totalizando nada menos que 3 400 páginas, conforme relata Villaça (1999, p.215). O PUB, no entanto, não se tornou o Plano diretor almejado, não sendo transformado em lei, contribuindo para a descrença do papel redentor do planejamento urbano (CAMPOS; SOMEKH, 2002).
} 
1970, já com uma população de 5.924.615 pessoas, a cidade crescia mais de 220.000 habitantes por ano. Esses habitantes foram absorvidos pela construção civil, pelos serviços e pelos setores industriais não especializados, e é justamente esta população que, depois da estagnação econômica dos anos 1980 passará a engrossar os contingentes marginalizados do anel metropolitano (REIS FILHO, 2004, p. 211-212).

Esse crescimento que configura o processo de metropolização reitera os impactos sobre a dimensão ambiental da cidade. Se a apropriação do espaço físico do território paulistano sob o impulso do sistema ferroviário implicou o irreversível processo de construção das várzeas como espaço habitável (FRANCO, 2005, p. 11), nesse segundo momento explosivo da expansão urbana apoiado na infraestrutura viária, a ocupação irregular e desenfreada das áreas de mananciais parece atualizar a degradação de recursos naturais, subjugados às demandas produtivas da cidade.

$\mathrm{Na}$ passagem da economia industrial para a financeira, esses problemas se agravaram. Ao adentrar as décadas perdidas, com a crise dos anos 1980, as demandas sociais, que já eram negligenciadas, sofreram um enfraquecimento ainda maior, pavimentaram o caminho para uma problemática urbana de proporções inconcebíveis:

\begin{abstract}
Não cabe qualquer dúvida sobre o forte efeito negativo que a globalização, dominada pelo ideário neoliberal, impôs, com a anuência das elites nacionais, às metrópoles brasileiras nas décadas de 1980 e 1990. As principais causas dessa tendência, já tratada em vasta bibliografia, se deveram à queda brusca do crescimento econômico com o aumento do desemprego e à retração do investimento público em políticas sociais. (...) As três políticas urbanas estruturais (ligadas à construção do ambiente construído) - transporte, habitação, saneamento foram ignoradas ou tiveram um rumo errático, com baixo investimento, por mais de 20 anos. (MARICATO, 2015, p. 2829)
\end{abstract}

Assim, o município de São Paulo adentrou o século 21 com 19,80\% da população morando em favelas (GROSTEIN, 2001), sendo que no início dos anos 70, esse índice era de apenas $1 \%$. O aumento da informalidade nas décadas recentes pode ser avaliado tanto pela diminuição da oferta de loteamentos legais quanto pelo seu contraponto: a oferta crescente de loteamentos irregulares e clandestinos na área de proteção aos mananciais (GROSTEIN, 2001). Mais do que exceção, os assentamentos precários e irregulares se tornaram um padrão do crescimento da cidade, demonstrando a incapacidade das políticas urbanas em incidir efetivamente sobre a complexidade e abrangência do problema. As favelas, por exemplo, seguem crescendo em termos populacionais a uma taxa maior que o da população municipal como um todo, sendo que quase $25 \%$ encontram-se às margens de cursos de água (PASTERNAK; D'OTTAVIANO, 2016). Os demais assentamentos se estendem às problemáticas faixas não edificáveis, na maior parte vinculadas a um espaço residual, justamente da implantação de infraestruturas: são áreas de domínio de rodovias, ferrovias, gasodutos e oleodutos, linhas de transmissão de energia. Também ocupam áreas de declividade acentuada, aterros e solos contaminados, demonstrando 
que a demanda habitacional negligenciada pelo Estado é de tal forma aguda, que passa a ser absorvida por qualquer tipo de terreno que estiver à disposição.

Essas contradições construídas sob a tutela do poder público têm alguns exemplos bastante ilustrativos vinculados às disfunções entre as infraestruturas urbanas e ambientais da cidade. É o caso da represa de Guarapiranga que, em princípio, teve seu potencial de lazer explorado com o fomento à construção de equipamentos náuticos, potencializando assim, a especulação imobiliária de alta renda. Foram empreendidos loteamentos de baixa densidade, particularmente na margem direita ao norte da represa, como é o caso do projeto da Companhia City para a Cidade Satélite Balneário de Interlagos de 1937. Mas também foi construída, na região, a cidade Dutra em 1940, que se destinava aos funcionários de companhias prestadoras de serviços públicos como a Light, a CMTC, a Cia. de Gás e os ferroviários. Nesse loteamento, foram edificadas mais de 2500 casas, o que impulsionou uma explosão demográfica no local. Em vinte anos, a Cidade Dutra receberia cerca de 27 mil habitantes (MENDES; CARVALHO, 2018, p. 51).

Na década de 1960, a implantação das vias marginais, ao lado do canal do Rio Pinheiros, também esforçou o direcionamento da expansão urbana para a zona sul, permitindo a consolidação do parque industrial de Santo Amaro. A evolução desse vetor está diretamente relacionada ao surgimento de loteamentos clandestinos em regiões que viriam a ser definidas com áreas de proteção ambiental. Eles se apresentariam como alternativa de moradia para a população de baixa renda.

Essa ocupação desenfreada em torno de áreas de mananciais relaciona-se à visão esquemática do Estado sobre os aspectos socioambientais da urbanização. Sua percepção tecnicista desses sistemas está intrinsecamente vinculada aos principais problemas que hoje afetam a metrópole. A legislação ambiental sobre as áreas de mananciais, principal instrumento de análise e intervenção nessas unidades territoriais por parte do poder público, também mostrou-se inflexível e limitada a parâmetros restritivos. Essa legislação de proteção aos mananciais, vigente desde 1975 (Leis Estaduais n. 898/75 e $1172 / 75$ ) não permitia nenhum tipo de ocupação compatível com os padrões de conservação exigidos pelo manancial. Assim, resultou em grandes extensões de terra ociosas e desvalorizadas pelo mercado imobiliário, que foram ocupadas em um processo irregular de expansão urbana na região do reservatório (SALES; FRANÇA; FILARDO JR., 2018, p. 72 ).

Esse quadro também evidencia a falência das soluções dadas em relação aos investimentos e políticas públicas para habitação de baixa renda. Esse processo dá forma a existência de grandes contingentes populacionais que se acumulam em terrenos frágeis de alta declividade nas áreas de proteção ambiental.

Percebe-se que processo de metropolização resulta em uma urbanização fragmentária e dispersa (MEYER; GROSTEIN; BIDERMAN, 2004), com severas consequências socioambientais, que reiteram as limitações do planejamento urbano em integrar essas problemáticas e 
atuar em sincronia com as políticas setoriais. A começar pelo reconhecimento tardio da cidade informal, bem como sua incorporação como questão de governo. Isso só apresentou alguma evolução com a abertura democrática e as discussões dos parâmetros da nova constituição brasileira (promulgada em 1988). Essas vastas áreas da cidade passaram a ganhar novo respaldo jurídico por meio de instrumentos como as "zonas especiais de interesse social", o "usucapião urbano", ou a "concessão do direito real de uso", que ampliaram as possibilidades de ação pública e permitiram alterar o foco de atuação nas áreas informais, excessivamente centrado em medidas de cunho jurídico administrativo - predominante nas políticas de regularização de loteamentos - para o campo das políticas públicas mais amplas de inclusão social e econômica e urbanística dos moradores dos assentamentos ilegais (GROSTEIN, 2001, p. 17).

Entretanto, como Grostein observará, a grande dificuldade nos processos de integração da cidade informal na cidade propriamente dita não se esgota na regularização fundiária. Isso porque a integração social e econômica destas áreas depende de programas que devem promover a combinação de ações econômicas, sociais, urbanísticas e ambientais. Do mesmo modo, esse processo precisa incorporar uma mudança estrutural na maneira como atuação pública vê esses problemas, nas palavras da autora: "de um loteamento ou favela, para a reconstrução de bairros precários; do proprietário do lote, para a comunidade beneficiada. Enfim, atender aos interesses dos moradores e à necessidade dos bairros, condicionados pelos interesses difusos da população e da cidade”. Os projetos analisados na cidade de São Paulo foram selecionados porque permitem uma reflexão sobre as condições do processo de metropolização, também nas relações estabelecidas com a infraestrutura urbana e o meio ambiente.

\subsubsection{Arquitetura urbana em São Paulo}

A cidade de São Paulo chegou ao final do século passado exibindo as marcas de seu crescimento explosivo. Algo que os projetos urbanos parciais ou equivocados em torno de visões tecnocráticas pouco conseguiram alterar. Esse quadro urbano refletiu os efeitos do desenvolvimentismo autoritário, que se firmou no país nos anos de ditadura (1964-1985). Mas, com a abertura política e a promulgação da Constituição de 1988, abriu-se um chamado à sociedade civil e a uma nova leva de governantes locais para realizar experiências no sentido de superação desse projeto político que levou o país a consolidar um abismo social. Assim, alguns municípios tiveram a oportunidade de ensaiar políticas urbanas inovadoras, mais participativas e democráticas. A redemocratização deu nova força aos movimentos sociais e às organizações de base que vinham se articulando em torno da Reforma Urbana. Ainda que essas experiências estivessem sujeitas ao recesso da economia brasileira diante do processo de globalização, o que seria um grande impedimento para que maiores mudanças fossem 
apoiadas por políticas nacionais entre os anos 1980 e 1990, nas chamadas décadas perdidas, conforme esclarece Maricato:

Não cabe qualquer dúvida sobre o forte efeito negativo que a
globalização, dominada pelo ideário neoliberal, impôs, com a
anuência das elites nacionais, às metrópoles brasileiras nas
décadas de 1980 e 199o. As principais causas dessa tendência,
já tratada em vasta bibliografia, se deveram à queda brusca do
crescimento econômico com o aumento do desemprego e à
retração do investimento público em políticas sociais. (...) As
três políticas urbanas estruturais (ligadas à construção do
ambiente construído) - transporte, habitação, saneamento -
foram ignoradas ou tiveram um rumo errático, com baixo
investimento, por mais de 20 anos. (MARICATO, 2015, p. 28-29)

Desse modo, é preciso observar na conquista de um novo aparato legal e institucional federal ligado às cidades, mesmo que em meio a muitas dificuldades, alguns avanços que visavam garantir o desenvolvimento pleno das funções sociais da propriedade urbana e da cidade, o direito a cidades sustentáveis e a participação nas gestões democráticas. Isso seria alcançado em 2001, com o Estatuto das Cidades (Lei Federal $\mathrm{n}^{\circ} 10.257 / 01$ ), que afinal regulamentaria o capítulo da política urbana da Constituição Brasileira de 1988, definindo as diretrizes gerais para sua implementação.

Assim como na Colômbia, as leis em torno desse tema deram ao poder local (município) maior responsabilidade da formulação e implementação de sua política urbana, introduzindo a participação social nas políticas setoriais, e criando novos instrumentos urbanísticos para garantir a função social da propriedade.

Esse foi o princípio da retomada dessa agenda no Brasil, e seria marcado por investimentos federais, movimento reforçado pela criação do Ministério das Cidades (2003), o qual articularia as políticas setoriais de habitação, saneamento e transporte. Isso possibilitou dotar importantes recursos para urbanizar e regularizar assentamentos precários, conquistando uma potência inédita para as ações públicas de enfrentamento da precariedade urbana, no sentido de garantir o direito à moradia e à cidade (ZUQUIM et al, 2017, p.14).

Esses investimentos se reportam também ao momento de um "milagrinho" econômico brasileiro, que se deu particularmente entre 2004 e 2010. Nesse período o Brasil conseguiu obter, junto com as taxas mais altas de crescimento, uma redução das desigualdades sociais e regionais, o aumento sustentado dos salários, a elevação do nível de emprego formal, a melhoria das contas públicas e externas, tudo isso mantendo a taxa de inflação sob controle, como sintetiza Laura Carvalho (2018). E isso está vinculado a políticas que, além da transferência de renda e de aumento do salário mínimo, também implicaram o investimento na infraestrutura física e social, particularmente com a grande aposta do Estado no Programa de Aceleração de Crescimento (PAC), a partir de 2007. Conforme a autora destaca, vislumbrou-se o grande efeito multiplicador que este programa teria com os investimentos públicos, induzindo também os investimentos privados. 
Mas aí também reside o paradoxo fatal que será observado por Maricato (2015), pois na volta dos investimentos federais em políticas urbanas - PAC e Minha Casa, Minha vida (MCMV) - alguns capitais (ligados ao ambiente construído) acabaram por tomar o comando das cidades. Esse fato resultou em todos os malefícios de uma agenda distorcida em nome do lucro sobre a terra urbana, ao mesmo tempo em que sua ação também levará ao enfraquecimento dos movimentos que criaram a agenda da Reforma Urbana, de modo que:

\begin{abstract}
Aparentemente a política urbana se tornou uma soma de obras descomprometidas com o processo de planejamento (...) Outros fatores como os interesses do mercado imobiliário, o interesse de empreiteiras, a prioridade às obras viárias ou de grande visibilidade deram o rumo para a aplicação dos recursos. O que mais se vê na conjuntura atual são planos sem obras e obras sem planos, seguindo interesses de articulações de capitais, proprietários de imóveis e o financiamento de campanhas eleitorais. (MARICATO, 2015, p. 40-41)
\end{abstract}

Diante desse cenário, percebe-se que a reforma urbana é o pano de fundo comum que perpassa as reformas constitucionais colombiana e brasileira no final do século 20 , mas que é ainda um direito a se materializar. Não é novidade que isso depende de vontade política, articulações institucionais e desenvolvimento de novos instrumentos. Tampouco que os direitos prefigurados pelas leis ainda estejam muito suscetíveis às flutuações conjunturais. Mas a verificação dos seus impactos no plano local, contribui para se averiguar, nesse terreno tão instável, quais foram as oportunidades efetivamente construídas diante de um cenário que, em meio a problemas estruturais, ainda assim oferecia novas regulações a serem incorporadas por instrumentos, planos e projetos urbanos.

Nas aproximações propostas entre as cidades de nosso interesse, no entanto, permanece a clara distinção de que toda a reflexão sobre a cidade de São Paulo passa, obrigatoriamente, pelas particularidades de sua dimensão física e pelo ritmo de crescimento vivido nas cinco primeiras décadas do século 20 (MEYER; GROSTEIN, 2010, p. 20). Isso afasta, de partida, São Paulo de Medellín. Além da escala da cidade, é fato que as conjunturas políticas locais dos últimos 15 anos dificultam a equiparação entre as condições de pensamento e produção no campo dos planos e projetos urbanos nas duas cidades. Em São Paulo, tornouse difícil encontrar, por causa da expressiva alternância entre mandatos com visões políticas muito díspares, um fio condutor para costurar a relação entre as experiências que se sucederam. Diferentemente, em Medellín, o Urbanismo Social foi relativamente capaz de aglutinar diferentes visões políticas na permanência de alguns programas e alinhamentos nas políticas urbanas. Ainda assim, quando da seleção de projetos em São Paulo que pudessem estabelecer um diálogo entre a infraestrutura urbana, paisagem e inclusão social, revelou-se o notável impacto de algumas políticas setoriais por detrás de projetos expressivos. Estas, além de responderem a problemáticas urbanas similares às de Medellín, também sinalizaram avanços no sentido de mapearem problemas da cidade informal que ganharam programas de 
ação de grande envergadura. Contribuíram também para que se formasse uma cultura institucional e de formação técnica que pôde sobreviver, em alguns casos, a mudanças de governo. Outras permanências são duramente conquistadas ao se incorporar parte desse aprendizado ao principal instrumento do planejamento da cidade, o Plano Diretor Estratégico. De modo que importantes oportunidades foram de fato construídas para experimentos no campo da A\&U, também em São Paulo. Assim, cabe avaliar como os projetos selecionados nessa cidade permitem reflexões cruzadas entre os temas enunciados pelas experiências de Medellín.

\section{CEUs, 2000-2004}

O percurso da análise de Medellín partiu das relações entre o sistema de transporte público e os Projetos Urbanos Integrais, que recuperaram sentidos simbólicos da paisagem e que colocaram em pauta a conexão entre o centro e a periferia da cidade. Isso foi trabalhado por meio da relação entre infraestrutura e espaço público, o que demandou complexas articulações projetuais que intermediam a escala local e a regional ativada pelo sistema de transporte. Não é possível encontrar clara simetria em São Paulo com o caso colombiano. A começar pelas amplas dimensões dessa cidade, dificultando o potencial que as sucessivas intervenções realizadas têm, de se dinamizarem e se qualificarem mutuamente. Os projetos implantados tendem a se isolar nas largas distâncias ou nas clivagens do tecido urbano produzidas pelo já constatado processo de ocupação e infraestruturação, dispersivo e fragmentador, este sim, comum às duas cidades.

Além disso, em Medellín, a expansão da rede de transporte de passageiros de média e alta capacidade tem sido repensada, vinculando-a a um trabalho de reintegração socioespacial do território. No sentido de vencer as distâncias e encolher tempos, aproximando, por essa dimensão, bairros isolados. No caso paulistano, no entanto, constatamos o alcance limitado da malha metroviária e ferroviária, e sua lenta expansão, como comprova Wilheim ${ }^{75}$. De modo que a maior parte dos bairros localizados nos extremos da cidade de São Paulo dependem majoritariamente do deslocamento por ônibus, que implica um aumento significativo no tempo de locomoção.

Isso contribui para a segregação das áreas periféricas e dificulta o acesso a outras oportunidades espalhadas pela cidade, notadamente mais numerosas e diversificadas nas regiões centrais. Em um simples exercício comparativo, como a simulação de um percurso partindo de

\footnotetext{
${ }^{75}$ Nesse artigo o autor sobrepõe ao mapa de São Paulo uma retícula de 500 metros para avaliar as distâncias percorridas pelos moradores da cidade para alcançar pontos de embarque ao sistema de transporte. A malha quadriculada adota a distância idealmente caminhável e a planta da cidade tem em destaque as linhas de metrô e trem existentes, em construção e projeto, bem como as linhas de ônibus em operação em 2013. Percebe-se com o mapa resultante a expressiva quantidade de bairros periféricos muito mal atendidos e a grande distância a ser percorrida a pé ou de bicicleta para acessar um meio de transporte. Uma vez que o sistema de transporte público até a data atual não sofreu significativas alterações em relação ao cenário ensaiado pelo autor, podemos considerar esse experimento e suas ponderações ainda válidos.
} 
dois bairros nas franjas das cidades de São Paulo e Medellín em direção aos seus respectivos centros, confirma-se essa diferença. A distância e o tempo gastos utilizando o transporte público, no caso paulistano, superam o triplo do que se demanda no caso colombiano ${ }^{76}$. Isso, considerando os percursos entre o Centro e dois novos equipamentos sociais construídos recentemente nessas duas cidades.

Os exemplos analisados foram o Parque Biblioteca España (2007), em Medellín, e o CEU Navegantes (2001) em São Paulo. Ambos são fruto de políticas urbanas gestadas no recente reconhecimento da necessária equalização da oferta de serviços e equipamentos públicos nos bairros de maior vulnerabilidade social. $\mathrm{O}$ exemplo colombiano está inserido na lógica dos PUI e na vinculação ao metrocable. Mas, no caso paulistano, a intervenção se encontra desarticulada à infraestrutura de transporte de alta capacidade e a um plano urbanístico mais abrangente, de modo que ela teve de cumprir suas atribuições urbanas, tão somente a partir das possibilidades alavancadas pelo seu lote e seu programa.

A formulação projetual dos Centros Educacionais Unificados, um conjunto de equipamentos de cultura, educação e esportes, no entanto, previa a ultrapassagem dessa contingência, confiando na concepção de um projeto sistêmico - padronizado - que forma uma rede de equipamentos. Essa medida tencionou adquirir um caráter infraestruturante para a cidade.

Após mais de 15 anos da implantação desses equipamentos, os deslocamentos entre essas expectativas e a realidade produzida, são obliterados, visto que os CEUs foram capazes de superar um grande problema: a letargia do poder público em atuar nos bairros periféricos. Por terem enfrentado esse impasse, os CEUs implantados são, sem dúvida, paradigmáticos. Nesse sentido deve-se considerar o fato de que a presença do Estado, nos bairros em que esses equipamentos se instalaram, caracterizava-se pelo atendimento restrito a questões críticas de políticas setoriais básicas: os problemas de saneamento, saúde, educação, habitação e transporte eram remediados com quesitos mínimos de atendimento. Mas, assegurada a sua importância, pontuase que, contraditoriamente, esse marco da arquitetura refletiu pouca discussão crítica sobre sua dimensão projetual, além de sua validação. Propomos então uma aproximação nesse sentido.

Os CEUs foram implantados em duas fases administrativas. A primeira se deu durante a gestão de Marta Suplicy (2001-2004), quando o programa foi concebido, os terrenos para 45 unidades foram selecionados e os primeiros 21 CEUs foram construídos $^{77}$. A gestão

\footnotetext{
${ }^{76}$ Em Medellín, a distância entre o Parque Biblioteca España e o Parque Berrio se percorre com o auxílio de metrocable e metrô, gastando em torno de 45 minutos, sendo que de automóvel o tempo para percorrer os $9 \mathrm{~km}$ cai para 25 minutos. Já a distância entre o CEU Navegantes e a Praça da Sé, que estão em torno de notáveis $31 \mathrm{~km}$, podendo levar, na melhor das hipóteses, de 1 hora e 10 minutos, sem tráfego com o auxílio de automóvel. Utilizando transporte público, esse tempo cresce em mais de uma hora, podendo atingir 2 horas e 30 minutos quando percorridos por ônibus. Os dados foram obtidos a partir das simulações de caminhos do Google Maps, considerando o dia 14/o1/2019, segunda feira, às 10:30 da manhã.

77 Com projeto de Alexandre Delijaicov, André Takyia e Valderlei Ariza, arquitetos da EDIF, departamento de Edificaçõe, órgão responsável pelo projeto das Praças de Equipamentos Sociais (PES) e dos Centros Educacionais Unificados (CEUs).
} 
seguinte, Serra-Kassab (2005-2008) ${ }^{78}$, acabou por construir os demais ${ }_{24}$ CEUs, respeitando a localização definida originalmente. Em que pese que tenham apresentado alterações significativas no modelo de gestão ${ }^{79}$ do equipamento, bem como de seu projeto arquitetônico, é notável que o programa tenha resistido à mudança partidária. Isso denota como ele foi bem acolhido pela população e o quanto isso se converteu em uma pressão sobre o poder público para a sua continuidade.

Sua formulação espacial, no entanto, padeceu de algumas contingências de partida. Os CEUs, enquanto complexo de equipamentos variados, foram viabilizados pelos recursos garantidos à educação. Junto a isso, eles também absorveram encargos frente ao processo de descentralização administrativa proposto pela gestão de Marta Suplicy, o que implicou a recuperação do conceito da Praça de Equipamentos Sociais (PES) como ideário subjacente ao CEU.

Essas praças foram originalmente projetadas como espaços públicos abertos, junto a edifícios de habitação social em bairros da periferia da cidade, durante o governo de Luiza Erundina (1989-1992). Embora não tenham sido construídas àquele tempo, a experiência deu corpo a um léxico e a uma sistemática projetual que os arquitetos da Edif, Alexandre Delijaicov, Vanderlei Ariza e André Takyia levariam adiante, quando da oportunidade de um novo governo aberto à essa ideia.

As PES deveriam constituir um espaço simbólico, como um paço municipal, ao articular variados equipamentos sociais nessa praça. Assim, esperava-se constituir novas centralidades nos distritos-sede de cada subprefeitura ${ }^{80}$. Pensou-se que esse conceito poderia ser estendido para outros bairros, mas se aplicaria primordialmente em bairros carentes, justamente porque essas praças constituiriam um polo de desenvolvimento local, e também porque seriam um emblema da chegada do Estado, que se mostrava ausente nessas regiões, que possuíam poucos espaços públicos qualificados e uma estrutura urbana deficitária. Essa ideia original, que foi apropriada à conjuntura específica do governo posterior de Marta Suplicy, se vinculava à educação pela dimensão pedagógica conferida à cidade, algo encampado por Paulo Freire, quando Secretário Municipal de Cultura no governo de Erundina.

Assim, pondera-se que a formulação dos CEUs retomou a ideia da criação de novas centralidades - espaços públicos e cívicos das PES - só que estando alojada no bojo do programa educacional. O que não é um pequeno deslocamento funcional. Essa alteração, no entanto, foi absorvida no projeto como um atributo simbólico e positivo, que

\footnotetext{
${ }^{78}$ Os últimos dois CEUs foram finalizados entre 2009 e 2010 (CEU Uirapuru e CEU Vila Formosa) como pendências da gestão anterior. A gestão de Kassab (2009-2012), na condição de prefeito reeleito, não significou a continuidade do programa. Pode-se somente considerar o Centro Educacional e Cultural de Heliópolis como $25^{\circ} \mathrm{CEU}$ que, assim como os demais da segunda geração foram projetados por Walter Makhohl, fora da EDIF (responsável pelos projetos originais)

${ }^{79}$ A gestão originalmente compartilhada entre Secretaria Municipal de Educação (SME) junto a Secretaria Municipal de Cultura e de Esportes, junto a órgãos responsáveis por os múltiplos setores atendidos por esse equipamento, em seu segundo ciclo, passa a ser atribuição unicamente da SME. Isso tendeu a diminuir a importância e a capacidade de investimento e expansão dos programas culturais e esportivos, particularmente para a autonomia destes como equipamentos abertos ao público em geral.

${ }^{80}$ Segundo entrevista de Alexandre Delijaicov a Lopes (2011)
} 
converteu o potencial educativo da cidade, à argumento central do projeto escolar (e também urbano). Entre grandes diferenças administrativas e gerenciais, por parte do poder público, e programáticas por parte da arquitetura, foram necessários, no entanto, poucos reajustes formais e argumentativos na adaptação do conceito das PESs para o projeto dos CEUs. E nisso algumas oportunidades, talvez, foram perdidas.

A condição de trabalho dos CEUs nasce de uma política setorial pautando uma estratégia urbanística. Isso gera um necessário enfrentamento das limitações da secretaria municipal de educação, algo que parece considerado de um modo vago no projeto. Esse acerto entre a concepção de projeto arquitetônico escolar e as demandas de um desenho para a estruturação do urbano, nos CEUs, se fez, segundo Alexandre Delijaicov (2011), pela articulação desses equipamentos públicos municipais em um "sistema de redes". Isto é, integrando esses equipamentos na lógica de conjunto dessa arquitetura da cidade. Esse conceito é ativado na classificação dos objetos arquitetônicos junto às redes que infraestruturam a cidade, sendo a urbanidade, resultante da soma de objetos e ações, discriminadas em três frentes:

$$
\begin{aligned}
& \text { Na primeira frente, estão os sistemas de redes integradas de } \\
& \text { infraestruturas urbanas e infraestruturas territoriais. Na } \\
& \text { segunda frente, os sistemas de redes de equipamentos públicos } \\
& \text { municipais, isto é, os equipamentos que amparam o cidadão } \\
& \text { desde as primeiras semanas de vida até a construção de seu } \\
& \text { caráter filosófico e de seu ser político. Essa formação permite } \\
& \text { que o cidadão seja um agente transformador de seu próprio } \\
& \text { lugar, já que a arquitetura que nos interessa é a arquitetura do } \\
& \text { lugar, a construção do nosso endereço. Tais equipamentos (do } \\
& \text { berçário à pós-graduação, o centro comunitário, a casa de } \\
& \text { cultura) vão construir a constelação de redes, que formam um } \\
& \text { mosaico dos espaços constituintes da cidade. A terceira frente } \\
& \text { é um espaço presente em tudo: a habitação produzida pelo } \\
& \text { poder público municipal, vinculada à(s) rede(s) de } \\
& \text { infraestruturas. (DELIJAICOV, 2oll, p. 3o) }
\end{aligned}
$$

Assim, o problema que os CEUs enfrentam, mas terminam por sublinhar, é o da segregação socioespacial, da falta de integração das diferentes partes da cidade, agravadas na ausência de uma rede ampla e equitativa de mobilidade.

Ao buscarem contribuir à problemática, pela criação de uma nova centralidade local, o fizeram por meio de uma leitura esquemática da urbanidade, limitando a praça a sua dimensão funcional e técnica de um espaço livre articulando edificações e usuários. O esquema projetual se descuida do fato de que o acesso de uma praça, intermediado por uma escola, a transformou em um grande pátio escolar. Visto que o arranjo do conjunto arquitetônico não previu a necessária desvinculação entre o rigor de segurança do edifício educacional, notavelmente diferente da flexibilidade das vivências e potenciais ativações do urbano dos seus equipamentos vizinhos. Isso acaba por abreviar as apostas amplificadoras de suas atribuições urbanas, o que fica claro com o cercamento do conjunto, e a decorrente condominialização desses equipamentos (WILDEROM, 2014).

Os pontos dessa rede de equipamentos se ressentiram de obras complementares, uma vez que o projeto foi realizado no âmbito de uma política educacional. Eventualmente, pontes atravessaram rios para 
conectar o lote dos CEUs às áreas habitacionais lindeiras (como é o caso do CEU Jambeiro). Além disso, os terrenos de alguns CEUs abrigam campos de futebol, áreas de tratamento de esgoto e bosques, na condição de espaços anexos ou como áreas contíguas devidamente mediadas por controles, resguardando a gestão do CEU de atribuições que escapassem a capacidade de uma instituição educacional ${ }^{81}$.

Até hoje, é possível dizer que a cidade não experimentou projeto de semelhante alcance. Visto que nenhum outro programa político, nesse intervalo de tempo, conseguiu abordar, de forma sistêmica e ampla ainda que não integrada como uma rede propriamente como se supôs as problemáticas desses bairros socialmente vulneráveis de São Paulo. Por outro lado, o CEU é testemunha das limitações enfrentadas: dadas pelas políticas setoriais e pelas interpretações estritamente funcionais dos atributos da urbanidade. Esses equipamentos não puderam cumprir o encargo de trazerem os benefícios da cidade oficial, de modo a irradiar transformações nos vastos territórios periféricos.

Ficou implícito, também, que o alcance da cidade informal pode, na ausência de debate sobre esse modelo de equipamento, se perpetuar como assunto supostamente solvível na somatória de demandas setoriais, de redes, prescindindo assim, de qualidades do desenho urbano. Essa falta é também sentida nas políticas habitacionais dedicadas a essas regiões, bem como nas estratégias de planejamento da cidade, que adiam a integração dessas territorialidades, tanto nas políticas desarticuladas do presente, quanto nos planos futuros que definem sua ocupação, perpetuando-os como enclaves na cidade.

\section{Territórios CEUs, 2013}

Em 2013 os CEUs foram retomados, recobrando o fôlego sob os inquestionáveis méritos e benefícios trazidos à sua população usuária. A nova geração de CEUs, chamada agora de "Territórios CEUs" pareceu ter incorporado uma autocrítica, ao promover a reinterpretação de sua estratégia de atuação pela cidade. As novas unidades que seriam construídas, foram pensadas no sentido de enfrentar o existente, requalificar e rearticular a rede existente de equipamentos públicos incluindo a intervenção em conjuntos arquitetônicos subutilizados. Essa proposta organizou-se em torno de um Plano de Articulação e Integração da Rede de Equipamentos Públicos e de um Plano de Gestão de Áreas Públicas, que nos importa aqui pela especial atenção desse programa à plataforma de dados que fosse capaz de reconhecer a realidade urbana, integrando equipamentos e espaços livres.

A nova geração de CEUs, com 22 unidades projetadas, ao agregar a palavra Território ao nome do programa, frisa sua preocupação em integrar-se ao entorno e, para isso, buscou a flexibilização do conjunto arquitetônico para implantar-se junto a equipamentos existentes. Para tanto, os blocos funcionais foram transformados em segmentos

\footnotetext{
${ }^{81}$ CEU Jambeiro (Subprefeitura de Guaianases), CEU Alvarenga (Subprefeitura de Cidade Ademar) e CEU Três Lagos (Subprefeitura de Capela do Socorro), respectivamente.
} 
intercambiáveis, que poderiam compor diferentes arranjos. Mas mantêm o padrão de edificações prismáticas, sob modulação estrutural e tipológica muito similar ao bloco didático original. Com a diferença de que o número de blocos e a proporção dos programas poderia variar caso a caso. Esses agrupamentos funcionais (educacional, cultural, múltiplo e esportivo) tentavam obter flexibilidade em seus arranjos diferenciados e na contextualização local, mediando-os pelo projeto de novos passeios e calçadas, praças e ciclovias.

No entanto, ainda trazem a marca de uma visão extremamente sistemática, algo justificado pelas difíceis condições de trabalho, de curtos tempos de oportunidades políticas que amparam a opção pela padronização. Confiou-se, no entanto, que o conjunto arquitetônico poderia ter sua potência indutora de urbanidade garantida, agora, com o aumento da variedade de soluções que surgiriam desses arranjos. É sob o grande volume arquitetônico que essa flexibilidade ocorre, no arranjo interno do grande edifício paralelepípedo, que eventualmente pode ser dividido em mais de um bloco.

Externamente, somam-se os acessos, percursos e praças externas nesse sistema que, desse modo, promoveria a variabilidade no conjunto arquitetônico. Destarte, a costura de relações mais francas com o entorno imediato e com a cidade não passou pela reformulação do objeto arquitetônico, que ainda padece de certo apreço à síntese da grande forma do edifício-sistema.

Ainda que os modelos eletrônicos dos projetos indiquem todas as intenções de um animado espaço público, assumem a impossibilidade de abrir mão das grades do equipamento educacional, mesmo que a representação gráfica dos projetos tenha se esforçado em atenuar sua presença ${ }^{82}$.

Sobre a dimensão do planejamento da rede de Territórios CEUs, o critério de seleção para os novos terrenos adotou o reconhecimento da demanda cruzando dados sobre a densidade demográfica e o Índice Paulista de Vulnerabilidade Social (IPVS) de 2010. Mas, também, como segundo critério urbanístico, buscou proximidade aos eixos de mobilidade, no sentido de ampliar o acesso, mas também o alcance territorial do futuro CEU. Com isso, previu-se uma articulação com o horizonte de planejamento do Plano Diretor Estratégico de São Paulo (PDE), sancionado em julho de 2014 (Lei Municipal n. 16.040).

Nesse sentido, podemos ver um paralelo entre os POT e a relação com a estrutura urbana e biofísica de Medellín, já que um dos principais aspectos do PDE foi reconhecer, nas especificidades de diferentes porções do território classificadas como macro áreas, potenciais de articulação de diferentes ações públicas. Dessas porções do território, destaca-se a Macro área de Estruturação Metropolitana (MEM), que abrange o entorno dos principais rios - Tietê, Pinheiros e Tamanduateí. Essa região foi reconhecida pela sua dimensão naturalmente estruturante do território - apesar de pouco perceptível na paisagem fragmentada resultante da urbanização - e também porque concentra a oferta de transporte de média e de alta capacidade (SÃO PAULO.

${ }^{82}$ Vide Painel CEUs e Painel Territórios CEUs. 
SECRETARIA MUNICIPAL DE DESENVOLVIMENTO URBANO SMDU, 2016).

Assim como em Medellín, o entorno dos rios em São Paulo concentra áreas em processo de desindustrialização, com baixa densidade de ocupação e com potencial para receber usos habitacionais e produtivos. De modo que a visão de fortalecimento da rede de centralidades, na revisão do $\mathrm{PDE}$, incorporou espaços e equipamentos públicos (assim como os PUI), não somente enquanto redes sobrepostas às outras redes infraestruturais, mas na integração e na ancoragem destas pequenas intervenções urbanas em estruturas espaciais metropolitanas.

Essas interpretações do marco regulatório têm como horizonte os projetos urbanos locais, como os novos CEUs, mas com especial atenção à rede de mobilidade, o que novamente faz aproximar do caso colombiano. Isso se daria a partir da estratégia de demarcação de "Áreas de Estruturação Local", um dos instrumentos urbanísticos dispostos no PDE que seriam aplicados a partir dos Projetos de Intervenção Urbana (PIU).

Percebemos assim que São Paulo vem demonstrando interpretações promissoras que promovem a equidade socioespacial, integrando a oferta de equipamentos públicos às diretrizes de planejamento, que reconhecem a estrutura urbana existente e a ela recorrem em uma dimensão prospectiva. Essa potencialidade se amplia, principalmente, como a intenção de integrar políticas setoriais, como às previstas pelo plano de mobilidade de São Paulo (PlanMob2015), que passaram a ser considerados nos instrumentos de regulação e planejamento urbano da cidade - no PDE 2014 e na LPUOS 2016. Mas, conforme apontam Longo e Muzi (2018), tais articulações esbarram nas imensas dificuldades em levar essa integração à implementação. Cada plano setorial traz consigo suas fragilidades e conflitos com as diretrizes mais abrangentes dos problemas urbanos lidos pelo PDE.

Somam-se a essas dificuldades o tradicional desafio de articular organizacionalmente a gestão intersetorial implícita nessa visão integradora de políticas urbanas, além da descontinuidade nas mudanças de mandatos. Os Territórios CEUs figuram como uma prova desse problema. O programa foi congelado na troca de gestão entre Fernando Haddad (2013-2016) e João Dória (2017-2018), tendo sido entregue somente a unidade Heliópolis.

Esse entrecruzamento de impossibilidades põe em segundo plano, mas não anula, o fato de que novamente, as formulações de urbanidade foram fragilmente expressas por sobreposições de sistemas de estratégias, e não por uma abordagem de interpretação e desenho mais arraigada à realidade morfológica e dinâmica desses diferentes espaços urbanos sistematizados pelo programa.

\section{Cantinho do Céu, 2008-2011}

Se, em 2001, os CEUs inauguraram uma nova leitura da problemática dos bairros com maiores índices de vulnerabilidade social, dotando-os de equipamentos sociais, entre os anos de 2005 e 2012, outra leva de 
projetos importantes, dessa vez via Secretaria Municipal de Habitação (Sehab), teria grande efeito sobre esses territórios. Essas experiências refletiram sobre as questões habitacionais, mas também sobre suas implicações ambientais, dialogando com a renovação da regulamentação referente à problemática dessas áreas. Assim, o projeto do Urbanização do Complexo Cantinho do Céu (2008-2011) ${ }^{83}$ e o do Parque Novo Santo Amaro (2009-2012) ${ }^{84}$ são mobilizados porque se inserem nesse contexto de compreensão integrada da problemática da cidade informal que permeia os bairros segregados e com baixos indicadores sociais da cidade. Isso permitiu intensa experimentação em urbanização de favelas, habitação de interesse social e intervenções urbanísticas e habitacionais em áreas de mananciais.

Esses projetos foram desenvolvidos na Sehab sob a coordenação de Elisabete França, que incorporou em sua atuação as experiências prévias do Programa Guarapiranga (1991-200o). Esse programa interviu de modo inovador no território na represa, que atingiu, à época, níveis críticos da qualidade da água do reservatório ${ }^{85} \mathrm{e}$, assim como o PRIMED em Medellín, repercutiu na cultura institucional em relação aos assentamentos irregulares e precários, também porque a complexidade e excepcionalidade do problema paulista demandou a integração de diferentes níveis de governo e instrumentos diferenciados de efetivação de políticas públicas. E esse esforço, nas duas cidades, só foi realizado quando o problema da cidade informal afetou a cidade como um todo. No caso de Medellín, o fenômeno desenfreado da violência extrapolou os limites dos bairros pobres e, no caso de São Paulo, o problema da ocupação dos mananciais passou a ameaçar o abastecimento de água do município (e de seus vizinhos).

Então, em São Paulo também foi necessário buscar um arranjo institucional intersetorial compatível com o problema. Isso envolveu a SABESP, companhia responsável pela água e saneamento do Estado, diversos órgãos e secretarias dos governos estaduais e municipais ${ }^{86}$ para dar suporte ao referido Programa Guarapiranga. Ele foi dividido em 5 subprogramas: serviços de águas e esgotos (1), coleta e disposição final de lixo (2); recuperação urbana (3); proteção ambiental (4); gestão da bacia (5). A condução do Subprograma 3 se deu pela Sehab na cidade de

\footnotetext{
${ }^{83} \mathrm{O}$ projeto teve grande reconhecimento recebendo diversos prêmios, dentre eles Menção especial no prêmio Future Cities - Planning for the 90 per cente 2012; $3^{\circ}$ lugar no concurso mundial de Habitação Social e Desenvolvimento Urbano da Bienal Pan-americana de Quito, 2010; Menção Honrosa do IAB 2010 na categoria Habitação de Interesses Social e o Prêmio Melhores da Arquitetura de 2010 da Revista Arquitetura e Construção (FRANÇA; COSTA, 2012, p. 99).

${ }^{84}$ Esse projeto é aqui apenas apresentado no seu contexto compartilhado com o Cantinho do Céu, devendo ser debatido em maior detalhe no próximo capítulo.

${ }^{85}$ Conforme vimos anteriormente, desde 1977 se percebia um aumento do nível de poluição diante da ocupação desenfreada da região, mas na década de 1990, com a crise econômica, a migração da população mais vulnerável à zona sul se acentua e nota-se o comprometimento do abastecimento de água.

${ }^{86} \mathrm{O}$ programa envolveu além da SABESP, a então Secretaria Nacional de Saneamento do Ministério de Ação Social, com apoio do Banco Internacional de Reconstrução e Desenvolvimento (BIRD). A partir de 1992 inicia-se um contrato de financiamento entre Governo do Estado e do Banco Mundial. Para esta ação integrada, a Secretaria de Energia e Saneamento do Governo do Estado (que se tornaria Secretaria de Recursos Hídricos, Saneamento e Obras) criou uma Unidade de Gerenciamento do Programa para a coordenação integrada junto a outras Secretarias Estaduais e a PMSP (FRANÇA, 2018, p. 28)
} 
São Paulo e pela CDHU atuando nos municípios de Itapecerica da Serra, Embu e Embu Guaçu.

Foi a partir daí que a Sehab passou a atuar na represa Guarapiranga, reconhecendo-a como o componente essencial do sistema hídrico integrado da Bacia Hidrográfica do Alto Tietê, mas também como a área onde residiam mais de 27 mil famílias fixadas há décadas na região. Desse modo, buscaria alternativas à remoção e reassentamento fora das áreas de mananciais, assim como a qualificação dos espaços públicos para incorporar a área como um bairro da cidade.

A recuperação urbana - em detrimento à política de remoçãotambém foi a melhor solução do ponto de vista econômico, conforme observa França (2018, p. 31). A experiência teve alcance local, mas contribuiu de maneira estratégica para a revisão da lei estadual de proteção dos mananciais da década de 1970 - em 1997 - deixando de ser essencialmente restritiva e passando a tolerar usos, desde que compatíveis com a dimensão de preservação dessas áreas ${ }^{87}$. E, também, forneceu aportes técnicos e metodológicos para os projetos da década seguinte. Com isso percebemos a importância de intervenções urbanas, projetuais e investigativas que podem estimular renovações nos marcos regulatórios.

Posteriormente a essa conquista da regulação ambiental, somou-se uma conjuntura importante. A base legal da constituição de 1988 e do Estatuto da cidade (2001), subsidiaram a ação do Ministério das Cidades (desde 2003). Isso resultou na proposição de uma nova agenda para a atuação dos governos subnacionais em habitação de interesse social, proposta pela Secretaria Nacional de Habitação que criou, em 2005, o Sistema Nacional de Habitação de Interesse Social (SNHIS) e o Fundo Nacional de Habitação de Interesse Social (FNHIS) ${ }^{88}$. Isso abriu uma linha de atuação e possibilidade de financiamento denominada como "urbanização e integração de assentamentos precários" que incluía loteamentos populares, conjuntos habitacionais degradados e favelas. Em 2007, com o Programa de Aceleração de Desenvolvimento ( $\mathrm{PAC}_{1}$ ), para a promoção do desenvolvimento econômico por meio do investimento em infraestrutura, também garantiu grandes aportes financeiros para esses projetos, visto que o PAC1 possuía a modalidade "Urbanização de Assentamentos Precários (PAC-UAP)" incluída no Eixo Infraestrutura Social e Urbana. Isso dava uma nova dimensão de ação para os governos locais, pois esse programa não só provia de recursos como também tinha uma visão compreensiva desses diversos arranjos institucionais das cidades inscritas no programa (CARDOSO; DENALDI, 2018) ${ }^{89} \mathrm{O}$ avanço desses marcos legais e de instrumentos de

\footnotetext{
${ }^{87}$ Isso porque a legislação ambiental era essencialmente restritiva e, sob uma visão engessada preservacionista, acabou acentuando a ocupação de assentamentos precários nas áreas que protegia.

${ }^{88}$ Lei Federal no 11.124, de 16 de junho de 2005.

${ }^{89}$ É importante destacar que referidos autores sublinham outros importantes programas e experiências em nível Federal como a do Programa de Erradicação de Submoradia (Promorar) em 1978; do Programa Habitar Brasil, em suas diferentes versões durante o governo Itamar Franco (1991-1994) e Fernando Henrique Cardoso (1995-1998/ 1999-2002). E em nível local destacam também as experiências do Governo de Luiza Erundina (1989-1992) em que se estruturou um Programa Municipal de Urbanização de Favelas com obras sendo executadas pela prefeitura, empreiteiras e mutirões. Os autores apresentam de maneira ampla outros aspectos e conjunturas que foram fundamentais para o estado da arte do debate e produção
} 
suporte às políticas urbanas, se deram, principalmente, quando do reconhecimento da real condição urbana brasileira

No contexto local, houve também a integração da política setorial de habitação e de proteção ambiental às diretrizes dispostas no Plano Diretor Estratégico do Município (2002) pela correlação desses programas com as ZEIS (Zonas Especiais de Interesse Social) 9o demarcadas, assim como implantação de parques lineares nos coletores troncos, na recuperação de rios e córregos para os sistemas de drenagem. Mas é importante destacar que a questão fundiária, central para a promoção da habitação em áreas de assentamentos subnormais, foi tocada pelo Programa de Regularização Fundiária (2004) em decorrência das referidas legislações quando da aprovação do Estatuto da Cidade (2001). Isso tornou possível que as famílias que moravam em favelas localizadas nas áreas públicas da cidade pudessem receber o título que lhes garantiu a posse da terra (FRANÇA, 2012, p. 30).

Sobre essa base, a Sehab iniciou seus projetos em 2005. Confiando em estratégias previamente testadas no programa Guarapiranga e se apoiando em um privilegiado alinhamento das políticas urbanas federais e estaduais, bem como do crescimento econômico do país. A conjuntura política desses anos propiciou à integração entre fundos municipais (Fundo Municipal de Saneamento), estaduais (CDHU) e federais (PAC). Com isso, em 2005, as verbas anuais eram de cerca de 150 milhões de reais por ano e sete anos depois, chegavam a 1,8 bilhão, um aumento de mais de 12 vezes, enquanto o orçamento da cidade multiplicou-se 2,5 no mesmo período (SERAPIÃO, 2012, p. 21).

A Sehab também buscou convênios com agências internacionais de fomento para estabelecer o método e os perímetros de intervenção integradas por sub-bacias hidrográficas ${ }^{91}$. O convênio de cooperação firmado com a Aliança das Cidades (Cities Alliance - AC) ${ }^{92}$ propiciou a elaboração de um conjunto de estudos técnicos para subsidiar o Plano Estratégico de Habitação Social ${ }^{93}$. Assim como o PRIMED, o grupo

sobre assentamentos precários urbanos. Mas, para o enfoque aqui proposto, nos atemos de maneira resumida a programas e aspectos mais significativos para a compreensão das condições de implantação mais específica dos projetos analisados.

${ }^{90}$ Os quatro tipos de ZEIS correspondem a porções de território que para fins de ações voltadas a políticas habitacionais, de regularização fundiária e/ou urbanística, são classificados como de ocupação irregular ou precária (1), subutilizados (2), edificações ou terrenos subutilizados em áreas centrais (3), ou glebas em áreas de proteção de mananciais (4).

${ }^{91}$ Conforme França (2018, p. 25) uma importante referência para o programa desenvolvido pela Sehab nesses anos também foi o desenho das intervenções programadas para a Ârea Metropolitana de Caracas pelo Cameba (Caracas Mejoramiento de Barrios). Esse foi um programa financiado pelo Banco Mundial, estruturado na escala de Unidades de Planejamento Físico, onde as características das bacias e sub-bacias hidrográficas eram os principais elementos por definirem a topologia dos sistemas matrizes de fornecimento de água, a disposição de efluentes e a drenagem pluvial. Esse será justamente o eixo para a estruturação dos territórios das áreas de intervenção. A autora, ex-superintendente da Sehab (2005-2012), também destaca como referência o Estudo para o Desenvolvimento Metropolitano em San Salvador.

92 A Aliança de Cidades é um consórcio internacional de cidades e organismos de desenvolvimento econômico e social que discutem soluções para redução da pobreza. Essa instituição tem como objetivo promover o papel de governos locais na estruturação de políticas de desenvolvimento urbano e melhoria em assentamentos urbanos, mobilizando o apoio internacional de agências bilaterais e multilaterais.

93 A AC doou verba para a contratação de uma equipe técnica que coordenou o desenvolvimento de um sistema de informações para dar suporte a estratégia de planejamento. Dentre os profissionais contratados para esse trabalho de coordenação das bases do Plano, por meio de repasse de verba realizado pelo Banco Mundial, está Tereza Herling. Ela também foi 
também recebeu apoio técnico para a capacitação da equipe por meio da Agência Alemã de Cooperação Internacional (GTZ) ${ }^{94}$.

Essas foram medidas para sanar o cenário de incertezas sobre a real demanda habitacional da cidade, algo que se pressentia diante da desarticulação e desatualização de dados sobre o tema, nos diversos departamentos da administração municipal. Por isso, entre 2005 e 2009 e apoiada por esses diferentes referenciais e auxílios técnicos, a Sehab desenvolveu um sistema de informações habitacionais - o Habisp -, com o objetivo de agregar, sobre cada área ocupada irregularmente ou de forma precária, diferentes dados e informações: geográficas, físicas, sociais, econômicas e legais (COELHO, 2012, p. 42-43) ${ }^{95}$. Além disso foi também desenvolvido um "Sistema de Priorização" para qualificar as informações sobre a precariedade. Sendo mais de 2 mil assentamentos precários existentes na cidade de São Paulo, era preciso adotar critérios claros de elegibilidade e prioridade de intervenções. Esse processo teve como referente um trabalho similar desenvolvido por parte da equipe para o Programa Favela-Bairro no Rio de Janeiro (FRANÇA, 2012, p. 27).

Ao dar destaque a o contexto de implantação dessas políticas, queremos chamar a atenção para o fato de que, antes de qualquer plano ou intervenção urbana mais acertada, foi de fato necessário, tanto em São Paulo quanto em Medellín, um grande esforço para reconhecer a matriz urbana real (que extrapola a cidade oficial) e suas demandas efetivas. Esse é um problema central para as cidades latino-americanas e de difícil solvência nas ordens política, econômica, e técnica e está sempre sujeita a retrocessos. As particularidades do território informal e a pressão causada na disputa pelo valor da terra demandaram articulações políticas e cooperações singulares nos dois casos. E também, se quer demonstrar que a integralidade do problema da cidade passa, essencialmente, por criar uma nova relação entre o problema da moradia e do meio ambiente. Nas duas cidades, isso levou mais de 30 anos, desde o começo dessas ocupações, para que os marcos regulatórios começassem a caminhar em um sentido minimamente disposto a absorver esses dados da realidade ambiental, habitacional e econômica.

Esses fatos embasaram o desenvolvimento do Plano Municipal de Habitação que foi pensado para ter um horizonte entre 2009 a 2024. Ele organizou a ação da Sehab entre 2005-2012, que passou a se orientar sob a delimitação de Perímetros de Ação Integrada (PAIs) baseados nas sub-bacias da cidade, se tornando a principal unidade de planejamento das intervenções da Sehab. Isso porque permitia que as ações habitacionais fossem articuladas com a implantação de redes de

Secretária Adjunta da Secretaria Municipal de Desenvolvimento Urbano da PMSP entre 201132016. E foi entrevistada em 07/12/2018 contribuindo com referências que contextualizam as políticas urbanas e as conjunturas institucionais que estão por detrás da produção dos projetos em São Paulo analisados por esta pesquisa.

${ }^{94}$ GTZ em alemão: Deutsche Gesellschaft für Technische Zusammenarbeit.

95 A autora também salienta a desarticulação entre os dois principais departamentos que detinham informações sobre o tema: o Departamento de Regularização do Solo (Resolo), responsável por atuar na regularização de loteamentos, e, a Superintendência de Habitação Popular (Habi), responsável por atuar na urbanização e regularização das favelas, além dos cortiços e empreendimentos habitacionais irregulares. Os dados eram trabalhados de forma individualizada em bancos de dados separados. 
saneamento, de parques lineares, de equipamentos sociais e espaços públicos, no sentido de tentar integrar a estrutura física da favela e do loteamento irregular à malha urbana da chamada cidade formal (HERLING, 2012, p. 93).

Cada PAI pressupunha um Plano Urbanístico que organizava diversos projetos de urbanização específicos para cada assentamento e visava integrar as diversas secretarias (projetos viários, de transporte, infraestrutura de grande porte, equipamentos públicos, parques, etc). Esse tipo de articulação entre plano e desenho urbano, que integra as políticas setoriais, é uma chave fundamental para as metas do Urbanismo Social. Mas, no caso paulista, com o final da gestão e a mudança de orientação da secretaria a maior parte desses programas foi abreviada.

Outro aspecto que aproxima São Paulo a Medellín está na promoção de concursos e a integração de equipes externas à prefeitura, como uma chave para experimentações em detrimento à padronização de projetos, no sentido de se reconhecer a limitação destes em atender às demandas da cidade real. Assim, em 2011 a Sehab promoveu o concurso Renova $\mathrm{SP}$, convocando os arquitetos a atuarem sobre 22 áreas na cidade.

Dessa experiência, nos cabe destacar que a metodologia do concurso dava o tom da exigência de aproximação destes com o contexto urbano do território informal. Era preciso que os arquitetos atuassem, ao mesmo tempo, em uma grande gleba para que demonstrassem o domínio urbanístico dessa específica estrutura urbana, assim como em três prédios de habitação social, para analisar a sensibilidade arquitetônica da equipe (SERAPIÃO, 2012, p. 27).

Os altos custos envolvidos nas obras e o caráter propagandístico na promoção desses projetos foi algo criticado à época. No entanto, destacamos a experiência como um importante laboratório que permite avaliar o estágio da reflexão projetual sobre habitação. Também porque isso se dá depois de décadas de críticas às estratégias modernas anteriores, dos grandes conjuntos habitacionais construídos pelo poder público. Assim, os dois projetos analisados na tese refletem a interação desses princípios e condicionantes.

Afinal, o Cantinho do Céu é uma reurbanização de parcelamentos irregulares e assentamentos precários percebida, principalmente, pelo resgate da paisagem. Isso porque ele se apresenta como um parque de $1,5 \mathrm{~km}$ que recuperou aos moradores locais e à cidade uma frente de água da represa Billings.

Mas, talvez, a principal qualidade do projeto, desenvolvido pelo escritório Boldarini Arquitetos, seja ter acomodado, sob um programa rico de espacialidades contemplativas e locais para atividades recreativas e esportivas, a solução de grandes problemas do tecido informal, tornando-os aptos a se integrarem nos complexos sistemas e nas representações da cidade oficial.

Com um desenho urbano mediador das diferenças entre favela e loteamento irregular, embrenhando-se em uma topografia e uma estrutura fundiária conflitantes, o projeto também teve de atender às exigências da legislação ambiental. Nisso, se recusou a consolidar os pressupostos de remoção de unidades habitacionais previstos no 
projeto básico realizado anos antes. Este denotava um certo distanciamento da realidade a que se dirigia.

A execução do projeto implicou em rever as diretrizes originais em campo. Assim, árvores, casas, caminhos e arrimos compunham, as unidades projetuais a serem integradas. Também se enfrentou à reestruturação da rede viária, enfrentando complexas soluções de drenagem urbana e de serviços de saneamento que fossem compatíveis aos problemas específicos da formação urbana existente. Isso implicou a mediação projetual dos parâmetros da recuperação ambiental exigidos pela legislação, mas também permitiu negociar e atenuar, dentro do possível, a remoção esquemática de unidades habitacionais anteriormente previstas. Nesse processo de projeto desenhado in loco conferiu-se uma dimensão sensível a interpretação de áreas de risco, de contenções de terra e dos níveis e regimes hídricos da represa. Entre esse embate técnico e fundiário, legal e administrativo, disciplinar e realista, foram desenhadas ruas, calçadas e espaços livres, costurando isso ao descortinamento de uma nova paisagem.

Werthmann (2009) faz uma importante síntese que aprofunda os significados dessas percepções aqui ensaiadas. $\mathrm{O}$ autor, ao se debruçar sobre o problema posto pelo projeto do Cantinho do Céu, depreende que essa experiência, na condição de um exercício exemplar de urbanização de favelas, indica um novo tipo paradigma projetual e de planejamento, no modo como se demanda a integração de infraestruturas ambientalmente sustentáveis e a produção de espaços coletivos socialmente inclusivos.

O autor também traz uma importante reflexão, ao perceber que não se trata de um método que reconhece finalmente e de maneira apropriada - em um ato benevolente - as necessidades da cidade informal. Mas justamente, por meio da cidade informal, é que se poderia descobrir uma ferramenta essencial para a sobrevivência da metrópole (como um todo). Isso porque ela sugere que transporte, a energia, a erosão, a água e os resíduos sejam tratados e resolvidos no lugar onde são produzidos para que não "exportem" os problemas locais para outras áreas. No caso das favelas em áreas de mananciais, a questão de que elas contaminam os recursos hídricos da metrópole sempre as colocam como grandes ofensores ao bem-estar geral da população. Mas percebe-se também que a cidade formal tem destinado a essas áreas periféricas a solução de seus problemas. São as áreas longínquas da cidade que recebem aterros de lixo e estações de tratamento de esgoto. Desse modo, a cidade formal é tão prejudicial à totalidade da cidade (incluindo suas áreas mais remotas) quanto a informal, o que reforça a dimensão integral - e não local - das problemáticas das periferias urbanas.

Assim, o Cantinho do Céu tem um potencial revelador que nos permite caminhar criticamente, até mesmo por suas limitações. A ausência de maiores atributos de mobilidade que permitam interação e acessibilidade mais expressivas entre centro e periferia, impediu que o desfrute desse parque fosse ampliado. Essa ponderação nos ajuda a reiterar que a distância e a falta de acesso à periferia, são fatores de segregação e estigmatização. Essa região talvez fosse reconhecida como 
patrimônio e também responsabilidade a ser compartilhada por toda cidade que se beneficia desse reservatório, caso o sistema de transporte contribuísse para a visibilidade e acesso dessa área.

Enquanto intervenções nessas áreas carentes da cidade forem entendidas como pautas assistencialistas restritas a esses habitantes ou demandas exclusivamente habitacionais, estamos insistindo que se trata de um problema dessa parte da cidade. São essas compreensões equivocadas que se propagam em disputas políticas cristalizadas nas retóricas partidárias. Isso é um entrave, na medida em que dificulta a conscientização da população, a apropriação e coletivização dos espaços da cidade, bem como do apoio dessas pautas com maiores investimentos políticos nesse setor.

\section{Centro de Formação Cultural Cidade Tiradentes, 2012}

Os anos de intensa atividade na Sehab coincidiram com a estagnação do programa dos $\mathrm{CEUs}^{96}$. A expectativa no potencial emancipador e irradiador de significados urbanos, depositados em um equipamento educacional e cultural, no entanto, não cessou. Durante a gestão de Gilberto Kassab (2006-2012), tendo a frente da secretaria de Cultura o cineasta e professor universitário Carlos Augusto Calil, foram realizadas obras importantes nessa área ${ }^{97}$, como a restauração do Teatro Municipal e da Biblioteca Mário de Andrade, a construção da primeira etapa da Praça das Artes ${ }^{98}$, nas áreas centrais da cidade., mas também do Centro de Formação Cultural Cidade Tiradentes (CFCCT).

O CFCCT é aqui destacado por estar localizado no distrito de Cidade Tiradentes, que tem baixos indicadores sociais e que foi marcado pelas experiências de habitação massificada, de pouca qualidade urbanística produzidas pelo poder público (Cohab e $\mathrm{CDHU}$ ), que reiteraram a segregação dessas áreas.

Como um centro de formação cultural, somou ao programa básico de centro cultural (biblioteca, teatro, espaço expositivo e oficinas de atividades), espaços habilitados para formar mão de obra vinculada à área de audiovisual. Pensou-se em explorar, conjuntamente, a dimensão cultural de lazer, a recreação do espaço e a demanda de geração de empregos, que poderia encontrar na crescente indústria brasileira nessa área, naquele momento, um potencial de promoção cultural que se aliava ao necessário desenvolvimento econômico da região de Cidade Tiradentes.

Das ideações, partimos para a verificação daquilo que foi ativado pela A\&U. Ao nos aproximarmos da região, vemos que a estrutura e a morfologia urbana têm pouca legibilidade. $\mathrm{O}$ espaço vivenciado parece

\footnotetext{
${ }^{96}$ Eles seriam retomados no mandato seguinte como "Territórios CEUs".

97 A virada cultural, evento que mobilizou milhares de habitantes a desfrutar dos espaços públicos e equipamentos culturais pela cidade,, também seria um importante programa desenvolvido por essa gestão.

${ }^{98}$ Esse projeto será analisado no capítulo 3.
} 
resultar tão somente da ordenação do território pela infraestrutura viária. Ao redor dela se intercalam grandes terrenos baldios, aglomerações de assentamentos informais com algum comércio, contrastando com as ilhas de habitação produzida pelo Estado. Desponta também na paisagem a Escola Estadual Sítio Conceição, obra do FDE, que se verticaliza em meio a casas de baixo padrão, tudo isso interligado por calçadas estreitas e descontinuadas.

Ao chegarmos ao CFCCT, bem à sua frente, vemos o padrão disperso de inclassificáveis terras desabitadas ser alargado por um campo de futebol que margeia um córrego. Nesse vasto território, cheio de pulsões sociais há, no entanto, poucas qualificações de um espaço urbano. O CFCCT desponta, então na paisagem, como um grande edifício cúbico e branco, com aproximadamente 15 metros de altura. Ao seu lado direito uma rua íngreme, ao fundo, o parque que não transpõe o córrego. Justamente, atrás separados por esse corpo de água estão a Vila Iolanda, Barro Branco, Vila Conceição, Ponte da Cachoeira. Nesses muitos bairros, burocraticamente isolados pela faixa de preservação ambiental do córrego, reside boa parte da população usuária do CFCCT. Aqui, diferentemente do Cantinho do Céu, esse problema não foi resolvido.

Na fala de Rollemberg ${ }^{99}$, um dos autores do projeto, surge como inspiração ao projeto, a referência aos parques biblioteca colombianos. Para ele, o CFCCT teria a mesma propriedade que o exemplo citado, enquanto equipamento que ativa uma ampla área verde, dotada de qualidades de espaço público. O que se percebe é, novamente, a construção de um projeto, que visa uma série de possibilidades de apropriação, mas cuja a base para isso - a intervenção arquitetônica/urbanística - parece oferecer poucos atributos relacionais. O edifício se coloca como depositário de funções educativas e culturais e como um percurso facilitador para a superação do desnível de 12 metros entre a cota mais baixa de acesso à edificação, pela Rua Inácio Monteiro (onde passam as principais linhas de ônibus), chegando a cota mais alta do parque criado na parte posterior do terreno, que se encontra cercado por grades. O trajeto interno à edificação, foi pensado assim por ser mais atrativo aos transeuntes, tendo como missão também expor as atividades desse equipamento a um novo público em potencial, segundo seus idealizadores.

A relação que se estabelece, de fato, entre áreas livres de uso público e o objeto arquitetônico, encontra pouca fricção programática e diluição formal, além da transposição de níveis por meio das rampas, e a criação de mirantes laterais. Todos, na sua ortogonalidade e síntese formal, receberam sem dificuldade a restrição burocrática de gradis e portões (algo que o projeto provavelmente não previa).

Lê-se, afinal, um projeto desenvolvido na adição de elementos: um parque, um objeto arquitetônico acessado por uma esplanada, atravessado por um grande vão central de onde saem seus acessos laterais, sem prejudicar a leitura do objeto-síntese unitário que arremata o vão com uma grande e flutuante viga de concreto. Por fim,

${ }^{99}$ Em entrevista ao programa Arquitetura Paulistana: junho de 2017. 
uma calçada larga contorna e interliga o conjunto. Tudo se organiza reiterando a lógica de um lote. Esse equipamento oferta, no entanto, oportunidades culturais de suma importância para o bairro.

Afinal, há na seleção desse caso e na soma de experiências que este proporciona, a reiteração de uma ausência de desenho urbano, que parece demandar a ruptura da estanqueidade objetual do elemento arquitetônico. Essa disfunção permanece ocultada pela confiança no objeto-equipamento em transcender suas capacidades funcionais em irradiações significativas. Novamente, denota-se uma vaga aproximação projetual do que seria a urbanidade ou uma dimensão relacional do fazer arquitetônico. Algo que se adéqua às limitações das políticas setoriais, à burocracia administrativa das entidades públicas, mas que também vem dar suporte à tendência objetual e antiurbana da arquitetura paulistana. Essas experiências põem sob suspeita o centro cultural como um equipamento soberano no fomento da cidadania, quando este prescinde de uma dimensão urbana mais efetiva.

\section{Parque da Juventude, 2003-2010}

Ao buscar equipamentos públicos de grande significação para a cidade, mas que estivessem, afinal, conectados a rede de transportes de comparáveis aos casos de Medellín, chegamos ao Parque da Juventude, conectado à estação Carandiru do metrô. Ele resultou de um concurso de projetos realizado em 1999 para a transformação da área do antigo complexo Penitenciário do Carandiru e, à época, foi comemorado por romper com um longo regime de concursos de arquitetura não executados (SERAPIÃO, 2008) o que o torna, de certo modo, um tanto quanto paradigmático.

O mote do projeto demandava refletir e agir sobre o Complexo Penitenciário que foi construído em 1920, mas que teve sua história marcada quando, em 1992, se deflagrou nessa casa de detenção, um massacre de pelo menos 111 presidiários sob tutela do Estado.

Assim, estava posta a necessária ressignificação de um espaço que se tornou símbolo de um desastre social e da perda de confiança no poder público. Isso trazia a esse projeto um grande encargo, ao enfrentar a ressignificação de expressivos 240.0oom2. A relação com o passado violento dessa localidade, permite aproximar este projeto à missão de reparação social das intervenções do Urbanismo Social. Além desses dados de partida, esse equipamento tem uma importância significativa para cidade, do ponto de vista da quantidade de usuários que ativa, visto que a frequência mensal é de cerca de 80 mil pessoas (PEREIRA, 2017).

Em 2002, com a desativação do complexo, o projeto do escritório Aflalo \& Gasperini, ganhador do concurso, começaria a ser construído. Segundo seus autores "A proposta buscou tirar partido da Estação Carandiru do metrô, vizinha do conjunto, por conferir uma condição ímpar para um equipamento urbano desse porte. O resultado é um conjunto de grande impacto transformador do entorno e um 
equipamento que foi apropriado pela comunidade em escala metropolitana" ${ }^{100}$.

O projeto foi afinal construído em 3 etapas e, da mesma forma, é perceptivelmente setorizado: Parque institucional (inaugurado em 2007), Parque Central (segunda fase do projeto entregue em 2004) e Parque esportivo (inaugurado em 2003, com 35 mil metros quadrados).

O setor institucional é onde funcionam duas Escola Técnica Estadual (ETECs), nos antigos pavilhões 4 e 7 que foram mantidos e totalmente reformados. A Biblioteca de São Paulo foi inaugurada somente em 2010 e tem sido um sucesso de público. É justamente o setor institucional que tem maior facilidade de acesso pela estação Carandiru, ainda que nenhuma relação tenha sido estabelecida entre a passarela original e a implantação, sendo tão somente um percurso a se vencer pela calçada que circunda as grades do parque, atravessando um acesso de veículos até alcançar efetivamente os portões há pouco instalados.

O parque central é talvez a área de maior expressividade da relação entre espaço livre e conjunto arquitetônico, pois integra o córrego Carajás e concentra a massa de árvores, as pérgulas remanescentes e o Bosque das Tipuanas. Trata-se do trabalho da arquiteta paisagista Rosa Kliass que destacou, entre a vegetação, as fundações dos antigos pavilhões atuando como um memorial ao passado do local. Além disso, os antigos muros da penitenciária passaram a funcionar como percursos e mirantes que percorrem a copa das árvores, permitindo uma vista privilegiada desse setor, com seus 90 mil metros quadrados.

Sem dúvida a facilidade de acesso à estação de metrô é privilegiada e tem sido um dos grandes fomentadores ao uso desse parque. Mas, ao buscarmos os elementos de interação entre o projeto, o sistema de transporte e as estratégias de integração com o entorno, percebe-se que são aspectos considerados por uma estratégia de sobreposição. Basicamente, a relação se estabelece tão somente pelas condições previamente estabelecidas, pela expressiva área do parque ofertada e pela intervenção abrigar dois equipamentos públicos estratégicos: uma escola e uma biblioteca. Os bem projetados objetos-edifícios se conectam por uma delgada marquise que parece amplificar a percepção da vasta esplanada, a qual ocupa a grande gleba onde foram implantados os três setores. Além dos acessos ao parque, as calçadas circundantes e a grande praça seca do acesso aos equipamentos, não se identificou nenhuma outra relação que possa descrever as internalidades e as externalidades que se constituem nesse parque. Tanto a rua que toca o perímetro do parque, quanto o presídio feminino ao fundo do mesmo receberam a mesma solução: o isolamento por muros. Assim, a indiscutível qualidade da Biblioteca Pública, e da Escola Técnica e do trabalho paisagístico que qualifica as áreas verdes, recreativas e esportivas, tem uma interação programática e espacial essencialmente funcional: um arquipélago de espacialidades individualizadas.

\footnotetext{
${ }^{100}$ Conforme consta no site do escritório Aflalo \& Gasperini Arquitetos. Disponível em https://aflalogasperini.com.br/blog/project/parque-da-juventude/ Acesso em 10/10/2018.
} 
Painel 2.8 CEUs e Territórios CEUs

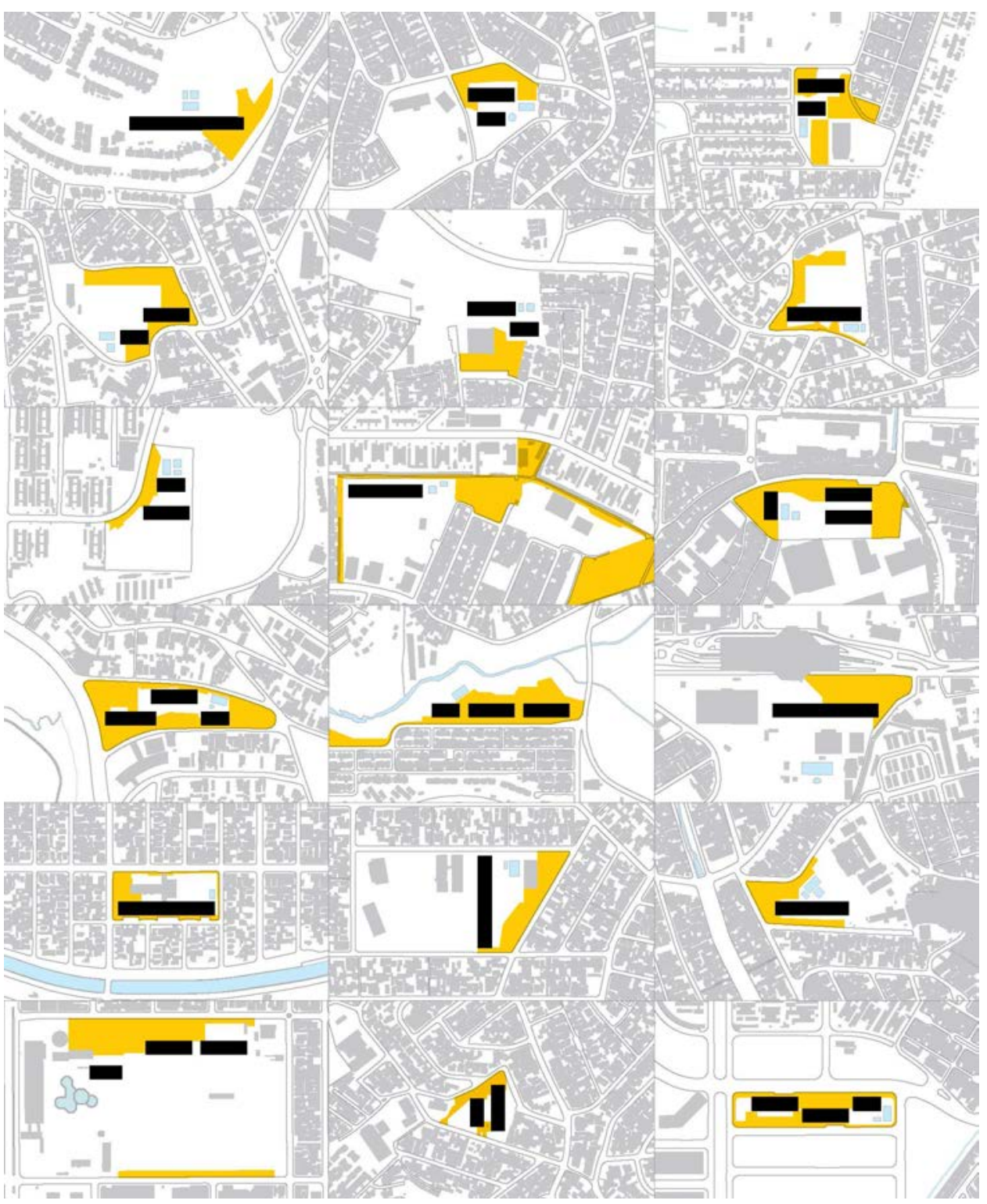

Praças públicas

2. Cidade Líder

3. Cidade Tiradentes

4. Ermelino Matarazzo

5. Freguesia do ó

6. Grajaú

7. Imperador - sapopemba

8. José de Anchieta

9. Novo Mundo

10. Parque doCarmo

11. Pinheirinho d'Água

12. Santo Amaro

13. São Miguel

14. São Pedro

15. Taipas

16. Tatuapé-Carrão

17. Tremembé

18. Vila Medeiros

Figura 2.8.1

Mapa de implantação 


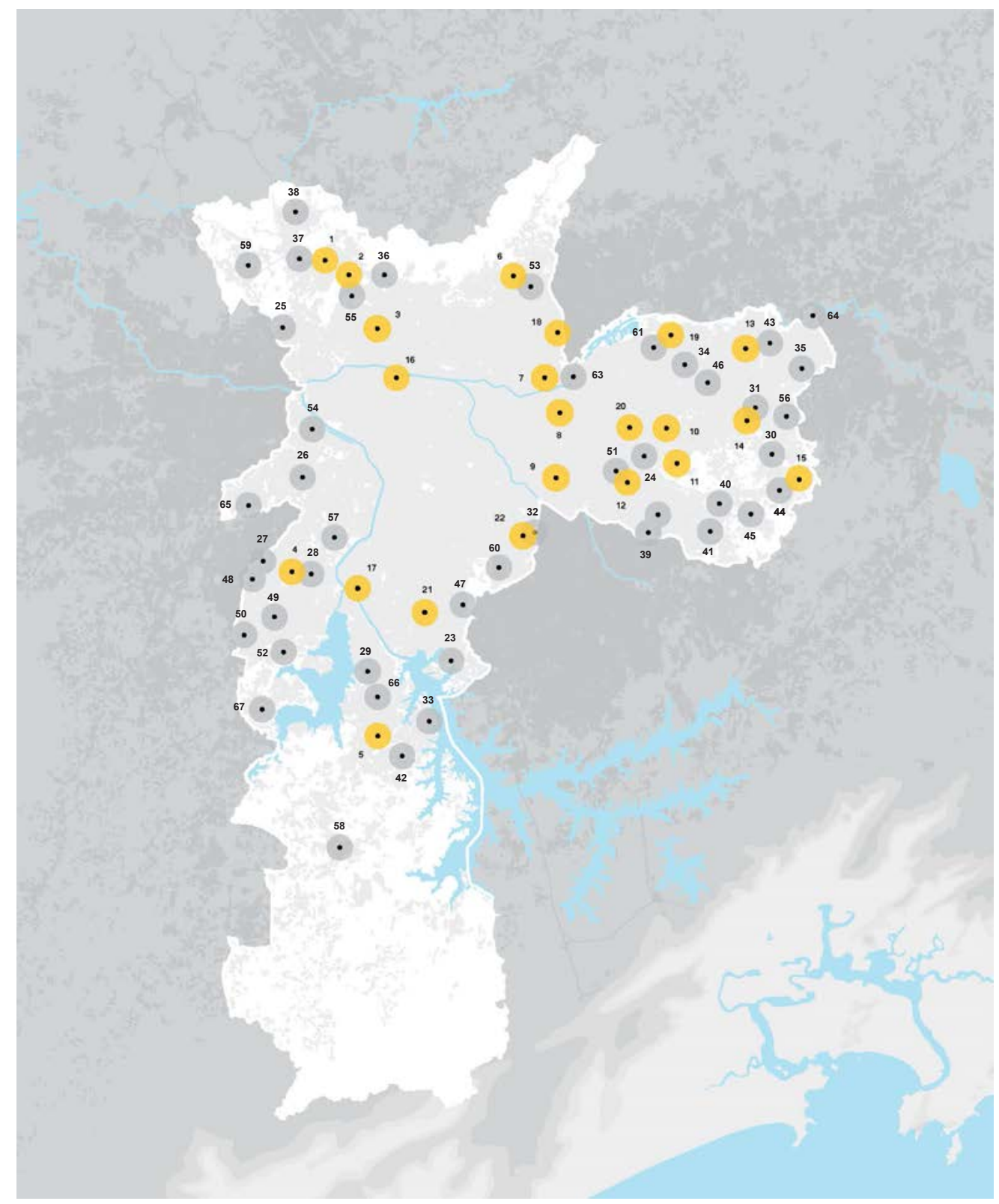

\section{- CEUs existentes \\ - CEUs 2013-2016}

CEUs do programa

1. Pinheirinho d'Água

2. Taipas

3. Freguesia do ó

4. Campo Limpo Piracuama

5. Grajaú

6. Tremembé

7. Novo Mundo

8. Tatuapé - Carrão

9. Vila Prudente

10. José de Anchieta

11. Parque do Carmo

12. Imperador - Sapopemba

13. São Miguel

14. São Pedro

15. Cidade Tlradentes

16. Água Branca

17. Santo Amaro

18. Vila Medeiros

19. Ermelino Matarazzo

20. Cidade Lider

21. Cidade Adernar

22. Heliópolis'

de 25i4

Fonte: SMDU, 2016

Figura 2.8.2

Mapa dosCEUs

\section{CEUs $2001-2004$}

$\begin{array}{lll}\text { 23. Alvarenga } & \text { 30. Inácio Monteiro } & \text { 37. Pera Marmelo } \\ \text { 24. Aricanduva } & \text { 31. Jambeiro } & \text { 38. Perus } \\ \text { 25. Vila Atlântica } & \text { 32. Meninos } & \text { 39. Rosa da China } \\ \text { 26. Butantã } & \text { 33. Navegantes } & \text { 40. São Mateus } \\ \text { 27. Campo Limpo } & \text { 34. Parque São Carlos } & \text { 41. São Rafael } \\ \text { 28. Casa Blanca } & \text { 35. Parque Veredas } & \text { 42. Três Lago } \\ \text { 29. Cidade Dutra } & \text { 36. Paz } & \text { 43. Vila Curuçá }\end{array}$

\section{CEUs 2005 - 2009}

$\begin{array}{llll}\text { 44. Água Azul } & \text { 51. Formosa } & \text { 58. Parelheiros } & \text { 65. Uirapuru } \\ \text { 45. Alto Alegre } & \text { 52. Guarapiranga } & \text { 59. Pq. Anhanguera } & \text { 66. Vila Rubi } \\ \text { 46. Azul da cor do mar } & \text { 53. Jaçanã } & \text { 60. Parque Bristol } & \text { 67. Vila do Sol } \\ \text { 47. Caminho do mar } & \text { 54. Jaguaré } & \text { 61. Quinta do Sol } & \\ \text { 48. Cantos do amanhecer } & \text { 55. Jardim Paulistano } & \text { 62. Sapopemba } & \\ \text { 49. Capão Redondo } & \text { 56. Lajeado } & \text { 63. Tiquatira } & \\ \text { 50. Feitiço da Vila } & \text { 57. Paraisópolis } & \text { 64. Três Pontes }\end{array}$


Figura 2.8.3

Esquema volumétrico do programa

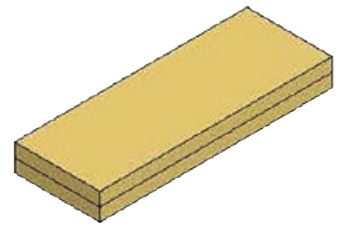

Educação

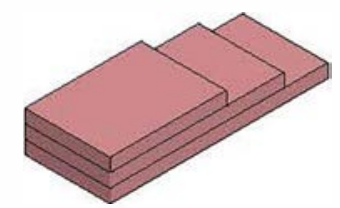

Cultura

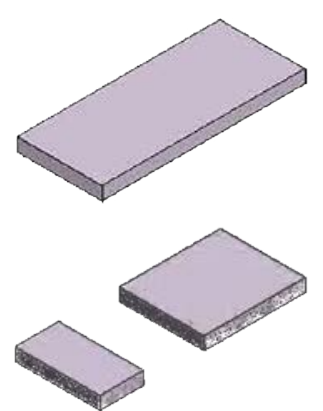

Uso múltiplo

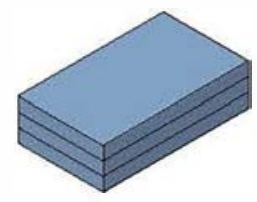

Esporte
Agrupamento
educacional

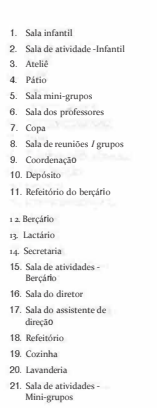

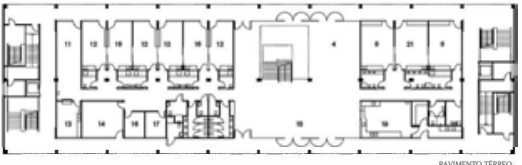
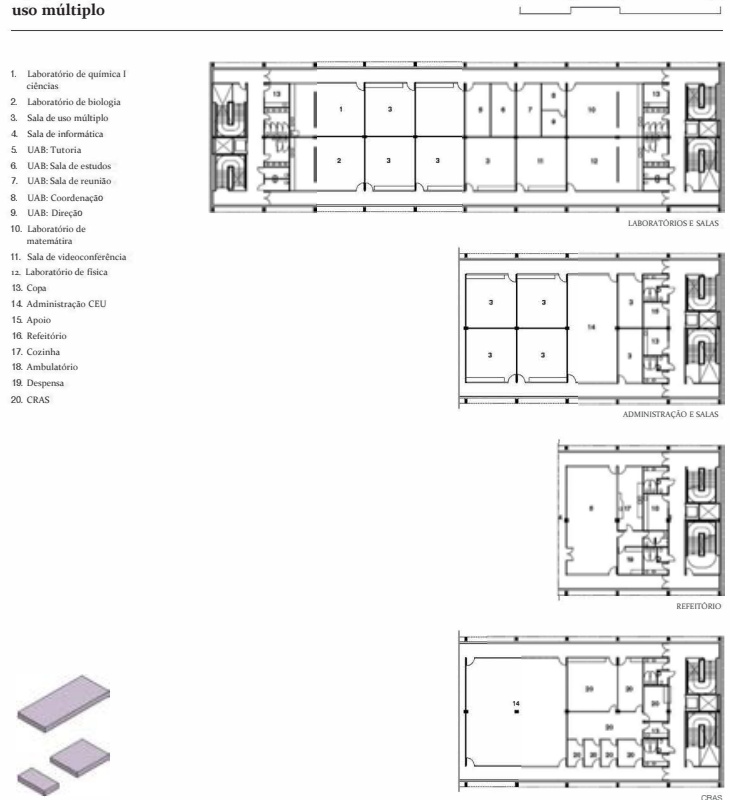

Agrupamento
cultural
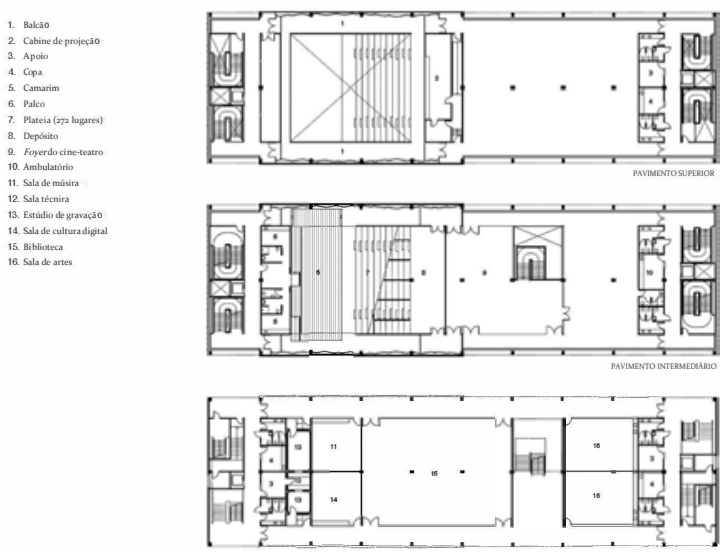

grupament

esportivo

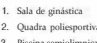
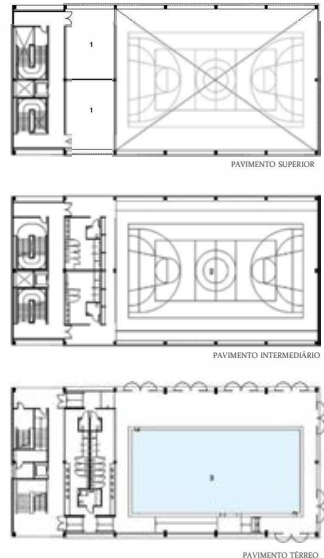

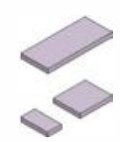

Figura 2.8.4

Plantas por programa 
Figura 2.8.5

Variação - Arranjos

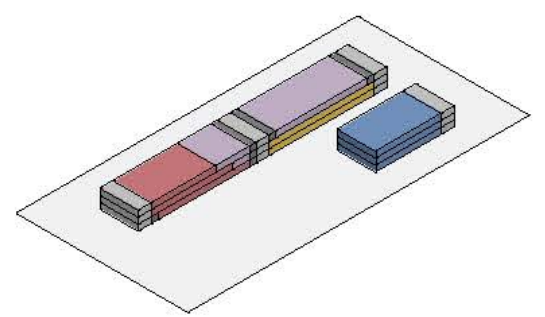

Arranjo linear

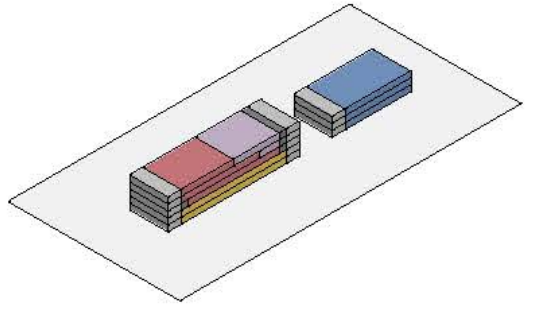

Arranjo vertical

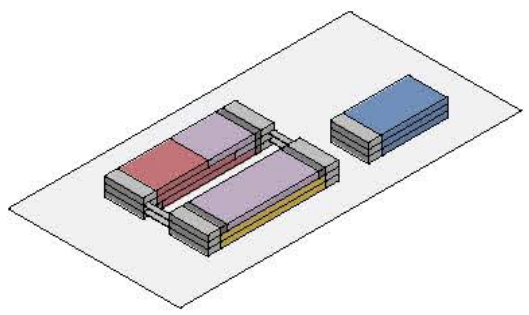

Arranjo paralelo
Imagens dos estudos para as implantações dos territórios CEUs

Figura 2.8.6

Perspectiva - CEU Grajaú

Figura 2.8.7

Perspectiva - CEU José de Anchieta

Figura 2.8.8

Perspectiva - CEU Tatuapé-Carrão
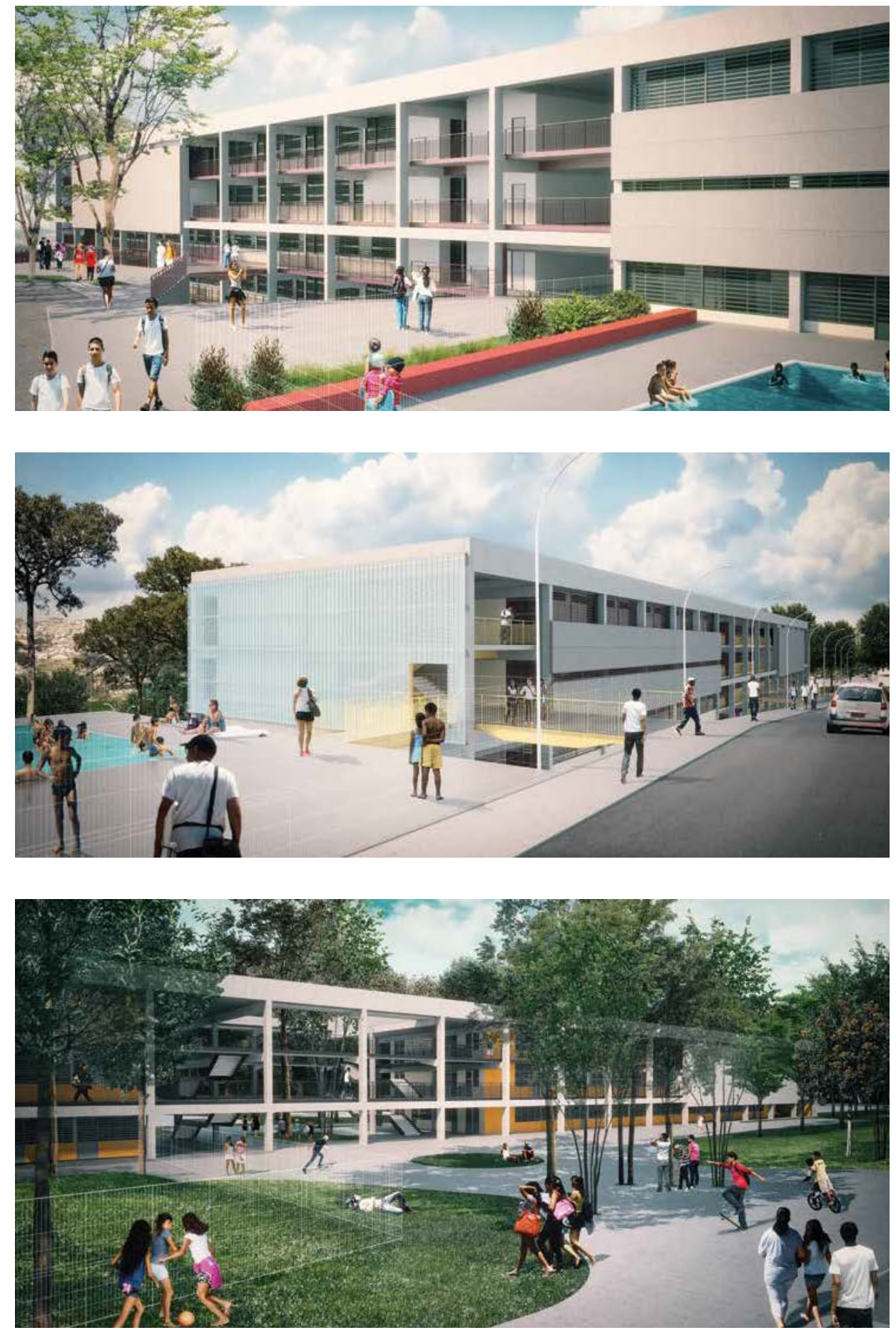


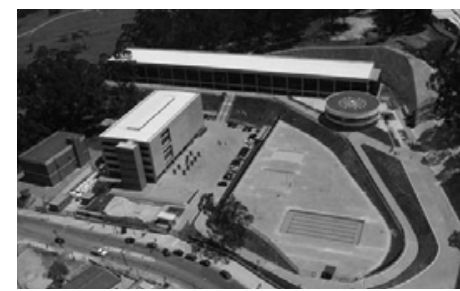

Figura 2.8.9 Alvarenga

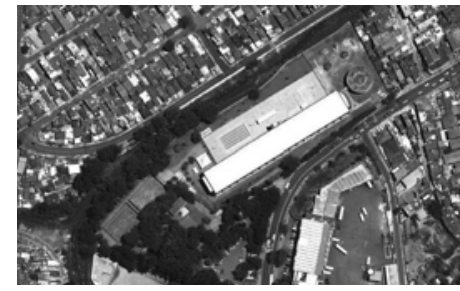

Figura 2.8.12 Campo Limpo

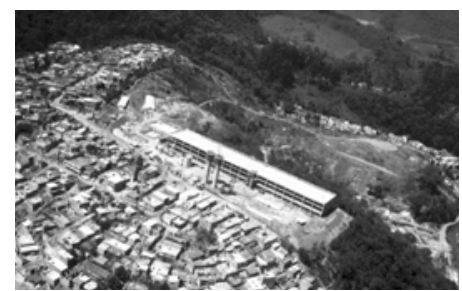

Figura 2.9.15 Paz

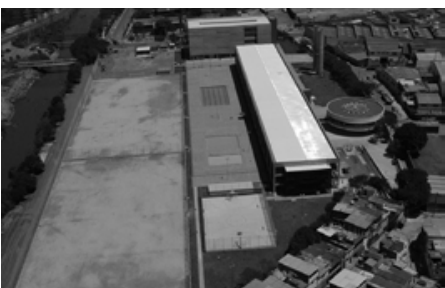

Figura 2.8.18 Meninos

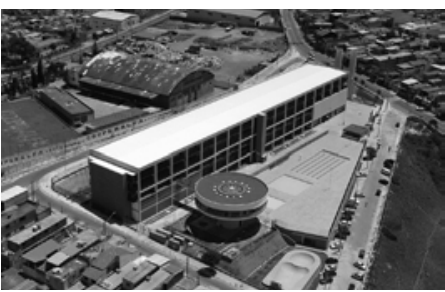

Figura 2.8.21 Parque Veredas

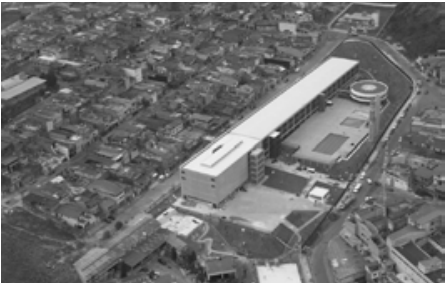

Figura 2.8.24 Rosa da China

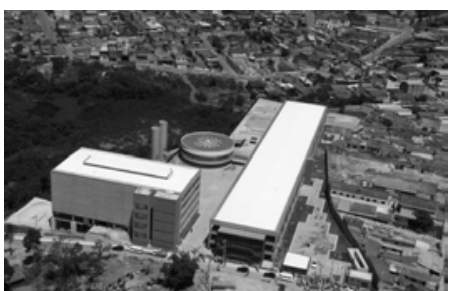

Figura 2.8.27 Três Lagos

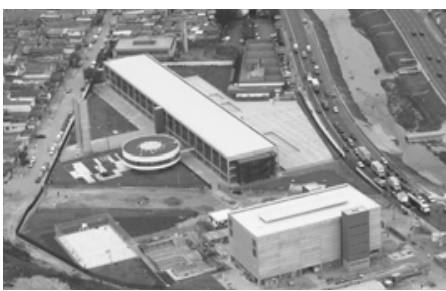

Figura 2.8.10 Aricanduva

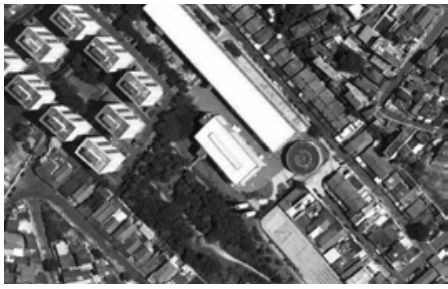

Figura 2.8.13 Casa Blanca

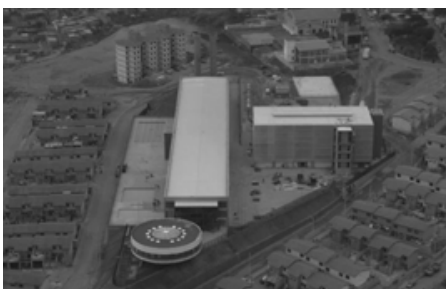

Figura 2.9.16 Inácio Monteiro

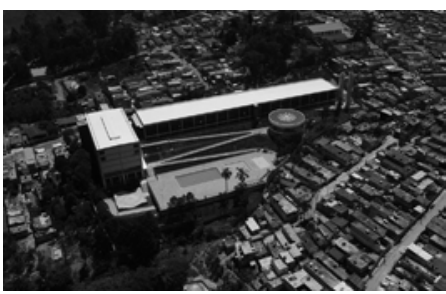

Figura 2.8.19 Navegantes

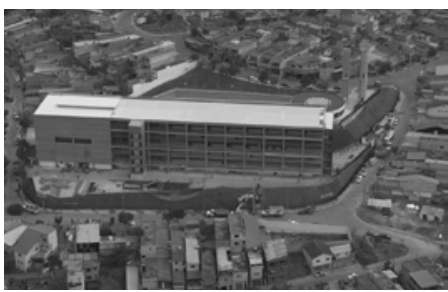

Figura 2.8.22 Pêra Marmelo

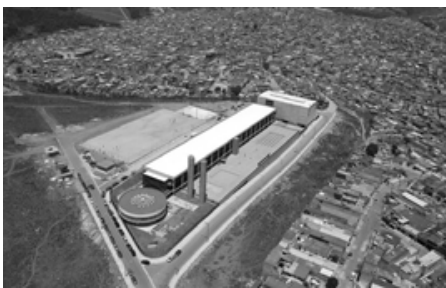

Figura 2.8.25 São Mateus

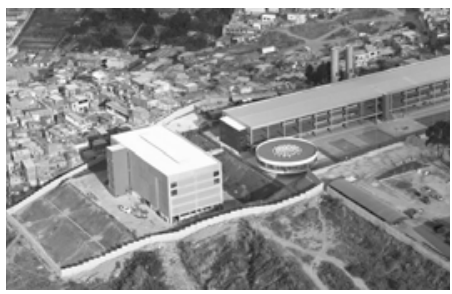

Figura 2.8.28 Vila Atlântica

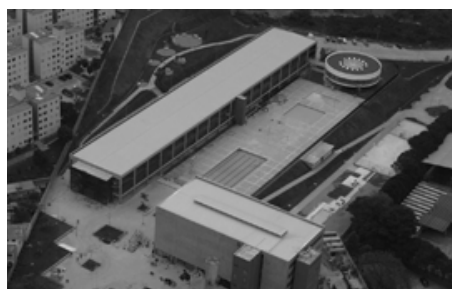

Figura 2.8.11 Butantã

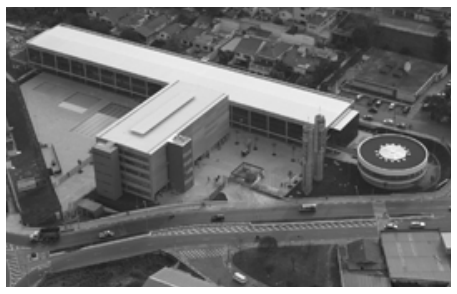

Figura 2.8.14 Cidade Dutra

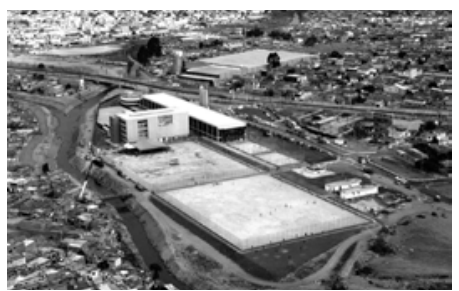

Figura 2.9.17 Jambeiro

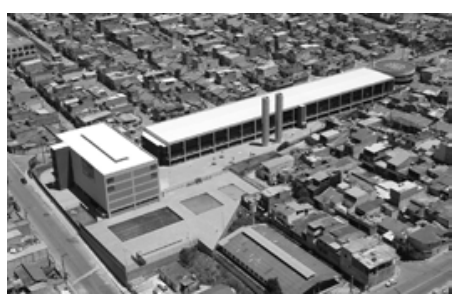

Figura 2.8.2o Parque São Carlos

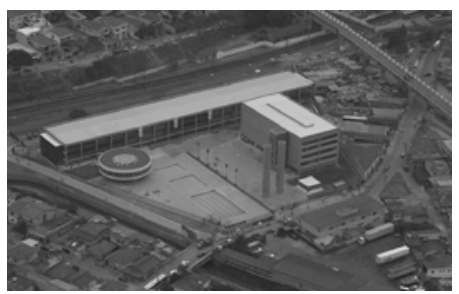

Figura 2.8.23 Perus

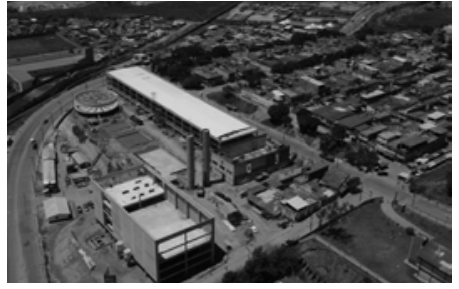

Figura 2.8.26 São Rafael

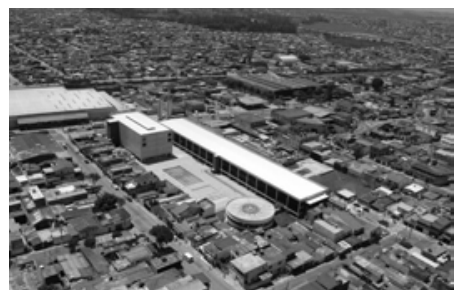

Figura 2.8.29 Curuçá 
Painel 2.9 Cantinho do Céu
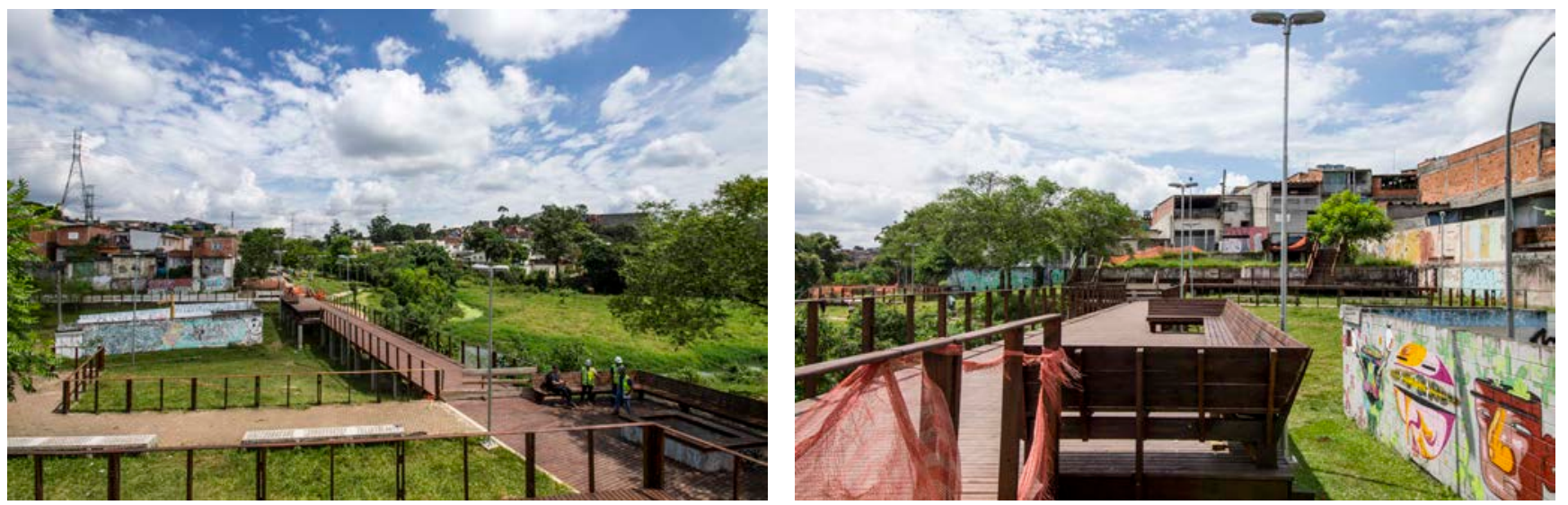
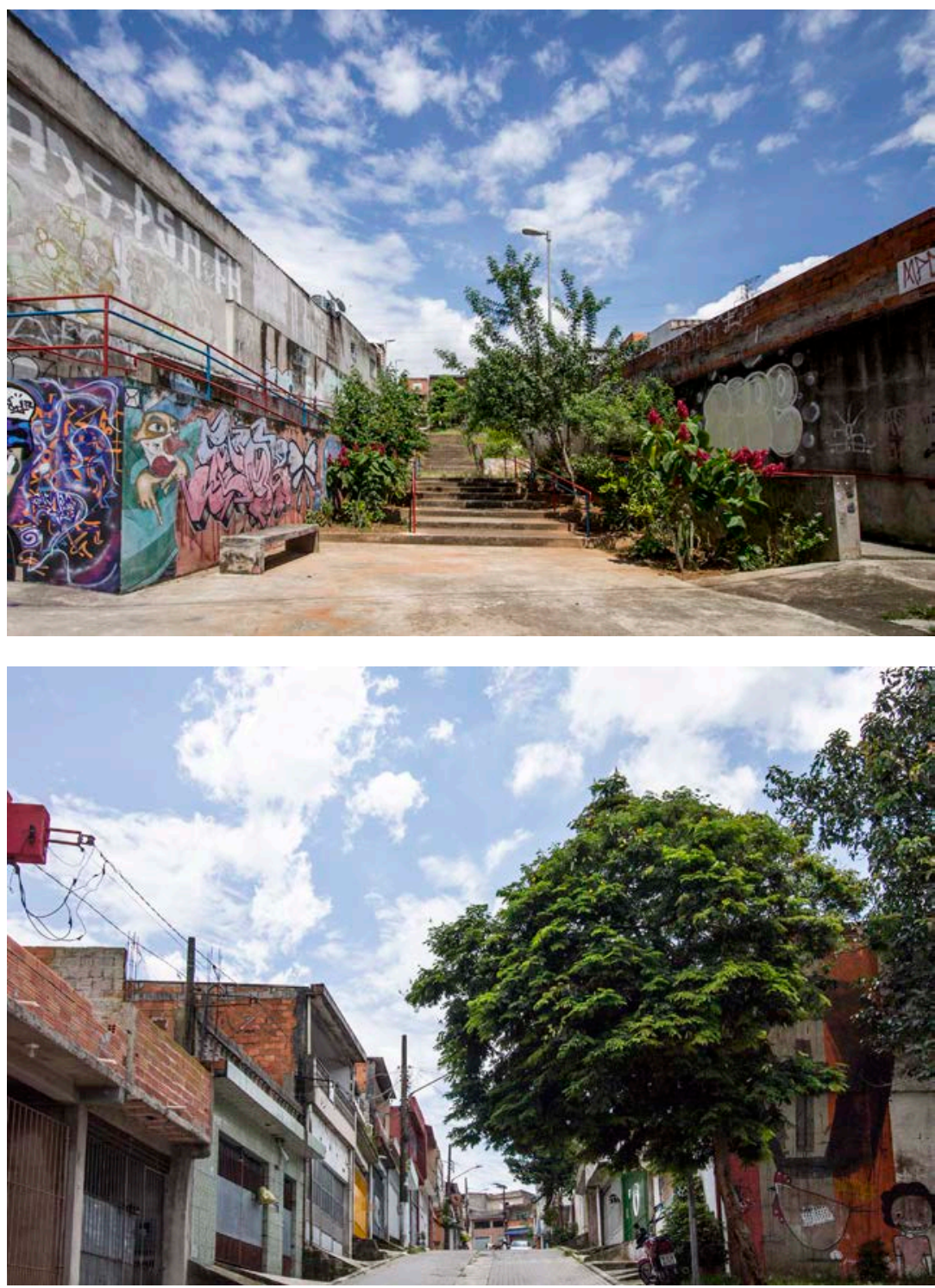

Figura 2.9.1

Figura 2.9.2

Figura 2.9.3

Figura 2.9.4

Novo trecho do parque em construção

Esta parte já estava prevista no projeto original Além dos percursos em deck de madeira sobre as áreas alagáveis toda a drenagem e o arruamento também recebem intervenções 
Figura 2.9.1

Figura 2.9.2

Figura 2.9.3

Figura 2.9.4

Trechos do parque original

em bom estado de conservação
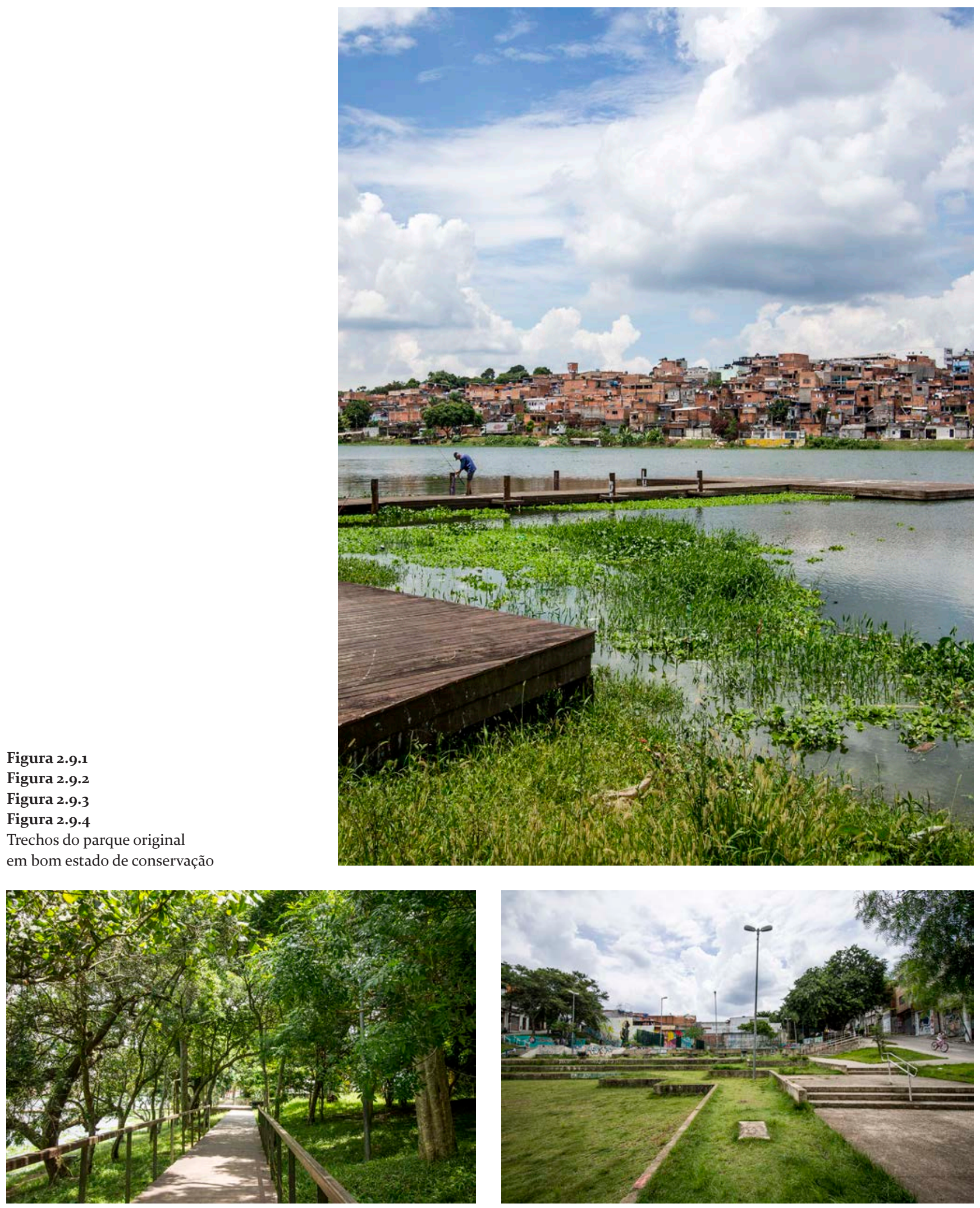
Painel 2.10 Parque da Juventude
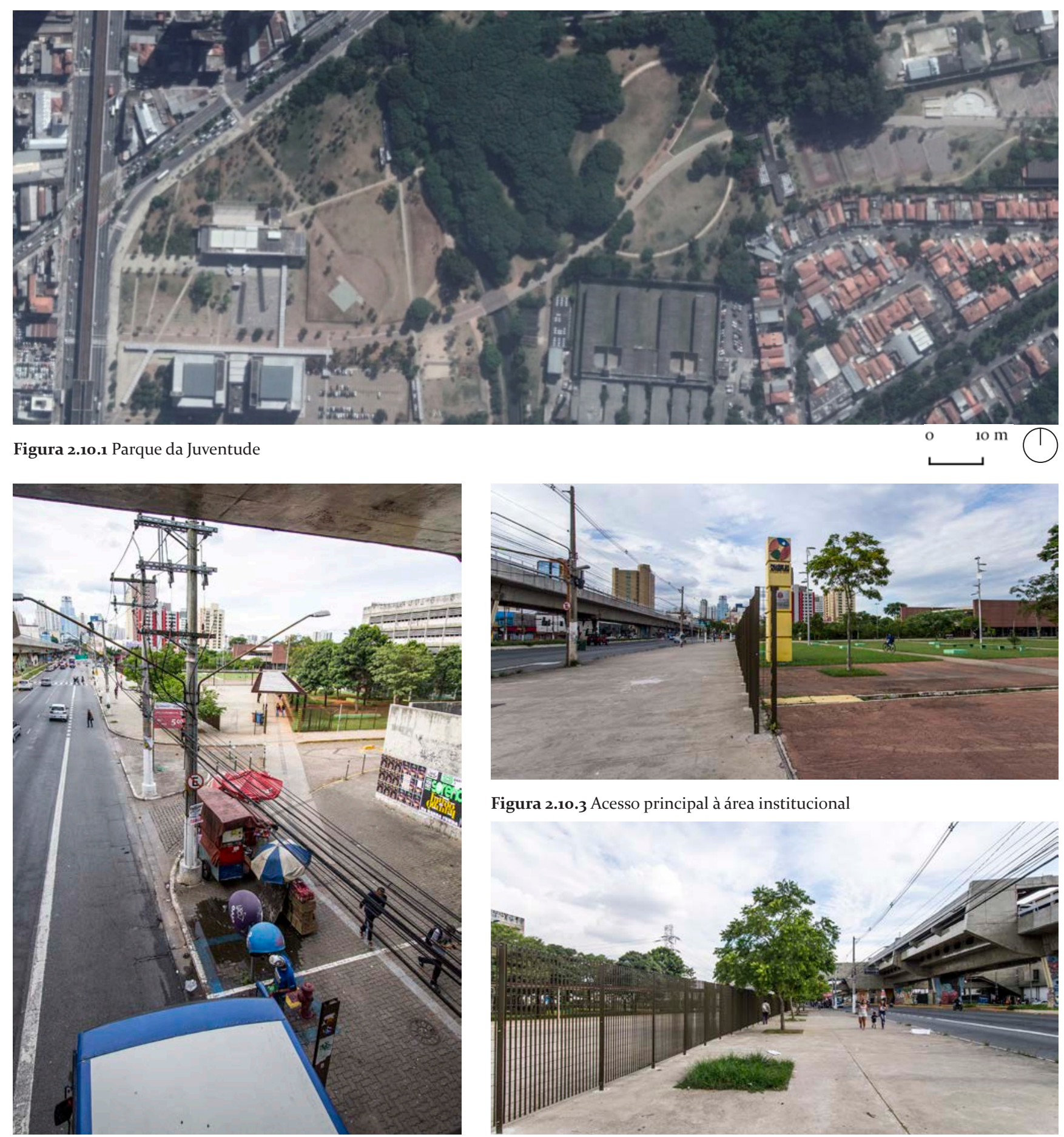

Figura 2.10.3 Acesso principal à área institucional

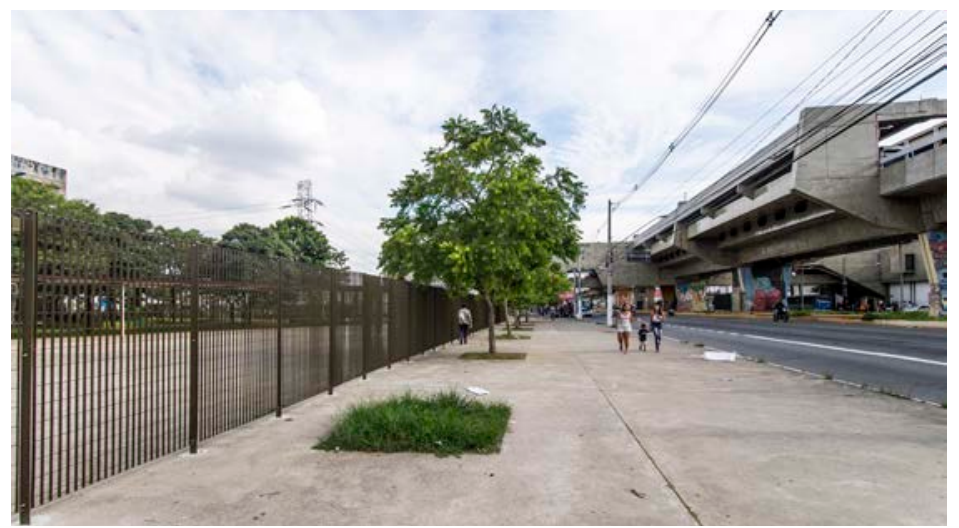

Figura 2.10.2 Vista do acesso ao parque a partir do metrô

Figura 2.10.4

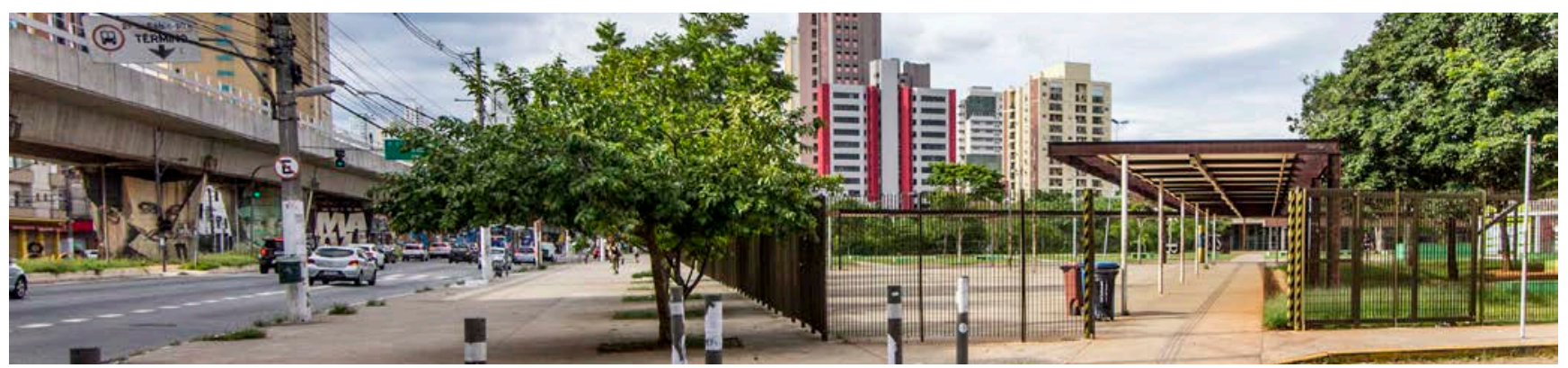

Figura 2.10.5 Percurso a partir do metrô 

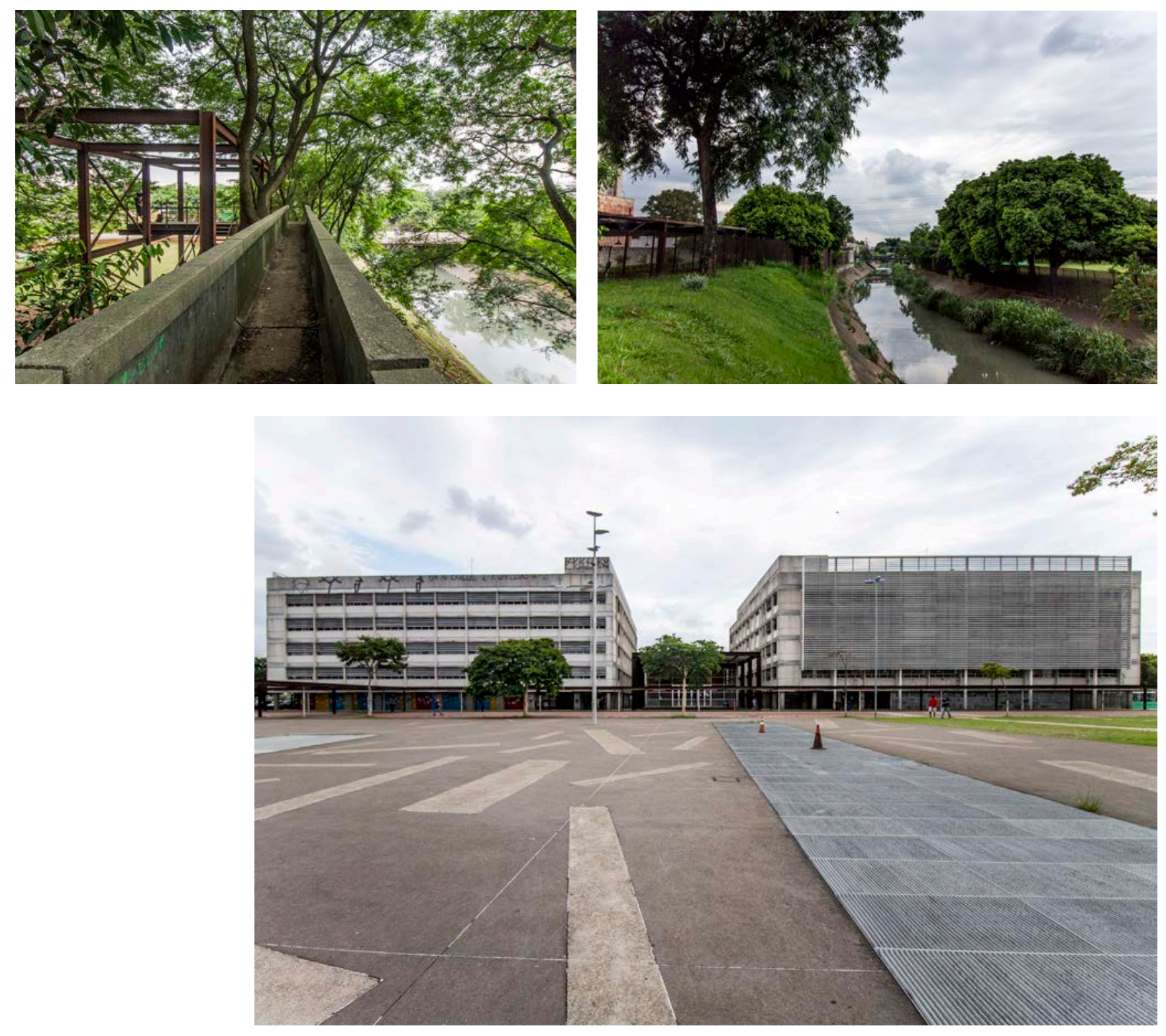

Figura 2.10.6

Figura 2.10.7

Figura 2.10.8

Figura 2.10.9

Contraste entre a área de intervenção do paisagismo e a área institucional. Grandes espaços vazios indeterminados dão destaque ao conjunto arquitetônico interligado por marquises

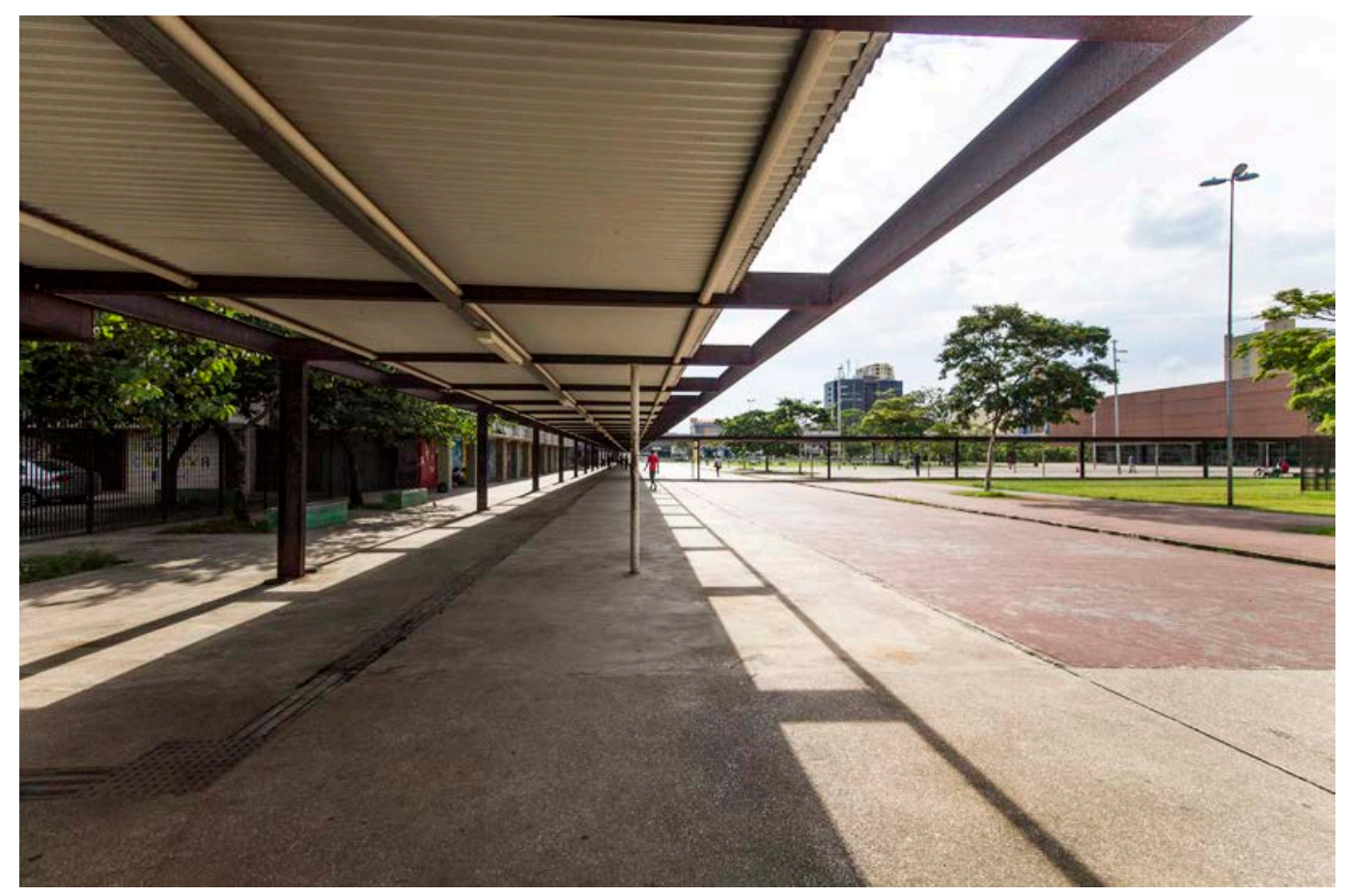


Painel 2.11 Centro de Formação Cultural Cidade Tiradentes
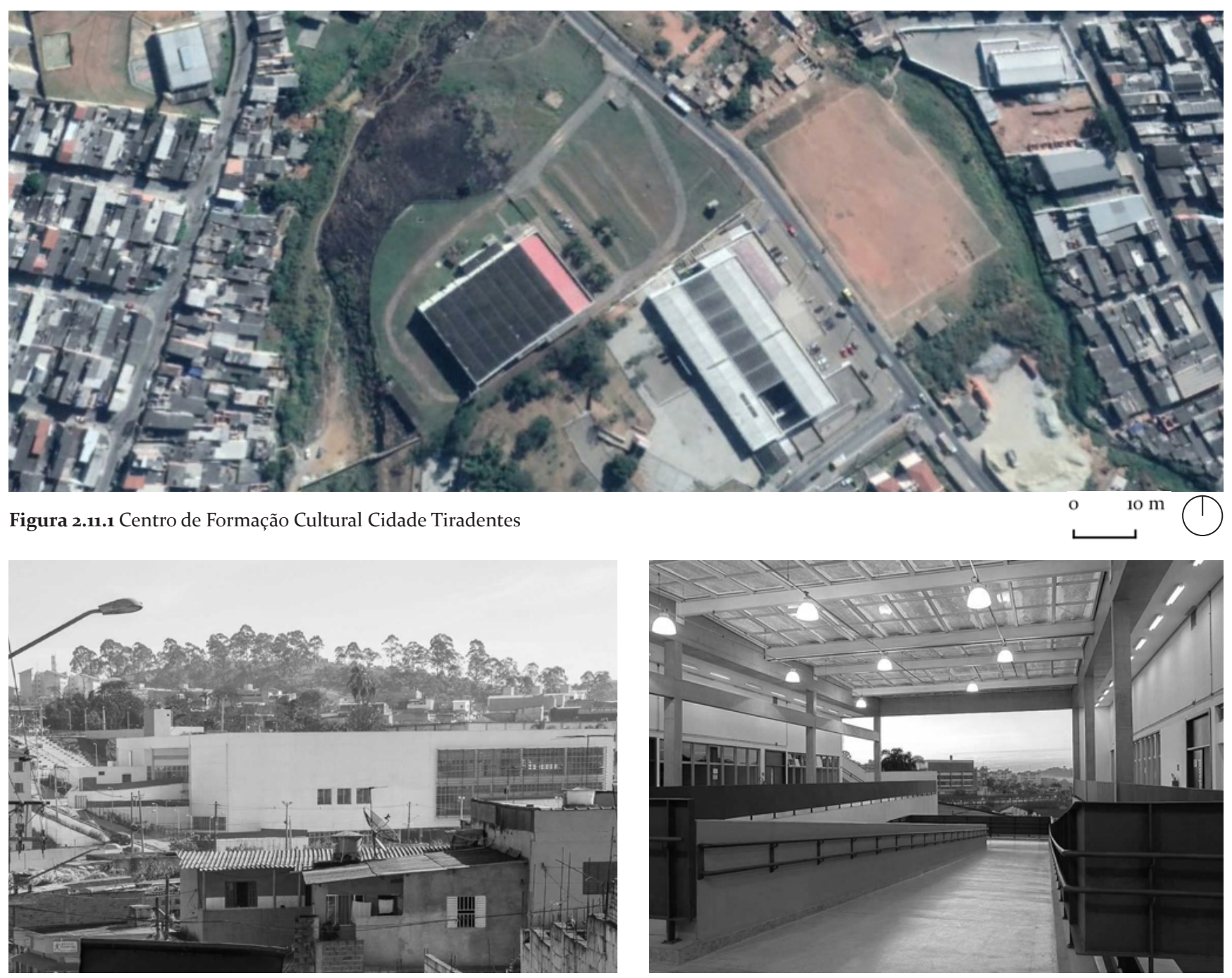

Figura 2.11.2

Figura 2.11.3

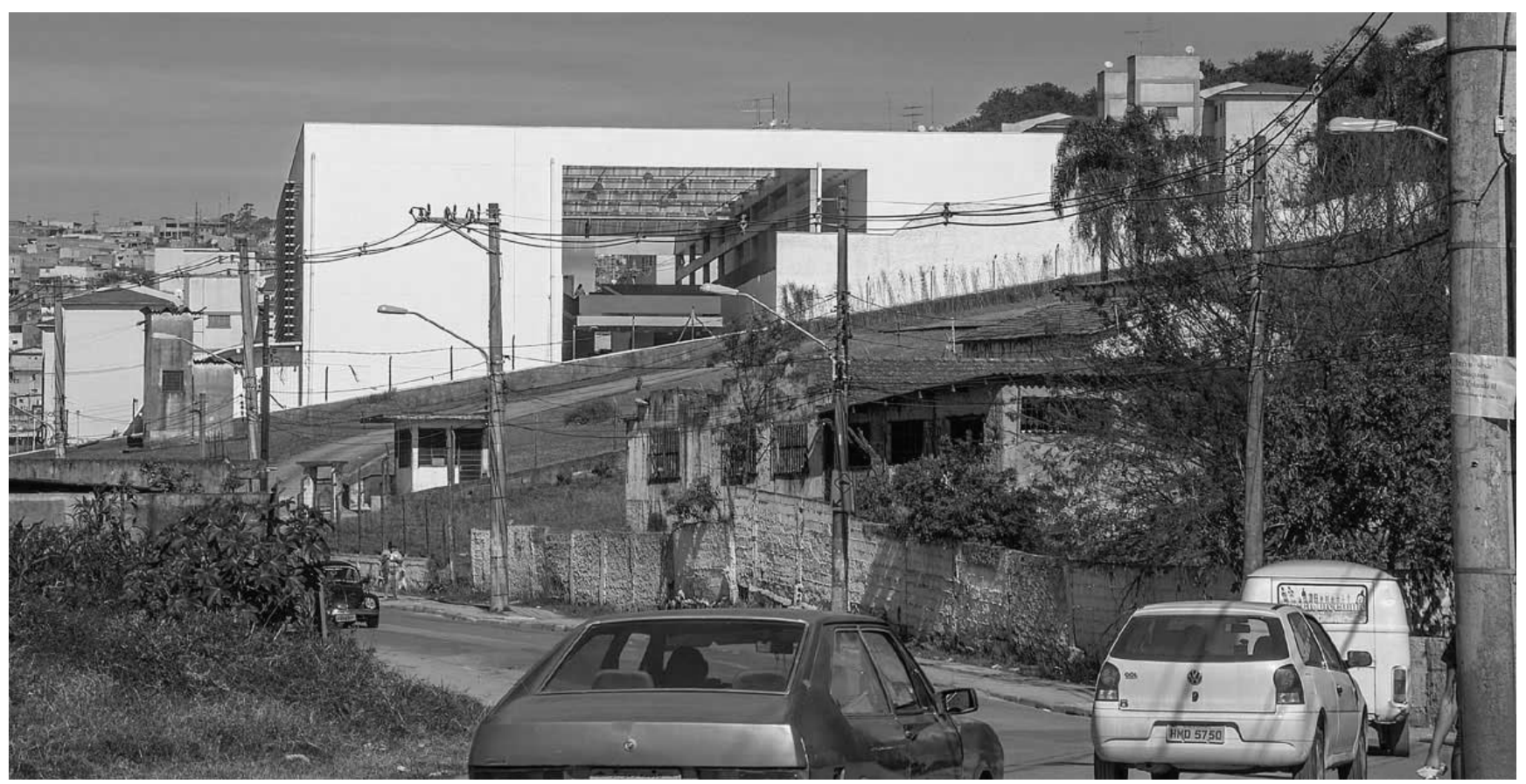

Figura 2.11.4 
Figura 2.11.5

Figura 2.11.6

Figura 2.11.7

Figura 2.11.8

Figura 2.11.9

Imagens do entorno do CFCCT

Nota-se pouca relação

programática entre as áreas

internas e externas
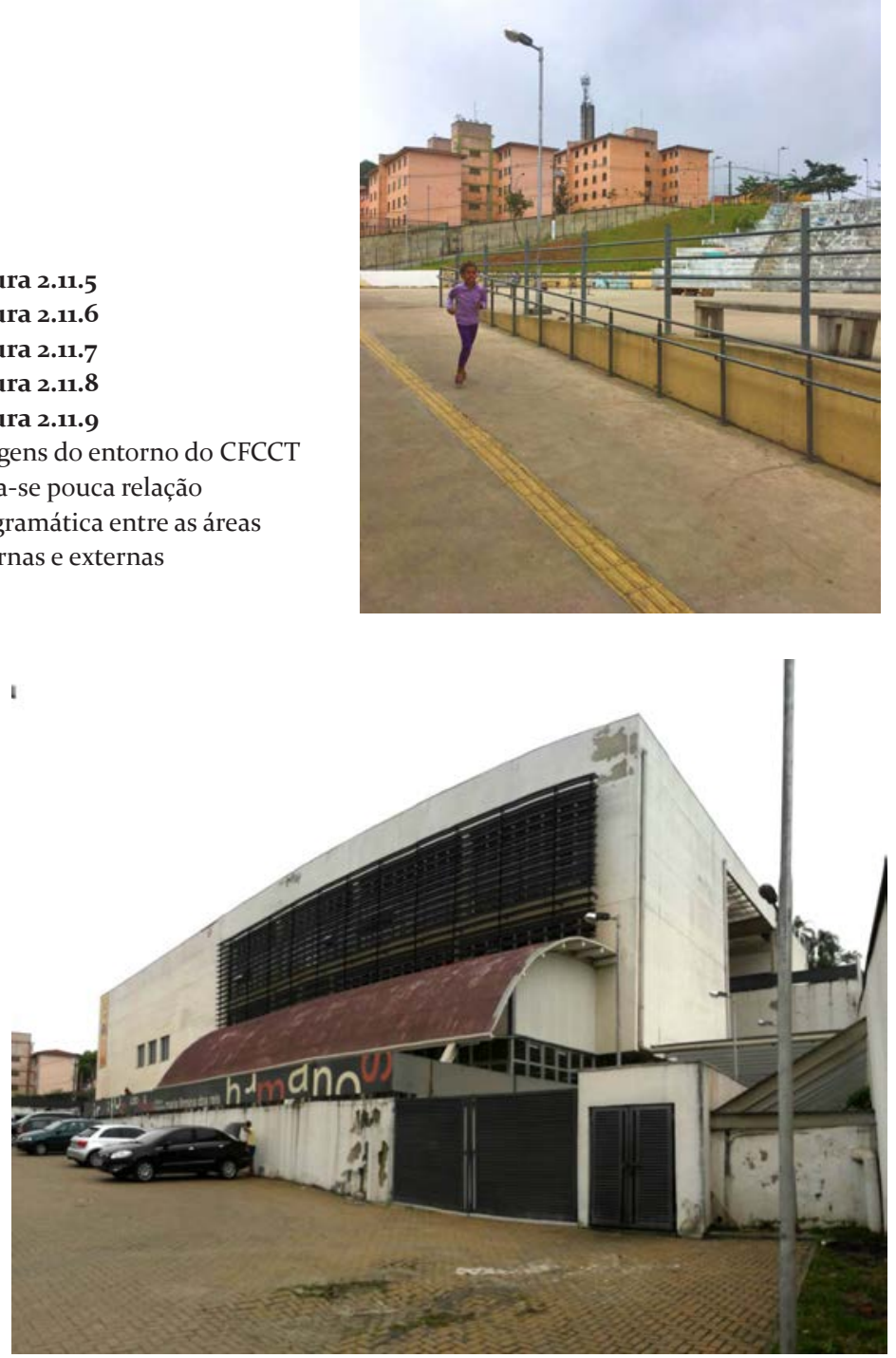

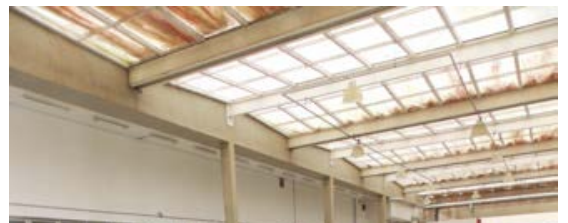

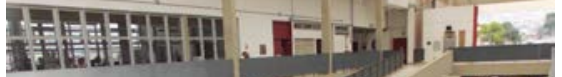
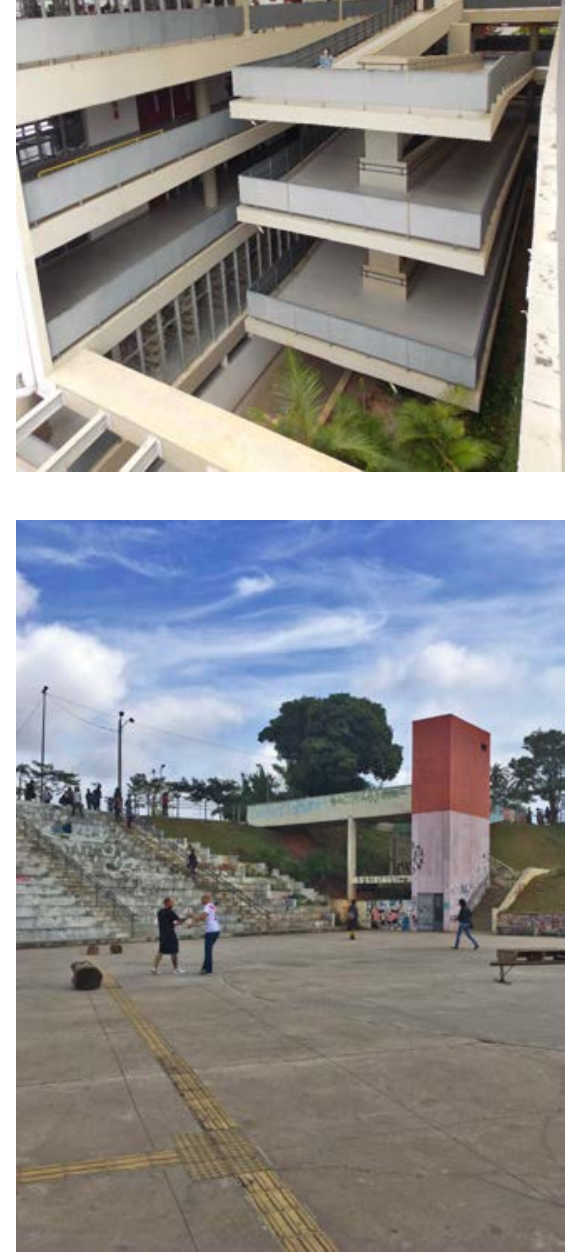

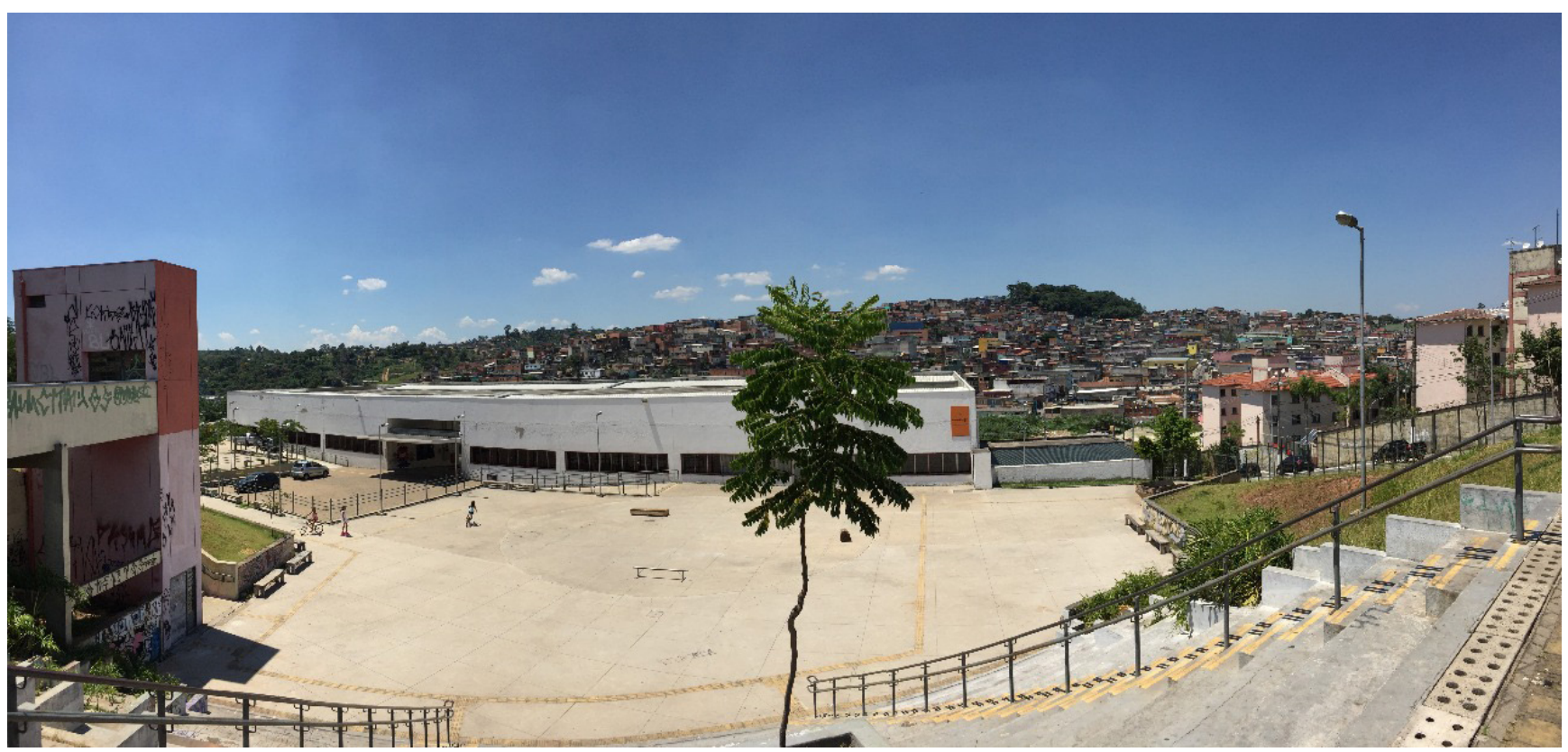




\title{
2.3 Recobrando uma paisagem urbana
}

De vilas a metrópoles, São Paulo e Medellín se transformaram por meio de uma urbanização que nos convencionou chamar de "produtora de não-lugares" ${ }^{101}$ porque se fez negando, segregando e excluindo, ao produzir o espaço da cidade. O termo pareceu dar conta da dimensão contraditória - produtiva e destrutiva - dessa urbanização, pautada pelo desenvolvimento econômico capitalista que ganhou contornos específicos nos países de modernização tardia. Nessas condições, esse processo dialético e disruptivo da urbanização se construiu notadamente pelo acirramento das clivagens sociais, solapando lugares potencialmente identitários, relacionais e históricos, digerindo patrimônios culturais e ambientais, para construir progresso econômico e cidade para poucos. Assim, a paisagem urbana sintetiza os ideários políticos formulados no plano nacional, seus rebatimentos locais, dando também uma dimensão física aos conflitos entre os diferentes agentes e seus interesses na produção do espaço social. A experiência da cidade exprime essa tensão e a sobreposição caótica de objetos urbanos, como bem descreve Sevcenko sobre a São Paulo dos anos 1970:

\begin{abstract}
O pesadelo tecnocrático se abatia sobre São Paulo para ocupar o vácuo aberto pela repressão política. Viadutos paralelos, cruzados, sobrepostos; praça de quatro andares, para maior conforto dos carros; corredores superexpressos de circulação; hipermercados; verticalização desenfreada; desapropriações, demolições, ocupação dos espaços públicos; condomínios privados, centros empresariais, grades de proteção, selva cerrada de antenas de captação, ponteada de altíssimas torres de radiotransmissão. A paisagem eleita pelos jesuítas, do maciço de colinas entrecortado pelos rios, lagos e vales verdes amplíssimos, por onde serpenteava o rio prateado até sumir sob a nuvem azulada de neblina fina, foi rapidamente substituída por um novo cenário de asfalto, concreto armado, aço, alumínio e vidro. Entremeado em todos os recantos de pontas de lanças, grades, guaritas, arame farpado, câmeras de vídeo e sistemas de alarme. (SEVCENKO, 2000, p. 110-111)
\end{abstract}

Esse espaço fragmentário e violento se reproduz sob processos agressivos que se intensificam na contemporaneidade. Assim, ao perscrutarmos os caminhos que levaram a esse padrão de urbanização, sob nosso interesse disciplinar, constatamos em alguns projetos impulsos de resistência a essa tendência desagregadora e excludente de produção do urbano. Eles se evidenciaram no movimento de análise que passa por convergências e afastamentos entre os casos comparados nas duas cidades. Nesse sentido, os principais avanços logrados por alguns desses projetos, confirmam a necessidade de se redescobrir a dimensão construtiva, reparadora, de interação entre a urbanização e a prática social, ainda que sob os imperativos econômicos que permanecem na direção oposta e os problemas que dele decorrem, em um processo de mutação cotidiano.

${ }^{101}$ Tomo a licença de aclimatar essa noção de Marc Augé ( 2012, p. 73-74) pela capacidade de síntese e complexidade descritiva do termo, muito apropriado ao problema constatado na pesquisa teórica como também o fenômeno percebido em campo. 
Esse é um potencial latente, mas que se consolida em pequenos movimentos no contrafluxo das tendências dominantes. A virtualidade da estratégia de resistência reivindica e, afinal, recobra uma paisagem urbana - num sentido de totalidade socioespacial - com uma dimensão coletiva, inclusiva e que ao mesmo tempo recupera qualidades obliteradas do meio ambiente.

As considerações sobre esse horizonte de atuação, que pode informar a $A \& U$, foram colhidas nas experiências analisadas nesse trabalho dentro da escala proposta pelo capítulo e são sintetizadas em três frentes de reflexão que expomos a seguir.

\subsubsection{Reconhecendo a matriz urbana real}

As primeiras tentativas de dar forma ao desejo de modernização das duas cidades, partiram dos modelos europeus. Eram projetos com intenções de desenho e de urbanidades alheias, com os decorrentes problemas de adaptação à realidade local. E não deram conta do crescimento econômico e demográfico que exigiu infraestruturas mais complexas e planos que pudessem organizar a mancha urbana em expansão. Isso porque as duas cidades enfrentaram ritmos galopantes de crescimento desde a década de 1930, dando corpo aos fenômenos que levaram ao quadro das cidades massificadas latino-americanas, como sintetizou J.L. Romero (2009). Entre a crise de 1929 e a Segunda Guerra Mundial, as relações entre os países centrais e periféricos se alteraram e exigiram reajustes na política econômica, nos mecanismos financeiros e nas relações entre capital e trabalho para administrar a crise e substituir as importações por uma produção interna. Esse momento, de intensificação da atividade industrial, tornou São Paulo e Medellín comparáveis, particularmente no modo como os capitais locais procuraram investimento na indústria, ao mesmo tempo em que os capitais estrangeiros vieram se instalar, como apontou Milton Santos (2010, p. 81).

Também, cada cidade explorou novas possibilidades de "canalizar os novos problemas de uma cidade transtornada" (ROMERO, 2009, p.255) diante do que se configurou como uma migração em massa do campo para a cidade, ao mesmo tempo em que as grandes cidades latinoamericanas tornaram-se os centros de articulações regionais e nacionais. Isso é válido para São Paulo e em Medellín, em que pese à decadência da indústria da cidade colombiana duas décadas depois. A cidade que exibia a maior taxa de crescimento industrial da Colômbia, perdeu seu posto para Bogotá em 1953, chegando a década de 1970 com uma exaustão da política de baixos salários, fazendo sofrer população e a economia urbana, em um quadro de involução, segundo avalia Milton Santos $^{102}$. Em todo caso, as duas cidades com potências econômicas diversas, compartilham, cada qual em sua escala, de extensas áreas periféricas.

\footnotetext{
${ }^{102}$ Cf. Santos, 2010
} 
Os diferentes planos formulados nas respectivas cidades - filtrando a realidade pela lente da modernidade - que tentaram responder a essa demanda, enfrentaram a pressão dos interesses e disputas fundiárias. Por meio de difíceis articulações políticas, demandando agendas técnicas de grande envergadura, os planos foram realizados sob prazos estendidos e intervenções parciais. Isso acometeria tanto o Plano de Avenidas de Prestes Maia, quanto o plano de Sert e Wiener para Medellín, sendo o segundo caso um projeto estrangeiro com abstrações significativas da realidade local. Por fim, as estruturas viárias e o zoneamento foram os elementos estruturantes que resistiram ao desmonte dos ideários, dando suporte à opção pelo automóvel em detrimento ao transporte sobre trilhos.

Entre os primeiros planos formulados para a cidade que se expandia de seus vetores centrais e aqueles que tentaram domar a mancha urbana descontrolada e permeada de assentamentos irregulares e precários, há muitas diferenças. Foi-se perdendo paulatinamente a capacidade de visualização de um ideal de cidade enquanto organismo único. Buscou-se diretrizes para a organização da cidade na implantação de infraestrutura e em regulações funcionais, restritivas ou quantitativas da forma urbana.

Apostava-se também em medidas de erradicação dos assentamentos informais que fugiam a esse sistema. Dos anos 1950 até o final dos anos 1970, no entanto, as duas cidades progrediram em diagnósticos e leituras mais acertadas sobre esses fenômenos socioespaciais. Mas estes não se converteram em instrumentos capazes de intervir e regular esse processo de modo mais equitativo. A formação dos tugúrios de Medellín, avançando sobre terrenos instáveis e áreas de proteção, é análoga a das favelas de São Paulo avançando sobre os mananciais, terrenos públicos e espaços residuais de implantação das infraestruturas. Eram efeitos colaterais indesejados.

Interessa-nos perceber que o exército de reserva representado pela massa de trabalhadores nos bairros periféricos são parte principal e funcional da equação do desenvolvimento econômico no capitalismo periférico, mas sua presença física é considerada disfuncional, um subproduto da urbanização. Essa contradição de fundo demonstra a visão excludente, de exceção, que impede uma ação sobre a totalidade do problema, esse é o caminho dos planos que se descolaram da realidade.

Essa patologia é comum as cidades latino-americanas, orientadas por visões externas, com missões econômicas desconectadas às suas realidades locais. Isso se evidencia nos diferentes ciclos de existência das cidades analisadas, problema que sob o olhar de Gorelik (2005, p. 114) e de Romero (2009), permitem vislumbrar a convivência tensa entre representações e realidades, entre o que fica do desígnio programático incompleto e desmentido, e a própria realidade que, em seu fracasso, esse desígnio chegou a constituir, de um modo ou de outro.

O percurso analítico intentou, assim, encontrar os pontos de descolamento entre as referidas representações e as realidades, motivado a partir do esquema interpretativo de Romero, visando o 
retorno necessário a existência das cidades latino-americanas. Este, parece estar no reconhecimento da cidade informal - o maior símbolo do descolamento do planejamento em relação à matriz urbana realcomo o ponto de partida para um horizonte de transformação socioespacial mais abrangente. Nas duas cidades o entendimento compreensivo dessas realidades levou algumas décadas. Isso denota, além de falta de vontade política e da funcionalidade da espoliação urbana, a inadequação dos instrumentos e marcos regulatórios à disposição. Eles não são apropriados aos problemas fundiários e às demandas sociais e ambientais, algo que está sendo gradativamente revisado. Mas que também requer do poder público dupla estratégia de ação: com medidas paliativas imediatas, relativas a questões mais prementes conectadas aos serviços sociais básicos e também estruturantes de longo prazo para esses territórios. Isso é fundamental para equidade de oportunidades, ultrapassando a segregação e estigmatização dos mesmos, fazendo-os parte da mesma lógica da cidade oficial.

A dimensão de aderência à realidade é requerida também ao arquiteto e urbanista, que é chamado a atuar em episódios propiciados principalmente pelo poder público, pesando sobre seus ombros - como já previa Tafuri - à leitura das conjunturas, das contradições e, afinal, das oportunidades que podem resistir às inúmeras contingências.

Isso deverá se traduzir em uma postura projetual a ser acionada sob o respaldo de grandes articulações políticas e institucionais tanto quanto sob as restrições de um evento arquitetônico pautado por uma secretaria (de habitação, de educação, de esportes, etc.).

São assim demandadas às experiências no campo da $A \& U$ o desdobramento de suas potências: de um objeto arquitetônico - à espera de melhores condições de interação social - a uma reação arquitetônica que rompe sua condição pontual e se expande em ações e significações - do símbolo estático à transformação das dinâmicas cotidianas.

\subsubsection{Reconectando planos e projetos urbanos}

As duas cidades tiveram experiências recentes que se propõem a reagir sobre a problemática da cidade informal, amparadas nas leis de reforma urbana que vieram a esteio das reformas constitucionais realizadas na virada dos anos 1980-1990. Foram medidas fundamentais para dar autonomia de planejamento territorial nos municípios e para propor a maior participação dos cidadãos nos sistemas de decisão política. Mas a capacidade de implementação dessas oportunidades depende, além de pautas e conjunturas políticas favoráveis às questões, do desenvolvimento de novos instrumentos, apoiados na renovação das estruturas institucionais, para dar capacidade técnica e administrativa, viabilizando políticas intersetoriais adequadas também às partes negligenciadas da cidade.

De certo modo, a proposta do Urbanismo Social demonstra essa integração de fatores, pois ao colocar ao centro das pautas políticas e 
urbanas a cidade informal, teve de recorrer a uma metodologia de intervenção especial para esse tipo de tecido urbanizado. Isso implicou a associação de políticas públicas, planejamento e também de estratégias no campo da $\mathrm{A} \& \mathrm{U}$, orientados por um processo participativo. Esse conjunto de ações e atores tiveram de atender às especificidades dessas áreas de grande vulnerabilidade social. E, enquanto um conjunto de abordagens e ideias, lograram ultrapassar as diferenças políticas, bem como as particularidades dos "Planes de Desarrollo" de cada prefeito. Podemos resumir como postulações do Urbanismo Social:

- grande investimento em equipamentos públicos (particularmente aqueles voltados à educação e cultura) começando pelos bairros mais vulneráveis;

- a integração destes equipamentos a projetos urbanísticos que vinculam infraestrutura de mobilidade, saneamento e proteção ambiental;

- a articulação vertical de planos nas esferas federal, departamental, metropolitana e municipal. Assim como das diferentes entidades, públicas e privadas, que financiam, gerenciam e administram os processos executivos que viabilizaram diferentes projetos ${ }^{103}$;

- o balanço contínuo dessas experiências implicando a revisão do "Plan de Ordenamiento Territorial". Como ocorreu em 2014, que se incorporou e compatibilizou uma série de ações políticas e administrativas, de planejamento físico e estratégico, com os projetos urbanos que já vinham sendo formulados e executados à margem do POT (JARAMILLO et al., 2015, p. 10);

- o acionamento do desenho urbano e da arquitetura como ferramentas de primeira importância na ancoragem simbólica desses projetos e planos, visando a reconstrução da visão geral da cidade sobre essas áreas, mas também atuando localmente na pactuação destes novos programas junto aos moradores.

São Paulo, no entanto, tem enfrentado a problemática essencialmente por meio de políticas setoriais que ganham maior força a depender de conjunturas de cada governo municipal, algo um tanto inconstante. Os grandes projetos urbanos em São Paulo, até a última revisão do PDE de 2014, ainda eram as Operações Urbanas Consorciadas. Elas se concentram no Centro Expandido da cidade, atuando sobre a requalificação de áreas com características diversas - aquelas que experimentam uma situação de esvaziamento, que estão subutilizadas ou demandam a otimização de seu potencial, visto que configuram áreas já dotadas de infraestrutura. As limitações das OUC se colocam por atuarem estritamente em áreas consolidadas da cidade oficial, mas também pela ausência histórica das qualidades de desenho urbano e controle dos resultados do projeto, sobretudo as Operações desenvolvidas na década de 1990 e início dos anos 2000, pois eram essencialmente definidas por regulamentações com pouco alcance morfológico, delegando ao empreendedor privado as principais decisões referentes a esse aspecto. Desse modo, as partes desprovidas

${ }^{103}$ Como também apontam, detalhadamente, Antonucci e Bueno (2018). 
de infraestrutura - amplamente relacionadas à cidade informal - ficam de fora do campo de ação e também de influência das OUC.

O Estado, em sua relação permissiva com a classe empreendedora nos eixos de investimento na cidade formal foi, da mesma forma, conivente com o loteador irregular no processo de expansão das periferias urbanas. Seja pela tolerância à clandestinidade ou sob ações urbanísticas pautadas estritamente pelo zoneamento urbano, ao invés de ampliarem benefícios para o conjunto da população, funcionaram como limitadores da oferta de espaço público, de moradias ou de loteamentos no mercado regular (Grostein, 2001). Essa paulatina transferência de atribuições ao setor privado, e diminuição da sua capacidade técnica e institucional de dialogar com os agentes e processos de produção do espaço, o coloca numa posição de retaguarda no processo de urbanização.

Coube então às políticas setoriais, alcançar as áreas e as problemáticas fora do radar do plano, que está coberta, principalmente, pela ação regulamentar das ZEIS (Zonas Especiais de Interesse Social). Estas não são menos importantes, mas ainda encontram grandes dificuldades de implementação e protagonismo nas prioridades da agenda urbana paulistana. Isso não significa que São Paulo não tenha garantido avanços significativos por meio de políticas setoriais, visto que a cidade logrou implantar numerosos equipamentos sociais e projetos expressivos em urbanização de assentamentos precários. Mas, o que se percebe é que os avanços em políticas setoriais se dão com ganhos urbanos desarticulados.

$\mathrm{Na}$ ausência de projetos urbanos, ou da oportunidade de integrar, via desenho urbano, diferentes intervenções na cidade, muito se construiu. De modo que equipamentos foram semeados, infraestruturas se expandiram, e a cidade que se fez enquanto o alinhamento dessas variáveis pairou no campo das incertezas.

\subsubsection{Reconciliando infraestrutura e território}

Recobrar a paisagem urbana, social e ambiental, é uma proposição que sintetiza articulações identificadas por detrás das experiências mais interessantes que foram repassadas em São Paulo e Medellín. Isso passa por rever a relação entre o sítio natural e a implantação de suas infraestruturas. A Bacia Hidrográfica de São Paulo e o Vale do Aburrá foram duas unidades territoriais que permitiram visualizar os efeitos continuamente atualizados da transformação dessas estruturas ambientais frente os diferentes ciclos econômicos, que moldam o território por meio desses sistemas técnicos.

Conforme demonstrou Franco (2005), em São Paulo, o sistema sobre trilhos concentrou a urbanização ao longo das vias férreas situadas nas várzeas e planícies fluviais, polarizada no entorno das estações e baseada no modal de transporte coletivo. O subsequente sistema sobre rodas, fundamentalmente coletivo no primeiro momento, preponderantemente individual com o passar do tempo, possibilitou uma urbanização extensiva, difusa e de baixa densidade. Mas, ainda 
segundo o autor, na transferência de hegemonia de um sistema para o outro, o sistema viário e o correlato sistema de transporte sobre rodas reafirmaram a destinação das várzeas e dos fundos de vale à passagem dos fluxos estruturais da metrópole. Assim, adentramos um terceiro momento em que as mudanças na estrutura produtiva introduzidas no país no final do século 20 agem diretamente sobre as áreas originalmente organizadas pela produção industrial, de modo que a acessibilidade das várzeas reafirma as vantagens de locação para as principais que emergem do setor de serviços (FRANCO, 2005, p. 18-19). Por isso, veremos que o poder público estará atento a esse processo e, colocando-se como um agente ativo na atualização da infraestrutura instalada, na esfera do planejamento, definiu a estrutura espacial dos principais rios e córregos (Tietê, Pinheiros, Tamanduateí, Aricanduva, Jacu e Águas Espraiadas) e de parte significativa das áreas fabris e ferroviárias subutilizadas como foco preferencial para as operações urbanas.

Mas, subordinadas exclusivamente aos interesses do desenvolvimento econômico, as várzeas acabaram por não cumprir uma destinação possível, que era a de conformar o sistema de áreas livres da cidade. A leitura de Franco (2005, p.250) demonstra que essa ocupação estritamente técnica e funcional nos sistemas de transporte nos eixos dos rios e várzeas reitera a dimensão estruturadora destes na grande escala, mas desestruturadora na esfera local:

\footnotetext{
O transporte sobre trilhos é um sistema restritivo, pois o acesso a esse serviço só se efetua junto às estações. Estas são pontos singulares no espaço devido a seu poder detração de dinâmica no seu entorno imediato. São lugares a partir dos quais ocorre uma mediação de escalas, da metropolitana para a local e vice-versa. Assim as estações conferem urbanidade aos nós de uma infraestrutura sistêmica, de grande capacidade e necessariamente segregada do tecido da cidade. Se há um lugar onde a sutura provocada pela presença dos trilhos pode ser facilmente revertida é justamente na estação, porta de acesso ao sistema e ponte de conexão entre as margens que definem sua orla.
}

Assim, o autor nos ajuda a concluir que o desafio do transporte, como instrumento de mobilidade, seria a construção de uma nova relação de urbanidade. Este é um potencial latente de cada estação, enquanto um nó de articulação de diversos meios de transporte, velocidades e escalas, local de coordenação entre fluxos provenientes tanto de áreas adjacentes quanto distantes. Isso demanda que o projeto contemple não só uma articulação sistêmica, mas que na mesma medida, estabeleça relações com o uso cotidiano da cidade.

Medellín, por sua vez, relatou fenômeno similar na implantação de infraestruturas vinculadas a evolução de seus ciclos econômicos. Sob essa orientação, o processo de urbanização se afastou de uma relação que incorporasse os atributos paisagísticos dos seus rios e quebradas aos espaços públicos da cidade. Nesse sentido, o projeto do Parques del Rio pretendeu realizar a articulação fundamental entre as questões infraestruturais da evolução metropolitana (previstas pelo POT), recobrando também a dimensão simbólica da paisagem do rio, constitutiva da apropriação socioespacial dessa importante parte da 
cidade. Assim, essa experiência parece apontar que cabe ao desenho urbano enfrentar a mediação entre as demandas técnicas, sobrepostas no tecido da cidade, e as potencialidades latentes na construção do espaço (social), entendido como urbanidade.

No mesmo sentido a mobilidade é um vetor estratégico, superando a questão técnica, porque representa transformações locais e sistêmicas, intervindo na segregação e na diferenciação espacial:

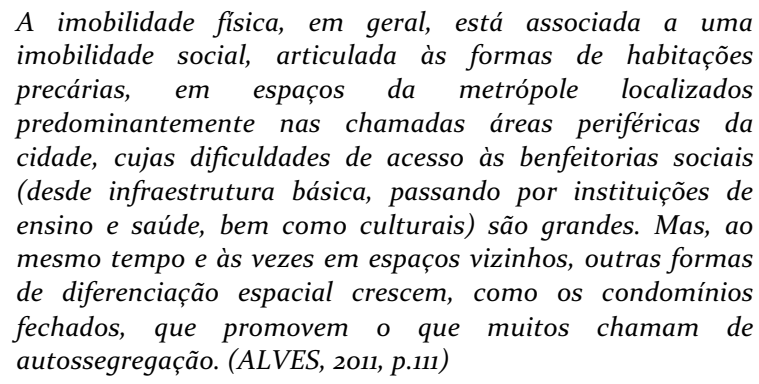

Reitera-se assim o fato de que a implantação do metrocable não só articulou uma conectividade entre cidade formal e informal por meio de um sistema de transporte inovador, mas também inaugurou uma metodologia de desenho reconciliador com o entorno das estações. Isso recobrou aos bairros periféricos um novo status na cidade. Essa renovação simbólica tocaria também a paisagem física, revelando o patrimônio pertencente a essa localidade: um primeiro passo na reversão da segregação social daquele bairro.

Também, o sistema de abastecimento de água foi transformado simbólica e espacialmente, enquanto um sistema de espaços públicos articulados nas franjas da cidade. O jardim circunvalar, último cinturão da mancha urbana, pontuou a integração entre a dimensão física de uma intervenção e a regulamentar, prevista na atividade de planificação e das metas macroestruturais que este pretende estabelecer. Ambas experiências valorizaram os atributos ambientais do sítio natural.

De modo que, quando retornamos ao problema paulistano, vemos que as melhores iniciativas que perpassam esses temas ainda estão isoladas desse tipo de articulação infraestrutural. Seu potencial a ser despertado pelo instrumental da arquitetura e urbanismo parece mais perdido no campo das atribuições extra-arquitetônicas.

Essa contradição ganha maior definição quando comparamos o caso ao extenso vocabulário decorrente do aprofundamento da experiência colombiana. Entre erros e acertos, os arquitetos e urbanistas de Medellín desenharam um amplo repertório de interações entre os objetos urbanos-arquitetônicos que ora se reportam - ou contestam - o ideário do POT, mas se fundem no ínfimo elemento de produção do espaço, na dimensão da materialidade. Mas de alguma forma se reportam às significações da cidade como um todo. 



\section{A segregação reafirmada no lote}

"O problema que temos que enfrentar é o da pobreza, cuja dimensão, portanto, não é somente econômica, mas também espacial; cuja definição não se esgota em termos contábeis, mas exige uma dimensão social."

Milton Santos ${ }^{104}$

A busca por uma cidade mais equitativa depende de fatores estruturantes, econômicos e políticos, mas também pressupõe superar sua decorrente segregação socioespacial. O fio condutor das análises propostas a seguir encontra orientação na centralidade desse problema. Isso porque, conforme aponta Simoni-Santos (2017), a noção de segregação se torna central para iluminar, além das interpretações locais da crise social contemporânea, aquela que é de âmbito mundial, no momento em que a globalização assume os conteúdos da urbanização completa da sociedade, como previa Lefebvre (1999).

Desse modo, a segregação diz respeito não só ao fenômeno de urbanização das cidades latino-americanas, mas também às geografias que surgem do desenvolvimento espacial desigual. Esse problema, que liga a escala local à mundial, está vinculado a um processo que emerge tipicamente por meio de uma interação contraditória entre processos rápidos e explosivos de urbanização e várias formas de estagnação, encolhimento e marginalização. E essas condições divergentes de riqueza e pobreza, crescimento e declínio, inclusão e exclusão, centralidade e marginalidade, reproduzem-se, mutuamente, em todas as escalas espaciais, do bairro a abrangência planetária (BRENNER; SCHMID, 2015, p. 151).

Essa é uma questão central e um desafio comum a ser enfrentado pelas disciplinas que refletem sobre o fenômeno urbano. No entanto, faltam categorias e métodos capazes de relacionar esses processos mundiais àqueles que envolvem a reprodução da vida cotidiana, que se refletem no espaço urbano imediato e em suas interações com as microdinâmicas do capital. Todos esses fatores estabelecem vínculos intrínsecos e indissociáveis na produção do espaço. Com essas observações queremos reforçar a potência do tema da segregação que propomos analisar, mas também demarcamos o caráter aproximativo e não explicativo - da discussão proposta, diante da abrangência e complexidade do mesmo.

Neste trabalho, a segregação foi constatada empiricamente na observação de campo, seja na organização e diferenciação entre bairros centrais e periféricos, como também na própria conformação de espaços mediados pela $\mathrm{A} \& \mathrm{U}$. A segregação apareceu transversalmente quando estudamos a evolução das estruturas urbanas, como vimos no capítulo anterior, o que envolve a ação do Estado e os ideários de planejamento que foram mobilizados nas cidades de São Paulo e Medellín. Além de criar imensas periferias urbanas, esse processo evoluiu em direção a representações espaciais dispersas desse desacerto

${ }^{104}$ SANTOS, M. O espaço dividido. 2a edição ed. São Paulo: Edusp, 2008 
social, contaminando integralmente o tecido da cidade e todas as relações que produzem o urbano.

Assim, prosseguimos na observação das possíveis contribuições que os projetos analisados oferecem no sentido de resistir à reprodução desse padrão de exclusão observado por Milton Santos:

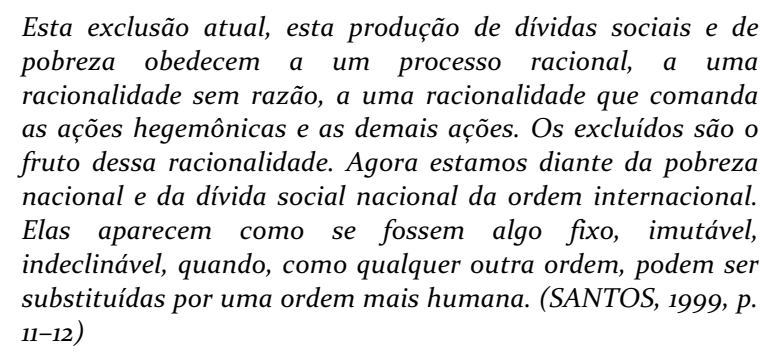

Esse processo é econômico e social, tanto quanto espacial - conforme a epígrafe de Milton Santos nos lembra - de modo que cabe também à disciplina da $A \& U$ reagir a essas dinâmicas socioespaciais segregadoras. Prefigura-se que uma estratégia possível esteja na oposição a essa racionalidade que perpetua as clivagens sociais, em direção a uma ordem mais humana e coletiva da organização do espaço. Elas devem se opor ao avanço dessas segregações que, no século 21, ficam claras a partir do isolamento do fenômeno de condominialização, que acomete a produção e reconfiguração dos espaços da cidade. Esse processo se agrava em um urbano que se faz na produção imobiliária lote a lote e no planejamento urbano que se restringe a ações de retaguarda.

A segregação é também reforçada pelas práticas socioculturais contemporâneas de forte acento individualizante. Como perceberam Hajer e Reindorp (2002, p. 53), a sociedade parece ter se tornado um arquipélago de enclaves, em que pessoas de diferentes origens desenvolveram estratégias espaciais cada vez mais eficazes para "conhecer as pessoas que querem conhecer e evitar as pessoas que querem evitar”. Ainda, segundo esses autores, esse processo está inevitavelmente vinculado a uma percepção coletiva de declínio na qualidade do ambiente, uma resposta à falta de segurança que reforça a tendência em se optar por uma cidade individual que seja construída o mais possível a partir de uma combinação de lugares cuidadosamente selecionados, seguros e socialmente homogêneos que podem ser alcançados facilmente, com a segurança e o conforto do carro.

No sentido contrário a essa tendência de esvaziamento do sentido público do espaço urbano, com a crise do capitalismo financeiro de 2008, assistimos a uma vitalidade e coletividade da cidade recobrada pelos movimentos sociais, conforme percebeu Harvey (2014), demonstrando que a sociedade demanda esforços nos sentidos integradores e compartilhados do espaço.

Assim, o tema da segregação dá ao debate disciplinar da A\&U um caminho para arriscar alguns passos, na dimensão crítica e na interação com o fazer urbano, no sentido indicado por Simoni-Santos (2017, p. 639): 
realização dos desejos e da elaboração de necessidades, assim como contém seus horizontes de satisfação. Nesses termos, a segregação atualiza a noção de alienação, como alienação do urbano; ela se define aqui como a manifestação extrema da alienação, definida no e pelo urbano. Na medida em que também, além do acesso aos serviços, aos signos de sociabilidade e bens de consumo, são as formas de apropriação do espaço que estão em jogo, é a compreensão da produção do espaço urbano que permite operar a passagem da marginalidade e da exclusão para o campo da segregação. É nesse sentido que a noção de segregação ganha interesse atualmente para o debate realizado sob uma orientação crítica.

Seguindo a estrutura proposta por esse trabalho, saímos da escala das grandes infraestruturas da cidade, para uma aproximação ao tecido urbano e à sua estrutura fundiária. Consideramos, a seguir, as particularidades da segregação como processo de Medellín e de São Paulo e analisamos seus impactos na produção do espaço a partir do lote, unidade de interação entre a arquitetura e o urbano. Em cada cidade, as estratégias projetuais desenvolvidas pelos arquitetos respondem a esses desafios, se opondo ou reinterpretando os problemas de seus contextos socioespaciais. Cabe avaliar quais as potências e possibilidades de reação às tendências dominantes da produção do espaço urbano que esses projetos puderam mobilizar.

\subsection{Segregação em Medellín}

O problema do conflito armado na Colômbia impactou a vida cotidiana, fazendo com que o medo da violência retirasse a população do convívio público. As fronteiras invisíveis dominadas por gangues em disputa por controle de território recortavam ruas e bairros inteiros, impedindo a livre circulação. Assim, ao fenômeno urbano da desigualdade e segregação socioespacial, vinculadas à pobreza, se sobrepuseram os efeitos de uma cidade sitiada, ameaçada também por paramilitares, narcotraficantes e os representantes das forças armadas oficiais. Esse conflito supera os problemas relacionados ao tráfico de drogas e é indissociável de fatores históricos fundamentais que devem ser destacados, na medida em que representam a base de operação das recentes estratégias do poder público. Essas estratégias investem na reconciliação entre Estado e sociedade civil, e o fazem, em grande parte, por meio da construção massiva de espaços e equipamentos públicos. A dimensão espacial do conflito, assim como da resposta política a esse problema, é uma importante chave interpretativa para a reversão de dívidas sociais, estas compartilhadas pelas duas cidades estudadas.

A exploração colonial é um ponto de origem dos interesses externos ao território, que influem diretamente na ordem interna da Colômbia, exercendo grande pressão sobre a sua conflituosa realidade socioespacial. Mesmo após a independência, a subjugação do país a conveniências exógenas se prolonga, dada sua economia dependente da exportação de bens primários, como a banana, o café e o petróleo. Isso 
ocorre também na sua relação submissa aos EUA, tanto pelos interesses comerciais deste país, quanto pela sua influência em assuntos militares, dada à posição geográfica estratégica colombiana. Todos esses fatores pesaram sobre a histórica e problemática disputa pela hegemonia do poder entre as elites regionais divididas em Liberais e Conservadores. Esse conflito foi o grande catalisador da violência na Colômbia.

Nesse fragmentado e desarticulado território colombiano, se deram ao menos três grandes ciclos de violência. $\mathrm{O}$ primeiro é conhecido como a Guerra dos Mil Dias (1899-1903), que matou 1 a cada 25 Colombianos (HYLTON, 2010, p. 68), e teve origem na disputa partidária que mobilizou e conflitou milícias camponesas. Outro episódio marcante, que não chegou a configurar um ciclo, é o Massacre de Santa Marta. Ele ocorreu em 1928, criando uma cicatriz na memória coletiva do país, pois resultou na morte de 1000 funcionários da empresa norte-americana United Fruit pelo exército colombiano. Esse massacre foi deflagrado, tão somente porque os funcionários fizeram uma greve por melhores condições de trabalho (CARO; ORTEGA, 2012, p. 40).

A polarização de poderes entre liberais e conservadores também causaria o sistemático assassinato de líderes populares dissidentes, ou de políticos que não se alinhassem ao sistema bipartidário ou às orientações políticas dominantes no momento. Isso caracteriza o ciclo chamado de La Violencia (1946-1957), tendo como o mais impactante episódio desse período - e talvez da história da Colômbia - o assassinato de Jorge Eliécer Gaitan. O fato ocorreu em pleno centro da cidade de Bogotá, em 9 de abril de 1948. Como um líder da esquerda liberalista e candidato à presidência, Gaitán teve sua posição e popularidade entendida como um desafio à estabilidade do partido conservador que, àquele momento, estava no poder. A revolta e o desespero popular que decorreram da sua morte resultaram em um episódio que ficou conhecido como "Bogotazo", conforme descreve Moncayo Cruz (2006):

\begin{abstract}
O assassino, Roa Sierra, foi linchado pela multidão ensandecida, fazendo aparecer o rosto do protesto social, o levante contra a fome e a exclusão. Foi impossivel conter os saques a armazéns e lojas. A ira também se voltou contra os símbolos do regime, cujos edifícios foram incendiados. A polícia se sublevou e aderiu ao movimento. Organizou-se uma junta revolucionária, controlaram-se as emissoras de rádio, que passaram a conclamar a formação de juntas similares em todo o país e a requisição de armas. Foi assim que o Bogotaço teve expressão nas duas semanas seguintes em numerosos povoados e bairros, que viram momentaneamente alterada a ordem institucional.
\end{abstract}

Essa resposta feroz da população dá a dimensão da opressão e violência desse período e a sua manifestação no espaço. Ela também originou um movimento radical de formação de guerrilhas liberais-comunistas para derrubar o governo conservador. Tratou-se de uma convocação popular, capitaneada por profissionais e estudantes gaitanistas, que 
começaram a formar essas juntas revolucionárias que se espalharam rapidamente por todo país. Nos anos de La Violência o combate armado político foi propagado em nível nacional e causou a morte de aproximadamente 300 mil pessoas, das quais $80 \%$ eram homens camponeses analfabetos (HYLTON, 2010, p. 72). Os números atestam também que a contratação de milícias para assassinar opositores passou a ser ferramenta para a defesa de interesses imobiliários, alavancando processos de expropriação de terras. Por fim, a solução para equilibrar essa disputa e estancar o que seria entendido como "ameaça comunista" pelo poder oficial, seria a criação da Frente Nacional (1957-1974). Ela consistiu em um acordo para restaurar o sistema bipartidário, estabelecendo a alternância de poder entre Conservadores e Liberais.

Nesse cenário, os representantes da sociedade que não conseguiram se incorporar ao jogo político, tiveram como único meio para o protesto social, a insurgência armada. As Forças Armadas da Colômbia (Farc), Exército de Libertação Nacional (ELN) e outros grupos menores surgem desse contexto. Poucos anos depois, em 1974, a resposta urbana a esse desconserto político, daria origem a outra força insurgente, o movimento M-19. Ele lutou pela abertura do sistema político para a concorrência eleitoral.

Durante todo esse processo, os civis ficaram expostos à violência cruzada entre as forças insurgentes, a repressão contra-insurgente do Estado e os paramilitares recrutados pelos latifundiários (com controversas cooperações entre esses dois últimos atores). E, todas essas relações conflituosas foram, posteriormente, atravessadas e contaminadas pelo caos do narcotráfico: fonte de financiamento do conflito armado ou riqueza rápida para uns, realidade imposta ou alternativa à miséria rural para tantos outros. Desse modo, o narcotráfico ativa e se mistura a uma série de problemas socioeconômicos e políticos que o precedem.

Isso é plenamente observável em Medellín, na década de 1980. Ainda que a cidade apresentasse uma desaceleração da migração, a inclusão social dos bairros pobres não havia apresentado nenhum progresso apreciável, o que resultava em um alto nível de precarização da vida urbana. Nesse mesmo momento, nessa cidade segregada, as fábricas têxteis de Antioquia e suas indústrias de apoio passaram por uma grande crise. As altas taxas de desemprego coincidiram com o crescimento do comércio de drogas e a ascensão do cartel de Medellín, particularmente nas áreas da cidade aonde o Estado não chegava. Destarte, a crise de violência nessa cidade não pode ser atribuída ao tráfico, muito embora ele tenha efeitos secundários de grande impacto. Ele promoveu o surgimento de gangues que passaram a atender grupos do setor privado e de extrema direita. De modo que a escalada do conflito armado, a partir dos anos 1980, tem a ver com o entroncamento entre motivos políticos, sociais e criminais (MELGUIZO; CRONSHAW, 2001, p. 114-115).

Afinal, a conturbada relação entre o Estado colombiano e a violência desafia a identificação dos atores e processos que contribuem, de fato, para uma melhoria nas condições de vida da população. $O$ enfrentamento desse problema passa por questões complexas e 
estruturais relativas à reforma agrária, à representatividade política de setores marginalizados da população, dentre outros processos socioespaciais que se agravam há mais de 50 anos.

A extradição de líderes do narcotráfico e as operações militares que tentam enfraquecer as guerrilhas, são iniciativas apoiadas pelos EUA. Estas últimas vêm adquirindo maior protagonismo e se apresentam como uma polêmica saída encontrada para combater os referidos problemas. Isso porque, novamente, a repressão militar avança sobre grupos insurgentes políticos, se colocando à serviço de interesses parciais e partidários. E os efeitos colaterais dessa violência, também praticada pelo Estado, recaem majoritariamente sobre a sociedade civil, nas suas práticas e espaços cotidianos.

Uma importante frente de ação que se propõe a responder ao problema da violência se dá por meio de negociações com grupos guerrilheiros, bem como de políticas de desmilitarização iniciados nos anos 1990. Eles levariam, posteriormente, à assinatura do acordo de paz realizada em setembro de 2016. No decorrer desses anos, com a desmobilização de alguns dos principais grupos responsáveis pela luta armada, se atestou uma melhoria expressiva nos índices de violência em Medellín. Considerando as taxas de homicídio entre 1985 e 2014, percebe-se que em quase 25 anos a cidade reduziu esses índices em mais de 90\% (DÁVILA, 2016). No entanto, pode-se ver uma delicada e instável situação, que ilustra também a abrangência de demandas para a reconstituição do tecido social e espacial da cidade.

No caso dos ex-paramilitares, que a partir do acordo de pacificação ${ }^{105}$ se tornaram cidadãos plenos, desmobilizados e descriminalizados, grande parte acabou também como um expressivo contingente de desempregados. Muitos procuraram legitimar seu controle anterior, encontrando como alternativa, a prática usual de qualquer líder político ou social à frente de sua comunidade.

Mas a resolução do desequilíbrio, fruto dessa reintegração formal de cidadãos marginalizados pelo conflito armado à sociedade civil, não se resume a esses casos. Nem se restringe à dissolução de um Estado paralelo, do bloqueio da atuação de seus membros e da violência decorrente de sua prática.

O jornalista Javier Sulé sintetiza os conflitos e contradições que surgem quando da reintegração desses cidadãos à sociedade civil, em uma reportagem do jornal espanhol El País de março de 2006 (SULÉ, 2016). Sulé denota uma delicada e ainda instável situação, expressa nos depoimentos da população. São histórias como a do jovem Lucho, de 35 anos, que foi um dos 868 membros do Cacique Nutibara ${ }^{106}$, o principal grupo das Autodefesas Unidas da Colômbia (AUC) em Medellín. Lucho fala sobre a desmilitarização:

\footnotetext{
${ }^{105}$ Processo realizado entre os anos de 2003 e 2006 durante o governo de Álvaro Uribe (20022006). Cf. ROJAS, 2016.

${ }^{106} \mathrm{O}$ Cacique Nutibara foi o primeiro das 31 frentes paramilitares à entregarem suas armas como parte das negociações de paz entre o governo colombiano e as AUC, assinado em julho de 2004 que, à época da publicação da matéria, contava com o número de 28 mil paramilitares desmobilizados, segundo a citada reportagem do jornal El País.
} 
Eu acho que este processo é sério. Esperemos que o Estado cumpra sua promessa continuando a nos dar seguro de saúde, emprego, formação e acompanhamento. Depende do Estado que eu não volte a segurar uma arma. Tenho dois filhos e não os imagino envolvidos com esta história. Precisamos que resolvam já nossa situação jurídica, para podermos permanecer tranquilos.

A fala de Lucho exprime a especificidade do acordo com o Estado, ao demandar condições integrais de cidadania. Mas também a dimensão humana do problema: a exaustão perante o conflito e o desejo de mudança. Seu depoimento ilustra a abrangência dos requisitos para transformar marginalizados em cidadãos com direitos. E, também, para oferecer perspectivas a uma nova geração, para que esta pudesse encontrar caminhos fora do circuito de marginalidade, exclusão e violência.

A sociedade colombiana encontrava-se profundamente cindida, de modo que a construção de uma ordem pública não se daria somente pela desmobilização e o subsequente atendimento aos direitos básicos moradia, emprego, saúde, etc. Era preciso buscar novas formas de sociabilidade e a sua representação espacial na cidade. Para exemplificar a importância dessa dimensão do problema da violência nos espaços e na vida cotidiana, podemos analisar o depoimento de uma moradora do bairro Santo Domingo Savio em Medellín, a Sra. Hermínia de 81 anos, vítima de paramilitares:

Peço a Deus para me dar força para olhar com olhos de perdão aos paramilitares. Eles mataram meu neto Julian, de apenas 17 anos e até recentemente passavam pela minha porta todos os dias.

Desse modo, requeria-se do Estado a construção de uma coesão social, que deveria encontrar meios para intervir na escala espacial e temporal do cotidiano do cidadão. As décadas de crescimento do conflito armado se alimentaram da falta de perspectivas dos jovens que nasceram na pobreza, do isolamento de suas problemáticas em relação à sociedade como um todo, facilitada pela segregação socioespacial que separa e estigmatiza aqueles em condições vulneráveis. Esse distanciamento abafou, até certo ponto, os ruídos dos problemas que se concentravam nessas áreas. Foi somente quando a crise excedeu o limite territorial da periferia e passou a impedir a vida pública de todos os cidadãos - isto é, quando da extrapolação do conflito para a cidade como um todo - que as alternativas começaram a ser construídas coletivamente. E se deram, fundamentalmente, pelo espaço.

Essa parece ser uma posição implicitamente acordada entre a sociedade civil, entidades privadas e o Estado, quando da eleição de Sergio Fajardo e, posteriormente, da disseminação das pautas do Urbanismo Social com o apoio da maior parte da população. Mas esse processo parece ter ultrapassado vontades políticas, tornando-se uma emergência e uma condição fundamental para que a sociedade se movesse em um sentido de transformação.

Os projetos analisados a seguir fazem parte de estratégias de intervenção no espaço urbano mediadas pela $A \& U$ que respondem a esse momento. Essa perspectiva que tem no lote o seu foco, 
complementa as intervenções vinculadas à infraestrutura urbana analisadas no capítulo anterior.

As estratégias projetuais mobilizadas se orientam sob uma diretriz importante de intensificação da vida coletiva e urbana - parte da agenda do Urbanismo Social - mas também como uma reação aos tempos de enclausuramento e proteção que decorriam da violência nas ruas e que demandavam uma nova urbanidade. Felipe Uribe de Bedout $^{107}$, arquiteto autor do Parque de los Pies Descalzos ${ }^{108}$ (1999) e do Parque de los Deseos (2004) ${ }^{109}$, descreve esse momento como uma decisão coletiva - seguida pelos arquitetos- em remover grades e muros. Para tanto, era preciso formular novos espaços abertos que dessem condições para a construção dessa sociabilidade.

\section{Colégio Antonio Derka, 2008}

O Colégio Antonio Derka, projeto do escritório Obranegra Arquitectos, localiza-se no bairro de Santo Domingo Sávio, integrando as intervenções do PUI-nor na ladeira noroeste da cidade. Ele faz parte da estratégia de Sergio Fajardo de vincular a renovação das políticas públicas a grandes e visíveis transformações do espaço urbano, priorizando as áreas mais vulneráveis da cidade.

Nesse sentido, a reforma e construção de novas escolas, bibliotecas, hospitais e espaços públicos foi mobilizada pelo prefeito, visando ativar novas relações de uso e apropriação desses equipamentos, bem como dos espaços públicos que sofreram intervenções em seu entorno. Beneficiando-se do fato de que esses edifícios têm a potência de concentrar usuários, intensificar a vida pública, promover a circulação pelas ruas, algo fundamental para construir novos espaços socialmente ativos. Também, esses projetos que se voltam ao público jovem representam uma aposta de que essa geração possa reinventar a relação entre vida pública e espaço urbano. Essa possibilidade encontrava maiores dificuldades de ser encampada pela geração anterior, que cresceu oprimida pela violência do conflito armado ${ }^{\text {110 }}$.

O projeto desse colégio recebeu essas incumbências, cabendo à arquitetura atender às ancoragens simbólicas e afetivas de renovação, assim como as estratégias de inserção urbana, em um contexto de pósconflito. Desse modo, foi preciso atender aos quesitos de segurança de

\footnotetext{
107 “Quando aparece a violência, a última coisa que se pode fazer é se fechar. Essa é grande lição de Medellín, quando estávamos no pior momento, decidimos nos abrir, remover grades e muros." Depoimento de Felipe Uribe de Bedout em entrevista à Juan Carlos Zapata e Santiago Torrado. (EL PAÍS, 26 de novembro de 2018).

${ }^{108}$ Junto a Ana Elvira Vélez, Giovanna Spera, LAUR Facultad de Arquitectura Universidad Pontificia Bolivariana. Ver ficha do projeto nos anexos.

${ }^{109}$ Junto à equipe de projeto formada por: Gerardo Olave Triana, Jheny Nieto Ropero, Alvaro Criollo López, Manuel Villa Largacha, Andrés Castro Amaya e Néstor Riascos. Ver ficha do projeto nos anexos.

no Esse é um objetivo importante dos programas dedicados à infância e à juventude desenvolvidos por Sergio Fajardo, segundo o arquiteto e urbanista Juan Diego Lopera Perez em entrevista a autora em o4/12/2016. Ele trabalhou na elaboração do Plan de Ordenamiento Territorial (1999), assim como em sua revisão em 2006, atuando por 17 anos nos departamentos de planejamento territorial de Medellín.
} 
um equipamento educacional em um território que ainda apresenta elevados índices de violência, sem fazer isso por meio de restrições ou hesitações diante da proposta de uma nova urbanidade. O lote da intervenção também se encontrava entre dois colégios, demandando ao novo edifício à interação com essas preexistências.

A estratégia projetual adotada investiu na ampliação da atribuição programática e espacial da cobertura do novo edifício incorporado ao conjunto. Ela se apresenta como uma expressiva praça de $3.900 \mathrm{~m}^{2}$. Ao fazer isso, o edifício educacional revela uma nova concepção de interação com o entorno, por meio dessa grande cobertura-mirantepraça de livre acesso. A forma da edificação obedece ao arranjo topográfico, criando uma fluência e dilatação da linha estreita da calçada, típica daquela região, em direção a esse amplo espaço público. O edifício deixa de ser um objeto arquitetônico, tornando-se uma situação arquitetônica-topográfica de proporções expressivas.

Com isso, a nova escola permanece seguramente resguardada sob a grande superfície plana de sua cobertura. A área de lazer adquire potência simbólica e de marco urbano, menos pela sua monumentalidade, e mais por se destacar em uma região tão íngreme e carente de espaços públicos planos e generosos.

A plataforma de chegada às escolas, que resulta da praça, resguarda também os antigos colégios, ainda que forneça privilegiada visão de ambos. Ela é compartilhada livremente com a vizinhança, além de marcar a paisagem em um nível supralocal, se tornando, assim, um ponto de interesse na cidade. É válido notar que se buscou essa expansão das funções da escola para o atendimento ao público externo também pela solução conferida ao auditório. Ele é destacado do corpo da edificação principal, se tornando um elemento independente que paira acima da praça, sem bloquear a passagem sob seu volume. Desse modo, tem o acesso separado ao da escola, uma estratégia importante, pois viabiliza o uso deste pela comunidade, evitando interações de difícil controle com os alunos.

\section{Lardínes Infantiles, 2009-2011}

Os quatro jardins de infância (Jardines Infantiles) apresentados a seguir, exprimem experiências tipológicas que experimentam soluções para estruturas fundiárias e relevos complexos. Ao mesmo tempo, esses projetos refletem sobre inserção e proteção das crianças em relação ao meio urbano.

Foram processos gradativos realizados por dois escritórios que, primeiramente, participaram de um concurso de arquitetura promovido pela Prefeitura de Medellín e, depois, foram diretamente contratados por ela. O concurso uniu os escritórios para o projeto de duas unidades, o que se desdobrou em duas outras experiências individuais de ambos, experimentando princípios similares sob ênfases distintas. $\mathrm{O}$ aprendizado resultante dessas implantações se tornou uma estratégia projetual incorporada pela equipe de arquitetos da EDU, que desenvolveu uma versão simplificada para a realização de outros 
numerosos projetos similares. Mesmo com algumas concessões da flexibilidade em relação ao esquema de projeto original, assim como algumas perdas de qualidade material, eles demonstram a importância da experiência anterior. Isso porque ela foi capaz de amplificar as atribuições de uma intervenção pontual, produzindo um sistema generativo de projeto, apropriado ao poder público.

Visto que ele necessita de agilidade e adaptabilidade para a expansão da rede de equipamentos. Essa ferramenta do partido projetual pareceu resistir, preservando suas qualidades de mediação entre programa, lote e cidade, até mesmo quanto do enfrentamento das mais duras contingências que lhe foram impostas, exemplificadas na instrumentalização e simplificação realizada pela EDU.

Um traço comum que perpassa esses projetos é o fato de que trabalham com células que produzem um "organismo arquitetônico", criando volumes que, ao mesmo tempo em que abrigam as funções, produzem contornos e superfícies de contato para qualificar o perímetro externo e interno. Assim, conformam a edificação e protegem as crianças, realizando a transição entre o mundo externo e o interno. Mas eles o fazem tomando o cuidado em não isolar os pequenos usuários da realidade do entorno. Janelas se abrem diretamente para fora, e os esquemas de fechamento do conjunto nunca bloqueiam as perspectivas visuais.

Imediatamente à frente da estação de metrocable La Aurora, encontra-se o Jardín Infantil de Pajarito, ao pé do conjunto de edifícios de habitação de interesse social produzidos pela municipalidade ${ }^{\text {III. }}$. Entre a grande massa edificada e a circulação intensa na rua provocada pelos usuários do metrocable, está o pequeno e adaptável volume arquitetônico de autoria da equipe formada pelos escritórios Plan:b Arquitectos e Ctrl+G. Essa equipe implantou o mesmo sistema projetual também no bairro de San Antonio Prado. Em ambos os casos, o jardim de infância pretende se integrar à paisagem, seja ela uma densa massa de edifícios ou vastas áreas livres (como é o caso da segunda unidade). Isso é buscado por meio do pequeno porte das células edificadas que contornam o pátio ajardinado central. Elas se associam e se adaptam a topografia e à geometria dos terrenos. Segundo seus autores, as formas resultantes derivam do estudo do diagrama de Voronoi $^{112}$ que, na matemática, pressupõe um tipo de decomposição do espaço por uma família de polígonos convexos que são como subconjuntos que integram o mesmo.

Assim, essas associações geométricas complementares modulam não somente os volumes edificados, como também as áreas livres derivadas de interstícios entre os blocos. Todos eles se articulam em torno de um pátio central que resulta da associação do conjunto de células que também é arrematado uma marquise, que protege as circulações. Os leves gradis, projetados estrategicamente, costuram o conjunto. Este é

${ }^{m}$ O Plan Parcial Pajarito é um macroprojeto de habitação de interesse social (Decreto 602 de 2002) também conhecido como Nuevo Occidente, que abriga cerca de 40 mil habitantes. Cf. Echevarría Ramirez et al., 2016.

${ }^{112}$ Cf. MESA; RESTREPO; BETANCUR, 2010. 
um recurso desenhado de modo cuidadoso para compor uma restrição de acesso, sem se apresentar como aparato de defesa, dada sua altura e porte de pouca expressividade. Esses leves tubos verticais se integram a linguagem dos detalhes da edificação, como os pilares metálicos que suportam a cobertura perimetral. São recursos de desenho que parecem atenuar a dimensão de uma reação à violência. Diferentemente de um ostensivo cercamento ou dispositivos mais drásticos de segurança como muros altos e empenas cegas.

A unidade mínima de projeto - a célula ou pétala - possui as condições para que possa ser repetida, girada ou multiplicada quantas vezes forem necessárias, de forma programática ou em função das demandas do terreno, em configurações fechadas ou abertas. Essas peças contém o programa coberto: salas para crianças, salas para professores, salas para a comunidade, cozinha e refeitório. Já o exterior do jardim foi também projetado como unidades intercambiáveis: floreiras, brinquedos, pequenos volumes topográficos para brincadeiras, superfícies com piso de borracha, ou esconderijos.

Já o projeto para o Jardín Infantil de Santo Domingo Sávio foi projetado somente pelo escritório Plan:b. Os recursos de um projeto modular também são utilizados para articular e qualificar os espaços internos e externos do conjunto arquitetônico. Mas essa estratégia projetual é mobilizada, nesse caso, para enfrentar um terreno mais complexo, extremamente recortado e íngreme, com $22 \%$ de inclinação. Assim, as peças flexíveis que configuram esse jardim de infância o fazem como uma serpentina que sobe três níveis, de modo que os tetos do conjunto edificado são também acessados por rampas que se integram ao jogo de geometrias recortadas e associativas. O modo como se integra a estrutura fundiária das áreas de assentamento precário é notável. Sua geometria condiciona e molda a edificação ao mesmo tempo em que qualifica escadarias, calçadas e acessos ao redor de sua implantação.

O projeto para o Jardín Infantil de Carpinelo foi projetado somente pelo escritório $\mathrm{Ctrl}+\mathrm{G}$. Também enfrenta um terreno íngreme com 30\% de inclinação em um bairro que faz divisa com a área rural, de modo que a urbanização do entorno é menos densa do que a de Santo Domingo. Então, ainda que se utilize dois pavimentos em algumas das unidades célula edificadas e uma rampa-ponte para fazer a conexão entre os blocos, o conjunto todo tem um lote de maior dimensão para estabelecer relações entre internalidades e externalidades. Nesse projeto também se utilizam blocos de concreto e elementos vazados que estabelecem uma relação material com as casas populares do entorno.

$\mathrm{Na}$ versão simplificada da EDU para os Jardins Infantis Buen Comienzo, as cores institucionais impostas a todo o volume, assim como as telhas e rufos que se sobrepõem aos perímetros da cobertura, anulam a leitura da célula-pétala do jardim original, em que a geometria as unidades do conjunto mantinham sua leitura individual clara. As variações das formas são agora determinadas por cumeeiras e as caídas da cobertura em telha metálica. O conjunto arquitetônico se torna mais esquemático, perde marquises e elementos intermediários 
entre os cheios dos ambientes encerrados pela alvenaria e o vazio do pátio criado pelas edificações. Mas isso não impede que a adaptabilidade topográfica e o esquema de qualificação mútua entre espaços internos e externos não siga produzindo cuidadosas experiências de relação com o entorno.

\section{Parques Biblioteca, 2007-2011}

Os 9 parques bibliotecas (PB) em funcionamento desempenham dupla função. Como equipamentos culturais, eles visam ressignificar as localidades onde estão inseridos em relação à cidade. Desse modo, pretendem alguma monumentalidade ou retórica projetual que atenda a essa configuração de marco referencial na paisagem urbana. Mas, também, dentro de um contexto atento à vulnerabilidade social das localidades em que os PB se inserem, se colocam como um equipamento local. Para tanto também deviam construir relações formais e programáticas mais tênues, para atuarem como centros comunitários, com espaços convidativos à apropriação e ao vínculo cotidiano.

As experiências projetuais, proporcionadas pelos diferentes arquitetos que participaram dos concursos para os 6 primeiros $\mathrm{PB}^{\mathrm{13}}$, utilizam de estratégias de interpretação do programa e sua relação com o urbano de forma muito variada: desde a formulação de blocos funcionais, como de outras unidades arquitetônicas que reinterpretam ao mesmo tempo o programa e o objeto construído em relação à topografia, ao gabarito do entorno, a contrastes com a paisagem, dentre outras estratégias. A dimensão urbana da intervenção arquitetônica se busca por esses recursos, como também pelo tamanho expressivo dos lotes. Haja visto que são parques bibliotecas.

Esses projetos podem ser lidos como centros culturais articulados a grandes parques, funcionando também como espaços de apoio para educação. Isso porque contam com instalações para acesso gratuito de Internet, galeria de exposições, sala de jogos, sala "meu bairro" com informações locais, espaços para apresentação, auditórios e em alguns casos se integram a cafés, lojas e papelarias. À primeira vista, não haveria maior novidade em relação às funcionalidades oferecidas pelos típicos espaços culturais das grandes cidades. No entanto, esses espaços acumulam mais atribuições, pois espera-se que tenham uma área de influência de 70 bairros e que atuem como centralidades cívicas, incorporando programas de desenvolvimento econômico e social local. Todos esses projetos incluem, por exemplo, programas como o Centro de Desenvolvimento de Negócios (CEDEZO) que oferece aconselhamento financeiro e empréstimos (microcrédito) à comunidade. Assim, os projetos precisam dar conta de ativar conteúdos representativos para muitos bairros desprovidos de espaços

\footnotetext{
${ }^{113}$ Dos 9 parques biblioteca, os seis primeiros foram projetados por meio de concursos de arquitetura. Já os 3 últimos são projetos da EDU. A saber: San Javier (2006); España (2007); La Quintana (2007); La Ladera (2007); Belén (2008); Fernando Botero (2009); José.Betancur (2011); Guayabal (2012); Doce de Octubre (2013).
} 
emblemáticos e identitários - na expectativa de se tornarem marcos arquitetônicos - ao mesmo tempo em que manejam certas particularidades de problemas prosaicos como o de uma agência bancária. A seguir são comentadas as características da implantação e da relação com o lugar de alguns dos principais Parques Bibliotecas.

O Parque Biblioteca San Javier (2005: Javier Vera) adequa o programa da biblioteca a um partido escalonado, adaptando-o ao terreno em aclive, distribuindo suas funções setorizadas em patamares que qualificam os espaços internos e externos. Com isso, surgem diferentes acessos para as variadas e independentes funções do conjunto arquitetônico: a galeria, a biblioteca e a ludoteca podem ser acessadas diretamente pela porta que abre para os patamares da praça. Essa área é, além da parte externa da biblioteca, uma ligação que se dá desde a estação de metrocable San Javier, passando por uma quadra poliesportiva, por um CEDEZO, pela Biblioteca e subindo em direção ao bairro. A abordagem projetual torna as transições entre o lote de implantação, a praça constituída no entorno da edificação e as calçadas que acessam o conjunto arquitetônico, um percurso contínuo.

O Parque Biblioteca España (2007: Giancarlo Mazzanti) se tornou um dos maiores símbolos de Medellín, pelos seus impactos positivos, bem como pelos seus problemas. O primeiro parque biblioteca da cidade possuía três torres negras, que se assemelhavam a imensas rochas de grande visibilidade. Cada uma abrigava, respectivamente, a biblioteca, o centro comunitário e o centro cultural, em volumes de alturas e formas diferentes, assim como seu funcionamento independente. A superfície escura e as poucas aberturas para o ambiente externo foram justificadas por Mazzanti ${ }^{114}$ como uma contextualização à paisagem. Internamente, esses objetos fechados propiciariam um necessário e calmo refúgio para seus usuários, seja de sua realidade da pobreza como também da paisagem urbana convulsionada que se faz onipresente em Santo Domingo.

Esse projeto fez parte do complexo de intervenções do PUI-nor, no trecho que conecta a estação de metrocable de Santo Domingo à biblioteca. O percurso inclui um CEDEZO, os melhoramentos do Colegio Candelaria, a praça contígua à biblioteca e o playground. Esses espaços são conectados por calçadas e mirantes que são qualificados pela mesma linguagem de pavimentação e mobiliário urbano vistos nas demais áreas de intervenção e na "cidade formal”.

Essas qualificações em torno do viário existente e de seus espaços residuais, transformando-os em lugares públicos, promoveram a continuidade entre o tecido existente e a plataforma-mirante de

\footnotetext{
${ }^{114}$ Em entrevista a Miguel Mesa. (MESA; RESTREPO, 2009, p. 148).
} 
implantação das três "rochas" do parque biblioteca. Esta última era a parte edificada que fazia a conexão entre os diferentes níveis de acesso do entorno em aclive. Nesse $\mathrm{PB}$, o parque é a área que resulta da interligação desses espaços urbanos pré-existentes.

A experiência da visita ao PB España, em 2012, apresentou um equipamento massivamente frequentado, com diversos espaços públicos ativados simultaneamente pelo fluxo de visitantes externos e usuários locais.

O projeto foi encontrado, na segunda visita em 2016, com todos os painéis da fachada em manutenção e a biblioteca totalmente interditada. $\mathrm{O}$ revestimento apresentou patologias vinculadas à fixação e à própria estrutura. $\mathrm{O}$ alto custo para reparos e os mais de 3 anos de obras despertaram grandes críticas à arquitetura de Giancarlo Mazzanti e à capacidade de gestão e manutenção da Alcaldía de Medellín ${ }^{115}$.

O Parque Biblioteca Leon de Greiff (2007: Giancarlo Mazzanti) também chamado de La Ladera, apresenta a implantação de um conjunto de três blocos edificados, interligados por uma galeria posterior, visto que estão cravados no ponto mais alto de um morro. Assim como na BP España, o conjunto arquitetônico torna-se legível pela presença de seus três volumes independentes - assentados sobre a ladeira - e a plataforma posterior de interligação que tenta mediar os diferentes níveis de acesso ao entorno. Essa conexão resulta em uma discreta galeria posterior, com trechos a céu aberto, acessando também um conjunto de salas com computadores públicos (um quarto elemento oculto acomodado no recorte da topografia).

Todas essas áreas foram previstas para funcionar de modo independente. Na cota mais alta de acesso, as coberturas parciais da galeria servem de elemento de ligação às três coberturas. Assim, compõem um conjunto de mirantes que convergem para o verticalizado centro da cidade.

Os três volumes se voltam, ao mesmo tempo, para o centro de uma grande área verde com uma quadra, bancos e equipamentos de lazer. De modo que a maior parte dos ambientes do conjunto: bibliotecas, auditório, salas de atividade, possuem grandes panos de vidro para a plena visualização desse espaço público.

O organismo formado pelos três volumes unidos pela galeria, atua como um elemento qualificador de uma vasta área pública. Ainda que guarde certa independência formal, frente ao grande plano inclinado do terreno, o conjunto encontra-se integrado ao seu entorno. Isso se dá por trechos pavimentados que ligam o equipamento, ao complexo esportivo posterior e às calçadas e ruas que chegam ao perímetro do parque. Não há nenhuma grade ou cerca que defina os limites de acesso e de horário de funcionamento. O fechamento do edifício se dá por

\footnotetext{
${ }^{115}$ A Sociedade Colombiana de Arquitetos, em nota divulgada em seu site, defende o escritório, afirmando que um laudo da Universidade Nacional da Colômbia constatou que a obra não corresponde ao projeto de arquitetura e, também, que o escritório de Mazzanti não possuía a atribuição de responder às decisões relativas à construção.
} 
duas portas no organismo arquitetônico: uma no início da galeria e outro ao fim.

O conjunto substitui o que foi, até a década de 1970, um complexo penitenciário incorporando o valor simbólico de transformação de um espaço prisional (em ruínas) em um grande equipamento público totalmente aberto.

A Biblioteca Belén (2008: Hiroshi Naito) localiza-se em um bairro residencial em uma porção plana da cidade, na região oeste da cidade. A implantação dessa biblioteca se dá de maneira sensível ao gabarito do seu entorno. Seus blocos funcionais são marcados pela concisão e se assemelham formalmente a um casario vernacular. Esses blocos edificados articulam-se no entorno de um grande espelho d'água quadrado, formando uma circulação perimetral protegida por uma cobertura simples com estrutura de madeira e telhas cerâmicas, que conecta os blocos.

$\mathrm{O}$ acesso se dá por duas praças opostas que se ligam às ruas paralelas que determinam os limites da quadra. O piso cerâmico claro estende a pavimentação do entorno das edificações, dissolvendo-se entre os espaços verdes, canteiros, escadas, tornando-se calçamento e encontrando, nas duas extremidades, as ruas. Esse percurso sinuoso, de cruzamento da quadra, passando pelo pátio da biblioteca e contornando a água, torna-se o principal elemento sensível da experiência de seus espaços. A ludoteca, um dos austeros blocos funcionais do conjunto do Parque Biblioteca Belén, apropria-se dessa fluidez dos espaços. Não existem muros, gradis ou qualquer barreira que separe a área externa, utilizada pelas crianças, da praça pública. Os próprios blocos que compõem o conjunto arquitetônico e seus interstícios criam diferentes formas e possibilidades para a apropriação das áreas públicas. Quando do fechamento da biblioteca são acionados discretos portões que interrompem as passagens intersticiais.

O Parque Biblioteca Tomás Carrasquilla, La Quintana (2007: Ricardo La Rotta) é um edifício em dois blocos de concreto que são atravessados por um conjunto de esplanadas escalonadas que acompanham um grande parque linear ao longo da quebrada de mesmo nome. Conectam duas ruas, tendo praças em suas duas extremidades, sendo que a da cota mais baixa conduz a uma área esportiva e ao grande parque. Os níveis que configuram o caminho até o acesso ao edifício se confundem, tanto em material quanto em proporção e transição dos terraços que já fazem parte da própria edificação. $\mathrm{O}$ conjunto todo - patamares de travessia do terreno e terraços dos blocos da biblioteca - são arrematados por uma grande cobertura metálica com pérgulas em madeira maciça. A pavimentação em tijolo maciço recobre as áreas externas e internas e, com sua cor marcante, desenham planos contínuos que se alternam entre o verde do entorno e o concreto dos 
volumes principais. Essa nova paisagem construída nos lembra o trabalho de Rogelio Salmona, com quem o arquiteto Ricardo da Rota colaborou em seus primeiros anos profissionais.

O Parque Biblioteca Fernando Botero (2012: Orlando Garcia) difere dos demais pelo tratamento dado ao terreno e a resposta arquitetônica. A edificação se resume a um grande volume único negro e, o terreno, a um lote retangular bem definido. Essa biblioteca se insere em um povoado antigo de baixa renda, de origem rural. O revestimento em pedra negra fosca, as aberturas retangulares variadas, o tornam um pano de fundo do casario de cerâmica vermelha. Novamente, não há grades e o perímetro do lote é gradativamente fundido às calçadas do entorno, ainda que o volume prismático crie linhas e circulações bem definidas pela influência de sua própria geometria e escala.

O Parque Biblioteca Jose Horacio Betancur (2011: EDU) articula um complexo de edificações que se assemelham a um conjunto de casas formado por quatro volumes. Foi projetado pela EDU seguindo a linguagem e organização espacial similar à da Biblioteca de Belén. As duas maiores edificações abrigam, respectivamente, a biblioteca e um centro educativo que possui uma galeria de arte e salas de aula para atividades culturais e esportivas.

O terreno acidentado demandou uma ponte interligando a cota de acesso do teatro (um volume negro assemelhado a PB España) à praça que se conecta às outras duas edificações referidas anteriormente.

Os volumes-casa possuem grandes vãos possibilitados pelas vigas em madeira laminada, seguindo - porém simplificando - os conceitos aplicados por Hiroshi Naito no PB Belén. A biblioteca fica em frente à UVA El Paraíso. Nessa região de transição entre o rural e o urbano, esses dois grandes complexos de equipamentos concentram serviços à comunidade. Mas o fazem de modo independente e integrado à estrutura fundiária existente transformando espaços residuais em áreas públicas qualificadas no entorno desses equipamentos.

\section{Centro Cultural Moravia, 2004-2007}

O Centro Cultural Moravia, de Rogelio Salmona, é aqui destacado pela situação urbana que enfrenta. Ele foi construído na região de um antigo depósito de lixo na área central em direção à região nordeste da cidade. O bairro de Moravia foi ocupado irregularmente por uma população de baixa renda que, entre os anos de 1977 e 1984, consolidou o assentamento precário, ao mesmo tempo em que iniciou a deposição de resíduos no que se tornou uma montanha de 35 metros de altura com 1,5 milhões de toneladas de lixo. 
Para requalificar o local e resolver o problema ambiental, a recuperação da região de Moravia envolveu a EDU, a Universidade de Antioquia, a Universidade Politécnica de Catalunya, em diversos estudos técnicos para converter a montanha em um experimento com plantas que contribuem para a biodigestão desses resíduos. Elas também conferem, mesmo tempo, tratamento paisagístico ao morro, que foi qualificado como um espaço esportivo ganhando uma quadra poliesportiva áreas de lazer. O processo de realocação da população nas imediações, em projetos de habitação de interesse social, se iniciou ainda em 1983. Em 2004 também se inaugurou um centro cultural vizinho a essa montanha, com projeto de Rogelio Salmona.

Esse projeto se vale de sua materialidade - sustentada pelo típico uso de ladrillos da tradição colombiana - como recurso para pavimentar, recobrir a área da praça que conecta o objeto arquitetônico à sua superfície de contato. A permeabilidade visual do volume também atenua a dimensão objetual da forma, o que deixa sua leitura em muito vinculada ao pano de fundo do casario que constantemente se avista, de todos os ângulos em que se contempla a edificação. O Centro Cultural incorpora um CEDEZO e faz parte de um PUI. Ao fundo, construiu-se posteriormente um jardín infantil pela EDU que, como o resto do conjunto, também não apresenta divisão de lotes ou gradis. Esses dois equipamentos e a praça se mesclam entre atalhos, caminhos, praças contemplativas e os limites de um córrego que arremata o conjunto.

\section{MIB Quebrada Juan Bobo, 2007-2011}

A consolidação habitacional Juan Bobo interveio em uma área de $6.935 \mathrm{~m}^{2}$ onde se localizavam 205 casas com 396 famílias em um total de 1273 habitantes. Essas casas foram construídas em palafitas no entorno de uma quebrada. Por meio do programa de Melhoramento Integral de Barrios, foi realizado um projeto piloto para remover a população das áreas de risco e reurbanizar essa região. As principais diretrizes resultantes dessa experiência foram aplicadas em La Herrera, uma quebrada a poucos metros da primeira área de intervenção.

É importante ressaltar que estes projetos estão dentro da área do PUInor e desfrutam da mobilidade que esta estratégia proporcionou. A escala da leitura do território permanece tangível ao longo da área do PUI, na medida em que a distância entre os projetos parece não exceder a capacidade cognitiva de reconhecê-los como parte de uma mesma vizinhança. Para visitarmos Juan Bobo utilizamos a linha $\mathrm{K}$ de metrocable, que sai da estação Acevedo do metrô (localizada no eixo do rio). Paramos a 1/3 da subida da encosta, cuja última estação da linha (a 8 minutos dessa parada) é de Santo Domingo Sávio. Por meio desta última, poderíamos acessar a BP España e o Colégio Antonio Derka. Mas, ao pararmos na estação Andalucía, tomamos contato com a calle 107. Ela é o eixo onde os pilares do metrocable tocam o chão. Dela, também irradiam as obras e conexões do PUI. Essa rua marca um grande eixo na encosta, que se destaca pelas suas grandes calçadas e 
pela vivacidade de seu comércio. Duas quadras abaixo e à direita, atravessamos uma ponte e estamos nos edifícios de La Herrera. Ou, se descermos 5 quadras e dobrarmos à esquerda, chegamos a Juan Bobo. A estação Andalucía está, afinal, a 15 minutos a pé da estação Acevedo. Uma descida expressiva de 130 metros de desnível, mas que representa tão somente 15 minutos de caminhada por ruas. Percurso facilitado quando estas foram devidamente qualificadas.

Prosseguindo para Juan Bobo, nesse projeto foram construídos 120 apartamentos novos para abrigar as pessoas removidas das áreas de risco imediatamente à beira da quebrada. Foram também realizados 116 melhoramentos de casas e 236 residências foram legalizadas. Em La Herrera se construíram 126 apartamentos e se realizaram 85 melhoramentos das casas, com os mesmos critérios utilizados no projeto piloto (LOPERA PÉREZ; AVENDAÑO GONZÁLEZ, 2017, p. 110).

Segundo Carlos Montoya ${ }^{116}$, arquiteto coordenador desse projeto, os assentamentos precários colocam em perspectiva as diferenças entre expansão, renovação e melhoramento urbano. Os dois primeiros são aplicáveis à cidade formal e o último aos assentamentos precários. O arquiteto destaca que a mediação entre o território, a população e as entidades é muito mais dinâmico nos casos da cidade formal. Isso porque se pode recorrer a certos níveis de abstração da realidade, visto que os entes envolvidos são regulados por leis, categorias e procedimentos padronizados e mais estáveis. Nesses casos, falamos da prefeitura, agentes imobiliários ou proprietários de lotes, clientes em potencial ou beneficiários previamente definidos. Já no melhoramento de bairros, as complexidades da cidade informal reverberam em todas as relações: regulamentares, institucionais, projetuais, negociais. Da concepção à implementação do projeto, todos os processos são repletos de excepcionalidades que perpassam a questão fundiária, ambiental e os acordos para remoção e realocação. Os procedimentos e análises devem ser realizados lote a lote, junto aos moradores. Isso demanda extrema capacidade interpretativa de todo o corpo técnico envolvido incluindo os arquitetos - assim como a participação direta da comunidade atingida pela intervenção.

Esse dado é relevante na medida em que ilumina nossa percepção sobre resultado construído. Este, reflete essa complexidade e integração que se buscou junto a dinâmica da cidade informal. Com exceção dos edifícios de habitação de interesse social implantados nas cotas mais altas do morro, toda a intervenção de consolidação se confunde com algo que, simplesmente, “já poderia estar lá”. No entanto, a melhoria das unidades habitacionais, a pavimentação e a requalificação de calçadas e espaços residuais, subentendidos como qualidades urbanas básicas, tiveram de ser cuidadosamente consolidadas e readequadas. $\mathrm{O}$ que exigiu procedimentos projetuais intensos realizados in loco. Isso porque só foram construídos edifícios novos para substituir as residências em situação de risco.

\footnotetext{
${ }^{116}$ Carlos iniciou seus trabalhos na prefeitura com projetos habitacionais no bairro de Moravia em 1983. Ele acompanhou toda a atuação do PRIMED na cidade e permaneceu dedicando-se a projetos de habitação junto à EDU, desde que esta assumiu essa frente de ação. Ele foi entrevistado pela autora em janeiro de 2019.
} 
As demais edificações receberam verbas e auxílio técnico para serem reformadas internamente e externamente, garantindo condições de habitabilidade e materialidade compatíveis com uma moradia digna. A melhoria das vias, a canalização do córrego e sua qualificação como parque linear, somados a instalação de mobiliário urbano, criaram áreas qualificadas com pavimentação, guarda-corpos e pequenas intervenções para transposição dos níveis, estabilização do solo e viabilização da drenagem. De modo que, depois dessas intervenções, deixaram de ser áreas residuais, passando a se integrar o tecido projetado da cidade.

A inexistência de recuos, que é típica da ocupação irregular, foi propositalmente mediada por instrumentos de projeto, segundo Carlos. $\mathrm{O}$ casario recebeu intervenções e reformas para criar uma extensa "frente de urbanidade" com suas fachadas organizadas em um alinhamento comum, escadas foram construídas para viabilizar acessos e vencer desníveis.

Assim, o principal atributo desse projeto foi diluir os limites entre o espaço privativo e o público, anulando a percepção dos lotes, integrando o dentro e o fora das casas, como é típico da apropriação dos espaços intersticiais dos assentamentos precários. Os edifícios de La Herrera e de Juan Bobo repetem majoritariamente a mesma tipologia de unidade habitacional, com $5 \mathrm{om}^{2}$ e dois dormitórios. A associação das unidades, nos blocos habitacionais, resulta em edifícioslâmina estreitos, com circulações horizontais avarandadas. Elas permitem o múltiplo engate desses planos elevados a outras cotas de nível do arruamento, visto que os edifícios se encontram em terrenos de acentuada declividade. Essas conexões são realizadas frequentemente, e se tornam vetores que acessam às dilatações dos espaços residuais para criação de pequenos mirantes, playgrounds e áreas de lazer. Esses microprojetos desenvolvidos pela EDU pontuam expressivas partes do território informal da cidade.

As áreas de implantação dos edifícios estão cravadas nesse jogo entre arruamento e espaços residuais qualificados. Essas particularidades são, de fato, comuns a urbanizações de favelas, sendo determinadas pelas poucas oportunidades de se encontrar superfície estável para uma edificação de maior porte. Mas as decisões projetuais foram responsáveis pelo modo como se conectam por todos os lados ao imbricado tecido de vielas, prescindindo de portaria e de entrada principal, dados os seus múltiplos acessos e conexões. As unidades no térreo foram destinadas ao comércio e são intensamente utilizadas. Os blocos cerâmicos vermelhos dos edifícios verticais e os elementos estruturais de concreto se confundem à paisagem dos assentamentos, tomada pelo mesmo material, ainda que construídas por técnicas precárias. Seja pela mobilidade ou pelos atributos dos projetos arquitetônicos, a estratégia empregada parece buscar, todo o tempo, a diluição dos limites: visuais, territoriais e materiais entre a cidade informal e a formal. 
O Parque lineal ciudad del rio (2009: Giovanna Spera e Juan Esteban Arteaga) consiste em uma grande área pública construída junto a novos empreendimentos imobiliários privados. Ele faz parte de um plano parcial previsto pelo POT de 2006, chamado Plan Parcial Simesa, que foi desenvolvido para a renovação da área de uma antiga usina siderúrgica (Valores Simesa) e de outras pequenas fábricas. O plano prevê a conversão dessa área em um novo tecido urbano que abrigaria um complexo residencial de alto padrão. A construção do parque público fazia parte das exigências do Plano Parcial e foram requisitadas e regulamentadas pelo Departamento Administrativo de Planejamento da Prefeitura de Medellín (DAP), prevendo que ele fosse totalmente autofinanciado pelo empreendimento.

Da área de aproximadamente 30 hectares, a indústria original ainda possui $46 \%$ do terreno, outras três possuem $49 \%$ e os $5 \%$ restantes estão distribuídos em 18 empresas, cada uma com menos de $1.250 \mathrm{~m}^{2}$. Essa área foi redesenhada para acomodar 37 edifícios em 13 lotes, reservando $37 \%$ do terreno para parques, áreas verdes e ruas. No espaço restante, foi aplicada uma taxa de ocupação de $80 \%$ em cada lote, para ser destinado a usos residenciais e comerciais. A soma total dos custos de urbanização na área correspondeu a $23 \%$ do valor total e foi totalmente financiado ou recuperado com o rendimento das vendas dos edifícios, ao mesmo tempo em que o valor do terreno aumentou $19 \%$ (SMOLKA, 2014, p. 57-58).

Esse complexo processo foi viabilizado por ferramentas de projeto e planejamento urbano, bem como por instrumentos de financiamento de intervenções urbanas. Também representou um processo de projeto que implicou a negociação e acordo entre as autoridades locais, a equipe de projeto e o grupo investidor. Isso porque o empreendimento reconfiguraria uma área significativa da cidade. Sendo assim, devia atender aos interesses dos proponentes do projeto (grupo privado), ao mesmo tempo em que obedecia aos padrões de urbanização e taxas de produção público regulamentadas pela prefeitura ${ }^{117}$.

O parque resultou num espaço de uso intenso por pessoas de diferentes partes da cidade. Isso porque a ele se articulou o Museu de Arte Moderna, que é facilmente acessado pelas estações de metrô Poblado ou Industriales. A grande atração do parque são os simples ambientes moldados por movimentos de terra e mobiliário urbano, além a pista de skate. $\mathrm{O}$ espaço não possui qualquer tipo de vigilância fixa ou controle de acesso.

A estratégia projetual do museu também favoreceu a integração entre o parque e as áreas do entorno. O projeto do escritório Ctrl+G (20092015) faz do pavimento térreo do museu uma galeria permanentemente aberta. Isso se dá pela composição de volumes que abrigam as unidades autônomas de duas lojas, do café e do hall de entrada do museu. Somando-se a esses espaços está um grande volume que integra um

\footnotetext{
${ }^{117}$ Para maiores informações sobre o processo ver dissertação de mestrado de Giovanna Spera (2018).
} 
palco para eventos e uma escadaria pública que se volta ao parque. Esse último também abriga, na sua parte posterior, banheiros públicos de livre acesso. Esses espaços ficam no e sob o museu, visto que as áreas expositivas do edifício são arranjados em "volumes-caixas" que cobrem esse conjunto de volumes do térreo. Nas suas coberturas, as caixas expositivas também ofertam terraços panorâmicos que podem ser acessados independentemente do museu. Isso é viabilizado por meio de escadas que contornam os volumes e chegam diretamente do nível da rua ao terraço.

Essa opção projetual, ao "empilhar caixas", revela-se mais do que uma escolha formal subjetiva, uma estratégia interessada em separar as partes privadas do museu, daquelas que poderiam ser acessadas publicamente e sem ingresso. A fluidez dos percursos e a autonomia dos acessos também demonstram intenções de maximizar as conexões entre o conjunto arquitetônico e o tecido urbano. Do parque ao museu vemos conexões e continuidades desenhadas para a promoção do uso coletivo dos espaços. Estas são buscadas em articulações projetuais que mediam as atribuições do espaço público e as demandas dos diferentes agentes envolvidos, privados e públicos.

\title{
$\underline{U V A s, 2015-2018}$
}

As UVAs são retomadas porque representam a contundente remoção de cercas e muros. A reversão da percepção de restrição, proibição ou contenção, é o principal argumento projetual explorado nesses projetos. Elas realizam, assim, a incorporação simbólica dos espaços dominados pelo aparato infraestrutural e abstrato do poder público, reintegrando-os ao território como áreas livres como descreve Valencia (2016):

\begin{abstract}
Os tanques de água foram abertos, as cercas foram removidas e seu entorno redesenhado para dar à infraestrutura um novo espaço público, criando novas conexões entre a comunidade, antes separada pelas barreiras da infraestrutura dos reservatórios. Os muros e fechamentos foram derrubados para criar um espaço para a igualdade, que agora vem substituindo a divisão e exclusão através do projeto.
\end{abstract}

Esse também foi um ato de grande confiança do poder público em relação à população, visto que tanques abertos como da UVA La Armonía, que são suscetíveis a contaminação e a acidentes de grande impacto para a população, foram, ainda assim, totalmente abertos à população.

A busca por continuidades de fluxos, a integração visual, fazem da linguagem arquitetônica das UVAs um diálogo formal ancorado em algumas estratégias projetuais que conectam os diferentes projetos. Segundo Carlos Pardo ${ }^{\text {118 }}$, arquiteto que foi contratado pela EPM para atuar junto ao DIUs e a Horácio Valência na ideação das estratégias das UVAs tanque, o desenho deriva da observação dos elementos simples já presentes na infraestrutura de abastecimento de água: muros de

${ }^{118}$ Em entrevista a autora em fevereiro de 2019. 
contenção, grelhas drenantes feitas de materiais duráveis como concreto e aço.

Em todas as UVAs as edificações construídas parecem estar subjugadas à constituição prioritária de praças, pontes, passagens e toda forma de conexões com o tecido do entorno, majoritariamente de assentamentos precários. A dimensão objetual do edifício se perde. As salas e dependências técnicas, enquanto formas construídas, colocam suas coberturas à serviço da criação de superfícies planas, ou se neutralizam quando recostadas a arrimos. Nesse sentido, percebe-se que todas as ferramentas projetuais são utilizadas no sentido de promover continuidades com o tecido urbano, qualificando-o, justamente onde antes haviam muros, aparatos de defesa contra invasão, justamente em áreas carentes de espaços públicos. As estratégias de arquitetura, nesses projetos, incorporam e se confundem aos argumentos projetuais de desenho urbano e de paisagismo. 
Painel 3.1 Colegio Antonio Derka
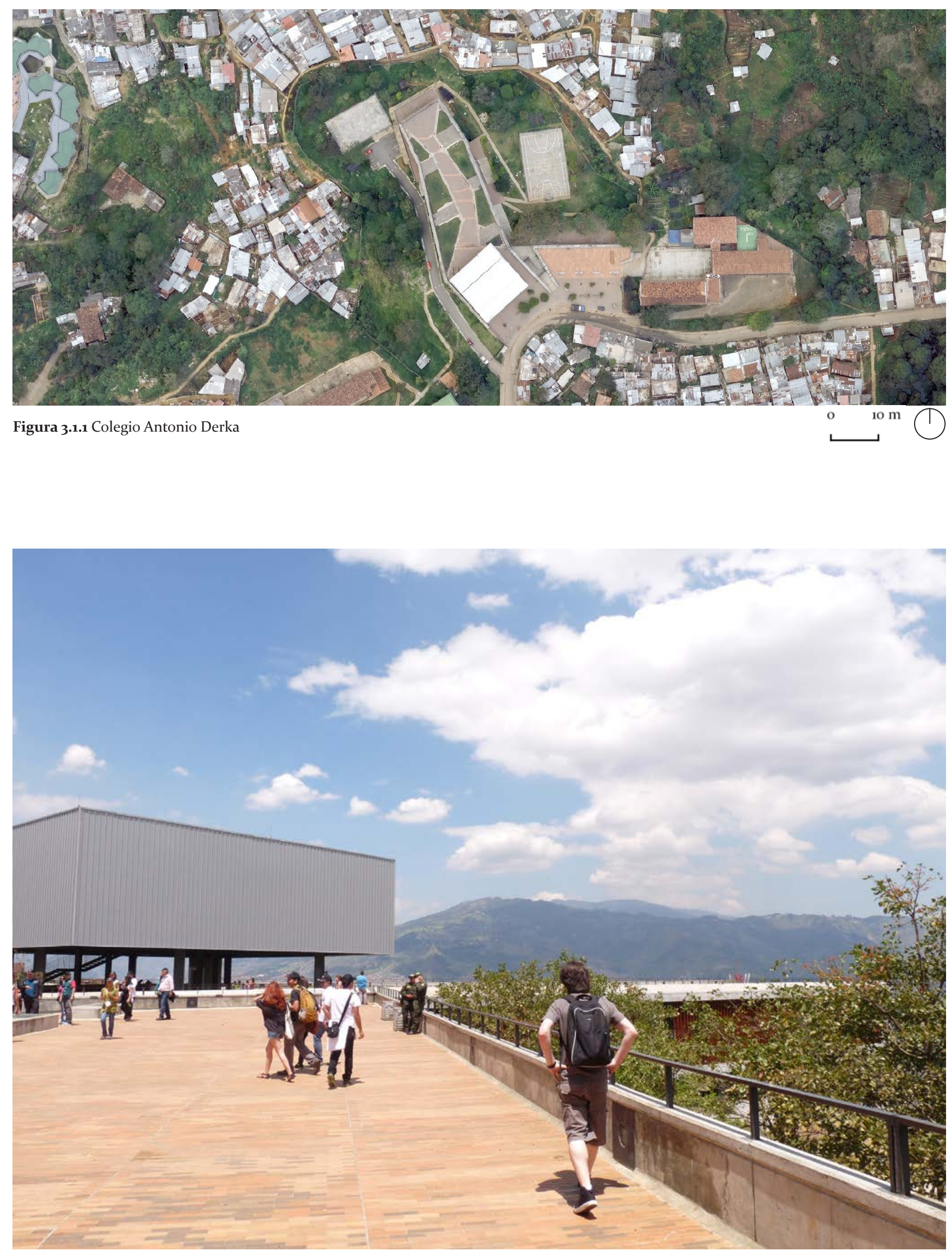

Figura 3.1.2

Figura 3.1.3 Praça de acesso 


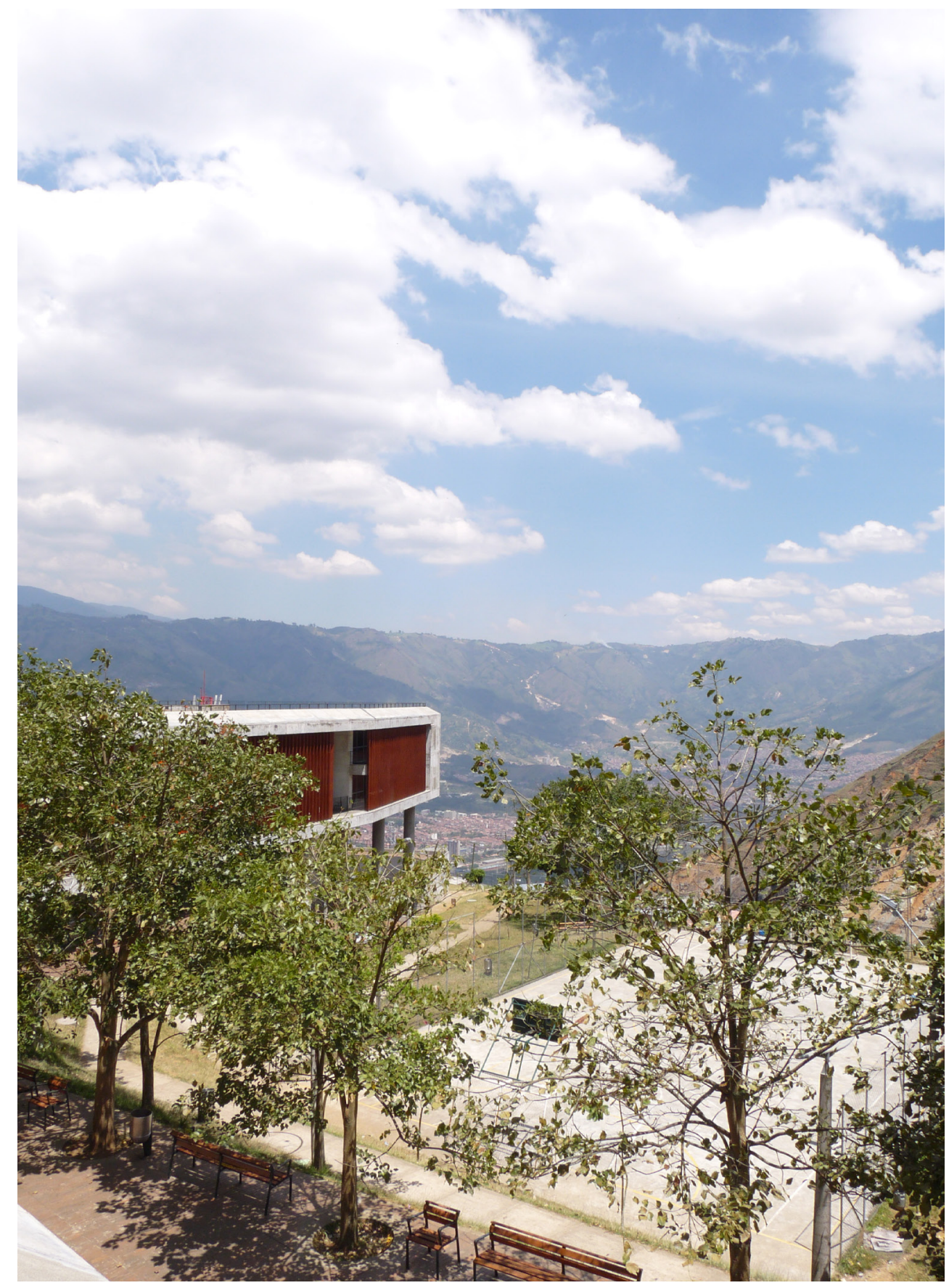



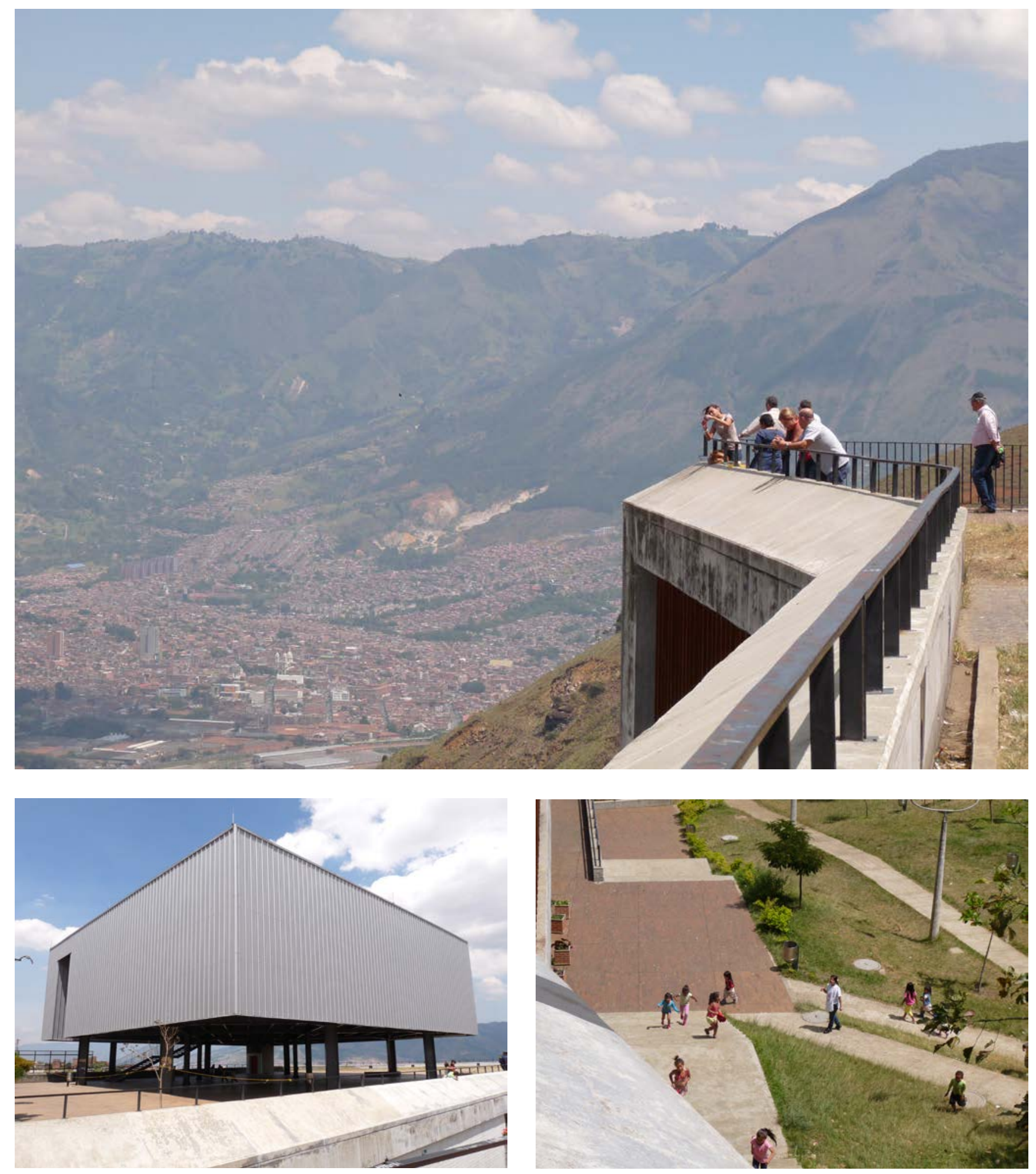

Figura 3.1.4

Figura 3.1.5

Figura 3.1.6

Vista da praça que resulta da

cobertura da edificação

O acesso ao auditório se dá

de forma independente aos

demais espaços da escola 
Painel 3.2 Jardines Infantiles
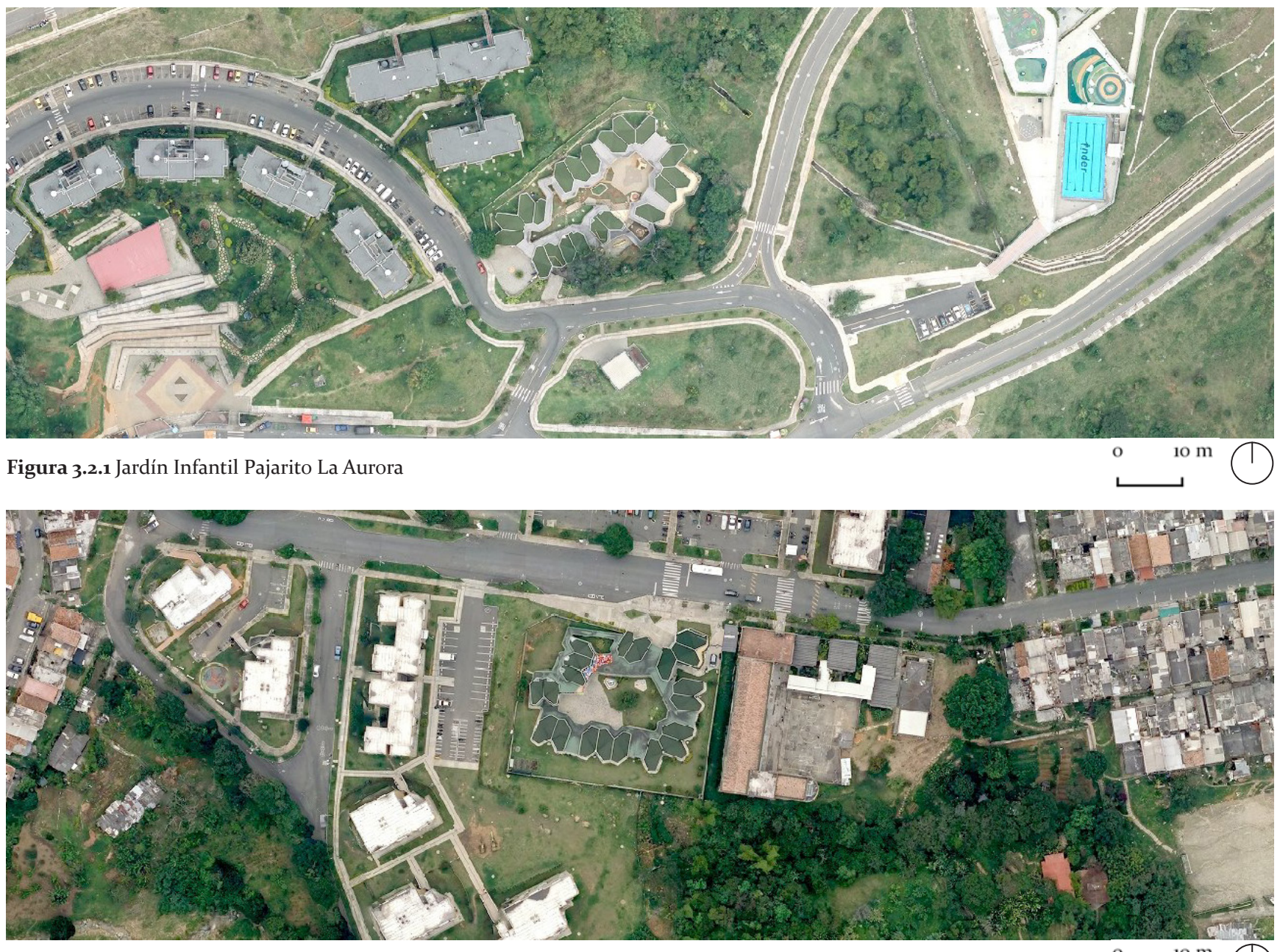

Figura 3.2.2 Jardín Infantil Santo Antonio de Prado

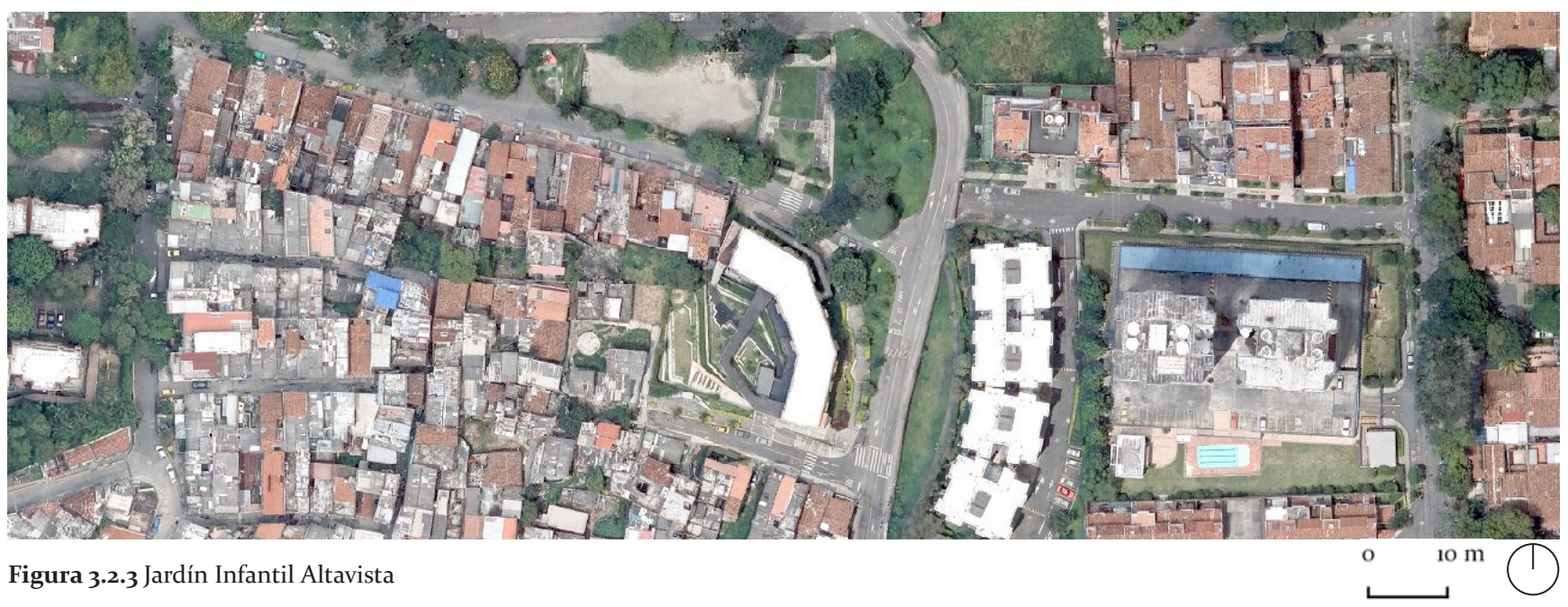




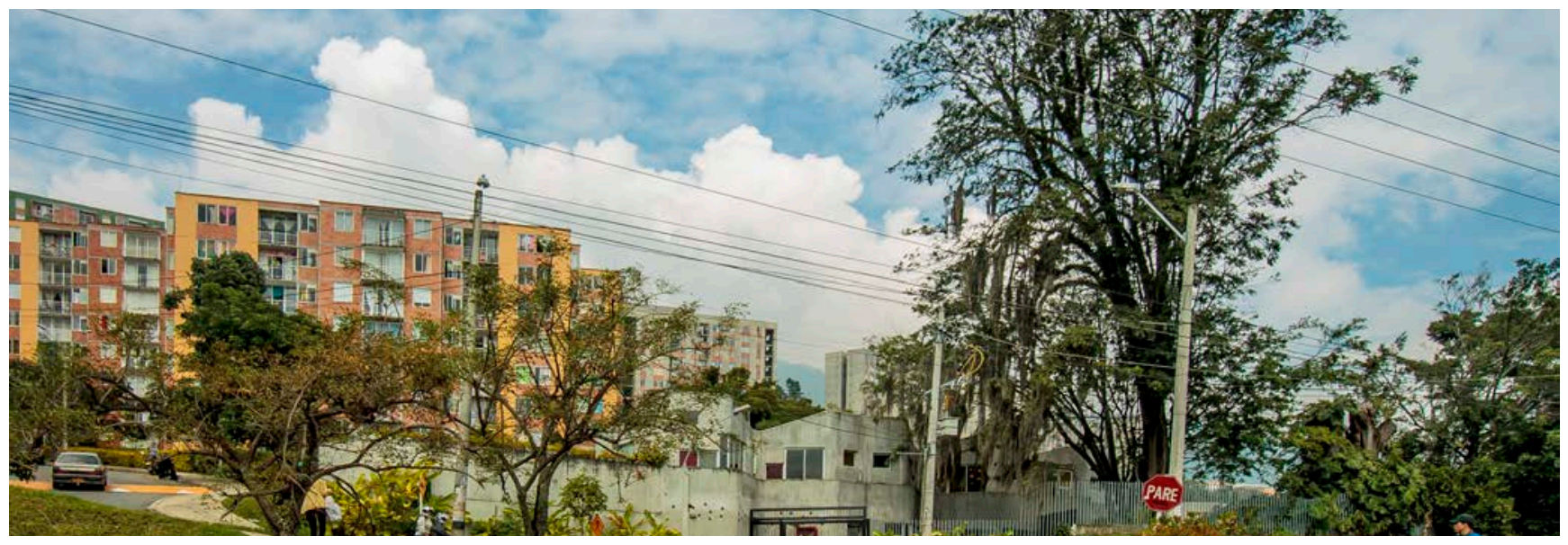

Figura 3.2.4 Jardin Infantil Pajarito La Aurora

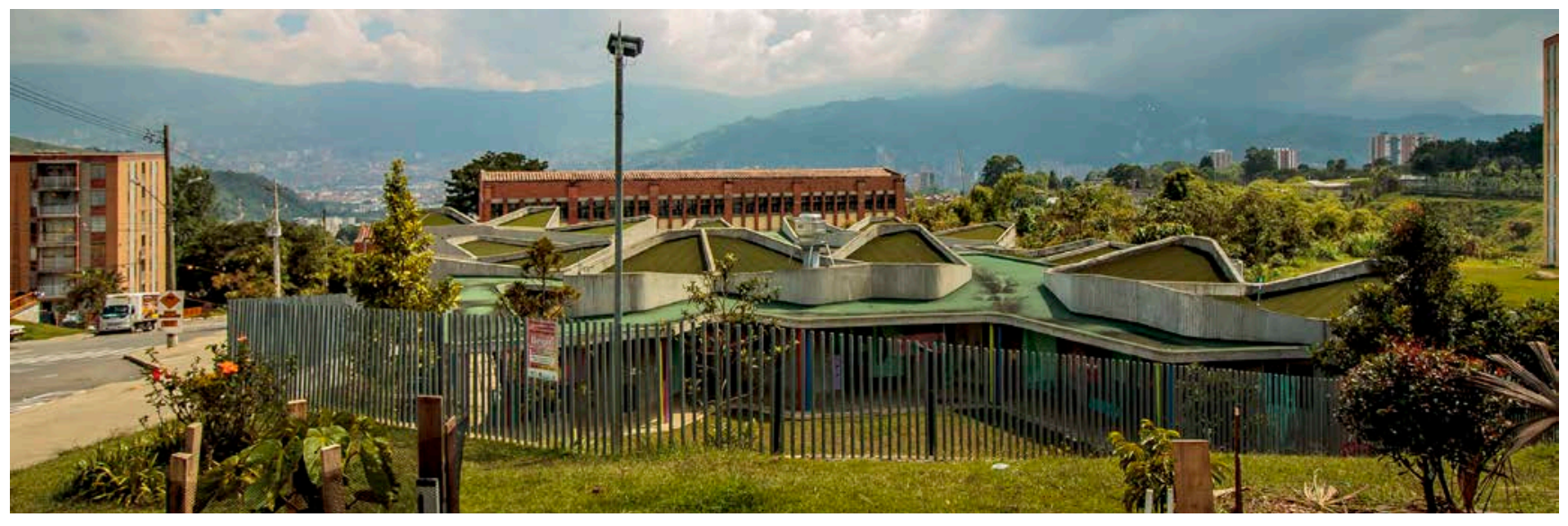

Figura 3.2.5 Jardín Infantil Santo Antonio de Prado

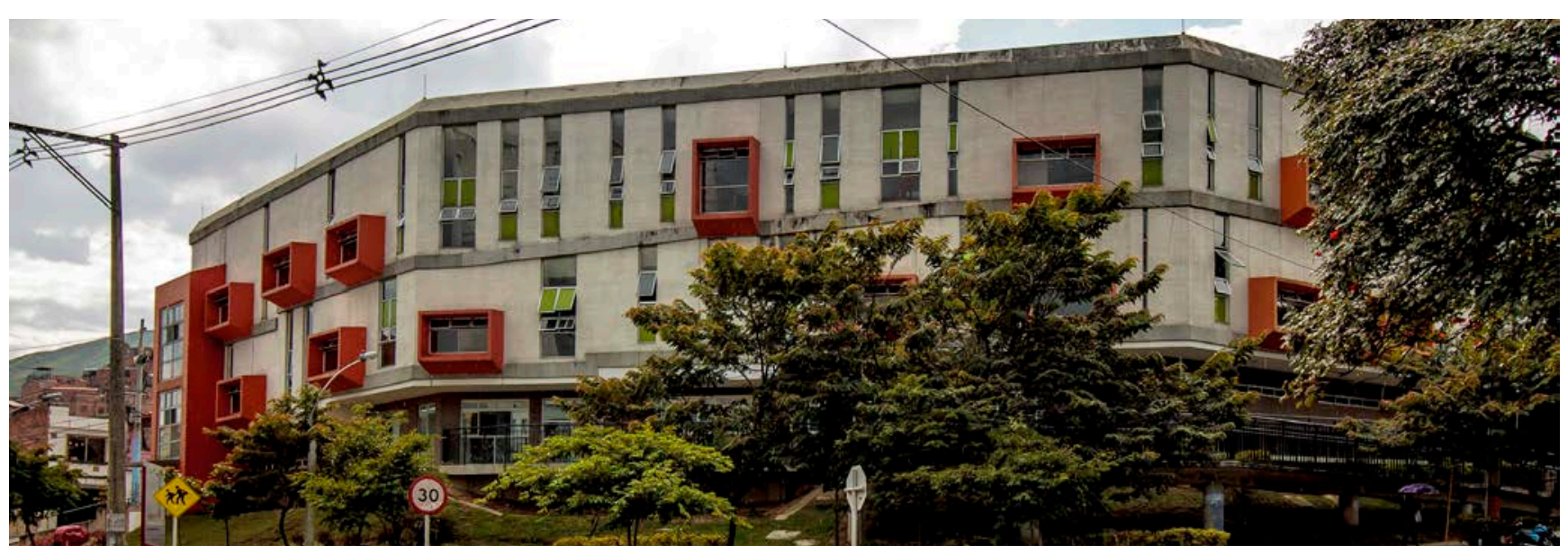

Figura 3.2.6 Jardín Infantil Altavista: um exemplo de simplificação da estratégia projetual realizado pela EDU (volume único perimetral). 

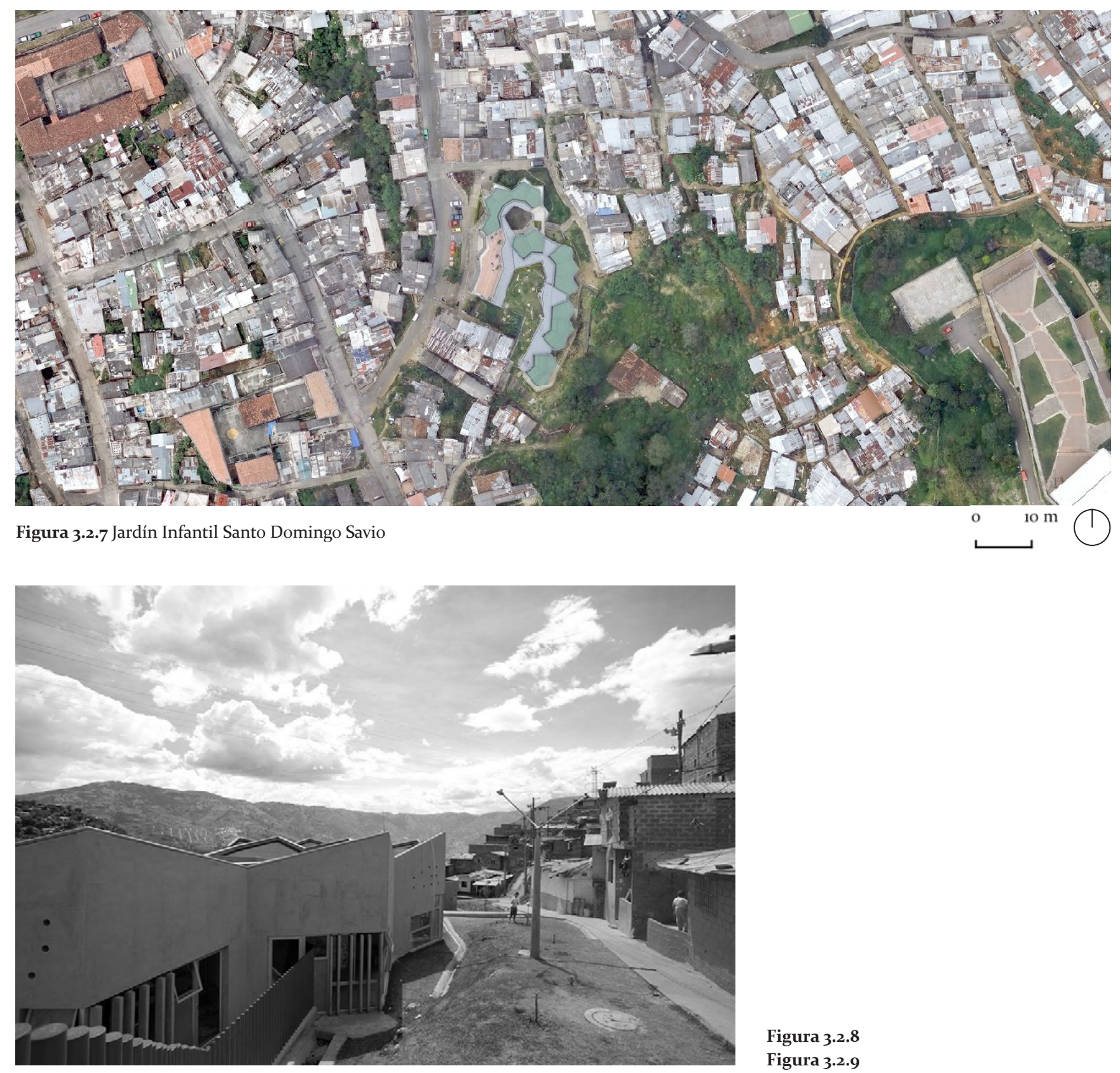

Figura 3.2.8

Figura 3.2.9

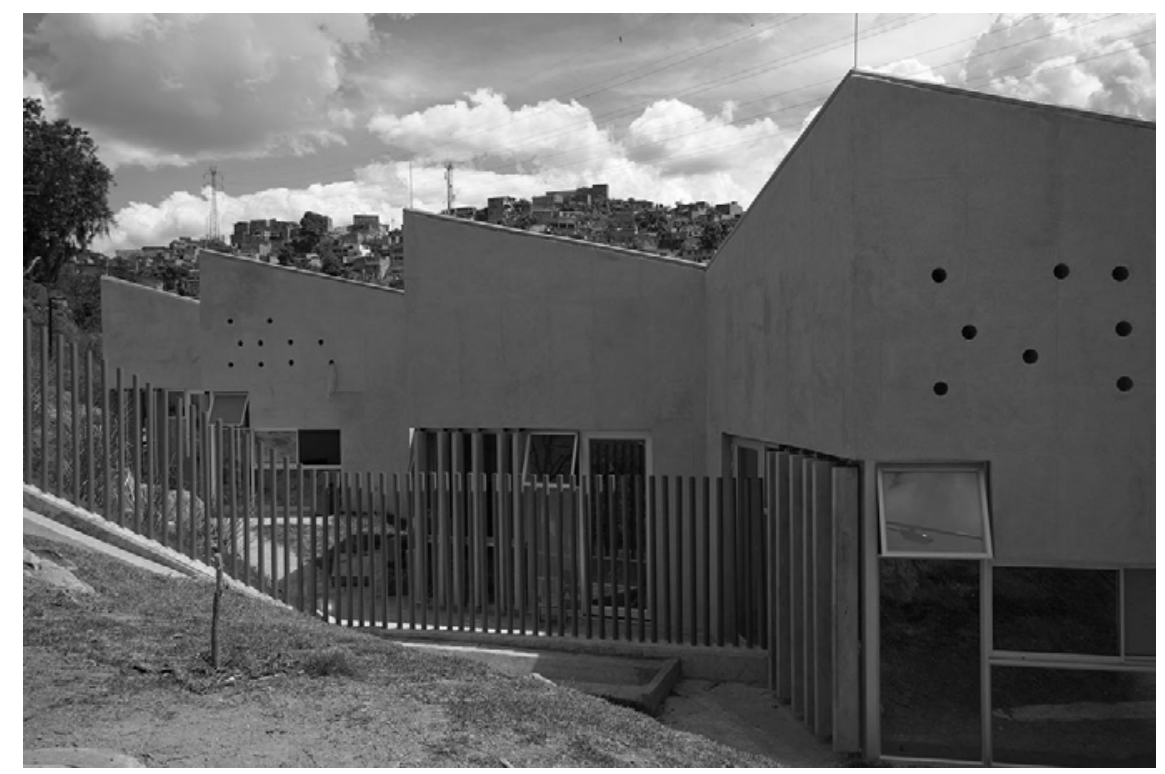

Figura 3.2.10

Figura 3.2.11

Figura 3.2.12

O próprio edifício cria boa parte das interfaces entre o tecido urbano e as áreas internas. Os gradis que se fazem necessários são incorporados aos elementos constitutivos do projeto 

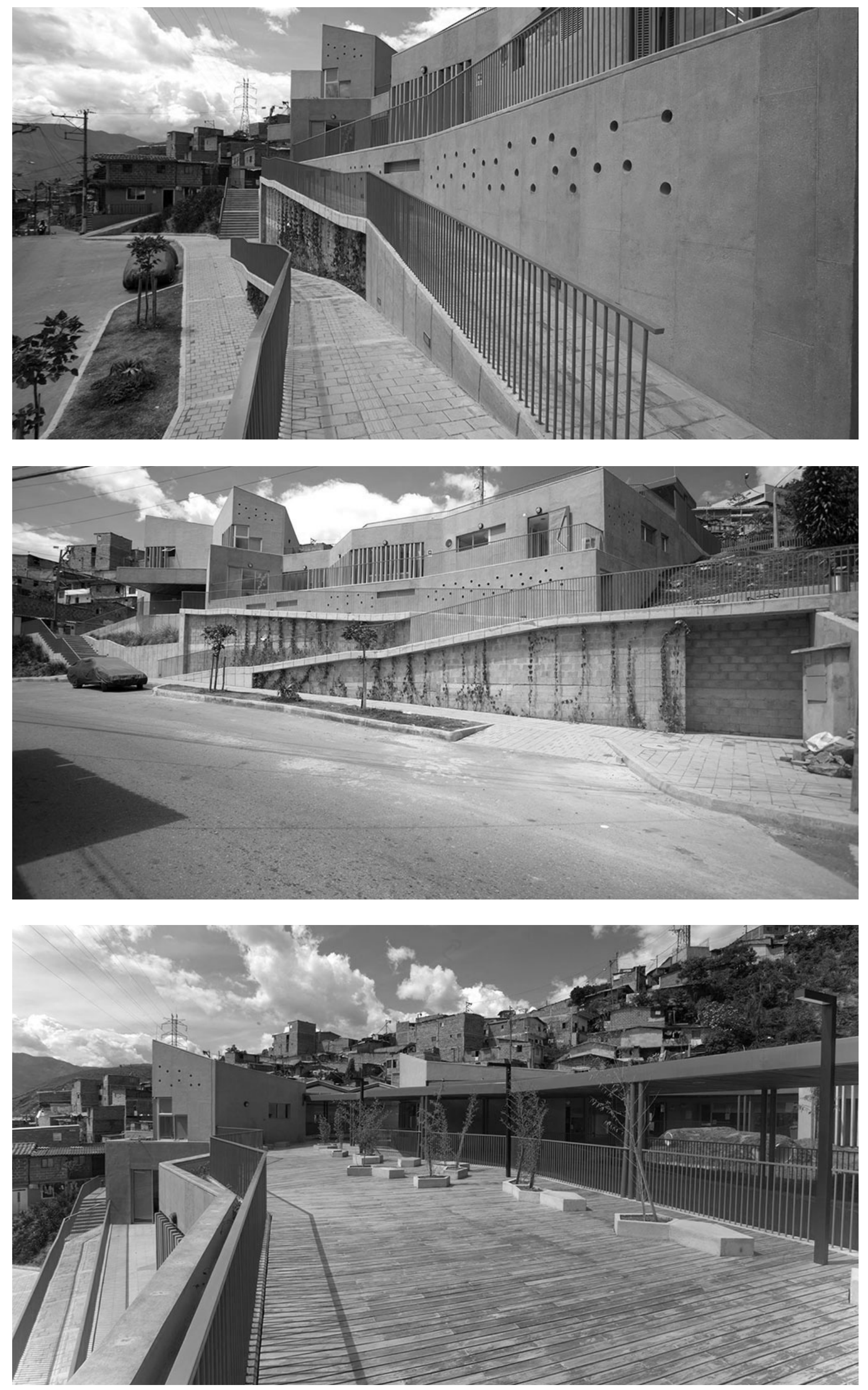


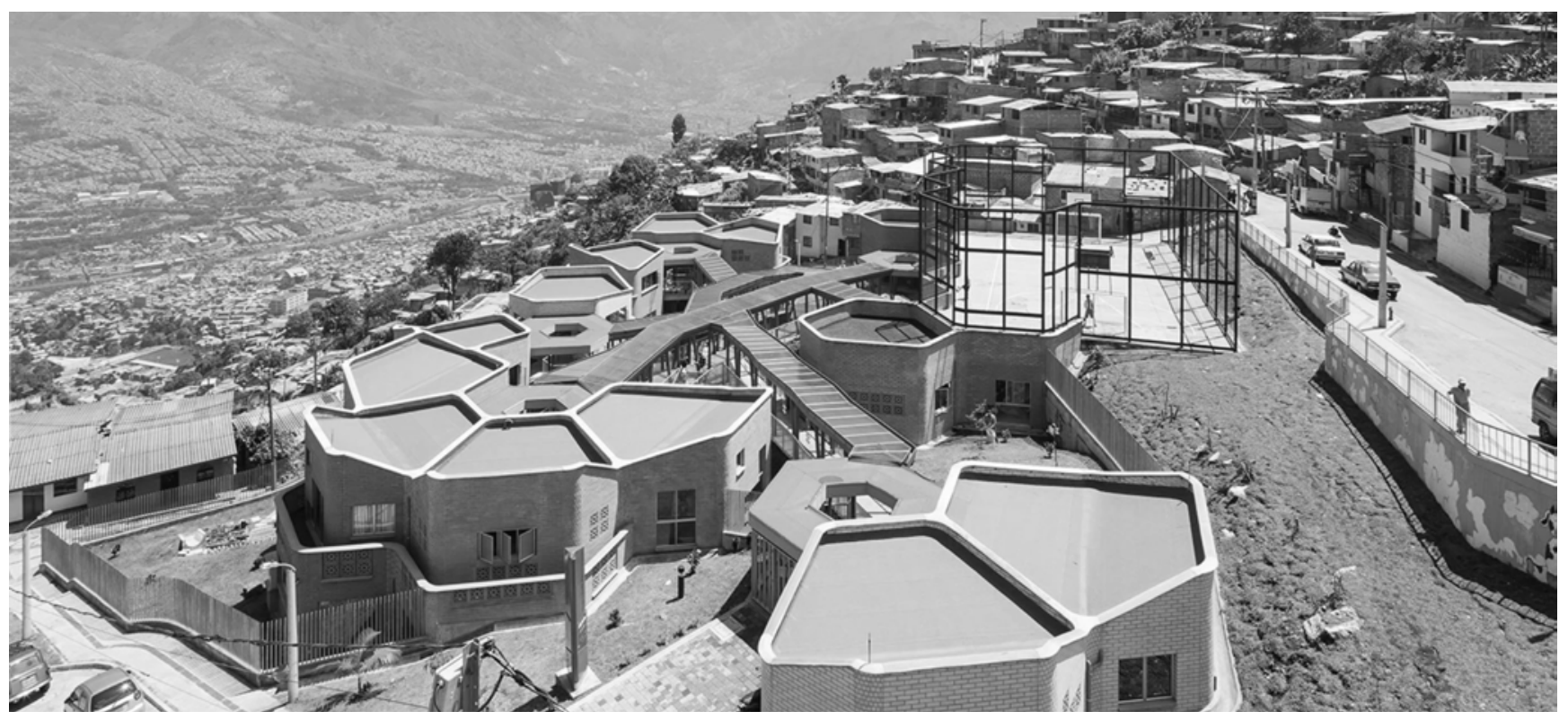

Figura 3.2.13 Jardín Infantil Carpinelo
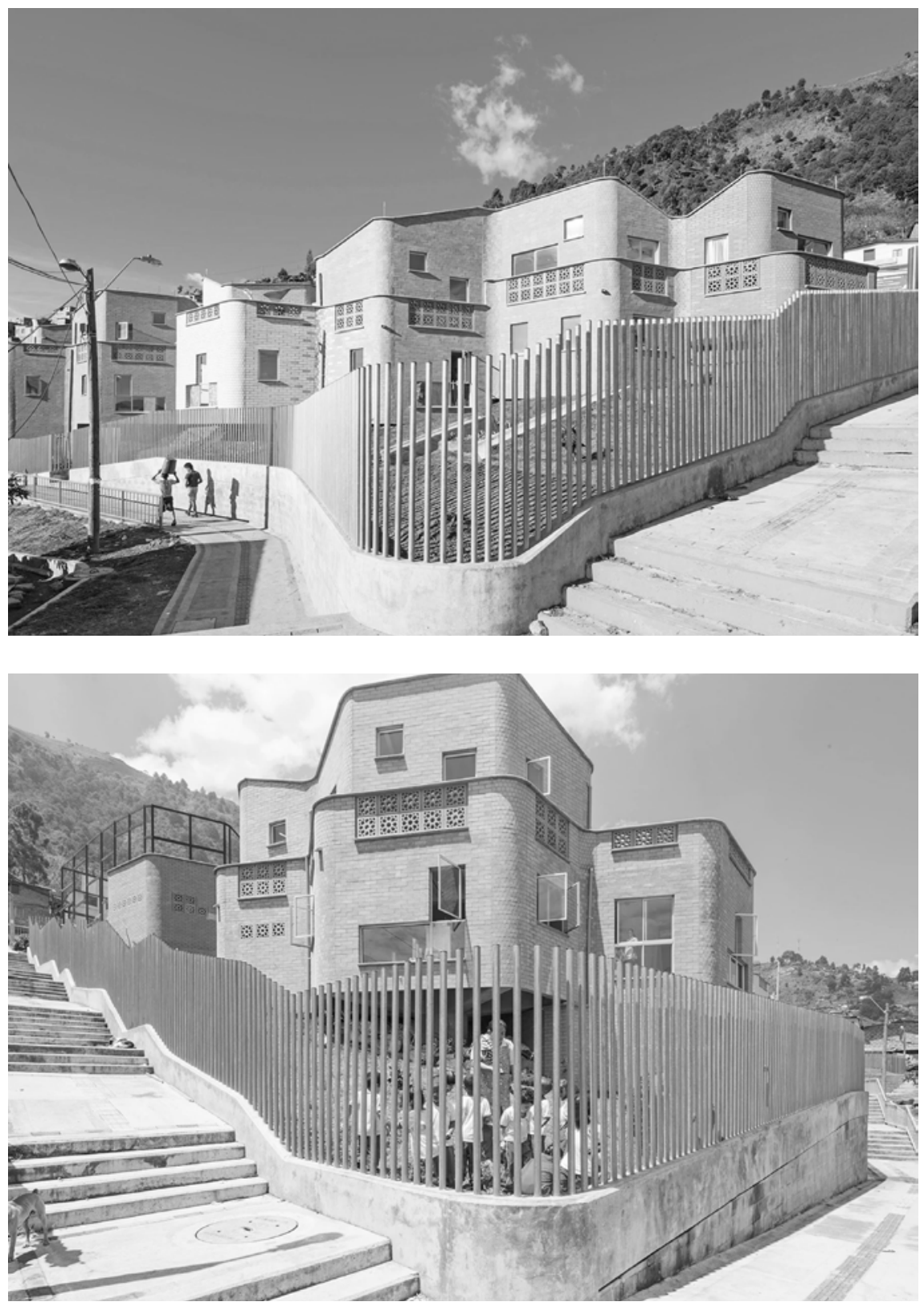

Figura 3.2.14

Figura 3.2.15

O Jardín Infantil Carpinelo desenvolve solução similar aos projetos que o precedem. Aqui, no entanto, o terreno é maior e os módulos se tornam mais perceptíveis nessa solução 

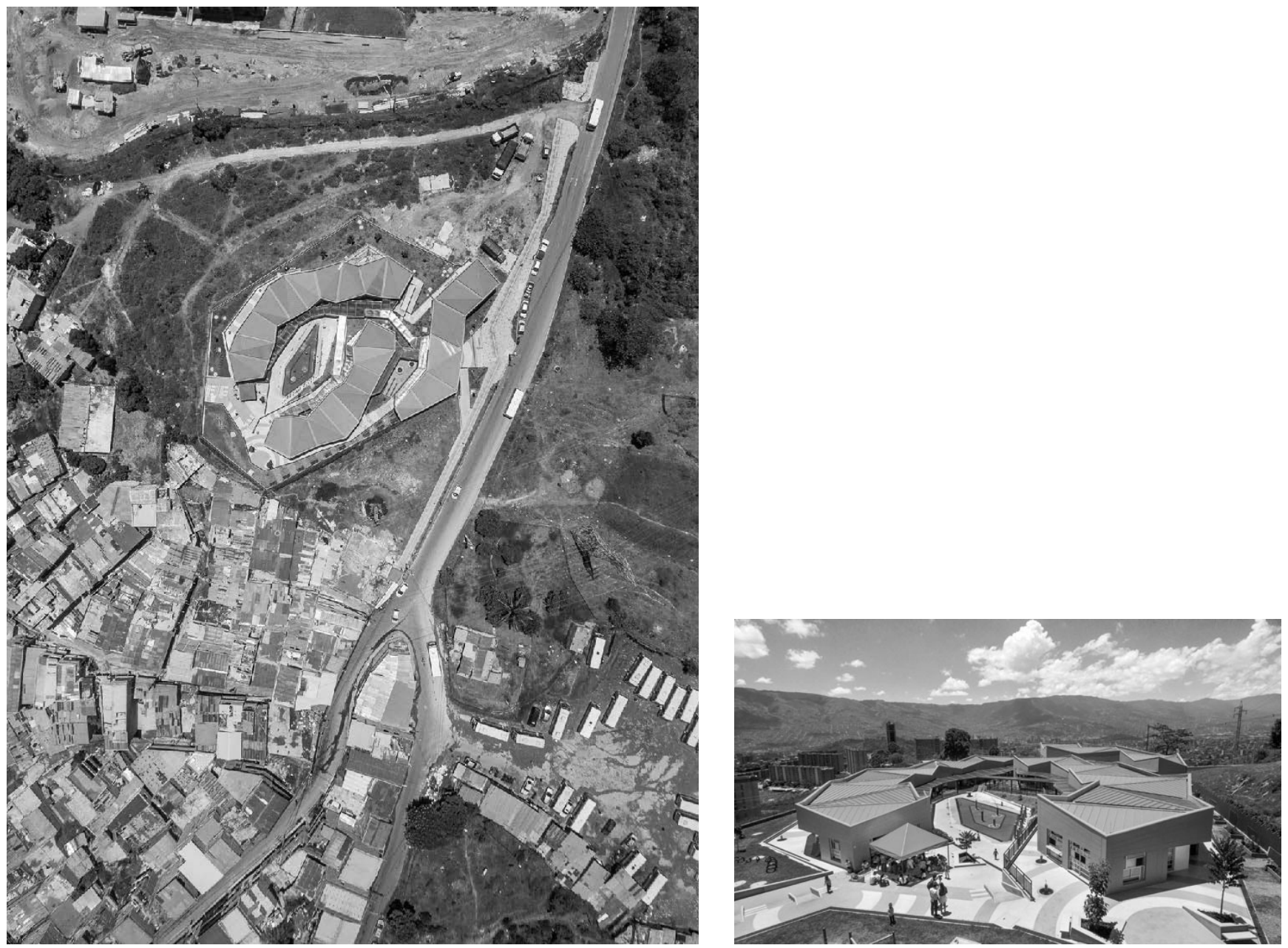

Figura 3.2.16 Jardín Infantil Calazania - Versão realizada pela EDU posterior aos projetos decorrentes dos concursos. Percebe-se uma simplificação nos materiais e na articulação dos módulos. No entanto, as estrategias de conformação dos espaços da creche em relação ao tecido urbano são mantidos.

Figura 3.2.17

Figura 3.2.18

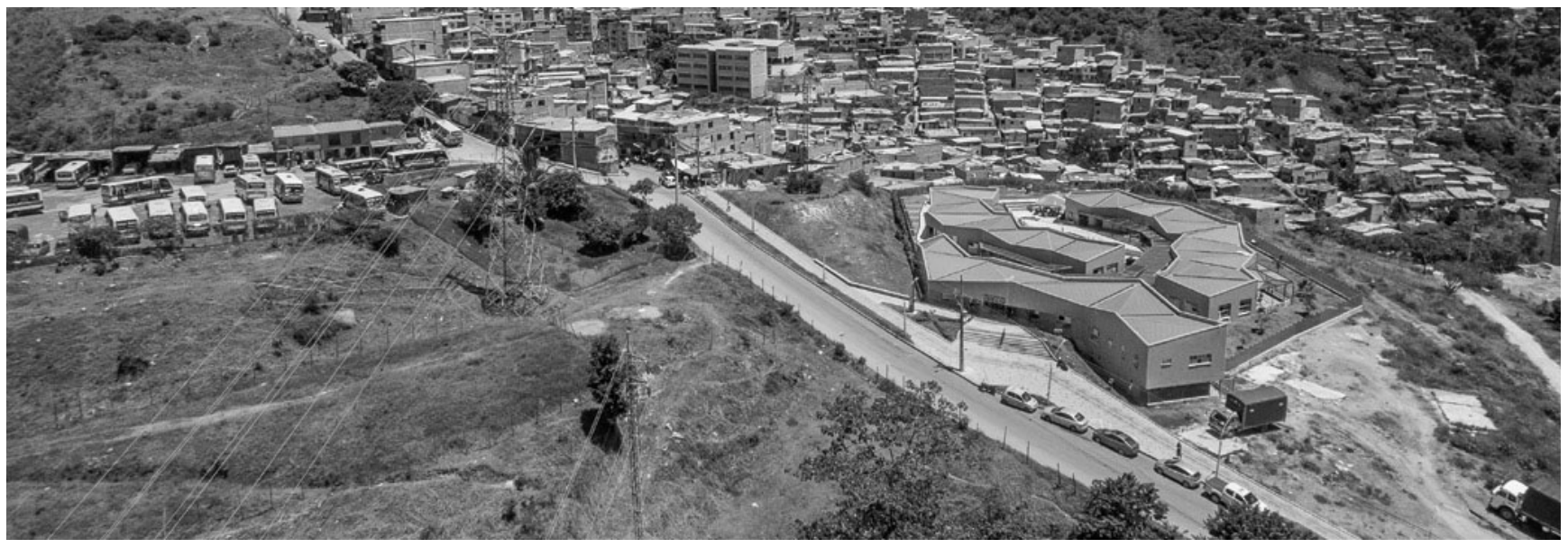


Painel 3.3 Parques Bibliotecas

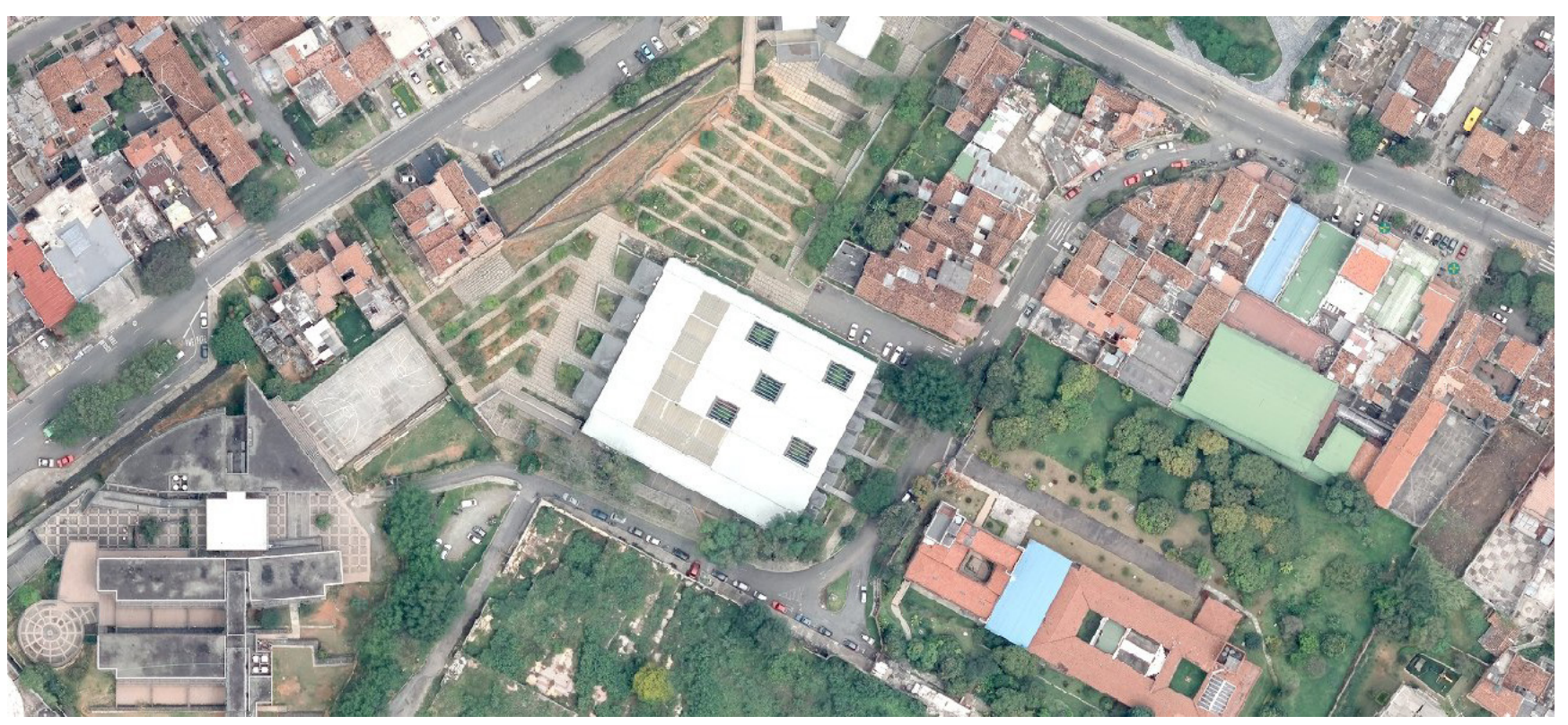

Figura 3.3.1 Parque Biblioteca San Javier

escala 1:1050

Figura 3.3.2

Figura 3.3.3

Figura 3.3.4

Parque Biblioteca San Javier Travessia de ponte que parte da estação de metrô com o mesmo nome Os espaços livres são apropriados mesmo quando a biblioteca está fechada. Não há qualquer restrição de acesso ao entorno. 

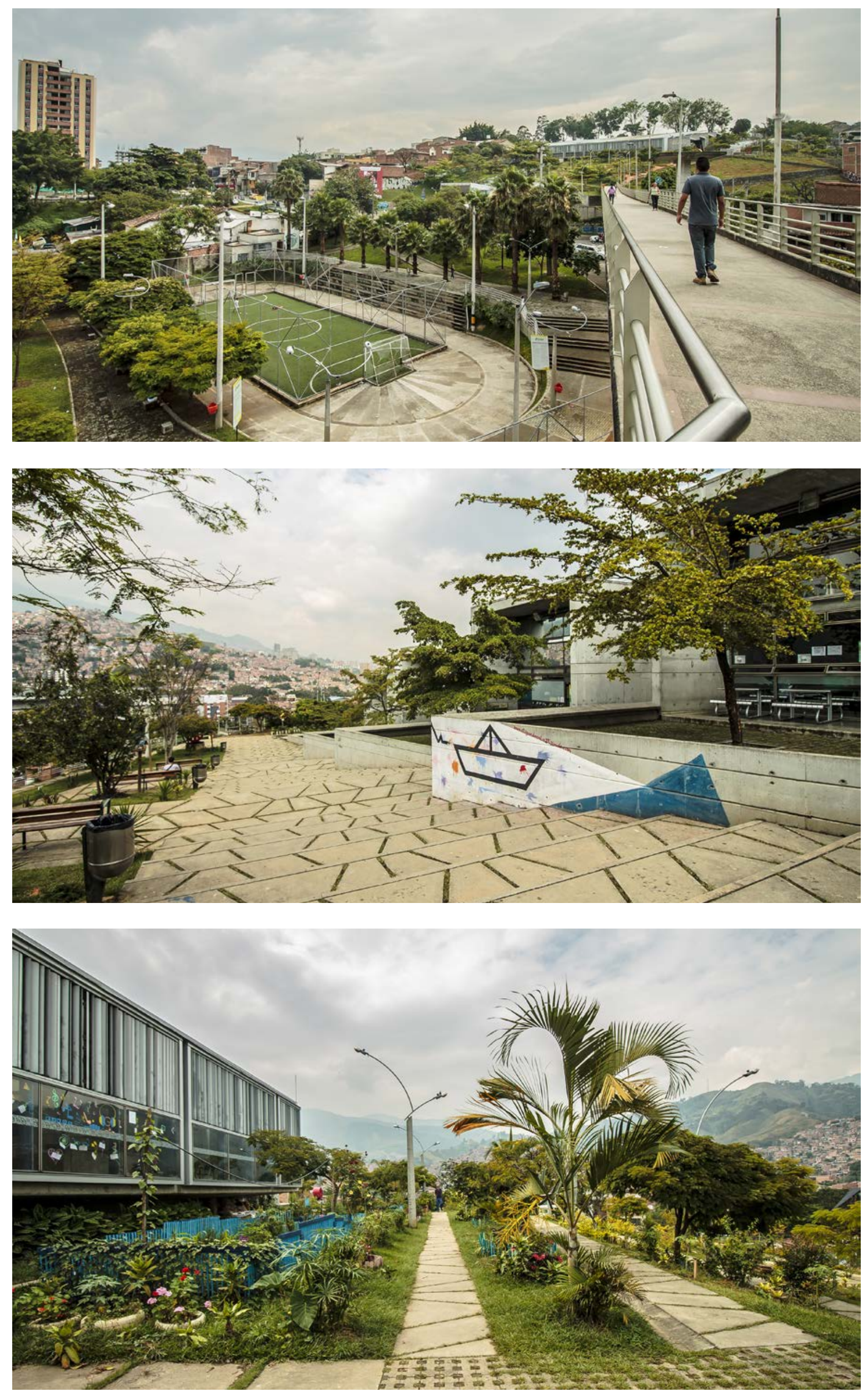


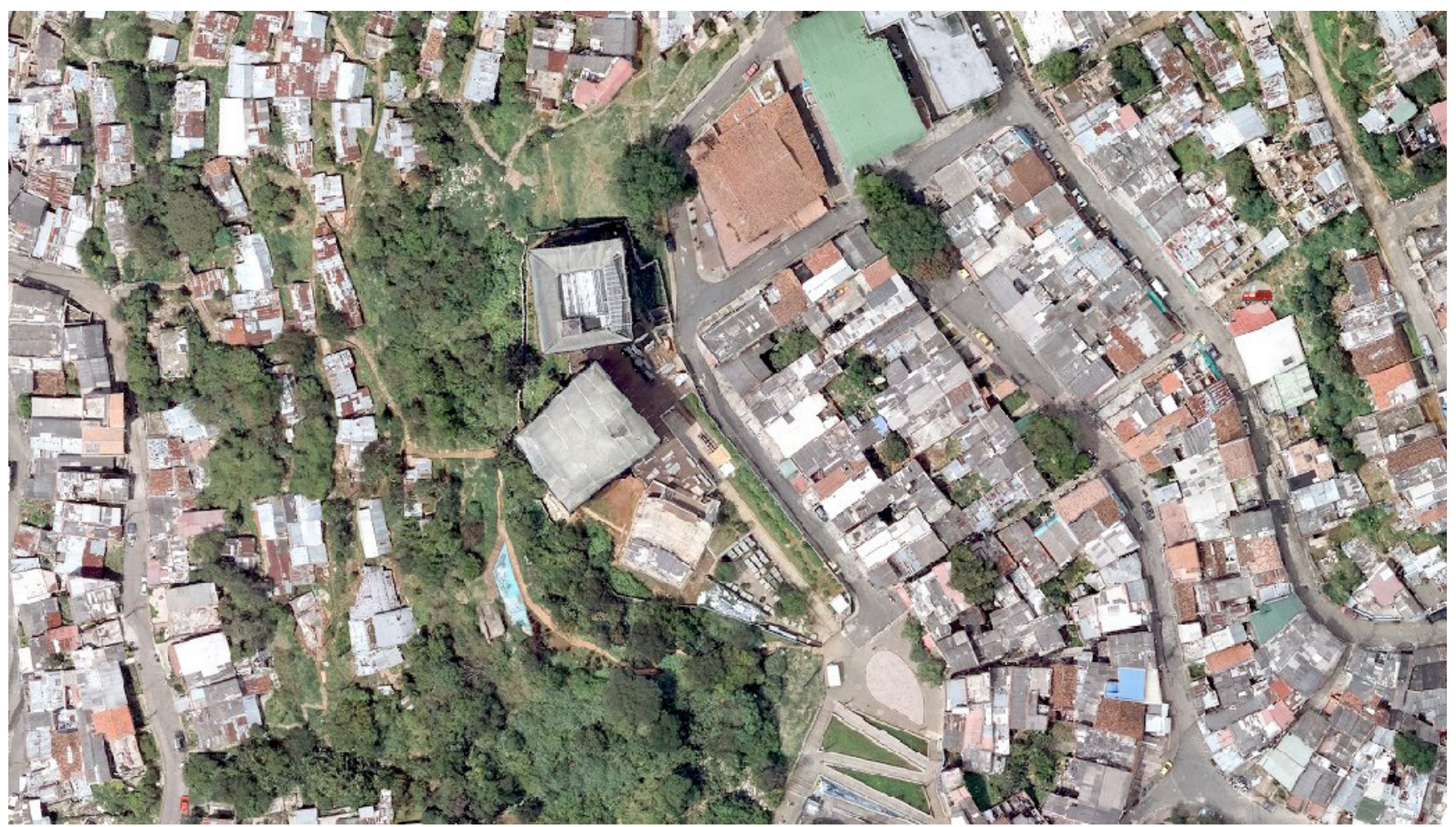

Figura 3.3.5 Parque Biblioteca España

escala 1:1050

Figura 3.3.7

Figura 3.3.8

Figura 3.3.9

Figura 3.3.10

Figura 3.3.11

Figura 3.3.12

Parque Biblioteca España fotos da visita em 2012

Figura 3.3.6

Parque Biblioteca España fotos da visita em 2016 A biblioteca já se encontrava interditada para manutenção

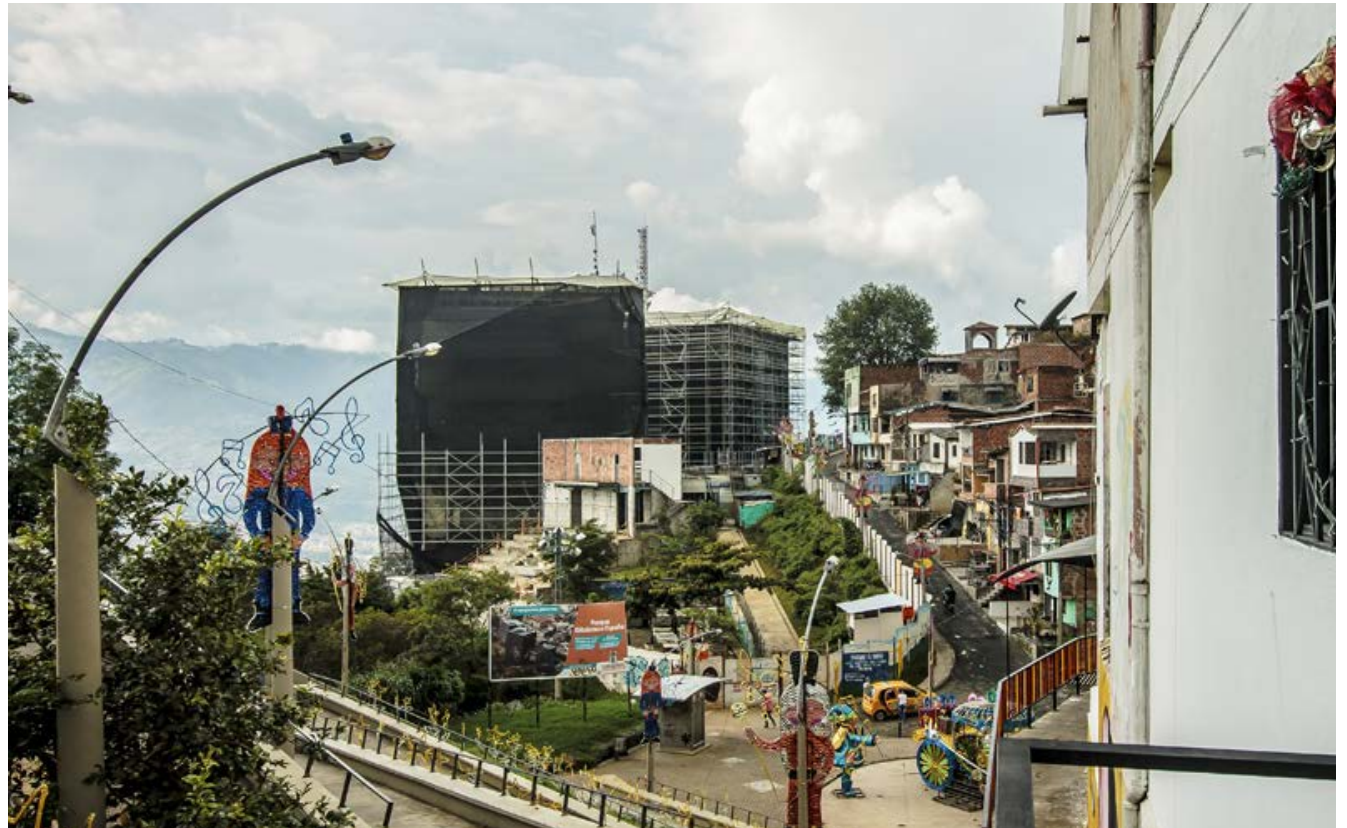



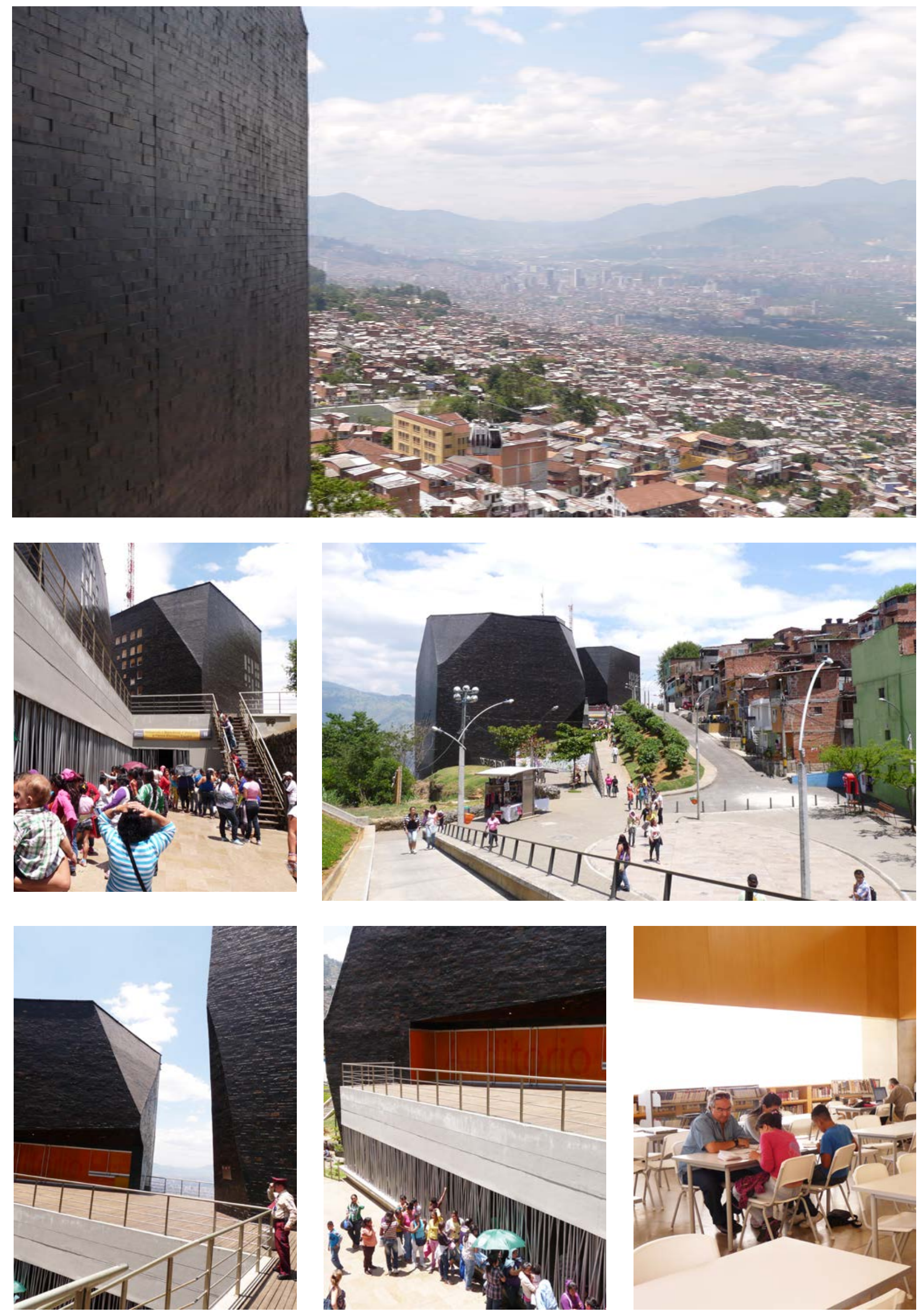


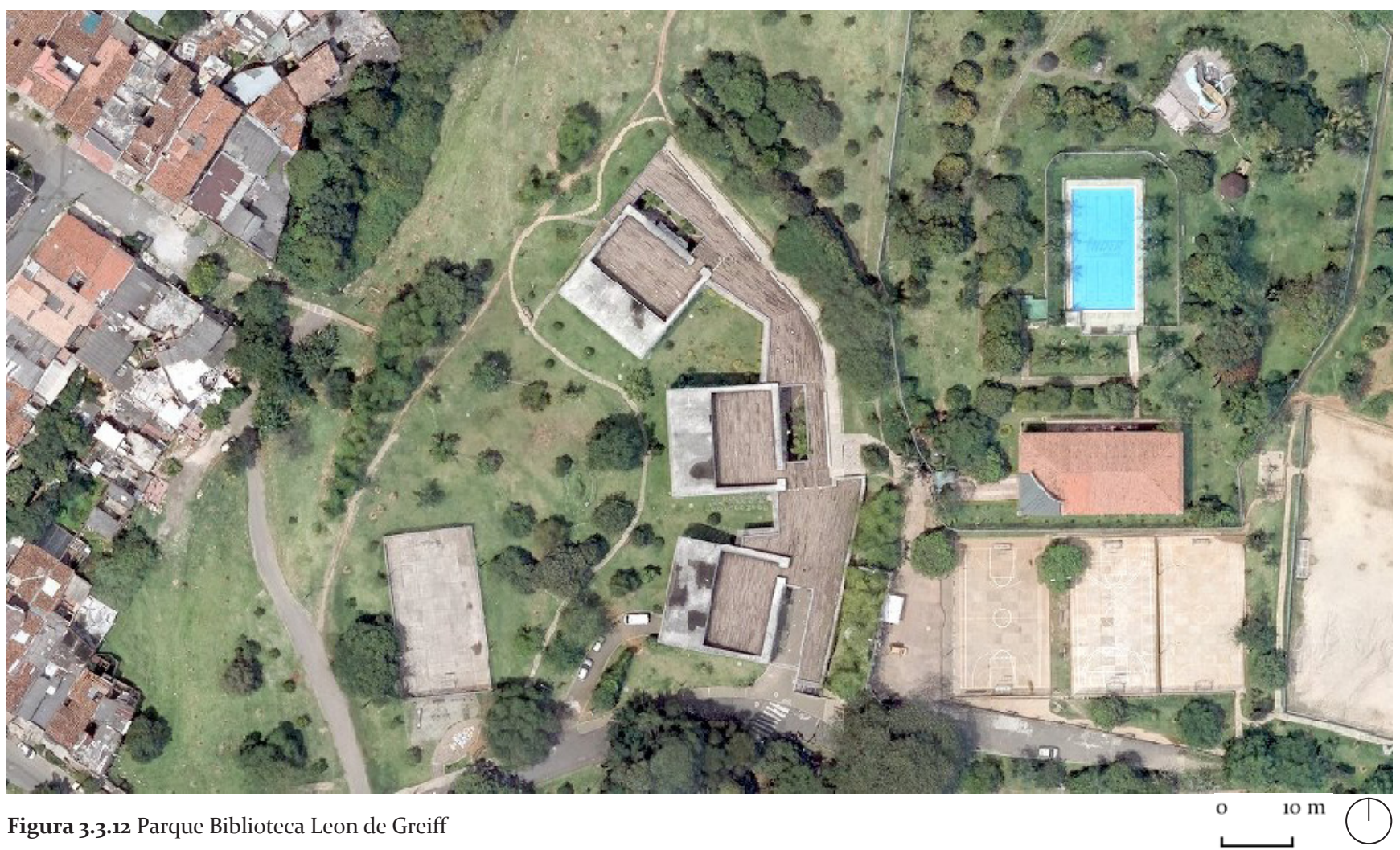

Figura 3.3.13

Figura 3.3.14

Parque Biblioteca Leon de Greiff

fotos da visita em 2016

A biblioteca apresentava patologias

internas e externas
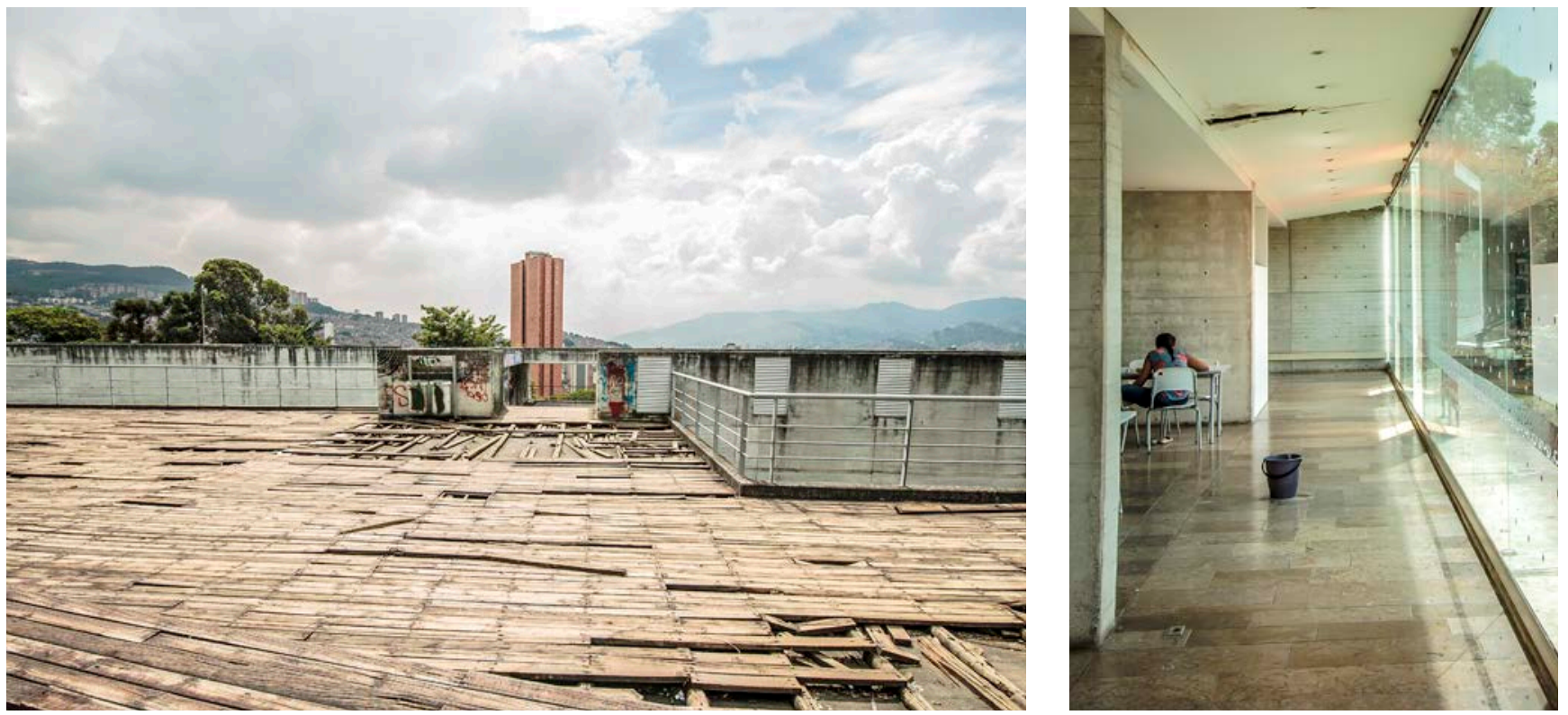
Figura 3.3.15

Figura 3.3.16

Figura 3.3.17

Figura 3.3.18

Parque Biblioteca Leon de Greiff

fotos da visita em 2012
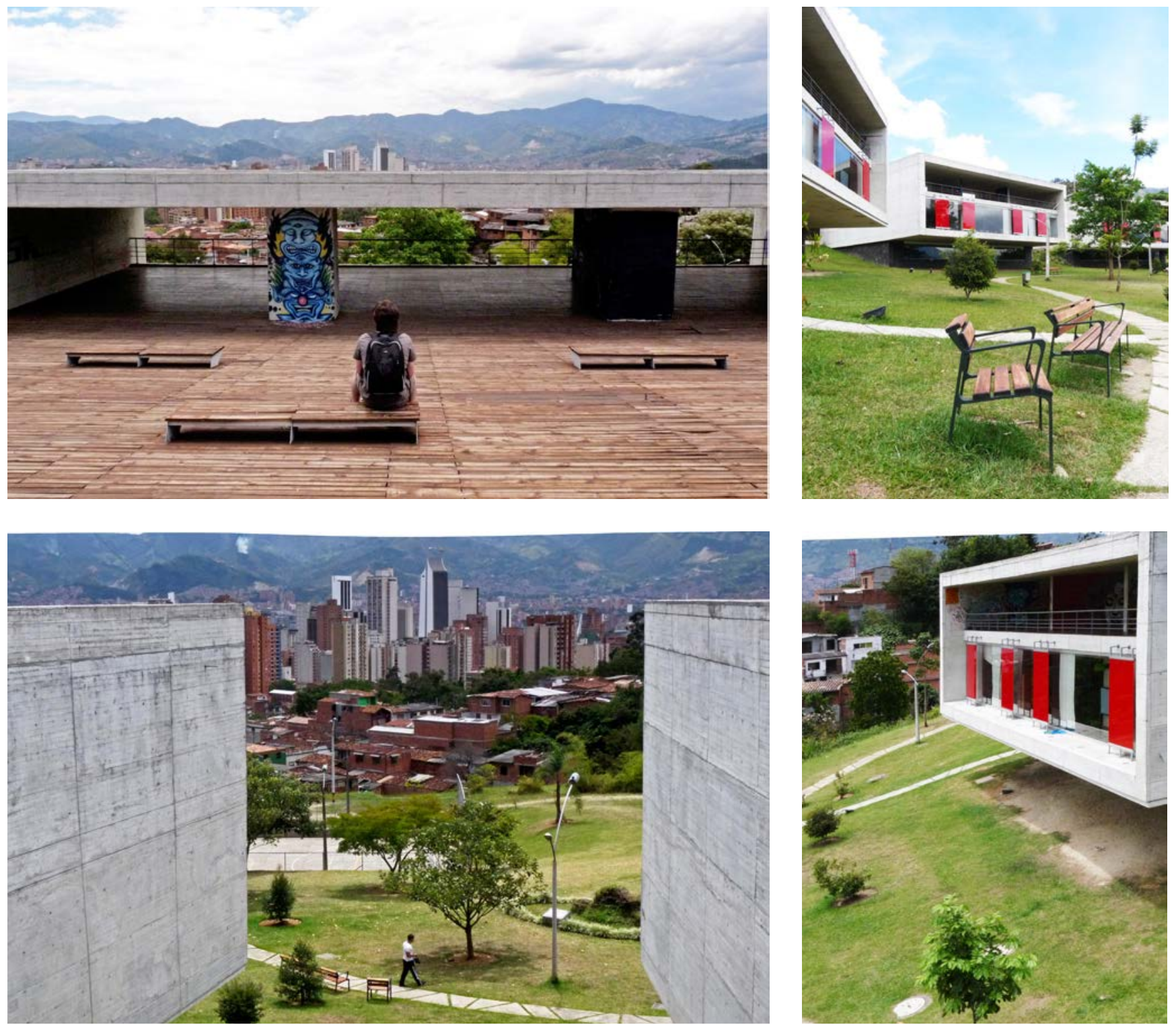

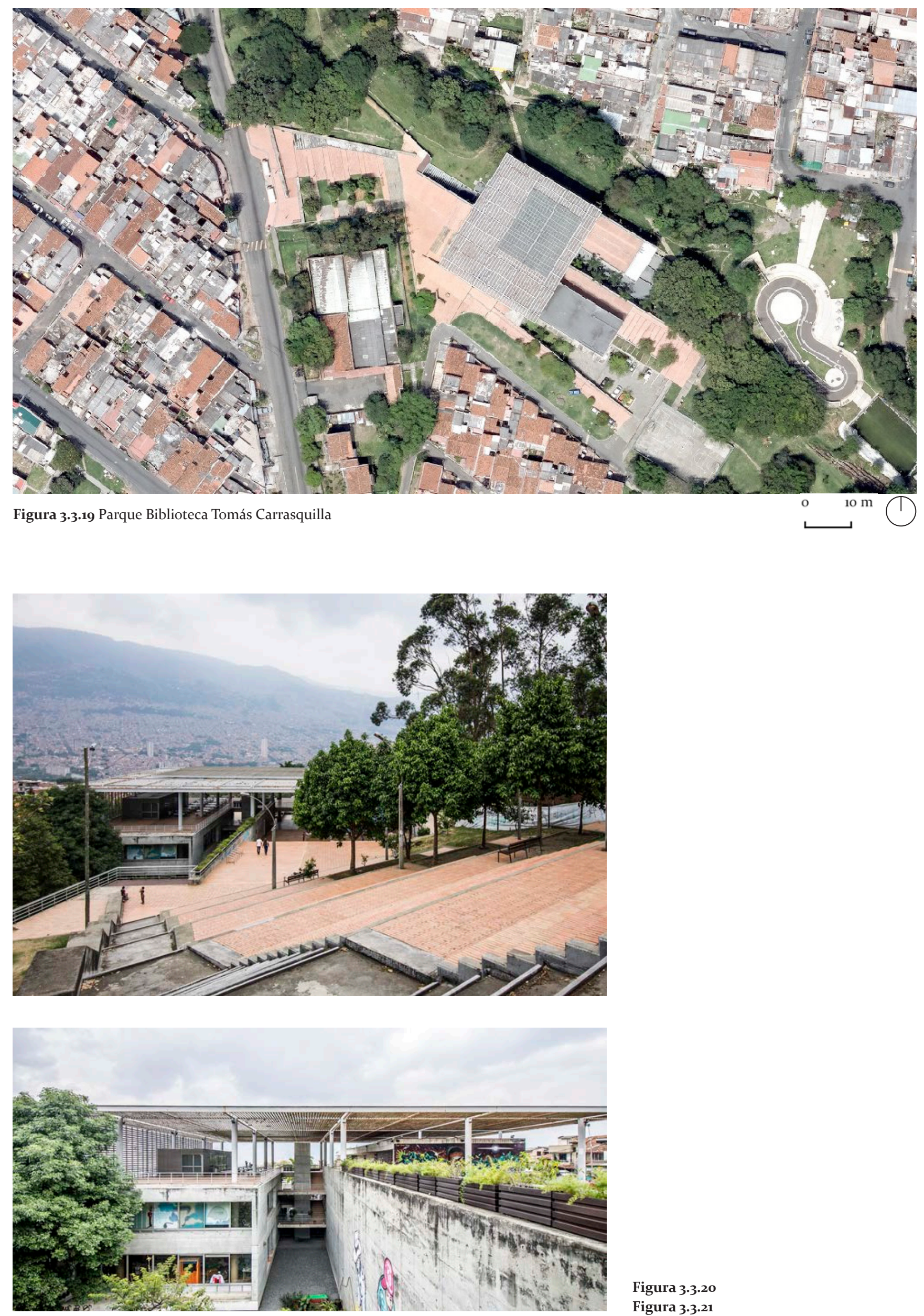

Figura 3.3.20

Figura 3.3.21 
Figura 3.3.22

Figura 3.3.23

Figura 3.3.24

Figura 3.3.25

Parque Biblioteca Tomás Carrasquilla

Vistas da praça de acesso e do terraço
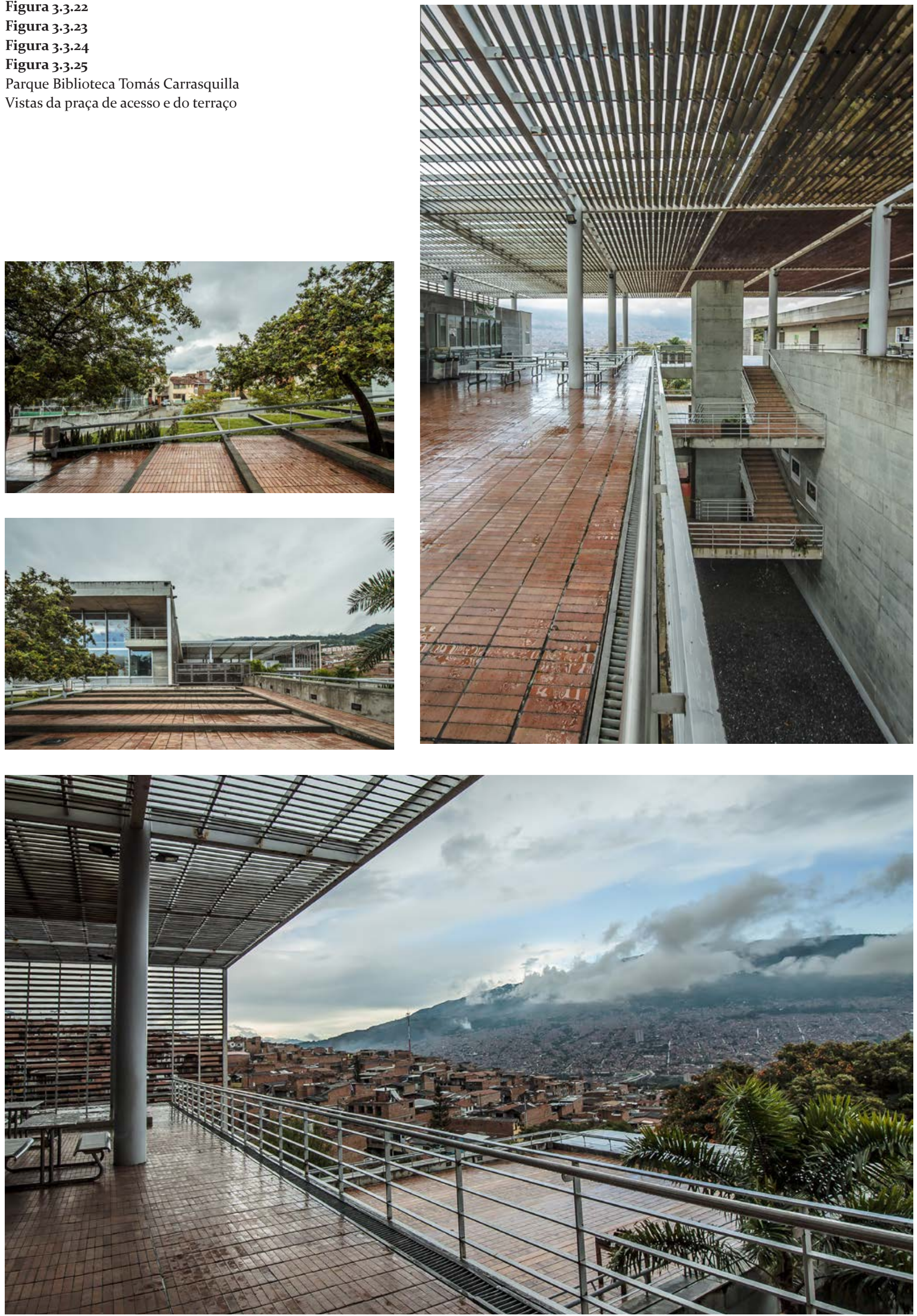


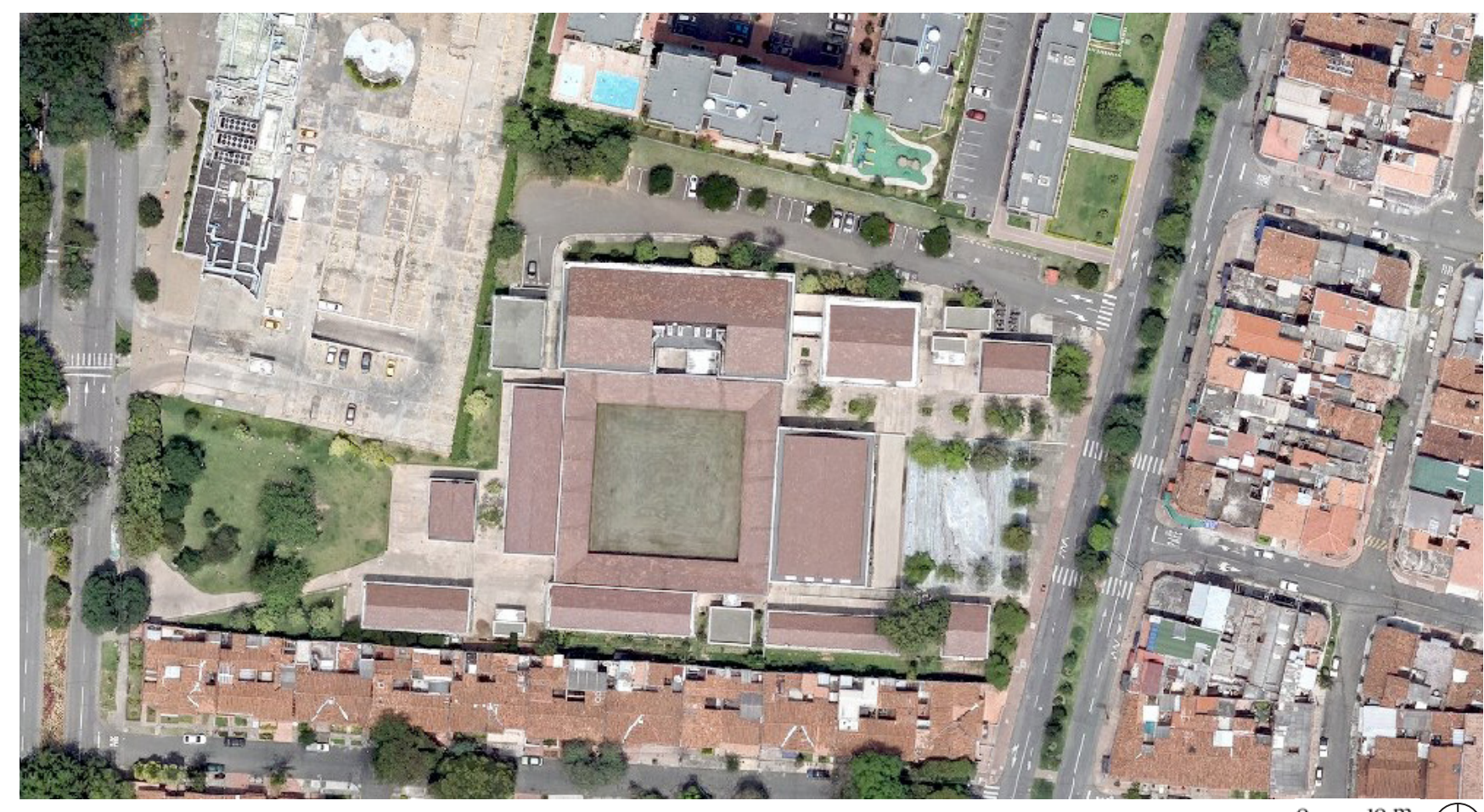

Figura 3.3.26 Parque Biblioteca Belén
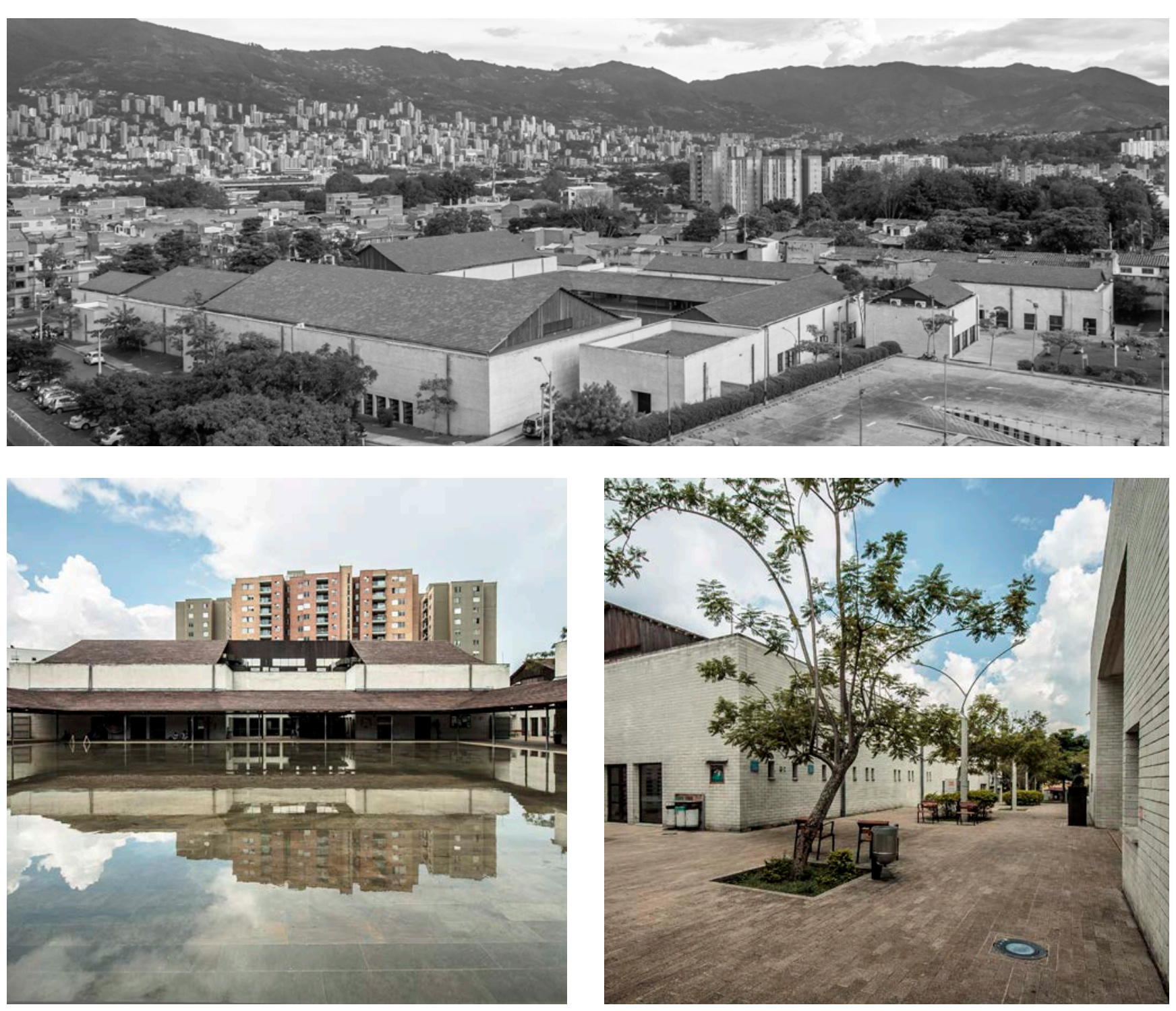


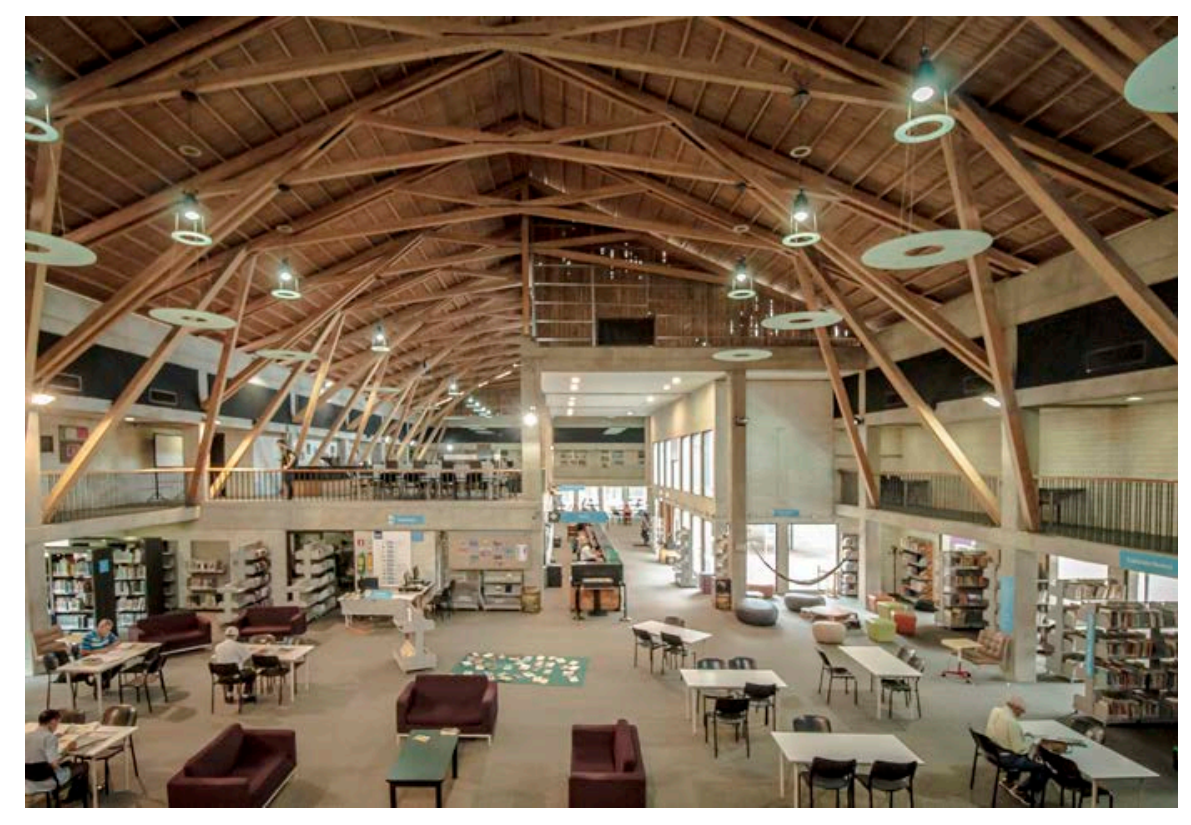

Figura 3.3.27

Figura 3.3.28

Figura 3.3.29

Figura 3.3.30

Figura 3.3.31

Figura 3.3.32

Parque Biblioteca Belén

Vistas do salão da biblioteca e dos percursos em torno dos blocos que compõem o conjunto
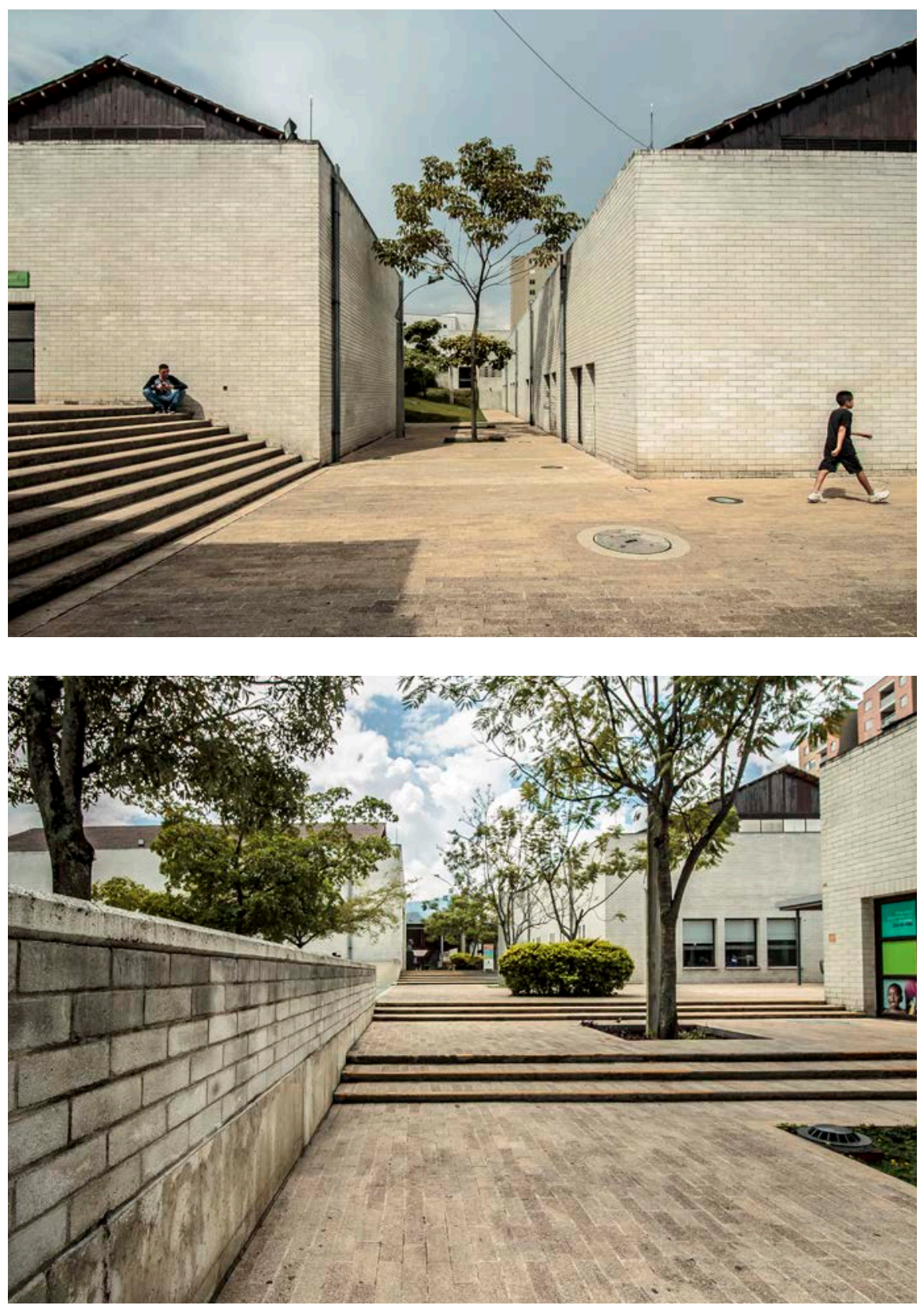

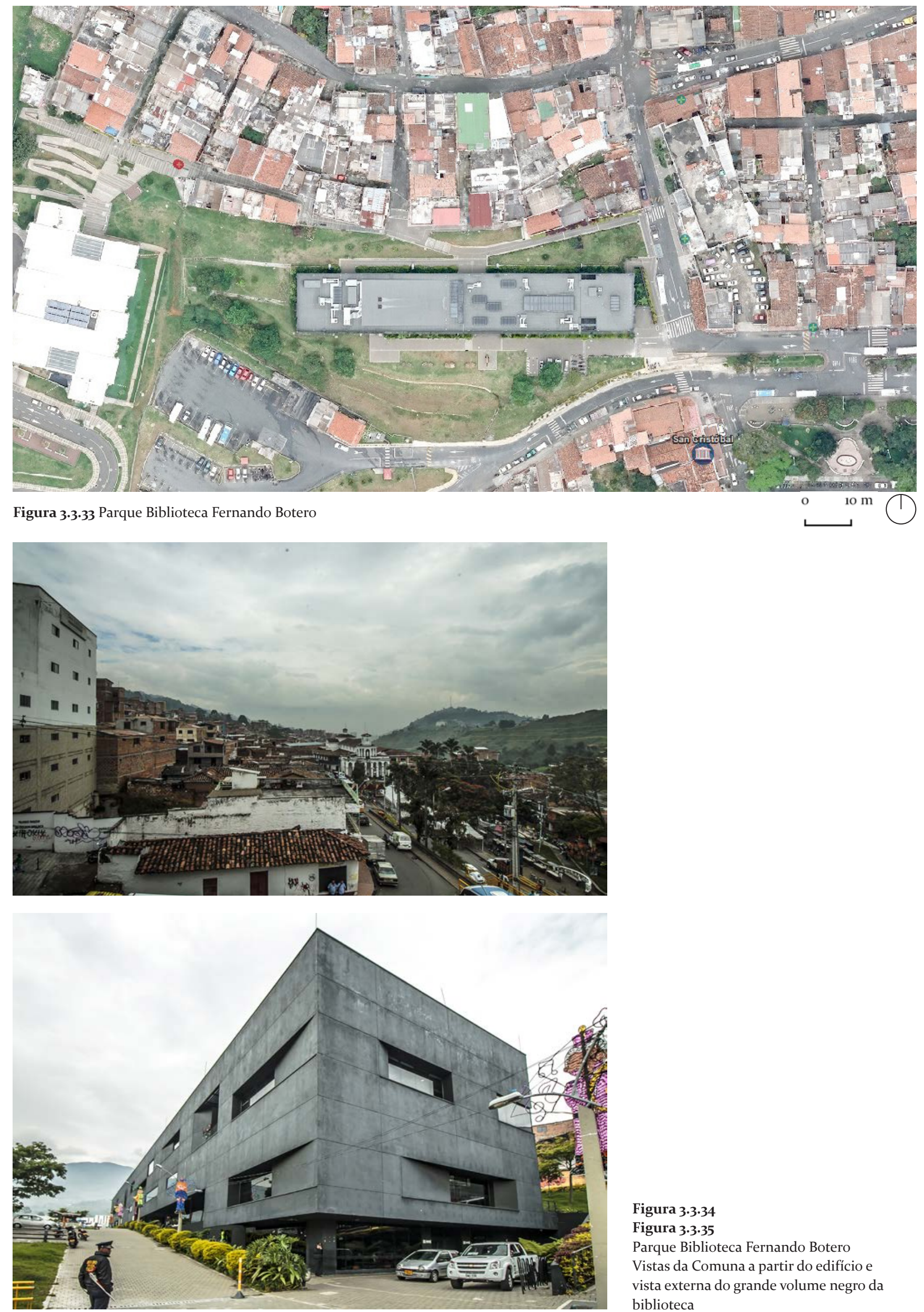

Figura 3.3.34

Figura 3.3.35

Parque Biblioteca Fernando Botero

Vistas da Comuna a partir do edifício e vista externa do grande volume negro da biblioteca 

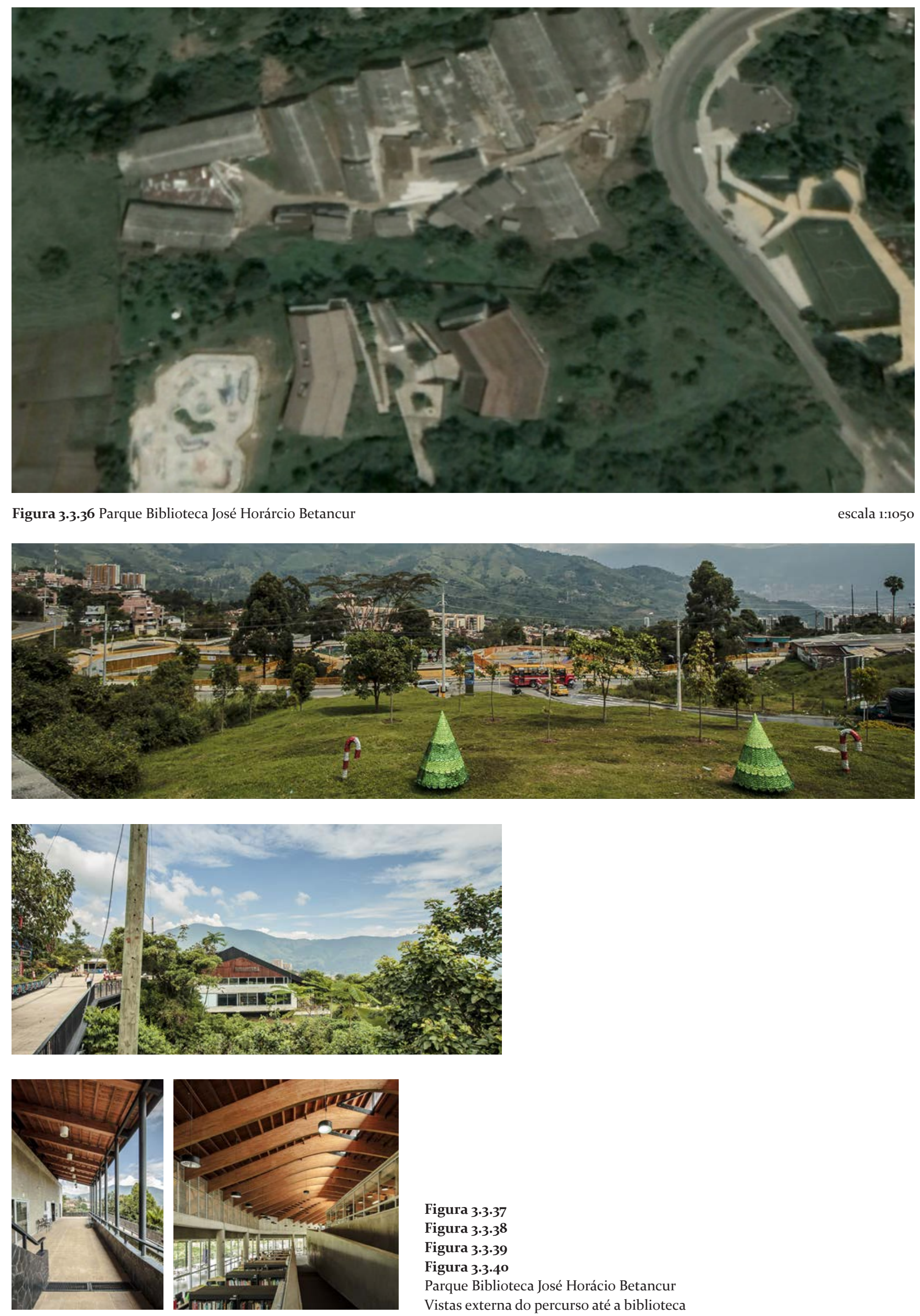

Figura 3.3.37

Figura 3.3.38

Figura 3.3.39

Figura 3.3.40

Parque Biblioteca José Horácio Betancur

Vistas externa do percurso até a biblioteca 

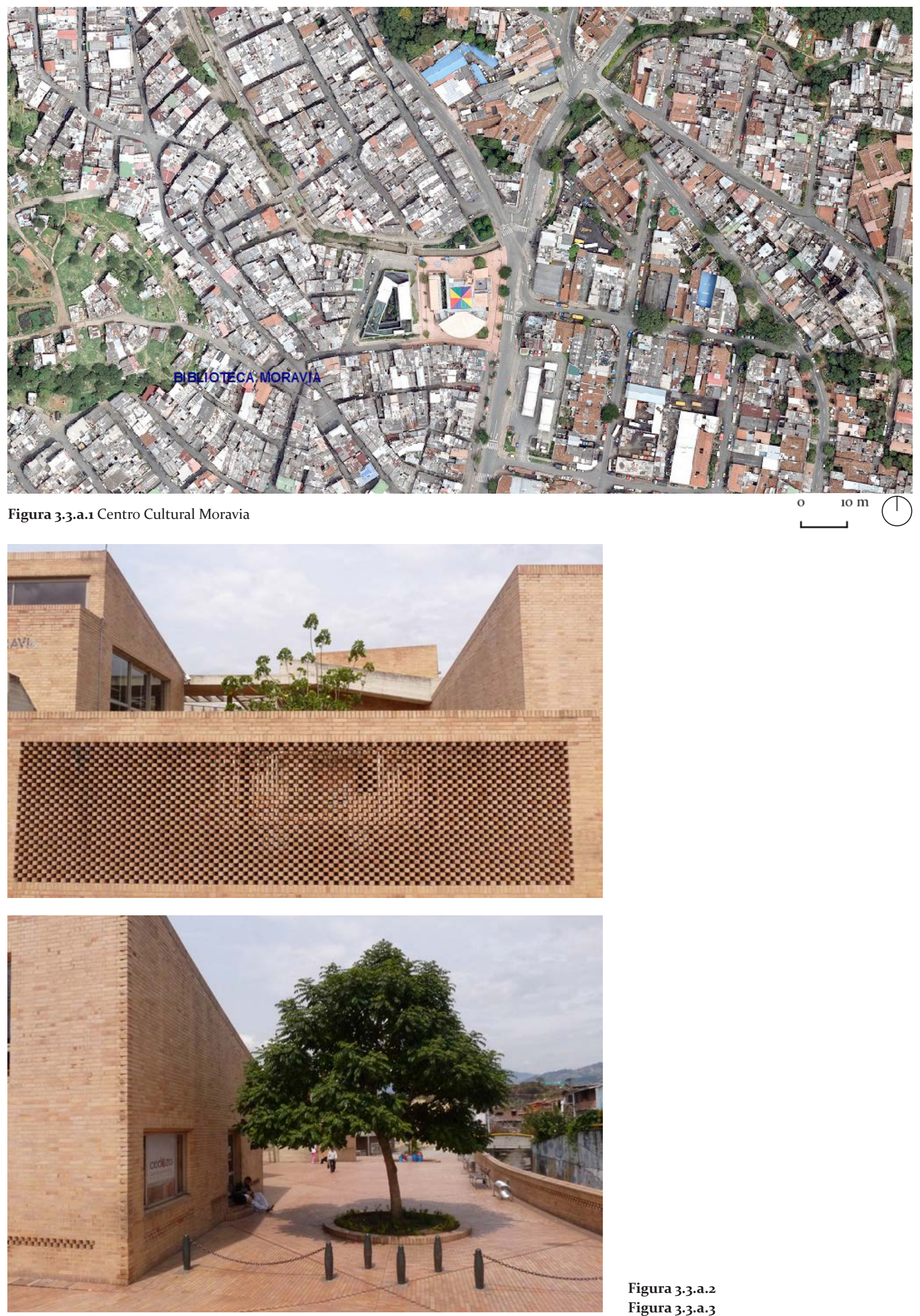

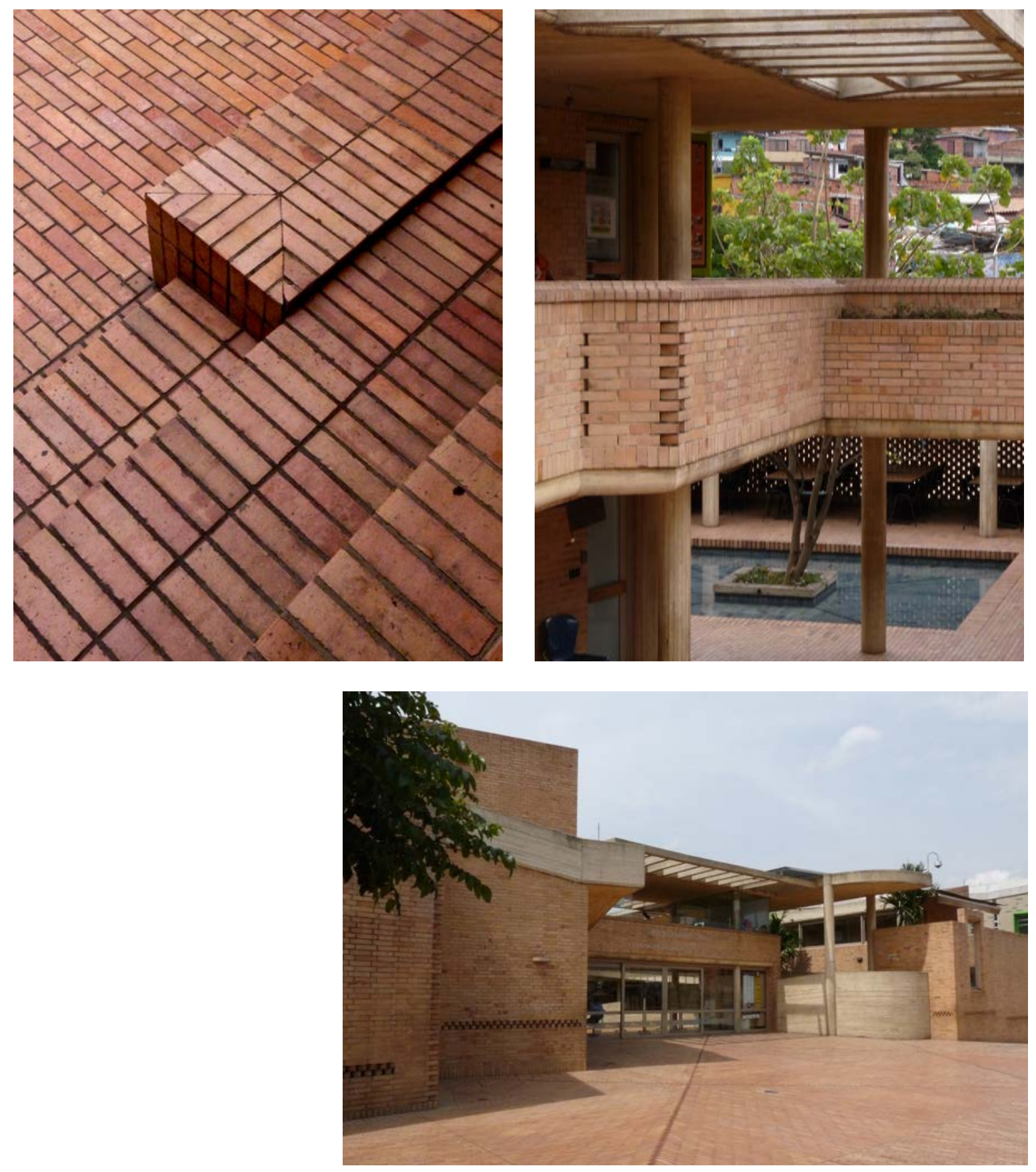

Figura 3.3.a.3

Figura 3.3.a.4

Figura 3.3.a.5

Figura 3.3.a.6

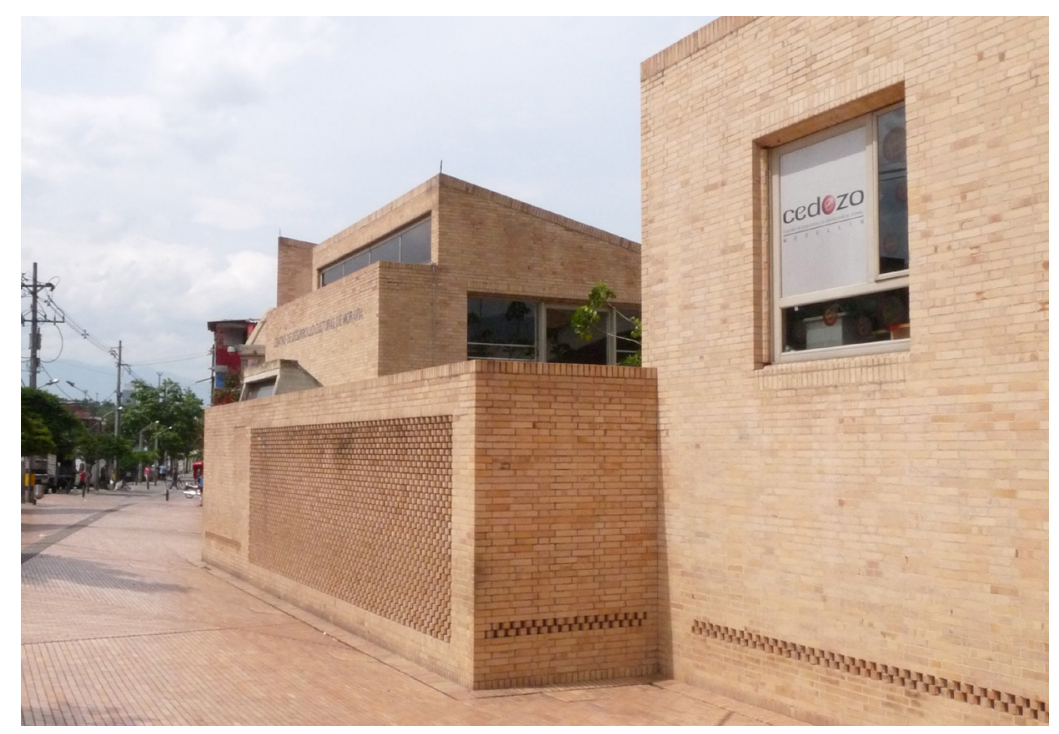


Painel 3.4 Parque Lineal Ciudad Del Río

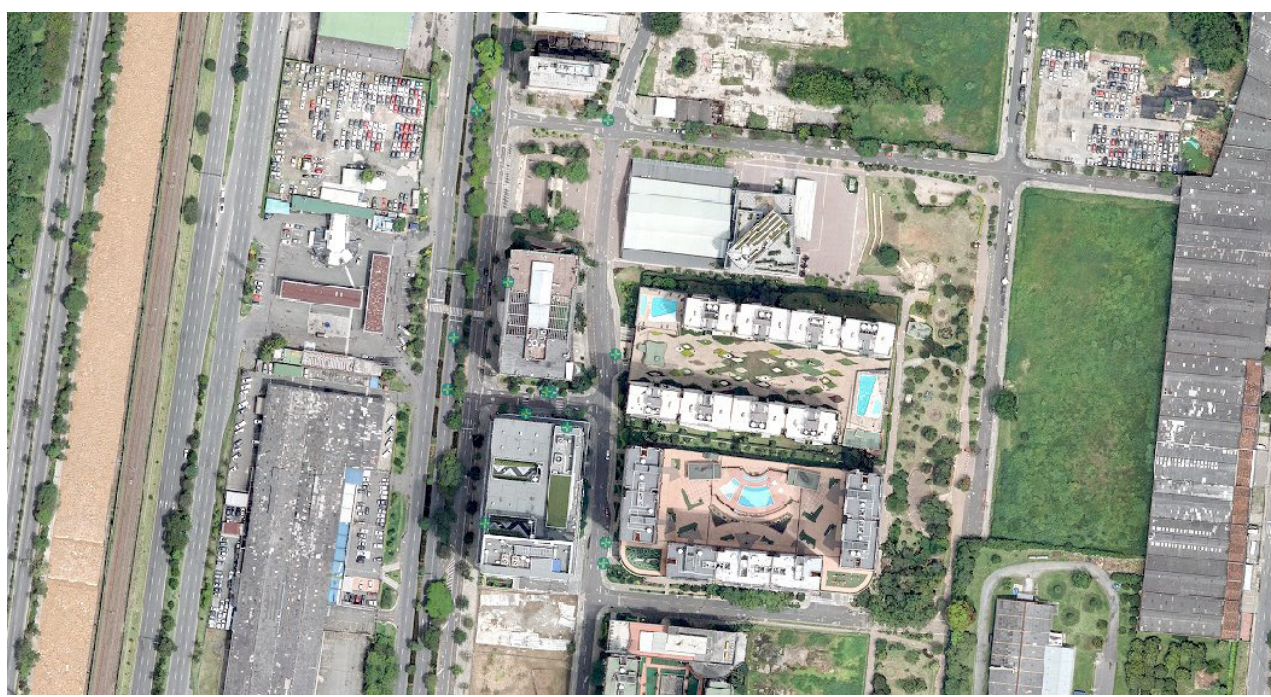

Figura 3.4.1 Parque Lineal Ciudad Del Río
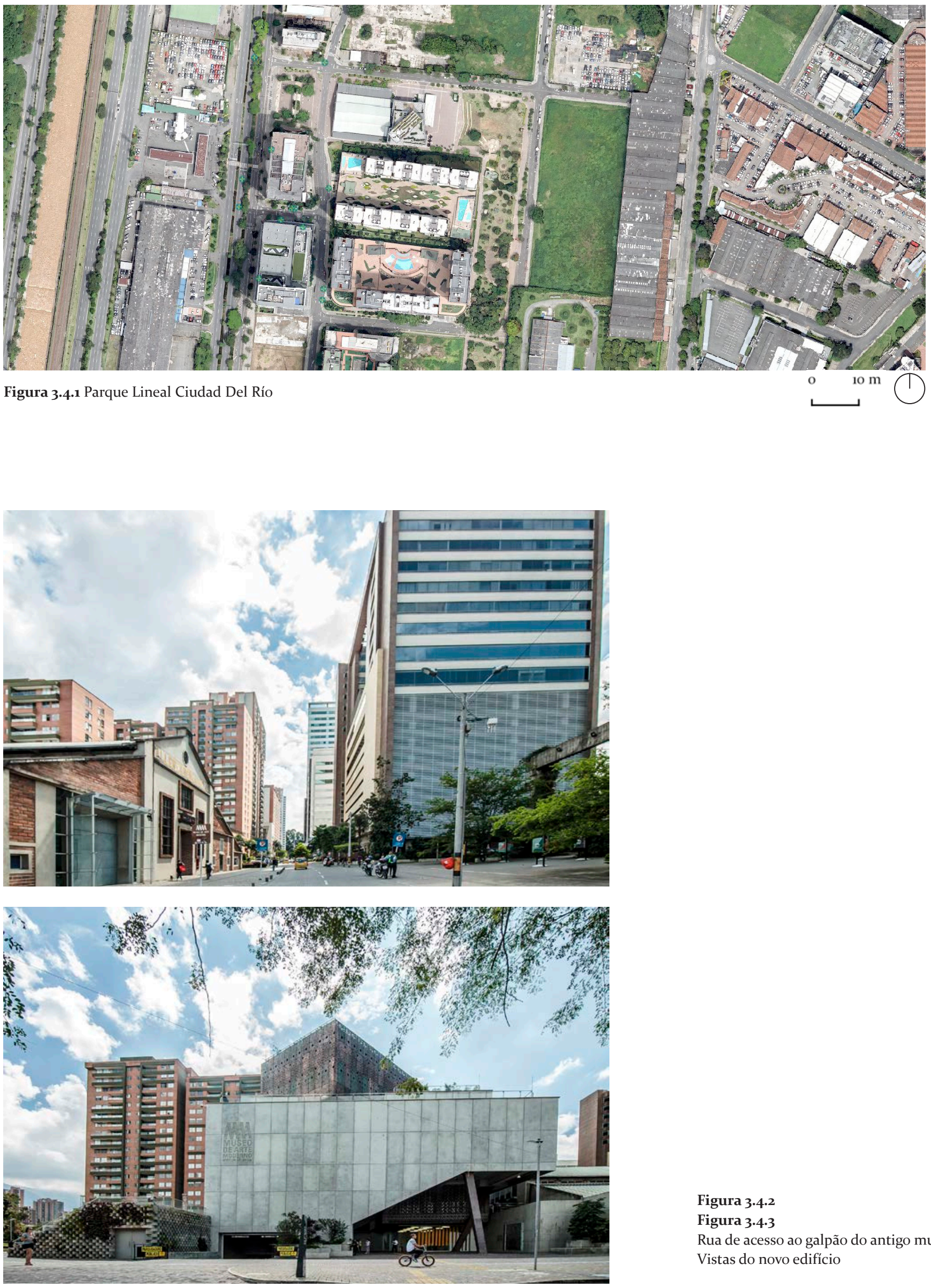

Figura 3.4.2

Figura $3 \cdot 4 \cdot 3$

Rua de acesso ao galpão do antigo museu Vistas do novo edifício 
Figura 3.4.4

Figura 3.4.5

Área de intervenção

durante a construção do parque e uma vista atual

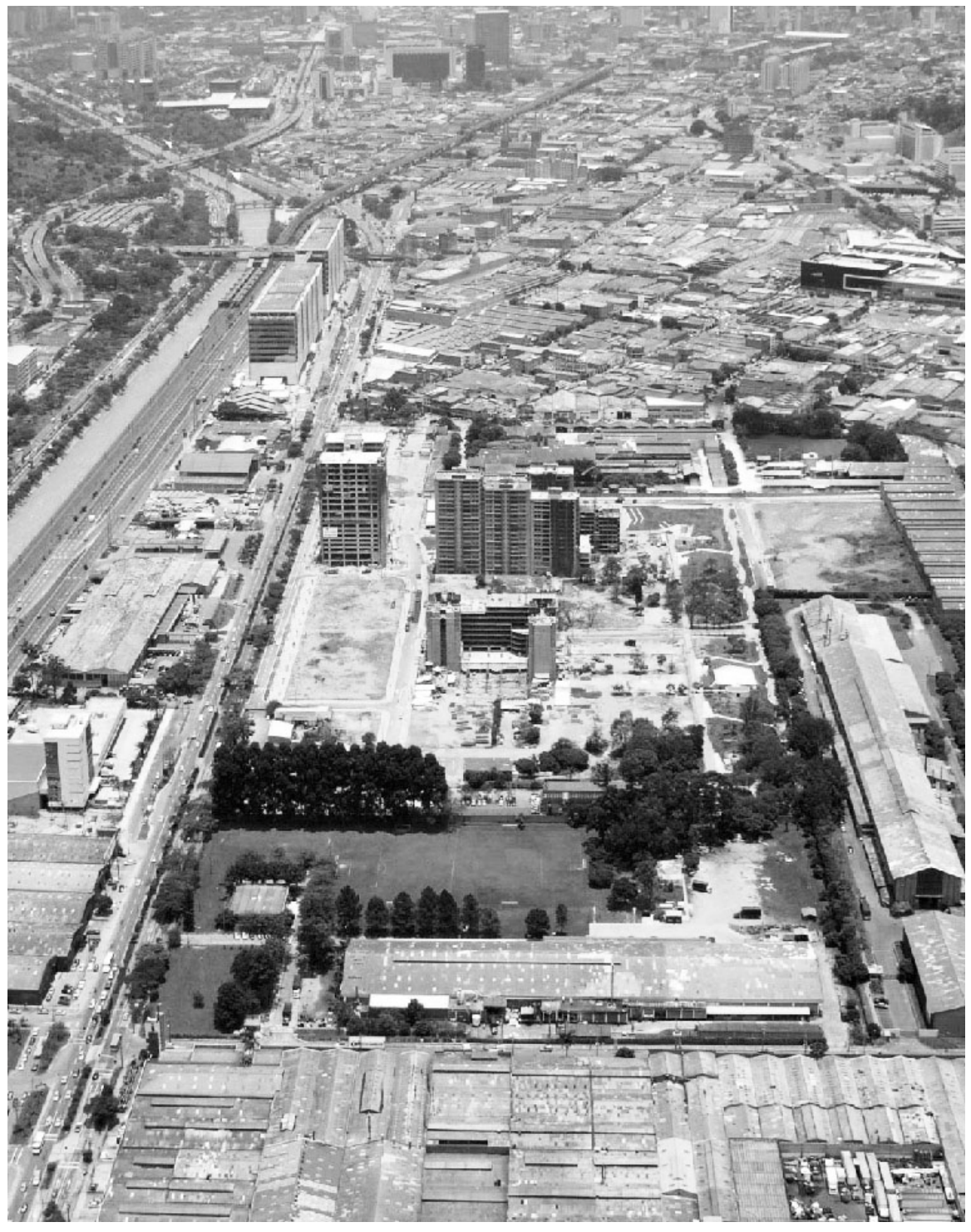

em um fim de semana

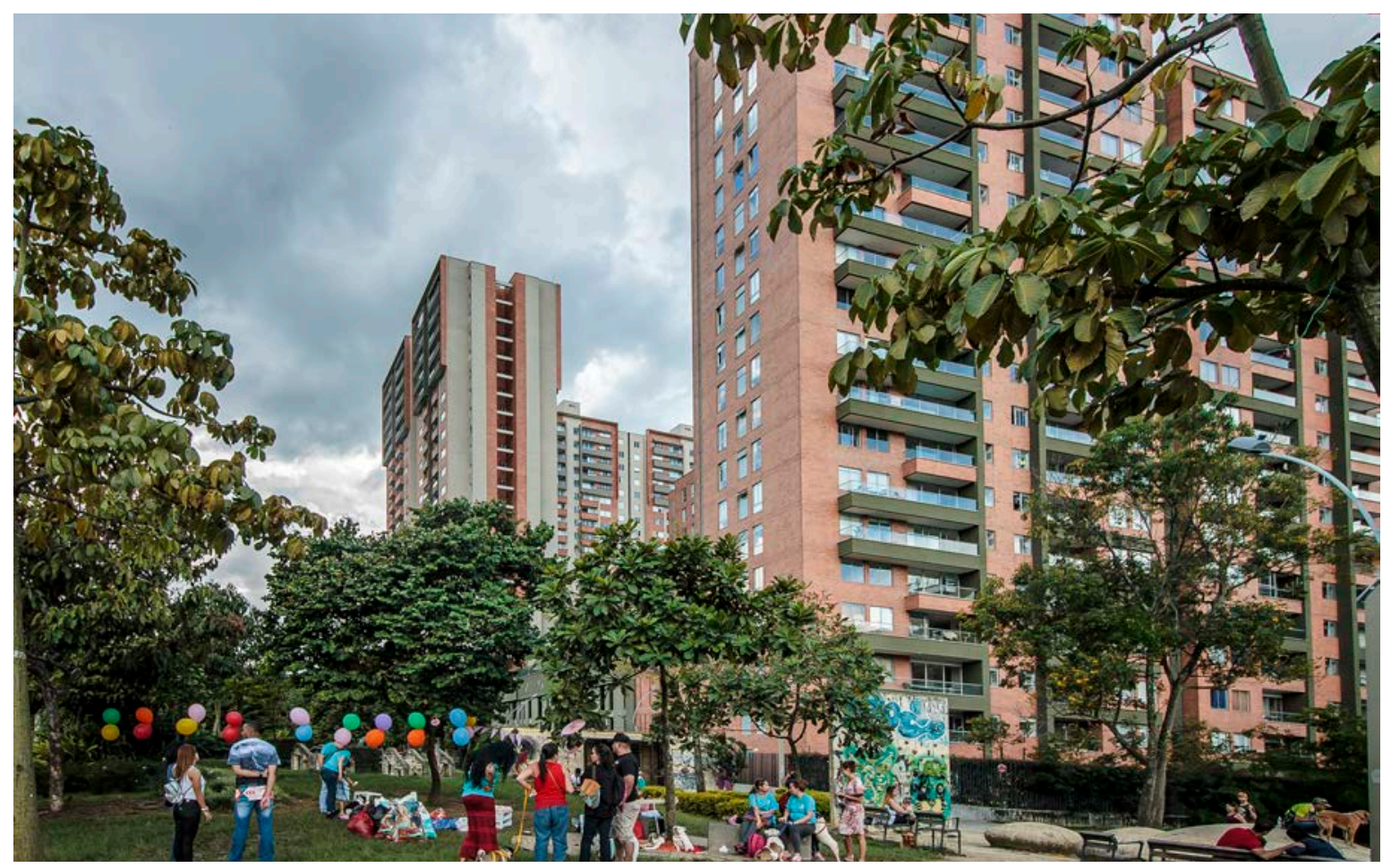


Figura 3.4.6

Figura 3.4.7

Parque Lineal Ciudad del Rio

Novos empreendimentos imobiliários ao

fundo do parque
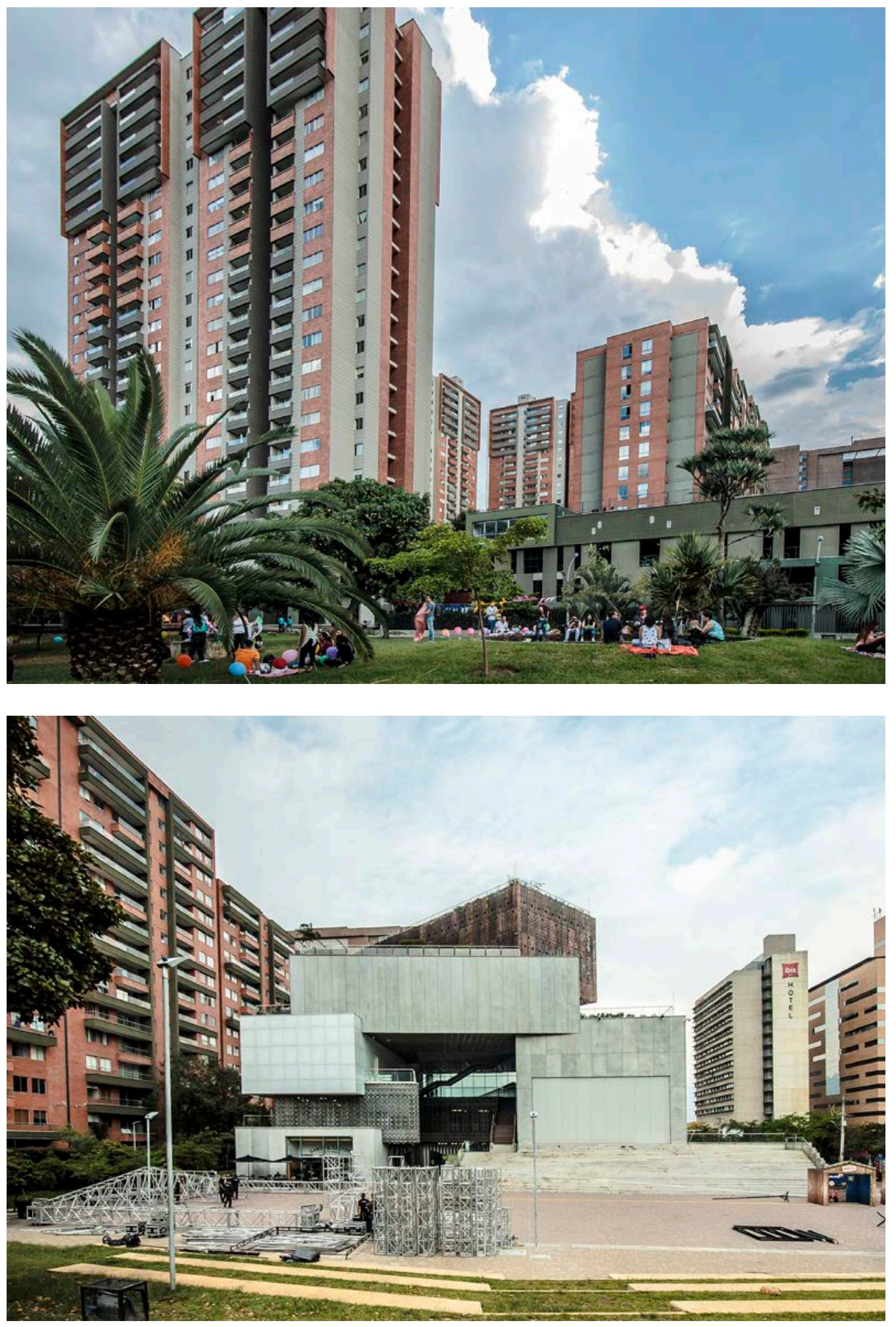


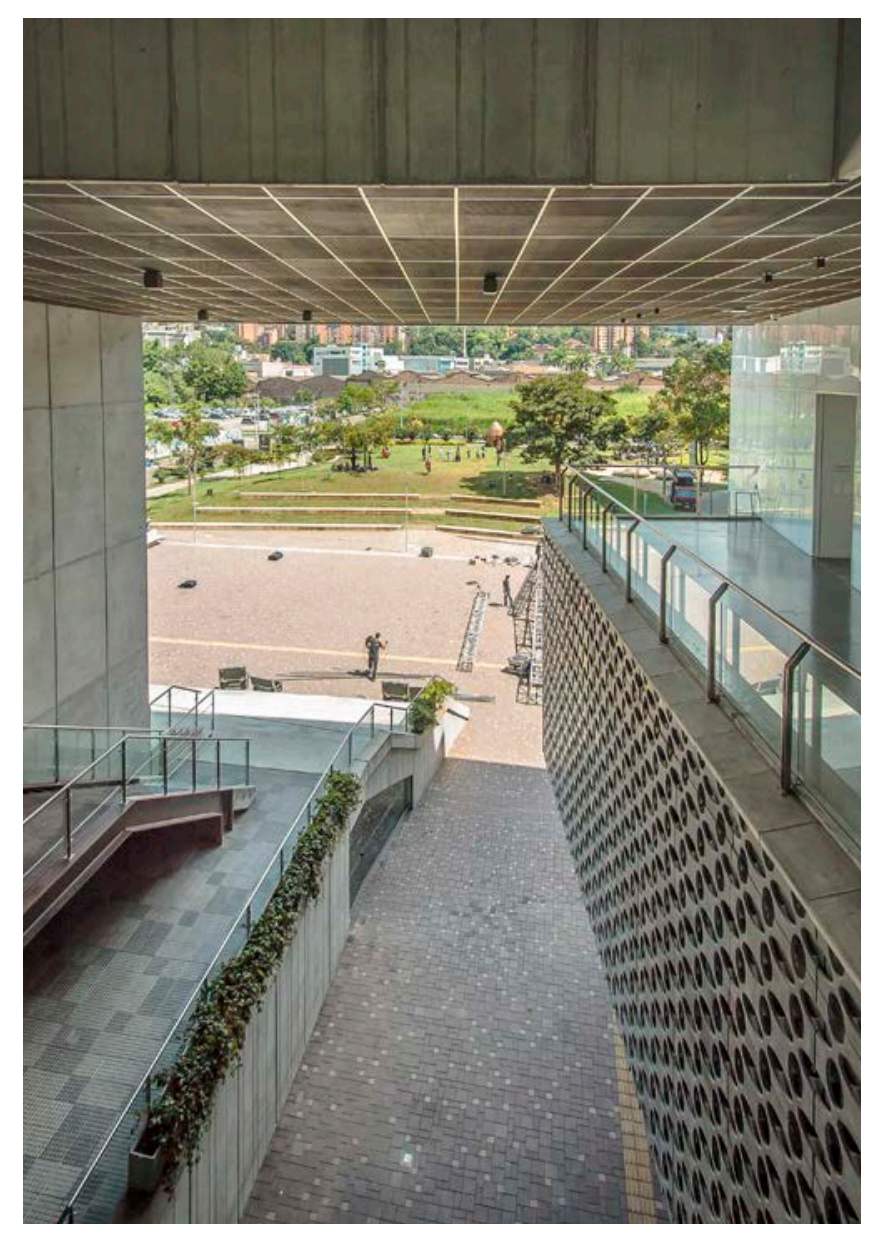

Figura 3.4.8

Figura 3.4.9

Museu de Arte Moderno de Medellín Permeabilidade do térreo e escadas que dão

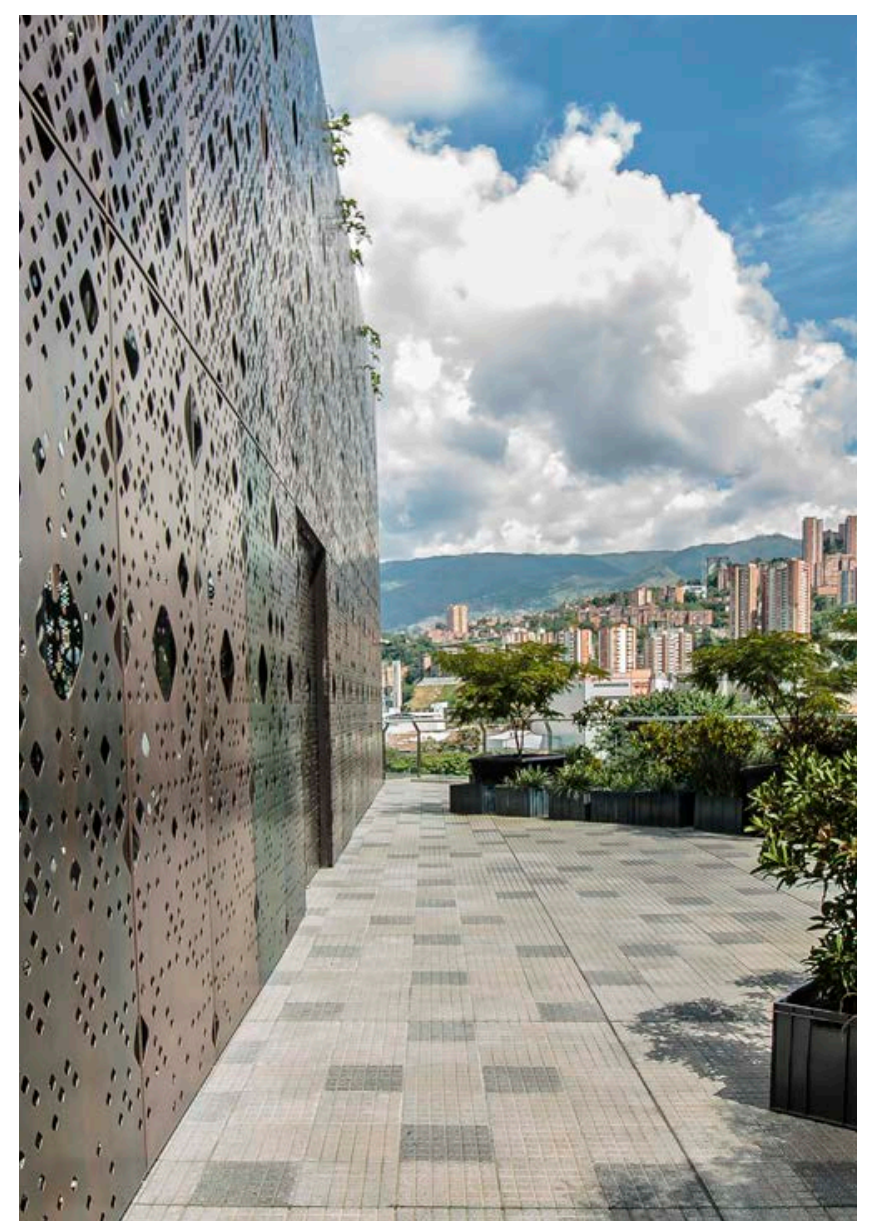


Painel 3.5 Quebrada Juan Bobo
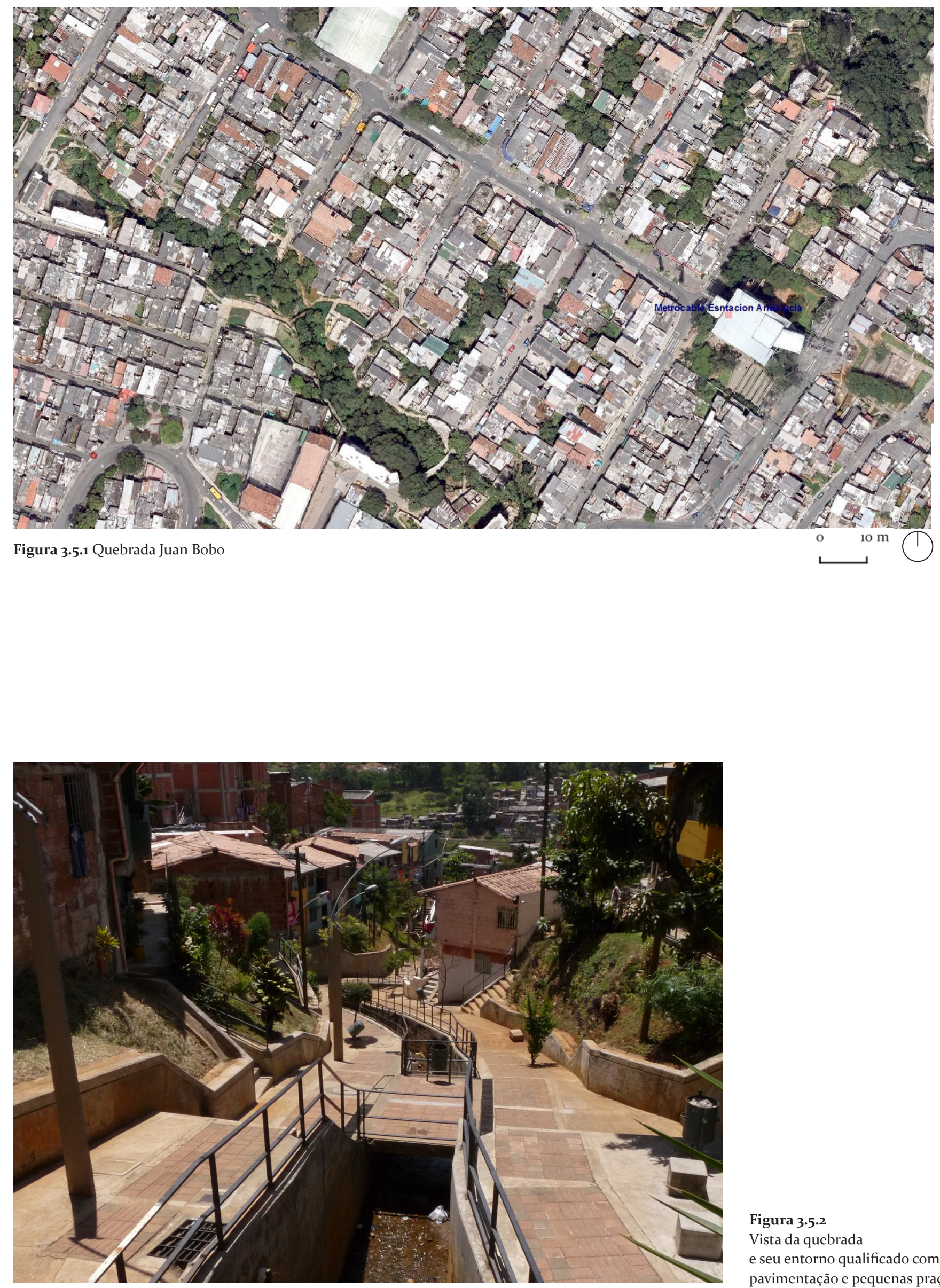

Figura 3.5.2

Vista da quebrada

e seu entorno qualificado com pavimentação e pequenas praças 

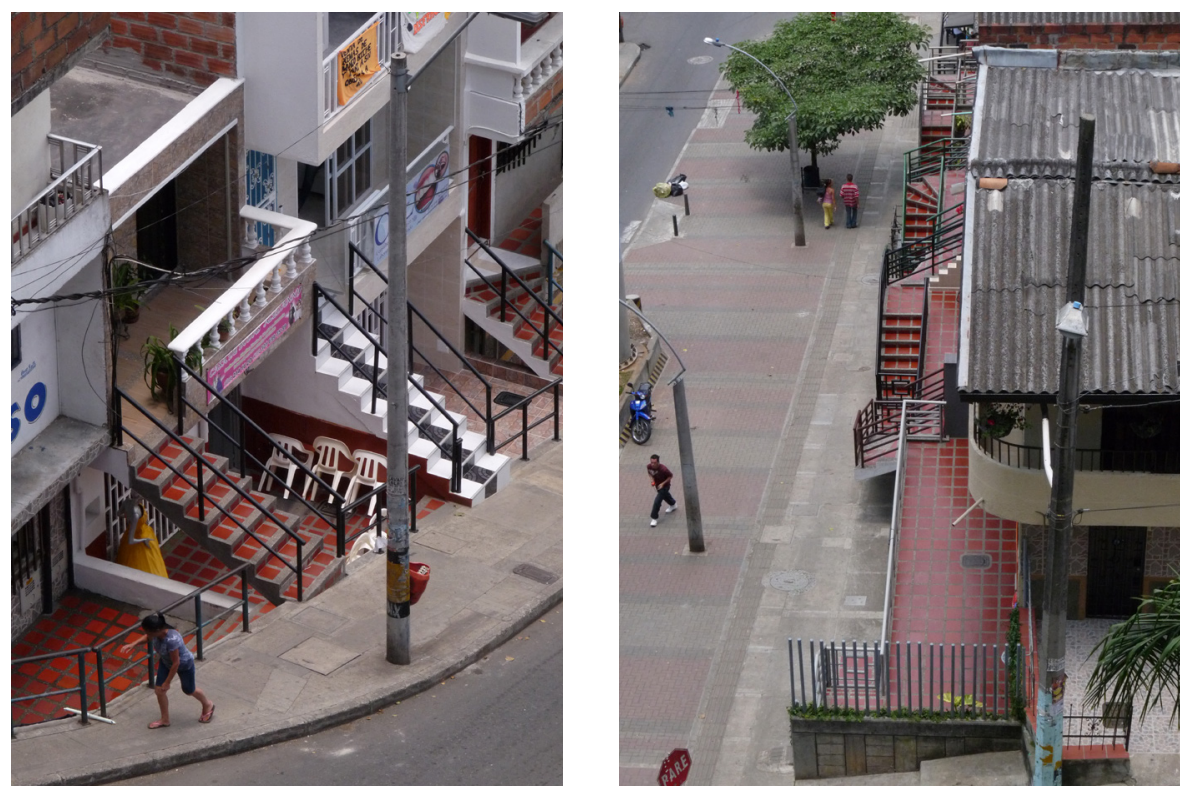

Figura 3.5.3

Figura 3.5.4
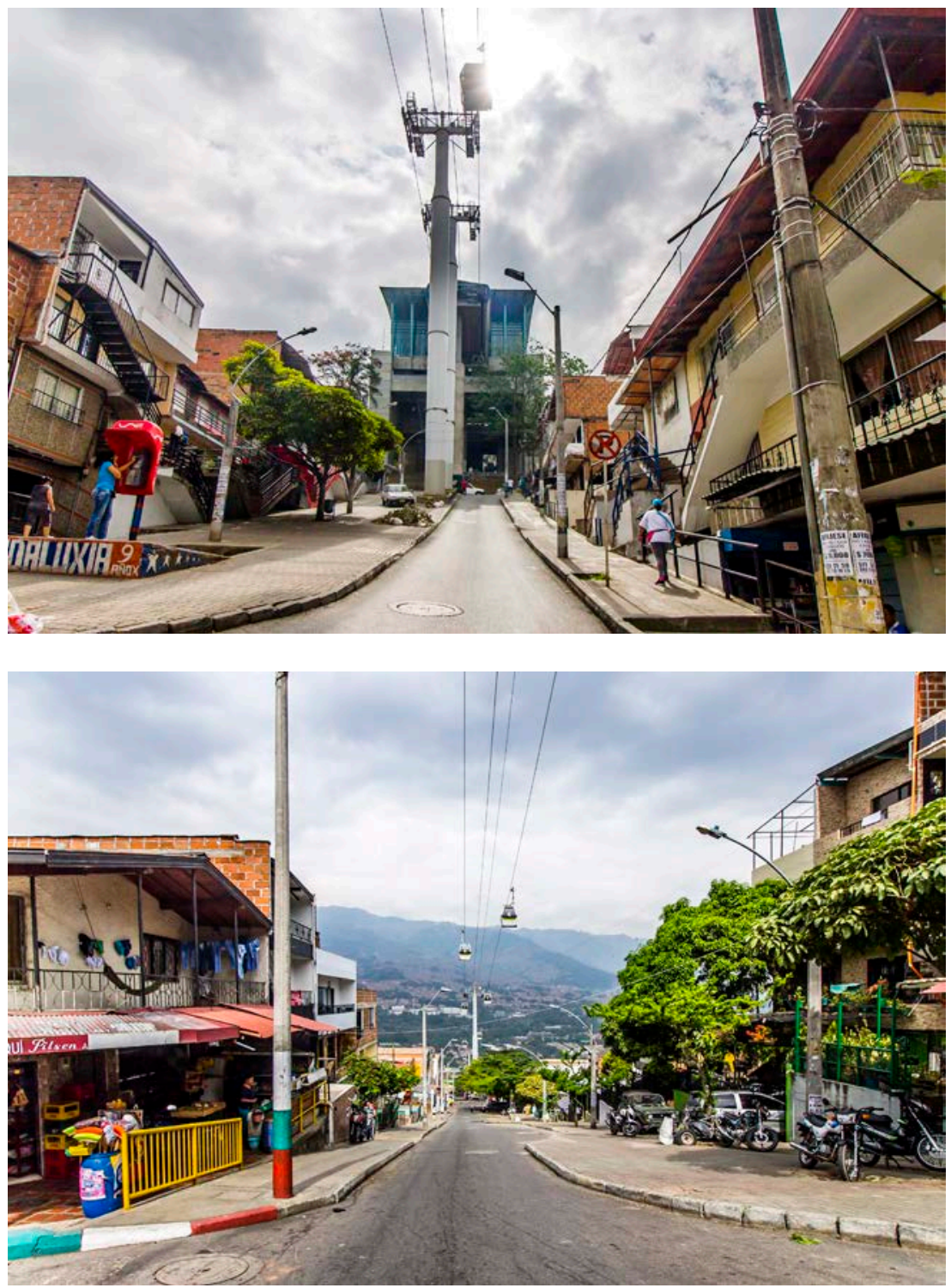

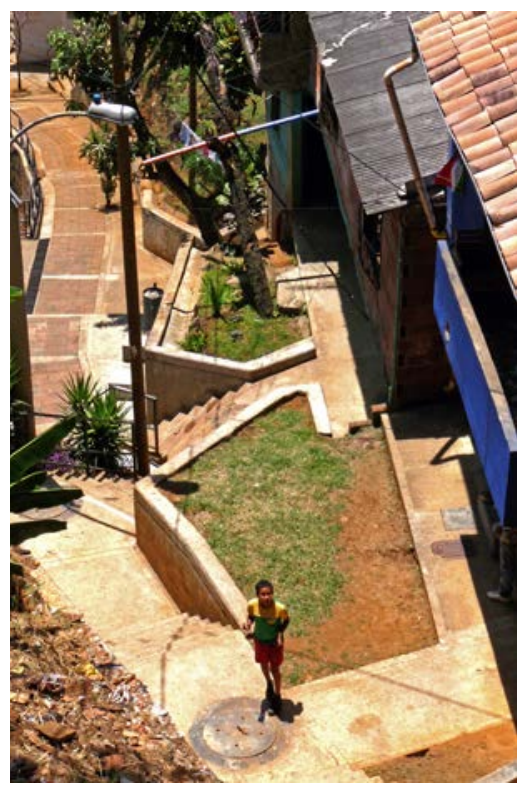

Figura 3.5.5

Casas no entorno da quebrada Juan Bobo A intervenção criou um sistema de acessos às casas com terraços compartilhados que se acomodam à topografia
Figura 3.5.6

Figura $3 \cdot 5 \cdot 7$

Calle 107

Eixo por onde passa o metrocable

As casas e os pequenos lotes comerciais receberam intervencões pontuais como a melhoria da calçada, dos acessos e das escadas 

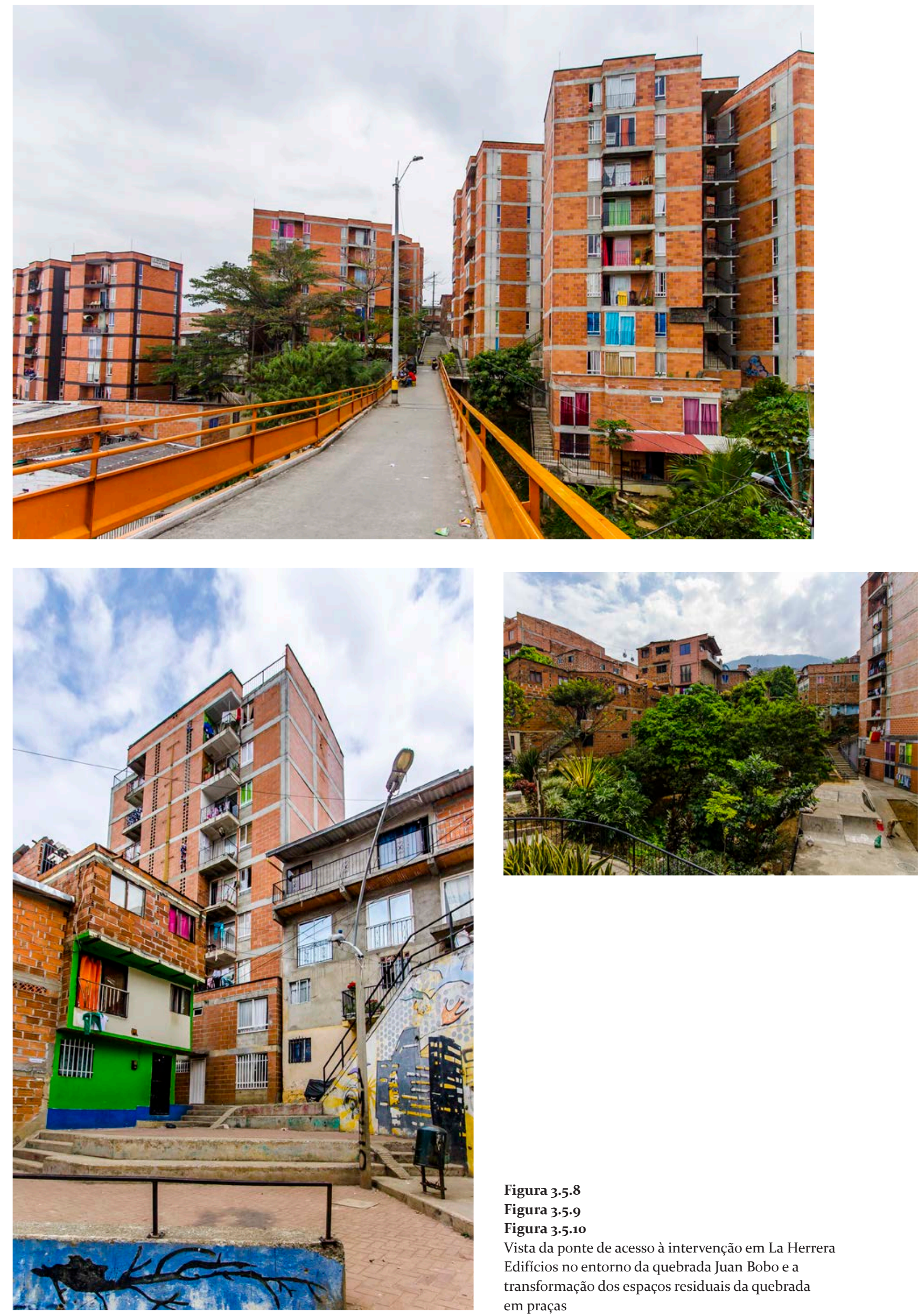

Figura 3.5.8

Figura 3.5.9

Figura 3.5.10

Vista da ponte de acesso à intervenção em La Herrera

Edifícios no entorno da quebrada Juan Bobo e a

transformação dos espaços residuais da quebrada

em praças 

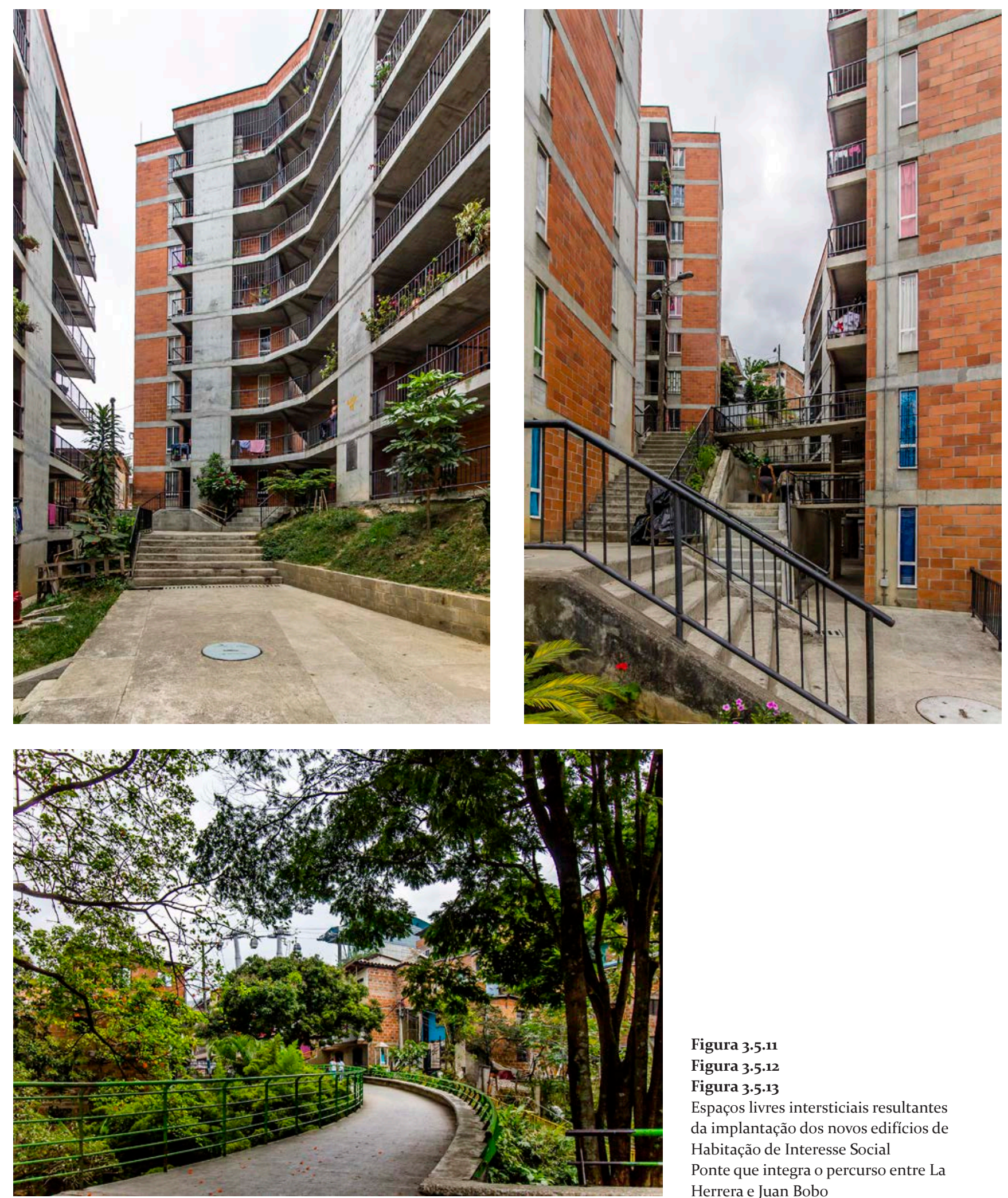

Figura 3.5.11

Figura 3.5.12

Figura 3.5.13

Espaços livres intersticiais resultantes da implantação dos novos edifícios de Habitação de Interesse Social

Ponte que integra o percurso entre La Herrera e Juan Bobo 
Assim como em Medellín, São Paulo produziu suas próprias formas de segregação socioespacial. Nas análises desenvolvidas por esse trabalho, a evolução da estrutura urbana dessa cidade foi percebida em seu estreito vínculo produtivo entre a cidade formal e a informal. Essa percepção se sustenta no processo que se deu ao fim da Segunda Guerra mundial, com a extensão do assalariamento, o acesso por ônibus à terra distante e barata da periferia, conforme aponta Mautner (1999, p. 248).

Segundo a autora, assim se configurou um sistema de produção de cidade que associou o loteamento popular ao ideário da casa própria, viabilizando-o por meio da autoconstrução. Essa se tornou a forma predominante de assentamento residencial da classe trabalhadora, como um modelo empobrecido de suburbanização norte-americana. A posse da casa própria, por sua vez, assegurou o acesso ao crédito para a compra dos bens duráveis recém-instalados no país, de modo que a modernidade foi incorporada à precariedade urbana da periferia.

Os loteamentos à margem da legalidade urbanística estabelecida expandiram ainda mais esse mecanismo de produção de cidade. E, pelo trabalho irregular e recursos técnicos precários, reproduziram um espaço urbano que também foi incorporado à cidade. A dura conquista de infraestrutura demandada aos governantes locais, acabou por promover a valorização e decorrente especulação imobiliária dessas áreas. Esse processo implicou a expulsão de muitos moradores, que se puseram a iniciar novas periferias em localidades ainda mais distantes, de modo que esse ciclo se renovou continuamente, conforme explica Mautner (1999).

Mas, se a integração econômica e produtiva desses processos é um dado claro, a sua correspondência na dimensão socioespacial aparece com o sinal trocado. Isto é, uma urbanização excludente, que estigmatiza e separa os cidadãos em diferentes estratos, ainda que todos estes estejam economicamente integrados. Sabemos que isso se deu de forma generalizada no Brasil, pelos níveis mínimos em que se garantiu a reprodução da força de trabalho. E com a total conivência do Estado e das elites econômicas que condicionam os rumos do país, dentro de um liberalismo econômico com suas particularidades locais. Isso diz respeito, afinal, a um problema de hierarquização e dominação social histórico e estrutural, como sintetiza Marilena Chauí (1986, p. 47-48):

\footnotetext{
O Brasil é uma sociedade autoritária, na medida em que não consegue, até o limiar do século XXI, concretizar sequer os princípios (velhos de três séculos) do liberalismo e do republicanismo. Indistinção entre o público e o privado, incapacidade para tolerar o princípio formal e abstrato da igualdade perante a lei, combate da classe dominante às ideias gerais contidas na Declaração dos Direitos do Homem e do Cidadão, repressão às formas de luta e de organização sociais e populares, discriminação racial, sexual e de classe, a sociedade brasileira, sob a aparência da fluidez (pois as categorias sociológicas, válidas para a descrição das sociedades europeias e norte-americanas, não parecem alcançar a realidade social brasileira), estrutura-se de modo
} 
Assim, essa sociedade que se define entre dominantes e dominados, reproduz separações e segregações, não somente entre centros e periferias, mas em todas as formas de interação socioespacial. Percebemos como a pobreza local e a dívida social - que reproduz estruturas da ordem internacional - encontra dificuldades de superação advindas, também, de barreiras históricas que impossibilitam a constituição do pacto social brasileiro.

Desse processo se origina grande parte da violência urbana e a dificuldade de se construir um espaço comum e democrático. Das origens desse processo social, passamos também às formas como ele se reproduz nas instituições, nas ações e nos espaços cotidianas. Isso se agrava e amplia no processo de modernização brasileiro, após as frustrações do projeto desenvolvimentista, a partir dos anos 1980. Isso porque essa crise econômica irá fazer decair socialmente o poder econômico da população, mas afetará, particularmente, a classe média. A perda de qualidade de vida e de benefícios ativará uma série de reações, que incluem a rejeição às classes mais baixas e a necessidade de diferenciação e de afastamento das mesmas. Esse processo traz ao cenário contemporâneo o acirramento, não só das diferenças, como também das representações dessas diferenças entre as classes. Algo que passa pela leitura da violência e da segregação e do modo como o discurso sobre esses temas se propaga:

\begin{abstract}
A fala do crime e o crescimento da violência na São Paulo atual indicam a existência de intrincadas relações entre violência, significação e ordem, nas quais a narração tanto combate quanto reproduz a violência. (...) A fala do crime é produtiva, mas o que ela ajuda a produzir é a segregação (social e espacial), abusos por parte das instituições da ordem, contestação dos direitos da cidadania e, especialmente, a própria violência. Se a fala do crime gera ordem, esta não é uma ordem democrática, igualitária e tolerante, mas exatamente o seu oposto. A democracia tem a ver com a abertura e indefinição de fronteiras [...], não com enclausuramentos, fronteiras rígidas $e$ distinções dicotomizadas. (CALDEIRA, 2011, p. 43-44)
\end{abstract}

Assim, vemos que na contemporaneidade a transformação do processo de segregação socioespacial, que originalmente surge como dicotomia centro-periferia, passa a se amplificar em outras escalas e circunstâncias. Assistimos à construção de intrincados discursos e manifestações socioespaciais que promovem a distinção e a separação de classes intrabairros, interlotes, superando a questão inicial, se reproduzindo à velocidade impressionante dos condomínios fechados que representam o tipo ideal da "situação social brasileira" (SAFATLE, 2015, p. 12). 
Sobre os condomínios, Teresa Caldeira (1997) esclarece o problema fundamental desse fenômeno que advém da noção de enclave, algo que nega as relações estruturantes que pressupõem a vida citadina:

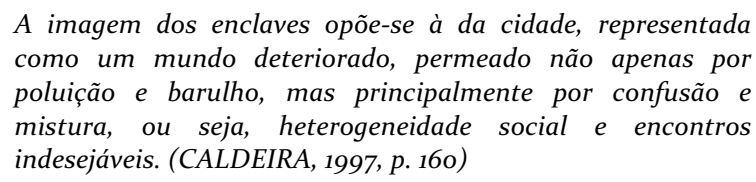

Desse debate, procuramos entender aquilo que caracteriza o condomínio, não como um tipo de loteamento, reduzido a peculiaridades de controle da organização espacial e rigor no gerenciamento e apropriação dessa ocupação urbana, mas como atributos formais e relacionais que o separam da lógica da cidade. Esses aspectos dizem respeito a matéria manipulada pela A\&U, como transições de acesso, dimensionamento de espaços vazios ou a invenção de distintas formas de bloqueio (reais e simbólicos), elementos típicos utilizados na condominialização dos espaços:

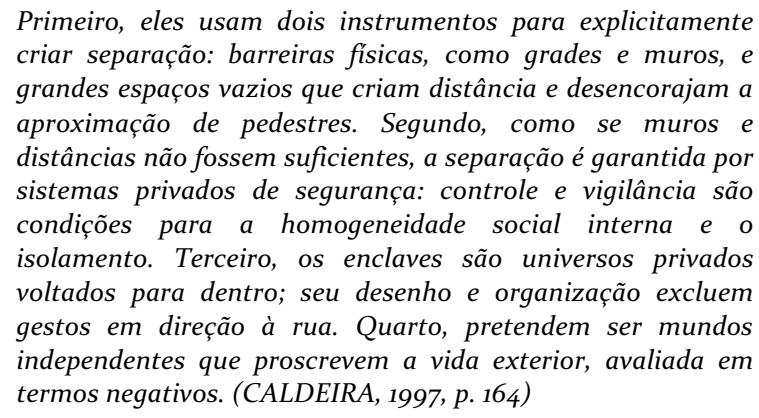

A pressuposta independência entre mundos internos e externos, na lógica da conformação desses espaços, é uma distorção da realidade cuja gravidade se sobrepõe à problemática demarcação literal da diferença por muros e grades. Ela exprime a falência da sociabilidade brasileira, que, fraturada, dá sinais de sua enfermidade até mesmo no controlado mundo recriado intramuros:

\footnotetext{
Apensar do marketing insistente das numerosas instalações para o uso comum em todos edifícios e condomínios em que fiz pesquisas seu uso é muito baixo, com exceção dos playgrounds. Talvez isso reflita como os moradores se sentem pouco à vontade com a ideia de partilhar um espaço residencial, uma coisa que os anúncios tentam rebater sugerindo que a sociabilidade seria possível "sem inconveniência” e que a densidade da população é baixa. [...] Só as crianças parecem desenvolver sua sociabilidade nos condomínios, mas mesmo isso parece não sobreviver depois que elas desenvolvem outras relações em suas escolas particulares ou nos clubes que as famílias não deixam de frequentar. (CALDEIRA, 2011, p. 268)
}

Dunker, ao analisar o caso modelo dos condomínios brasileiros, elege Alphaville como seu maior representante, que se configurou em 1973 com a aquisição de uma vasta área nos arredores de São Paulo. Para o autor, de um modo um tanto irônico, esse modelo tornou-se, depois de 
Brasília, um signo maior de nossa capacidade de planejamento e construção de novas formas de vida (DUNKER, 2015, p. 48). Isso porque o condomínio, com suas especificidades brasileiras, se tornou o antídoto aos problemas de convivência entre classes, que advém de nossa dívida social histórica:

\begin{abstract}
Ao contrário das gated communities norte-americanas, que se baseiam no conceito de comunidade anterior, ou do condominium anglo saxônico, derivado do uso e da propriedade estabelecida, o estatuto português e brasileiro do condomínio provém do conceito de defesa, cujo modelo é o forte de ocupação. Não se trata aqui de portões, que restringem e orientam a circulação de pedestres, ou de cercas, que delimitam simbolicamente o pertencimento e a obrigação de cuidado do território, mas de muro de defesa, cujo objetivo militar é impedir a entrada, ocultar a presença de recursos estratégicos e facilitar a observação do inimigo.
\end{abstract}

Sobre essas mesmas bases de separação defensiva, podemos ver as relações espaciais e temporais fluidas da contemporaneidade disseminarem padrões de sociabilidade análogos. Como demonstra Dunker (2015, p. 42), estendendo a leitura psicanalítica e antropológica para uma crítica social, é possível identificar a formação de uma patologia do social brasileiro, mais clara a partir dos anos 1970, que se manifesta com a vida em forma de condomínio. Ela caracteriza uma unidade espacial contemporânea de inserção do nosso mal-estar no capitalismo à brasileira. O autor chamará de lógica de condomínio o sintoma de nossa modernidade, que se amplia e se replica de maneira atualizada. Dunker estabelece assim, uma leitura sobre a lógica da formação do condomínio que relaciona a dimensão espacial à comportamental. Desse modo, a segregação surge, primeiramente, do fracasso em articular a diferença e a divisão. Por isso se torna necessário estabelecer muros, fronteiras, marcas que fixam o lugar dentro e o lugar fora, as zonas de passagem e as zonas de interdição.

Surge, em seguida, uma nova divisão. Dessa vez, entre o espaço produtivo e o espaço reprodutivo. Por vida reprodutiva entenda-se um conjunto de procedimentos securitários, morais, estéticos, higiênicos, alimentares, bem como um conjunto de cuidados, atenções, disposições, atualizações, advertências e um conjunto de encargos, taxas, obrigações "necessárias" para a vida continuar a funcionar. A função do síndico é também importante, na medida em que ele se põe a gerir o sofrimento da vida em espaço reprodutivo para torná-los formas palpáveis de insatisfação, que ele poderá administrar. $\mathrm{O}$ síndico não se ocupa do espaço produtivo, mas do espaço no qual a vida se reproduz, se repõe, se restaura. Sua função é mostrar que onde lemos apenas variações amorfas e modalidades de vida há um potencial de uso e de consumo (DUNKER, 2017, p.55).

Nesse processo conectam-se os problemas da sociabilidade brasileira - ainda sem resolução - às atenuações oferecidas pela lógica de consumo, que só acirram individualidades em direção à total abstração da dimensão coletiva. Algo que torna cada vez mais difusa a 
compreensão da interdependência da vida em sociedade e das concessões intrínsecas ao convívio coletivo.

Do individual ao corpo social, Dunker (2017, p.68) nos leva a perceber, por fim, no problema do condomínio enquanto enclave fortificado contra a pobreza, uma aproximação do fenômeno que Milton Santos (1999) chamou de pobreza incluída. Ele seria o sinal de uma nova interpretação sobre a diferença social e a desigualdade: não se trata mais de fazer desenvolver os atrasados, mas de localizar e conter o resíduo da pobreza estrutural globalizada.

Esse roteiro foi percorrido para subsidiar a compreensão da amplificação da segregação socioespacial. Visto que ela se desdobrou nos diferentes níveis da vida, atingindo a produção e a reprodução do espaço social brasileiro. Isso se torna matéria fundamental do campo de ação da $A \& U$, na medida em que toda fronteira, todo limite espacial, se torna um exercício de reinterpretação dos processos de inclusão e exclusão social, na exata amplitude desses termos.

Ao se analisar a disciplina em contato com os influxos do cotidiano, têm-se como horizonte avaliar suas contribuições para a necessária reconciliação desse mundo coletivo, criando as condições para uma nova urbanidade, para um novo pacto social. Esta é, talvez, sua maior incumbência no mundo contemporâneo. E, aqui, se torna importante fonte de questionamentos aos projetos selecionados: as estratégias de desenho favorecem a criação de enclaves ou de conciliações entre o mundo externo e o interno?

\section{CEUs, 2001}

Os CEUs são retomados aqui pelas suas afinidades programáticas com os projetos de Medellín. E, também, porque representam uma tipologia arquitetônica e uma estratégia de intervenção urbana, que sintetiza abordagens comuns a uma parte significativa dos projetos paulistas analisados: blocos funcionais que constituem um conjunto arquitetônico. O desenho tende assim a confiar à importância dos equipamentos de cultura e educação e à sua potência simbólica, a construção da urbanidade, algo que deveria irradiar-se a partir do lote de intervenção.

Aos edifícios dos CEUs coube a solução do problema funcional que dá origem aos atributos formais do projeto em blocos. Esses, também evocam a racionalidade estrutural, que busca a legibilidade e austeridade dos objetos prismáticos do conjunto arquitetônico. Com isso, parece atribuir ao terreno funções de suporte, ainda que carregadas de expectativas de apropriação, porque torna-o pano de fundo do sistema de objetos arquitetônicos. Sem prever - ou se abstendo em promover uma reação - às dinâmicas contraditórias socioespaciais de seu entorno. Por fim, o conjunto arquitetônico acaba encerrado por grades.

Esse destino fatal acomete e frustra diálogos mais francos com a cidade, previstos na ideação do equipamento. Quando da reafirmação do perímetro do lote por dispositivos de contenção de acesso, por 
vezes, o que resta ao urbano é um contorno de exíguas calçadas. Até mesmo quando da incorporação de áreas verdes e recreativa à área de intervenção, a funcionalização desses espaços dentro do conjunto de atividades escolares, faz desse potencial uso qualificador do tecido urbano algo que deve permanecer gerenciada dentro da área de acesso controlado.

As diferentes estratégias de implantação, enfrentando as situações topográficas e os contextos urbanos variados e as decorrentes relações espaciais exploradas, vinculam-se a arranjos ortogonais, a acomodação das praças em platôs de diferentes níveis e a incorporação de recursos como rampas e escadas às áreas livres.

Em que pese o fato das escolhas projetuais estarem vinculadas a uma série de condicionantes e dificuldades anteriormente discutidas por esse trabalho, o problema posto pelos CEUs propicia a formulação de algumas perguntas: estaria a transformação socioespacial garantida somente pela existência das novas oportunidades e vivências ofertadas pelo espaço interno ao equipamento? Quais seriam as contribuições da arquitetura, quando encerrada por portões, a esse campo de forças do urbano?

Pondera-se que os 21 primeiros CEUs foram construídos, ocupando grandes terrenos entre $10.500 \mathrm{~m}^{2}$ e $70.000 \mathrm{~m}^{2}$, variando de $12.000 \mathrm{~m}^{2}$ a $14.000 \mathrm{~m}^{2}$ de área construída. Isso é uma porção significativa do tecido urbano. O complexo de equipamentos, em suas diferentes implantações, resultou da articulação dos mesmos cinco elementos: três edificações (blocos funcionais), um conjunto de três piscinas e duas torres dos reservatórios de água. $\mathrm{O}$ maior bloco funcional é o didático $^{119}$, um prisma retangular de 140x21,80m de largura com dois pavimentos, o bloco cultural e esportivo é também um paralelepípedo de 45×21,8om com quatro pavimentos, já o bloco da creche é um volume cilíndrico de 22,5 metros de diâmetro e um pavimento.

Sem dúvida, os CEUs se tornaram um marco notório no padrão majoritariamente imbricado, de pequenos lotes, nos bairros periféricos da cidade. Foram também amplamente apropriados, o que os levou a serem replicados por outras prefeituras ${ }^{120}$. Proporcionaram um aumento expressivo na oferta de cultura, lazer e esportes, com qualidade de serviços e atrações culturais equivalentes às oferecidas nos melhores centros culturais da cidade. Mas o fizeram por meio das relações espaciais intermediadas pelos seus portões.

\footnotetext{
${ }^{119}$ Além das salas de aula, o primeiro bloco conta com biblioteca, vestiários, e telecentros. O programa cultural é composto por um teatro bem equipado, estúdios de música e gravação, ateliês, espaços expositivos, laboratório de fotografia além de salas multiuso e do conselho gestor. A quadra poliesportiva, os vestiários, o salão de dança e ginástica encontram-se abrigados no mesmo bloco.

${ }^{120}$ Foram construídos equipamentos de educação, cultura e esportes intitulados CEUs em Osasco, Guarulhos e São Bernardo.
} 
O edifício-sede do Projeto Viver (2004: FGMF Arquitetos) foi expressivamente premiado por suas contribuições socioespaciais a uma região carente da cidade de São Paulo ${ }^{121}$. Por isso, torna-se importante objeto de análise para esta pesquisa. Construído por uma associação sem fins lucrativos, formada por colaboradores do Banco Votorantim entre 2003-2006, ele se localiza no Jardim Colombo, que faz parte do complexo Paraisópolis ${ }^{122}$, na zona sul de São Paulo. Essa instituição se tornou um importante e potente núcleo comunitário na sua região, atendendo a uma população que alcança $18 \mathrm{mil}$ habitantes (CALLIARI, 2014).

Como uma plataforma para projetos sociais do banco, a instituição oferece atividades culturais, educacionais e esportivas destinadas a crianças e jovens de 6-18 anos. As crianças frequentam o local no contra turno escolar. Para os jovens, há uma série de programas voltados ao encaminhamento da vida profissional e pessoal. Essas atividades regulares atendem em torno de 300 usuários diariamente.

O espaço que recebe essa potência programática foi concebido pelos seus arquitetos como um conjunto arquitetônico em dois blocos funcionais que organizam o programa. Sendo a área externa definida por 4 praças: uma praça esportiva (a quadra de esportes), uma praça coberta (sob as salas de aula), uma praça plana (no centro, articulando os demais espaços), uma praça em patamares (no acesso, aproveitando a topografia acidentada) e uma praça elevada (na cobertura dos prédios).

O espaço funciona aberto até as $22 \mathrm{~h}$ para uso livre. Atividades aos fins de semana, como festas, aproximam o público jovem aos demais membros da comunidade. Familiares dos frequentadores também buscam diariamente os assistentes sociais da instituição. Normalmente, o fazem diante de problemas e conflitos que podem ser resolvidos com acesso a serviços públicos. Eles encontram, na instituição, um local de aconselhamento sobre seus direitos. E um espaço para conscientização da sua própria cidadania. Isso faz com que esse conjunto arquitetônico não seja somente um centro de cultura, educação e esporte, mas também uma ponte entre o cidadão e o Estado ${ }^{123}$.

Diante da necessidade de subsidiar o funcionamento da instituição, para além dos aportes obtidos por meio do Banco que se demonstravam insuficientes, organizou-se uma atividade de produção de lanches, que podem ser encomendados para empresas ou eventos. Essa atividade comercial criou inúmeros desafios que incluem a adaptação do espaço para atender as regulações de vigilância sanitária e da logística de

\footnotetext{
${ }^{121}$ O projeto ganhou o Prêmio Eduardo Kneese de Melo, IAB-SP, 2005; Menção Honrosa, na Bienal de Arquitetura de Brasília, 2006; e em 2015 ganhou o Prêmio Latino-Americano de Arquitetura Rogelio Salmona.

${ }^{122}$ O Complexo Paraisópolis, composto pelas favelas Paraisópolis, Jardim Colombo e Porto Seguro é a segunda maior favela de São Paulo, com aproximadamente 60 mil habitantes em cerca de 18 mil domicílios (MAZIVIERO; SILVA, 2018).

${ }^{123}$ As informações sobre as demandas da população, a adaptação e o uso do espaço, assim como a rotina do Projeto Viver baseiam-se no depoimento de Gládis Andréia de Oliveira, gerente da instituição, entrevistada pela autora em 13/03/2018.
} 
transporte e distribuição das mercadorias produzidas. Esse processo acaba por responder também a problemas de outros estratos da comunidade, como as mães que passaram a trabalhar nesses serviços e extrair uma fonte de renda.

Sobre o ambiente construído, percebe-se a vivacidade do pátio, corredores, biblioteca, bem como pelas salas cheias nos horários de curso. De modo que esse espectro da problemática do programa, isto é, sua dimensão funcional, parece bem acolhido pela concepção projetual. $\mathrm{O}$ uso intenso do equipamento pela comunidade e a complexidade de relações alavancadas a partir dele, fica expressa no modo como o ele foi apropriado e alterado. Isso demonstra demandas muito mais ricas e complexas que a oferta de serviços sociais negligenciada pelo Estado.

O Espaço Viver foi o ganhador do $70^{\circ}$ Prêmio Jovens Arquitetos, de 2015, e do Prêmio Rogélio Salmona, de 2014. O projeto foi aclamado pelo júri pela sua capacidade de melhorar o entorno, ao articular os espaços públicos existentes. A permeabilidade dos volumes também teria permitido a integração física e simbólica com a comunidade, fato a ser ressaltado como um atributo oriundo da escolha dos materiais e da manipulação das formas ${ }^{124}$.

A luz desses argumentos, alguns problemas parecem surgir. A importância dos serviços oferecidos é indiscutível e as adaptações ao uso são, de fato, questões inerentes à apropriação. Mas elas parecem iluminar um contraste entre a leitura funcionalista do projeto e as demandas socioespaciais em expansão. Essas são dinâmicas fluidas e potentes, ainda que contraditórias, e são fatores inerentes a esses territórios.

A resposta dada ao projeto, para esses problemas e para a dimensão urbana que ele encontra, é resolvida por espaços-unidade. Particularmente percebida pelo atributo funcionalizado do elemento "praça". É ele que confere a todas interpretações do programa externo a intenção de uma dimensão simbólica que conecta as funções (esporte, educação, recreação) à cidade (praça).

Essas categorias parecem insuficientes na contribuição para a ancoragem do novo tecido projetado às dinâmicas e estruturas espaciais do entorno. Nos 10 anos entre sua construção e a situação atual da edificação, ocorreram algumas alterações significativas em relação à concepção original desses espaços que apontam para essa percepção. E é difícil atribuí-las tão somente a opções de gestão ou alterações nas demandas programáticas. No decorrer do processo, houve a contundente instalação de gradis encerrando o terreno ${ }^{125}$. Mas as grades, guarda-corpos e rampas de acessibilidade que tiveram de ser construídas são, afinal, recursos coerentes com a leitura funcional das circulações e acessos do próprio projeto. Esses elementos são adições

\footnotetext{
${ }^{124}$ Segundo o juri: "Atiende con precisión y calidad el programa de actividades a la vez que proporciona un acceso digno al barrio mejorando notablemente su entorno. Com un esquema compositivo sencillo y eficaz organiza, con mucha sensibilidade y bajo condiciones topográficas difíciles, espacios colectivos articulados a los espacios públicos existentes, adecuados a eventos y actividades variadas (deportivas, sociales, culturales y educativas). La cuidadosa selección de materiales nobles y ligeros y la permeabilidad de los volúmenes consiguen su integración física y simbólica con la comunidad, sin mimetismos ni concesiones" (FUNDACION ROGELIO SALMONA, 2014).

${ }^{125}$ Assim como a adição de uma cobertura no terraço.
} 
pertinentes à lógica do projeto, cujo perímetro do lote já separava - de modo claro - as calçadas externas que acompanham os níveis do arruamento, do nível inferior do grande plano que recebia o conjunto arquitetônico. De modo que a adição posterior só reiterou a ausência de conexões daquilo que, pelo desnível entre o tecido urbano e a cota de implantação do conjunto arquitetônico, já estava separado.

Essa configuração, então, não é apenas um imprevisto, mas algo também propiciado pelo desnível perigoso aos usuários. A calçada existente atinge um desnível de 4 metros em relação a cota majoritária da implantação. Esse platô foi construído para abrigar os edifícios e suas praças. O único acesso em nível privilegia o estacionamento. Percebe-se que o partido projetual concentra-se na formulação de espaços prismáticos construídos sobre planos livres. Isso contrasta com a lógica do entorno, em que se busca o acesso direto e fluído entre as calçadas e vielas que reinterpretam a todo tempo a topografia. Essa acomodação busca conectar os acessos das casas e criar a fluidez entre os pequenos espaços coletivos do entorno, algo que parece faltar à implantação desse conjunto arquitetônico.

\section{Jardim Edite, 2008-2013}

O complexo habitacional Jardim Edite representa uma importante experiência de habitação de interesse social, que enfrenta a articulação desse programa a outras questões urbanas de grande complexidade. $\mathrm{O}$ projeto se assenta, justamente, na área que sofreu um dos maiores processos de renovação urbana ocorridos na cidade. E que resultou em uma nova centralidade, abrigando as sedes das grandes empresas internacionais do setor terciário avançado. Nessa mesma região e em meio a esse processo, encontrava-se a Favela do Jardim Edite que, em 1995, contava com cerca de 12 mil moradores. Ela foi paulatinamente removida e seus moradores foram reassentados pelo poder público em localidades distantes, incluindo áreas de proteção de mananciais. Isso se deu para viabilizar a construção da Avenida Roberto Marinho (uma via expressa).

Em 2001, com a aprovação da Operação Urbana Consorciada Água Espraiada ${ }^{126}$ e com o Plano Diretor Estratégico de 2002, se estabeleceu a Zona Especial de Interesse Social garantindo a urbanização dessa favela e o direito dos moradores a permanecerem no local. Somente em 2008, firmou-se um acordo entre a Prefeitura de São Paulo, a Defensoria Pública, o Ministério Público e a Associação de Moradores do Jardim Edite, garantindo a construção de unidades habitacionais no local.

Esse contraditório pano de fundo que antecede o projeto, com a ação do Estado em consonância com os interesses do capital imobiliário, foi descrito por Fix (2001) em detalhes, como um avassalador processo de exclusão social. Tendo ponderado as controvérsias que incidiram sobre esse território, nos interessa aqui compreender como essas condições

${ }^{126}$ Lei n. 13.260 de 28 de dez. 2001. 
em torno do projeto impactaram suas formulações projetuais e a sua relação com a cidade.

$\mathrm{O}$ projeto dos escritórios MMBB e $\mathrm{H}+\mathrm{F}$ conta com $25.500 \mathrm{~m}^{2}$ de área construída. Ele ocupa a localização da antiga favela de mesmo nome, no cruzamento das avenidas Engenheiro Luís Carlos Berrini e Jornalista Roberto Marinho, na zona Sul de São Paulo, e abriga parte de seus exmoradores. Esse projeto de habitação de interesse social conforma um conjunto edificado que se assemelha à morfologia urbana geral e a verticalização dessa região.

Como relata Olczyk (2015), a elaboração desse projeto foi um longo e complexo processo, pois envolveu a conciliação de várias diretrizes advindas das diferentes instituições do poder público envolvidas, tais como Secretaria Municipal de Habitação de São Paulo (Sehab) e a Companhia de Engenharia de Tráfego (CET). Também foi necessário incorporar as demandas dos futuros moradores expressadas nas audiências públicas e enfrentar a confluência de marcos regulatórios como a legislação vigente relacionada à Zona Especial de Interesse Social (ZEIS), assim como da Operação Urbana Consorciada Água Espraiada OUCAE.

O Jardim Edite tornou-se um ensaio projetual significativo, porque se propôs a integrar habitação social em meio a um uso misto de uma das áreas mais ricas da cidade. E pretendeu fazer isso sem se tornar uma exceção no urbano, como aponta Milton Braga ${ }^{127}$, um dos autores do projeto.

O complexo possui três torres de 17 pavimentos e duas lâminas de quatro pavimentos, totalizando 252 unidades habitacionais de $5 \mathrm{om}^{2}$. Também possui um embasamento que articula o Restaurante Escola, a Unidade básica de Saúde (UBS) e a Creche, utilizados tanto pelos moradores do conjunto quanto pela comunidade da região.

Em se tratando de uma região da cidade marcada pelo crescimento do setor financeiro e de serviços, as torres residenciais são hábeis em mesclarem-se às formas dos edifícios comerciais do entorno, apresentando fachadas com geometria limpa e contundente. Isso se dá pelos volumes contínuos e horizontais de armários corridos sob as janelas em uma das fachadas. Mas também pelo padrão xadrez dos rasgos verticais que abrem alternadamente o vedo das circulações horizontais na fachada oposta.

Esses padrões gráficos que dominam as faces dos edifícios visam evitar a estigmatização dos conjuntos residenciais de baixa renda. Nesses casos, as fachadas são marcadas pelos elementos massificados de janelas de diferentes tamanhos, denotando o padrão mínimo econômico de modelos comerciais e a repetição desse agrupamento referente a cada unidade.

A integração à paisagem da cidade, que o padrão gráfico dos edifícios consegue estabelecer, enfrenta desafios de outra ordem, para se desdobrar no nível do usuário, no perímetro imediato no entorno do conjunto. Localizado em um cruzamento de avenidas de alto tráfego e

${ }^{127}$ Em depoimento à Galeria de Arquitetura, cf. BARROS, 2014. 
ao lado do arranque de uma ponte de grande porte, as qualidades do tecido urbano já pareciam, de partida, ameaçadas.

Sob essas condições, o projeto redesenha as quadras em duas grandes faixas para reduzir o impacto da circulação de veículos e lança mão da lógica do sobressolo, que eleva os edifícios-lâminas e traz as áreas comuns compartilhadas pelos moradores para a cobertura desse embasamento. Confere, assim, ao fechamento do perímetro do projeto o papel de mediador direto entre o urbano, o semi-público e o privativo. Esses vedos, ainda que com alguma permeabilidade visual, tenderam a atuar como proteção aos usos internos, como é o caso da creche, da UBS e do restaurante escola. Isso preserva o usuário, mas também diminui a friç̧ão entre os programas internos e as dinâmicas do mundo externo. Uma parte da área condominial no térreo (estacionamento e lazer) acabou circundada em seu perímetro por grades.

Concentra-se assim a vitalidade e a ativação do urbano, nesse projeto, por meio dos acessos às edificações, o que se dá diretamente à rua. No caso das torres, eles estão localizados na Avenida Berrini e na Rua George Ohm. Já o acesso às lâminas e aos equipamentos públicos se voltam à Rua Charles Coulomb. Na frente desses acessos, se constituiram pequenas praças, com calçadas largas, árvores e bancos que são plenamente apropriados. Isso é algo que falta à longa fachada voltada à Avenida Roberto Marinho, que não possui nenhum acesso, o que se justifica pela relação pouco acolhedora aos transeuntes diante da configuração viária expressa e do acesso à Ponte Octavio Frias de Oliveira.

\section{Parque Novo Santo Amaro V, 2009-2012}

O parque Novo Santo Amaro V é um projeto de habitação de interesse social localizado em uma área de proteção de mananciais. Sua situação urbana, muito diversa do Jardim Edite, denota também grandes complexidades socioespaciais que se colocam entre o tecido urbano e o programa habitacional, o que motiva sua seleção para o presente estudo. O projeto está situado no extremo sul da cidade, na Subprefeitura do M'Boi-Mirim, a pouco mais de $3 \mathrm{~km}$ da represa Guarapiranga. O lote de $21.900 \mathrm{~m}^{2}$ compreende uma situação topográfica de fundo de vale, com um córrego passando em sua porção central. Tratava-se de uma propriedade municipal, que não poderia ser edificada, mas que foi ocupada irregularmente a partir dos anos 1980.

Os dados de partida são típicos da ocupação de áreas ambientalmente frágeis que foram ocupadas com a extensão das periferias da cidade de São Paulo. O terreno apresentava um relevo acentuado, com o córrego recebendo o esgoto a céu aberto, tendo suas margens completamente ocupadas. As cotas mais baixas e mais próximas ao nível da água apresentavam construções e condições sanitárias piores. Assim, além de produzir novas unidades habitacionais e retirar as pessoas das áreas de risco, era preciso enfrentar a relação com o padrão da ocupação do entorno. O que demandava reconhecer as estruturas e dinâmicas 
existentes para tentar contribuir com uma melhoria integrada e, ao mesmo tempo, abrangente.

O projeto de Hector Vigliecca propôs a construção de 201 novas unidades. Elas foram realizadas de modo que os edifícios habitacionais pudessem conformar estruturas urbanas. Assim, os $14.673 \mathrm{~m}^{2}$ de área construída representam a tentativa de criar um conjunto urbano capaz de ser lido como uma "estrutura embrião" (VIGLIECCA, 2014, p. 224), uma matriz de ocupação para esse território especial. Algo que pudesse ser estendido, replicado, e que contribuísse para formular táticas para intervir nessas regiões carentes de espaços públicos e qualidades urbanas da cidade formal.

A radicalidade e a dimensão experimental desse projeto são características reconhecidas pelo próprio arquiteto ${ }^{128}$. E foram também aspectos contatados pelas análises próprias desse trabalho. Isso justifica a seleção desse projeto para estudo de caso, em detrimento a outros realizados nesse mesmo período pela Sehab, como discutido no capítulo 2. Nesse projeto o problema habitacional não se restringe às unidades habitacionais, mas também não expande suas mediações a partir de leituras estritamente funcionais dos problemas do local. De modo que a transposição dos níveis, a solução para o córrego, a oferta de equipamentos complementares, a organização dos fluxos de pedestres, as conexões com o tecido urbano e a malha viária existente não são problemas resolvidos na somatória de soluções, mas na confluência e mescla das mesmas.

O projeto busca atender a essas demandas como outras experiências contemporâneas $^{129}$ para assentamentos precários, isto é, confere tratamento urbanístico além de produzir as unidades habitacionais. Mas ao fazer isso, resolve questões funcionais subordinando-as a nexos formais e relacionais. Assim, as estruturas novas tentam estabelecer interações com o seu universo de inserção, de modo que o desenho do edifício se torna uma tarefa de mediação. Buscou nexo e coesão das partes novas de modo a integrá-la à lógica do tecido existente. Uma tarefa difícil, na medida em que a busca por uma nova sintaxe espacial que pretende gerar formas urbanas se dá em áreas nas quais a ocupação não pode se valer de qualquer resíduo cultural citadino para organizar a vida comum (RECAMÁN, 2015, p. 25).

Resulta desse esforço uma sequência de edifícios habitacionais que contornam o lote alternadamente, mas de modo predominantemente longitudinal. Essa estrutura habitacional urbana viabiliza também a transposição dos níveis, que é realizada por pontes e escadas que, ora tem autonomia, ora se engatam aos volumes edificados para otimizar e interligar as passagens. A transposição do vale, viabilizada pela ponte principal que atravessa o conjunto, visa facilitar o acesso a escola que se encontra em uma das extremidades do projeto. Assim, o volume edificado tenta responder aos problemas cotidianos da região. Também, nesse sentido, ao centro do conjunto foi criado um amplo espaço público, um parque linear que resulta da canalização do

\footnotetext{
${ }^{128}$ Cf. VIGLIECCA, 2014, p. 193.

${ }^{129}$ Como é o caso do projeto de reurbanização para a Favela do Sapé.
} 
córrego. Espelhos d'água arrematam as áreas livres ao mesmo tempo em que captam a água limpa das pequenas nascentes do terreno. Essa espacialidade que atravessa o conjunto residencial, articula também equipamentos recreacionais como uma pista de skate, um playground e o campo de futebol. Essas áreas foram pensadas para mitigarem a ausência de espaços públicos que acomete a região.

A variabilidade da fachada, das alturas dos edifícios, é algo que resulta das 11 tipologias diferentes criadas para o conjunto. Mas também reflete a incorporação dos atributos de pontes, conexões, portais de acesso, e anteparos urbanos que o organismo de edifícios assumiu.

Ao tentar produzir uma unidade urbana conectada ao padrão de ocupação existente, o projeto reproduziu os acessos dos edifícios que se dão diretamente na calçada - como se observa em todas as ocupações do entorno - buscando, assim, a vitalidade observada nas ruas do local. Evitou grades e separações, intermediando a dimensão privativa da pública, por meio de resguardos criados pela inter-relação entre os volumes edificados. Algo que tem sido alterado pelos moradores que passaram a controlar os acessos às escadarias e aos edifícios, reproduzindo os fechamentos com grades, típicos dos condomínios que povoam a cidade.

Isso se deve, em parte, por um conflito entre os moradores locais e os novos usuários dos espaços públicos recém-criados. Em uma área carente dessas oportunidades urbanas, a existência desse complexo tem atraído pessoas de toda a região. Um dos problemas é que os visitantes utilizam esse espaço para realizar grandes festas conhecidas como "pancadões"130. Essa apropriação eventual, utilitária e que captura as possibilidades do espaço com a mesma intensidade e rapidez com que o abandona (após consumi-lo), parece irreconciliável com o ritmo repetitivo e moderado do uso cotidiano, que a ela reage.

Esse exemplo permite compreender como as carências e demandas negligenciadas pelo poder público geram tensões relativas às dinâmicas estruturais da cidade. E como elas interferem diretamente - e desproporcionalmente - na pequena porção do território que sofre uma intervenção. $\mathrm{O}$ arquiteto, ao mobilizar instrumentos da $\mathrm{A} \& U$ para gerar uma resposta a esses problemas, configurou novas estratégias projetuais que fogem a abordagem essencialmente funcionalista dos programas. Procurou, com isso, criar novas tipologias para o espaço social. Esse processo, exposto aos influxos da realidade, esteve sujeito a criação de novas dinâmicas e contradições, mas também propiciou outras tantas possibilidades interpretativas para futuras experiências.

SESC 24 de maio, 2017

As questões relativas a perímetros, divisas e à separação entre o urbano e a unidade projetual, são problemas também verificáveis em edifícios verticais e nas áreas de alta densidade como é o caso do centro de São

${ }^{130} \mathrm{Cf}$. TRONCOSO, 2015. 
Paulo. A dimensão da urbanidade, nessas áreas, também é instada a configurar usos renovados, a criar novas dinâmicas que sejam capazes de ressignificar esta parte da cidade que enfrentou uma crise ao final dos anos 1980, diante de um novo ciclo produtivo e a perda das suas atribuições originais.

Nesse sentido, o SESC 24 de maio representa uma importante oportunidade para reflexão. O projeto resulta da reforma do edifício da Mesbla, uma antiga loja de departamentos, e da demolição de um edifício vizinho para a construção de um anexo. A edificação original se desenvolvia como um "L" de 10 andares, com um grande vão central coberto por uma cúpula para iluminação natural. A esquina entre a Rua 24 de Maio e a rua Dom José de Barros também era marcada pelo chanfro da edificação que, não só abrigava o letreiro com o nome da loja em destaque, mas também marcava a grande entrada da loja, com o convidativo pé direito duplo.

A adaptação da estrutura existente para receber o programa do SESC incluiu a inserção 4 pilares que integram uma robusta e nova estrutura no vazio central do edifício principal. Isso possibilitou preencher esse vão nos andares em que áreas maiores eram requisitadas ao programa. Esse reforço também foi necessário para aguentar a carga da piscina localizada na cobertura que, assim como o penúltimo andar $\left(12^{\circ}\right)$ foram adicionados ao à estrutura original. Ela resulta em um impactante mirante, ainda que de acesso restrito aos usuários matriculados. Um subsolo também foi escavado, aprofundando o estacionamento original, para abrigar o teatro. A demolição do edifício vizinho, de um terreno de 7X2om, possibilitou a construção de uma torre anexa para acomodar sanitários e espaços auxiliares ao programa principal.

Além da piscina-mirante, outro argumento que estrutura o partido projetual são duas praças elevadas. A primeira, é uma praça no terceiro andar que abriga a convivência, uma área livre de uso flexível. Esse espaço, muito utilizado como ponto de encontro, mas também para leitura e contemplação, possui o perímetro aberto e pé direito simples. Na extremidade desse pavimento há um surpreendente vão de pé direito sêxtuplo. Essa área possui uma qualidade espacial similar a um terraço. A segunda praça, no $11^{\circ}$ andar, abriga o café e possui um espelho d'água que foi animadamente apropriado pelos visitantes, ainda que o projeto não previsse originalmente a interação dos usuários com a água. Esse espaço possui café o que, somando-se a sua condição de mirante, transforma o espaço em uma área de recreação e lazer que atrai um grande público.

O conjunto de rampas também pode ser destacada pela potência discursiva do projeto. Ele torna a circulação vertical propensa a encontros, e também permite o desfrute de um deslocamento que se delonga em encontros e situações arquitetônicas mais ricas. Uma torre de elevadores interna ao conjunto arquitetônico viabiliza a circulação vertical expressa, visto que esse SESC recebe, em média, 5 mil visitantes ao dia.

Desse modo, os principais atributos do edifício se encontram nos andares superiores e na potência de urbanidade internalizada. O esquema espacial produz essa condição de espaços de fluxo e 
programáticos interconectados por uma lógica fluída com um desenho claro.

$\mathrm{O}$ acesso do edifício pelos calçadões atende à funcionalidade da recepção e encaminhamento do alto fluxo de usuários. Mas elas também negam a tradicional vitalidade da esquina, algo apropriado por todas as lojas e edifícios da região. No Sesc 24 de maio a esquina se encontra fechada. Assim, adentrar lateralmente o edifício parece tarefa mais propícia a quem está previamente informado do convite aberto que a instituição pretende oferecer, algo menos propenso a fomentar espontaneidades. Do mesmo modo, utilizar o espaço como uma passagem é uma tarefa realizada por intenções muito específicas. Pois, para fazê-lo, é preciso enfrentar o afunilamento das entradas laterais e os contrastes entre internalidade institucional e a externalidade convulsionada da rua.

A oferta de serviços que o SESC oferece e o franco acesso aos seus espaços é uma característica notável da instituição que é plenamente acolhida pelo projeto arquitetônico. $\mathrm{O}$ número alto de usuários também é a prova da funcionalidade desse equipamento. Mas ponderase aqui, que o grande diálogo com a cidade se estabeleceu, afinal, por relações indiretas.

A cidade, espelhada nas faces de vidro do volume único, atesta outras possibilidades. A Galeria Presidente, vizinha refletida na fachada do SESC voltada à rua Dom José, testemunha o recurso projetual das galerias comerciais típicas da região. Estas, com pés direitos duplos e fachadas permeáveis, comunicam a oportunidade da travessia e o acolhimento ao pedestre. $\mathrm{O}$ fazem integrando-se às superfícies e ao fluxo da cidade, buscando a continuidade da rua que adentra o seu lote. Essa formulação alternativa de espacialidades, nos fazem refletir sobre a urbanidade recriada dentro do volume vertical do SESC. Urbanidade que existe e é rica, mas parece encontrar-se funcionalizada para aqueles que adentram o edifício como usuários.

\section{Parque Jardim das Perdizes, 2011-2017}

Assim como Parque Ciudad del Rio, de Medellín, o Parque Jardim das Perdizes é um espaço público construído por meio de instrumentos e estratégias de regulação do uso do território. Sua experiência reflete as potencialidades e problemas da mediação entre os interesses do capital imobiliário e a necessidade do Estado de regular e, por esse meio, promover benefícios coletivos à cidade. Essa questão não se esgota nos marcos regulatórios, demandando instrumentos projetuais precisos e fundamentais para transformar lotes em tecido urbano, bem como áreas efetivamente públicas. A importância do desenho urbano como instrumento de mediação entre diferentes agentes que constroem a cidade motiva a escolha desse estudo de caso.

O parque deriva da construção do segundo maior condomínio da cidade de São Paulo ${ }^{131}$, que foi viabilizado pela Operação Urbana Água

${ }^{131}$ Cf. ZANCHETTA, 2013 
Branca (OUAB) ${ }^{132}$. Os $91 \mathrm{mil} \mathrm{m}^{2}$ construídos acima do permitido pela lei, foram viabilizados por meio da compra de Certificados de Potencial Adicional de Construção (Cepacs). E, também, resultaram de uma contrapartida acordada junto à Prefeitura de São Paulo, que obrigou as incorporadoras responsáveis pelo empreendimento a construírem um parque de cerca de $30 \mathrm{mil} \mathrm{m}^{2}$.

Esse empreendimento imobiliário da Tecnisa e da PDG foi projetado por Itamar Berezin. $\mathrm{O}$ arquiteto optou por localizar a área pública ao centro das 25 torres residenciais e de seus 11 condomínios independentes ${ }^{133}$. Ainda que a proximidade de cerca de $2 \mathrm{~km}$ da estação de metrô da Barra Funda facilite o acesso a esse equipamento por visitantes de outra localidade, o parque resulta pouco integrado às dinâmicas da cidade. Isso porque seu desenho está claramente subordinado à qualificação de "condomínio-clube" do empreendimento. Assim, a função primordial de valorização das unidades habitacionais de alto padrão, fez com que esse espaço público fosse projetado tendo como pressuposto sua segregação - proteção - do tecido urbano.

O parque é pouco visível a quem passa pelas imediações do "novo bairro". A área, afinal, se configura como uma ilha de baixa densidade, cercada pelas torres residenciais e permeada por controles de segurança. A experiência do espaço contribui para constatar que a linguagem arquitetônica do empreendimento, estendida a essa área pública, torna indistintas as áreas livres e públicas do parque das dependências reguladas e de acesso controlado do próprio condomínio. As câmeras de segurança espalhadas ao longo de todo o empreendimento e tornadas mais visíveis em totens que se espalham no entorno do parque reforçam a ideia da lógica condominial que domina amplamente o espaço. Essas relações ambíguas em que os usuários não sabem se estão sujeitos aos códigos comportamentais de um espaço privado ou livres à apropriação permitida por um espaço público são sintomas dessa commodificação da cidade, como demonstrou Cuthbert (2011).

A falta de assimilação dessa expressiva área às dinâmicas espontâneas da cidade e sua capacidade reduzida de qualificar amplamente a região é percebida como consequência da ausência do projeto urbano, conforme apontam Alvim et al (2011). Segundo os autores, com a supressão desse instrumento de interlocução entre Prefeitura, empreendedores, proprietários e moradores, os objetivos de reestruturação urbana da OUAB, isto é, a ocupação das áreas vazias e a promoção do adensamento com novos padrões de uso e ocupação do solo desse setor da cidade, foram severamente comprometidos.

Para além de comprovar os limites de transformação da cidade por meio de operações urbanas, um tema que tem suscitado amplo debate e que excede o alcance desse trabalho, percebe-se que a qualidade do espaço público está intrinsecamente vinculada à liberdade de uso, a

\footnotetext{
${ }^{132}$ Lei no $11.774 / 1995$.

${ }^{133}$ Cf. VIEIRA, 2011.
} 
espontaneidade da apropriação e a heterogeneidade da situação urbana. Algo muito distante do ambiente controlado e das grades do condomínio que se estendem ao Parque dos Jardins das Perdizes. Limites e dispositivos de segurança precisamente projetados. 
Painel 3.6 CEUs
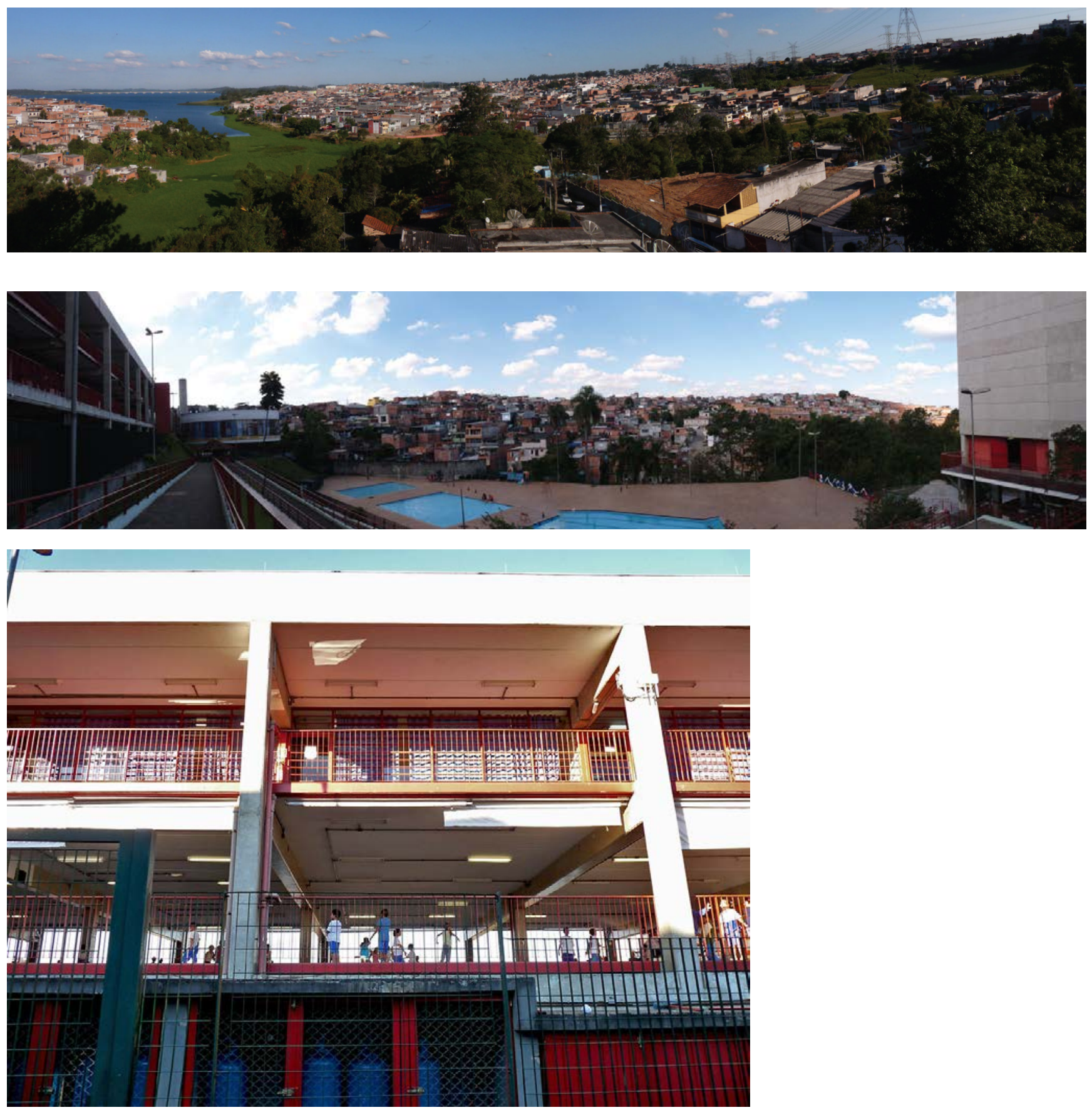

Figura 3.6.1

Vista Panorâmica do entorno do CEU

Navegantes

Figura 3.6.2

Vista Panorâmica da implantação do cEU

Navegantes

\section{Figura 3.6.3}

Vista do Bloco didático do CEU Navegantes

a partir da rua de acesso 
Figura 3.6.4

Figura 3.6.5

Acesso ao CEU Navegantes
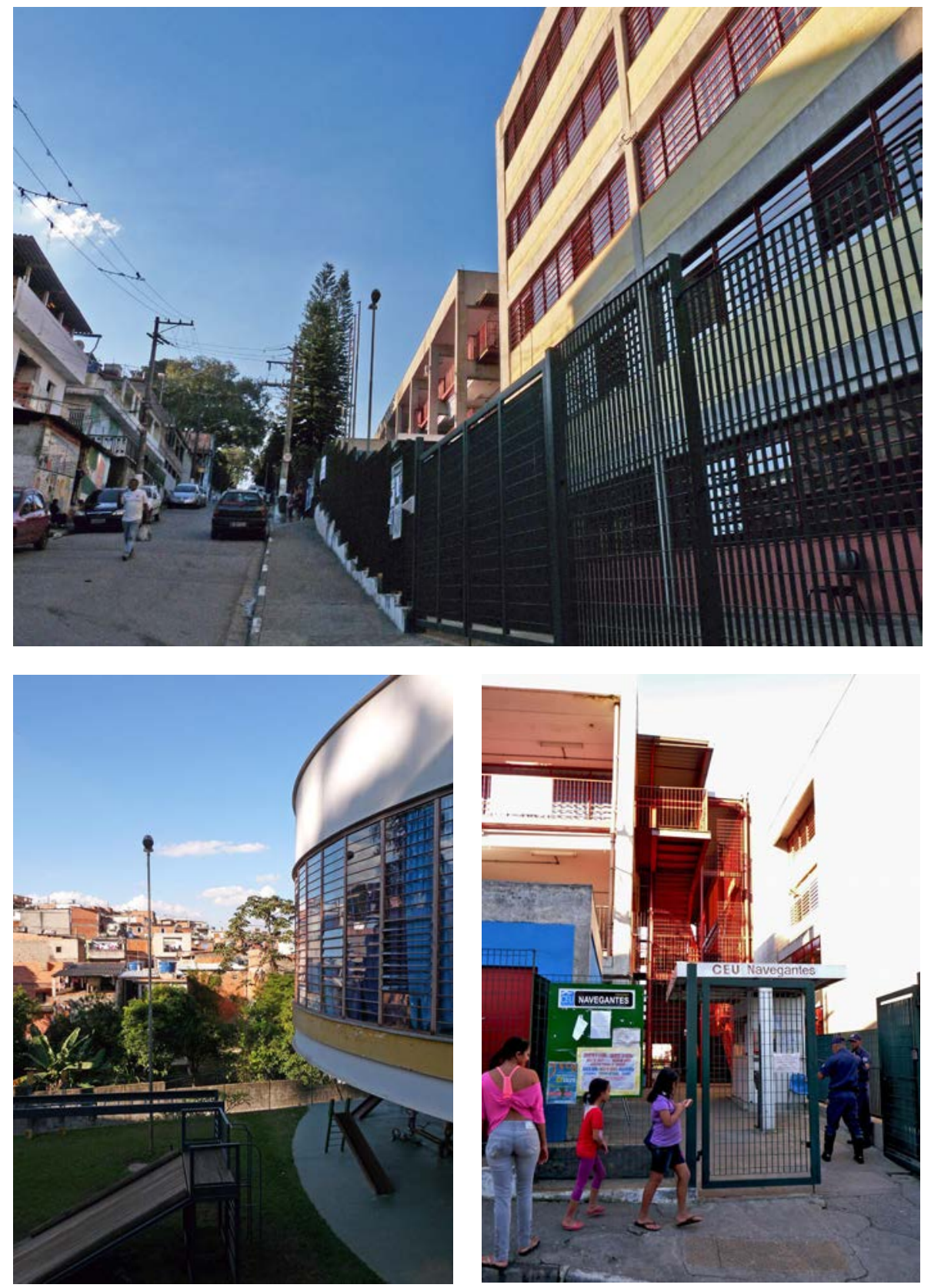

Figuras 3.6.6-3.6.7

Imagens dos pátios e varandas do CEU

A racionalização do sistema estrutural e dos componentes construtivos

Varandas proporcionam a integração [visual] com a cidade
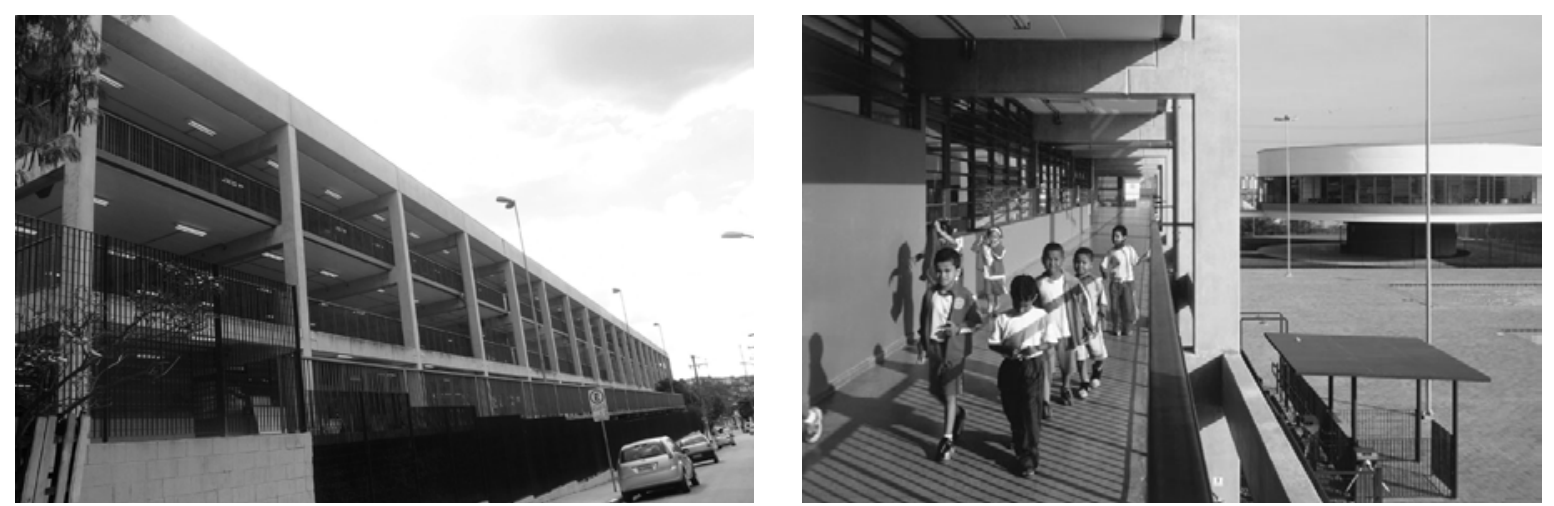
Painel 3.7 Escola Projeto Viver
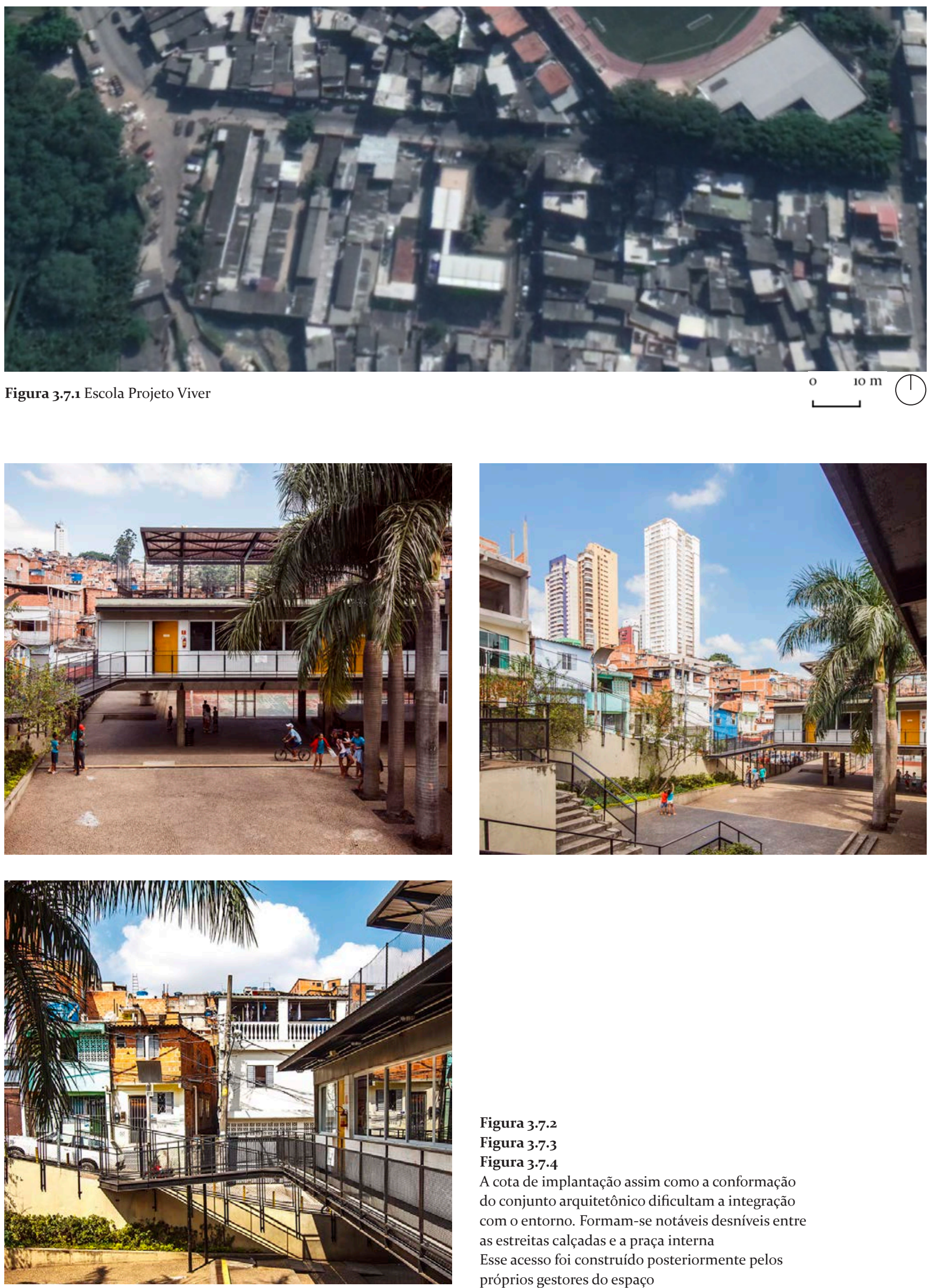

Figura $3 \cdot 7 \cdot 2$

Figura $3 \cdot 7 \cdot 3$

Figura 3.7.4

A cota de implantação assim como a conformação do conjunto arquitetônico dificultam a integração com o entorno. Formam-se notáveis desníveis entre as estreitas calçadas e a praça interna Esse acesso foi construído posteriormente pelos próprios gestores do espaço 

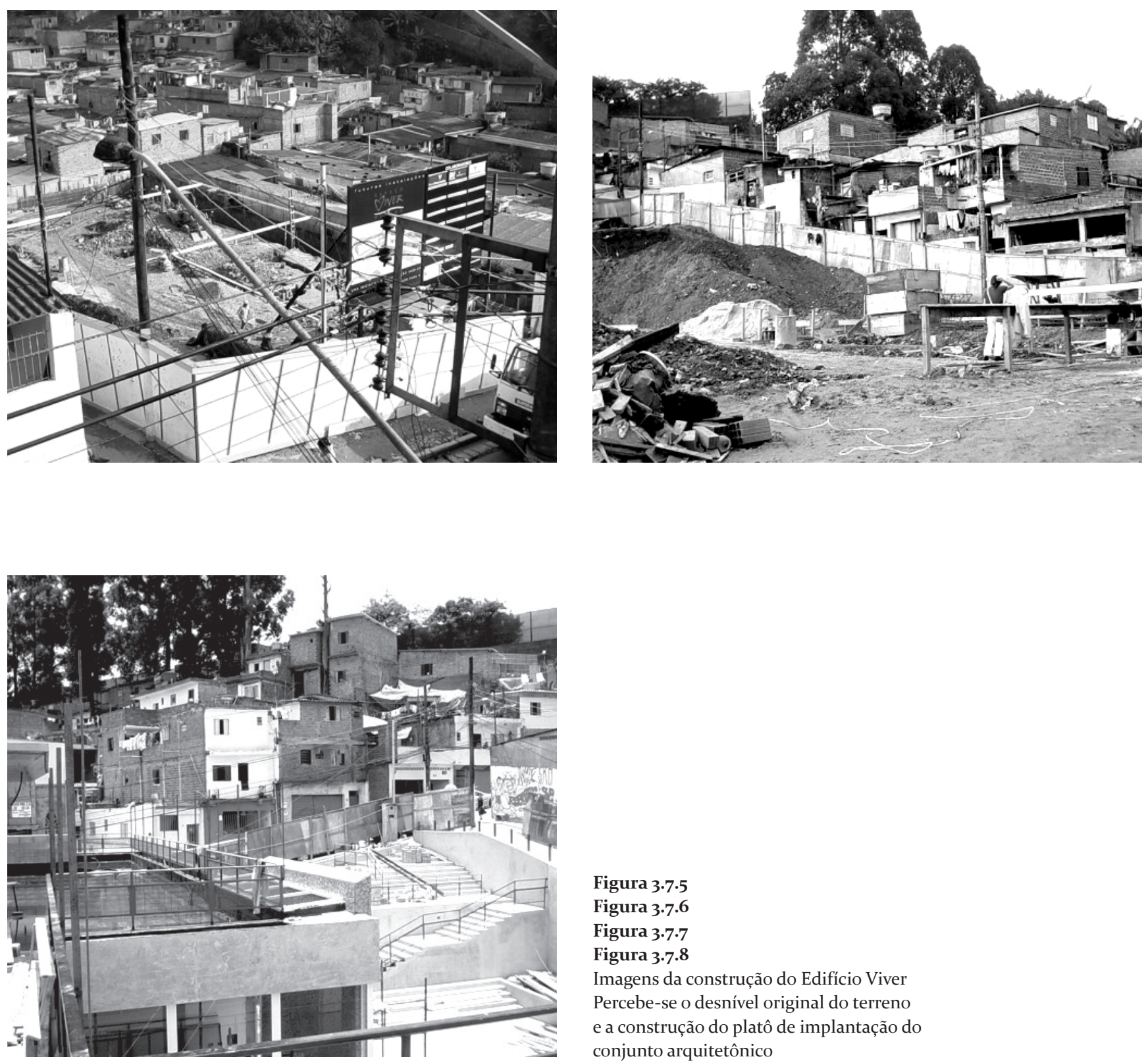

Figura 3.7.5

Figura 3.7.6

Figura $3 \cdot 7 \cdot 7$

Figura 3.7.8

Imagens da construção do Edifício Viver Percebe-se o desnível original do terreno e a construção do platô de implantação do conjunto arquitetônico

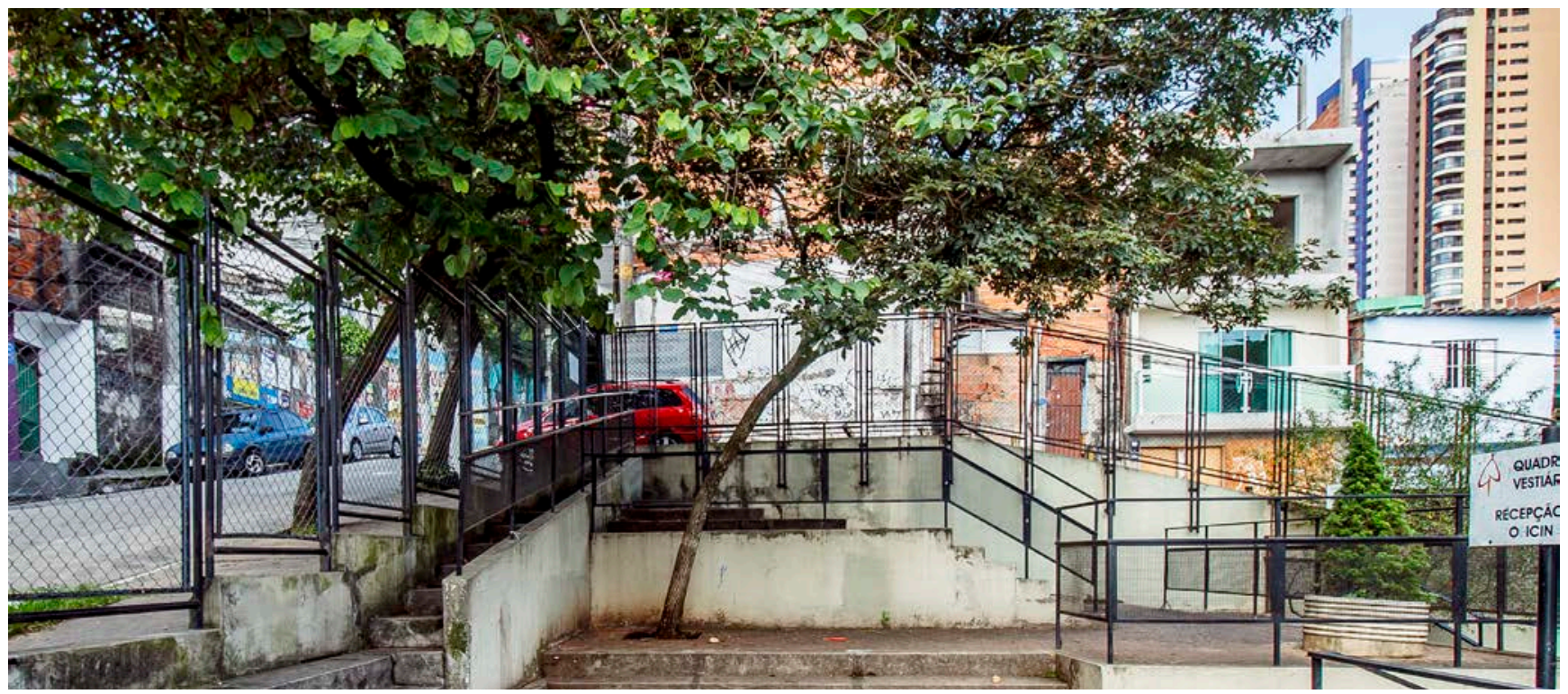



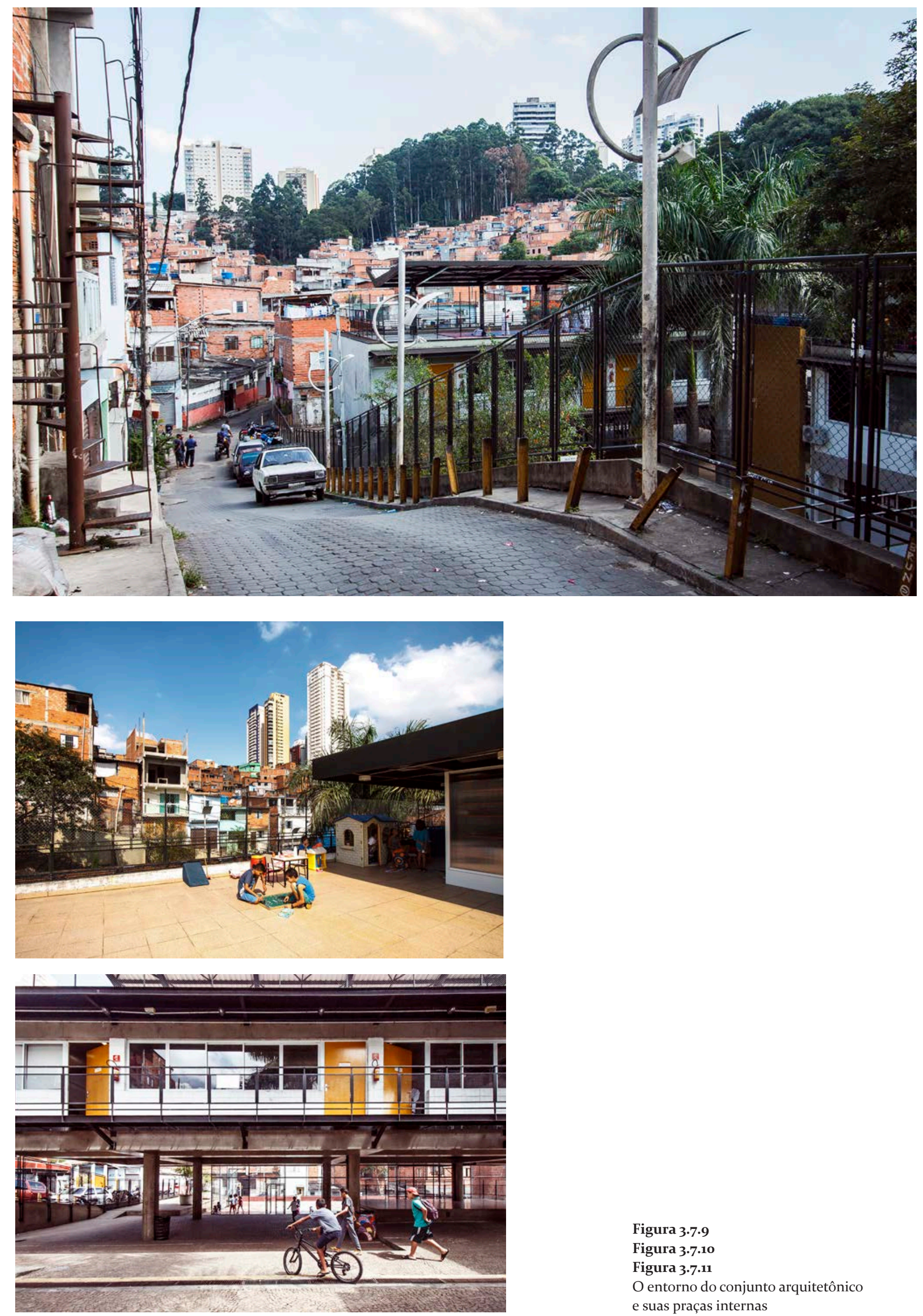

Figura 3.7.9

Figura 3.7.10

Figura 3.7.11

O entorno do conjunto arquitetônico

e suas praças internas 

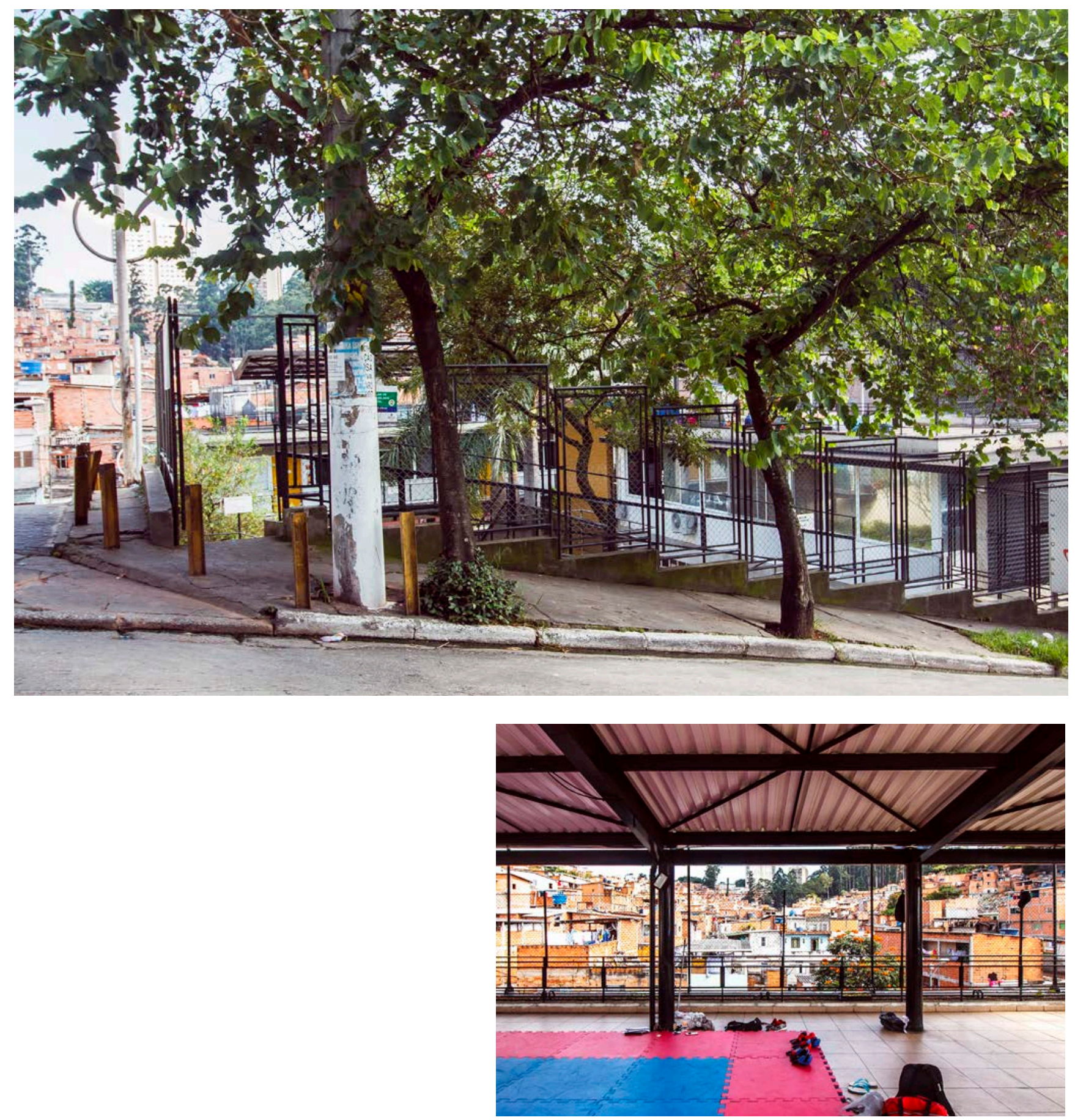

Figura 3.7.12

Figura $3 \cdot 7.13$

Figura 3.7.14

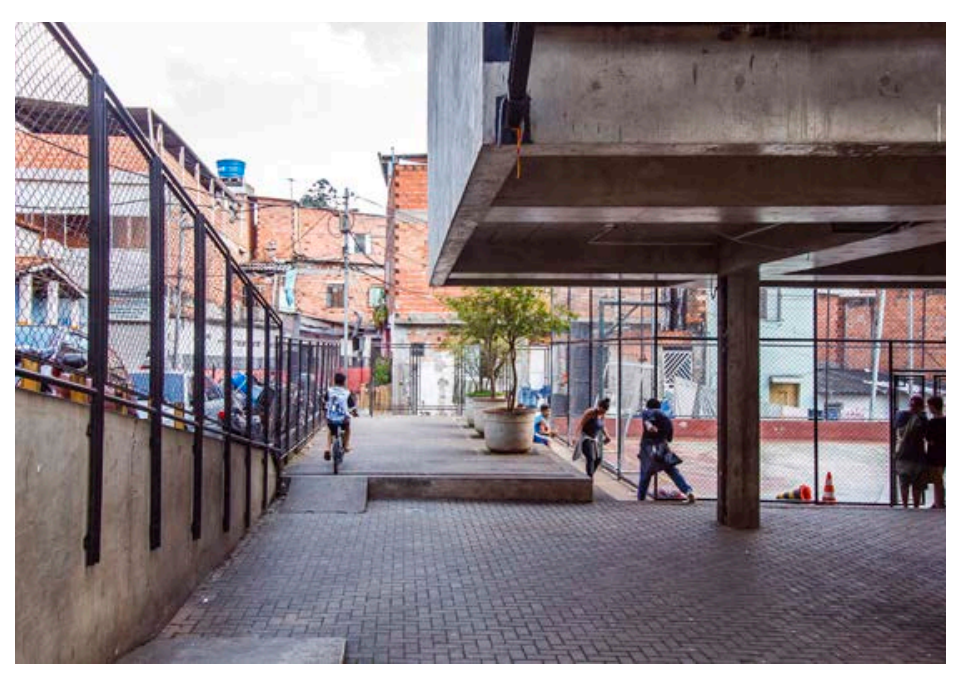


Painel 3.8 Sesc 24 de Maio
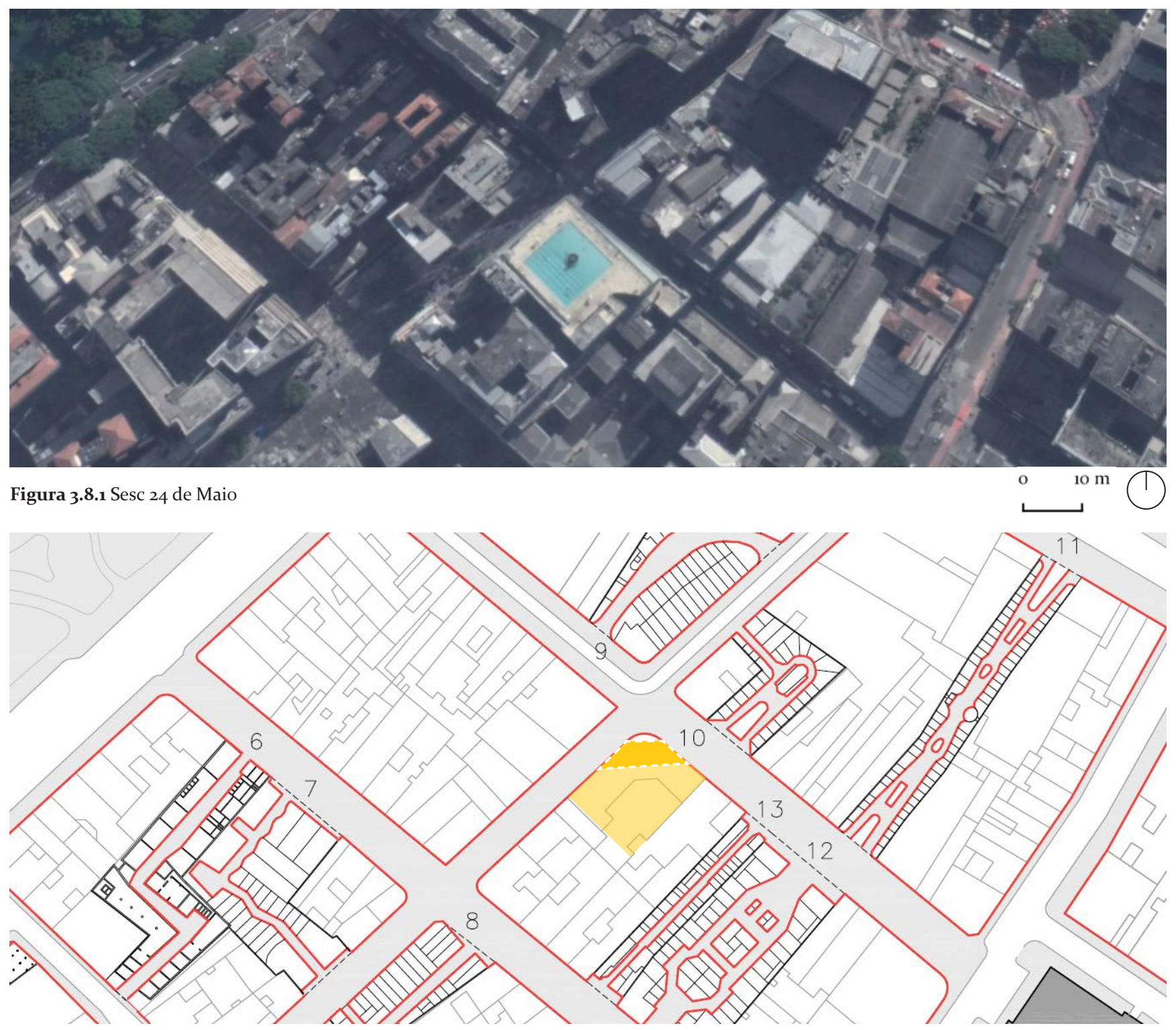

Figura 3.8.3

Figura 3.8.2 Esquema da permeabilidade do

Figura 3.8.4

térreo do SESC em relação às galerias

Figura 3.8.5

Vistas suscessivas do perímetro do SESC 24 de maio: nota-se a

esquina fechada e pouca visibilidade dos espaços internos
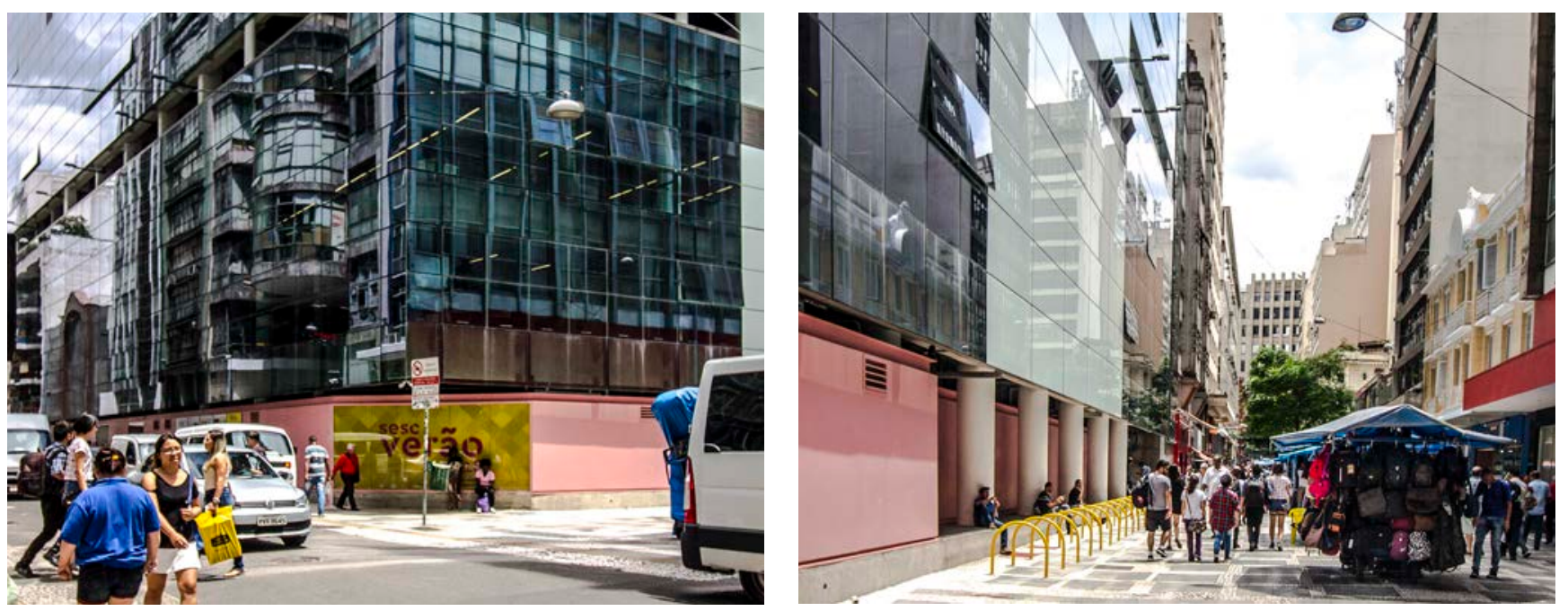

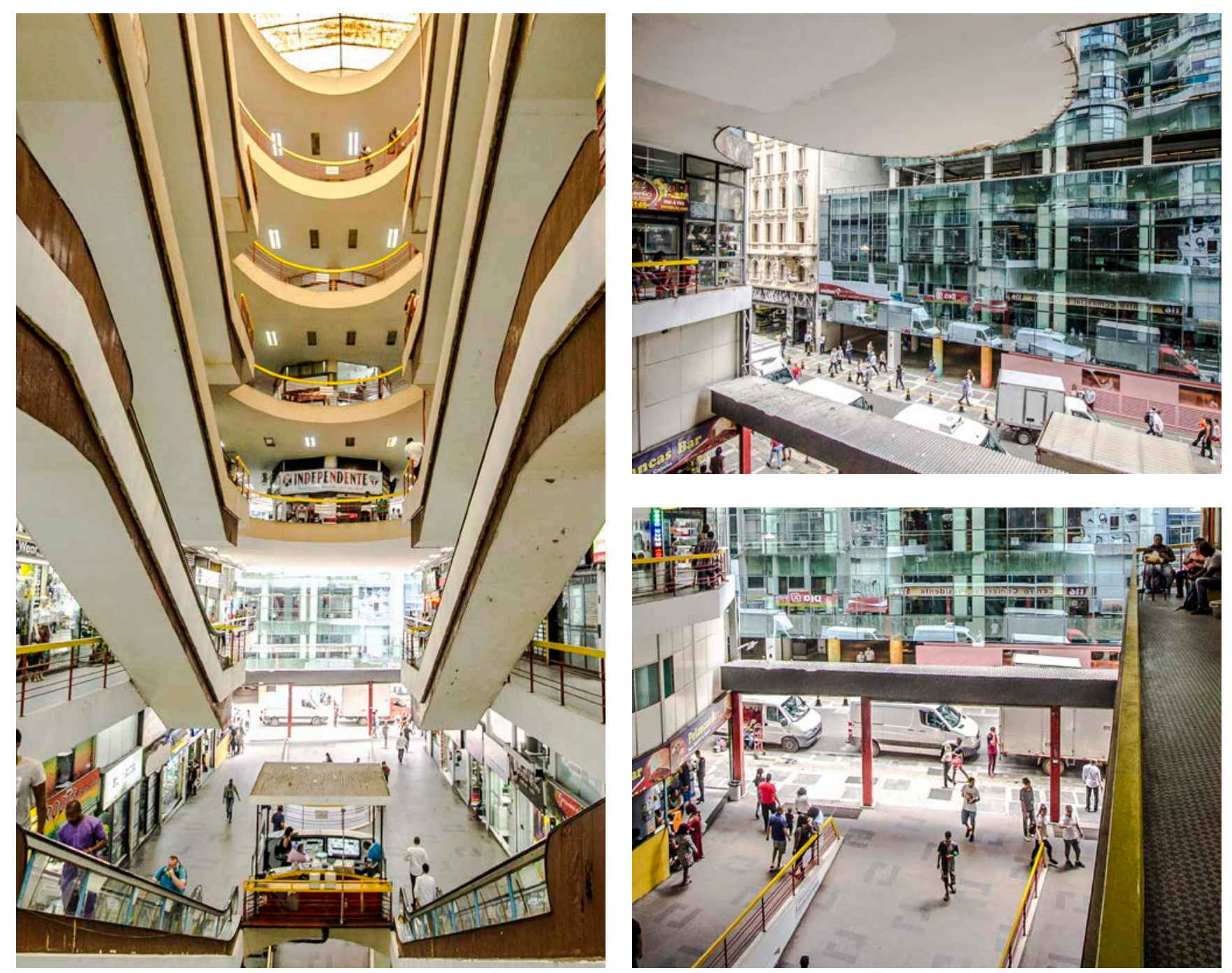

Figura 3.8.6

Figura 3.8.7

Figura 3.8.8

Galeria em frente ao SESC 24 de maio

O pé direito, a conformação da sua fachada

côncava reforçam a integração com à rua

Figura 3.8.9

Figura 3.8.10
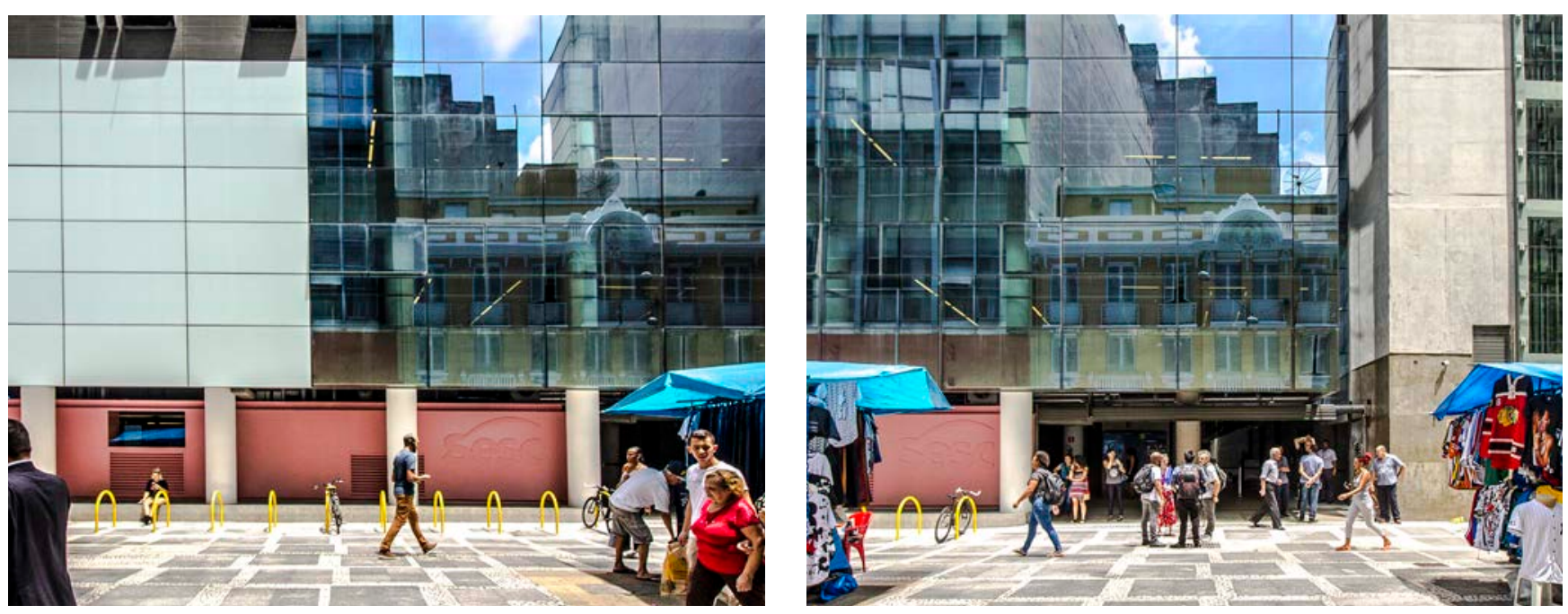


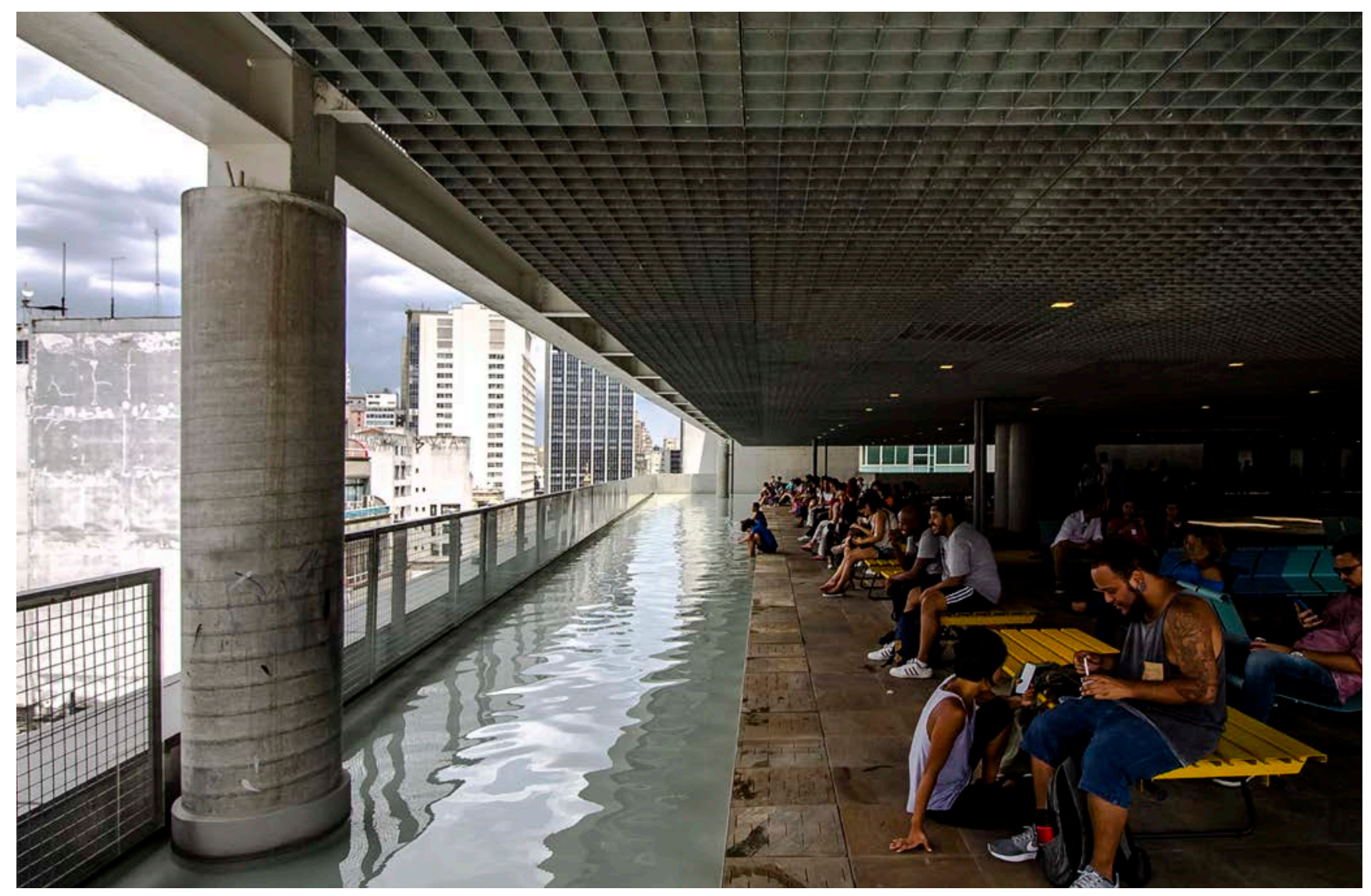

Figura 3.8.11

Figura 3.8.12

Figura 3.8.13

As relações visuais estabelecidas entre as praças elevadas e $o$ entorno da cidade

Vista do pavimento térreo
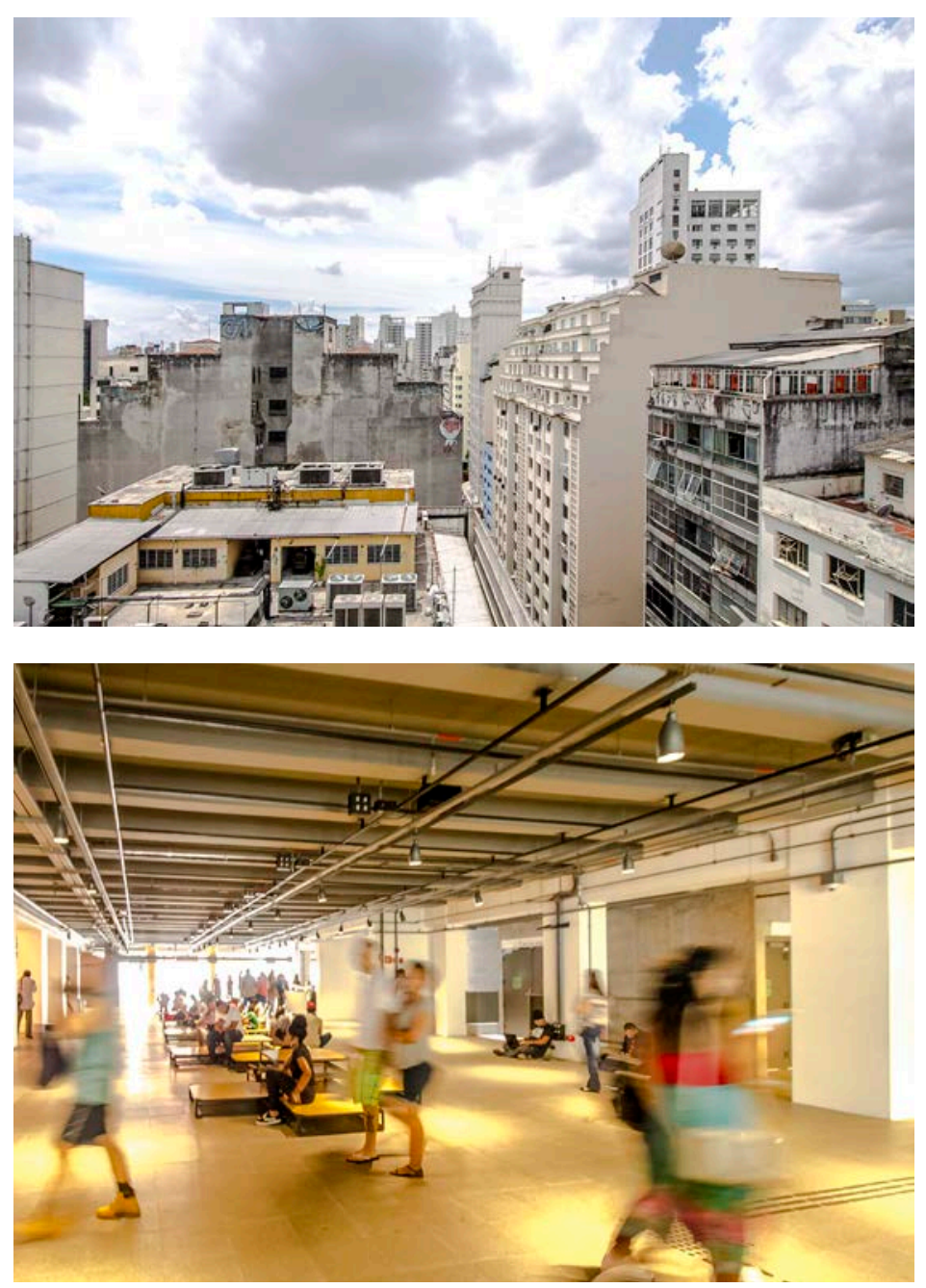

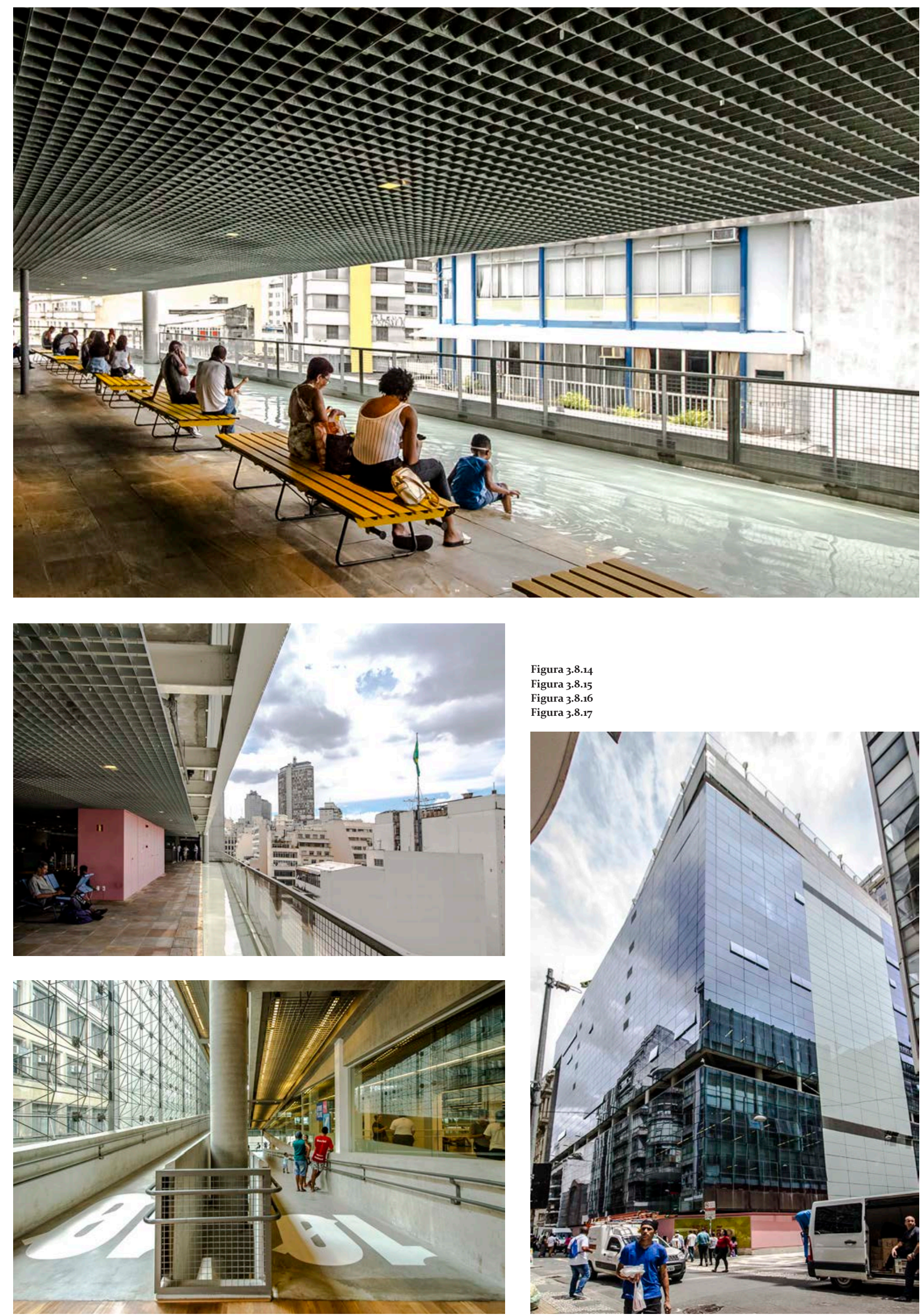
Painel 3.9 Jardim Edite

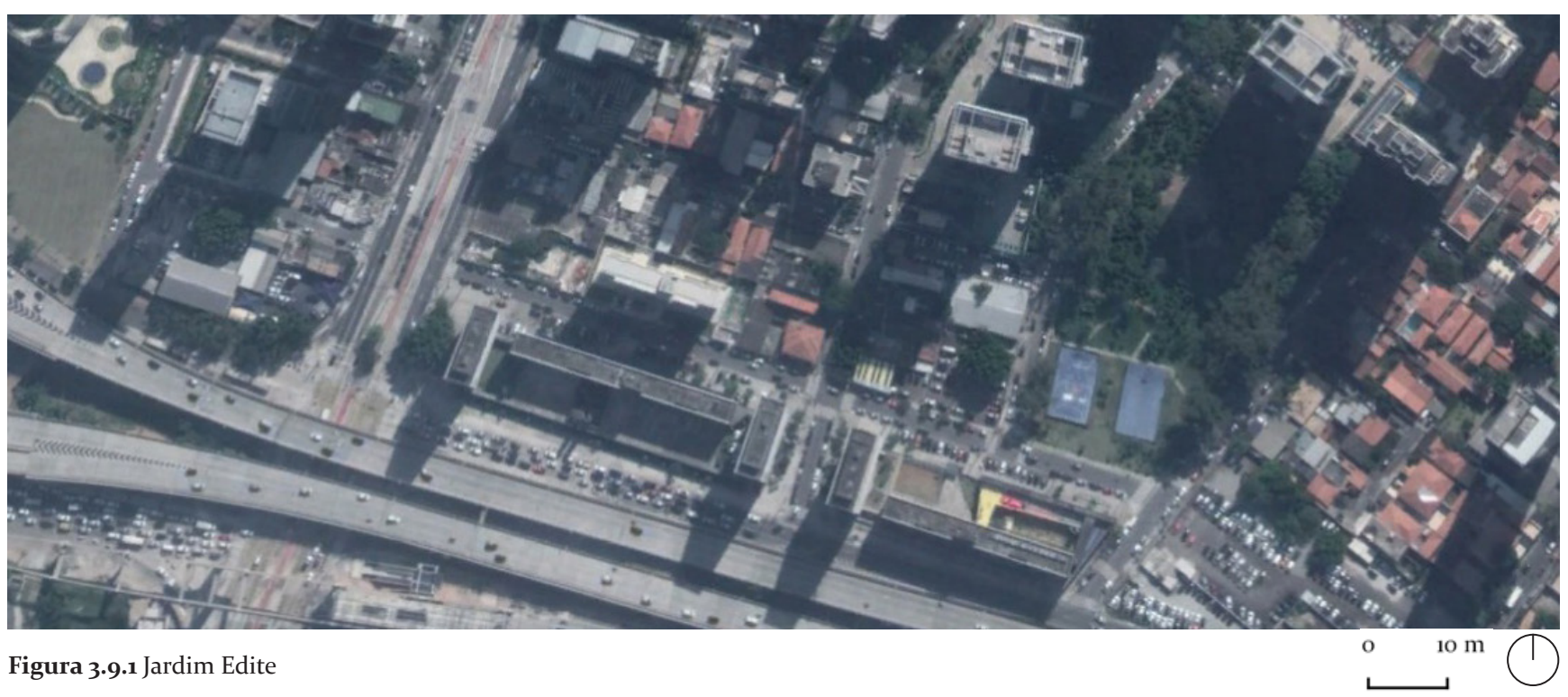

Figura 3.9.2

Figura 3.9.3

Figura 3.9.4

Figura 3.9.5

Entorno do Jardim Edite
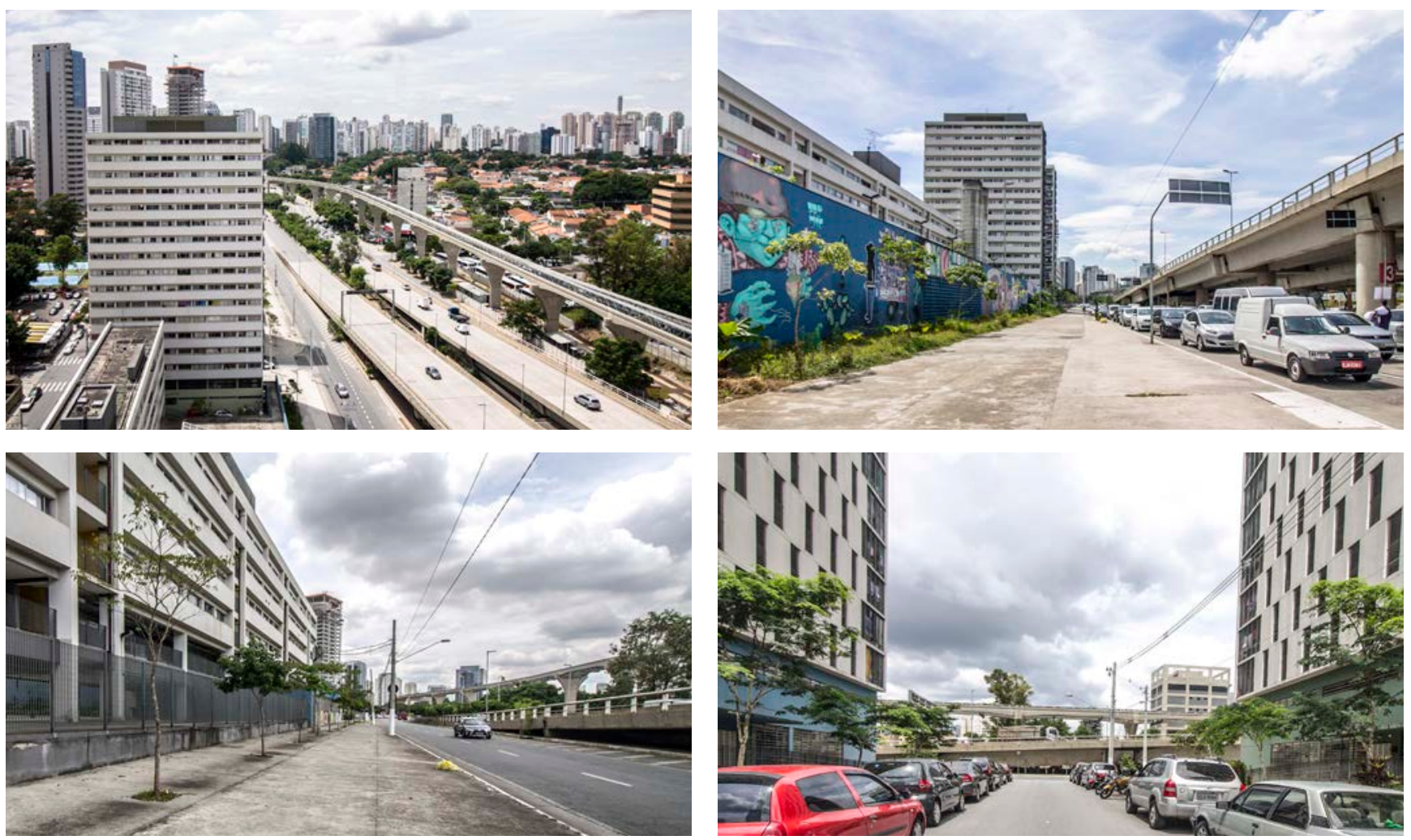

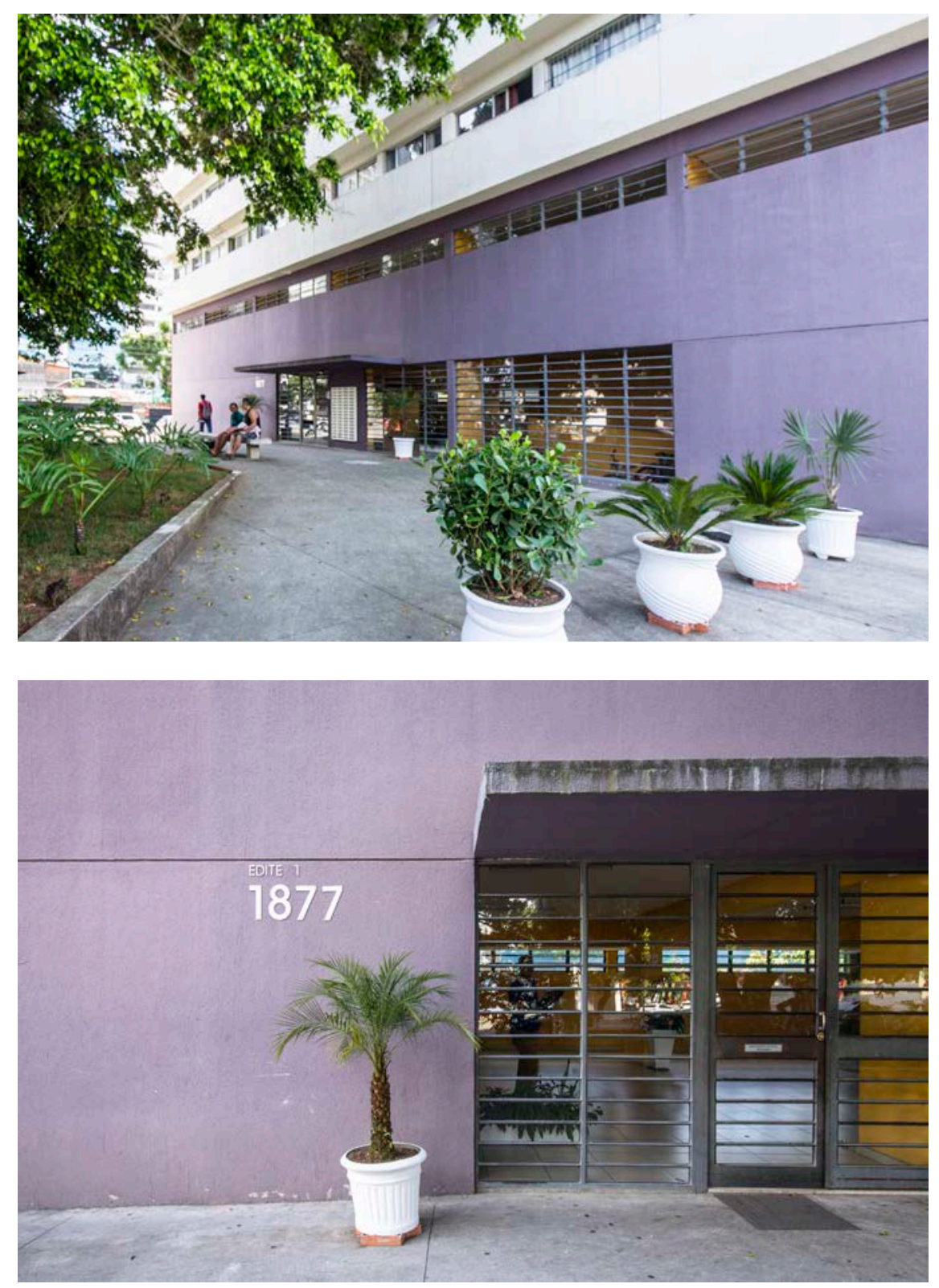

Figura 3.9.6

Figura 3.9.7

Figura 3.9.8

Figura 3.9.9

Praça de acesso e portaria da torre

Vista posterior do conjunto

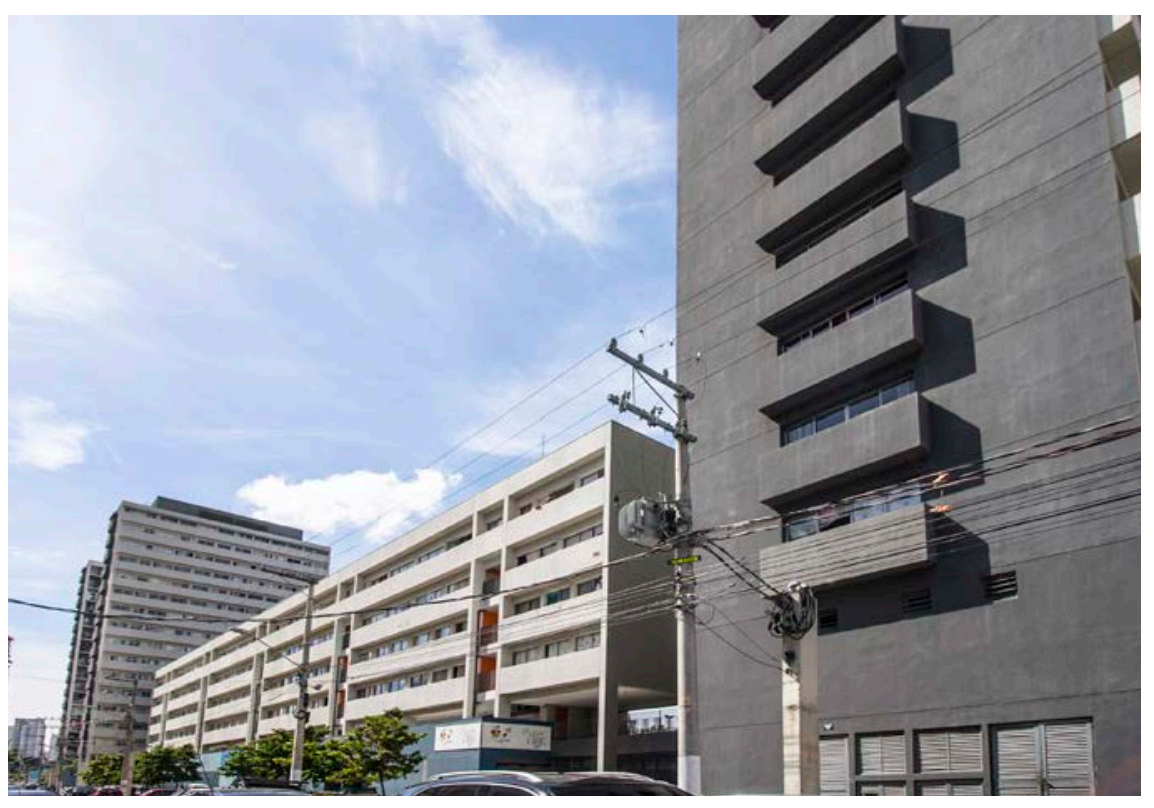



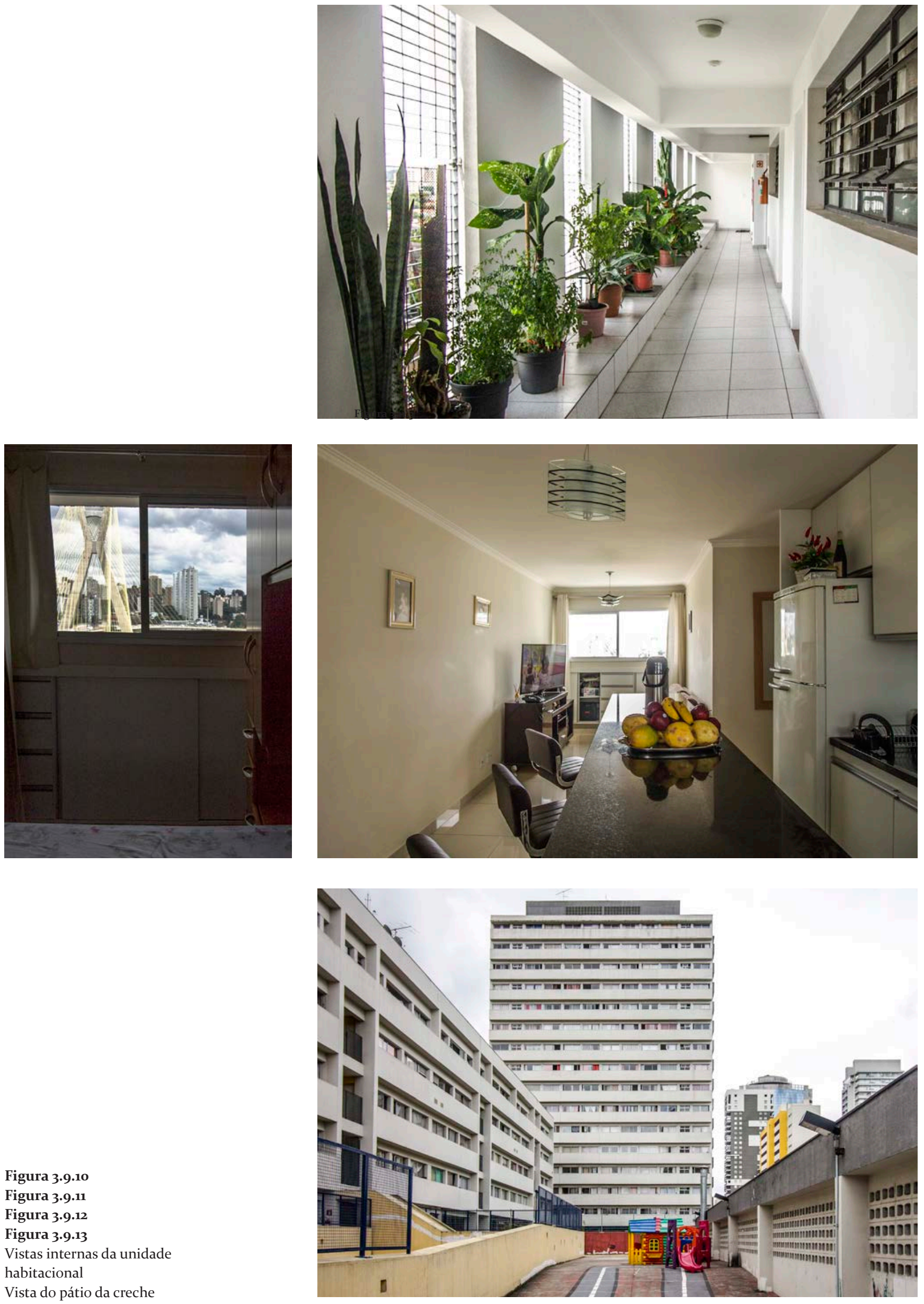

Figura 3.9.10

Figura 3.9.11

Figura 3.9.12

Figura 3.9.13

Vistas internas da unidade habitacional

Vista do pátio da creche 

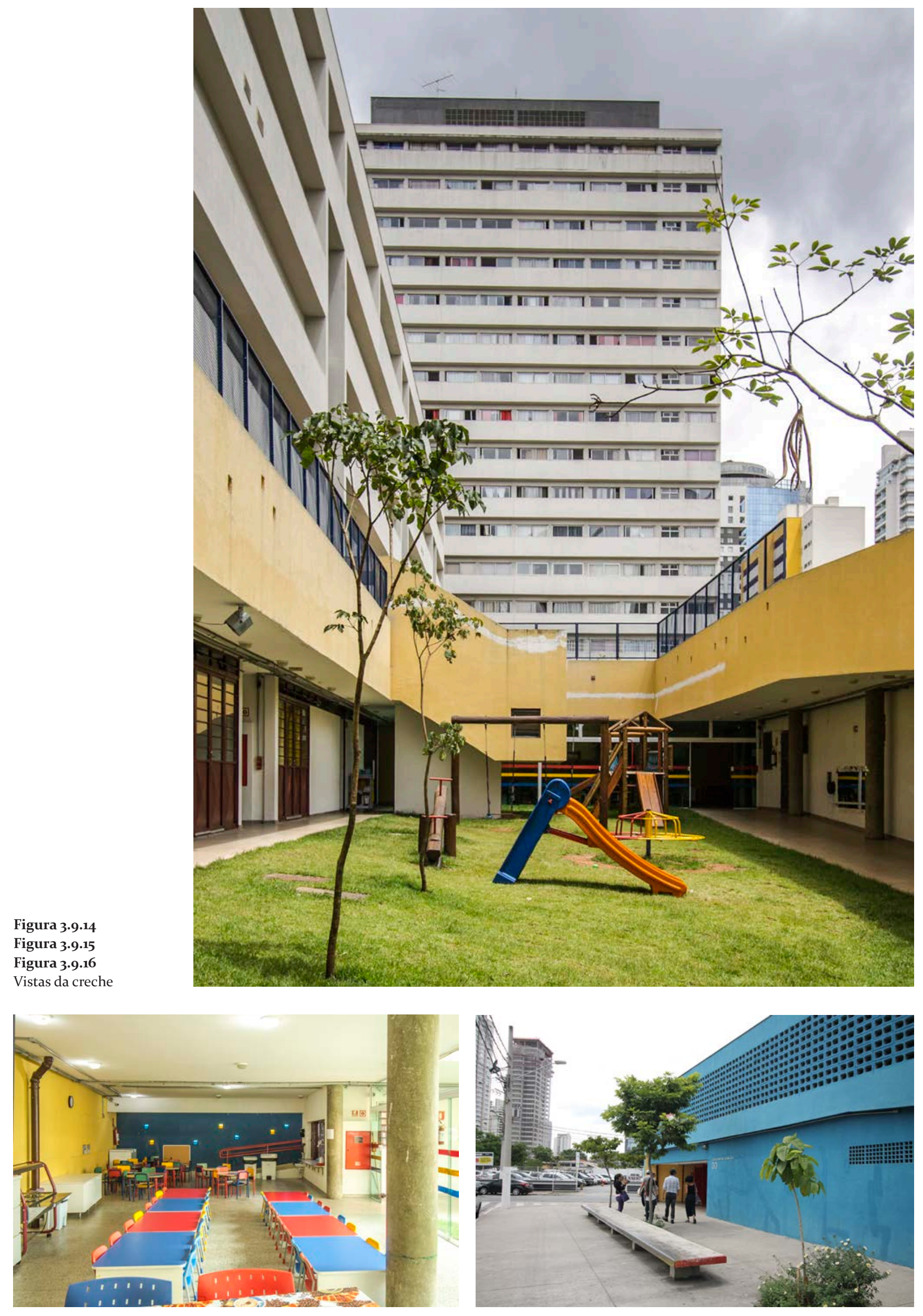
Painel 3.9.a Parque Novo Santo Amaro V
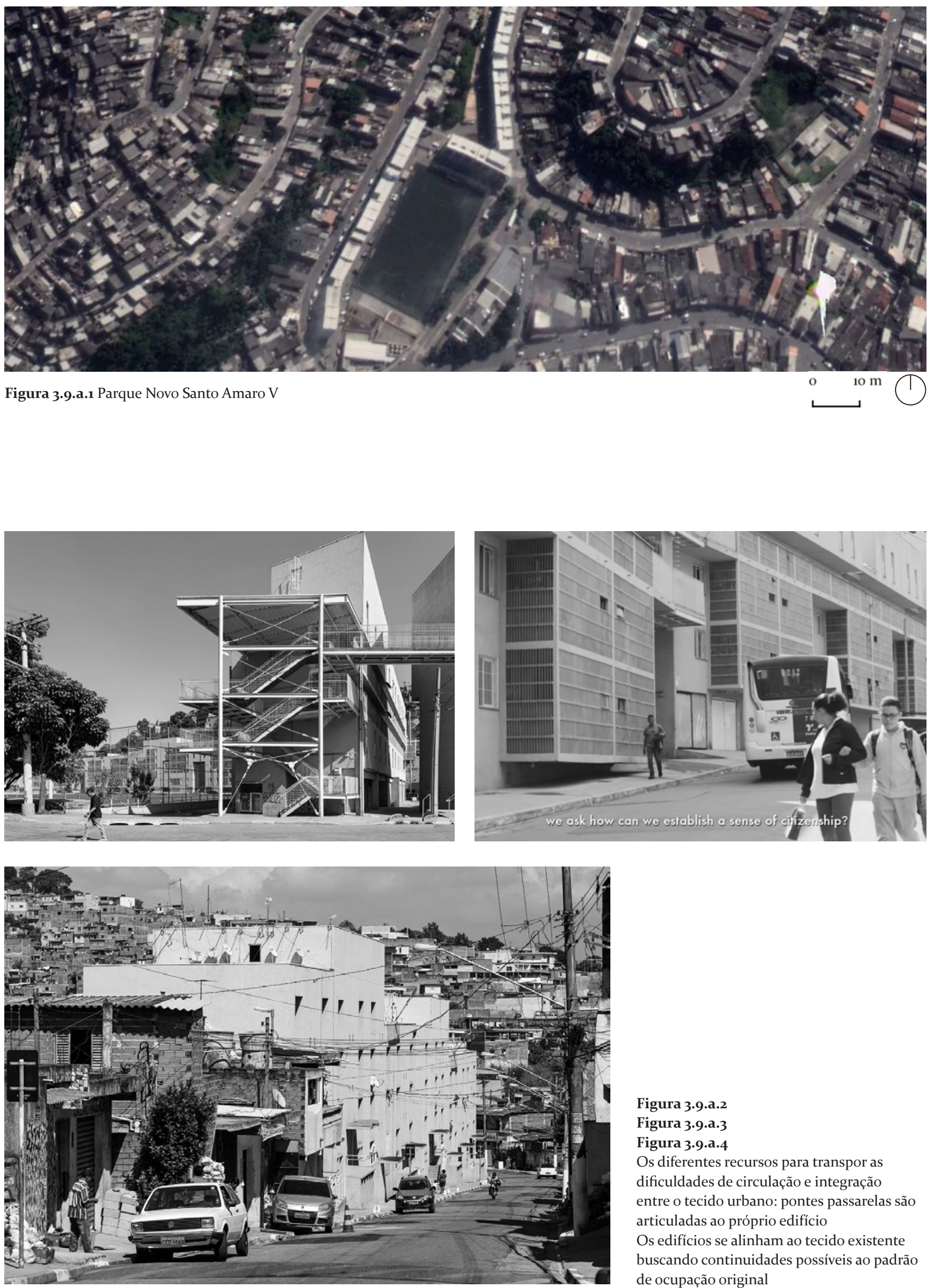

Figura 3.9.a.2

Figura 3.9.a.3

Figura 3.9.a.4

Os diferentes recursos para transpor as

dificuldades de circulação e integração

entre o tecido urbano: pontes passarelas são articuladas ao próprio edifício

Os edifícios se alinham ao tecido existente buscando continuidades possíveis ao padrão de ocupação original 

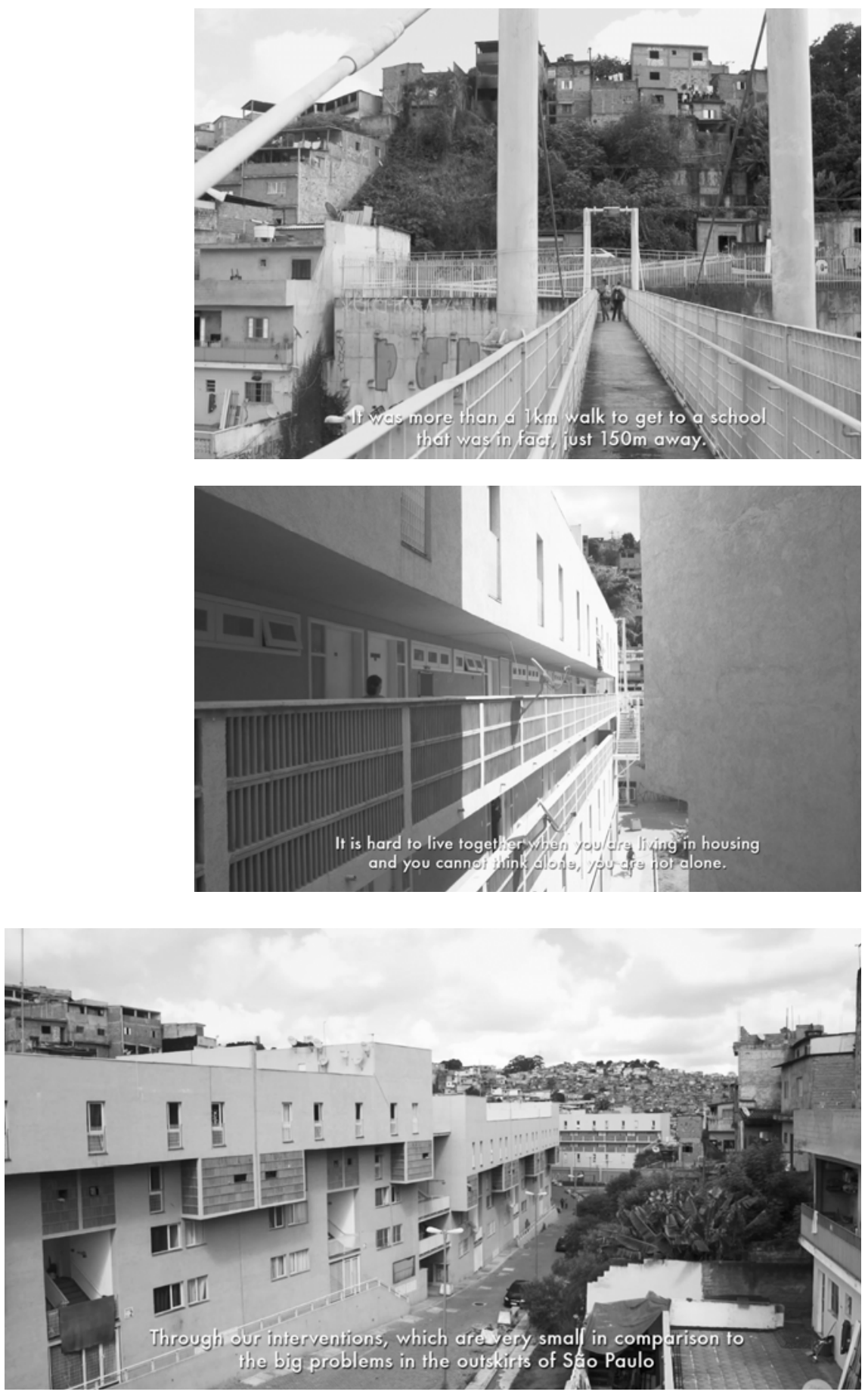

Figura 3.9.a.5

Figura 3.9.a.6

Figura 3.9.a.7

Figura 3.9.a.8

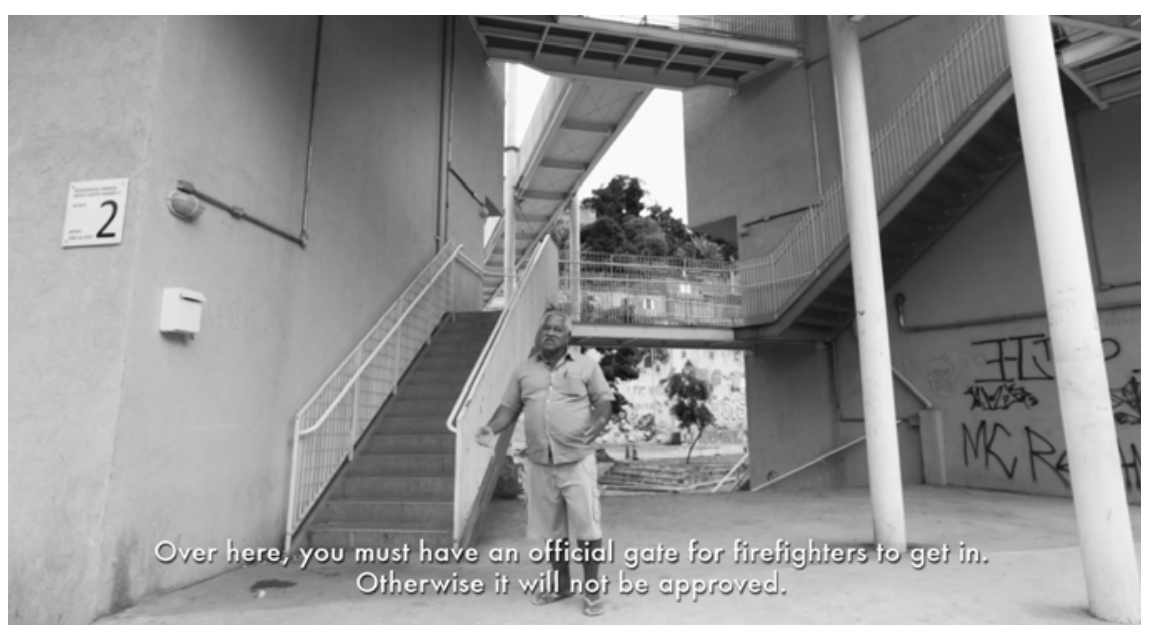


Painel 3.10 Jardim das Perdizes
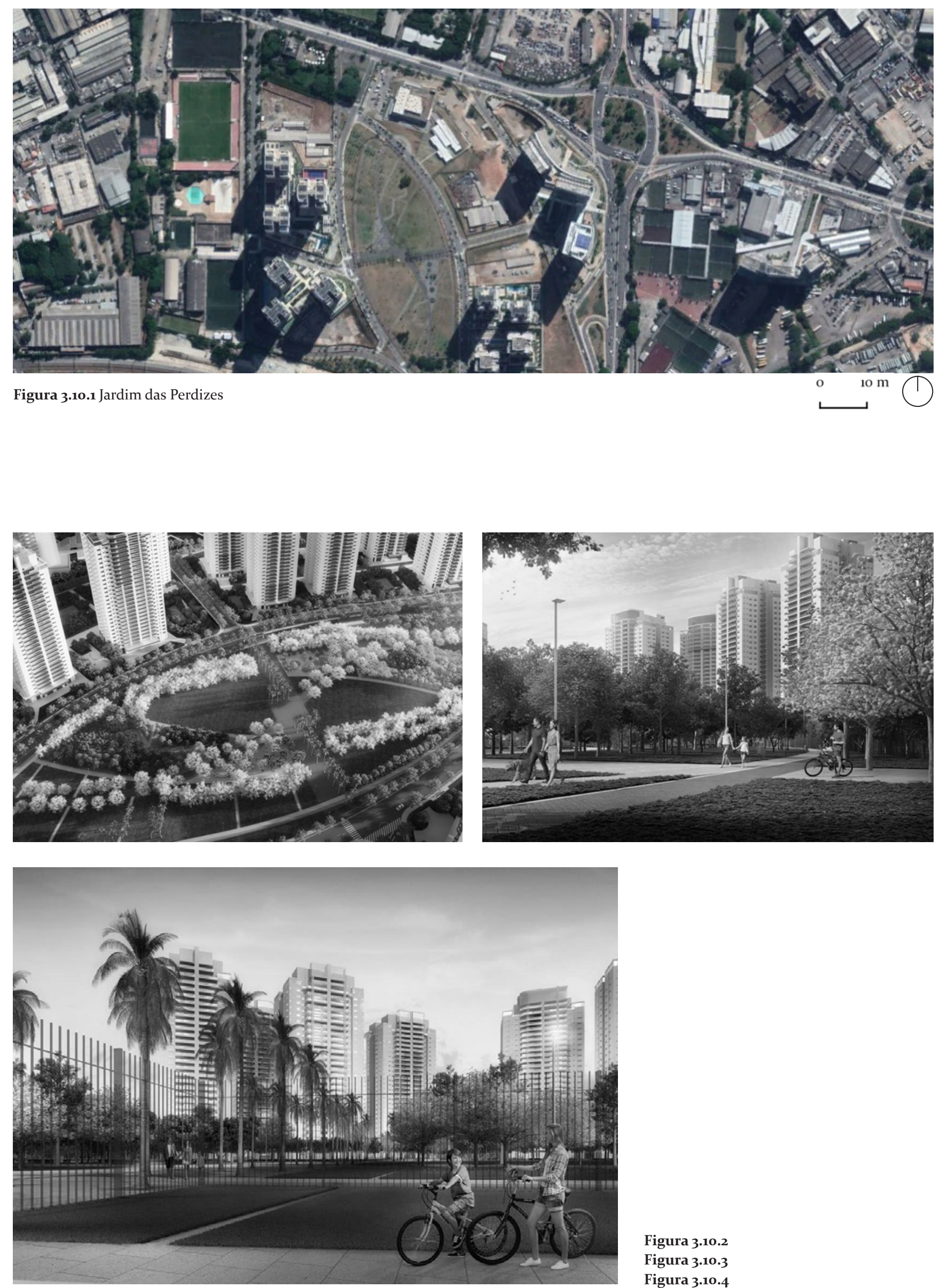

Figura 3.10.2

Figura 3.10.3

Figura 3.10.4 

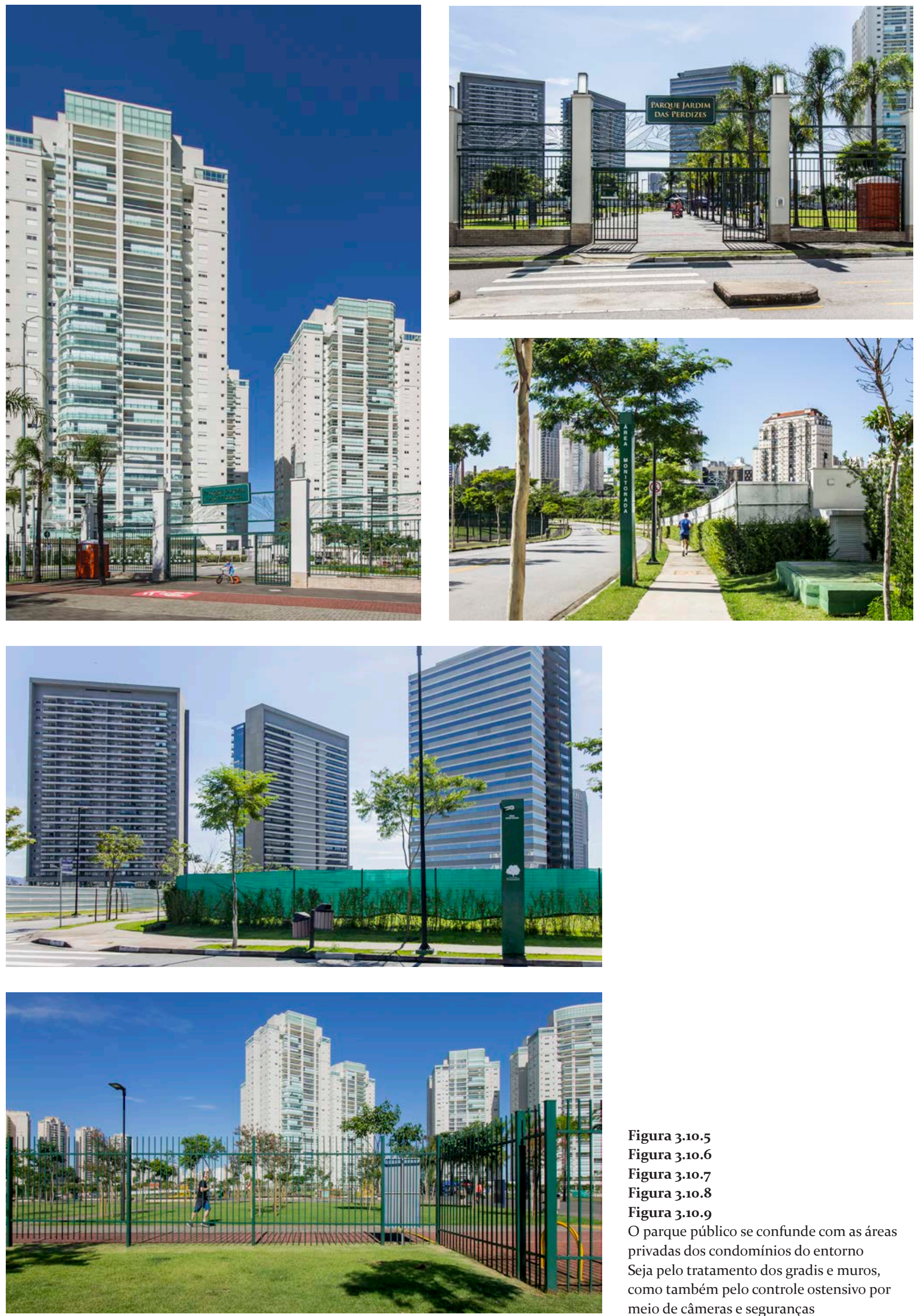

Figura 3.10.5

Figura 3.10.6

Figura 3.10.7

Figura 3.10.8

Figura 3.10.9

O parque público se confunde com as áreas privadas dos condomínios do entorno Seja pelo tratamento dos gradis e muros, como também pelo controle ostensivo por meio de câmeras e seguranças 


\subsection{Desfazendo limites, dissolvendo diferenças}

Solá-Morales (1992) define o espaço coletivo das cidades como itinerários da vida cotidiana. Isso independe do fato de serem ou não espaços públicos ou privados, pois são caracterizados, afinal, pelas suas continuidades. Trata-se do caminho do bar da esquina à escola, à banca de jornal e à estação do metrô. Para o autor, esse tecido que pressupõe essa extensão do urbano, é um aprendizado da riqueza das cidades históricas. Mas ela também conforma a estrutura principal para uma cidade futura, possível. São condições que surgem na interação entre a escala projetual da arquitetura e aquela da morfologia urbana.

Construir continuidades parece ser, então, o grande desafio lançado aos projetos analisados. Assim, a reformulação dos limites e suas transposições são temas de suma importância, se queremos nos opor às segregações e evitar a constituição de enclaves. Ao menos, a revisão dos problemas das fronteiras invisíveis e do debate da lógica de condomínio parecem ter apontado para esse caminho.

Foram justamente estes temas que tentamos abordar em todos os projetos. Eles pressupõem a interpretação de linhas de interação, conexão ou obstrução que surgem quando se torna necessário mediar diferenças: de níveis, de acordos, de possibilidades de uso.

Entre a proibição, a indefinição e a transição convidativa, existem formas que comunicam diferentes possibilidades. Parece que são essas pequenas mediações realizadas pelos instrumentos da $A \& U$ que permitem as continuidades dos espaços coletivos defendidas por SoláMorales. Elas, mais do que conferirem qualidades subjetivas ao projeto, resultam em condições determinantes à apropriação dos espaços públicos. Convidando ao uso e à descoberta dos espaços em meio a itinerância pela cidade. Isso é fundamental se buscamos reforçar a dimensão coletiva das relações socioespaciais. Dentre as análises realizadas, algumas considerações sobre essas mediações que transformam níveis e divisas (diferenças) em interfaces (pontos de contato) emergem.

A noção mais geral de implantação em projetos de arquitetura parece, de partida, pressupor a distinção clara das duas instâncias que a definem: o perímetro do lote da implantação e o volume edificado. No projeto do Colégio Antonio Derka, assim como os dos PB España, PB La ladera e PB Tomás Carrasquilla de Medellín são oferecidos alguns exemplos de subversão dessa separação, quando do enfrentamento de terrenos complexos com altas declividades. Por vezes, nesses projetos tornam-se ambos - lote e volume edificado - organismos indistintos. Com isso, acabam facilitando as conexões com as calçadas e os caminhos das imediações, por se mostrarem mais compreensivos a adaptações morfológicas aos níveis do terreno, por meio de habilidosos arranjos topográficos. Mas, a condição geográfica que se impõe e demanda esse esforço projetual é mais interessante, se não simplesmente absorvida por essa arquitetura como um dado do meio físico a ser transposto funcionalmente por rampas e escadas.

Esse processo se torna mais rico quando a questão topográfica encontra no programa e em elementos que podem surgir do diálogo 
com o entorno imediato, alguma razão para orientar a forma e os demais procedimentos projetuais: como é o caso da grande cobertura que se torna a praça-mirante do Colégio Antonio Derka. Ao se unir ao desejo de continuidade a dimensão programática comunitária e recreativa da escola, criou-se solo urbano, espaço público e, talvez, um novo paradigma espacial. Algo passível de ser investigado e produzido em outras circunstâncias projetuais.

De certo modo, é o que as UVAs fazem. Ao demolirem seus muros, os projetos para as UVAs (tanques) propuseram prolongamentos dos passeios públicos, mirantes, ambientes escalonados que se vinculam intrinsecamente ao volume edificado. O edifício é acionado, nessa implantação, buscando apagar, deliberadamente, a leitura dos limites que antes marcavam a proibição do acesso.

Diferentemente, observando os CEUs, o CFCCT e o Projeto Viver, percebemos que a abordagem perante o perfil natural do terreno tende a decompor sua existência em um arranjo funcional, domesticando cotas de nível para que toquem ou interajam com o argumento projetual principal, que pertence essencialmente ao volume edificado.

Assim, os níveis viram patamares, rampas, escadas e pontes. Essas entidades são ressaltadas com alguma funcionalidade que lhe valoriza a forma-volume principal. Tornam-se elementos de ligação, plataformas para as vistas que se tem do edifício ou a partir dele. $\mathrm{O}$ objeto arquitetônico, em si, de um modo recorrente é puro, prismático, contendo somente inflexões ortogonais ou modulações passíveis de interrupção ou subtração. A austeridade é compreensível, como um gesto de integridade, adequado a um país em que a arquitetura pública recebe poucos recursos financeiros e espaços de atuação. Entende-se, nessa postura, que qualquer nota dissonante ou forma que exceda a racionalidade do prisma, possa soar como uma frivolidade inconsequente. E a arquitetura resultante não é desprovida de uma poética espacial com seus desníveis, grandes aberturas e pés-direitos duplos incorporados às atmosferas internas. Mas nos interessa aqui perceber a sujeição de todas as decisões à forma do edifício. E também suas dimensões urbanas internalizadas, que derivam dessa concepção em torno da síntese buscada no arranjo formal arquitetônico.

Isso aparece no SESC 24 de maio, quando a interface entre a vitalidade da rua e aquela criada dentro da edificação é funcionalizada, entendida como uma relação visual e uma disponibilidade de acessos. Algo implícito à decisão de desconectar as vitalidades do projeto das continuidades da rua, quando se opta por localizar as grandes praças de convívio nos pavimentos superiores. Entende-se que essas escolhas projetuais implicam perdas no potencial de construção de uma outra urbanidade, talvez a demanda mais premente às nossas ferramentas disciplinares da $\mathrm{A} \& \mathrm{U}$ na contemporaneidade.

Quando o terreno ou o entorno imediato são interpretados como uma superfície que abriga, cruza, ou contorna, mas que sempre permanece como elemento claramente discernível, parece não ser possível transpor as diferenças. Do mesmo modo, se as questões programáticas, conexões e contiguidades encontram-se sujeitas ao argumento projetual do volume-ideia, sendo lidas como adições, guardando sempre certa 
independência e frequentemente marcando sua presença na exacerbação do seu argumento estrutural. Assim, os elementos distintos que se somam entre edifício e terreno, em suas junções, parecem tornar o conjunto mais suscetível a grades e controles burocráticos. Visto que essas questões também tendem a não ser previstas pelo projeto, que em sua ideação não considera a condição de uma sociedade que se quer segregada.

Outros contrapontos são oferecidos também quando não se trata de um terreno acidentado. Esse é o caso do PB Belén, com seu conjunto arquitetônico de elementos heterogêneos, mas que fazem parte da mesma lógica. A relação entre os diferentes volumes e a atenção ao qualificar a praça e os percursos entre eles e a cidade, cria um tecido pronto para ser apropriado, atravessado e descoberto.

Além disso, os volumes generativos e geométricos nos Jardins infantis, não só se adaptam à topografia e a estrutura fundiária irregular, eles também se anteciparam em desenhar as interfaces entre o mundo interno e externo. Eles preveem, assim, as dificuldades de mediação entre essas duas dinâmicas e a vulnerabilidade de seus usuários. Nesse caso, a relação interioridade $\mathrm{x}$ exterioridade é central na abordagem projetual e contribui para orientar o programa em direção à autonomização e adaptabilidade de suas unidades em um sistema de salas-célula.

Em São Paulo, também encontramos alternativas nesse sentido. No caso do Parque Novo Santo Amaro V e do Jardim Edite, os próprios edifícios são a interface entre a totalidade do urbano e suas atribuições programáticas específicas. Assim, as divisas, interfaces e as transposições de níveis são incorporadas à tipologia do edifício habitacional. Isso demanda o acionamento de ferramentas projetuais que procuram reinventar as categorias e as relações das formas arquitetônico-urbanas para criar as margens desse projeto e sua condição de parte - não autônoma- do tecido urbano.

A urbanização do complexo Cantinho do Céu, em São Paulo também foi capaz de combinar questões funcionais dos sistemas de infraestrutura da cidade às demandas por espacialidades contínuas e qualificadas do tecido urbano. As melhorias do sistema viário, as soluções de drenagem urbana e os problemas das áreas de proteção ambiental foram integrados ao projeto de um sistema de espaços livres que, apesar de possuir áreas recreativas e contemplativas, resistiu à segregação por grades e os regimes de uso regulados, que configuram os parques da cidade.

Esses projetos, ao desfazerem limites buscam, afinal, dissolver diferenças. Os edifícios-interface deixam de antagonizar o dentro e o fora, de demarcar o convidado e o excluído, o privado e o público, reconhecendo que essa tomada de posição simbólica também deixa de reproduzir a segregação, em favor das continuidades possíveis e das mediações generosas. Essa proposição dos espaços é realizada a partir de um léxico reconhecido ou reconhecível que não se confunde com estratégias abstratas de homogeneidade e amplidão.

A delimitação e a separação (lote, grade, cercamento do espaço idealizado como livre), pode ser uma patologia da sociedade que se 
condominializa e, nesse sentido, configura algo que foge do controle do projeto, quando esse se torna a realidade do cotidiano, sujeita aos síndicos, como nos avisa Dunker (2015). No entanto, o que propusemos neste capítulo foi colocar a questão da criação de novas urbanidades, de continuidades do espaço coletivo, no centro das preocupações projetuais da arquitetura. Considerando esse posicionamento uma reação às impossibilidades da construção social coletiva, que persistem nas reafirmações e reproduções das diferenças formuladas no espaço. 


\title{
4. A fragmentação dos espaços cotidianos
}

\begin{abstract}
É o uso do território, e não o território em si mesmo, que faz dele objeto da análise social. Trata-se de uma forma impura, um híbrido, uma noção que, por isso mesmo, carece de constante revisão histórica. O que ele tem de permanente é ser nosso quadro de vida. Seu entendimento é, pois, fundamental para afastar o risco de alienação, o risco da perda do sentido da existência individual e coletiva, o risco de renúncia ao futuro.
\end{abstract}

Milton Santos ${ }^{134}$

No percurso proposto pela tese, passamos da segregação observada no processo de urbanização - com a formação dos centros e periferias àquela reproduzida no lote, pelas dinâmicas socioespaciais e também pela intermediação da $A \& U$. Esse processo estrutural e, ao mesmo tempo desagregador, atinge, afinal, a vida cotidiana: tema que perpassa as análises que desenvolveremos a seguir.

A fragmentação dos espaços cotidianos, título do capítulo, refere-se ao processo desagregador do espaço social, que decorre da homogeneidade-fragmentação-hierarquização que atinge o urbano na modernidade. Esse processo também foi observado, com suas particularidades, nos processos de urbanização das cidades de São Paulo e Medellín. Assim como em algumas formulações da A\&U que entendiam o urbano como uma somatória de funções. Trata-se de um problema intrínseco à racionalidade moderna que também, como observou Lefebvre (1971), se desdobra com imensa potência na reprodução do espaço pela resposta técnica e tecnocrática do urbanismo (e do Estado). Essa ciência parcelar, com sua leitura funcionalista das coletividades urbanas, pretendeu esgotar e sistematizar as possibilidades funcionais da vida humana, suas vinculações e suas estruturas. Procedia em uma síntese integral que pudesse criar um conjunto funcional totalizante: a vida sendo espelhada exatamente em uma estrutura espacial idealizada.

Como percebeu o autor, essa hipótese jamais daria conta de se integrar à espontaneidade da vida, algo impossível de ser transformado em uma síntese operativa. As aspirações e necessidades (individuais e sociais, inseparavelmente) jamais poderiam coincidir com funções assumidas formalmente por um projeto urbano. Além disso, o funcionalismo integral traria, como resultado, o aborrecimento profundo do ser que realiza pontualmente essas funções (LEFEBVRE, 1971, p. 107-108).

Essa crítica às respostas do urbanismo, indissociáveis aos procedimentos funcionalistas da arquitetura moderna, se estendem aos novos problemas que decorrem da implosão-explosão das cidades. Mas Lefebvre reconheceria, até mesmo nas gigantescas aglomerações como

${ }^{134}$ SANTOS, M. O Retorno do Território. OSAL: Observatorio Social de América Latina, n. 16, jun. 2005, p.255. 
São Paulo, o urbano como uma possibilidade a ser revelada (LEFEBVRE, 1986).

Diante dos problemas expostos, o autor descarta a hipótese de buscar uma forma urbana comunitária, algo que ele identificava como uma aspiração de sociólogos e urbanistas que, àquele momento (década de 1960) se colocavam em defesa da escala humana e do senso de vizinhança e de comunidade. $O$ filósofo ponderava que isso pressupunha estipular limites muito claros para um contingente populacional que pretendesse manter um nível de conhecimento mútuo, algo que incorreria na recriação de um universo provinciano. Descartando essa hipótese, como uma utopia abstrata, o autor apontava para uma solução virtual, hipotética e especulativa, uma direção em defesa de um humanismo dialético. Assim, Lefebvre argumentou que seria necessário um estudo crítico das funções, no tipo de análise que separa os elementos (as variáveis) para romper a sua unidade.

$\mathrm{O}$ autor também aponta um caminho por meio da incorporação ao urbano do jogo, do lúdico, do imprevisível, da emoção e da surpresa. A vida espontânea que goza de si mesma e tende a plenitude e à satisfação. Desse modo, o autor pondera que, possivelmente, as funções não seriam, outra coisa que meios (LEFEBVRE, 1971, p. 108).

\section{A arquitetura como modo de imaginação}

As considerações de Lefebvre sobre os problemas da racionalidade moderna, agindo sobre a vida cotidiana, de certo modo coincidem a direção da própria crítica disciplinar do pós-Segunda Guerra. Mais especificamente, essas considerações iluminam alguns pontos e localizam onde a arquitetura produz suas próprias contradições, o que nos motiva a percorrer seu trabalho.

Nesse sentido, nos interessa também mobilizar o modo como o autor avalia o papel do arquiteto, uma vez que este interage com os contextos socioespaciais. Lefebvre reconhece a sua atuação - ainda que com ressalvas - pela sua vinculação estreita com a produção do espaço (social):

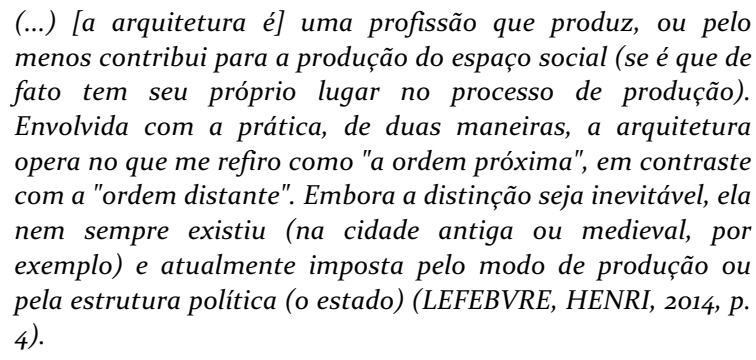

Lefebvre destaca aqui a ordem próxima do cotidiano em que a arquitetura atua, em contraste com a ordem distante do planejamento urbano. Ele propõe pensar a arquitetura que produz o espaço em um nível específico, que vai do móvel a paisagem (LEFEBVRE, 2014, p.3) ${ }^{135}$.

${ }^{135}$ Do texto original: "What I propose to understand by "architecture" is the production of space at a specific level, ranging from furniture to gardens and parks and extending even to 
E, assim, distancia - em um primeiro momento e teoricamente - a prática da arquitetura das impossibilidades encontradas pela funcionalização do espaço no modo de produção capitalista:

\begin{abstract}
Esse isolamento é o único caminho para avançar em direção a um pensamento claro, a única maneira de evitar a incessante repetição da ideia de que não há nada a ser feito, nada a ser pensado, porque tudo está "bloqueado", porque o capitalismo governa e coopta tudo, porque "o modo de produção" existe como sistema e totalidade, para ser rejeitado ou aceito de acordo com o princípio de "tudo ou nada". Qualquer outra abordagem só pode incorporar o status quo, em outras palavras, a aniquilação do pensamento - e, portanto, da ação não importa o domínio. (LEFEBVRE, 2014, P.4)
\end{abstract}

Conforme destaca Stanek (STANEK, 2014, p. xiii), Lefebvre restitui à arquitetura suas potencialidades. Menos em um sentido de tecer leituras sobre a profissão e mais enquanto modo de imaginação. $\mathrm{O}$ principal argumento em torno das capacidades da arquitetura em interagir com a produção do espaço se faz por meio da ideia de utopia concreta. Ao contrário da utopia abstrata dos planos urbanos e das arquiteturas que buscaram a positividade do real, a utopia concreta reage e imagina, por meio daquilo que nega:

\begin{abstract}
Não há espaço social sem estoque de possibilidades desigualmente distribuído. Não só o real não se separa do possivel mas, em um sentido, é definido por ele e, portanto, por uma parte da utopia. Esse caráter utópico ficou evidente na abordagem do espaço em toda a sua manifestação: moradias, cidades, monumentos. Portanto, não pertence apenas aos sonhos, às imaginações do futuro, mas a toda espacialidade (mesmo a mais realista e utilitária, como a arquitetura militar). Os chamados projetos utópicos, em voga em certas eras (a Renascença, o século dezoito), meramente arrancaram do "real" os aspectos mais utópicos. Eles os reuniram, acentuando seu caráter utópico sem produzi-lo. (...) Hoje, no entanto, a utopia abstrata depende de tecnocratas, eles são os que querem construir a cidade perfeita. Eles se preocupam com o "real": necessidades, serviços, transporte, os vários subsistemas da realidade urbana e o próprio urbano como um sistema. Eles querem organizar as peças do quebracabeças para criar um ideal. Compare isso com a utopia concreta, que é negativista. É preciso uma hipótese estratégica a negação do cotidiano, do trabalho, da economia cambial. Também nega o Estado e a primazia do político. Começa com prazer e procura conceber um novo espaço, que só pode basear-se num projeto de arquitetura.(LEFEBVRE, 2014, P.148)
\end{abstract}

Segundo Lefebvre, essa nova postura negativa pressupõe que a arquitetura desista de estabelecer "espaços envolventes" para impor e preservar as relações que ela antes desenvolvia. Seria preciso revelar todos os seus efeitos redutores, para rumar em direção a um projeto novo:
Um projeto totalmente diferente está envolvido, um de virar o mundo de cabeça para baixo e estabelecer uma base que é diferente das bases anteriores, uma fundação diferente de fundações mais íntimas. O que está sendo determinado, o que está no trabalho é uma questão de direção. Mas não uma direção para "pesquisa", mas sim uma maneira de orientar a vida que procura mudar, praticamente, socialmente

landscapes. I exclude, however, urban planning and what is generally known as "land use planning". Tradução nossa. 
Essa tomada de consciência da arquitetura, como forma de imaginação de uma nova vida, que envolve o corpo individual e social, não é aqui tomada como uma tarefa, mas como um quadro crítico e provocativo, necessário diante da crise disciplinar e do imobilismo deflagrado por Tafuri. As considerações de Lefebvre sobre a arquitetura como modo de imaginação, se tornam um pouco mais nítidas quando do esclarecimento das especificidades do projeto, e das condições para a superação da abordagem projetual estritamente funcional:

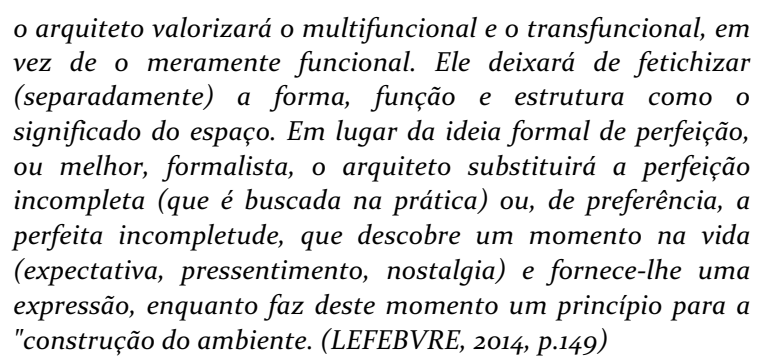

Negando a fetichização da forma, da função e da estrutura, caberia à arquitetura, então, sua capacidade de agir sobre significantes múltiplos e abertos:

\begin{abstract}
Isso significa que o arquiteto não age de maneira geral, ou de um significado particular, mas de significantes (múltiplos, abertos, com significado entre outros), sem, no entanto, "transformar" esses significantes. Suas preocupações e preocupações estão em ambos os lados de tais significantes e significados, fora da relação entre significante e significado. Seu poder, limitado mas real, é importante na medida em que ele pode selecionar o referente (natureza, sensorialidade, materiais). (LEFEBVRE, 2014, p.151)
\end{abstract}

\section{Entre espaços vazios e vastas indeterminações}

Os termos mais gerais em que Lefebvre realiza sua crítica aos paradigmas espaciais modernos parecem coincidir em alguns pontos com o debate dos anos 1960 e 1970 da A\&U. Pois, de fato, durante esses anos, pretendeu-se reavaliar a relação entre arquitetura e cidade, depois da crise das estratégias de planejamento moderno pós-guerra. Ainda que as posições tenham sido diferentes nos principais centros de reflexão - Inglaterra, Itália e EUA - a relação com as formas urbanas existentes passa a ser o fundamento da esperada reinvenção da disciplina arquitetônica, no esgotamento ideológico e sua pretensa autonomia abstrata e funcional cada vez mais restrita ao jogo formal do edifício. O urbano compreendido como street (movimento e vida coletiva), tradição (tipologias e formas simbólicas) ou comunicação

\footnotetext{
${ }^{136}$ Do texto original:"An entirely different project is involved, one of turning the world upside down and establishing a base that is unlike the earlier bases, a foundation unlike ealier foundations. What is being determined, what is at work is a question of direction. But not a direction for "research", rather, a way of orienting life that seeks to change it, practically, socially poetically. For the body is the source of poetry: poiesis". Tradução nossa.
} 
(automóvel e imagem publicitária) incidiam sobre a lógica da arquitetura, desde a sua integração ao meio, até a sua diluição programática (RECAMÁN, 2015, p. 16).

Dois exemplos (e conflitos) permitem uma aproximação maior entre as aproximações propostas por Lefebvre, o debate realizado pelos próprios arquitetos e os termos em que essa reflexão crítica pode impactar as estratégias disciplinares. Particularmente pelo modo como incorporam a dimensão da vida coletiva e da diluição programática a uma reflexão sobre as estratégias projetuais da arquitetura. Esses referidos exemplos podem ser extraídos do debate realizado por alguns membros do Team ${ }^{10}{ }^{137}$. Este grupo heterogêneo e cambiante de arquitetos realizou importantes críticas aos preceitos da arquitetura moderna defendidos nos CIAMs. Mas também desenvolveram pesquisas importantes sobre a vitalidade das ruas nos bairros operários, a importância da infância e da brincadeira na cidade e de outros espaços, como os assentamentos precários no norte da África.

Essa reflexão sobre o papel da arquitetura diante da cidade existente se deu por meio de investigações projetuais e escritas, extremamente preocupadas em estruturar uma reflexão sobre a modernização e a modernidade, mas também elaborar respostas e instrumentos projetuais para ela, algo que por vezes foi identificada como uma utopia do presente, como apontam Heuvel e Risselada (2005).

Dessa extensa e variada produção do Team 10, destacamos o trabalho de Aldo Van Eyck para os parques infantis construídos em Amsterdam, logo após a segunda guerra mundial. Essa experiência enfrenta a demanda pelo espaço público que advém de uma manifestação social, pós-conflito. A necessidade de reocupar as ruas foi atendida por meio de um processo participativo e um sistema projetual extremamente aberto e flexível. Um notável caso de sucesso de comunicação entre as ferramentas da disciplina e as demandas da sociedade, ainda mais se considerarmos alguns números: os arquivos de Amsterdam contam com mais de 190 cartas de cidadãos solicitando e interagindo com o processo de implantação desses playgrounds. E isso resultou em quase mil playgrounds construídos entre 1947 e 1968 (uma média de 5o por ano). Esse processo teve origem no trabalho de Cornelis van Eesteren, a frente do Departamento Municipal de Serviços Públicos (Municipal Department of Public Works), envolvendo também Jacoba Mulder, arquiteta do serviço público, além do próprio Van Eyck.

Todos esses projetos foram construídos em terrenos residuais, espaços intersticiais e foram pensados para funcionarem como uma rede de espaços públicos comunitários. Importante notar que a ideia de rede, aqui, tem a ver como uma experiência real e não como uma abstração de um sistema. Os parques, ainda que pequenos eram tão numerosos, que alteraram a percepção dos espaços públicos que se tinha na cidade.

Talvez, o principal mérito desta experiência - algo que nos motiva a destacá-la como interesse dessa pesquisa - é que não configuraram nela

\footnotetext{
${ }^{137} \mathrm{O}$ team 10 era um grupo de indivíduos que variou ao longo dos anos, entre o círculo interno e convidados que muito dificilmente se distinguem. Os sete participantes mais ativos e mais envolvidos no discurso do Team 10, podem ser considerados: Jaap Bakema, Georges Candilis, Giancarlo De Carlo, Aldo van Eyck e Alison e Peter Smithson e Shadrach Woods (HEUVEL; RISSELADA, 2005).
} 
demolições, grandes renovações ou interrupções no tecido urbano. Pelo contrário, realizavam conexões em tecidos preexistentes, sem buscar autonomizá-los como novos espaços públicos.

Apesar de serem projetados individualmente, eram extremamente simples, espaços livres, qualificados por meio de um repertório simples, apesar de cuidadosamente projetado, que constava de brinquedos, bancos, pavimentação, pequenos abrigos que se combinavam diferentemente em cada intervenção. Uma arquitetura feita para o cotidiano com pouquíssimas determinações programáticas, além de serem espaços propícios para brincadeiras infantis. ${ }^{138}$

É interessante notar que esta experiência realizada pelo jovem Van Eyck representa uma concepção projetual que parece ir se transformando, na carreira do arquiteto, em um desejo por maior controle projetual sobre as indeterminações da vida e do espaço urbanos. Ao menos, essa parece ter sido a percepção que Alison e Peter Smithson tiveram das ideias posteriores desenvolvidas por Van Eyck durante os debates no Team 10. Isso criaria uma diferença de opinião que traria debates acalorados ao grupo. E nos interessa, na medida em que expõe as diferenças de concepções em relação ao uso, ao vazio e a forma arquitetônica (HEUVEL, 2003).

Van Eyck se referia a uma unidade projetual do "espaço entre" (in between) desenhado por edifícios e formas urbanas, isto é, uma concepção do in between que parece ser condicionado e delimitado por ferramentas de projeto - seria algo parecido com a determinação do espaço envolvente que Lefebvre criticava?

Para os Smithsons, no entanto, este era, deliberadamente, um espaço deixado livre. Conceito que, depois, evoluiria para um vazio carregado, ou como eles chamavam, charged void - algo como um vazio carregado de energia (das pessoas, ou dos próprios edifícios a sua volta) ${ }^{139}$.

Isso reflete o entendimento dos Smithsons sobre o desenho, enquanto uma estrutura totalizante que determina tudo, das escalas grandes às pequenas. E era esse tipo de estratégia, excessivamente desenhada e fechada, que eles pretendiam evitar. Isso porque buscavam um certo afastamento da dimensão do planejamento urbano e desse pensamento de que vários elementos e estruturas se somam para constituir a cidade (algo que Van Eyck também explorava). Isso se deu também como uma autocrítica diante de seus próprios projetos.

Pelo contrario, eles estavam buscando uma nova situação urbana, eliminando as fronteiras, reagrupando aquilo que havia sido separado pela modernização. As ideias e o trabalho dos Smithsons buscavam o reconhecimento dessas novas fronteiras, para permitir a realização de intervenções conectivas no urbano. Para eles, estabelecer uma ligação acontecia na mesma medida em que se criava uma distância, em uma nova forma de associação: um vazio mágico, com os conteúdos necessários para um equilíbrio entre relaxamento e intensidade, separação e conexão, como definiu Risselada (2011, p. 353).

\footnotetext{
${ }^{138}$ Alguns desses parques incluíam um mural artístico nas empenas dos edifícios do entorno feitos pelo grupo COBRA.

${ }^{139}$ Conforme entrevista de Max Risselada à autora em 28/06/2018.
} 
Assim, neste capítulo, os projetos selecionados em Medellín e em São Paulo nos convidam a pensar sobre as significações projetuais mobilizadas, justamente, em espaços vazios. Ao passarmos das ponderações de Lefebvre sobre a não fetichização da forma (em direção a manipulação aberta de significantes), para as experiências do Team 10, vemos que acomodar a vida cotidiana, promover a apropriação do espaço público, assim como o prazer e a felicidade da convivência coletiva, pouco tem a ver com desenhar funções. Quem sabe, estejamos diante da necessária criação de "condições de possibilidade", como nos falava Jameson (1985) - e como discutimos no capítulo 1. Deste modo, nos três casos estudados, indagamos como os espaços vazios foram projetados e carregados de intenções de renovação, como mediações entre o existente e suas novas possibilidades imaginadas.

Estudamos também a intensidade programática, aqui entendida como o nível de qualificação desses espaços vazios - sem determinações estritamente funcionais - para que convidem a apropriação e conectem o novo tecido projetado à dinâmica do tecido urbano existente. Esta é uma pergunta que se estendeu a todos os projetos da tese: quais são as estratégias projetuais que logram se aproximar a essa ativação do vazio conectivo? Isso como uma possível reação ao problema da fragmentação dos espaços cotidianos e a funcionalização da vida.

Apresentamos, ao final do capítulo, um estudo gráfico das implantações. Elas pretender complementar a percepção colhida em campo, ilustradas e debatidas ao longo da tese. Tencionamos, com isso, registrar e diferenciar os projetos que utilizam o vazio como espaço residual entre os limites do lote ou como estratégia de valorização do objeto arquitetônico, daqueles que o manipulam em sua dimensão relacional aqui debatida.

A potência do tema também se confirma em sua capacidade de aglutinar as questões em torno da crítica ao movimento moderno. Tornando-se, aqui, a porta de entrada para estabelecer as últimas ponderações sobre a cultura arquitetônica por detrás das experiências projetuais analisadas nessas duas cidades. 
As particularidades da arquitetura moderna na Colômbia, como a assimilação tardia e crítica aos preceitos modernistas compartilhados internacionalmente - conforme debatido no capítulo 1 - também se refletirão no período subsequente. A produção colombiana foi atingida por boa parte da referida crítica europeia e norte-americana ao movimento moderno, em direção à cidade. Desse modo, seus arquitetos sujeitaram-se aos problemas e possibilidades advindas dessa trajetória reflexiva. Enfrentaram a escassez de referências ofertadas pelas tipologias urbanas históricas existentes, para suas formulações projetuais. E, particularmente, no caso de Medellín, transitaram sobre uma base moderna menos celebrada e impactada por cânones de mestres, diferentemente da influência de Salmona em Bogotá e da vanguarda da arquitetura moderna brasileira.

Desse modo, em Medellín as estratégias projetuais não se reportavam a uma escola. E, se a produção pós-moderna não produziu experiências de grande qualidade nesse período, parece, no entanto, que permitiu aos arquitetos permanecerem investigativos e autocríticos. Silvia Arango $^{140}$ também destaca certa moderação projetual, isto é, a pouca afeição à dimensão icônica na produção modernista colombiana, que se dedicou mais a experimentações contextuais e topológicas. Isso também teria favorecido uma abertura maior a um processo de contínua experimentação.

A recente produção em Medellín acaba por refletir essas condicionantes e também à abertura a uma série de referências importantes dos anos 1970 e 1980. Isso é verificável pela penetração do debate de Aldo Rossi, Rob e Leon Krier no âmbito acadêmico, algo testemunhado nos debates dos SAL ${ }^{141}$, como também pelos depoimentos dos arquitetos de Medellín. O contexto de formação dos arquitetos da cidade, incorpora essas referências, até mesmo por meio da experiência direta em centros de formação espanhóis, italianos e ingleses.

Os anos de extrema violência urbana e pouca atividade profissional, em virtude da crise econômica e política, contribuíram para que muitos arquitetos buscassem alternativas de formação e atuação profissional fora do país. Muitos voltaram, posteriormente, como docentes. E isso terá considerável impacto sobre a geração seguinte, que atuará na universidade, mas também na municipalidade, à frente dos projetos urbanos ou participando dos concursos públicos.

Grande parte dos profissionais envolvidos nos projetos analisados são egressos da Universidade Pontifícia Bolivariana ${ }^{142}$ (UPB). Verifica-se, nessa universidade, a criação do Laboratório de Arquitetura e Urbanismo (LAUR) que recebeu colaboração direta do Laboratório de Urbanismo de Barcelona (LUB) da Universidade Politécnica de

\footnotetext{
${ }^{140}$ Conforme entrevista a autora em 31/01/2019.

${ }^{141}$ Algo que Barcellos (2013) relatou mas também foi confirmado por Silvia Arango em entrevista a autora em 31/o1/2019.

${ }^{142}$ Cf. GIRALDO ECHEVERRI; TOBÓN CASTRO; RESTREPO JARAMILLO, 2017..
} 
Catalunya (UPC) a partir de 1996. Isso contribui para explicar a grande ênfase nos temas urbanos e, principalmente, o desenvolvimento de uma metodologia de desenho assessorada pela escola de Solá-Morales.

O planejamento, em Medellín, vincula-se a determinação da morfologia urbana e a escalas de atuação que pressupõem o controle do desenho da cidade, dentro da ideia de um projeto de projetos (DE SOLÁ MORALES, 2008). Isso se verifica implementação efetiva das sucessivas aproximações de planificação que vão desde o Plan de Ordenamiento Territorial, se desdobrando em aproximações e definições no Macroproyecto, no Plan Parcial chegando, por fim, na Unidad de Actuacion Urbanística Mínima, algo que chega à escala projetual de um pequeno agrupamento de quadras.

A trajetória de estudos dos principais arquitetos envolvidos nas recentes transformações da cidade também demonstra a contínua abertura ao debate internacional contemporâneo ${ }^{143}$. Algo que tem grande impacto na cidade, visto que tanto a UPB quanto a Universidade Nacional da Colômbia (sede Medellín) despontam como grandes colaboradoras diretas da municipalidade e das instituições públicas, com consultorias técnicas, estudos e participação ativa nos projetos urbanos. Haja visto que os projetos que analisaremos a seguir foram projetados junto ao LAUR.

Soma-se a essas condições, a predisposição a construir aprendizados pela prática, como aponta Perez Jaramillo (BARBOSA, 2006). Essa "Medellinidade", segundo Vélez White (2000), é de um certo pragmatismo destrutivo-construtivo, um traço marcante da cultura local. Algo que também se reforça no discurso, após o enfrentamento das condições extremas de segregação e violência que demandaram a transformação do tecido urbano, em uma reação coletiva.

Assim, a fala dos arquitetos dessa geração que atuou intensamente sobre a cidade reproduz essa percepção. Em geral, eles hesitam em debater suas preferências teóricas, ao se dizerem arquitetos práticos. Respondem às indagações sobre formação falando não de seus anos formativos na universidade, mas de suas primeiras experiências projetuais . E, frequentemente, ao descreverem seus projetos, tendem a incorporar à explicação dos pressupostos iniciais vinculando-os diretamente às condições (e contingências) dos processos de trabalho. Algo exemplificado por Andrés Perea Ortega ao comentar o trabalho do Plan B arquitectos como "muito realista, que revela um esforço preciso diante das precariedades" (MESA, 2006) ${ }^{144}$.

As três diferentes gerações: entre profissionais dos anos 1980 que se tornaram professores; a geração seguinte por eles formada e os novos alunos incorporados em seus estúdios e nas equipes técnicas das ativas instituições se mesclam em parcerias. Isso também se deve pela agenda intensa de concursos que favoreceu o trabalho em equipe e a contaminação cruzada dessas abordagens. Algo que ampliou a gama de

${ }^{143}$ Alejandro Echeverri (diretor da EDU no governo Fajardo), Felipe Uribe de Bedout, Carlos Pardo Botero (Obranegra Arquitectos), Felipe Mesa (Plan B Arquitectos), Catalina Patiño e Viviana Peña (Ctrl G), Miguel Mesa (Mesaestandar editores) todos formados na UPB.

${ }^{144}$ Vide quarta capa. 
experimentações e contribuiu para difundir certas estratégias projetuais tais como:

- fomento à abertura irrestrita do espaço público como resposta ao contexto prévio de violência;

- ativação de estratégias de restrição, proteção e segurança não ostensivas;

- o enfrentamento do problema da topografia como argumento requalificador do programa e das estratégias formais;

- a incorporação de estratégias paisagísticas que se mesclam à qualificação dos espaços livres e à formulação de seus volumes edificados;

- a estratégia generativa de arranjos geométricos em que as unidades formam um todo adaptável a topografia, a formações espaciais mais complexas derivadas de associações simples;

- a fricção programática entre internalidades e externalidades;

- o desenvolvimento de atributos programáticos recreativos e abertos para os espaços livres.

Essa caracterização do cenário de pensamento e produção da A\&U em Medellín em sua abertura experimental serve para compreender a heterogeneidade dos projetos percorridos ao longo da tese. E também permite perceber como o tema urbano adquire um sentido morfológico, contextual, que mescla a proposta do projeto arquitetônico ao do projeto urbanístico.

Os projetos analisados a seguir representam a confluência desses aspectos e a referida ênfase no espaço vazio como argumento central da estratégia de desenho. Os dois parques analisados a seguir são, na verdade, grandes áreas públicas abertas, talvez mais perceptíveis como praças. Ambos foram desenvolvidos no sentido de conectar ou ressignificar edifícios pré-existentes, buscando uma nova relação destes com o tecido urbano. Os instrumentos projetuais mobilizados visam também atenuar situações problemáticas, mediar preexistências inconvenientes, algo que pressupõe uma reação sobre algumas matérias que não podem ser alteradas diretamente. Isso acontece na medida em que, nas duas situações, as "praças" encontravam-se rodeadas de vias de alto tráfego. Assim, elas têm a difícil função de recobrar alguma qualidade para a experiência do usuário, tão somente a partir da área de intervenção. Nesse sentido seus espaços devem enfrentar a aridez estruturante dessa conformação urbana, bem como os ruídos circundantes.

Ao enfrentarem essa equação de necessidades - cuja função se dilui em direção a uma dimensão programática mais aberta- os arquitetos enfrentam o desenho de espaços para expectativas um tanto quanto difusas. Visto que "recuperar", "ativar", "revitalizar" não pressupõem soluções previsíveis ou estratégias claras. A resposta a esse contextoproblema, que permite aproximar as duas experiências, pode ser lida também pela fusão de tipologias arquitetônicas. Algo que torna indistintos os atributos de qualificação de uma situação urbana, uma praça e um equipamento público. 
O projeto do Parque de los Pies Descalzos foi desenvolvido por Felipe Uribe de Bedout, Ana Elvira Vélez e Giovanna Spera, junto ao LAUR da UPB. A empresa consultou a universidade para o desenvolvimento de um estacionamento em frente a sua recém-inaugurada sede, o Edifício Inteligente das Empresas Públicas de Medellín (1997).

Os arquitetos responsáveis pelo projeto (acadêmicos e docentes) se depararam com uma área que já havia recebido intervenções que tentavam reabilitar os terrenos da Estrada de Ferro, visto que se situavam estrategicamente no limite da região central da cidade. Nesse sentido, entre 1970 e 1980 também haviam sido construídos o pavilhão do Palácio de Exposições (1975), o Centro Administrativo La Alpujarra (1987) e o Teatro Metropolitano (1987); e também havia sido realizada a reabilitação da antiga estação de Ferrocarril de Medellín.

O conjunto La Alpujarra seguia as ideias de Wiener e Sert ao criar um novo centro representativo e simbólico da cidade, deslocando essa função do centro tradicional para esse novo Centro Cívico. No entanto, a soma dessas intervenções resultava em diversos edifícios isolados com grandes avenidas que os rodeavam, como a Avenida Regional, a Rua San Juan e a Avenida del Ferrocarril. Além disso, eram notáveis os diversos lotes vacantes nas imediações. Essa percepção de desconexão com o tecido urbano se sobrepunha até mesmo ao fato de duas estações de metrô terem sido construídas nas proximidades do setor (1995) visando integrar estes novos espaços com a cidade e o território metropolitano (SPERA VELÁSQUEZ, 2018, p. 85).

Diante dessas condições, os arquitetos começam como um exercício de desenho urbano, mas afinal realizaram uma contraproposta que, em uma facilidade de articulação política à época ${ }^{145}$, se tornou um Plano Parcial, na tentativa de aplicar este novo instrumento de planejamento definido na Lei 388 de 1997. Isso também decorre do fato de que naquele mesmo momento se estava formulando o primeiro Plano de Ordenamento Territorial, aprovado em 1999 através do Decreto o62. É interessante perceber que nesse momento, estratégias de desenho começam a pautar o planejamento na cidade.

Conforme esclarece Spera (2018), é possível compreender a intervenção do Parque de los pies Descalzos como estratégia de criação de espaços públicos que conectam o tecido da cidade por meio de dois principais elementos: o redesenho do viário para articular as peças arquitetônicas pré-existentes, prevendo caminhos para pedestres e transposições de barreiras. E o segundo elemento, que corresponde a uma quadra de 1,6 hectares, com uma praça seca que funciona como uma antecâmara para o acesso do edifício EPM. Essa área é tratada com árvores e pequenas intervenções que qualificam esse espaço de maneira heterogênea, com espaços para recreação e contemplação.

${ }^{145}$ A diretora de planejamento à época era a arquiteta Zoraida Gaviria, também arquiteta e preocupada com a deterioração do centro. Também o gerente da EPM é nomeado diretamente pelo prefeito da cidade de Medellín, o que favoreceu a proximidade do grupo de trabalho com a equipe de administração responsável pela formulação do primeiro Plano de Ordenamento Territorial, provocando discussões sobre o futuro da cidade e sobre os potenciais urbanísticos dessas áreas (SPERA VELÁSQUEZ, 2018, p. 98). 
A qualidade desses espaços livres está na criação de uma morfologia urbana acolhedora, visto que no centro do quarteirão foi desenhado estrategicamente - um prédio de três andares que abriga um museu da EPM, mas que, acima de tudo, qualifica os espaços vazios. Também se investiu na criação de condições de permanência no espaço público para aqueles que simplesmente visitam o espaço para desfrutar dos espelhos d'água e dos espaços sensoriais interativos que dão nome ao parque.

Nesse sentido, o arquiteto Felipe Uribe de Bedout (2006, p. 45) descreve o edifício como uma estrutura de apoio para atividades complementares da área livre e, também, como um extenso fundo longitudinal que a condiciona. Percebe-se que o volume edificado é acionado para acolher os usuários da praça. Mas também para resolver demandas simples e cotidianas, ao abrigar pequenos restaurantes e serviços voltados tanto para a face mais imediata da rua quanto para o centro do parque. Assim se resolvem as demandas básicas e prosaicas da vida, como sanitários, abrigo, um espaço para descanso. Mas também se desenha uma forma urbana estratégica para conter o impacto do fluxo dos carros nas ruas do entorno. O edifício, anteparo urbano, deixa, no entanto, os pedestres passarem livremente pelo seu pavimento térreo, completamente e permanentemente aberto, como um portal para o parque.

\section{Parque de los Deseos, 2004}

O projeto de Felipe Uribe de Bedout surge de uma solicitação da fundação EPM para renovação do interior do planetário da cidade. O arquiteto descreve que encontrou, além de um edifício deteriorado, um estacionamento logo a frente que, assim como a situação urbana do entorno, denotavam um estado de abandono. Diante desse cenário, o arquiteto - novamente - oferece uma contraproposta, para um parque e um cinema ao ar livre. Estratégia que julgou ser interessante para aquele lugar que era principalmente conhecido por ser perigoso, argumentando, ainda, que esta seria um tipo de intervenção que, talvez, pudesse conter a espiral de violência da época ${ }^{146}$.

Para tanto, propôs-se transformar o planetário, de modo que sua fachada sul se tornasse uma tela e um fundo. Para cumprir a norma de estacionamentos que um parque deveria ter, Felipe desenhou um edifício cultural que, em princípio, foi apresentado como um estacionamento de três níveis atendendo a normativas, dando tempo ao arquiteto para futuras negociações. Posteriormente, ele pretendia convencer o futuro prefeito a transformar este espaço em uma Casa da Música para a orquestra juvenil de Medellín. Hoje, este é o funcionamento do espaço.

O Parque dos Desejos se percebe como uma grande praça aberta e retangular, de 12 mil metros quadrados. A vasta superfície da praça, no entanto, parece apresentar um vazio meticulosamente projetado. Ela

${ }^{146}$ Cf. (DE BEDOUT, 2018) 
apresenta dobras, topografias, texturas, espelhos d'água, brinquedos de água para crianças, uma série de pequenas espacialidades com tratamentos diferentes (ainda que estejam conectadas pela mesma linguagem da praça). E esses recursos projetuais parecem estruturar a relação entre os volumes construídos e as diferentes áreas livres que surgem em seu entorno, ou até mesmo como uma reação as suas superfícies.

Isso aparece nas descrições que o próprio arquiteto faz de seu trabalho. Falando de cavidades projetadas, Felipe Uribe de Bedout (2018) discute a função de subtrair dos edifícios certa parte de sua materialidade e de seu conteúdo programático, para permitir ao transeunte atravessar o volume sem necessidade de entrar em aéreas que contém funções específicas: cruzar, ao invés de rodear. Essas perfurações, segundo o arquiteto, além de garantirem uma permeabilidade do edifício em relação a seu entorno, permitem criar passagens cobertas que favorecem o descanso e criam a condição de que se construa, para além da vitalidade cívica, um suporte para espectadores da mesma.

Ao buscar as explicações do próprio arquiteto, algumas percepções subjetivas começam a ser entendidas como estratégias projetuais. A fala do arquiteto é permeada por transições de escala projetuais, que se atravessam do detalhe da pavimentação ao projeto urbano. O vazio algo que percebemos ser central para Van Eyck e os Smithsons adquire diferentes possibilidades de experimentação. A começar pela defesa da sujeição do edifício ao seu contexto urbano, ou a construção de ocos no volume edificado, para a qualificação dos espaços livres circundantes, como se refere o arquiteto. Ele a posiciona como uma tática importante que cria relações recíprocas entre os espaços internos e externos. Preocupações que reconhecem a necessidade de se criar espaços para privacidade - dotados até de um certo censo de domesticidade - tanto como áreas propícias para reunião coletiva, nos espaços públicos. Esse esforço, segundo De Bedout, é central para uma arquitetura que pretende fomentar a interação e integração social e, ainda, se posicionar contra os conceitos paranoicos de privacidade e segurança. É nesse sentido que a variedade de escalas deve buscar a ativação das percepções variadas, evitando espacialidades únicas e contínuas.

Essas preocupações não deixam de lado uma leitura sobre a dimensão formal do conjunto arquitetônico, algo que o arquiteto aborda a partir da ideia de se criar "perspectivas vinculantes". Nesse sentido, De Bedout parece se reportar a uma noção de morfologia urbana, algo perceptível somente em uma escala macro que considera o tecido urbano, para que se estabeleçam conexões das partes com o todo.

Superfícies são também debatidas do ponto de vista das continuidades e da fricção dos espaços. A primeira, pode ser obtida pela unidade de materiais, permite desfazer limites e comunicar aos transeuntes que o espaço está disponível para a ação. A segunda, no entanto, denota que é preciso que se reduza o ritmo, que se atraia certa fixidez para que os espaços formulados não sejam reduzidos a lugar de passagem. Para tanto, além de atributos programáticos, o arquiteto 
propõe o uso de um amplo repertorio (de variadas escalas) para plataformas, muros baixos, rampas, peitoris que modelam os espaços livres, algo que o arquiteto chama de desníveis estacionários. 
Painel 4.2 Parque de los Piés Descalzos
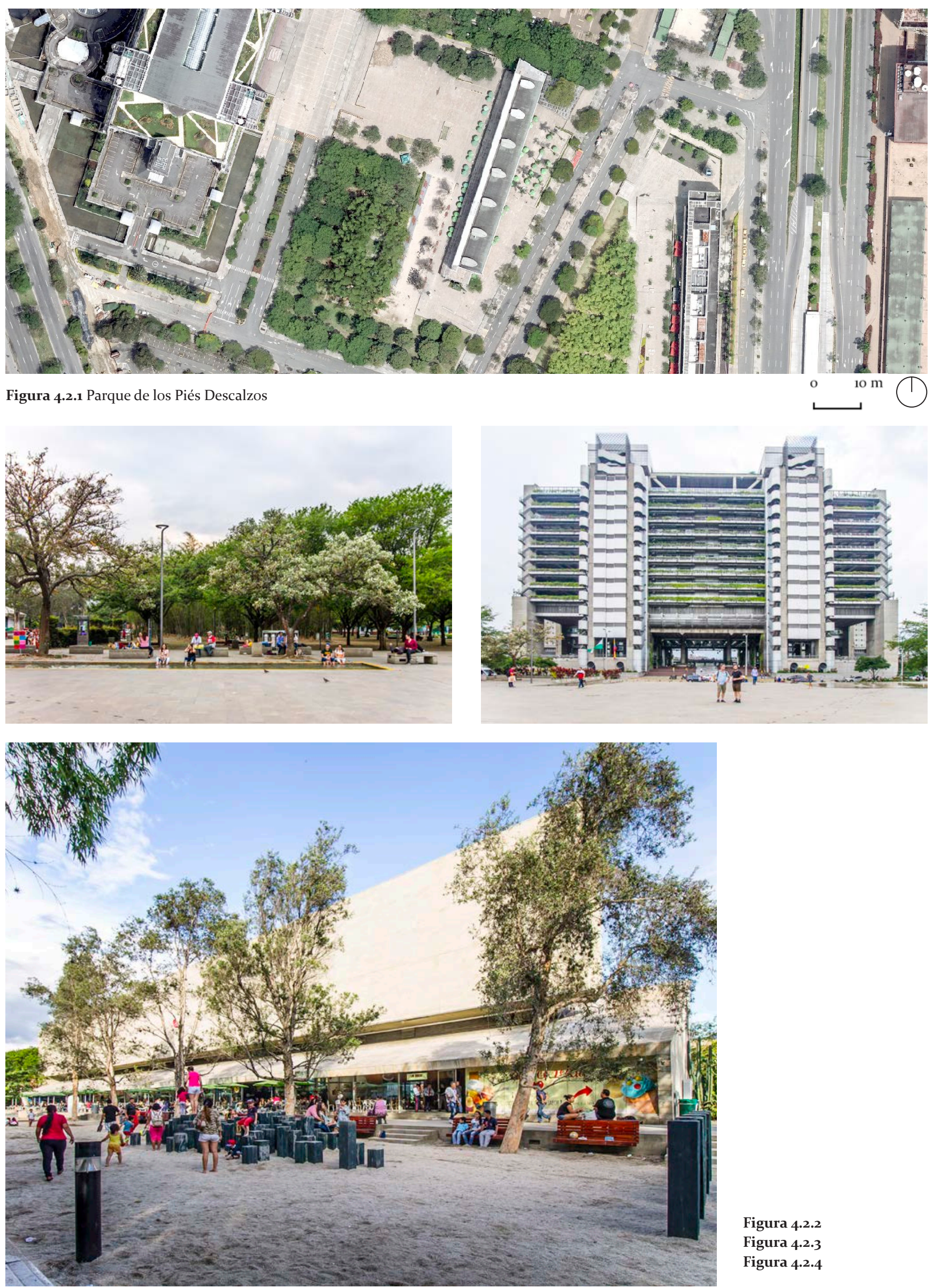

Figura 4.2.2

Figura 4.2.3

Figura 4.2.4 
Figura 4.2.5 $\mathrm{O}$ parque não possui fechamento ou perímetro delimitado. Trata-se de uma área central que apresenta uso intenso aos fins de semana

Figura 4.2.6 Figura $4 \cdot 2 \cdot 7$
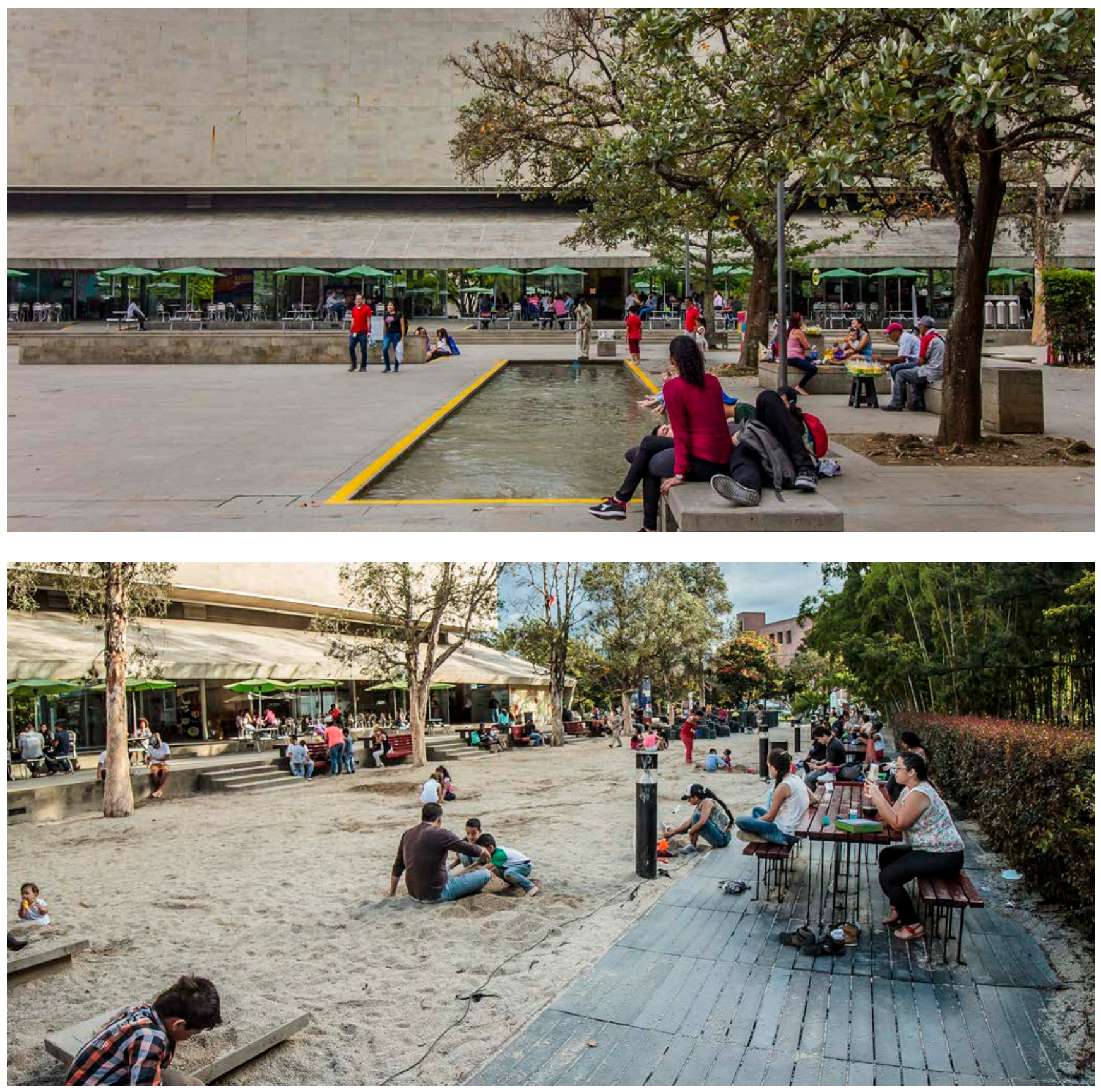
Painel 4.3 Parque de Los Deseos
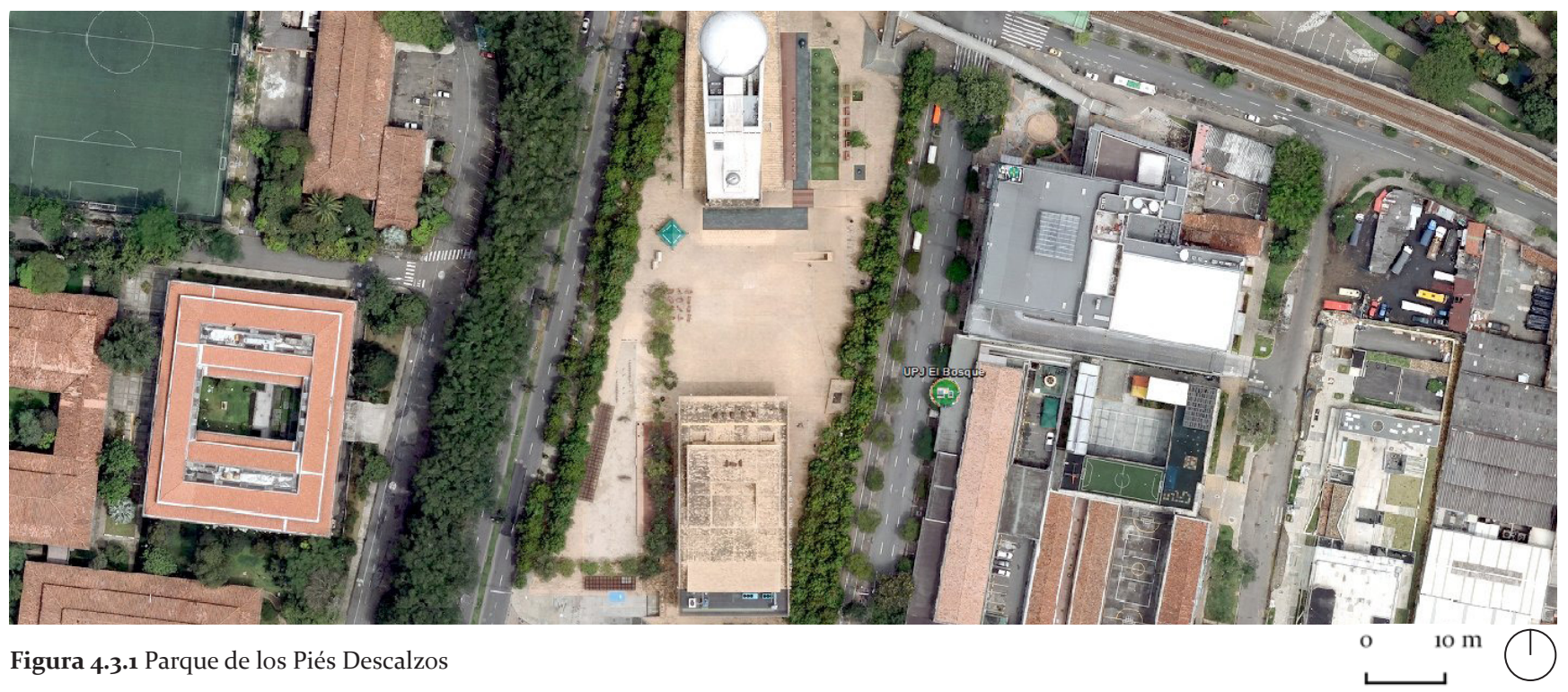

Figura 4.3.1 Parque de los Piés Descalzos
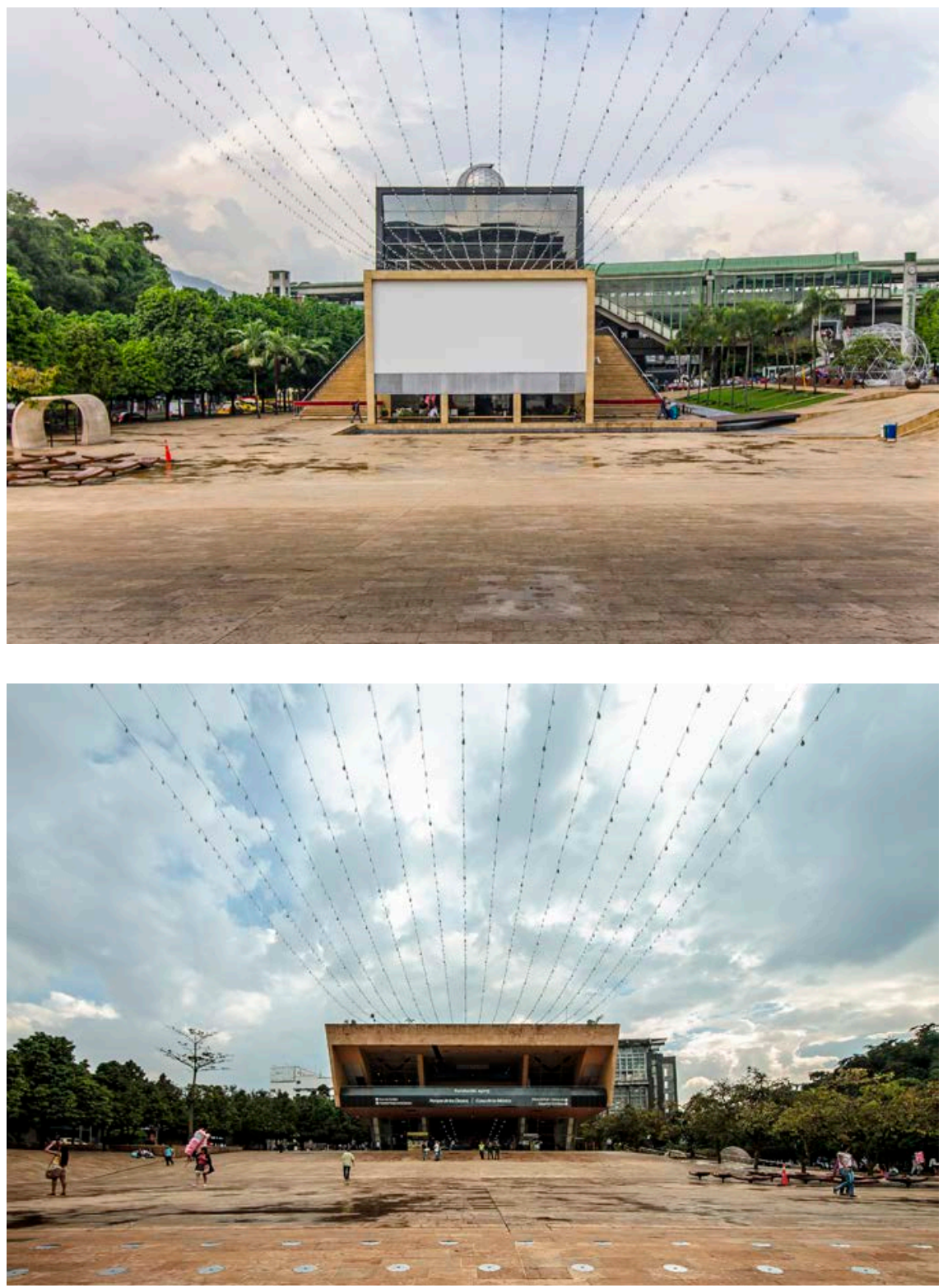

Figura $4 \cdot 3 \cdot 2$

Figura $4 \cdot 3 \cdot 3$

Figura 4.3.4

Figura 4.3.5

Parque de los Deseos

Vista do Planetário

Vista do Edifício Cultural 

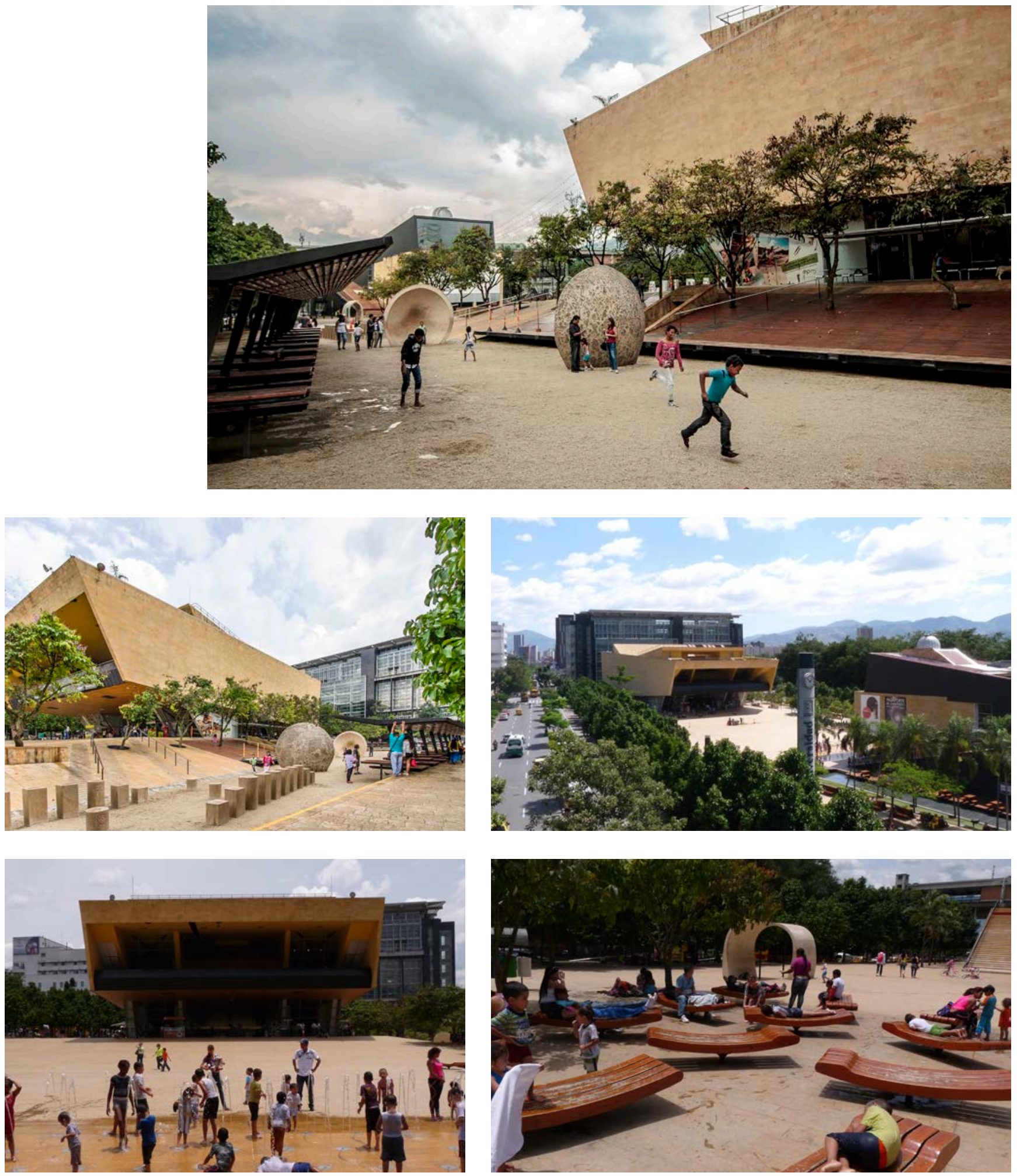

Figura 4.3.6

Figura 4.3.7

Figura 4.3.8

Figura 4.3.9

Figura 4.3.10 
O percurso de análise sobre a evolução da Escola Paulista percorrido por Mônica Junqueira de Camargo (2009), contribui para a compreensão de uma produção arquitetônica baseada em avanços programáticos, mas que explorou, acima de tudo, a plasticidade das estruturas na arquitetura. Ao mesmo tempo, pondera que a produção dessa escola desenvolveu seus traços mais característicos em um momento de isolamento das questões construtivas, dos temas habitacionais e também da problemática da cidade.

Ainda que a autora veja no cenário contemporâneo uma produção mais diversa, que explora outras frentes projetuais, são raras as abordagens que não coloquem ao centro do problema da arquitetura a racionalidade estrutural. Essa questão funciona como argumento plástico e parece condicionar de modo determinante suas formulações espaciais. Ao menos, nessa pesquisa, parte significativa dos projetos analisados apresentava uma aproximação maior a essa estratégia interpretativa dos problemas da arquitetura, do que uma maior reflexão sobre as especificidades do problema urbano circundante.

A origem para esse enfoque pode ser compreendida pelo fato de a institucionalização do ensino de arquitetura ter se dado, majoritariamente, por meio das escolas de engenharia. Isso implicaria em uma vinculação da arquitetura paulista às questões técnicas, reforçando também a sua autonomia em relação à capital do país, que se voltava ao ensino de Belas Artes.

Mas seria a partir de 1950, com a assimilação das ideias brutalistas em circulação no panorama internacional, particularmente provenientes dos projetos de Le Corbusier do pós-segunda guerra, que essa produção encontraria um caminho definidor:

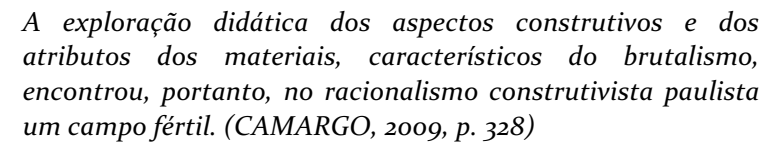

A consolidação dessa vertente projetual se deu a partir do Plano de Ação Carvalho Pinto (1959-1963), elaborado no alinhamento com a plataforma do nacional-desenvolvimentismo de Juscelino Kubitschek. Isso porque o plano visava, principalmente, o investimento no interior do Estado de São Paulo, o que implicou na construção expressiva de infraestrutura e equipamentos sociais e na contratação massiva de arquitetos:

O Plano de ação do Governo Carvalho Pinto (1959-1963) que promoveu a contratação de mais de quatrocentas obras, envolvendo a participação de mais de uma centena de arquitetos, abriu um campo privilegiado de investigação $e$ garantiu a visibilidade da produção desses arquitetos, lançando-os no panorama nacional a ponto de, em 1970, ter sido escolhido, numa atitude inédita, o projeto de um paulista para o Pavilhão do Brasil na Feira Internacional de Osaka. A intensa quantidade e alta qualidade da produção paulista desse período, e sua nítida diferenciação da consagrada produção carioca, especialmente da de Oscar Niemeyer, fez com que a produção de um grupo de arquitetos, principalmente de Milan, Guedes, Penteado e Mendes da 
Em que pese a essa experiência, a qual produziu numerosas escolas, edifícios de justiça, dentre uma série de equipamentos públicos de grande qualidade, Camargo (2009) destaca a falta de integração da arquitetura com uma noção de desenvolvimento. Algo que podemos estender a uma constatação da desarticulação destas experiências em relação às problemáticas do planejamento e do desenho urbano. $\mathrm{O}$ processo tampouco promoveu o diálogo entre os próprios arquitetos que participaram do programa:

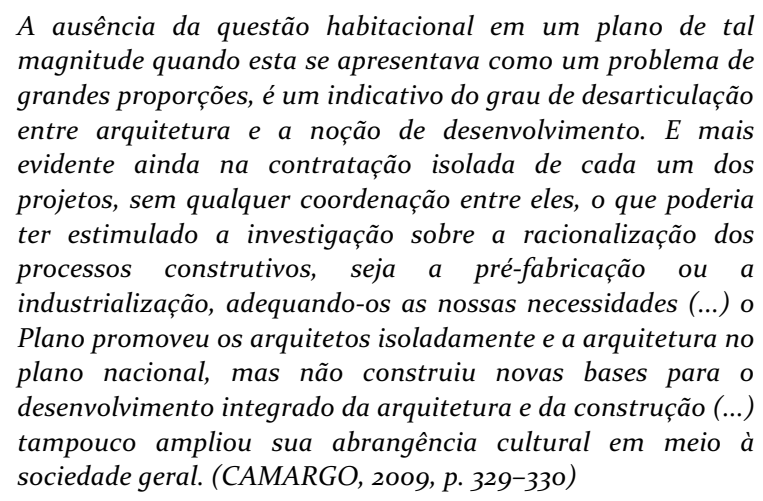

A indiscutível originalidade plástica e a difusão do concreto aparente como solução estrutural, que proporcionaram sua ampla especulação formal, parece ter se sobreposto a outras possibilidades de investigação. Uma rara exceção é a da arquitetura escolar, que avançou nas suas experiências na racionalização construtiva, apropriando-se da tradição do concreto armado no desenvolvimento de sistemas de pré-fabricados.

A preponderância dessa abordagem projetual na produção arquitetônica de São Paulo se apoia, não somente na consolidação de um ideário, mas se reporta também, ao isolamento preponderante da produção brasileira do debate internacional:

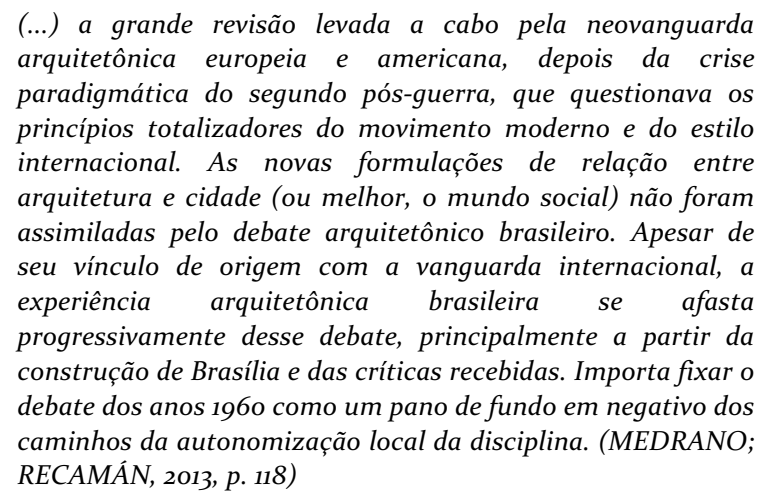

Esses problemas se somam às condições de produção e de pensamento da arquitetura paulistana, considerando também a centralidade do problema da antiurbanidade, comum a parte significativa das estratégias projetuais dessa arquitetura. Isso se confirmou, particularmente, quando esta se concentrou na 
objetualidade do edifício, conforme discutimos ao longo dos capítulos 2 e 3 .

Assim, o campo disciplinar local ainda parece influenciado por uma tradição moderna que restringe as possibilidades de ação da A\&U. Essa percepção é reforçada, nesse trabalho, pela oposição ao caso de Medellín, que parece abrir frentes investigativas mais amplas, algo que ultrapassa a questão das condicionantes privilegiadas por um momento político, haja visto que São Paulo também apresentou projetos significativos no mesmo período, ainda que em menor número.

Com o agravamento dos problemas da cidade, a agenda da arquitetura parece demandar maiores esforços no enfrentamento dos desafios que relativos ao urbano. Essa necessidade se fortalece, nessa pesquisa, sob a leitura dos potenciais de interação nas dinâmicas socioespaciais prefigurados por Lefebvre. Isso também é verificado, de certo modo, pela importância que a arquitetura adquiriu, nos debates da Europa do pós-Segunda Guerra, em relação à cidade. Essas questões foram exemplificadas aqui, pela complexidade dos problemas debatidos em um cenário crítico de grande engajamento social, por parte de arquitetos como os Smithsons e Van Eyck.

Apesar de podermos caracterizar estratégias - mais ou menos conscientes - do que foi acima chamado de escola paulista, temos de reconhecer que nos últimos anos a profusão de influências tem conseguido por vezes alterar certas características estruturantes que destacamos.

A urbanização do Cantinho do Céu e o Parque Novo Santo Amaro podem exemplificar estratégias "contra-hegemônicas", em sua contribuição ao tema discutido nesse capítulo. Esses projetos enfrentaram as dinâmicas e problemas dos assentamentos precários, demonstrando um deslocamento do campo estritamente funcional, em direção a mediações mais abrangentes. Nesses projetos, o programa passa a incorporar questões fora do seu escopo básico originalmente previsto.

Assim, no primeiro caso, a reurbanização, o redesenho viário e as soluções ambientais foram integradas na criação de um sistema de espaços livres, atento às atratividades programáticas (espaços de lazer e esporte) que garantiriam sua apropriação, sem reduzi-los a somatória de funções.

E, no segundo, a questão da moradia ultrapassa o problema da unidade habitacional, de modo que o projeto se torna a interface entre os problemas morfológicos e estruturantes do local. Ao mesmo tempo, realiza-se um ensaio projetual para a criação de um espaço público que receba e fomente a vida cotidiana, considerando os percursos diários até a escola (resolvendo a travessia dos pedestres) e as dinâmicas da vizinhança. Mas também expande esse escopo, ao qualificar um parque que tem, ao mesmo tempo, a dimensão acolhedora para os usuários do edifício e que busca também equilibrar o déficit de espaços públicos daquela região da cidade.

Rememorar estes exemplos nos serve aqui para retomar a discussão sobre a funcionalização e a segregação da vida e de seus espaços cotidianos. Os projetos anteriormente mencionados se afastam da ideia 
de divertir-se no parque, estudar na escola, morar no conjunto habitacional, realizar compras no centro comercial, adquirir cultura no centro cultural. Eles evitam essa estanqueidade programática que, quando se "essencializa" nas formulações espaciais, contribui para perpetuar uma vida feita de funções e não usos. Lembrando da epígrafe de Milton Santos: são os usos do território que produzem a moldura da vida, algo que requer relações tão mais complexas, quanto abertas.

À luz da problematização lançada pelo projeto colombiano do Parque de los Pies Descalzos, o qual que se conecta em autoria e em estratégias projetuais ao Parque de los Deseos, selecionamos como último projeto para análise desta tese a Praça das Artes. O projeto difere de todos de São Paulo aqui selecionados, por enfrentar a cidade formal, consolidada, propondo a criação de um diálogo morfológico com o tecido existente da cidade, trazendo ao centro da proposta, a criação de um vazio.

\section{Praça das Artes, 2012}

O complexo de edifícios culturais localizado no centro de São Paulo, entre a avenida São João, a rua Conselheiro Crispiniano e o Vale do Anhangabaú, abriga os anexos do Teatro Municipal: Orquestras Sinfônica Municipal e Experimental de Repertório, Corais Lírico e Paulistano, Balé da Cidade, Escolas de Música e de Dança, Centro de Documentação Artística, Museu do Teatro Municipal, Administração e Salas de Recitais.

$\mathrm{Na}$ primeira parte construída, existem três módulos principais: o edifício destinado aos corpos artísticos (formado pela sobreposição de dois volumes retangulares ao lado do Edifício $\mathrm{CBI}$ ), a praça e o prédio das escolas de dança e de música (bloco que acompanha lateralmente a praça de acesso à Rua Conselheiro Crispiniano) e o centro de documentação, que fica ao lado do edifício restaurado do Conservatório Dramático e Musical de São Paulo (acesso pela avenida São João). A praça que dá acesso à rua formosa/Anhangabaú, o volume que incorpora a fachada do antigo Cine Cairo, o anexo administrativo, a ampliação da sala de ensaios e orquestra, bem como o restaurante ainda não foram finalizados.

O projeto do escritório Brasil Arquitetura se propõe a realizar um conjunto arquitetônico cuja organização do programa é desenvolvida promovendo a modelagem de volumes, vazios e passagens que tentam valorizar o miolo da quadra como um espaço de lazer. A estratégia da arquitetura para se incorporar à massa disforme e variada dos edifícios do entorno, passa pela pigmentação do concreto, de sua notável massa opaca subtraída de uma constelação de pequenas aberturas. O organismo de concreto adquire tons terrosos variados: vermelhos, ocre, que se combinam ao cinza próprio do concreto. Assim, o volume arquitetônico, colorido com sua paleta de tons rebaixados, adquire identidade ao mesmo tempo em que se mescla à heterogeneidade e vitalidade das pré-existências. 
Os rasgos variados nas maciças empenas de concreto, as faces desalinhadas, as escadas e passarelas que se destacam do corpo principal edificado são contrapontos formais, distorções, que parecem desafiar a estabilidade visual do conjunto. Esses ruídos morfológicos parecem se contrapor à síntese e à funcionalidade estrutural, que tipicamente se transforma em argumento formal, nas arquiteturas de concreto paulistas. Acabam por figurar como recursos projetuais que atendem a uma leitura do lugar de inserção. Reconhecendo a condição um tanto caótica do território do projeto, desses lugares que "contém marcas e memórias de diferentes épocas" e que resultam de "desacertos de um urbanismo que sempre se submete a ideia do lote, a logica da propriedade privada da terra”, conforme apontam os arquitetos ${ }^{147}$.

O espaço vazio projetado se coloca como um risco na tentativa de diálogo com outro imenso vazio de 8 hectares. Ou melhor, um dos mais ambíguos espaços livres da cidade de São Paulo: o vale do Anhangabaú. Um gigantesco parque aberto à cidade que tanto carece de espaços públicos, desde 1991, com projeto paisagístico de Rosa Kliass. Esse generoso espaço público, conectado ao sistema de transporte de alta capacidade, encontra-se também envolto por uma área de intensa atividade comercial e de espaços culturais e simbólicos da cidade. A pressuposta vitalidade do seu contexto, no entanto, não se reflete na ocupação desse espaço. O Anhangabaú figura como um lugar de passagem ou de hesitante apropriação e nunca conseguiu, de fato, ocupar o lugar na cidade que seu projeto vislumbrou: um espaço pulsante e plenamente apropriado.

Cabe agora, ao projeto da Praça da Artes, certa expectativa de que seu destino se cumpra. Isto é, quando da abertura da "travessa das artes", que será viabilizada com a conclusão das obras e a liberação da passagem que finalmente conectará o Anhangabaú diretamente ao centro da quadra. Resta saber se uma nova relação entre espaços urbanos se estabelecerá.

É válido ponderar se o vazio que decorre dos eixos dos terrenos e das passagens sob os volumes logra, afinal atingir o potencial conectivo, no sentido amplo proposto pelos Smithsons. Hoje, ao se vivenciar as áreas livres abraçadas pelo edifício-organismo, a indeterminação programática parece se impor, acusando também a falta da fricção entre o conjunto construído e os espaços livres, contando com poucos desníveis estacionários. Algo de suma importância para a ativação do espaço público pela permanência, como nos alerta de Bedout. No projeto original está prevista uma galeria no térreo do edifício a ser inaugurado, com alguns serviços comerciais. Essa possibilidade talvez possa prover vitalidade ao espaço e alterar essas relações.

${ }^{147}$ Cf. FANUCCI; FERRAZ; CARTUM, 2013. 
A ausência de uma arquitetura da cidade, como previa Aldo Rossi, impulsiona São Paulo e Medellín a buscar, em meio a caminhos incertos de nosso processo de urbanização explosivo e segregacionista, uma arquitetura para nossas cidades. As reconciliações necessárias entre o espaço urbano e a sociedade - algo que esse trabalho se propôs a denotar - passam pelas infraestruturas, lotes e chegam ao uso do espaço, onde se reproduz a vida.

O caso de Medellín nos apontou que a apropriação tão intensa de suas novas praças/parques urbanos indicou um caminho ao poder público. Assim, a transformação que se fez no espaço da cidade apostou, primordialmente na transformação dos espaços públicos pelos instrumentos da $\mathrm{A} \& \mathrm{U}$. Investiu-se mais intensamente nas periferias da cidade, com os parques biblioteca e, talvez, de modo ainda mais expressivo com as UVAs. Esse processo se deu cada vez menos no sentido de promover espaços funcionalmente programados, buscando espacialidades complexas, mas abertas, visando uma apropriação espontânea e menos direcionada.

Em São Paulo, no entanto, a arquitetura vem perdendo espaço de contribuição para a reformulação do urbano. Em parte, por questões conjunturais econômicas e políticas. E pelas suas dificuldades em enfrentar as contradições que atravessam lotes e programas. Isso contribui para que seu papel seja visto como de segunda importância, em relação às estratégias que atuam diretamente na regulação fundiária e nos usos do território.

Ainda que a cidade compartilhe de uma agenda que espelha boa parte dos temas do Urbanismo Social de Medellín, e que tenha promovido recentemente transformações no uso de espaços importantes da cidade, foram poucas as transformações nos aspectos morfológicos da cidade. À parte do grande investimento nas ciclovias, a proposta de transformação se fez, primordialmente, pela alteração das regras que atuam sobre os usos, com os programas Centro Aberto e Ruas Abertas. O primeiro, promovendo oficinas participativas para ocupação de espaços nas áreas centrais da cidade. $\mathrm{O}$ segundo, abrindo a avenida paulista ao uso livre de pedestres e ciclistas aos domingos (HADDAD et al., 2018). A disposição dos paulistanos em se apropriar desses espaços e, até mesmo de locais da cidade um tanto quanto áridos (como o "Minhocão"), indicam que o potencial de transformação socioespacial existe e que a direção aponta para a reformulação dos espaços urbanos coletivos.

Afinal, o retorno - tardio - à cidade latino-americana implica encontrar algum caminho entre a superada determinação totalizadora do urbanismo funcionalista - e da arquitetura com seu racionalismo esquemático (que fetichiza formas, funções e estruturas) - e o laissez faire urbano, que se faz diante de uma disciplina paralisada pelos imperativos do modo de produção capitalista que avança sobre a cidade. $\mathrm{O}$ que esse capítulo pretendeu ponderar é que o caminho indicado por Lefebvre, assim como aquele experimentado pelos Smithsons, indicava a manipulação de variáveis pouco reconhecíveis 
pela disciplina, até então. Seja a capacidade relacional do vazio, ao ser mobilizada diante do existente e das energias advindas do contexto urbano e social. Bem como das novas categorias experimentadas pelas arquiteturas mais promissoras que se arriscam no campo topológico e relacional, dialogando com os comportamentos humanos responsivos às mais diferentes formas urbanas, partindo da indeterminação do vazio e se afastando da ênfase no objeto arquitetônico.

\section{$\underline{\text { A dimensão sociourbana da arquitetura }}$}

Os impasses à reformulação integral da estrutura social e do espaço urbano são grandes, particularmente para cidades como as latinoamericanas, que acumulam uma dívida social histórica e um tecido urbano que se desenvolve na reprodução das diferenças e das clivagens sociais.

As soluções encontradas com a abertura da gestão e produção do espaço da cidade à participação dos diversos agentes que compõem o urbano (os chamados stakeholders), incluindo tanto os proprietários e agências financeiras, como também a participação da população enfrenta grandes desafios, como podemos ver tanto em São Paulo quanto em Medellín. Isso porque torna-se difícil balancear e mediar as diferentes capacidades de organização e articulação de interesses desses grupos, conforme salientam Irazábal e Angotti (2017). Desse modo, somam-se inúmeros motivos para se desconfiar de "boas práticas" gestadas sob essas condicionantes, conforme alertam os autores.

Além disso, as contradições e comprometimentos ideológicos desses "novos paradigmas" de planejamento foram claramente expostos por Arantes, Vainer e Maricato (2011), seja por constatarem nessa "novidade" apenas uma atualização dos preceitos e problemas dos modelos anteriores, ou, talvez, pelo ponto mais crítico do planejamento (estratégico): sua crença na integração social pelo "valor de troca" recorrendo à distinção de Lefebvre. Isso é particularmente grave num país de desigualdades extremas, submetidas ao choque desestruturante do engate nos fluxos globais (ARANTES, 2011). Os problemas desse modelo são facilmente verificáveis, a exemplo dos conhecidos processos de gentrificação, associados aos processos de revitalização urbana.

Entretanto, o urbano se reproduz e demanda à A\&U algum posicionamento. Algumas direções podem ser apontadas no resgate da postura realista do pós-Segunda Guerra europeu, com algumas atualizações. Isto é, buscando informar o fato arquitetônico das dinâmicas socioespaciais, de suas contradições, se afastando do esquema funcional idealista moderno.

O potencial emancipador do urbano, que cabe a A\&U ativar, se impõe assim, como uma dupla tarefa no sentido contra-hegemônico. É preciso encontrar respostas internas à disciplina, contra a funcionalização e fragmentação da vida cotidiana, e externas a ela, contra o processo análogo, redutor e alienante do fazer urbano a serviço da economia capitalista. Atuando nesse sentido contrário à confluência de processos 
que tendem a suprimir as capacidades reflexivas e críticas do homem, como bem resumiu Lefebvre:

No final do século XIX, um pensamento (se é possível dizer) urbanístico, tão forte quanto inconscientemente redutor, pôs de lado e literalmente entre parênteses, o habitar. Ele concebeu o habitat, função simplificada, restringindo o "ser humano" a alguns atos elementares: comer, dormir, reproduzir-se. Nem ao menos se pode dizer que os atos funcionais elementares sejam animais. A animalidade tem uma espontaneidade mais complexa (LEFEBVRE, 1999, p. 78)

\section{Do arquiteto intérprete ao arquiteto mediador}

Na capital paulista, vemos que o enfrentamento da cidade informal ainda fica reservado às políticas setoriais e, também, a arquitetos habilitados a atuar em urbanizações de favela. Isso denota que essa parte significativa do território e esse problema social de suma importância, ainda figuram, disciplinarmente, como um efeito colateral da urbanização oficial. Assim, visto como exceção à regra, suas especificidades espaciais e suas dinâmicas pouco tem informado ao pensamento da $A \& U$, que não àqueles dedicados que se especializam no tema.

Ao ouvir os arquitetos que trabalham nesse território, particularmente nas urbanizações de assentamentos precários, se sobressai a noção de que a disciplina da $A \& U$, para esses arquitetos, é uma relação de mediação. Essa postura ultrapassa o campo projetual e se estende da articulação política, ao reconhecimento das condicionantes de ação, à mediação em campo - do começo ao fim da obra - absorvendo as difusas demandas da população. O arquiteto passa a mediar, também, os contratempos da execução, os problemas técnicos em territórios de grande dificuldade de intervenção, e as demandas de diversos atores que são mobilizados - algo que Tafuri já havia nos alertado, conforme debatemos no capítulo 1.

Dessa forma, o arquiteto move-se em meio a poucas certezas. Tendo raras leis e regulações à disposição, que sejam capazes de resguardar qualquer estabilidade à implementação dos projetos. Isso transparece na análise das condicionantes dos projetos registradas nas publicações oficiais dos programas municipais (marcada por descontinuidades). Mas também, ao se pesquisar, o processo projetual junto a seus arquitetos, que ainda dependem de soluções e reflexões solitárias.

Ficam claras as dificuldades de se rever continuamente os marcos regulatórios, adaptando-as à realidade de áreas que até pouco tempo era ignoradas pelo poder público. Muito além dessa primeira barreira, também são necessárias imbricadas e raras conjunturas políticas para por em movimento alguma ação mais integrada, que não remediadora ou emergencial, ante as problemáticas socioespaciais que só se agravam. Aos arquitetos que enfrentam esses temas, restam poucas trocas entre esses profissionais, isolados em suas especialidades técnicas, restritas à cooperação com o poder público com suas problemáticas polarizações partidárias. Mais exíguos ainda, são os 
espaços de debate, impedindo que os problemas da cidade informal sejam trazidos tanto ao centro das políticas urbanas quanto ao dos debates da $A \& U$. Essas observações trazem à tona a diferença entre o arquiteto demiurgo, que pode interpretar à distância os problemas da realidade, e aquele demandado pelos problemas da cidade contemporânea, exposto às contradições do campo profissional e da realidade urbana. 


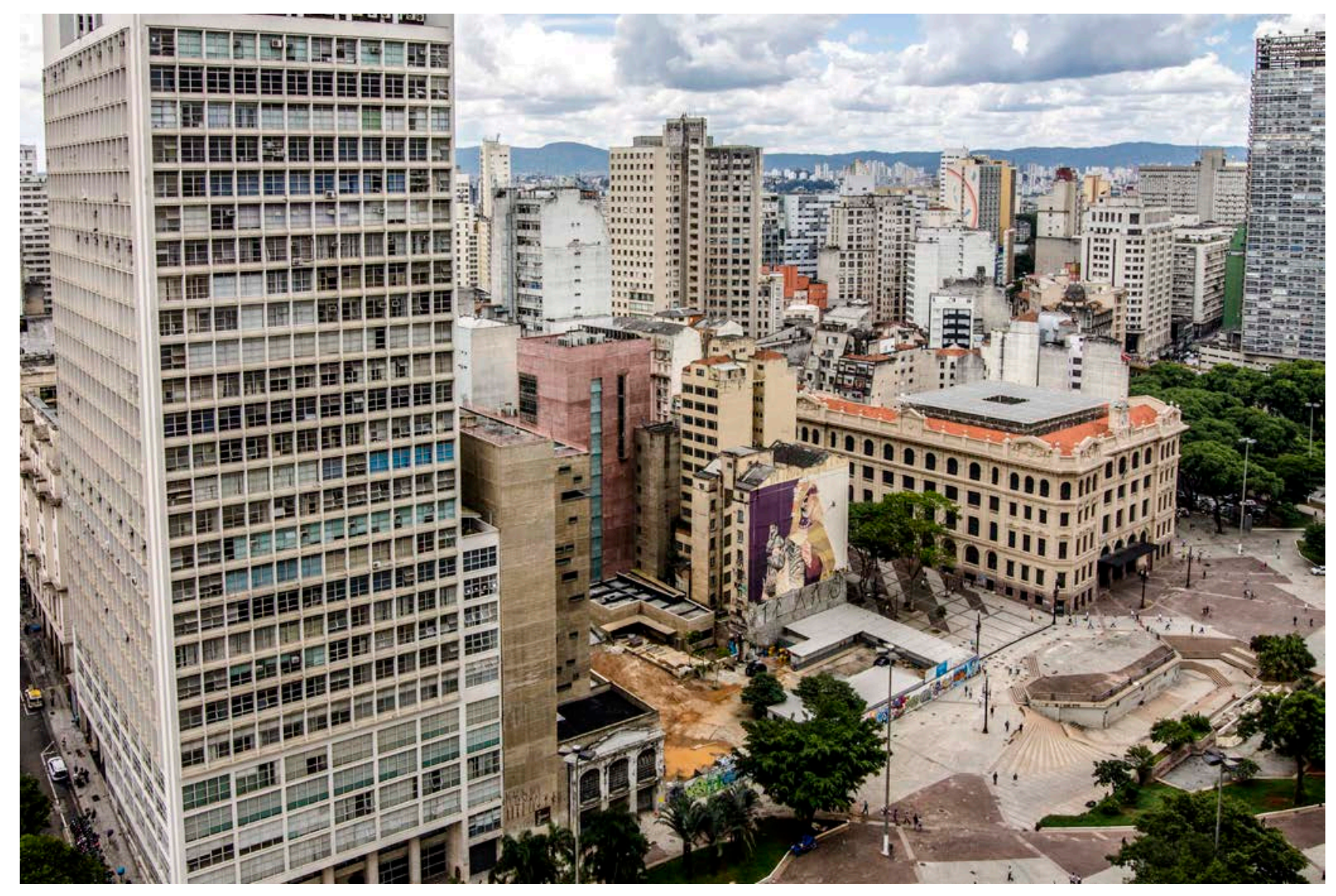

Figura 4.4.5

Figura 4.4.6

Figura 4.4.7 
Painel 4.4 Praça das Artes
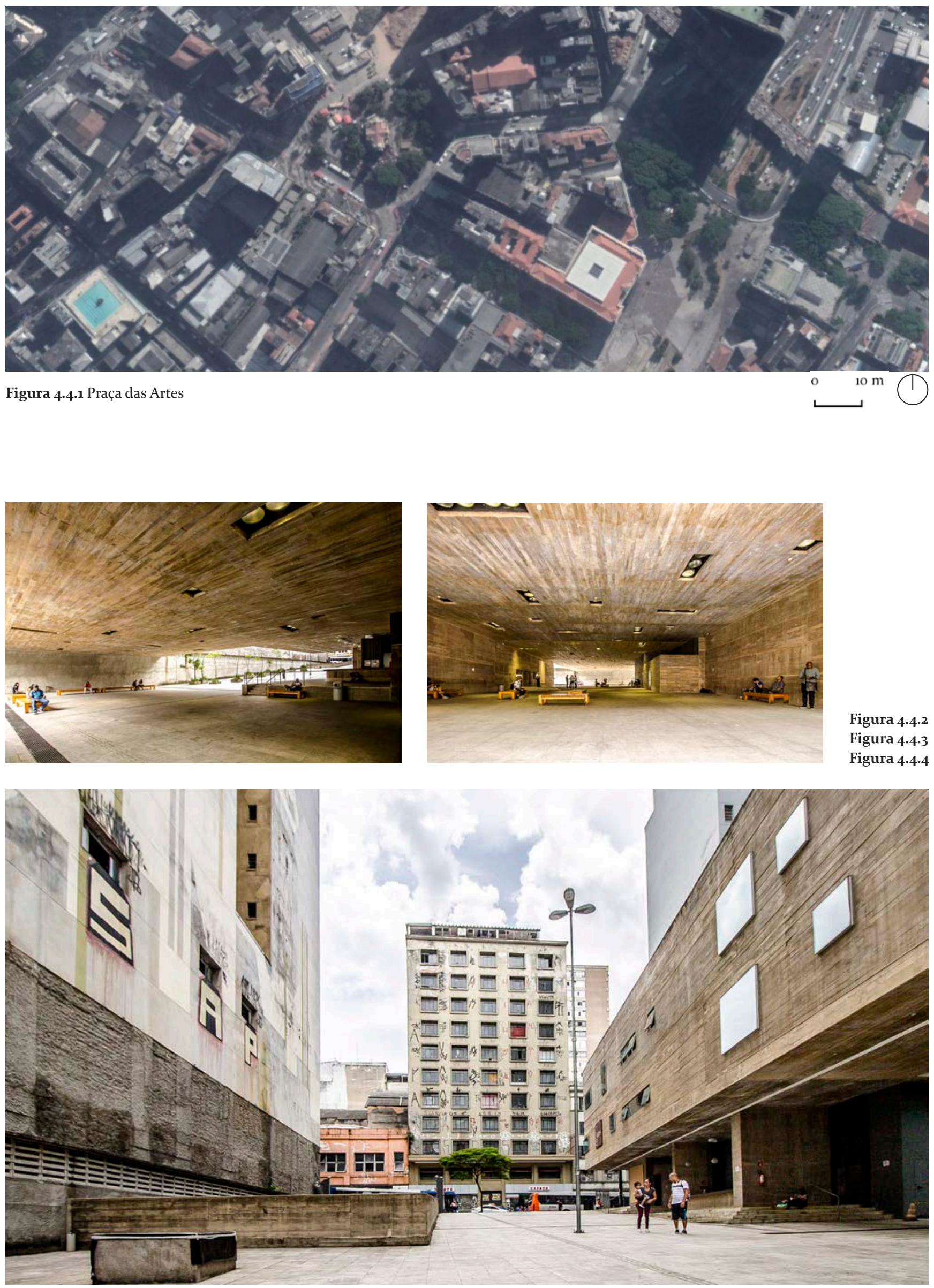

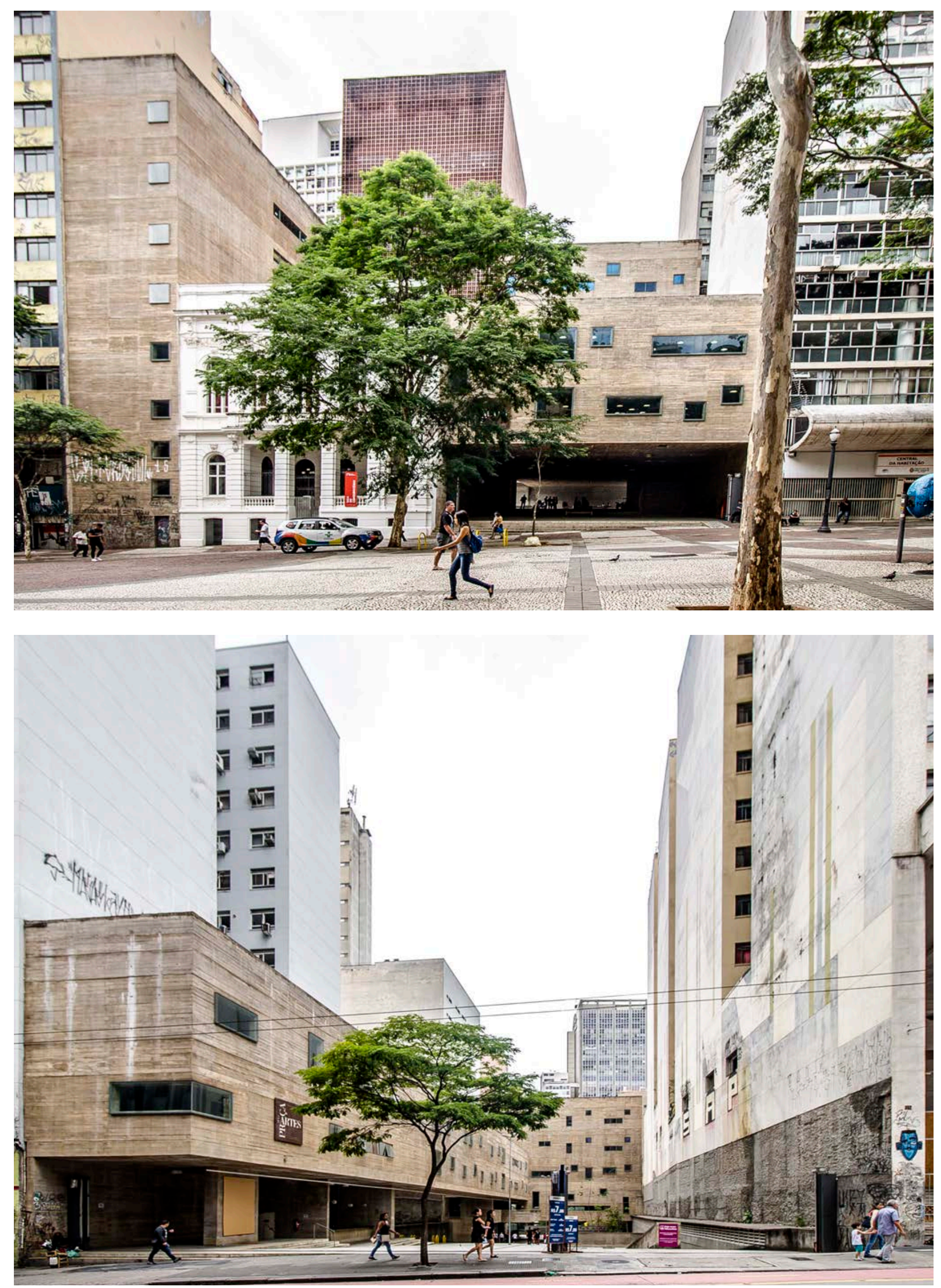
Painel 4.1 Medellín
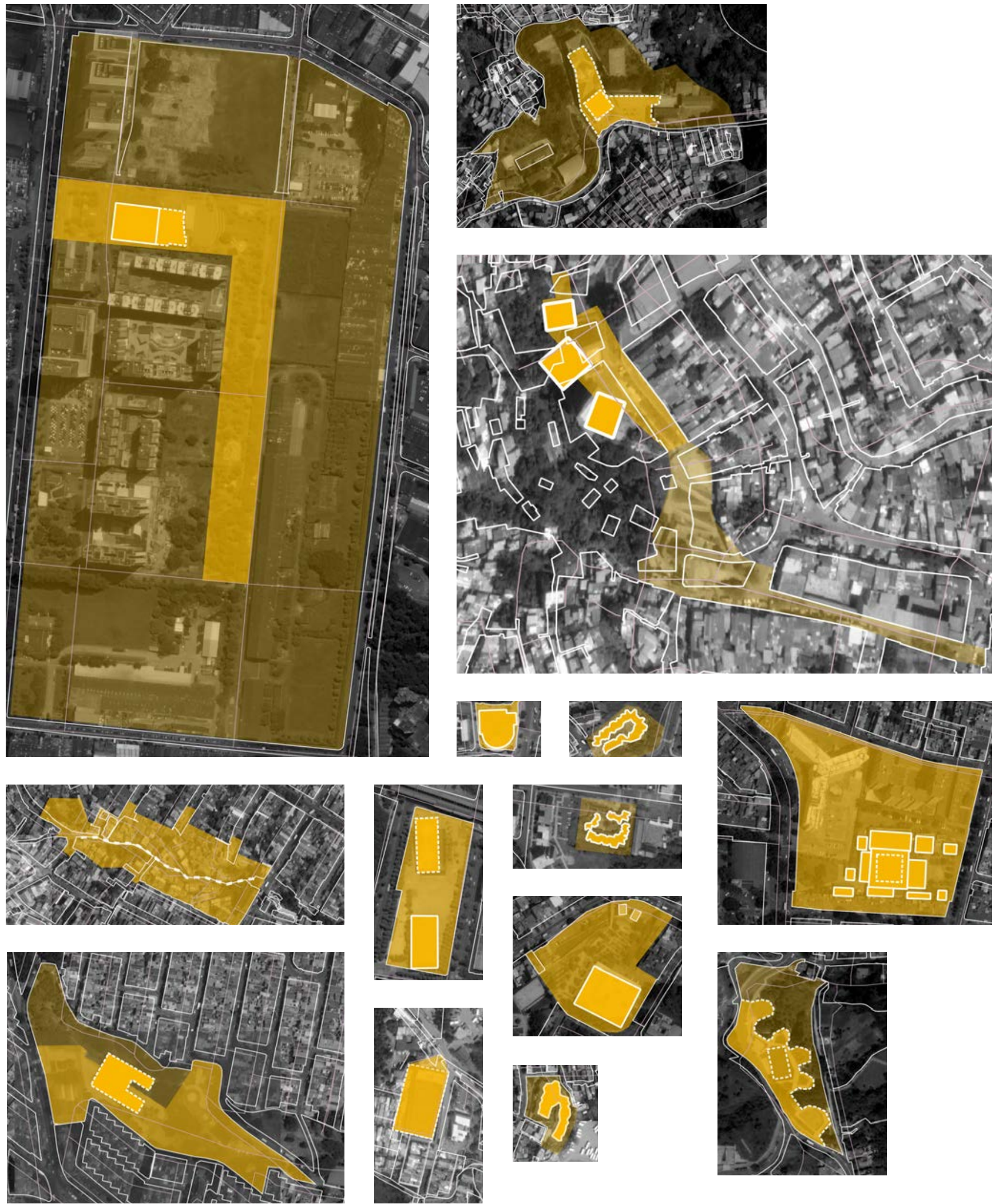

Figura 4.1.3

O esquema pretendeu avaliar graficamente determinadas percepções obtidas nas visitas. Considera-se pouca intensidade programática quando as áreas livres restringem-se a espaços contemplativos. Quando estes são qualificados com atributos de lazer ou atividades lúdicas considera-se média intensidade. A alta intensidade é reservada ao volume edificado. 

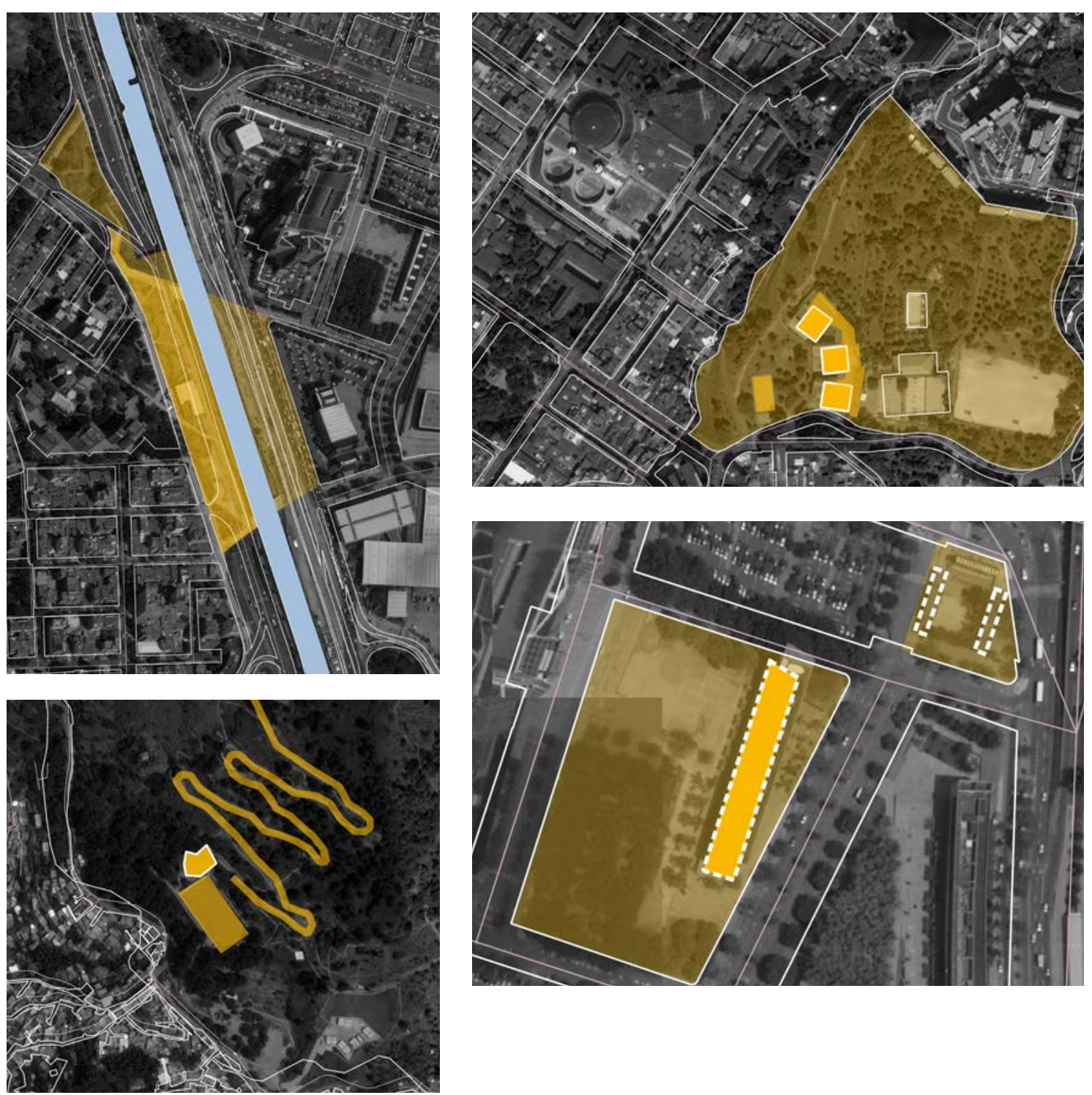

\section{Em Medellín}

As intensidades programáticas parecem realizar uma transição gradativa entre o volume edificado e as áreas livres

Os espaços públicos e praças não possuem restrição de acesso

\begin{tabular}{|c|c|}
\hline \multicolumn{2}{|l|}{ Legenda } \\
\hline & Pouca intensidade programática \\
\hline & Média intensidade programática \\
\hline & Alta intensidade programática \\
\hline 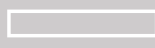 & Limites \\
\hline ing & Limites transponíveis/Volumes permeáveis \\
\hline & Edificações na área de influência do projeto \\
\hline & Hidrografia \\
\hline
\end{tabular}


Painel 4.1 São Paulo
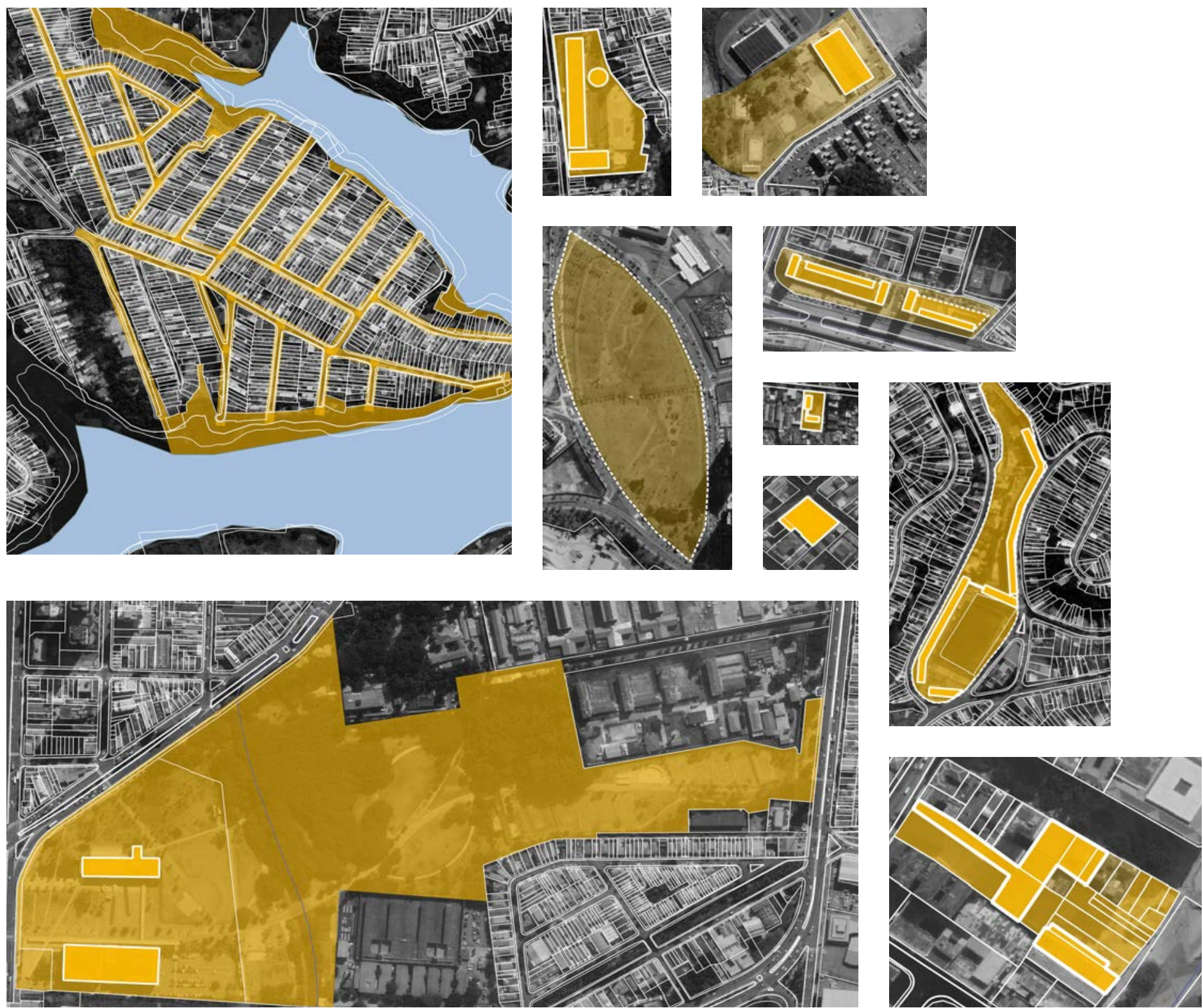

Figura 4.1.4

A aplicação dos mesmos critérios em São

Paulo parecem evidenciar o maior contraste entre áreas vazias e com pouca densidade programática em contraposição ao objeto arquitetônico e sua síntese volumétrica

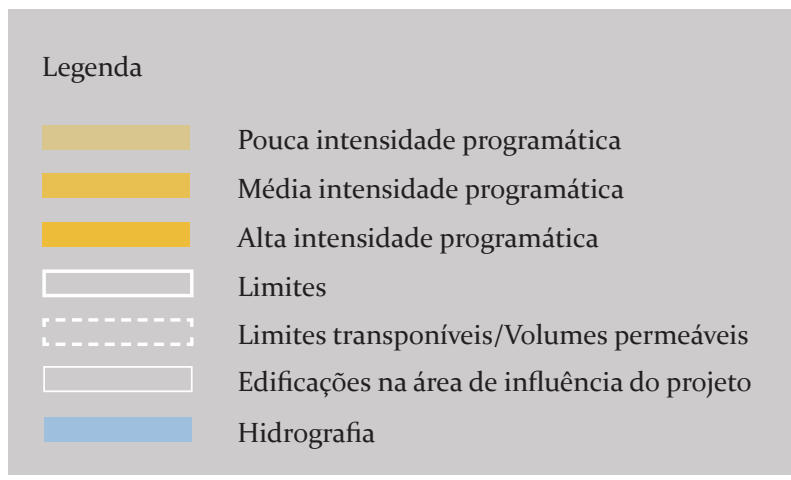
$100 \mathrm{~m}$ 

"Mas ao cabo dos séculos os homens perceberam
que entre as coisas e seus nomes se abria um
abismo".

Octávio Paz ${ }^{148}$

Para além das questões específicas que prontamente se colocam em torno do tema proposto por esse trabalho - a arquitetura contemporânea de São Paulo e Medellín - há uma questão fundamental que estruturou essa iniciativa. Trata-se da necessidade de ampliar os termos pelos quais a A\&U entendem o universo material, social e conceitual com os quais a disciplina interage. Um desafio que se amplia continuamente, perante a complexidade dos problemas socioespaciais contemporâneos.

Esse problema se refletiu nas referências mobilizadas e nas questões de fundo da tese, influenciando diretamente o modo como as análises foram propostas. Tratou-se, afinal, de uma tentativa de afastamento da reprodução de definições cristalizadas no discurso da arquitetura. Partindo da realidade local, elas não só pareciam por vezes esquemáticas na maneira como figuravam no debate corrente, como também se colocavam como cúmplices da reprodução de paradigmas espaciais de tendências antiurbanas.

Assim, buscou-se no primeiro capítulo delinear alguns caminhos para refletir sobre a necessidade da A\&U recobrar um significado socioespacial enfrentando, desse modo, o problema posto por Manfredo Tafuri. Nesse sentido, as condições de partida vinculadas à cultura arquitetônica colombiana e à brasileira diferiam significativamente. Na Colômbia, a crítica ao movimento moderno foi incorporada ao mesmo tempo em que se assimilavam suas ideias principais. Desse modo, já se configurava uma abertura às necessárias reformulações disciplinares que seriam demandadas atualmente. Já no Brasil, a trajetória da arquitetura moderna, com as devidas acomodações locais, na sua adesão a um projeto do Estado alçou a criação de símbolos tão potentes que permaneceram enevoando a sua necessária autocrítica.

Buscamos nas "condições de possibilidade" de Jameson, e nas práticas contra-hegemônicas - que sua leitura de Gramsci e Lefebvre pleiteava um caminho para perscrutar esses impasses. A análise preliminar dos projetos escolhidos constatou, nas formulações espaciais analisadas, uma vinculação de estratégias que se relacionavam menos pelo programa que por determinadas atitudes perante o contexto urbano. Dessas aproximações comparativas se originaram os temas transescalares que organizaram a discussão, correspondendo aos três capítulos subsequentes. Recupera-se, aqui, esse processo porque esses temas talvez sejam a maior contribuição que essa tese pôde oferecer ao

${ }^{148}$ PAZ, O. O arco e a lira. São Paulo: Cosac \& Naify, 2012, p.37. 
campo, na medida em que abrem questões que podem ser continuamente exploradas.

Assim, prosseguiu-se iluminando algumas das referidas questões por meio da análise comparativa dos diferentes projetos nas duas cidades. Isso conduziu a um percurso (por vezes exaustivo) de contextualização das problemáticas do meio físico e social em que os projetos se inseriam. Sem desconsiderar, também, as condições políticas e institucionais em que se produziram. No entanto, isso se justificou em uma tentativa de equacionar essa teia de fatores que pautam o desenvolvimento desses projetos, para, finalmente, podermos nos lançar a pensar as atribuições que cabiam aos instrumentos disciplinares. Até mesmo para ponderar como incumbências de mediação entre esses universos também deveriam ser incorporadas ao arquiteto que compreende a realidade de seu tempo. A partir dos marcos teóricos e metodológicos iniciais, e dos temas que conjugavam essas questões, percorremos as análises que atravessam as múltiplas escalas da $A \& U$.

O primeiro tema abordado (capítulo 2) referiu-se à Urbanização produtora de não-lugares. A partir dele, foram analisados os aspectos do processo de metropolização das cidades de Medellín e São Paulo, em seu estreito vínculo com os problemas da modernização tardia e com processos socioespaciais compartilhados pelas maiores cidades latinoamericanas. Observou-se, tanto em São Paulo quanto em Medellín, que a infraestrutura urbana se instalou com a violência e a rapidez necessária para engatar as economias nos sistemas econômicos mundiais. Isso não significou a criação de uma cidade equitativa e ainda contribuiu para desarticular e segregar o território. No sentido contrahegemônico, o que esperar da $A \& U$ ? Considerando que as questões nesta escala estão ainda mais suscetíveis aos imperativos políticos e econômicos, ainda assim ponderamos que cabia a $A \& U$ a capacidade de Recobrar uma paisagem urbana mais humana, buscando um equilíbrio social e ambiental. Para tanto, vislumbravam-se três frentes de ação. Em primeiro lugar, seria preciso reconhecer as especificidades do seu espaço, por isso abordamos a necessidade de se Reconhecer a matriz urbana real.

Isso porque ambas as cidades, após o momento de explosão demográfica e de apaziguamento das disfunções dos seus processos urbanos, vêm tentando recuperar - até devido a emergências socioambientais - sua capacidade de compreender suas dinâmicas territoriais e a estrutura que resulta dela. Em segundo lugar, mostrou-se fundamental reconectar planos e projetos urbanos. Isso surgiu com a clareza de que os avanços nos marcos regulatórios, nos instrumentos urbanísticos ou até mesmo nos planos das políticas setoriais que interagem com o território não são o suficiente para compatibilizar as demandas socioespaciais. Somente mediante ferramentas de desenho urbano seria possível atuar sobre aspectos morfológicos estratégicos para a reformulação desse urbano em crise. Na ausência dessa ferramenta, algumas intervenções que são gestadas para resolver problemas estruturantes da cidade, podem ter efeitos disruptivos no plano local. Isso ficou mais evidente em relação aos sistemas 
infraestruturais, levando-nos a salientar a necessidade de reconciliar infraestrutura e território, menos em um sentido de eficiência e mais em um sentido de potencializar suas transformações sociais.

O segundo tema abordado (capítulo 3) foi o da Segregação reafirmada no lote. Ao buscar um aprofundamento das questões colocadas por meio do olhar abrangente sobre as grandes estruturas do território, percebe-se no lote a potência de reflexão sobre a questão da segregação. A diferenciação entre centro-periferia nas cidades analisadas se produz por aspectos sociais, econômicos e políticos de base. Mas essa diferença também se reproduz na unidade de atuação mais comum à arquitetura: o lote. A leitura do caso colombiano contribuiu para perceber que este é um tema central, até mesmo para o enfrentamento dos problemas da violência urbana que se agravam com a segregação e estigmatização socioespacial. A leitura do caso paulistano não só se beneficia dessas ponderações, como pôde acrescentar a esse debate a importante contribuição de Tereza Caldeira e Christian Dunker.

Os autores permitiram introduzir no debate o reconhecimento das marcas da violência nos elementos de organização do espaço, para ponderar como elas se reproduzem e se propagam na cidade, algo que também se estende a uma psicopatologia do social. O entrecruzamento desses processos que implica entraves à consolidação de um pacto socioespacial, atravessa e permite problematizar toda a proposição da $A \& U$ que pretende contribuir para a dimensão coletiva do espaço urbano. Ao vermos como os projetos reagem a essa tendência hegemônica de separação, diferenciação e hierarquização, pretendemos ter chamado à atenção a temas que permitem à $A \& U$ localizarem impulsos de reação. A saber: limites, divisas, interfaces. Conclui-se que cabe à arquitetura estratégias propositivas sentido contrário, construindo continuidades e diluindo as diferenças.

A fragmentação dos espaços cotidianos (capítulo 4) referiu-se a um problema transversal aos demais temas, que é o da racionalização funcionalista da arquitetura e do urbanismo, algo que se tornou mais claro a partir dos influxos modernos. Esse processo contribuiu para a hierarquização do espaço e a fragmentação da vida cotidiana, que são o oposto daquilo que se reconhece pela mistura e eventualidade da vida urbana, como demonstrou Lefebvre.

Constatou-se que a superação desses preceitos implica uma reinterpretação do nível de determinação que a arquitetura pode exercer sobre a vida. De certo modo, percebeu-se que as leituras essencialmente programáticas e formais não alcançam mais a complexidade do espaço social. Reconhecemos em Lefebvre a indicação de um caminho, na superação da ideia de função na arquitetura, apontando para a capacidade da disciplina em dialogar com significantes, ao invés de se ater aos significados. Buscamos também aclarar esta complexa problematização analisando projetos que enfrentaram o campo das indeterminações ao se afastarem da noção de função, buscando no vazio um elemento conectivo.

Refletindo sobre o percurso da tese, esse capítulo pretendeu apontar que quando recorremos a uma crítica da modernidade, o fazemos na 
impossibilidade de buscar uma arquitetura da cidade para responder aos anseios que decorrem do processo. Em contrapartida, ao denotarmos nossas próprias dificuldades, reconhecemos também a importância de uma arquitetura para a cidade. E que também, ao esclarecer essa dimensão sociourbana da arquitetura, surge uma necessária mudança no papel do arquiteto. De um intérprete da vida na cidade, distante das contradições da produção do espaço, mostra-se premente aproximar-se do real, como um mediador. Nesse movimento, alteram-se claramente as prioridades. A leitura das condicionantes, de suas contradições e impossibilidades, torna-se o motor das pesquisas projetuais.

As contínuas atualizações do nosso descompasso social, mobilizadas funcionalmente pelas forças produtivas e políticas de nosso país problema comum ao bloco latino-americano - pareceu nos convencer de que restam apenas tarefas de retaguarda ao arquiteto e urbanista. Mas, na posição de resistência ou de impulsos contra-hegemônicos, há qualidades que urgem serem reveladas. Nesse sentido esse trabalho representou um esforço em realizar uma crítica às posturas projetuais que pareceram levar-nos a uma conivência desavisada com os processos de desestruturação, segregação (individualização) e funcionalização da vida urbana.

O debate proposto esperou esclarecer os limites do prolongamento de estratégias projetuais pouco responsivas às demandas do espaço social que enfrentam. Algo que se verifica na insistência das estratégias de intervenção no espaço derivadas da modernidade, como particularmente alguns estudos de caso na cidade de São Paulo puderam demonstrar. Assim, a $A \& U$ deve buscar não só uma notável qualidade de espacialidades e refinadas articulações formais de seus recursos técnicos, nem tampouco restringir-se à adequação dos conteúdos programáticos. $\mathrm{Na}$ atual condição de segregação e acirramento das tensões sociais, a arquitetura e o urbanismo são instados a se colocarem como parte estruturante e reagente na composição de uma nova urbanidade.

A experiência de Medellín, ainda que passível de muitas problematizações, não oblitera o fato de que essa cidade colocou em primeiro plano a disciplina da Arquitetura e Urbanismo como ferramenta para a transformação socioespacial que se pleiteava. As conjunturas políticas, os instrumentos e potentes meios de financiamento das políticas urbanas, o engajamento da sociedade civil e das entidades privadas, além de uma estrutura institucional intersetorial são, naturalmente, os outros elementos que interagem com esses objetivos.

Mas o que motiva a mobilização dessa experiência, é que se buscou dinamizar o potencial de transformação da forma social, fundamentalmente por meio da forma urbana. Isso parece recobrar o sentido social da disciplina, tão fragilizada em meio aos imperativos da gestão capitalista do espaço. Ainda que estas intervenções estejam em andamento, demonstrando contradições e problemas a serem superados, na mesma medida em que se realizam eventuais avanços, 
Medellín forneceu questões para ampliar o debate disciplinar pretendido.

Finalizado o percurso, denota-se certa assimetria não só na quantidade de projetos analisados, mas nos desdobramentos analíticos que resultam da experiência colombiana, em detrimento à paulista. É possível que isso decorra do fato de que as perguntas surgem dos projetos de São Paulo e as respostas, como não poderiam deixar de ser, são maiores. Além de serem percorridas com olhares curiosos sobre uma realidade que é estrangeira. Mas, pondera-se também que responder as questões devolvidas a São Paulo, pelas experiências de Medellín, denotaram que, além de numerosas, elas foram suscitadas pela maior variedade de estratégias projetuais, o que demandou proporcional processamento analítico. Por essa via, o contraste torna-se também um indicador fornecido pela pesquisa. Pondera-se que não há problemas, quando não conseguimos reconhecê-los. Seja pela ausência de termos para descrevê-los ou de perguntas que possam iluminar áreas obliteradas - risco que também acompanha esta pesquisa.

Procurou-se, afinal, isolar ou dimensionar as condicionantes comuns que interferem nos processos projetuais. Elas foram percebidas na condição de subdesenvolvimento, na explosão demográfica, na segregação, nas dificuldades da legislação e nos desafios impostos à política urbana. Isso se fez no sentido de aclarar o principal indicador das diferenças de estratégias de A\&U: uma abordagem urbana ancorada na tradição que se seguiu à crise do movimento moderno. No caso colombiano, uma cultura arquitetônica muito variada se desenvolveu em fase com a discussão realista e contextual que dominou o debate europeu e americano depois dos anos 1960. No Brasil, no entanto, essa critica se voltou à produção da mercadoria e no desvendamento dos mecanismos sociais da segregação urbana. Esse processo deixou a questão da cidade e de sua arquitetura à margem desses debates. Os grandes conjuntos habitacionais testemunham os impactos dessa ausência, que favorece a permanência da solução segregadora, produtiva e disciplinar.

Tendo reconhecido as fragilidades de uma pesquisa, na sua condição intrinsecamente exploratória, espera-se que o diálogo com a experiência colombiana tenha sido capaz de fornecer subsídios para renovados debates nos estudos da arquitetura e do urbanismo contemporâneos. Pode-se dizer que, o exercício de aproximação entre esta realidade e a de São Paulo, pretendeu-se ao menos contribuir nessa perspectiva. 

ÁlVAREZ ARBOLEDA, C. A.; CHICANGANA BAYONA, Y. A. Inicios del alcantarillado en Medellín (Colombia), 1920-1955. HiSTOReLo. Revista de Historia Regional y Local, v. 7, n. 14, p. 251-284, 30 jun. 2015.

ALVES, G. DA A. A mobilidade/imobilidade na produção do espaço metropolitano. In: CARLOS, A. F. A.; SOUZA, M. L. DE; SPOSITO, M. E. B. (Eds.). A produção do espaço urbano: agentes e processos, escalas e desafios. São Paulo: Contexto, 2011. p. 109-122.

ALVIM, A.; ABASCAL, E. H.; MORAES, L. Projeto urbano e operação urbana consorciada em São Paulo: limites, desafios e perspectivas. Cadernos Metrópole, v. 13, n. 25, p. 213-233, 2011.

ANELLI, R. L. S. Centros Educacionais Unificados: arquitetura e educação em São Paulo. Arquitextos. Vitruvius, n. 055.02, dez. 2004.

ARANGO, S. Historia de la Arquitectura en Colombia. Bogotá: Centro Editorial y Facultad de Artes Universidad Nacional de Colombia, 1990.

ARANGO, Silvia. Ciudad y arquitectura. Seis geraciones que construyeron la América Latina moderna. Colombia: México: FCE, 2012.

ARANTES, O. B. F. O lugar da arquitetura depois dos modernos. $3^{\mathrm{a}}$ Edição ed. São Paulo: Edusp, 2015.

ARAVECCHIA BOTAS, N. Ciudad Kennedy: uma fronteira no processo de urbanização de Bogotá. Anais do XV Seminário de História da Cidade e do Urbanismo, set. 2018.

ARBOUIN-GÓMEZ, F. Derecho urbanístico y desarrollo territorial colombiano. Evolución desde la colonia hasta nuestros días. Vniversitas, n. 124, p. 17-42, 2012.

ARISTIZÁBAL, M. A. El pensamiento Urbano de Ricardo Olano (19oo1940). Dissertação de Mestrado-Medellín: Universidade Nacional da Colômbia, 2016

ARTIGAS, J. B. V. Arquitetura e Construção. In: Caminhos da Arquitetura. São Paulo: Cosac Naify, 2004. p. 119-121.

AVERMAETE, T.; TEERDS, H. The Roles of the Architect: Toward a Theory of Practice. In: FRAUSTO, S. (Ed.). . Lexicon No 1: On the Role of the Architect. Rotterdam: The Berlage Center for Advanced Studies in Architecture and Urban Design, 2015. p. 7-11.

BARBOSA, L. S. Sin futuro, Medellín decidió hacer. Territorio México, ago. 2016.

BARCELLOS, G. Tessituras híbridas ou o duplo regresso: Encontros latino-americanos e traduções culturais do debate sobre o Retorno à Cidade. Tese de Doutorado-São Paulo: Faculdade de Arquitetura e Urbanismo da Universidade de São Paulo, 2013.

BARROS, C. Jardim Edite: Habitação integradora. Disponível em: $<$ https://www.galeriadaarquitetura.com.br/projeto.aspx?idProject=889\&escrito rio=hf-arquitetos_mmbb-arquitetos_\&projeto=jardim-edite>. Acesso em: 24 fev. 2019 
BAYÓN, D.; GASPARINI, P. Colombia, R. Salmona. Barcelona / Paris: Editorial Blume / Unesco, 1977.

BONDUKI, N. Origens da habitação social no Basil: Arquitetura Moderna, Lei do Inquilinato e difusão da casa própria, São Paulo: Estação Liberdade: FAPESP, 2017.

BOTERO, F. El espejismo de la modernidad en Medellin, 1890-1950. Lecturas de Economia, n. 39, p. 13-57, jul. 1993.

BRENNER, N.; SCHMID, C. Towards a new epistemology of the urban? City, v. 19, n. 2-3, p. 151-182, 4 maio 2015.

CALDEIRA, T. P. DO R. Enclaves fortificados: a nova segregação urbana. Novos Estudos CEBRAP, n. 47, p. 155-176, mar. 1997.

CALDEIRA, T. P. DO R. Cidade de muros: crime, segregação e cidadania em São Paulo. 3. ed. ed. São Paulo: Editora 34; Edusp, 2011.

CALLIARI, M. Escola Projeto Viver. A criação de um espaço de uso coletivo a partir de uma escola. v. ano 14, n. 164.01, ago. 2014.

CAMARgO, M. J. DE. Razão e Construção: Conversa de Paulista. Tese de Livre Docência-São Paulo: Faculdade de Arquitetura e Urbanismo da Universidade de São Paulo, 2009.

CAMPOS, C. M. Os rumos da cidade: Urbanismo e Modernização em São Paulo. São Paulo: Editora Senac, 2002.

CAMPOS, C. M.; ACKEL, L. Antecedentes: a modernização de São Paulo. In: A cidade que não pode parar: planos urbanísticos de São Paulo no século XX. São Paulo: Editora Mackenzie / Mackpesquisa, 2002. p. 13-32.

CARDOSO, A. L.; DENALDI, R. Balanço. In: Urbanização de Favelas no Brasil: um balanço preliminar do PAC. Rio de Janeiro: Letracapital, 2018. p. $17-48$.

CARLOS, A. F. A.; SIMONI-SANTOS; ALVAREZ, I. Geografia urbana crítica: teoria e método. São Paulo: Contexto, 2018.

CARO, J. E. E.; ORTEGA, A. V. The workers' massacre of 1928 in the Magdalena zona bananera - Colombia. Memorias: Revista Digital de Historia y Arqueologia desde el Caribe Colombiano, n. 18, p. 33, Diciembre 2012.

CARVALHO, L. Valsa Brasileira: do boom ao caos econômico. São Paulo: Todavia, 2018.

CASTRILLÓN ALDANA, A.; CARDONA OSORIO, S. El urbanismo y la planeación moderna Glocalidades en la formación de la modernidad urbana de Medellín. Historia y Sociedad, n. 26, p. 17-51, 10 jul. 2014.

CHAUÍ, MARILENA. Conformismo e resistência: aspectos da cultura popular no Brasil. São Paulo: Brasiliense, 1986.

COELHO, E. C. R. Do Intuitivo ao Concreto. In: FRANÇA, E.; COSTA, K. P. (Eds.). . Plano Municipal de Habitação: a experiência de São Paulo. São Paulo: Secretaria Municipal de Habitação da Prefeitura Municiapl de São Paulo, 2012. 
CORREA RESTREPO, J. S. El ferrocarril de Antioquia: empresarios extranjeros y participación local. Estudios Gerenciales, v. 28, n. 123, p. 149-166, abr. 2012.

CUTHBERT, A. R. Designing Cities. Oxford: Routledge, 2003.

DÁVILA, L. F. Violência urbana, conflicto y crimen em Medellín: una revisión de las publicaciones académicas al respecto. p. 15, 2016.

DE BEDOUT, F. U. Copia Monográfica: Felipe Uribe de Bedout Arquitecto. Medellín: Mesa Editores, 2006.

DE BEDOUT, F. U. Anfitrión: Felipe Uribe de Bedout. Medellín: Mesaestandar, 2018.

DE SOLÁ MORALES, M. De cosas urbanas. Barcelona: Gustavo Gilli, 2008.

SOLÁ-MORALES, M. DE S. Espacios públicos / Espacios colectivos. La Vanguardia, p. 5, 12 maio 1992.

DeliJAiCOV, A. Arquitetura do Lugar. Revista Piseagrama, n. 03, p. 30-31, 2011.

DUNKER, C. I. L. Mal-estar, sofrimento e sintoma: uma psicopatologia do Brasil entre muros. 1. ed. ed. São Paulo: Boitempo Editorial, 2015.

ECHEVARRÍA RAMIREZ, M. C. et al. Otras voces sociales. Recorridos territoriales alrededor de los derechos. In: Retos del habitat: Por la vida, la equidad y los derechos territoriales. Medellín: Universidad Nacional de Colombia, 2016. p. 58-72.

ECHEVERRI, A; ORSINI, F. Informalidad y Urbanismo Social en Medellín. In: HERMELÍN, M.; ECHEVERRI RESTREPO, A.; GIRALDO, J. (Eds.). . Medellín: medio ambiente, urbanismo, sociedad. 1. ed ed. Medellín: URBAM, Centro de Estudios Urbanos y Ambientales, Universidad EAFIT, 2010. p. 130-152.

ESCOBAR, ARTURO. La invención del tercer mundo. Construcción y deconstrucción del desarrollo. Caracas: Fundación Editorial el perro y la rana, 2007

ESCOBAR, LUIS FERNANDO GONZÁLEZ. Ciudad y arquitectura urbana en Colombia 198o-2o1o. Medellín: Universidad de Antioquia, 2016.

FANUCCI, F.; FERRAZ, M.; CARTUM, M. A praça das Artes. In: Praça das Artes. São Paulo: Azougue Editorial, 2013.

FELDMAN, S. Planejamento e Zoneamento. São Paulo 1947-1972. São Paulo: Edusp/FAPESP, 2005.

FRANÇA, E. Plano Municipal de Habitação - uma construção coletiva. In: FRANÇA, E.; COSTA, K. P. (Eds.). Plano Municipal de Habitação: a experiência de São Paulo. São Paulo: Secretaria Municipal de Habitação da Prefeitura Municiapl de São Paulo, 2012.

FRANÇA, E. O programa de saneamento ambiental e recuperaçao urbana da Bacia do Guarapiranga e a Prefeitura de São Paulo. In: CARDOSO, A. L.; DENALDI, R. (Eds.). Urbanização de Favelas no Brasil: um balanço preliminar do PAC. Rio de Janeiro: Letracapital, 2018. p. 19-37. 
FRANCO, F. DE M. A construção do caminho. Tese de doutorado-São Paulo: Faculdade de Arquitetura e Urbanismo da Universidade de São Paulo, 2005.

GARCÍA-HUIDOBRO, F.; TORRES TORRITI, D.; TUGAS, N. ¡El tiempo contruye! Barcelona: Editorial Gustavo Gilli, 2008.

GIRALDO ECHEVERRI, B. E.; TOBÓN CASTRO, D.; RESTREPO JARAMILLO, J. Facultad de Arquitectura Universidad Pontificia Bolivariana, 75 años: Medellín 1942-2017. [s.l: s.n.].

GONZÁLEZ ESCOBAR, L. F. Medellín, los orígenes y la transición a la modernidad: crecimiento y modelos urbanos 1775-1932. Medellín: Escuela del Hábitat-CEHAP, Facultad de Arquitectura, Universidad Nacional de Colombia, Sede Medellín, 2007.

GONZÁLEZ ESCOBAR, L. F. Ciudad y Arquitectura Urbana en Colombia 1980-2010. Medellín: Editorial Universidad de Antioquia, 2010.

GONZÁLEZ ESCOBAR, L. F. El Medellín futuro o el ángel del progreso. Revista Universidad de Antioquia, n. 317, p. 92-101, set. 2014.

GORELIK, A. A produção da "cidade latino-americana”. Tempo Social, v. 17, n. 1, p. 111-133, jun. 2005.

GROSTEIN, M. D. Metrópole e expansão urbana: a persistência de processos “insustentáveis”. São Paulo em Perspectiva, v. 15, n. 1, p. 13-19, jan. 2001.

GUTIÉRREZ, R. Arquitetura Latinoamericana. Haciendo camino al andar. In: GUTIÉRREZ, R. (Ed.). Arquitectura latinoamericana en el siglo XX. Lunwerg/Barcelona: Cedodal/Buenos Aires, 1998.

HADDAD, F. et al. Urbanismo social em São Paulo Política pública fundiária e instrumentos indutores desenvolvidos no período 2013-2016 (gestão Haddad). Arquitextos. Vitruvius, n. 219.06, p. 12, ago. 2018.

HAJER, M.; REIJNDORP, A. In Search of New Public Domain. Rotterdam: NAi Publishers, 2002.

HARVEY, D. O direito à cidade. Lutas Sociais. ISSN 1415-854X, n. 29, p. 73-89, 2012.

HARVEY, D. Cidades Rebeldes. São Paulo: Martins Fontes, 2014.

HERLING, T. Planejamento Integrado. In: FRANÇA, E.; BARDA, M. (Eds.). . Entre o céu e a água: o cantinho do céu. São Paulo: Prefeitura de São Paulo, 2012. p. 92-96.

HEUVEL, DIRK VAN DEN. The Spaces Between. In: HEUVEL, DIRK VAN DEN; STEIGENGA, MADELEINE; VAN TRIEST, JAAP (Eds.). . Lessons: Tupker/Risselada a double portrait of dutch architectural education 1953/2003. Amsterdam: Sun, 2003. p. 96-153.

HEUVEL, D. VAN DEN; RISSELADA, M. (EDS.). Team 10: in search of a Utopia of the present. Rotterdam: NAi Publishers, 2005.

HINCAPIÉ BALLESTEROS, L. A.; GUTIÉRREZ TAMAYO, A. L. Formación histórica y proyevto urbano integral: tensiones por la inclusíon social. In: Barrios populares Medellín: favelas São Paulo. São Paulo: FAUUSP, 2017. p. 8o-106. 
HYLTON, F. Medellín’s Makeover. New Left Review, n. 44, p. 70-89, abr. 2007.

HYLTON, F. A revolução colombiana. São Paulo: Editora Unesp, 2010.

JAMESON, F. Architecture and the Critique of Ideology. In: OCKMAN, J. (Ed.). . Architecture Criticism Ideology. Princeton: Princeton Architecture Press, 1985. p. 51-87.

JARAMILLO, J. P. et al. El Plan de Ordenamiento Territorial de Medellín 2014: un modelo territorial para la intervención estratégica. VII Seminario Internacional de Investigación en Urbanismo, p. 17, jun. 2015.

KOWARICK, L. A espoliação urbana. São Paulo: Paz e Terra, 1993.

LEFEBVRE, H. Introdução à modernidade. Rio de Janeiro: Paz e Terra, 1969.

LEFEBVRE, H. Los nuevos conjuntos urbanos. In: GAVIRIA, M.; GONZALEZPUEYO, J. (Eds.). . De lo rural a lo urbano. [s.l.] Península Barcelona, 1971. v. 41p. 103-121.

LEFEBVRE, H. L'Urbain. In: Le retour de la dialectique : douze mots clefs pour le monde moderne. Traducao Margarida Maria Andrade. Paris: Messidor/Éditions Sociales, 1986.

LEFEBVRE, H. Direito À Cidade. 4. ed. São Paulo: Editora Moraes, 1991.

LEFEBVRE, H. A Revolução Urbana. Belo Horizonte: Editora UFMG, 1999.

LEFEBVRE, H. Prefácio: a produção do espaço. Estudos avançados, v. 27, n. 79, p. 123-132, 2013

LEFEBVRE, HENRI. Toward an Architecture of Enjoyment. Minneapolis/ London: University of Minnesota Press, 2014.

LEIBLER, L.; BRAND, P. Movilidad e inclusión social : la experiencia desde la periferia de Medellín y el primer Metrocable*. Bulletin de l'Institut français d'études andines, n. 41 (3), p. 363-387, 31 dez. 2012.

LONGO, M. R.; MUZI, A. Mobilidade e desenvolvimento urbano: um panorama das estratégias recentes nos planos urbanísticos e de mobilidade municipais em São Paulo. Anais do V Enanparq 2018 - Eixo Infraestrutura e Mobilidade, p. 10768-10786, 2018.

LOPERA PÉREZ, J. D.; AVENDAÑO GONZÁLEZ, D. P. La vivienda: ¿derecho o mercancía? In: SÁNCHEZ, L. M.; ZUQUIM, M. DE L. (Eds.). Barrios Populares Medellín, Favelas São Paulo. São Paulo: Universidade de São Paulo, 2017.

LOPERA PÉREZ, J. D.; GONZÁLEZ AVENDAÑO, D.; SÁNCHEZ, L. M. Entre luchas sociales y avances jurídicos para la garantía de derechos. In: Barrios populares Medellín: favelas São Paulo. São Paulo: FAUUSP, 2017. p. 18-32.

MARICATO, E. Para entender a crise urbana. São Paulo: Expressão Popular, 2015 .

MARTIN, G.; MARTIN, M. Proximity, Crime, Politics and Design. In: KLAUFUS, C.; OUWENEEL, A. (Eds.). . Housing and Belonging in Latin America. New York / Oxford: Cedla Latin America Studies, 2015. p. 43-79. 
MAUTNER, Y. A periferia como fronteira da expansão do capital. In: DEAK, CSABA; SHIFFER, SUELI (Eds.). . O processo de urbanização no Brasil. São Paulo: Fupam, 1999.

MAZIVIERO, M. C.; SILVA, A. S. DA. O caso do Complexo Paraisópolis em gestões: diferenças conceituais em programas de intervenção em favelas em São Paulo. urbe. Revista Brasileira de Gestão Urbana, v. 10, n. 3, p. 500-520, 4 jun. 2018.

MEDRANO, L.; RECAMÁN, L. Vilanova Artigas. Habitação e cidade na modernização brasileira. Campinas: Unicamp, 2013.

MEDRANO, L.; RECAMAN, L. Space and society in the 21st century. e case of São Paulo. Bitácora Urbano Territorial, v. 28, n. 1, p. 71-83, 1 jan. 2018.

MEDRANO, L. S. et al. A presença de Henri Lefebvre no debate acadêmico contemporâneo da arquitetura. PARC Pesquisa em Arquitetura e Construção, v. 8, n. 3, p. 170, 31 jan. 2018.

MELGUIZO, R. C.; CRONSHAW, F. The Evolution of Armed Conflict in Medellín: An Analysis of the Major Actors. Latin American Perspectives, v. 28, n. 1, p. 110-131, 2001.

MENDES, D.; CARVALHO, M. C. W. DE. A ocupação da Bacia do Guarapiranga: perspectiva histórico-urbanística. In: CARDOSO, A. L.; DENALDI, R. (Eds.). . Urbanização de Favelas no Brasil: um balanço preliminar do PAC. Rio de Janeiro: Letracapital, 2018. p. 38-67.

MESA, M. (ED.). Plan:b arquitectos: acuerdos parciales. [s.l.] Mesa Editores, 2006.

MESA, M.; RESTREPO, V. (EDS.). Alfabetos: variaciones en la arquitectura de Giancarlo Mazzanti. Medellín: Mesa Editores, 2009.

MESA, M.; RESTREPO, V.; BETANCUR, V. (EDS.). Archipiélago de Arquitectura. Medellín: Mesa Editores, 2010.

MEYER, R. M. P.; GROSTEIN, M. D. A leste do centro: territorios do urbanismo. São Paulo: Imprensa Oficial do Estado de São Paulo, 2010.

MeYer, R. M. P.; GROSTein, M. D.; BIDERMAN, C. São Paulo Metrópole. São Paulo: Editora da Universidade de São Paulo: Imprensa Oficial, 2004.

MONCAYO CRUZ, V. M. Jorge Eliecer Gaitan. In: MARTINS, C. E. (Ed.). . A Latinoamericana: enciclopédia contemporânea da América Latina e do Caribe. [s.1.] Boitempo Editorial /LPP-Uerj, 2006.

NARANJO GIRALDO, G.; VILLA MARTÍNEZ, M. I. Entre luces y sombras: Medellín: espacio y políticas urbanas. Medellín: Corporación Región, 1997.

NAVARRETE HEREDIA, J.; ÁNGEL BERNAL, M. M.; DONOVAN, M. (EDS.). Equidad Territorial en Medellín: La Empresa de Desarrollo Urbano, EDU, como motor de la transformación urbana. Medellín: EDU Empresa de Desarollo Urbano; Alcaldía de Medellín; Banco interamericano de Desenvolvimento, 2014.

NESBITT, K. (ED.). Uma nova agenda para a arquitetura: antologia teórica (1965-1995). São Paulo: Cosac Naify, 2006. 
OLIVEIRA, F. Crítica à razão dualista. In: Crítica à razão dualista: o ornitorrinco. 1. ed. São Paulo: Boitempo Editorial, 2013a. p. 25-120.

OLIVEIRA, F. Crítica à razão dualista: o ornitorrinco. 1. ed. São Paulo: Boitempo Editorial, 2013b.

PASTERNAK, S.; D’OTTAVIANO, C. Favelas no Brasil e em São Paulo: avanços nas análises a partir da Leitura Territorial do Censo de 2010*. Cadernos Metrópole, v. 18, n. 35, p. 75-100, jun. 2016.

PAZ, O. O arco e a lira. São Paulo: Cosac \& Naify, 2012.

PEREIRA, M. Parque da Juventude: Paisagismo como ressignificador espacial. ArchDaily Brasil., 4 out. 2017.

PERFETTI DEL CORRAL, V. Las transformaciones de la estructura urbana de Medellín. La colonia, el ensanche y el plan regulador. Tesis de grado para optar al título de Maestría en Historia-Madrid: Escuela Técnica Superior de Arquitectura, 1995.

PRECIADO ZAPATA, B. Canalizar para industrializar. La domesticación del río Medellín en la primera mitad del siglo XX. Bogotá: Uniandes, 2015.

QUINTANA GUERRERO, I. Q. Os colaboradores latino-americanos de Le Corbusier em Paris (1932-1965). Tese de Doutorado-São Paulo: Faculdade de Arquitetura e Urbanismo da Universidade de São Paulo, 2016.

RAMÍREZ NIETO, J. Intervalo Nacional-Moderno de la Arquitectura Latinoamericana 1929-1939. Tese de Doutorado-Hamburg: HafenCity Universität-Hamburg Stadtplanung, 2009.

RAMÍREZ PATIÑO, S. P. Cuando Antioquia se volvió Medellín, 1905-19. Anuario Colombiano de História SOcial y de la Cultura, v. 38, n. 2, p. 217253, jul. 2011.

RECAMÁN, L. Oscar Niemeyer: forma arquitetônica e cidade no Brasil moderno. Tese de doutorado-[s.l.] Faculdade de Filosofia, Letras e Ciências Humanas da Universidade de São Paulo, 2002.

RECAMÁN, L. As virtualidades do morar: o espaço impossível da casa. In: RECAMÂN, L.; MEDRANO, L. (Eds.). . Artigas e a metrópole. São Paulo: FAUUSP, 2015a.

RECAMÁN, L. Arquitetura em tempos difíceis. In: O terceiro território: habitação coletiva e cidade. São Paulo: la mar en coche, 2015b. p. 12-39.

RECAMÁN, L. O problema da formação da arquitetura moderna brasileira. Tese de Livre Docência-São Paulo: Faculdade de Arquitetura e Urbanismo da Universidade de São Paulo, 2018.

RECAMAN, L.; WILDEROM, M. Escola (des)fazendo cidade. Revista Contraste, n. 5, fev. 2018.

REIS FILHO, N. G. Sao Paulo: vila, cidade, metropole. São Paulo: Prefeitura de São Paulo, 2004.

RISSELADA, M. (ED.). The space between. In: Alison \& Peter Smithson A Critical Anthology. Barcelona: Ediciones Polígrafa, 2011. p. 346-353. 
RISSELADA, M.; HEUVEL, D. VAN DEN. Looking into the mirror of Team 10. In: HEUVEL, D. VAN DEN; RISSELADA, M. (Eds.). . Team 1o: in search of a Utopia of the present. Rotterdam: NAi Publishers, 2005.

ROJAS, J. C. Etapas del conflicto armado en Colombia: hacia el posconflicto. Latinoamérica. Revista de Estudios Latinoamericanos, v. 62, p. 227-257, jan. 2016.

ROMERO, J. L. América Latina: as Cidades e as Idéias. Rio de Janeiro: Editora UFRJ, 2009.

SAFATLE, V. Prefácio: depois dos muros de Alphaville, o mato. In: Mal-estar, sofrimento e sintoma: uma psicopatologia do Brasil entre muros. 1. ed. ed. São Paulo: Boitempo Editorial, 2015. p. 9-12.

SALES, M. M. L. DE; FRANÇA, E.; FILARDO JR., A. S. A ocupação da represa e as ações do Programa Guarapiranga. In: CARDOSO, A. L.; DENALDI, R. (Eds.). . Urbanização de Favelas no Brasil: um balanço preliminar do PAC. Rio de Janeiro: Letracapital, 2018. p. 38-67.

SALMONA, R. Colombia, R. Salmona. In: BAYÓN, D.; GASPARINI, P. (Eds.). . Panorámica de la arquitectura latino-americana. Barcelona / Paris: Editorial Blume / Unesco, 1977.

SANTOS, M. As formas da pobreza e da dívida social. São Paulo: Edições Loyola, 1999.

SANTOS, M. Por uma Geografia Nova: Da Crítica da Geografia a uma Geografia Crítica. São Paulo: Editora da Universidade de São Paulo, 2004.

SANTOS, M. O Retorno do Território. OSAL: Observatorio Social de América Latina, n. 16, p. 255-261, jun. 2005.

SANTOS, M. O espaço dividido. za edição ed. São Paulo: Edusp, 2008.

SANTOS, M. O papel das cidades na formação das regiões na América Latina: Uma interpretação da evolução econômica de Medellín (Colômbia) e sua região. In: Ensaios sobre a Urbanização Latino-americana. São Paulo: Edusp, 2010. p. 77-92.

SÃO PAULO. SECRETARIA MUNICIPAL DE DESENVOLVIMENTO URBANO - SMDU. Território CEU: Rede de equipamentos e espaços públicos. São Paulo: SMDU, 2016.

SCHNITTER CASTELLANOS, P. Sert y Wiener en Colombia. La vivienda social en la aplicación del urbanismo moderno. Revista Electronica de Geografia y Ciencias Sociales, v. VII, n. 146, 1 ago. 2003.

SEGAWA, H. Arquitectura Latinoamericana Contemporânea. Barcelona: Editorial Gustavo Gilli, 2005.

SERAPIÃO, F. Aflalo \& Gasperini Arquitetos: Parque da Juventude Prédios Institucionais marcam a fase final do Parque da Juventude. Projeto Design, n. 344, out. 2008.

SERAPIÃO, F. A guerrilheira urbana. Revista Monolito, n. 7, p. 18-34, mar. 2012.

SEVCENKO, N. São Paulo, laboratório cultural interdito. In: Pindorama revisitada. São Paulo: Peirópolis, 2000. 
SIMONI-SANTOS, C. Da marginalidade à segregação: contribuições de uma teoria urbana crítica. Economía, Sociedad y Territorio, v. XVII, n. 55, p. 619646, 2017.

SINGER, P. Economia Política da Urbanização. São Paulo: Editora Brasiliense - Edições CEBRAP, 1973.

SMOLKA, M. O. Recuperação de Mais-Valias Fundiárias na América Latina: Políticas e Instrumentos para o Desenvolvimento Urbano. Cambridge: Lincoln Institute of Land Policy, 2014.

SOJA, E. Taking space personally. In: The spatial turn: interdisciplinary perspectives. New York: Routledge, 2009. p. 11-35.

SPERA VELÁSQUEZ, G. La relación entre planificacíon, renovacíon y espacio púlbico: un ejercício pendiente el caso de Medellín, Colombia. Tesis de Maestria-Bogotá: Pontificia Universidad Javeriana, nov. 2018.

STANEK, L. Henri Lefebvre on space: architecture, urban research, and the production of theory / Lukasz Stanek. Minneapolis, MN: University of Minnesota Press, 2011.

STANEK, Ł. Introduction. In: Toward an Architecture of Enjoyment. Minneapolis/ London: University of Minnesota Press, 2014.

TAFURI, M. Projecto e Utopia. $1^{a}$ Edição ed. Lisboa: Editorial Presença, 1985. V. 16

TRONCOSO, U. Parque Novo Santo Amaro V in São Paulo by Vigliecca \& Associados. The Architectural Review, 8 jun. 2015.

URREA UYABÁN, T. U. De la Calle a la Alfombra. Un espacio abierto en Bogotá. Tese de Doutorado-Barcelona: Universidade Politécnica de Catalunya, 2014.

VALENCIA, N. Como Medellín transformou seus reservatórios de água em verdadeiros parques públicos. Disponível em: $<$ http://www.archdaily.com.br/br/791843/como-medellin-transformou-seusreservatorios-de-agua-em-verdadeiros-parques-publicos>. Acesso em: 5 jan. 2019 .

VÉLEZ WHITE, M. L. La medellinidad, sus edificios. Informe sobre el trabajo de sabático-Medellín: Facultad de Arquitectura de la Universidad Nacional, 2000 .

VIEIRA, I. Jardim das Perdizes. Disponível em: $<$ https://www.galeriadaarquitetura.com.br/projeto/itamar-berezinarquitetura_/jardim-das-perdizes/316>.

VIGLIECCA, H. Território e estruturas habitacionais urbanas. In: O Terceiro Território: habitação coletiva e cidade. São Paulo: Arquiteto Hector Vigliecca \& Associados, 2014. p. 193.

VILLAÇA, F. Uma contribuição para a história do planejamento urbano no Brasil. In: DEÁK, C.; SCHIFFER, S. (Eds.). O processo de urbanização no Brasil. [s.l.] Edusp, 1999.

WERTHMANN, C. O desafio. In: WERTHMANN, C. (Ed.). Operações Táticas na cidade informal. São Paulo: Prefeitura do Município de São Paulo; Secretaria Municipal da Habitação - SEHAB, 2009. p. 34-39. 
WILDEROM, M. Conversa com Carlos Pardo: arquitetura educacional como intervenção urbana. Vitruvius - Entrevista, ano 14. n. 056.1, p. 3, out. 2013.

WILDEROM, M. Espaço educacional contemporâneo: reflexões sobre os rumos da arquitetura escolar na cidade de São Paulo (1935-2013). Dissertação de Mestrado-São Paulo: Faculdade de Arquitetura e Urbanismo da Universidade de São Paulo, 2014.

WILDEROM, M. Dupla periferia: repensando os horizontes disciplinares da relação entre arquitetura e urbanismo. Anales del X Seminario Internacional de Investigación en Urbanismo (SIIU) organizado pela Universitat Politécnica de Catalunya, n. Barcelona, 2018a.

WILDEROM, M. Urbanismo social e a matriz urbana real: relfexnøes sobre as experiências de Medellín. 25th APDR Congress on Circular Economy, Urban Metabolism and Regional Development, n. Lisbon, 2018b.

WILDEROM-CHAGAS, M. Arquiteturas possíveis para políticas urbanas inovadoras: diálogos entre São Paulo e Medellín. Anais do II Simpósio Internacional Pensar e Repensar a América Latina, ECA/USP, 2016, 2016.

ZANCHETTA, D. Prefeitura aprova minibairro na Barra Funda. O Estado de São Paulo, 10 set. 2013.

ZUQUIM, M. DE L.; SÁNCHEZ, L. M.; MAUTNER, Y. (EDS.). Barrios Populares Medellín, Favelas São Paulo. São Paulo: Universidade de São Paulo, 2017. 


\section{Fontes das imagens}

Figura 1.1.1 Mapa elaborado pela autora.

Figura 1.1.2 IBGE Censo Demográfico, 200o. Projeção Estatística da Amostra.

Figura 1.2.1 Mapa elaborado pela autora.

Figura 1.2.3 Mapa elaborado pela autora.

Figura 1.2.5 Taller de Diseño EDU. Equidad Territorial en Medellín, 2014, pág 38.

Figura 1.2.6 PMSP - Prefeitura Municipal de São Paulo

Figura 1.2.7 Mapa elaborado pela autora.

Figura 1.3.1 Foto da autora.

Figura 1.3.2 Foto da autora.

Figura 1.3.3 ROSSO, André.

Figura 1.3.4 Foto da autora.

Figuras 1.3.5-1.3.8 Foto da autora.

Figuras 1.4.1-1.4.4 NIEMEYER, Oscar. Croquis dos conjuntos arquitetônicos.

Figura 1.5.1 WOLFF, S. F. S. Espaço e educação: os primeiros passos da arquitetura das escolas públicas paulistas. São Paulo: Dissertação (Mestrado em História da Arquitetura e do Urbanismo) Faculdade de Arquitetura e Urbanismo da Universidade de São Paulo, 1992.

Figura 1.5.2 TAKIYA, André. Edif 6o anos de arquitetura pú blica. 2009. Dissertação (Mestrado em Projeto de Arquitetura)

- Faculdade de Arquitetura e Urbanismo, Universidade de São Paulo, São Paulo, 2009.

Fonte: Google Street View

Figura 1.5.3 FERRATA, Carlos Augusto. Escolas públicas em São Paulo (1960-1972). Dissertação (Mestrado em Projeto de Arquitetura) - Faculdade de Arquitetura e Urbanismo, Universidade de São Paulo, São Paulo, 2008.

Figura 1.5.4 REATO, Marina. CEU, desenho, cidade. São Paulo: Trabalho final de graduação. Faculdade de Arquitetura e Urbanismo da Universidade de São Paulo, 2011.

Figura 1.6.1 Autor não identificado.

Figura 1.6.2 Paolo Gasparini

Figura 1.6.3 Fonte da PLANTA: TELLEZ, G. Rogelio Salmona: Obra Completa. Bogotá: Escala, 2013, (p.124)

Figura 1.6.4-5 ZALAMEA, A.; MONTENEGRO, F.; VELÁSQUEZ, R (org.). Fernando Martinez Sanabria. Bogotá: Molinos Velásquez Editores, 20o8, p.89-91.

Figura 2.1.1 Elaborado pela autora.

Figura 2.1.2 NISIDA, Vitor Coelho. Disponível em <https:// www.flickr.com/photos/weeth/28691898726/>. Último acesso em 4/2/2019.

Figura 2.1.3 Elaborado pela autora.

Figura 2.1.4 Empresa de Desarrollo Urbano - EDU.

Figuras 2.1.5 e 2.1.6 Geosampa.

Figuras 2.1.7 e 2.1.8 Mapas Medellín.

Figura 2.1.9 Taller de Diseño EDU. Equidad Territorial en Medellín, 2014, pág 35 .

Figura 2.2.1 FRANCO, Fernando Mello de, Tese de doutoramento - Universidade de São Paulo, São Paulo, 2005

Figuras 2.2.2-2.2.4 Geosampa.

Figura 2.2.5 Mapas Medellín.

Figuras 2.2.6 e 2.2.7 MEJÍA, Francisco. Biblioteca Pública Piloto de Medellín, Archivo Fotográfico.

Figura 2.2.8 PÉREZ, Gabriel Carvajal. Biblioteca Pública Piloto de Medellín, Archivo Fotográfico.

Figura 2.2.9 MEJÍA, Francisco. Biblioteca Pública Piloto de Medellín, Archivo Fotográfico.

Figuras 2.2.10 e 2.2.11 Biblioteca Pública Piloto de Medellín, Archivo Fotográfico

Figura 2.3.1 Disponível em <file:///Users/claudia.kim.kim/Downloads/7859-16022-1-SM.pdf>. Último acesso em 22/2/2019.

Figura 2.3.2 Disponível em <http://blogs.virtual.unal.edu. co/hacolombia/2011/10/23/2-el-urbanismo-cientifico/attachment/410/>. Último acesso em 4/2/2019.

Figuras 2.3.3 e 2.3.4 Taller de Diseño EDU. Equidad Territorial en Medellín, 2014, págs. 49 e 51.

Figuras 2.4.1-2.4.22 Fotos da autora.

Figura 2.5.1-2.5.3 Empresa de Desarollo Urbano - EDU.

Figura 2.5.4 Mapas Medellín.

Figuras 2.5.5-2.5.10 Fotos da autora.

Figura 2.5.12 Mapas Medellín.

Figuras 2.5.13-2.5.14 Fotos da autora.

Figura 2.5.15 Mapas Medellín.

Figuras 2.5.16-2.5.17 Fotos da autora.

Figura 2.5.18 Mapas Medellín.

Figuras 2.5.19-2.5.21 Fotos da autora.

Figura 2.5.22 Google Earth.

Figuras 2.5.23-2.5.26 Fotos da autora.

Figura 2.5.27 Mapas Medellín.

Figuras 2.5.28-2.5.30 Fotos da autora.

Figura 2.6.1 Mapas Medellín.

Figuras 2.6.2-2.6.3 Fotos da autora.

Figuras 2.6.4-2.6.5 Taller de Diseño EDU. Equidad Territorial en Medellín, 2014, pág 47.

Figura 2.7.1 Mapas Medellín.

Figuras 2.7.2-2.7.6 Fotos da autora.

Figuras 2.8.1-2.8.8 Secretaria Municipal do Desenvolvimento Urbano - SMDU. Território CEU: Rede de equipamentos e espaços públicos. São Paulo: SMDU, 2016. Disponível em <https:// gestaourbana.prefeitura.sp.gov.br/rede-de-equipamentos/territorios-ceu/arquivos/>

Último acesso em 16/1/2019.

Figuras 2.8.9-2.8.29 REATO, Marina Nobrega, Trabalho final de graduação - Universidade de São Paulo, São Paulo, 2011.

Figuras 2.9.1-2.9.4 Fotos da autora.

Figuras 2.9.5-2.9.9 DUCCI, Daniel. Entre o céu e a água - Cantinho do Céu. Prefeitura de São Paulo, 2012.

Figura 2.10.1 Google Earth.

Figuras 2.10.2-2.10.9 Fotos da autora.

Figura 2.11.1 Google Earth.

Figura 2.11.2-2.11.4 Disponível em <https://www.arcoweb.com. br/projetodesign/arquitetura/jose-rollemberg-de-mello-filho-e-lara-melo-souza-centro-de-formacao-cultural-cidade-tiradentes-cfcct-sao-paulo>. Último acesso em 23/2/2019

Figuras 2.11.5-2.11.9 ARTIGAS, Marco.

Figura 3.1.1 Mapas Medellín. Disponível em <https://www. medellin.gov.co/MAPGISV5_WEB/mapa.jsp?aplicacion=o $>$. Último acesso em 30/o1/2019.

Figuras 3.1.2-3.1.6 Fotos da autora.

Figuras 3.2.1-3.2.3 Mapas Medellín. Disponível em <https:// www.medellin.gov.co/MAPGISV5_WEB/mapa.jsp?aplicacion $=0>$. Último acesso em 30/o1/2019.

Figuras 3.2.4-3.2.6 Foto da autora.

Figura 3.2.7 Mapas Medellín. Disponível em <https://www. medellin.gov.co/MAPGISV 5 _WEB/mapa.jsp?aplicacion=o $>$. Último acesso em 30/01/2019.

Figuras 3.2.8-3.2.12 Disponível em < http://www.planbarq. com/\#/jardn-infantil-sd/>. Último acesso em 31/o1/2019.

Figuras 3.2.13-3.2.15 PIRRIONE, Sergio. Disponível em <https://www.vivianapena.com/jardin-infantil-carpinelo>. Último acesso em 23/02/2019.

Figuras 3.2.16-3.2.18 EDU - Empresa de Desarollo Urbano.

Figura 3.3.1 Mapas Medellín. Disponível em <https://www. medellin.gov.co/MAPGISV5_WEB/mapa.jsp?aplicacion=o $>$. Último acesso em 30/01/2019.

Figuras 3.3.2-3.3.4 Fotos da autora.

Figura 3.3.5 Mapas Medellín. Disponível em <https://www. medellin.gov.co/MAPGISV5_WEB/mapa.jsp?aplicacion=0 $>$. 
Último acesso em 30/01/2019.

Figuras 3·3.6-3.3.12 Fotos da autora.

Figura 3.3.12 Mapas Medellín. Disponível em <https://www. medellin.gov.co/MAPGISV5_WEB/mapa.jsp?aplicacion=0 $>$. Último acesso em 30/o1/2019.

Figuras 3.3.13-3.3.18 Fotos da autora.

Figura 3.3.19 Mapas Medellín. Disponível em <https://www. medellin.gov.co/MAPGISV5_WEB/mapa.jsp?aplicacion=o $>$. Último acesso em 30/01/2019.

Figuras 3.3.20-3.3.25 Fotos da autora.

Figura 3.3.26 Mapas Medellín. Disponível em <https://www. medellin.gov.co/MAPGISV5_WEB/mapa.jsp?aplicacion=0 $>$. Último acesso em 30/01/2019.

Figuras 3.3.27 EDU - Empresa de Desarollo Urbano.

Figuras 3·3.28-3·3.32 Fotos da autora.

Figura 3.3.33 Mapas Medellín. Disponível em <https://www. medellin.gov.co/MAPGISV5_WEB/mapa.jsp?aplicacion=0 $>$.

Último acesso em 30/01/2019.

Figuras 3·3·34-3.3.35 Fotos da autora.

Figura 3.3.36 Mapas Medellín. Disponível em <https://www. medellin.gov.co/MAPGISV5_WEB/mapa.jsp?aplicacion=0 $>$. Último acesso em 30/01/2019.

Figuras 3·3·37-3·3.40 Fotos da autora.

Figura 3.3.a.1 Mapas Medellín. Disponível em <https://www. medellin.gov.co/MAPGISV5_WEB/mapa.jsp?aplicacion=0 >. Último acesso em 30/o1/2019.

Figuras 3·3.a.2-3·3.a.6 Fotos da autora.

Figura 3.4.1 Mapas Medellín. Disponível em <https://www. medellin.gov.co/MAPGISV5_WEB/mapa.jsp?aplicacion=0 $>$. Último acesso em 30/01/2019.

Figuras 3.4.2-3.4.14 Fotos da autora.

Figura 3.5.1 Mapas Medellín. Disponível em <https://www. medellin.gov.co/MAPGISV5_WEB/mapa.jsp?aplicacion=o $>$. Último acesso em 30/o1/2019.

Figuras 3.5.2-3.5.13 Fotos da autora.

Figuras 3.6.1-3.6.5 Fotos da autora.

Figuras 3.6.6 e 3.6.7 REATO, Marina Nobrega, Trabalho final de graduação - Universidade de São Paulo, São Paulo, 2011.

Figura 3.7.1 Google Earth.

Figuras $3 \cdot 7 \cdot 2-3 \cdot 7 \cdot 4$ Fotos da autora.

Figuras 3.7.5-3.7.7 SCANDAROLLI, Marcelo. Disponível em $<$ https://www.galeriadaarquitetura.com.br/slideshow/newslideshow.aspx?idproject $=1206 \&$ index $=0>$. Último acesso em 01/02/2019.

Figuras 3.7.8-3.7.14 Fotos da autora.

Figura 3.8.1 Google Earth.

Figura 3.8.2 SANABRA, Joel Barges. Dissertação de mestrado

- Universidade de São Paulo, São Paulo, 2015.

Figuras 3.8.3-3.8.17 Fotos da autora.

Figura 3.9.1 Google Earth.

Figuras 3.9.2-3.9.16 Fotos da autora.

Figura 3.9.a.1 Google Earth.

Figuras 3.9.a.2-3.9.a.8 Disponível em <https://www.architectural-review.com/today/parque-novo-santo-amaro-v-in-so-paulo-by-vigliecca-and-associados/8682725.article>. Último acesso em 23/02/2019.

Figura 3.10.1 Google Earth.

Figuras 3.10.2-3.10.4 Disponível em <https://www.galeriadaarquitetura.com.br/projeto/itamar-berezin-arquitetura_/jardim-das-perdizes/316>. Último acesso em 23/02/2019.

Figuras 3.10.5-3.10.9 Fotos da autora.

Figuras 4.1.1 e 4.1.2 Mapas elaborados pela autora.

Figuras 4.1.3 e 4.1.4 Google Earth.

Figura 4.2.1 Mapas Medellín. Disponível em < https://www. medellin.gov.co/MAPGISV5_WEB/mapa.jsp?aplicacion=0 > Último acesso em 1/3/2019.

Figuras 4.2.2-4.2.7 Foto da autora.
Figura 4.3.1 Mapas Medellín. Disponível em < https://www. medellin.gov.co/MAPGISV5_WEB/mapa.jsp?aplicacion=0 $>$ Último acesso em 1/3/2019.

Figuras 4.3.2-4.3.10 Fotos da autora.

Figura 4.4.1 Google Earth.

Figuras 4.4.2-4.4.7 Fotos da autora. 
Anexo 
$+14+1$
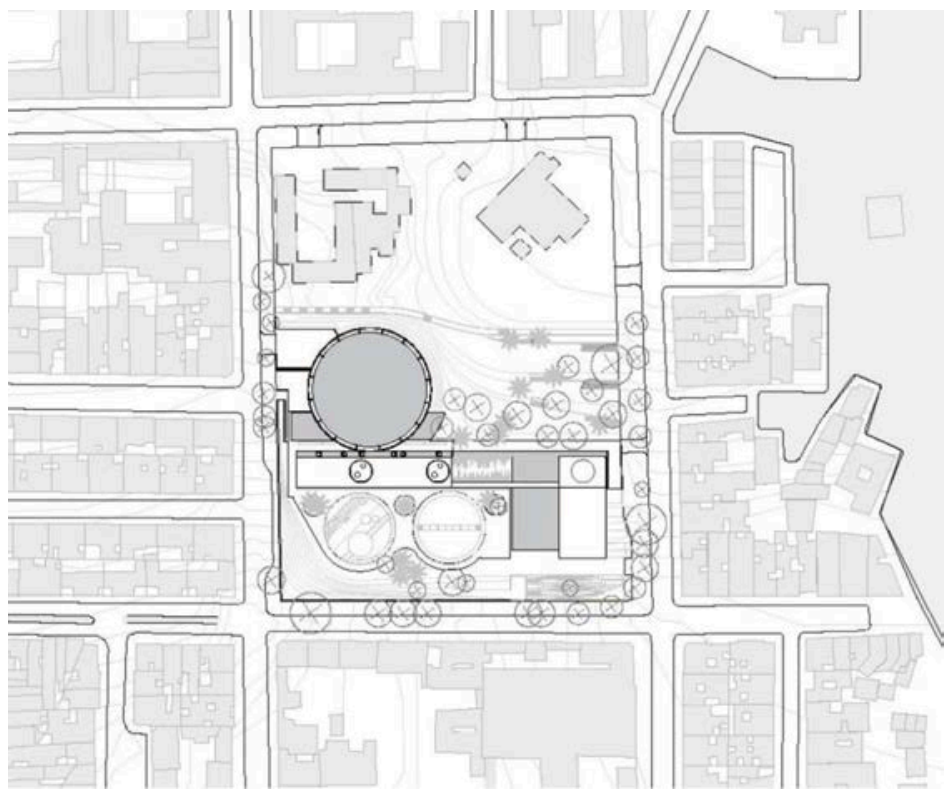

Figura 5.1.

Planta localização

Figura 5.1.2

Cortes
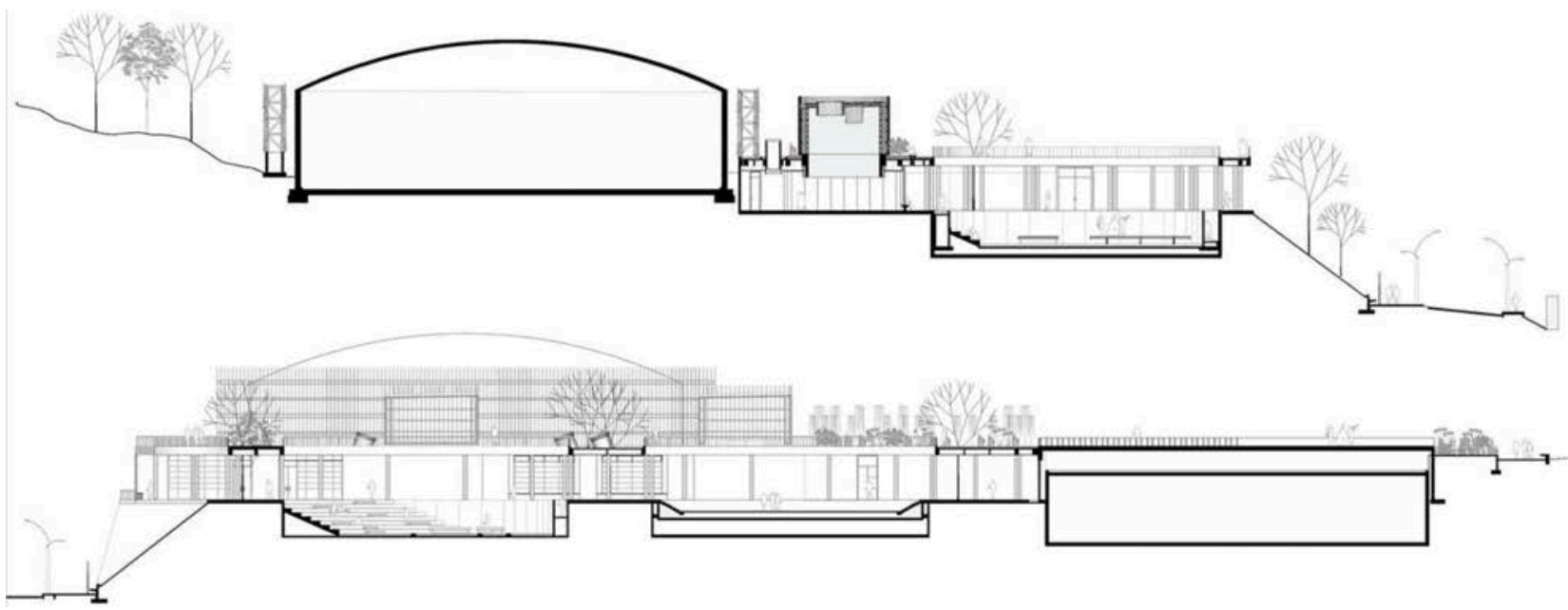

Figura 5.1.3

Figura 5.1.4
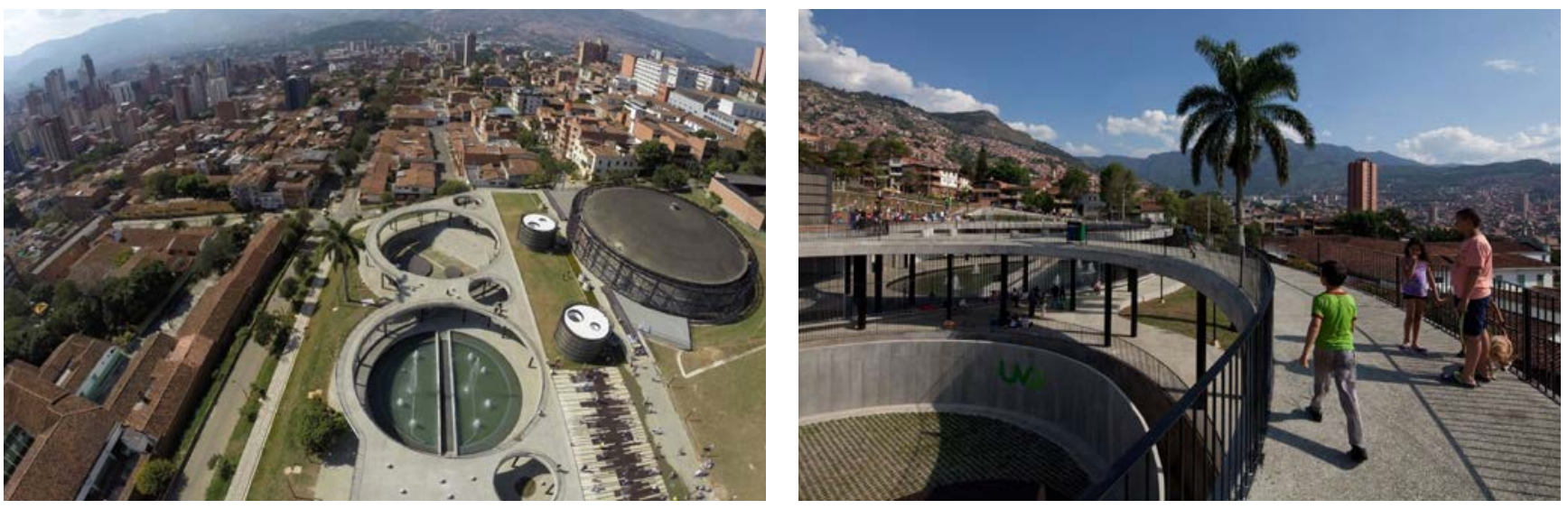


\section{UVA La Imaginación}

Autores COLECTIVO 720 SAS. Mario Fernando Camargo Gómez, Luis Orlando Tombé

Equipe Andrés Felipe Alvarez, Diana Medina, Cesar Aragon Carvaja, Stephanny Fiat Cabezas, Guillermo Buitrago Zuñiga, Julian David Mejia Cardona, Gustavo Salazar Cosme, Laura Santa Rodriguez, Isabela Hincapie Beron, Fabian Steven Mostacilla, Fiorella Gomez Silva.

\section{Data do projeto 2014}

\section{Data da construção 2015}

Área construída $12.600 \mathrm{~m}^{2}$

Localização Cl. 62 \# 39 - 21, Colombia, Medellín

Cliente EPM - Empresas Públicas de Medellín - Concurso

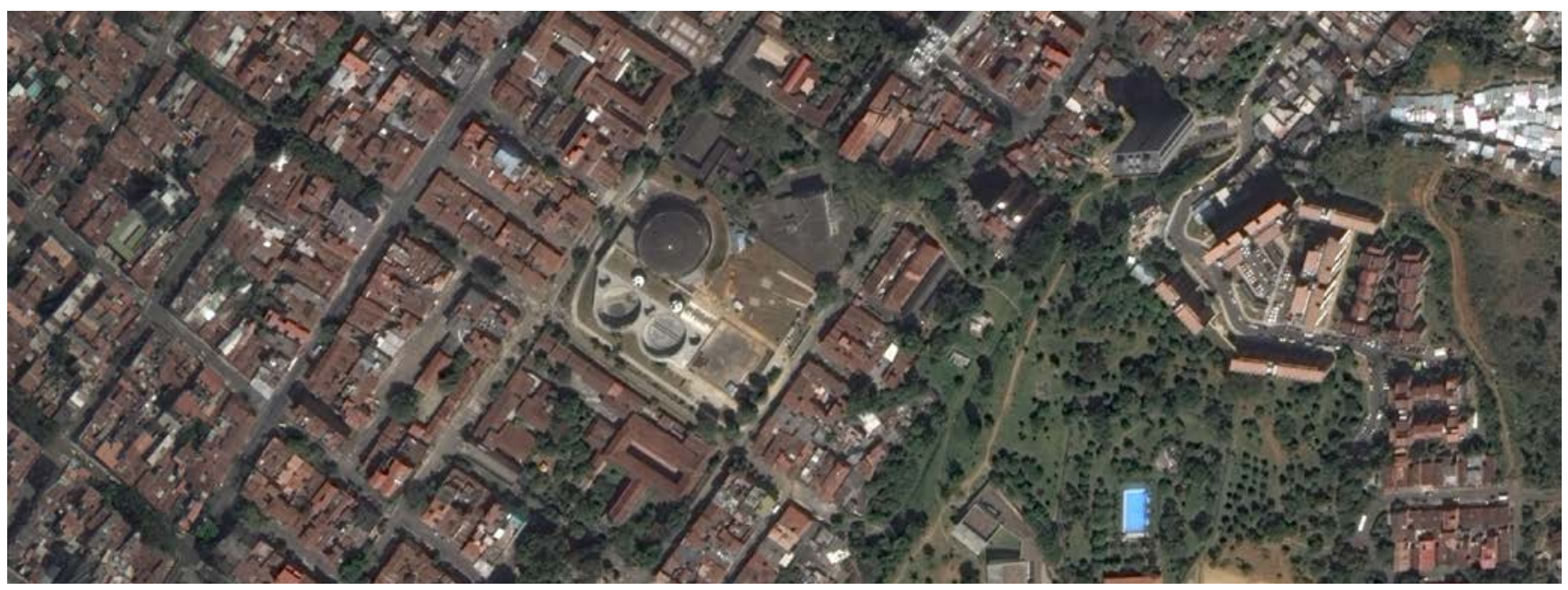

Figura 5.1.5

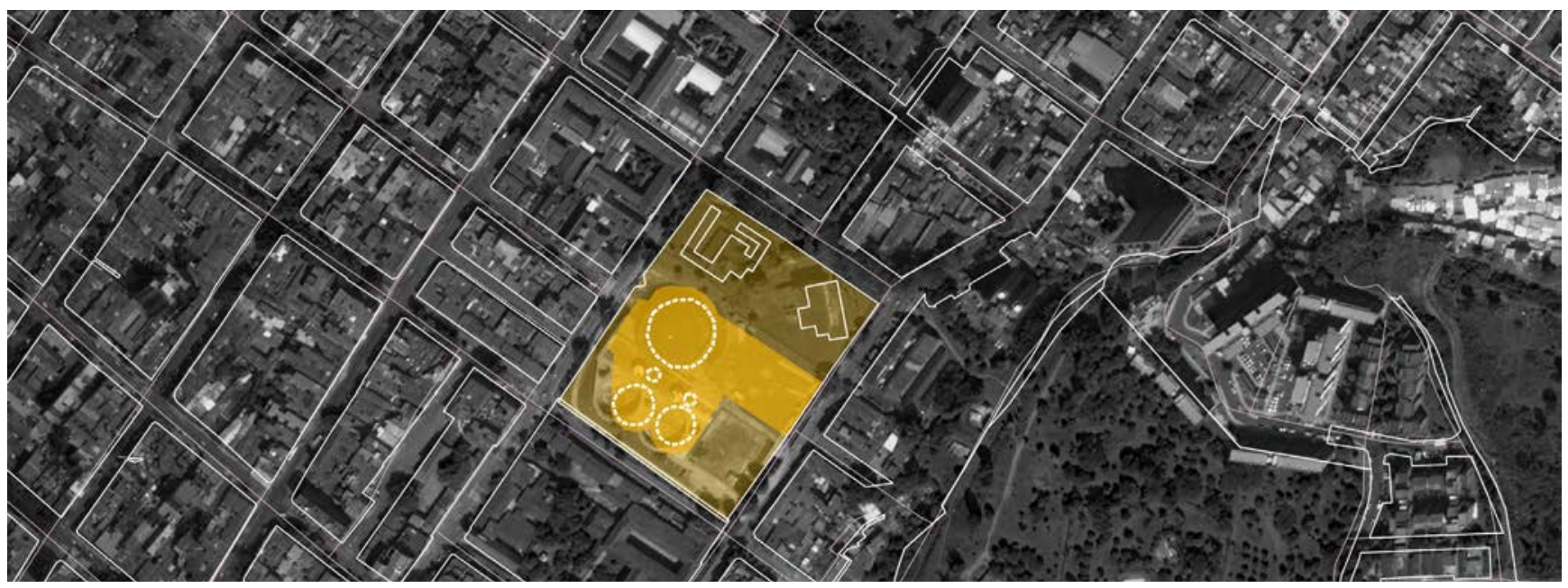

Figura 5.1.6

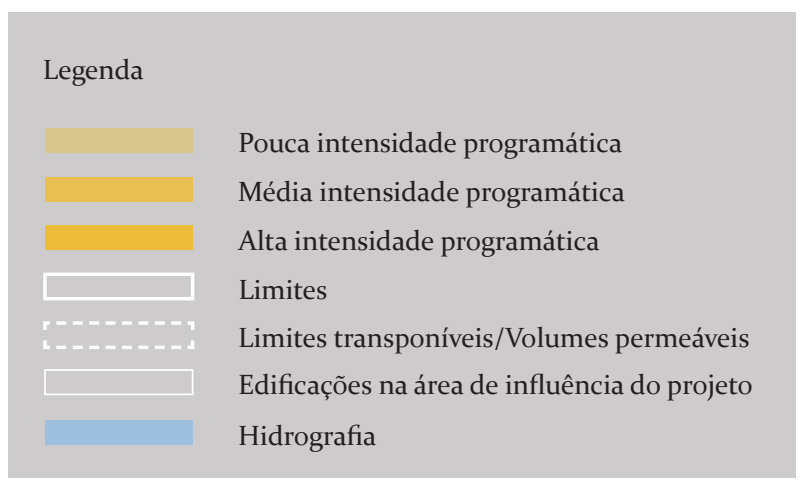




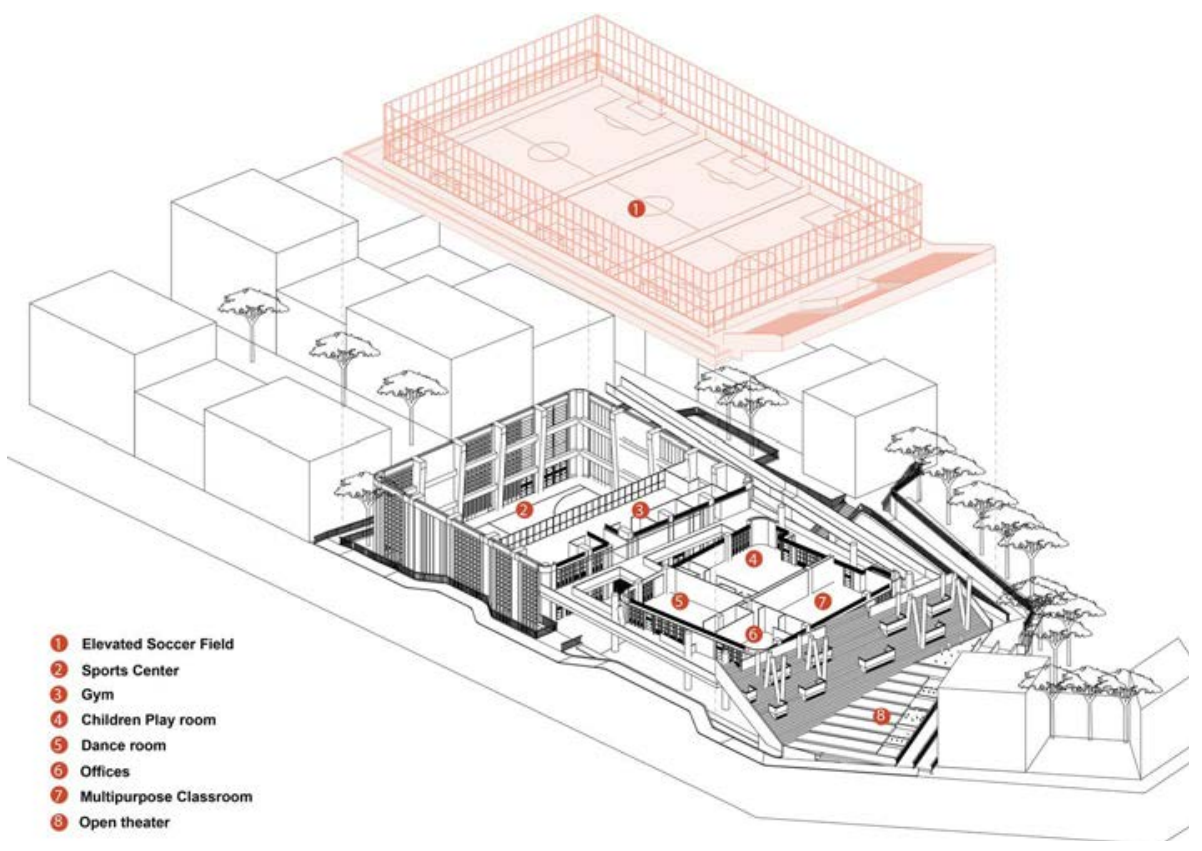

Figura 5.2.1

Diagrama

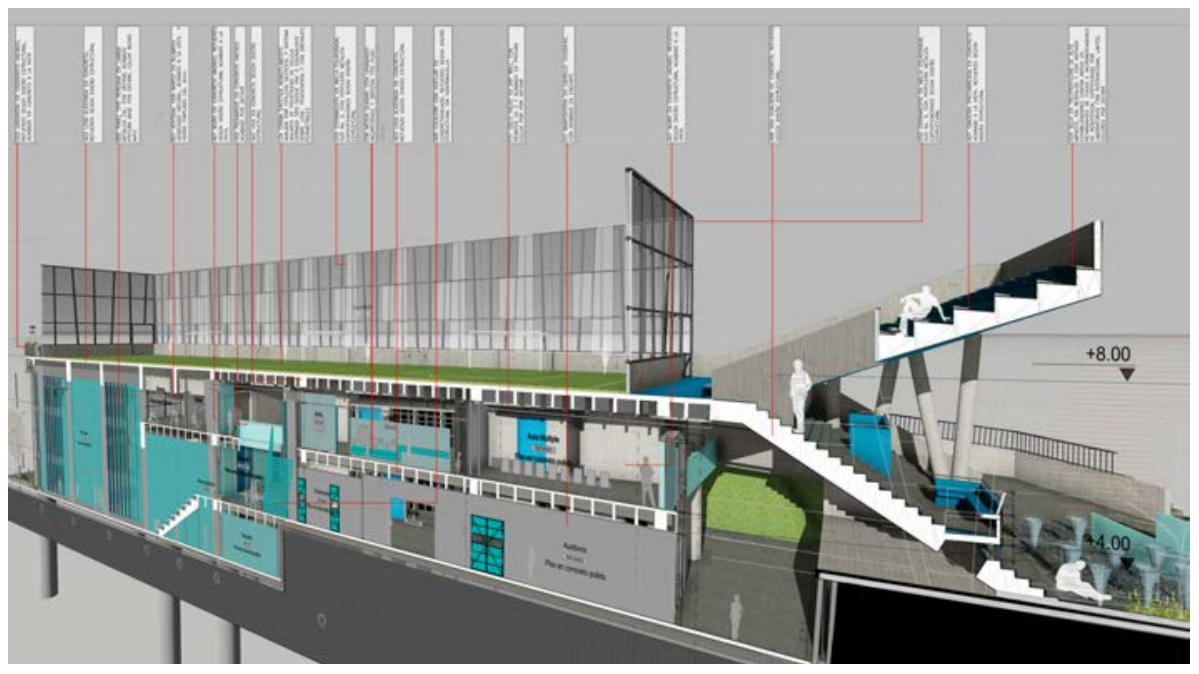

Figura 5.2.2

Corte

Figura 5.2.3

Figura 5.2.4
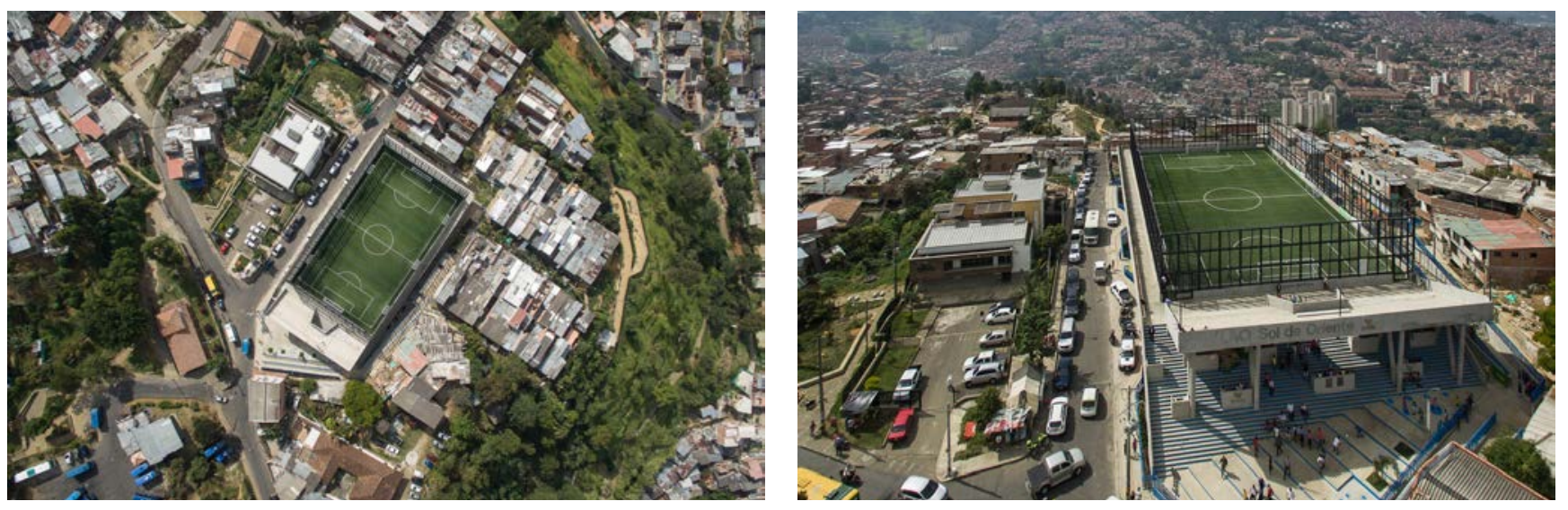


\section{UVA Sol do Oriente}

Autor Arquiteto EDU John Octavio Ortiz Lopera

Equipe Victor Hugo Garcia Restrepo, Gustavo Andres Ramirez

Mejia, Ana Carolina Restrepo acosta, Juan pablo Ramos Gaviria,

Catalina Ochoa Rodriguez, Jorge Ramirez, Julián Camilo Yepes,

Julián Esteban Gómez Carvajal

\section{Data da construção 2015}

Área construída $3.719 \mathrm{~m}^{2}$

Localização Cra. 6 \#4c-107 4c-289 - San Antonio de Prado, Medellín, Antioquia

Cliente INDER - Instituto de Deportes y Recreación de Medellín

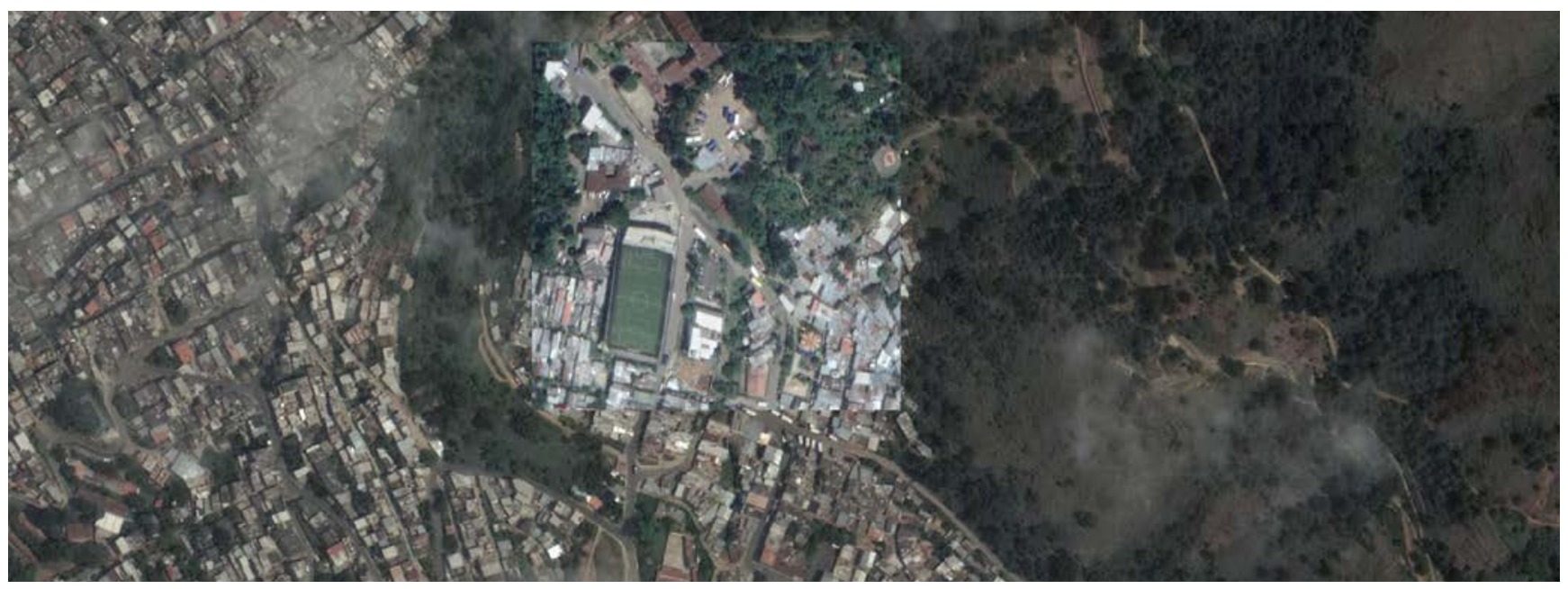

Figura 5.2.5

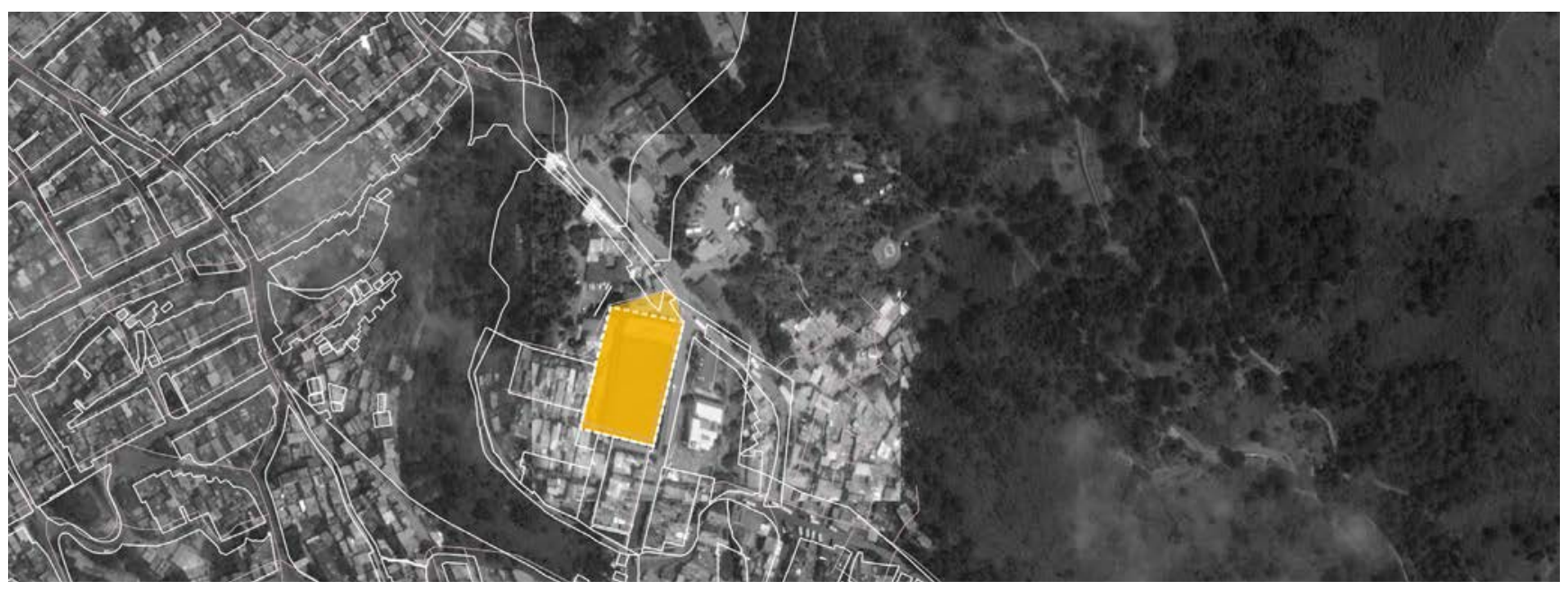

Figura 5.2.6

\begin{tabular}{|c|c|}
\hline \multicolumn{2}{|l|}{ Legenda } \\
\hline & Pouca intensidade programática \\
\hline & Média intensidade programática \\
\hline & Alta intensidade programática \\
\hline & Limites \\
\hline : & Limites transponíveis/Volumes permeáveis \\
\hline & Edificações na área de influência do projeto \\
\hline & Hidrografia \\
\hline
\end{tabular}




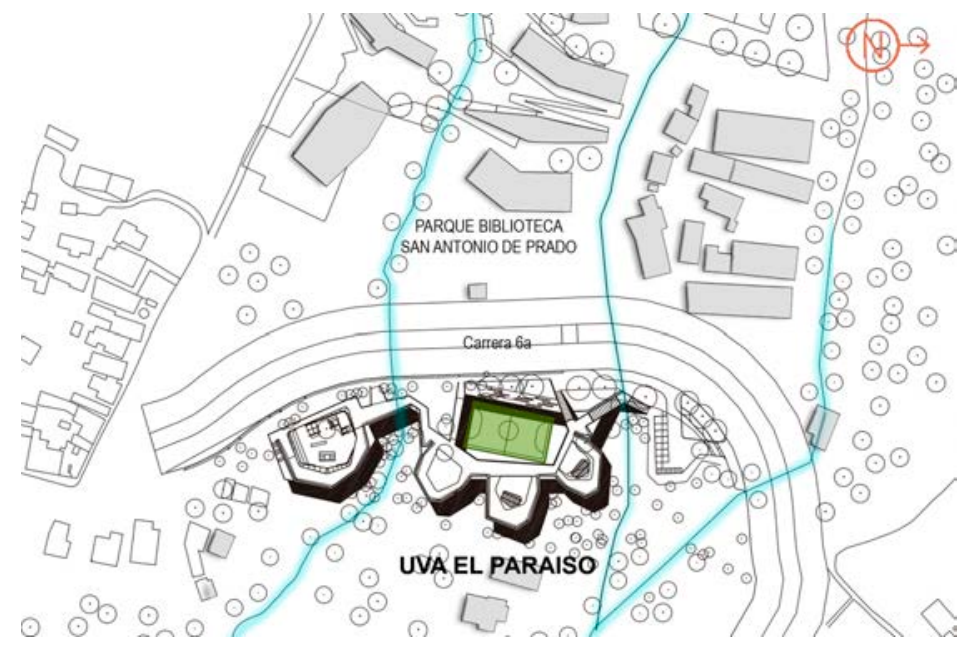

Figura 5.3.1

Entorno

Figura 5.3.2

Corte AA

Figura 5.3.3

Corte BB

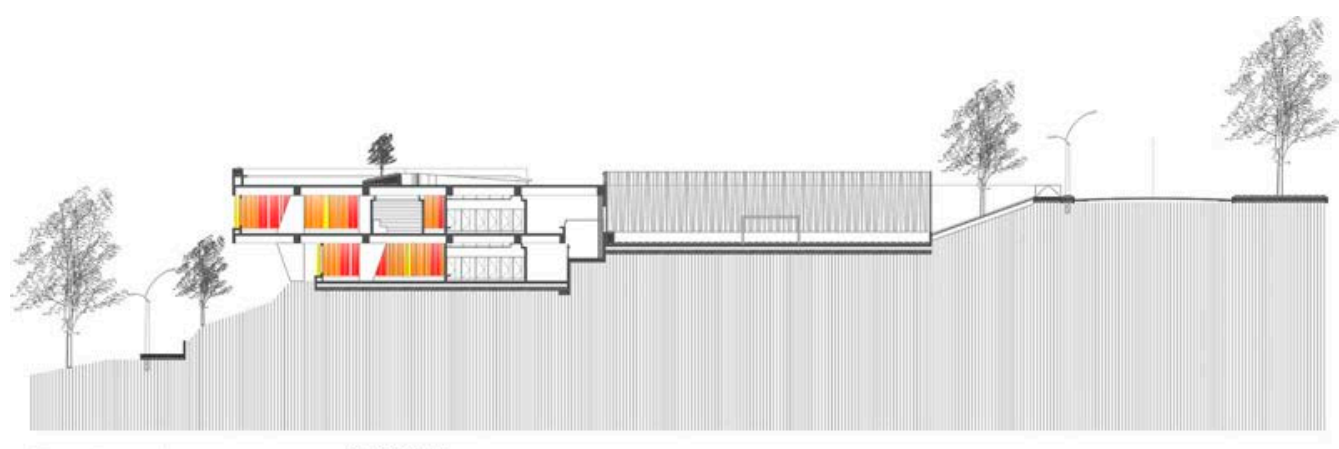

SECCION AA

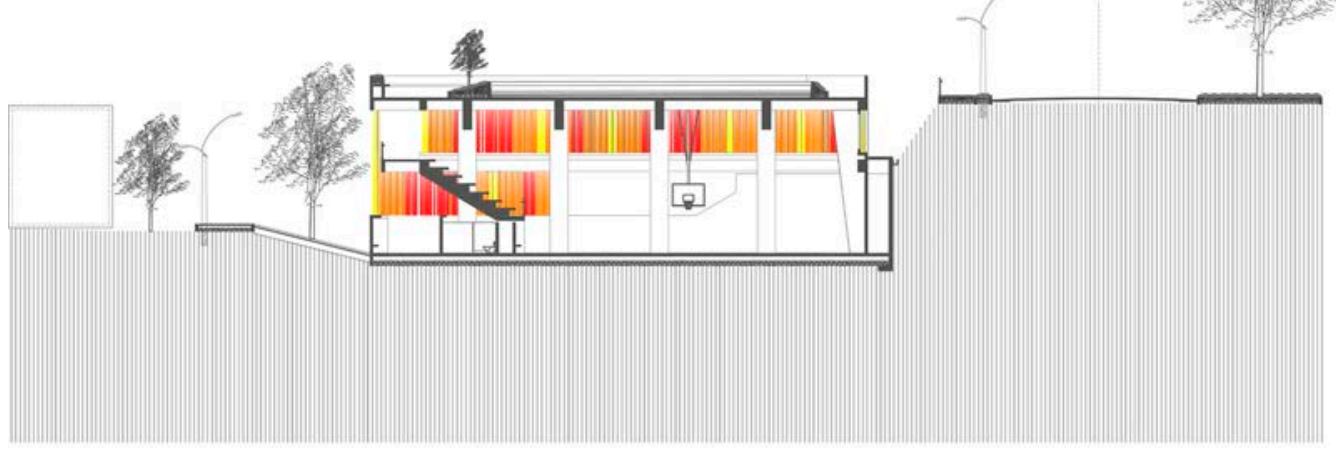

SECCION BB

Figura 5.3.4

Figura 5.3.5
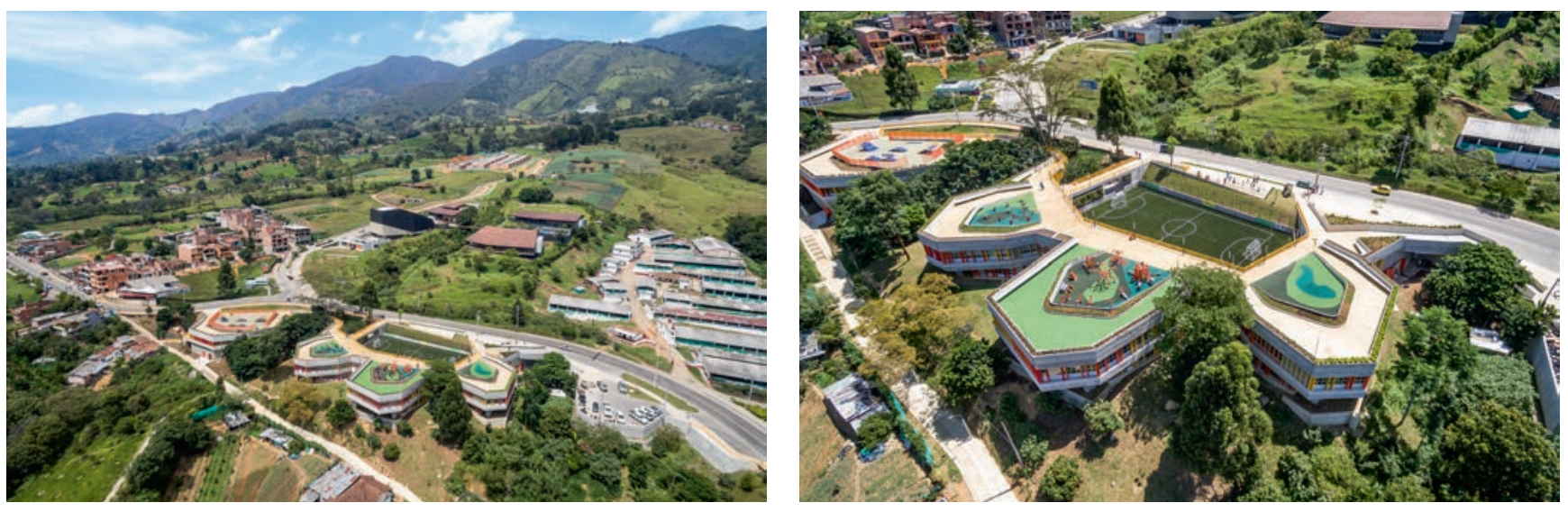


\section{UVA El Paraíso}

Autor Arquiteto EDU John Octavio Ortiz Lopera

Equipe Victor Hugo Garcia Restrepo, Gustavo Andres Ramirez

Mejia,Ana Carolina Restrepo Acosta, Juan Pablo Ramos Gaviria, Catalina Ochoa Rodriguez, Jorge Ramirez, Julián Camilo Yepes, Julián Esteban Gómez Carvajal

\section{Data da construção 2015}

Área construída $3.879 \mathrm{~m}^{2}$

Localização Cra. 6 \#4c-107 a 4c-289, San Antonio de Prado, Medellín, Antioquia, Colômbia

Cliente INDER - Instituto de Deportes y Recreación de Medellín

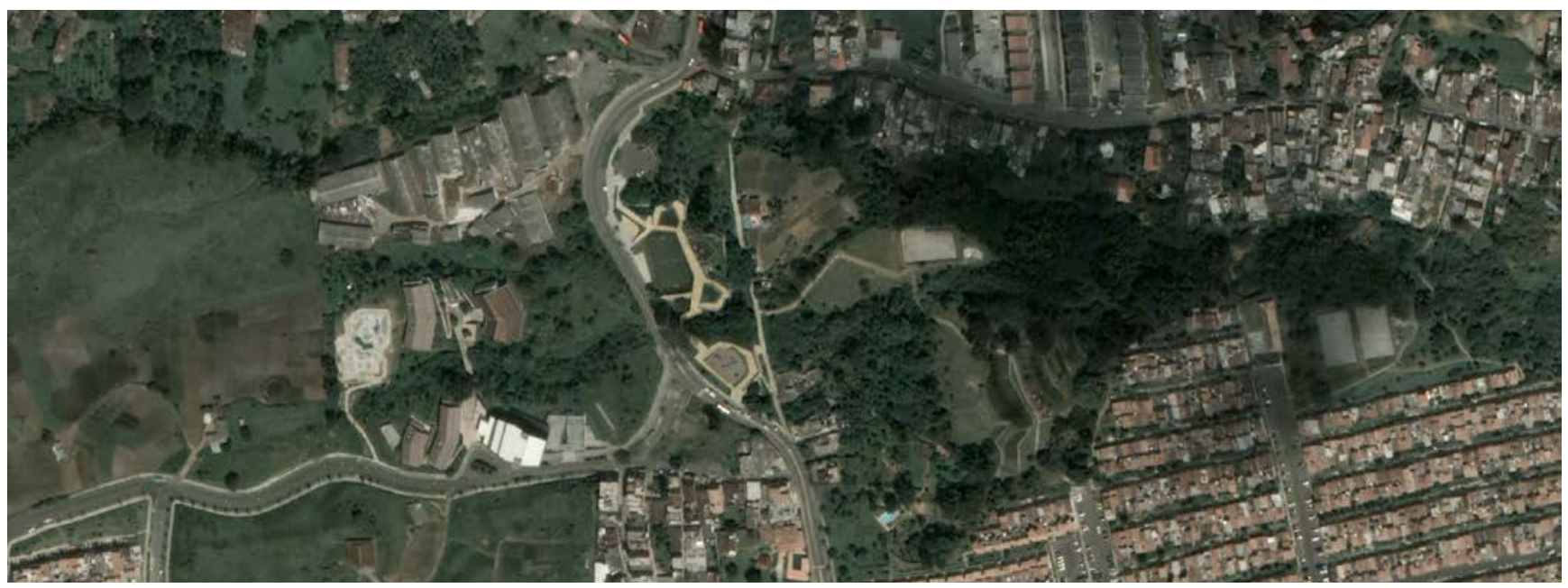

Figura 5.3.6

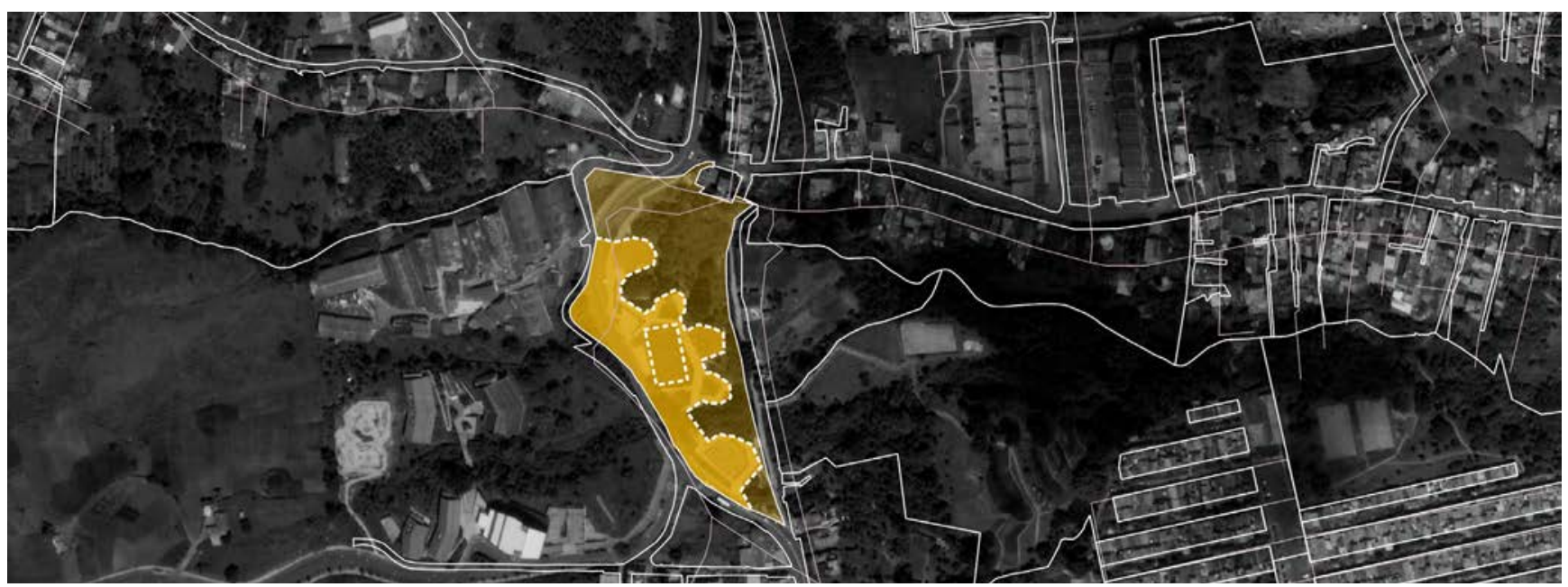

Figura 5.3.7

\begin{tabular}{|c|c|}
\hline \multicolumn{2}{|l|}{ Legenda } \\
\hline & Pouca intensidade programática \\
\hline & Média intensidade programática \\
\hline & Alta intensidade programática \\
\hline & Limites \\
\hline 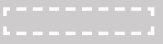 & Limites transponíveis/Volumes permeáveis \\
\hline & Edificações na área de influência do projeto \\
\hline & Hidrografia \\
\hline
\end{tabular}



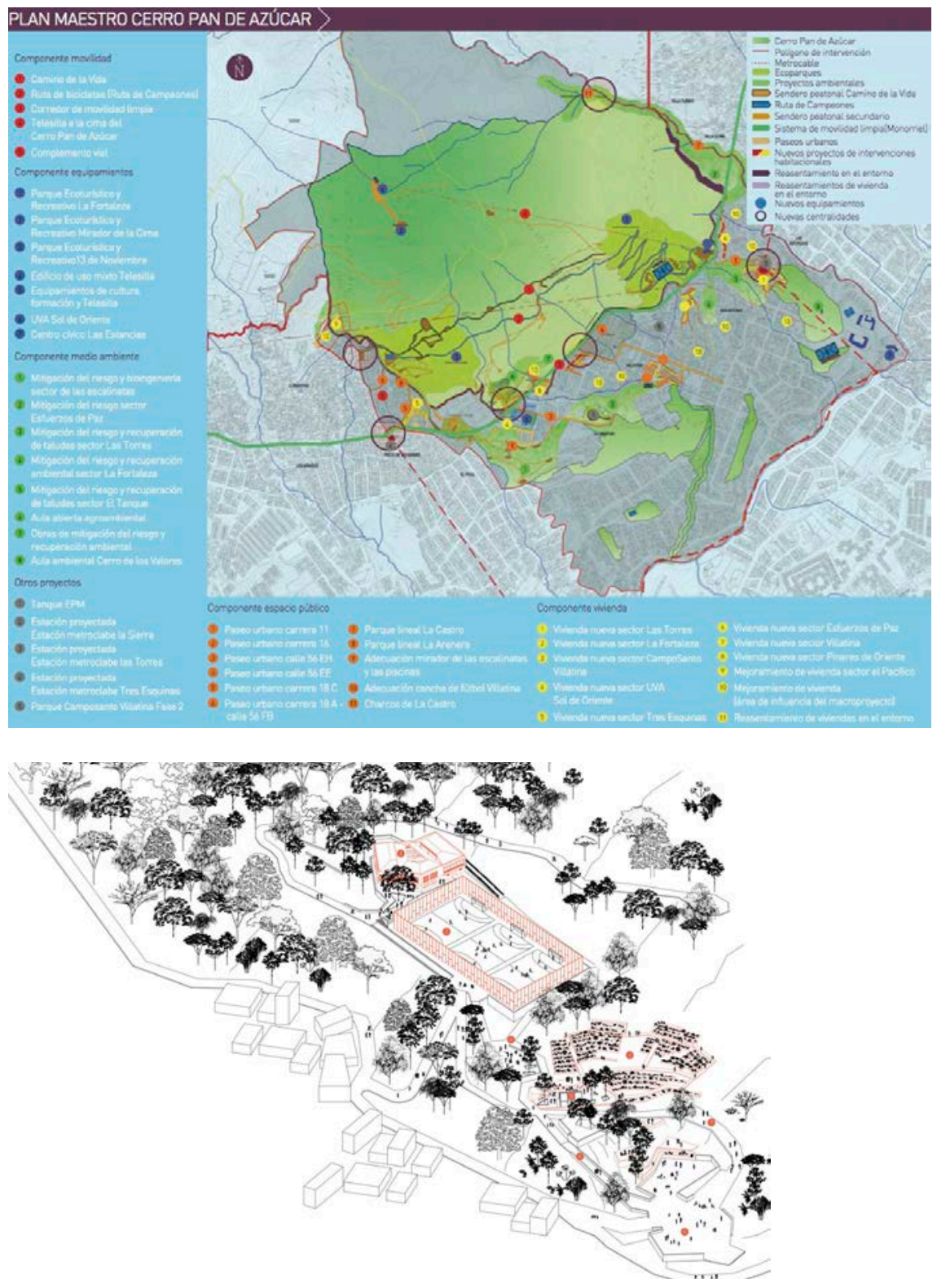

Figura 5.4.1

Ecoparque Las Tinajas, Jardin Circunvalar de Medellín - Comuna 8

Figura 5.4.2

Planta geral Cerro Pan de Azúcar
Figura 5.4·3

Figura 5.4.4

Vista do Jardín Circunvalar. À esquerda, a UVA Sol do Oriente. Ao fundo, o centro verticalizado da cidade e os cerros Nutibara (à esquerda) e Volador (à direita).
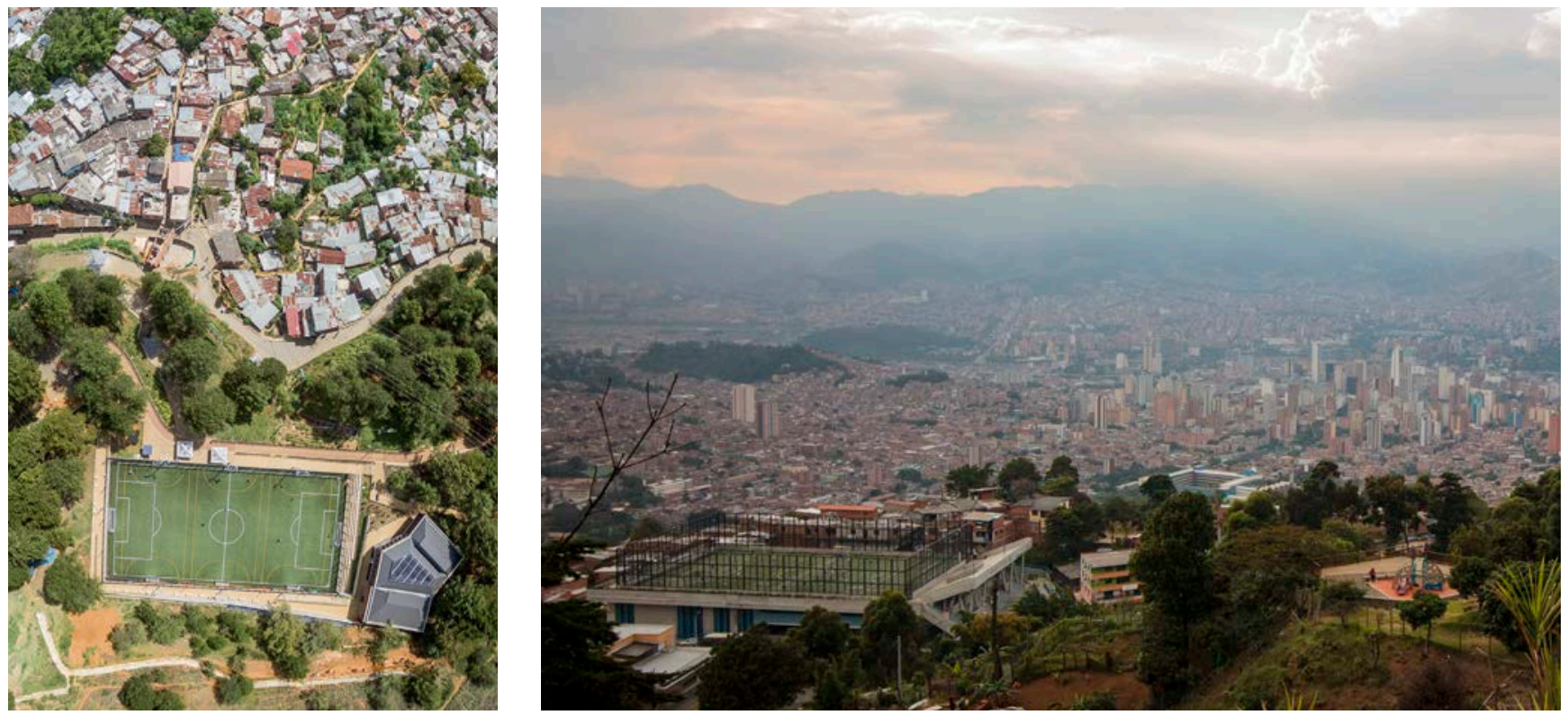
Jardin Circunvalar - Ecoparque Las Tinajas

Autores EDU - Empresa de Desarollo Urbano

Data do projeto 2012

Data da construção 2014
Área do lote $23.500 \mathrm{~m}^{2}$

Localização Calle 56EE n.11, cerro Pan de Azúcar

Cliente INDER - Instituto de Deportes y Recreación de Medellín

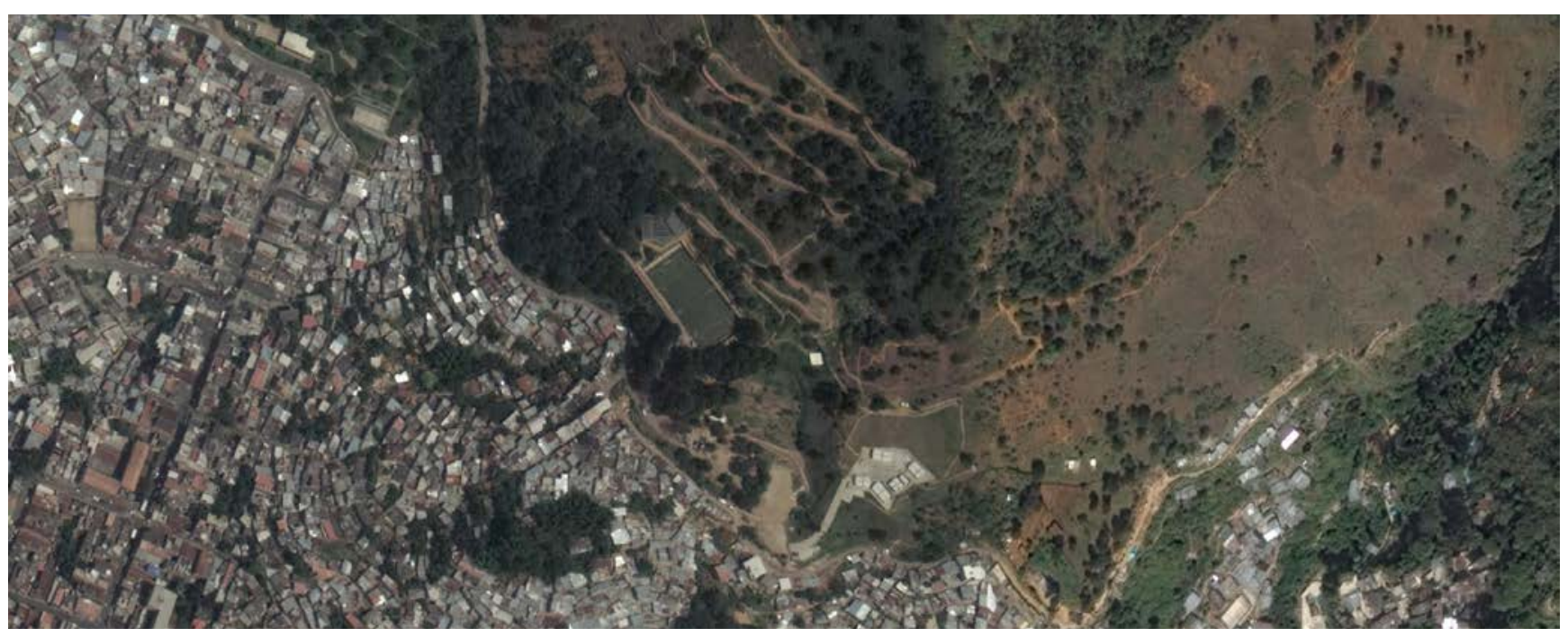

Figura 5.4.5

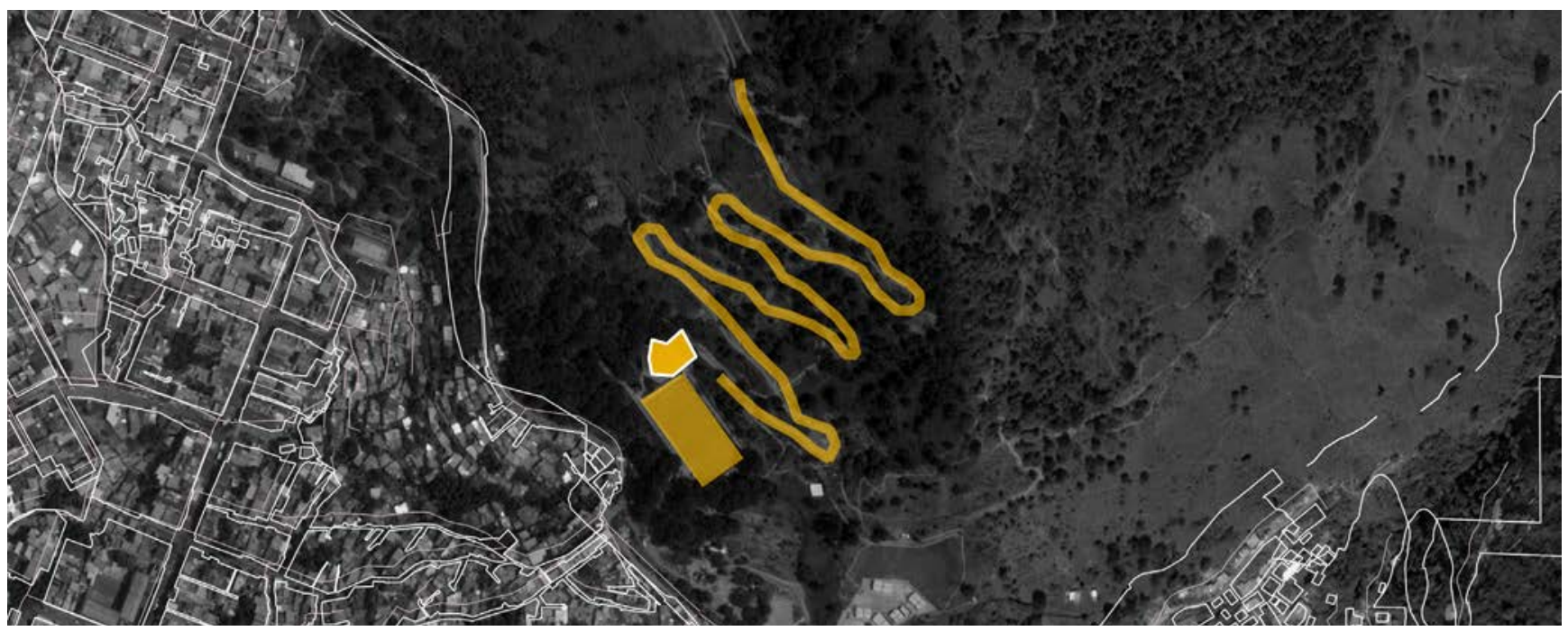

Figura 5.4.6

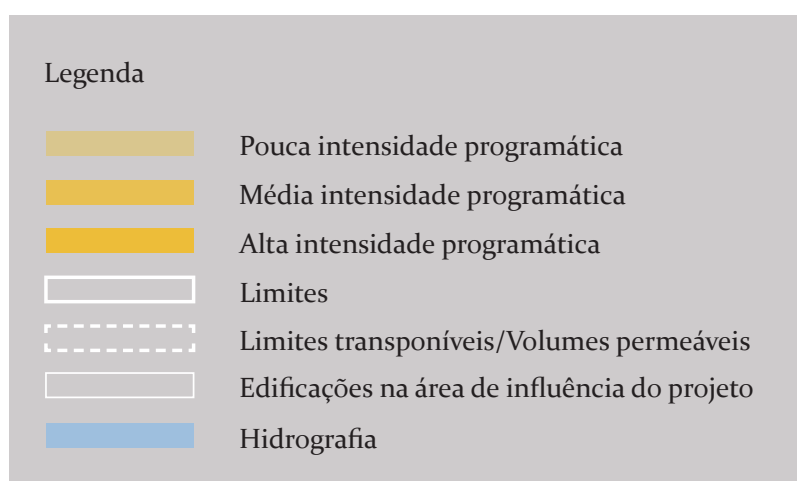




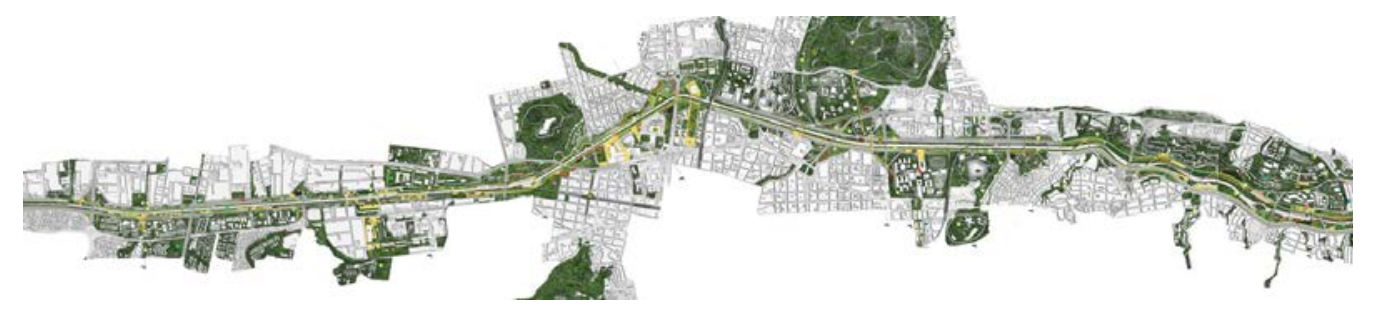

01
Figura 5.5.1

Planta

Figura 5.5.2

Corte Centro Puente

Guayaquil

Figura 5.5.3

Corte Norte La Iguana

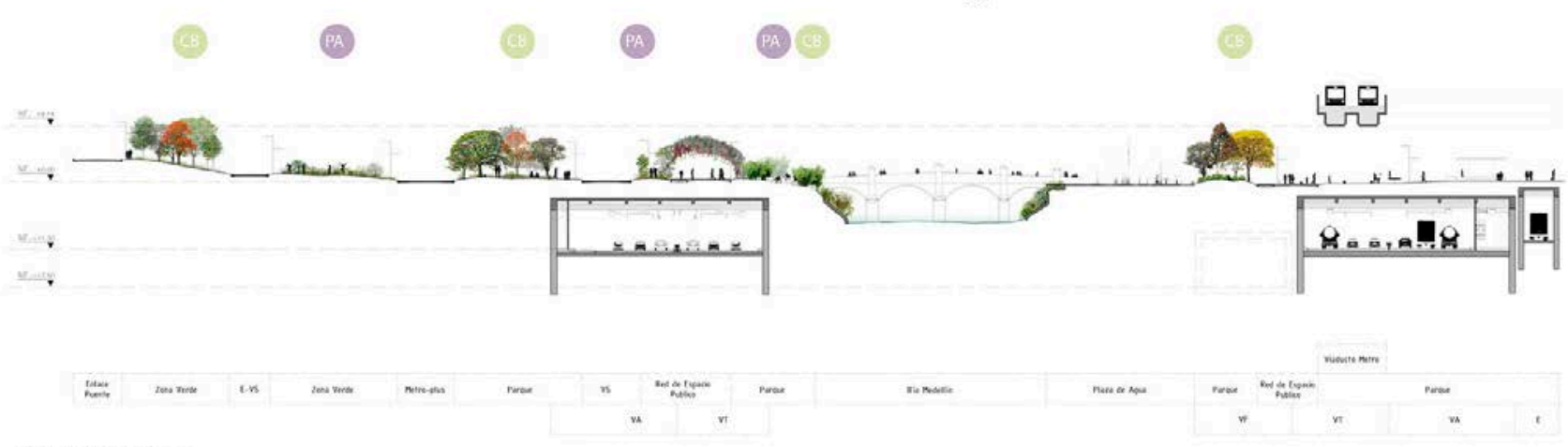

01

03

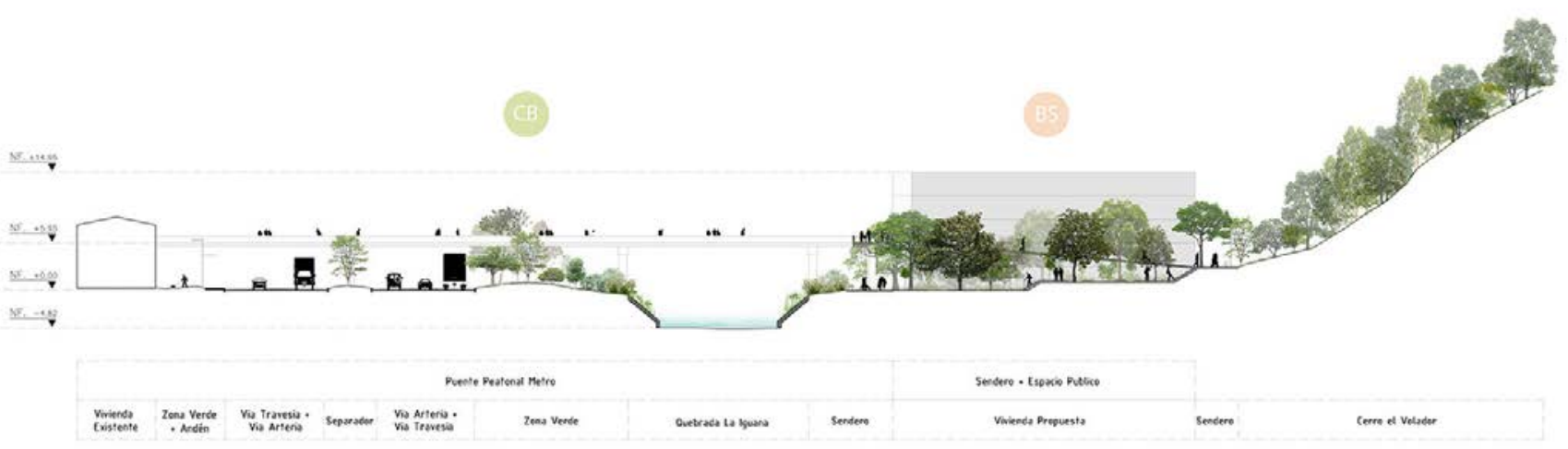

SECCIÓN POR QUEBRADA LA IGUANA
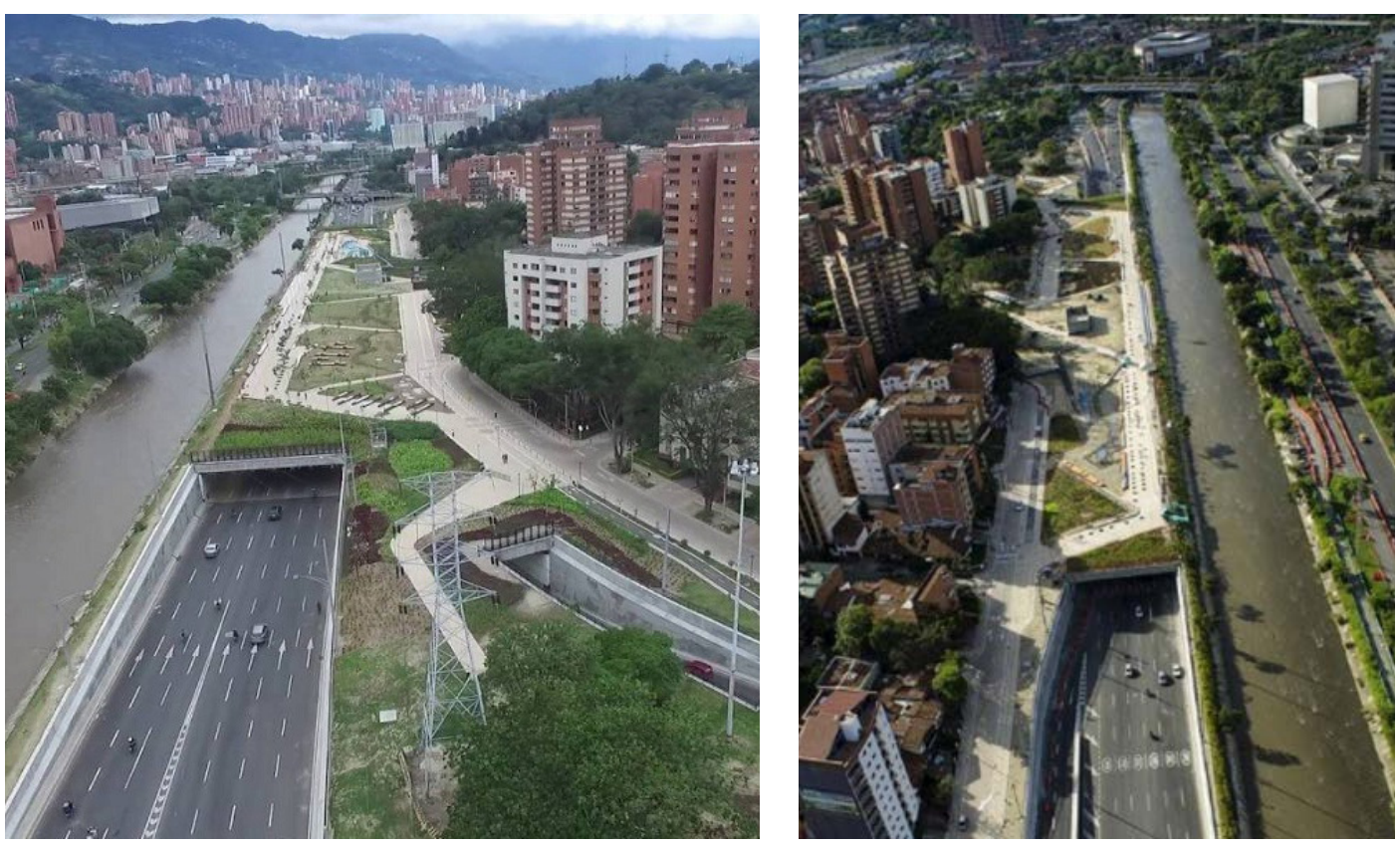

Figura 5.5.4

Figura 5.5.5 


\section{Parques Del Río}

Autores Latitud Taller de Arquitectura y Ciudad

Data do projeto 2013

Data da construção 2016
Área do lote $3280.000 \mathrm{~m}^{2}$

Localização Autopista del Sur, Medellin, Colômbia

Cliente Concurso Público Internacional de Anteproyecto de Parques del Río

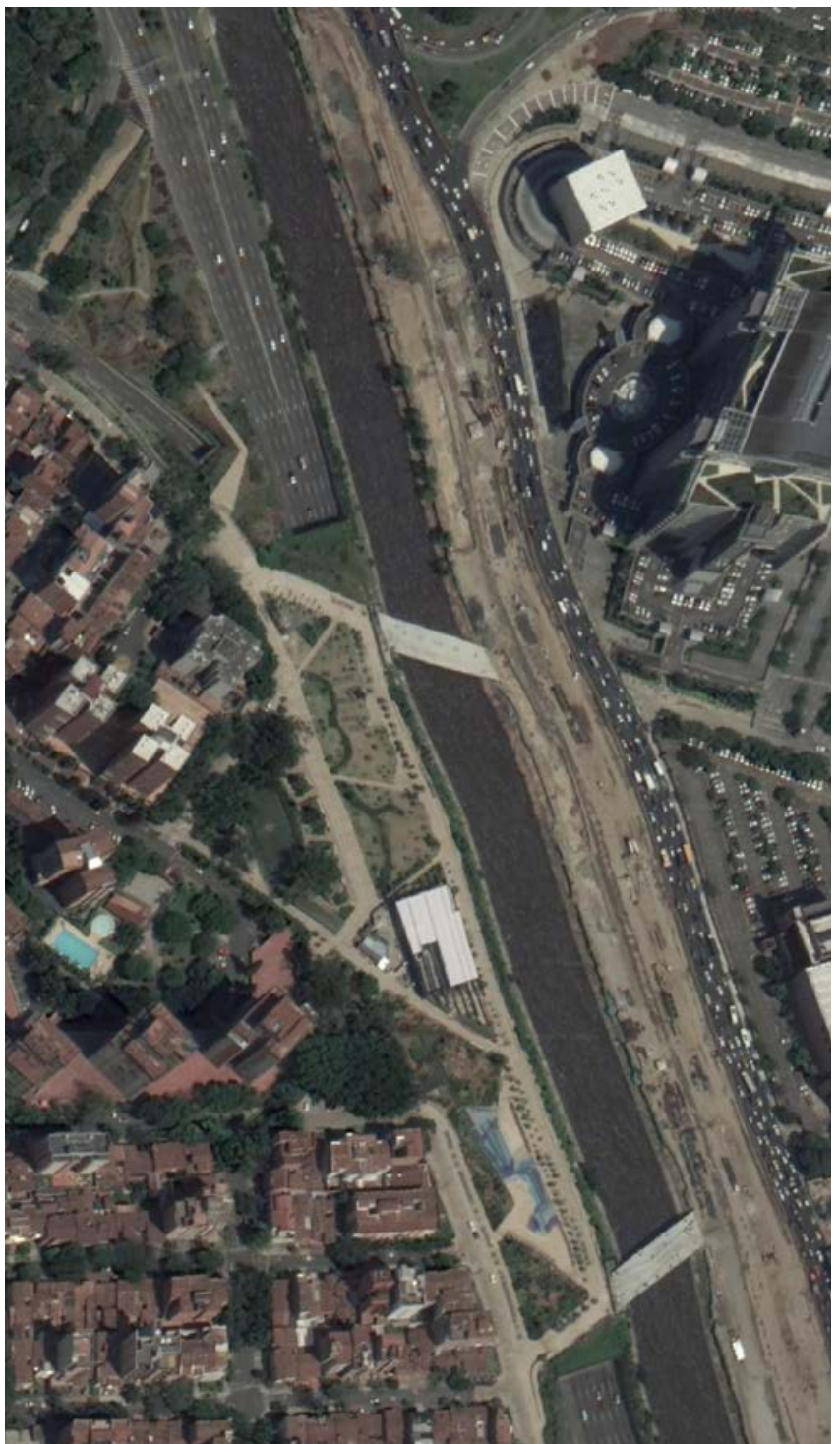

Figura 5.5.6

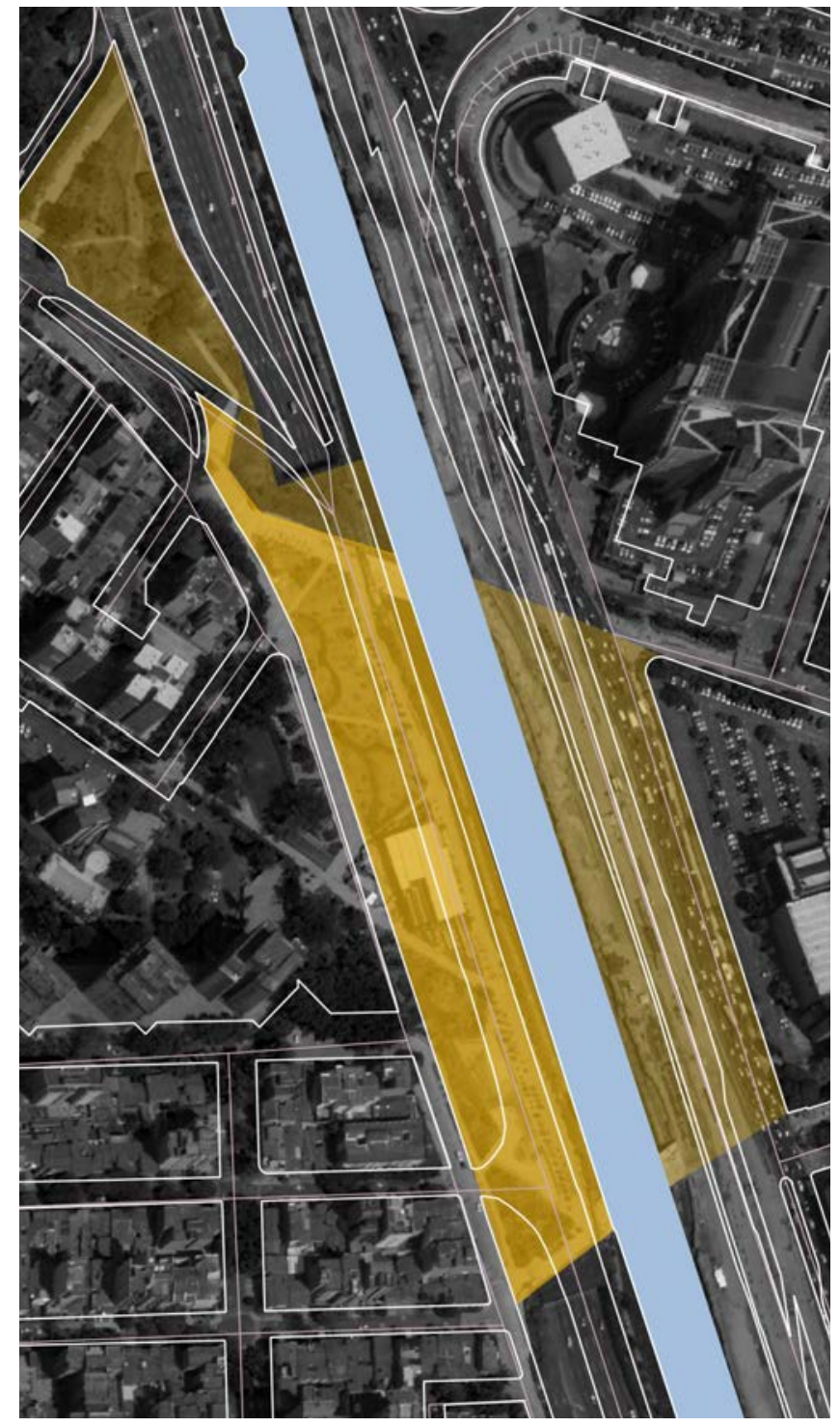

Figura $5 \cdot 5 \cdot 7$

\begin{tabular}{|c|c|}
\hline \multicolumn{2}{|l|}{ Legenda } \\
\hline & Pouca intensidade programática \\
\hline & Média intensidade programática \\
\hline & Alta intensidade programática \\
\hline & Limites \\
\hline 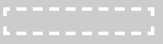 & Limites transponíveis/Volumes permeáveis \\
\hline & Edificações na área de influência do projeto \\
\hline & Hidrografia \\
\hline
\end{tabular}



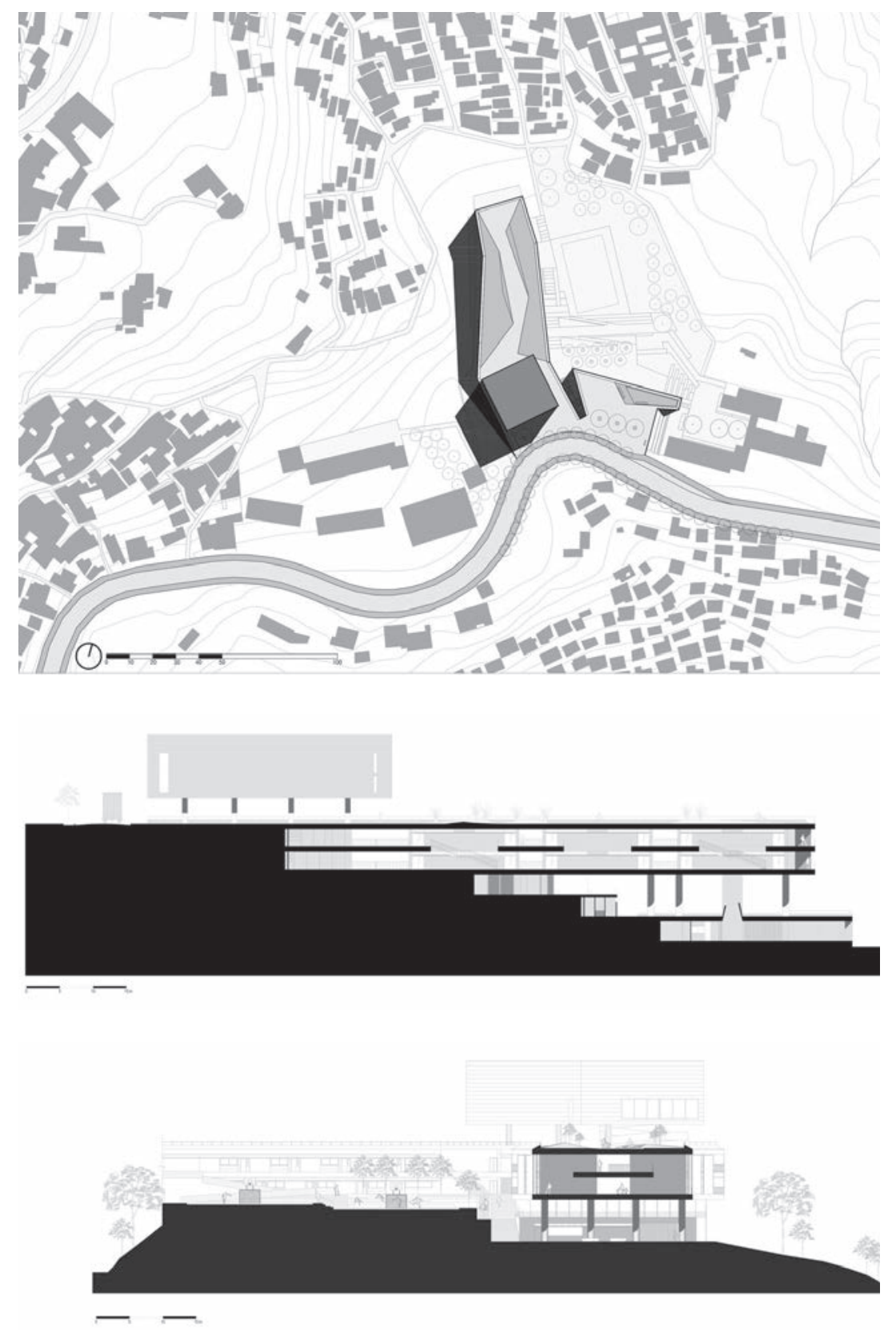

Figura 5.6.1 Situação

Figura 5.6.2

Corte 1

Figura 5.6.3

Corte 2

Figura 5.6.4

Figura 5.6.5
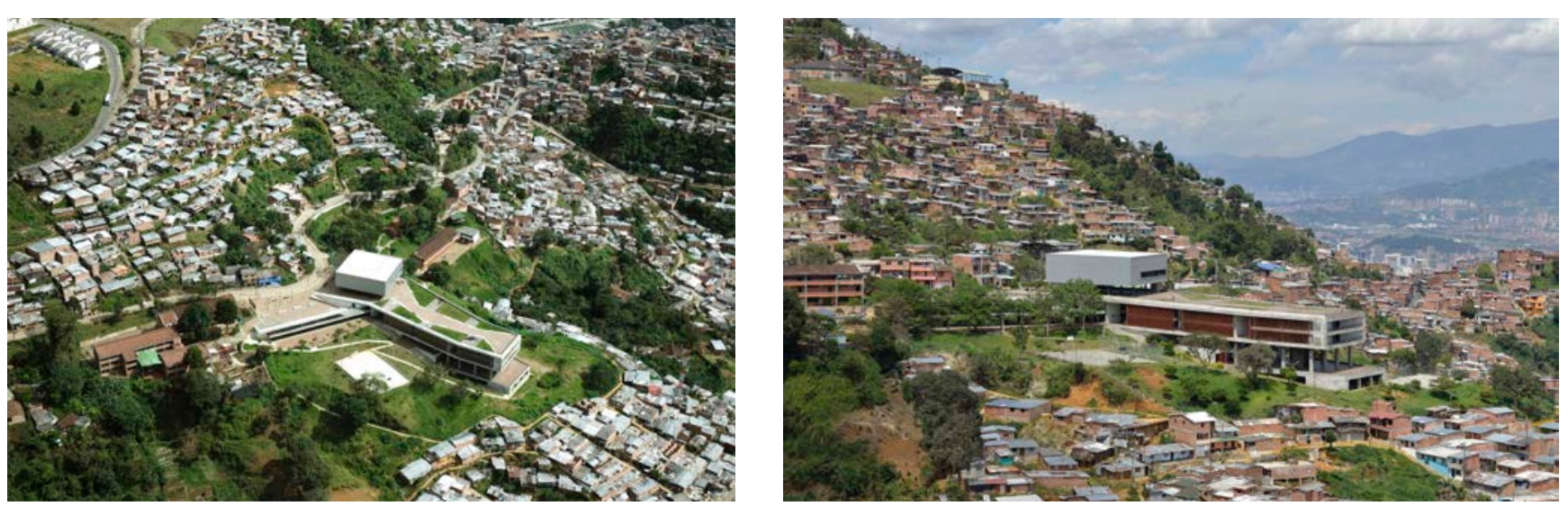


\section{Colegio Antonio Derka}

Autores Obranegra Arquitectos

Equipe Carlos Pardo, Maurício Zuloaga e Nicolás Vélez

Data do projeto 2005

Data da construção 2008
Área construída $7.500 \mathrm{~m}^{2}$

Localização Cra. 28 \#107-295, Medellín, Medellín, Antioquia, Colombia Cliente EDU - Empresa de Desarollo Urbano

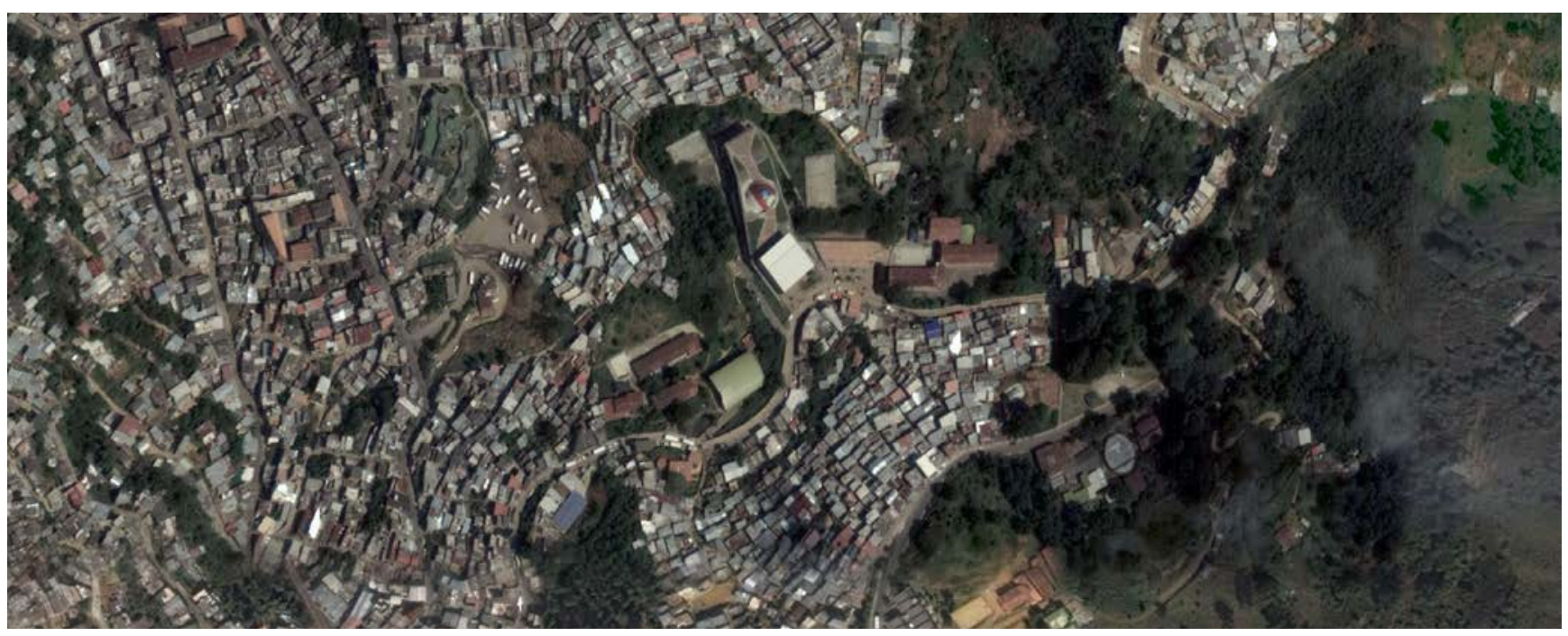

Figura 5.6.6

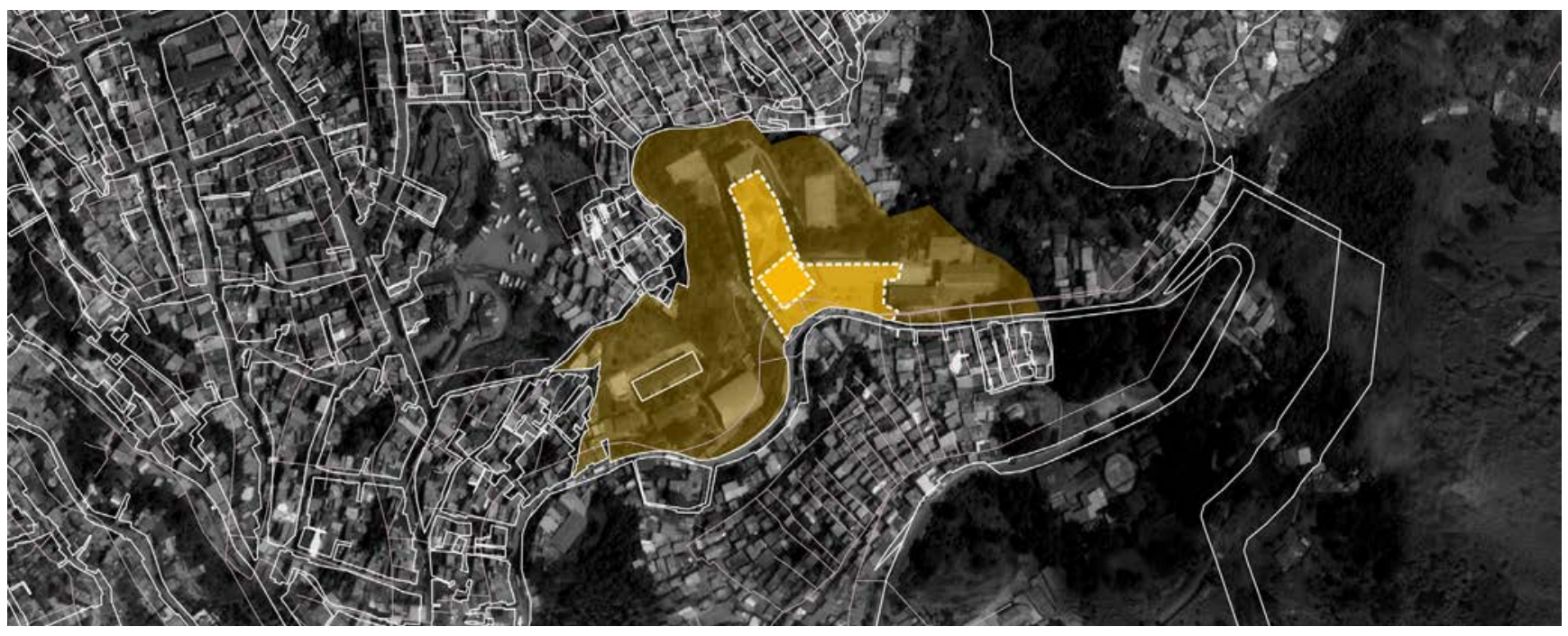

Figura 5.6.7

\begin{tabular}{|l|l|}
\multicolumn{1}{|c}{ Legenda } \\
\\
Pouca intensidade programática \\
Média intensidade programática \\
Alta intensidade programática \\
Limites \\
\hline Limites transponíveis/Volumes permeáveis \\
Edificações na área de influência do projeto \\
\hline Hidrografia
\end{tabular}




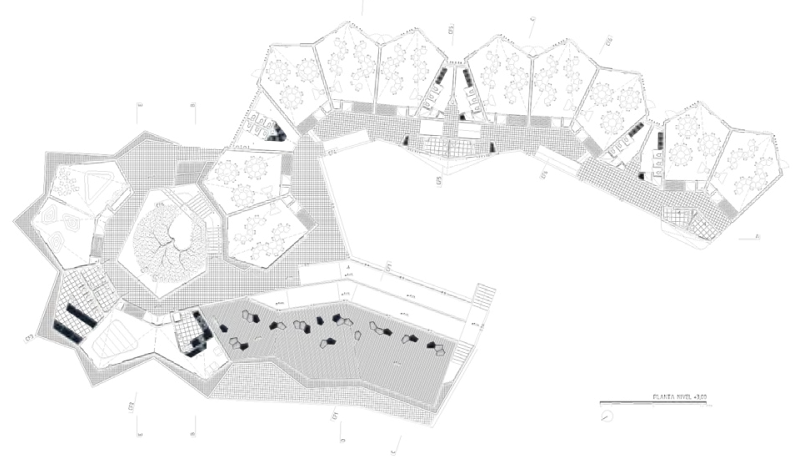

Figura 5.7.1

Planta Nível +3.0o

Figura 5.7.2

Corte Transversal C

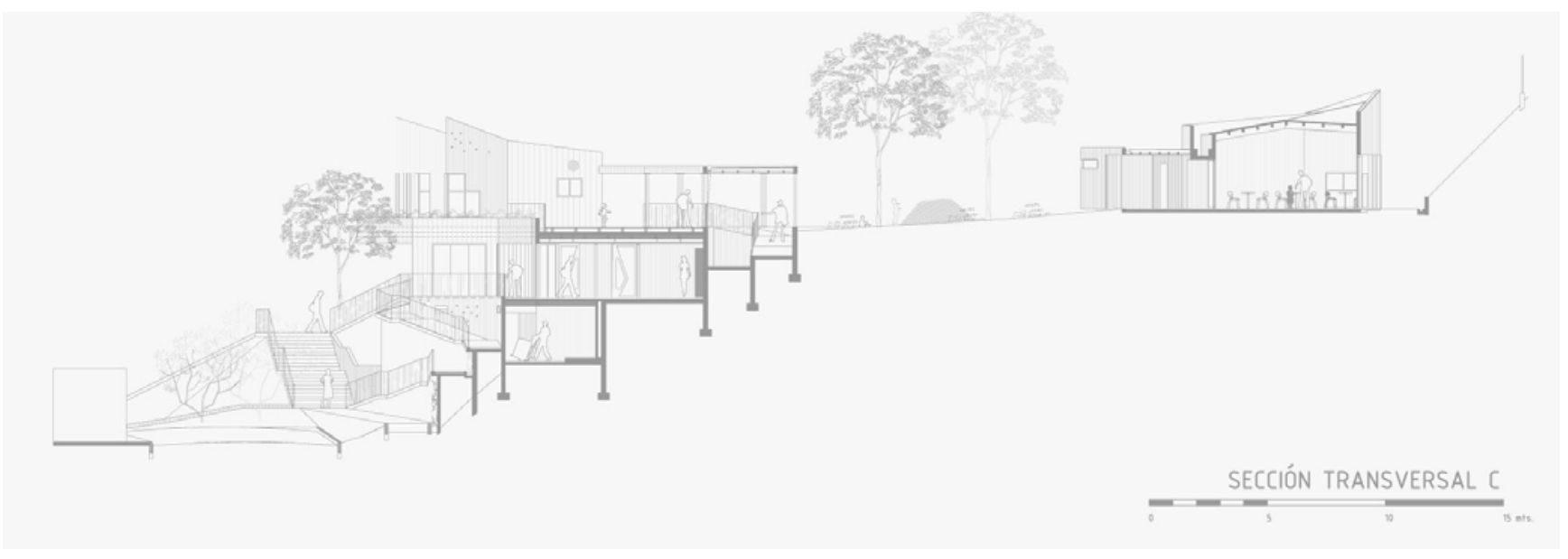

Figura 5.7.3

Figura 5.7.4
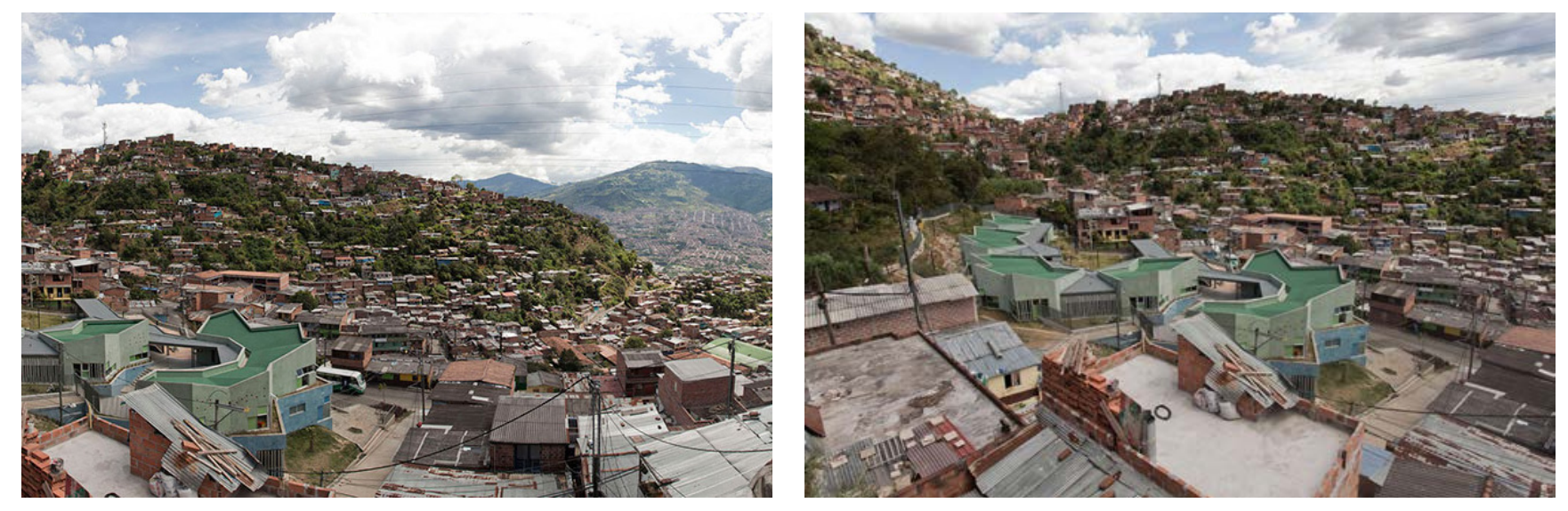


\section{Jardín Infantil Santo Domingo Savio}

Autor Plan:b Arquitectos

Equipe Felipe Mesa, Federico Mesa, Juan Pablo Giraldo, Juan Camilo Ramirez, Miguel Martos, Carlos Blanco

\section{Data da construção 2011}

Área construída $1.500 \mathrm{~m}^{2}$

Localização \#108a- a, Cra. 28e \#108a52, Medellín, Antioquia, Colômbia Cliente Alcaldía de Medellín (Programa "Buen comienzo")

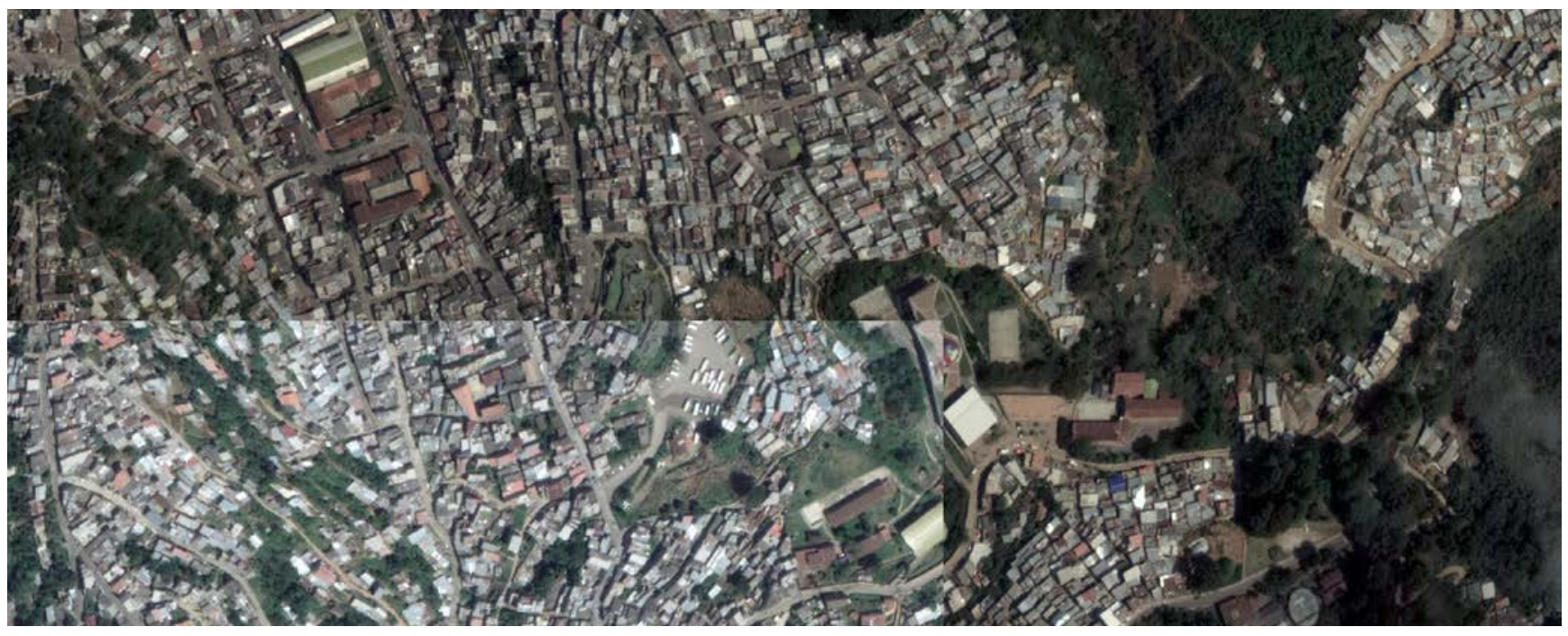

Figura $5 \cdot 7 \cdot 5$

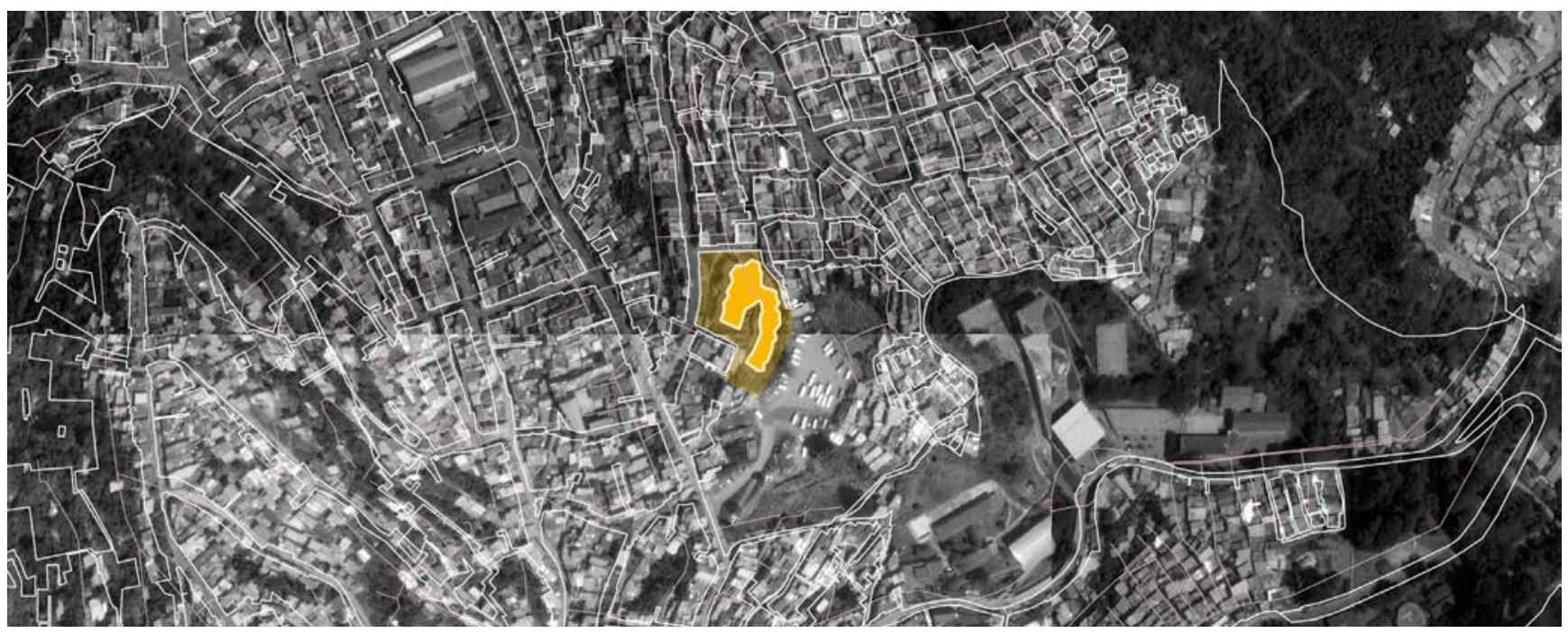

Figura 5.7.6

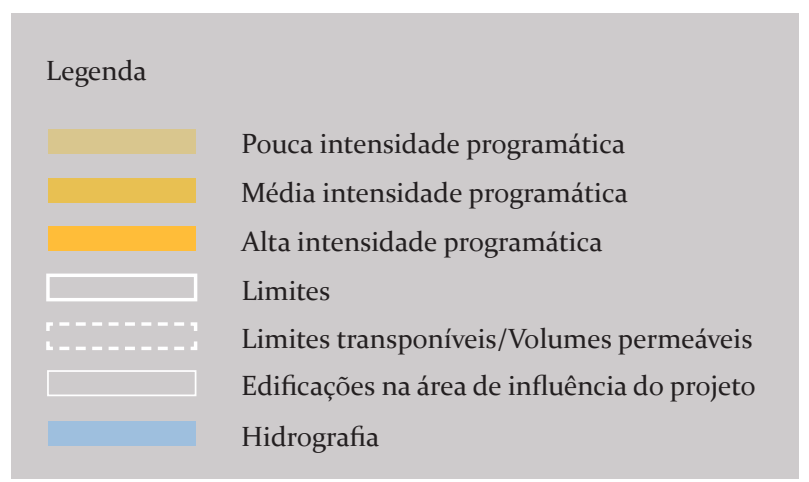

o

$100 \mathrm{~m}$ 


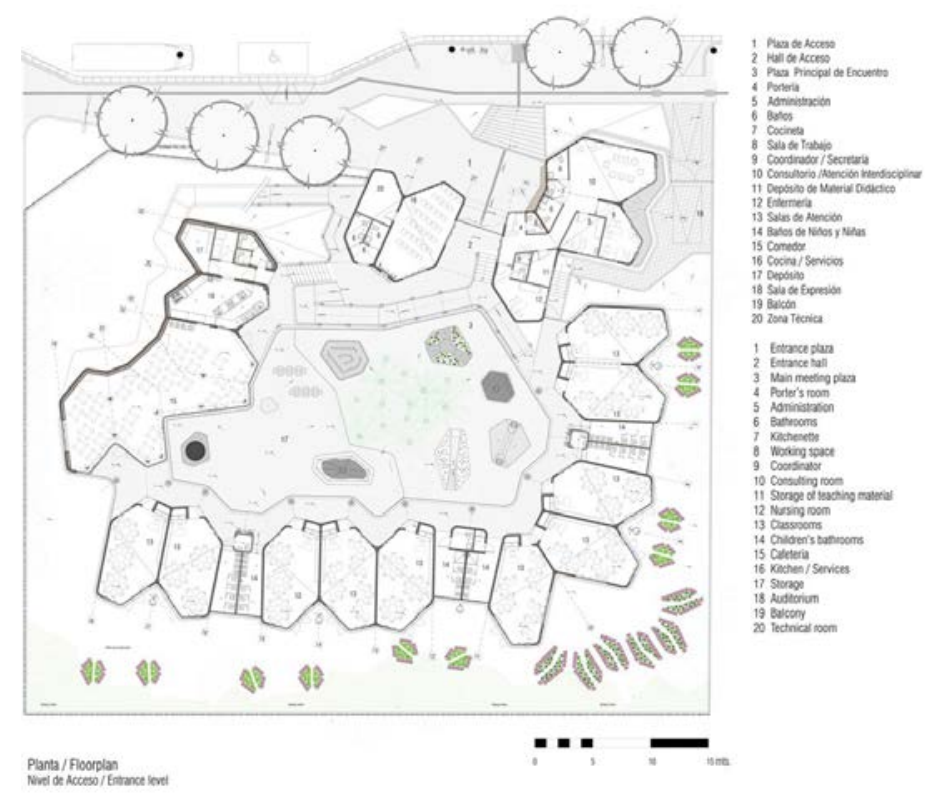

Figura 5.8.1

Planta Nível Acesso

Figura 5.8.2

Corte AA

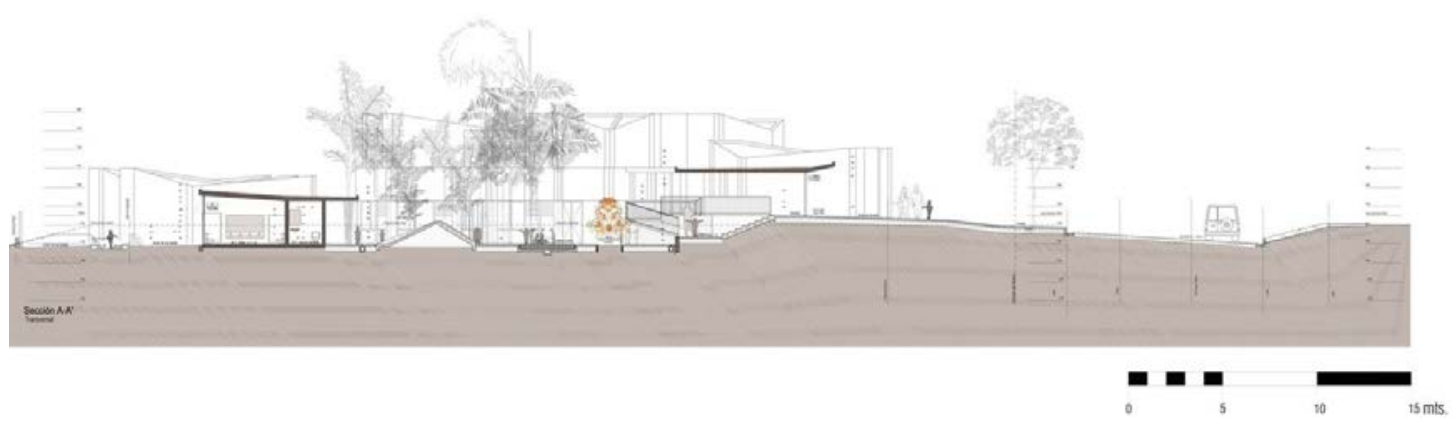

Figura 5.8.3

Imagem concurso

Figura 5.8.4
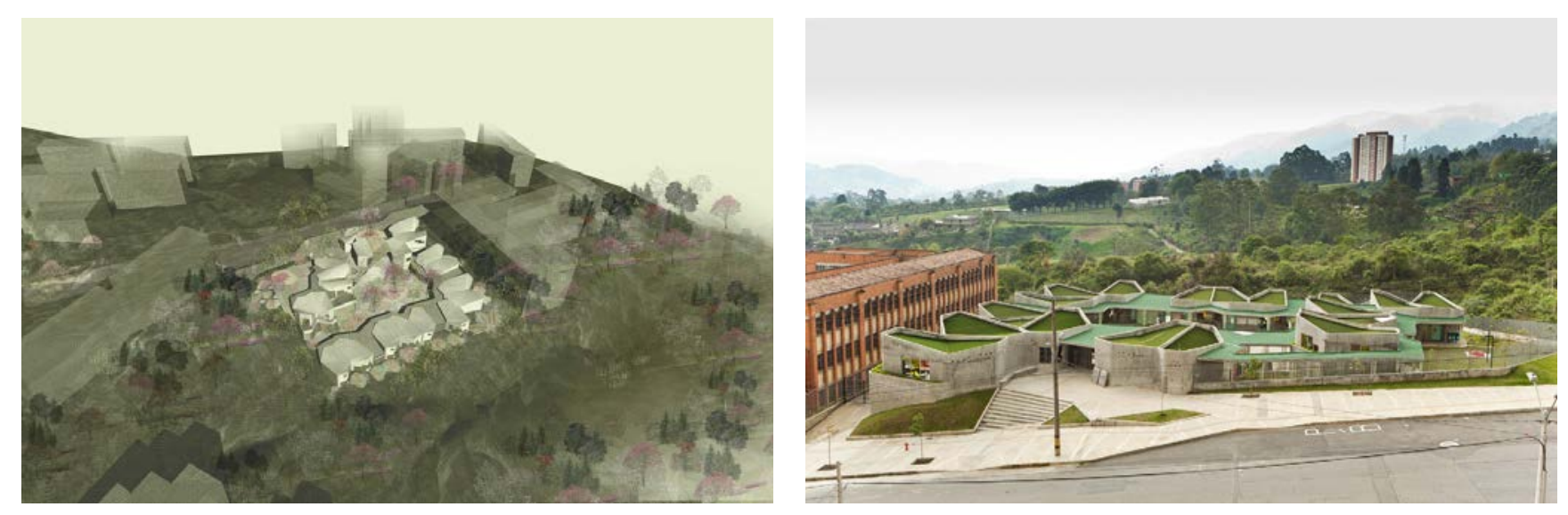


\section{Jardín Infantil Santo Antonio de Prado}

Autores Catalina Patiño, Viviana Peña e Eliana Beltrán (Ctrl G estudio de arquitectura) + Federico Mesa (Plan:b)

Equipe Juan Pablo Giraldo, Juan Camilo Ramirez, Miguel Martos, Carlos Blanco

\section{Data do projeto 2009}

Data da construção 2011

Área construída $1.500 \mathrm{~m}^{2}$

Localização Calle 3 \#1B Este-99, barrio El Limonar - Medellín, Colombia Cliente Empresa de Desarrollo Urbano y Buen Comienzo (programa para la primera infancia de la Alcaldía de Medellín)

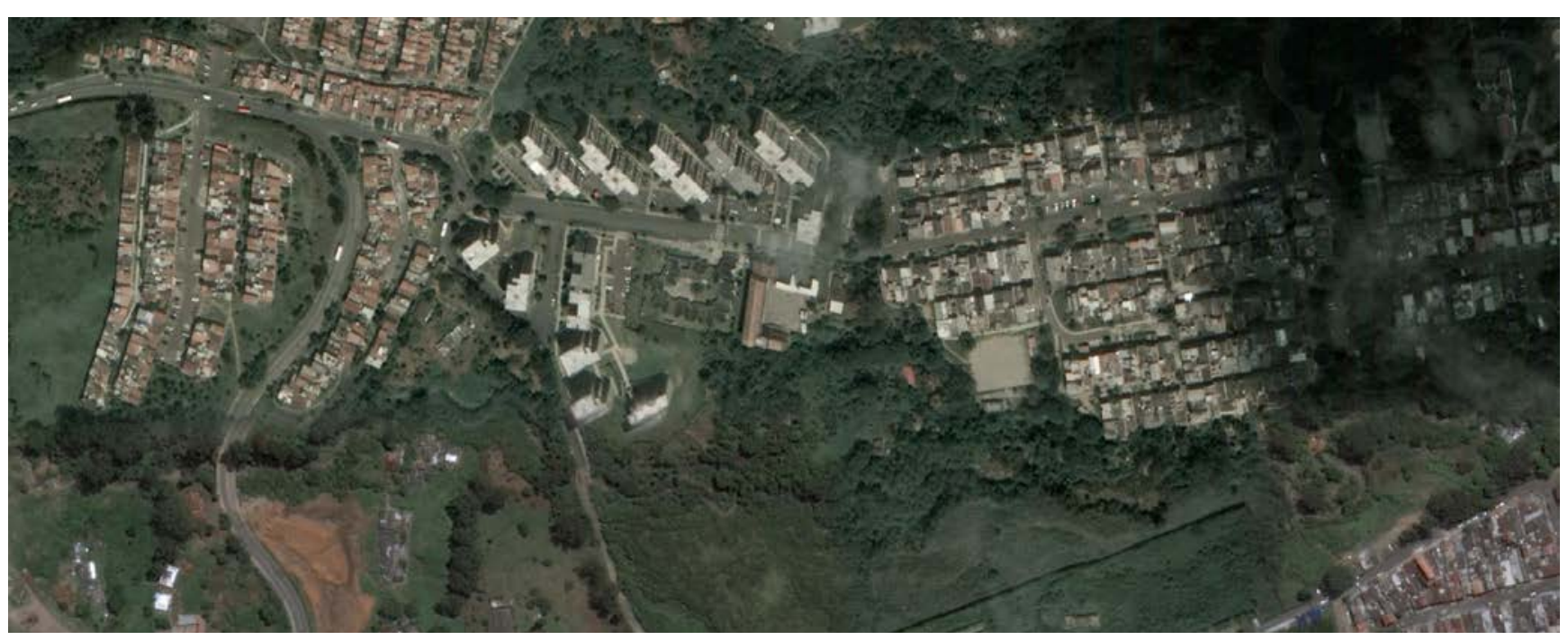

Figura 5.8.5

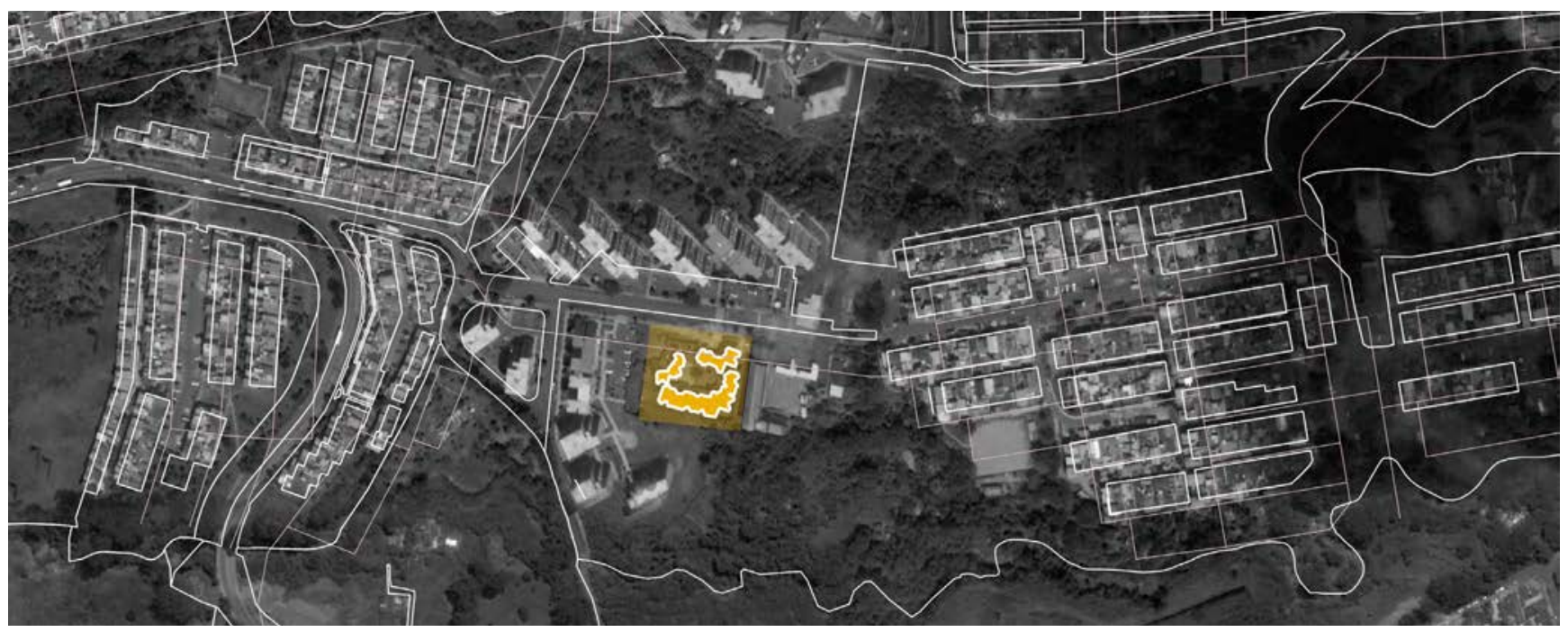

Figura 5.8.6

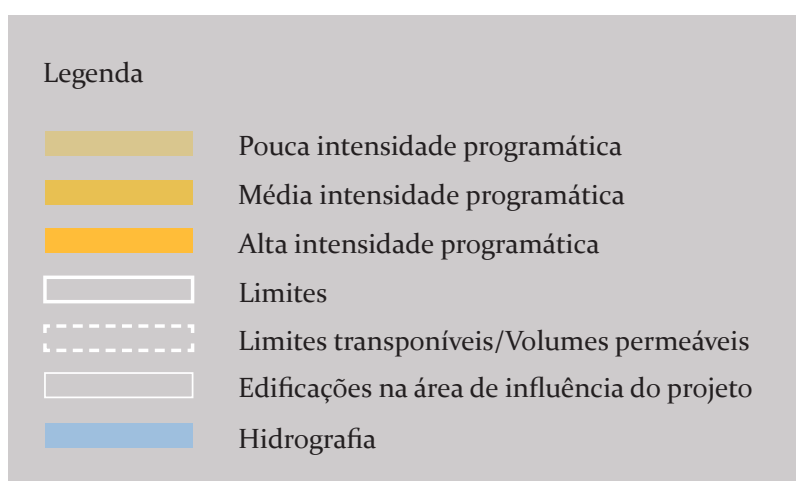

o 


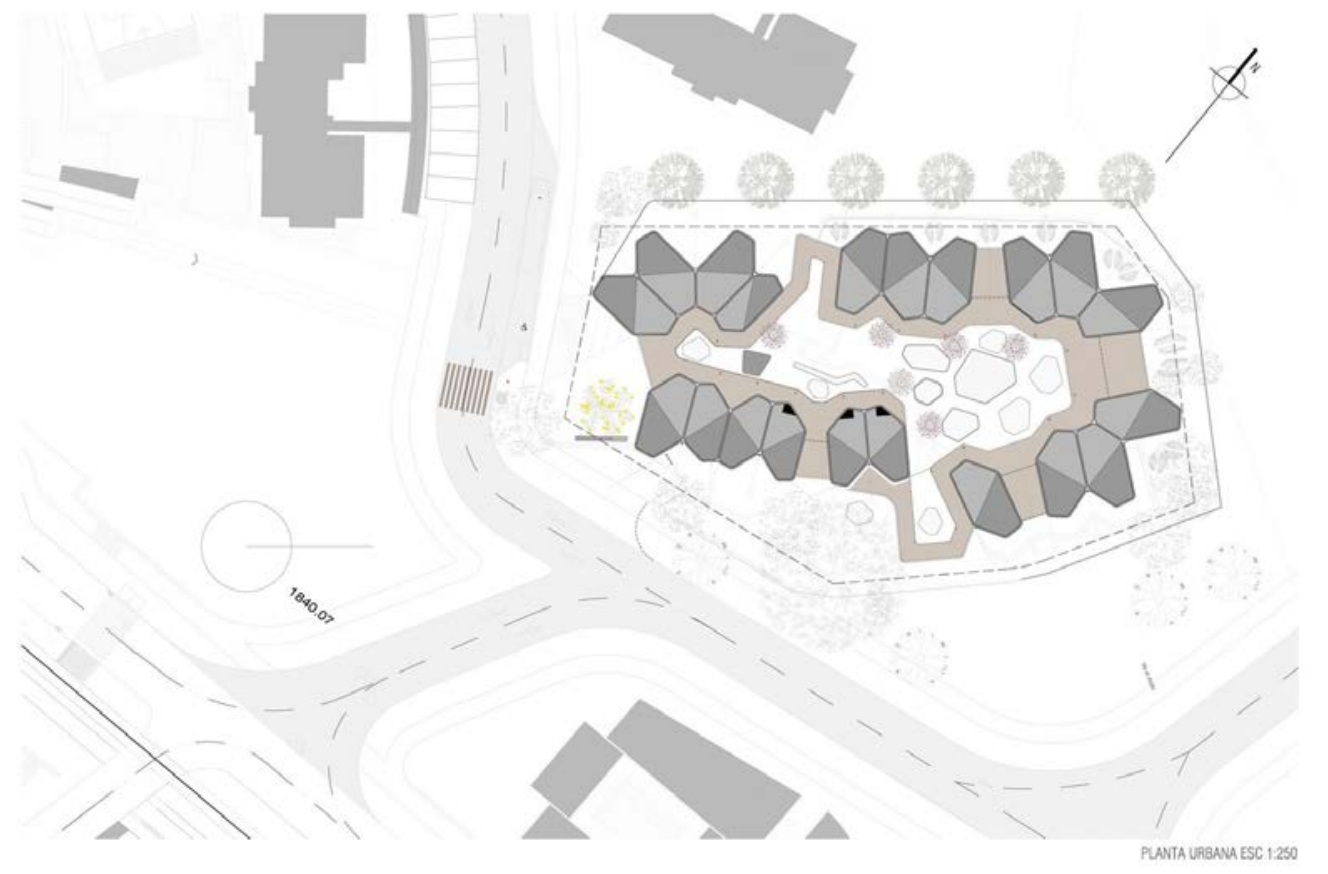

Figura 5.9.1

Localização

Figura 5.9.2

Corte transversal

Figura 5.9.3

Corte longitudinal

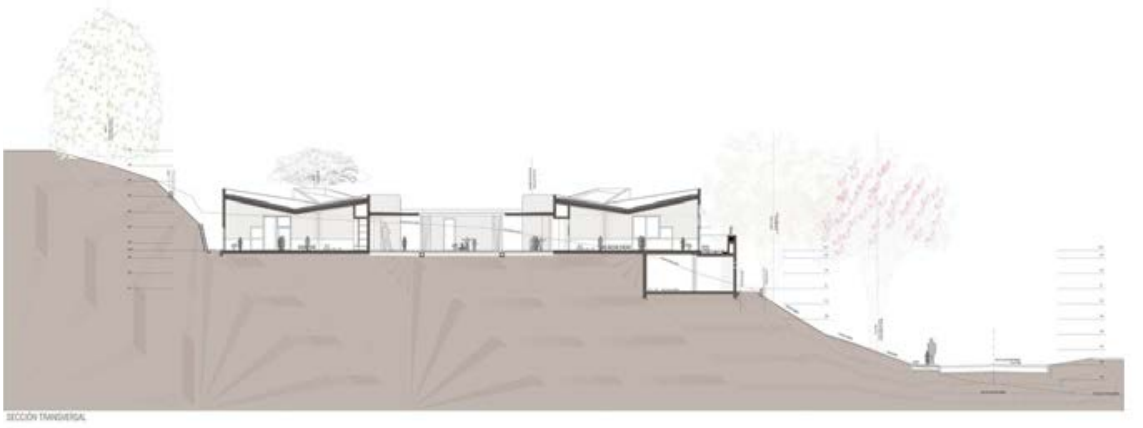

Figura 5.9.4

ext

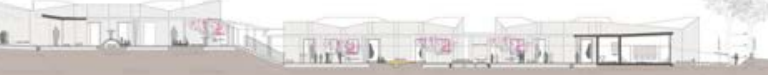

Figura 5.9.5
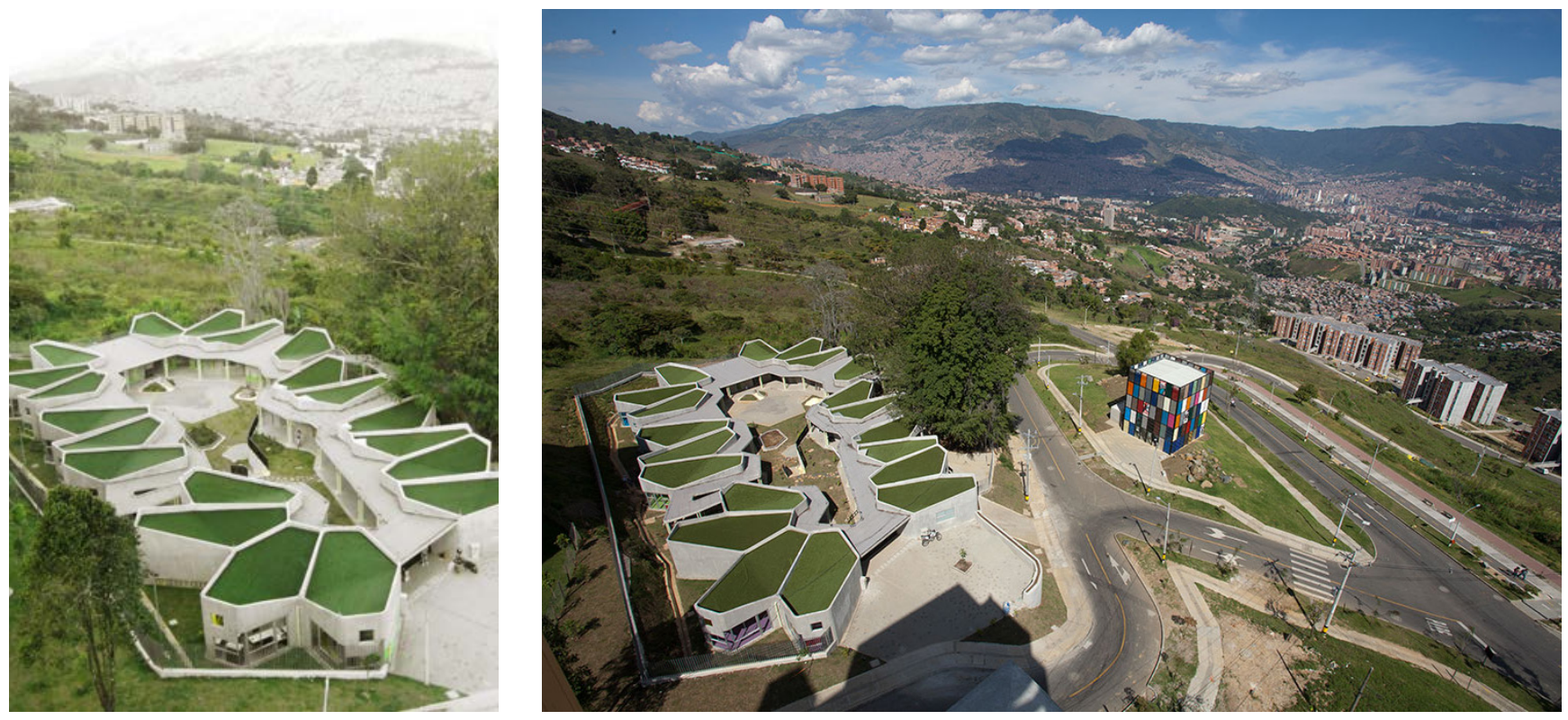


\section{Jardín Infantil Pajarito La Aurora}

Autores Federico Mesa (Plan:b arquitectos) + Catalina Patiño, Viviana Peña and Eliana Beltrán (Ctrl G)

Equipe Luisa Amaya, Juan Pablo Giraldo, Juan José Ochoa, Jorge Gómez

Interns: Clara Restrepo, Diana Rodríguez, Juliana Montoya, Carolina Vélez, Felipe Vanegas

\section{Data do projeto 2009}

Data da construção 2011

Área construída $1.500 \mathrm{~m}^{2}$

Localização Cl. 64BC \#103-93, Medellín, Antioquia, Colômbia

Cliente Empresa de Desarrollo Urbano y Buen Comienzo (programa para la primera infancia de la Alcaldía de Medellín)

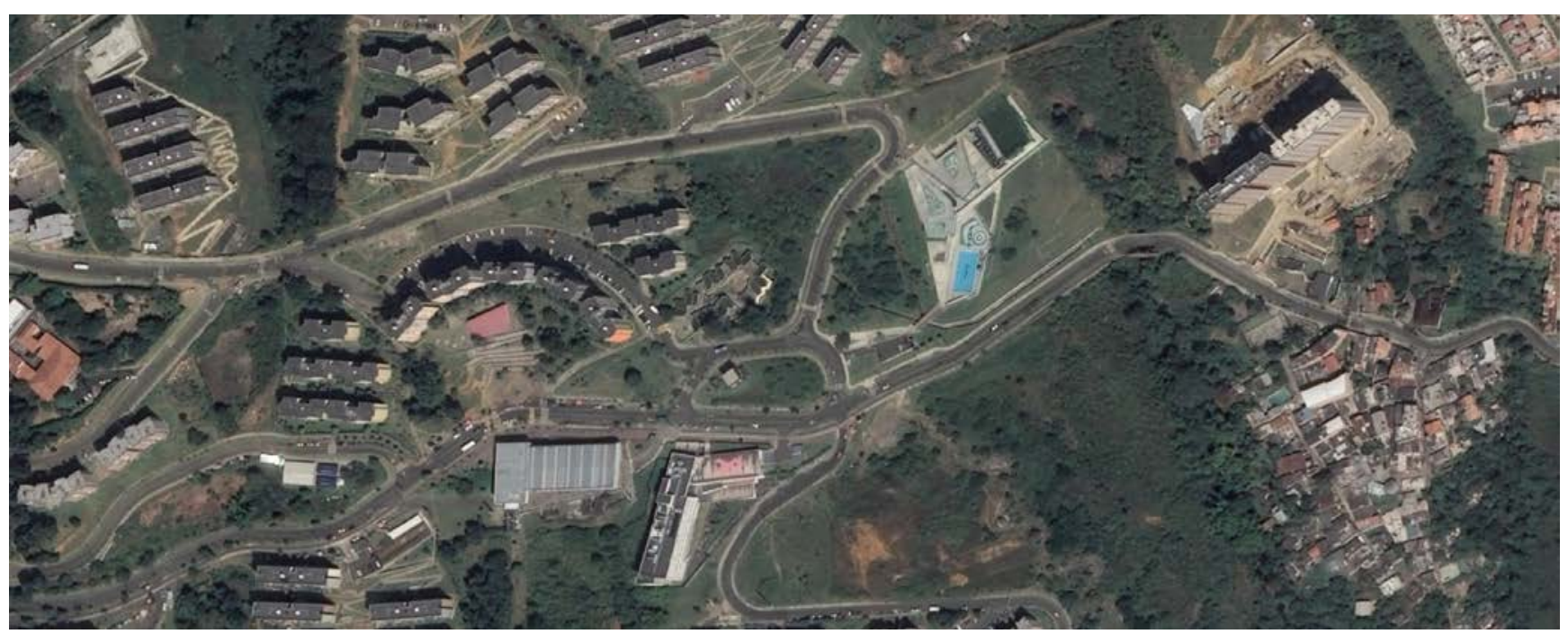

Figura 5.9.6

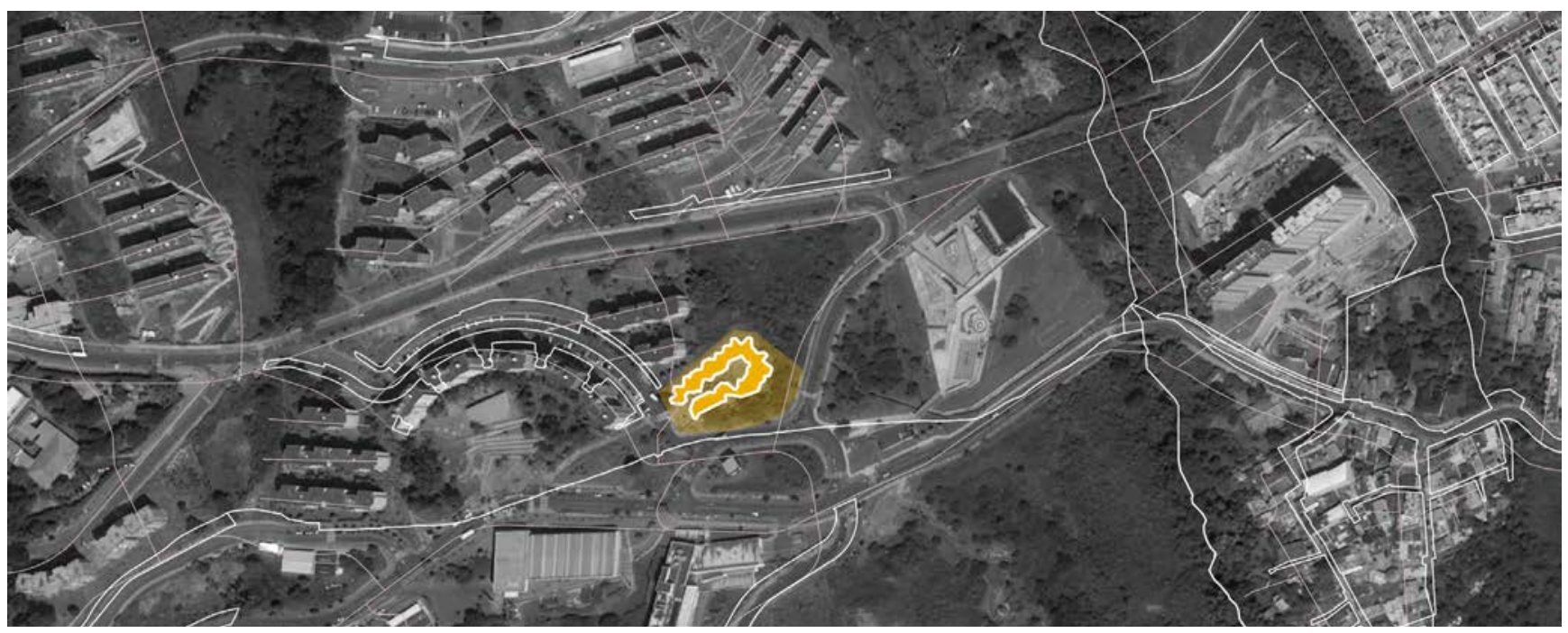

Figura 5.9.7

\begin{tabular}{|c|c|}
\hline \multicolumn{2}{|l|}{ Legenda } \\
\hline & Pouca intensidade programática \\
\hline & Média intensidade programática \\
\hline & Alta intensidade programática \\
\hline & Limites \\
\hline 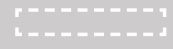 & Limites transponíveis/Volumes permeáveis \\
\hline & Edificações na área de influência do projeto \\
\hline & Hidrografia \\
\hline
\end{tabular}




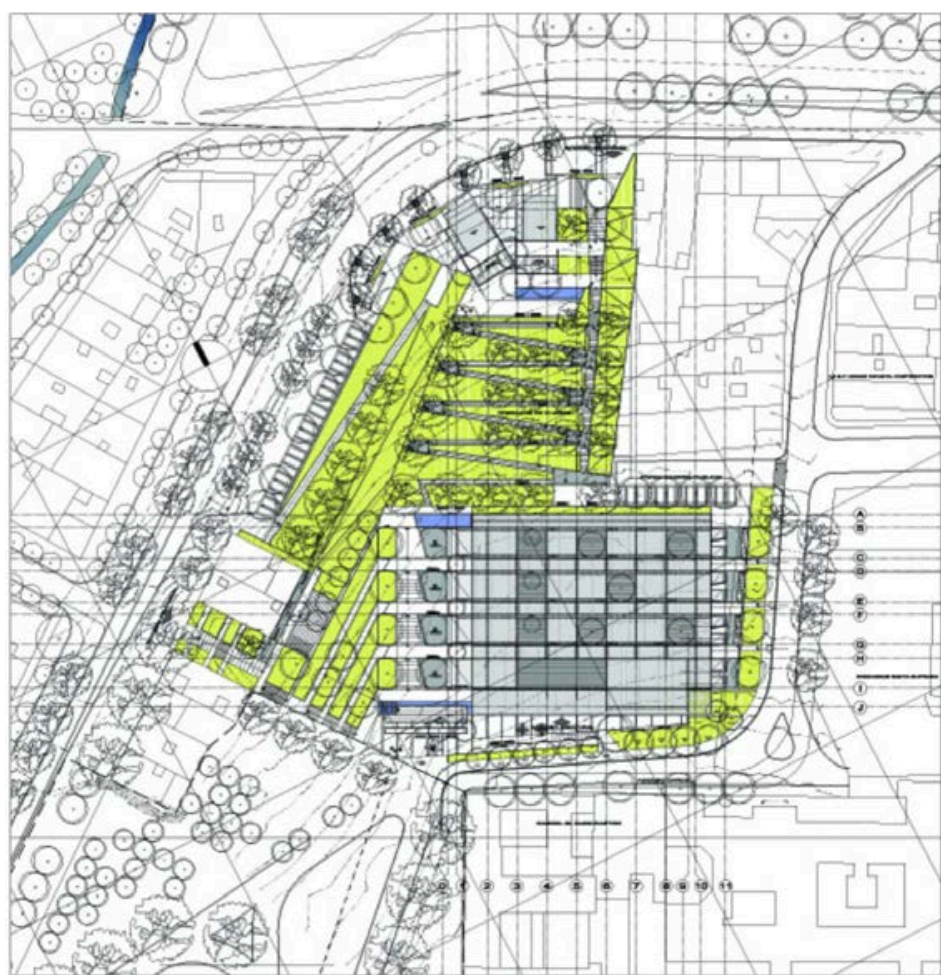

Figura 5.10.1

Localização

Figura 5.10.2

Corte Transversal

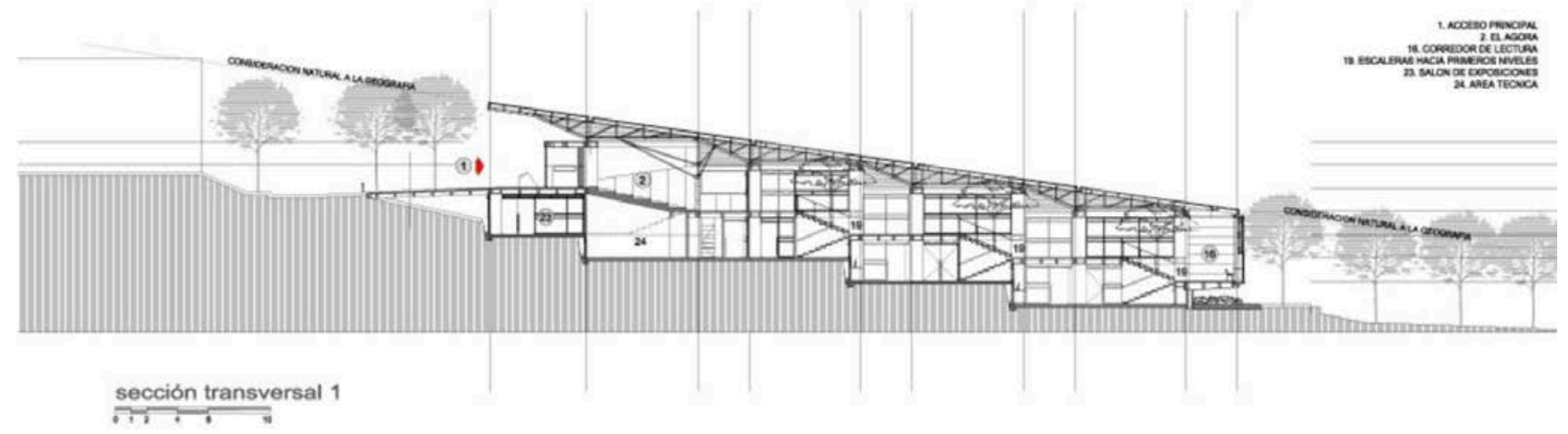

Figura 5.10.3

Figura 5.10.4
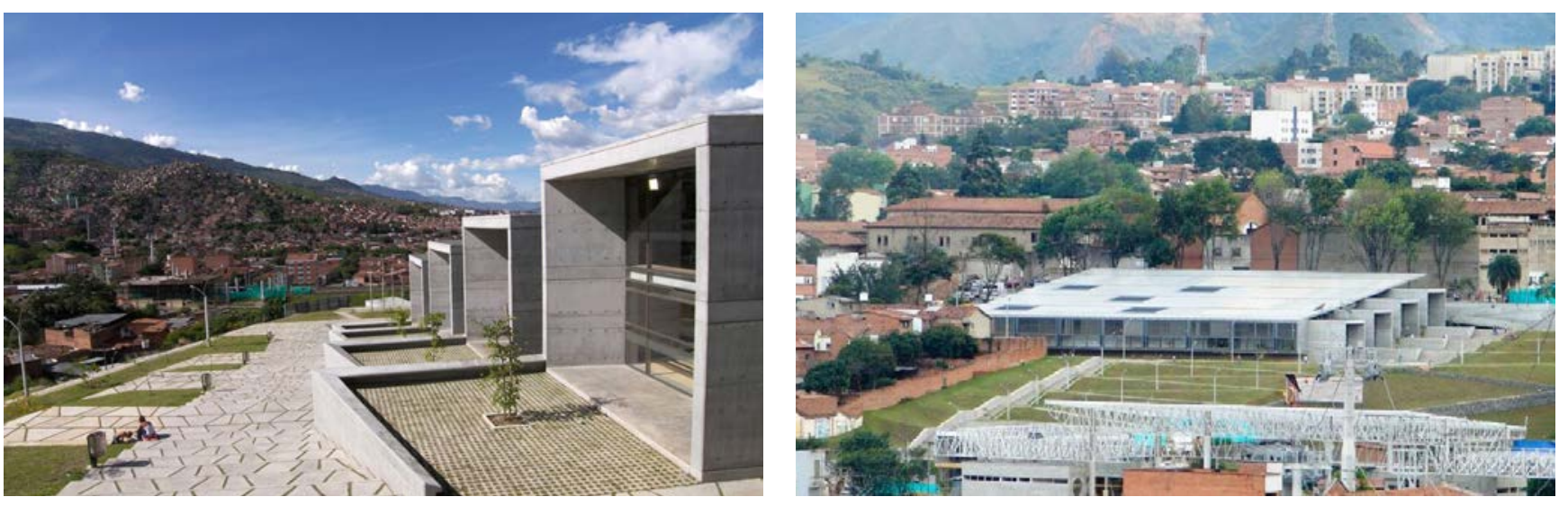


\section{Parque Biblioteca San Javier}

Autores Javier Vera

Equipe Adriana Agudelo, Alejandro Velásquez e Ana Isabel Valencia

Data do projeto 2005

Data da construção 2008
Área do lote $15.500 \mathrm{~m}^{2}$

Localização Cl. 42C \#95-50, Medellín, Antioquia, Colômbia / Comuna San Javier, Occidente de Medellín

Cliente Concurso Público - EDU (Empresa de Desarrollo Urbano - Alcaldía de Medellín)

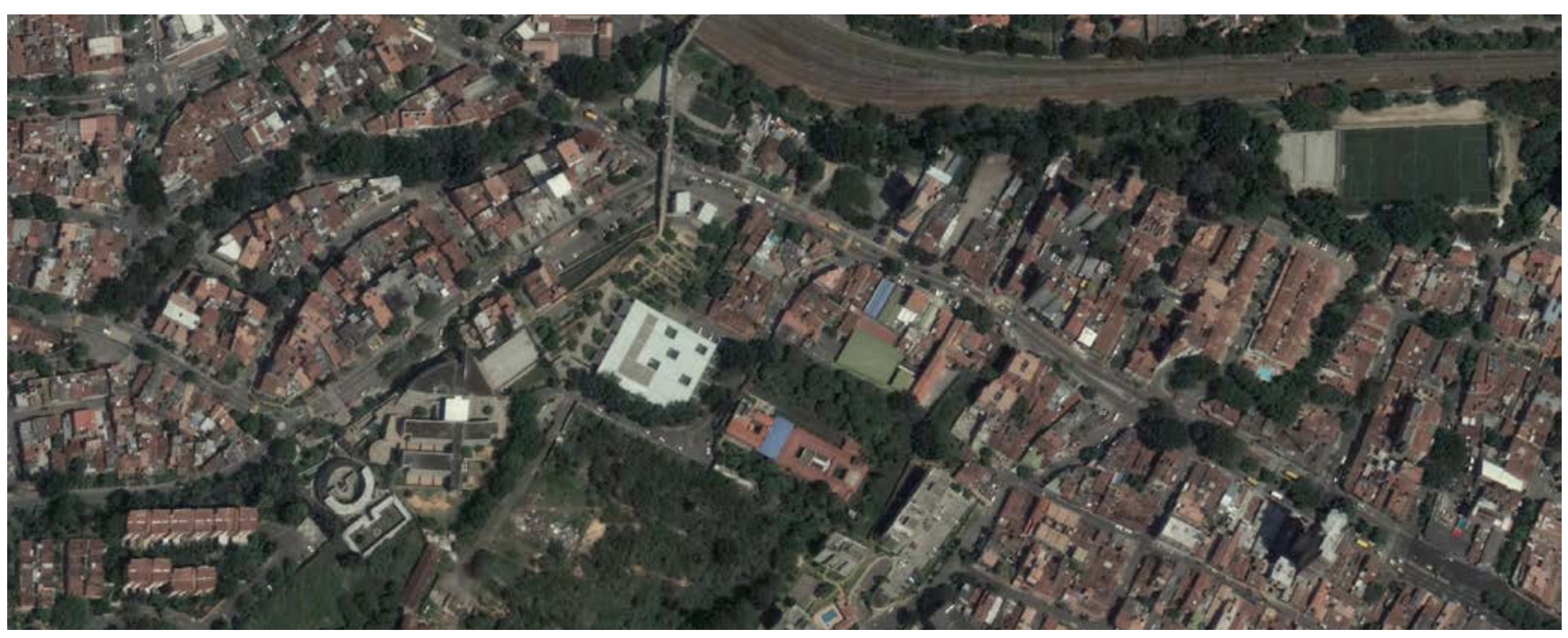

Figura 5.10.5

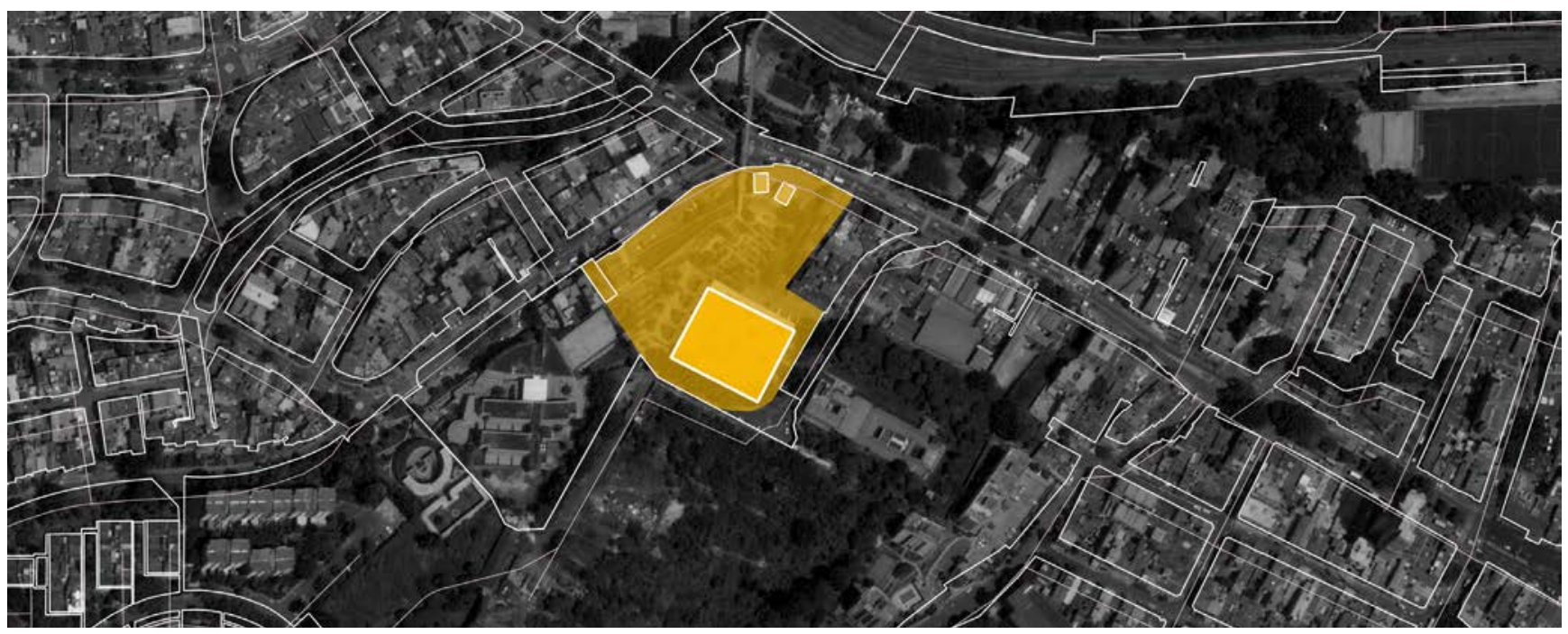

Figura 5.10.6

\begin{tabular}{|c|c|}
\hline \multicolumn{2}{|l|}{ Legenda } \\
\hline & Pouca intensidade programática \\
\hline & Média intensidade programática \\
\hline & Alta intensidade programática \\
\hline & Limites \\
\hline 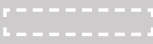 & Limites transponíveis/Volumes permeáveis \\
\hline & Edificações na área de influência do projeto \\
\hline & Hidrografia \\
\hline
\end{tabular}




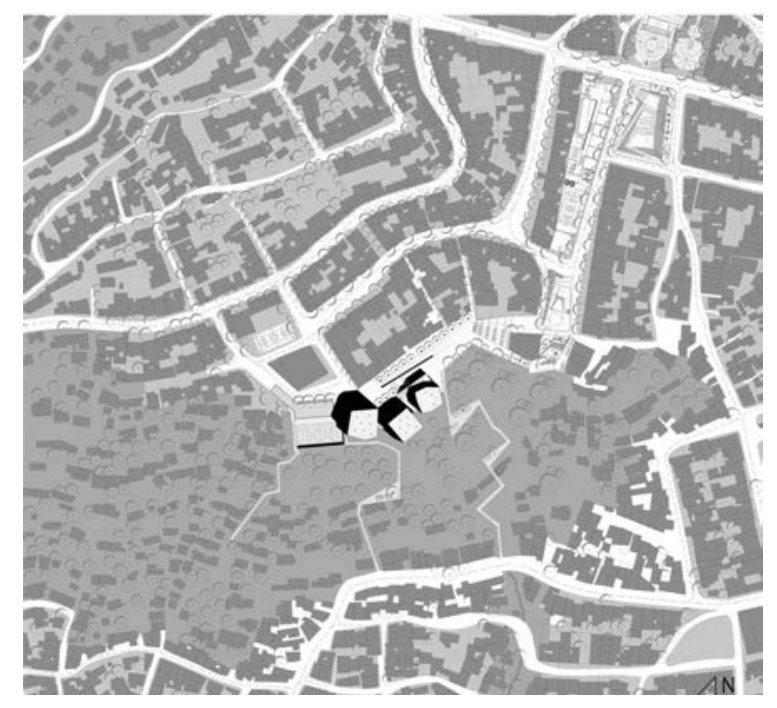

Figura 5.11.1

Localização

Figura 5.11.2

Corte 1

Figura 5.11.3

Corte BB
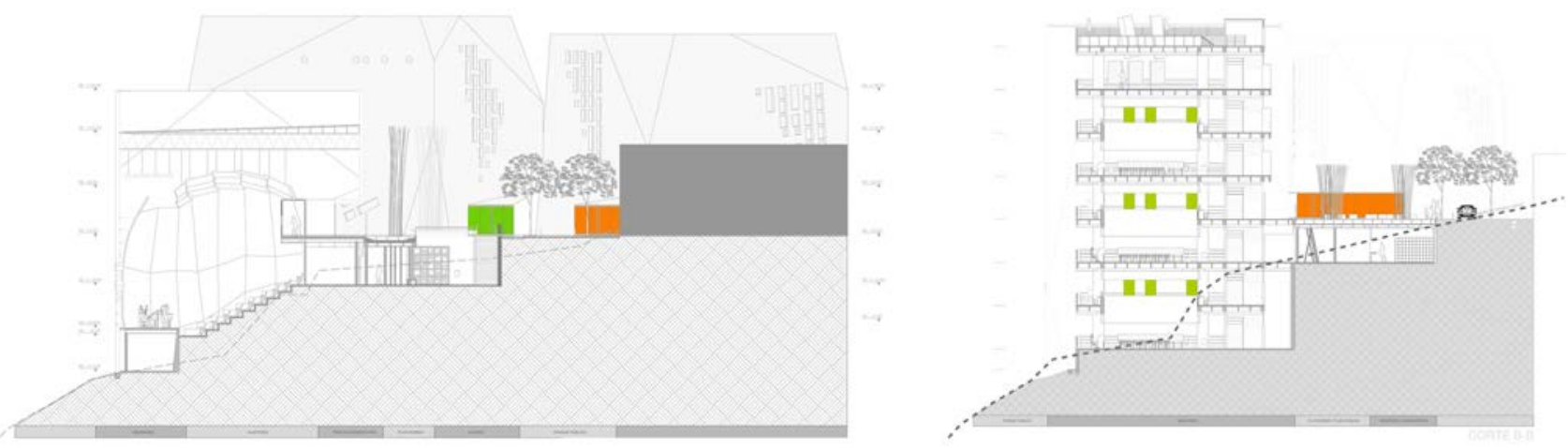

Figura 5.11.4

Figura 5.11.5
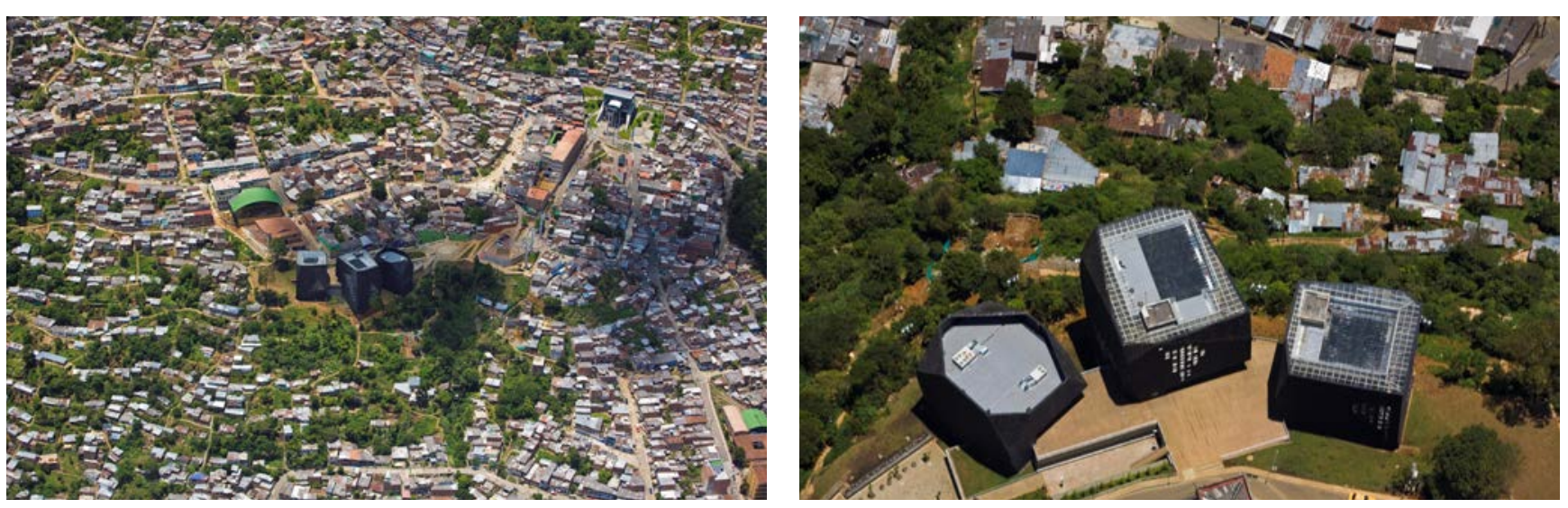


\section{Parque Biblioteca España}

Autor Giancarlo Mazzanti

Equipe Andrés Sarmiento, Carlos Bueno, Jairo Ovalle, Julián Moreno

Data da construção 2007
Área construída $5.500 \mathrm{~m}^{2}$

Localização Cra 33B \# 107A-100, Medellín, Antioquia, Colombia

Cliente Concurso Público - Agencia Española de Cooperación Internacional. Embajada de España

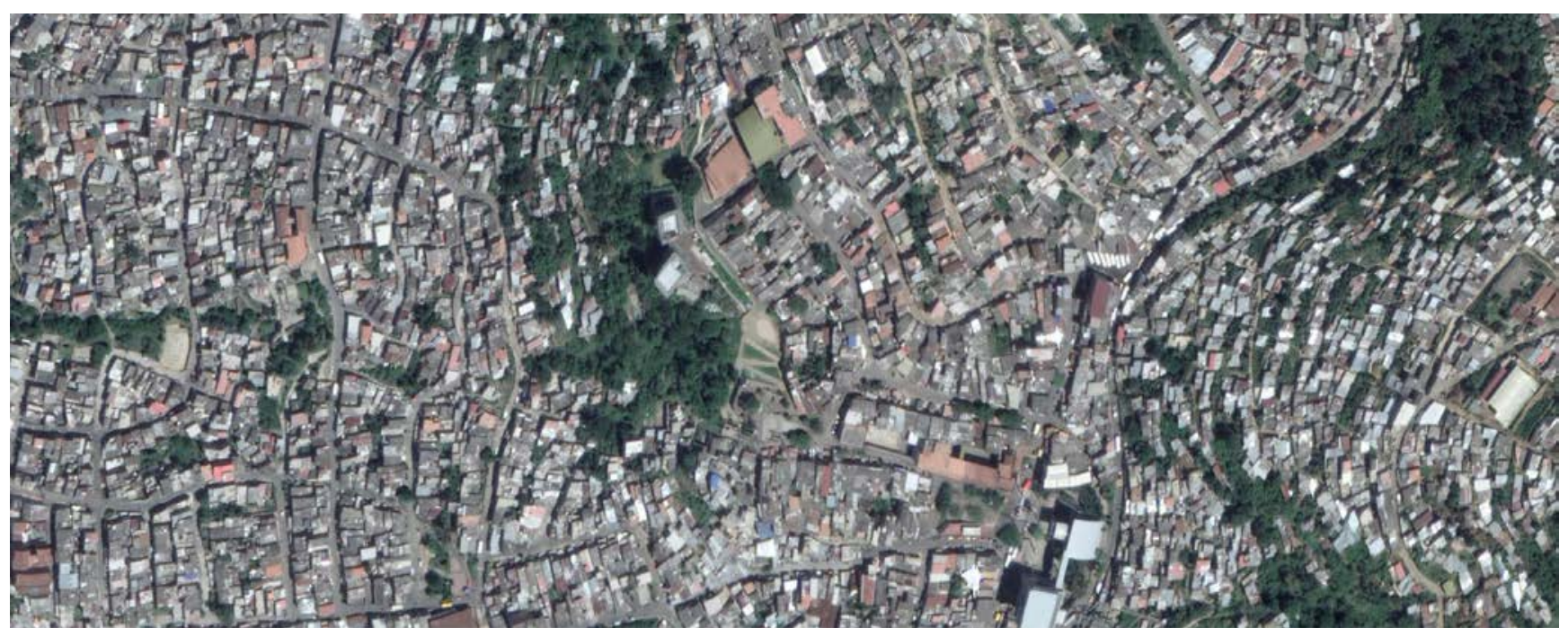

Figura 5.11.6

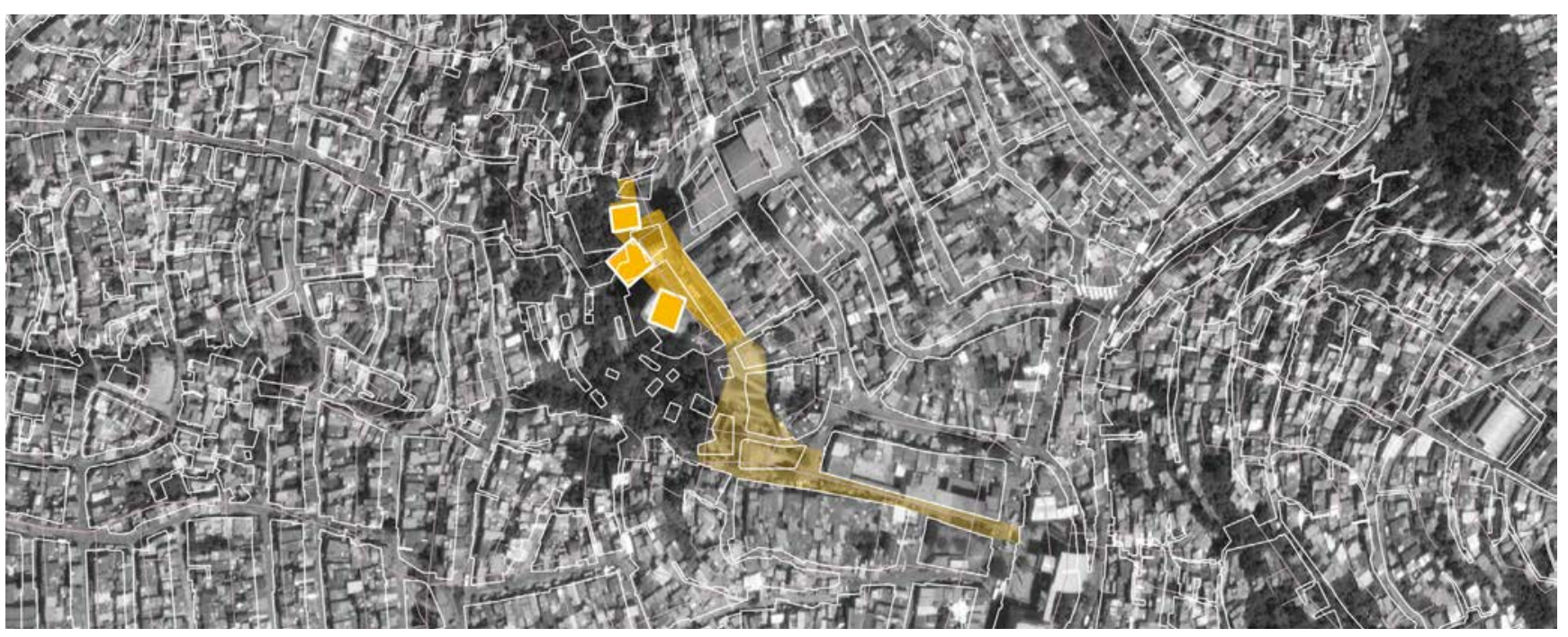

Figura 5.11.7

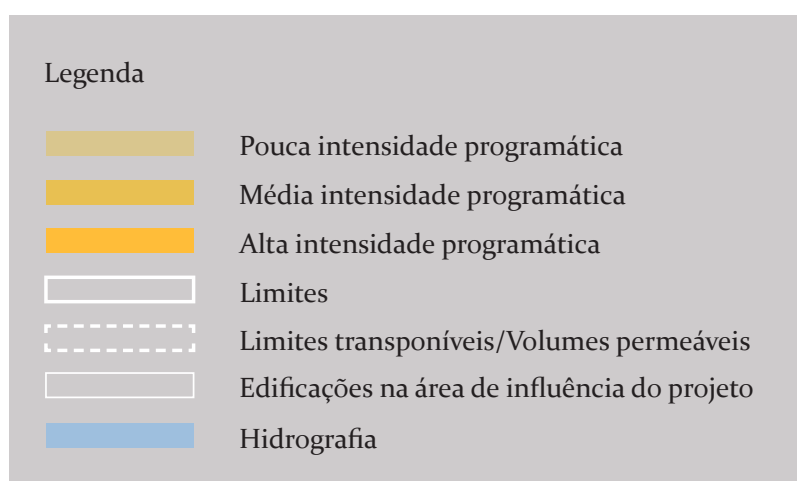

o

$100 \mathrm{~m}$ 


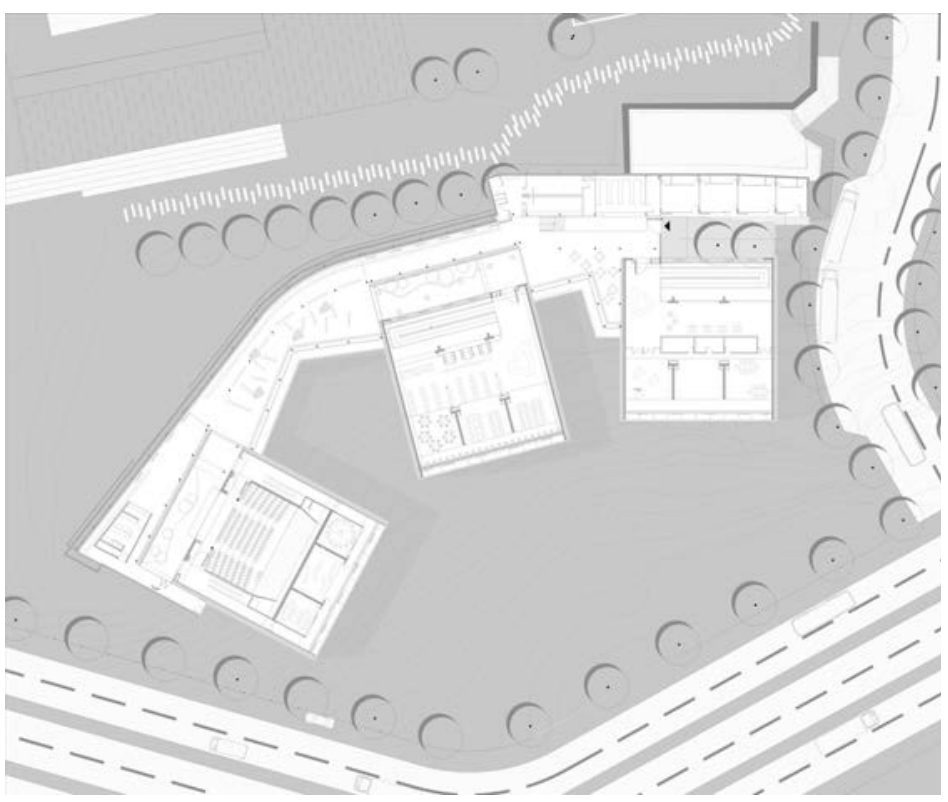

Figura 5.12.1

Planta 1

Figura 5.12.2

Corte Biblioteca

\section{Figura 5.12.3}

Corte Longitudinal
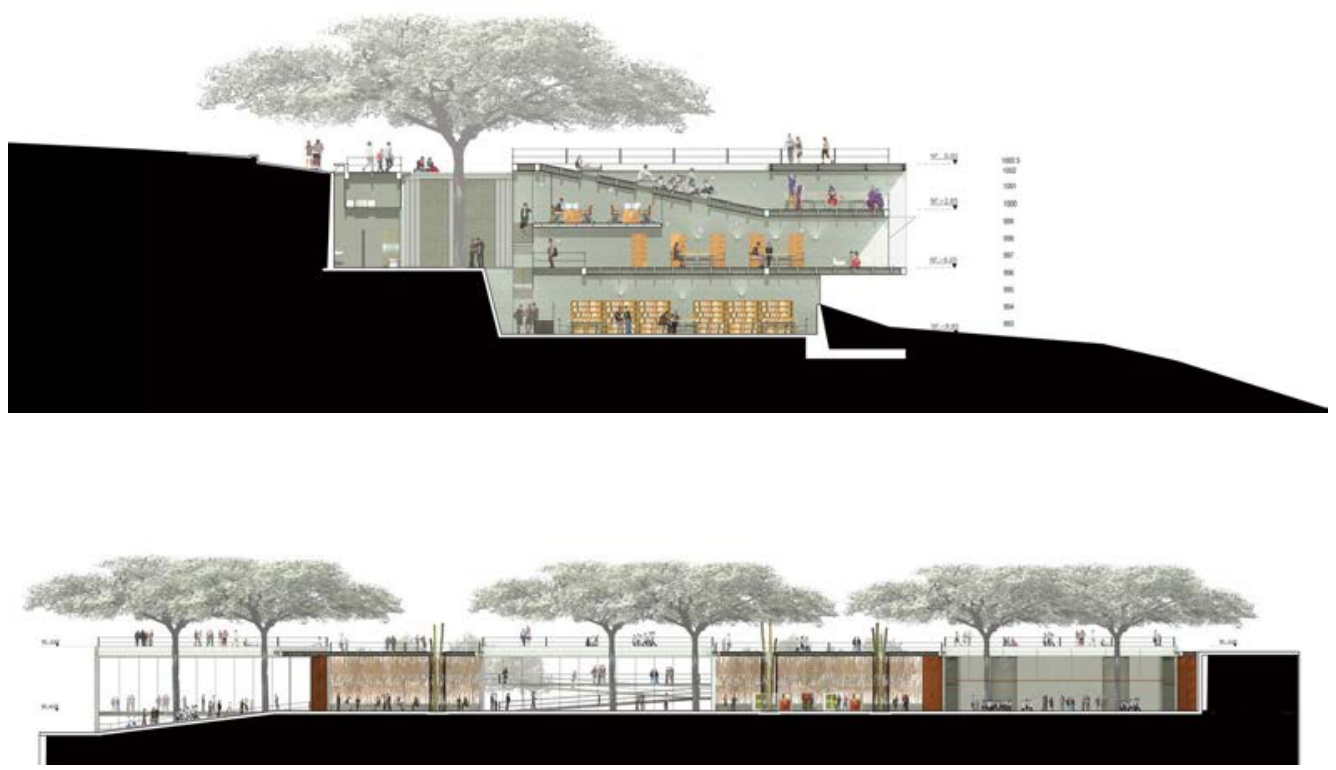

Figura 5.12.4

Figura 5.12.5
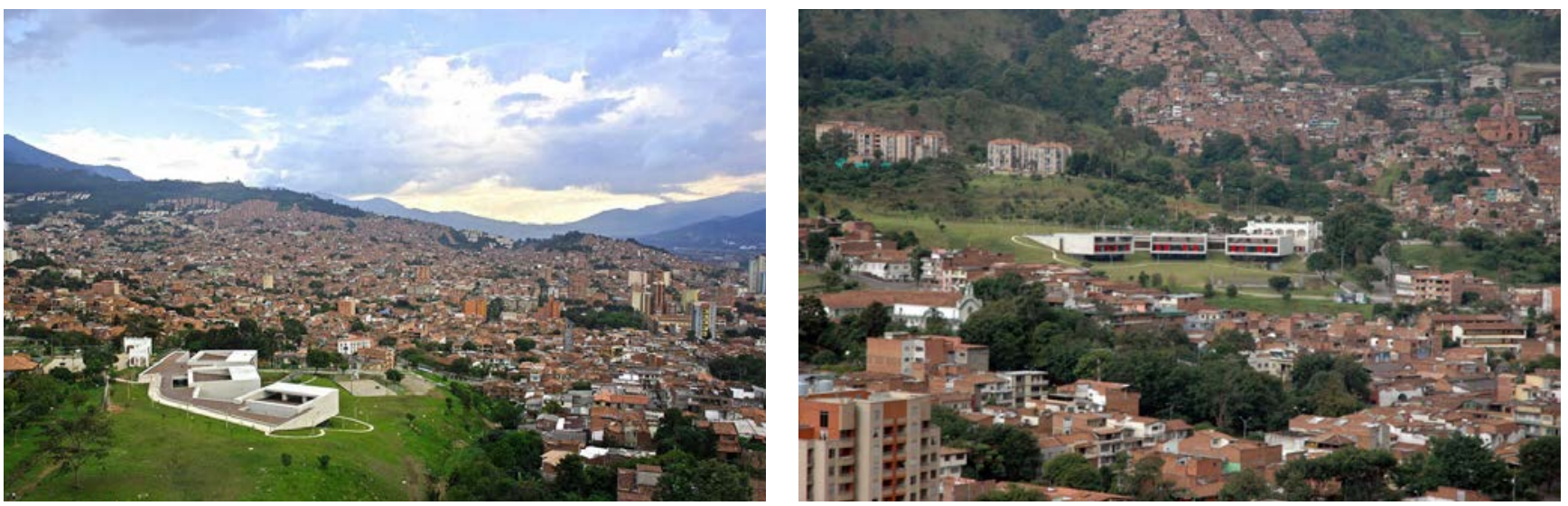


\section{Parque Biblioteca Léon de Greiff}

Autor Giancarlo Mazzanti

Equipe Andrés Sarmiento, Juan Manuel Gil, Freddy Pantoja,

Camilo Mora, Pedro Saa, Alejandro piña, Iván Ucros, Gustavo

Vásquez

Data do projeto 2006

Data da construção 2007
Área construída $37 \cdot 546,72 \mathrm{~m}^{2}$

Localização Cl 59A \#3630, Medellín, Antioquia, Colômbia

Cliente Concurso Público - EDU (Empresa de Desarrollo Urbano) - Alcaldía de Medellín

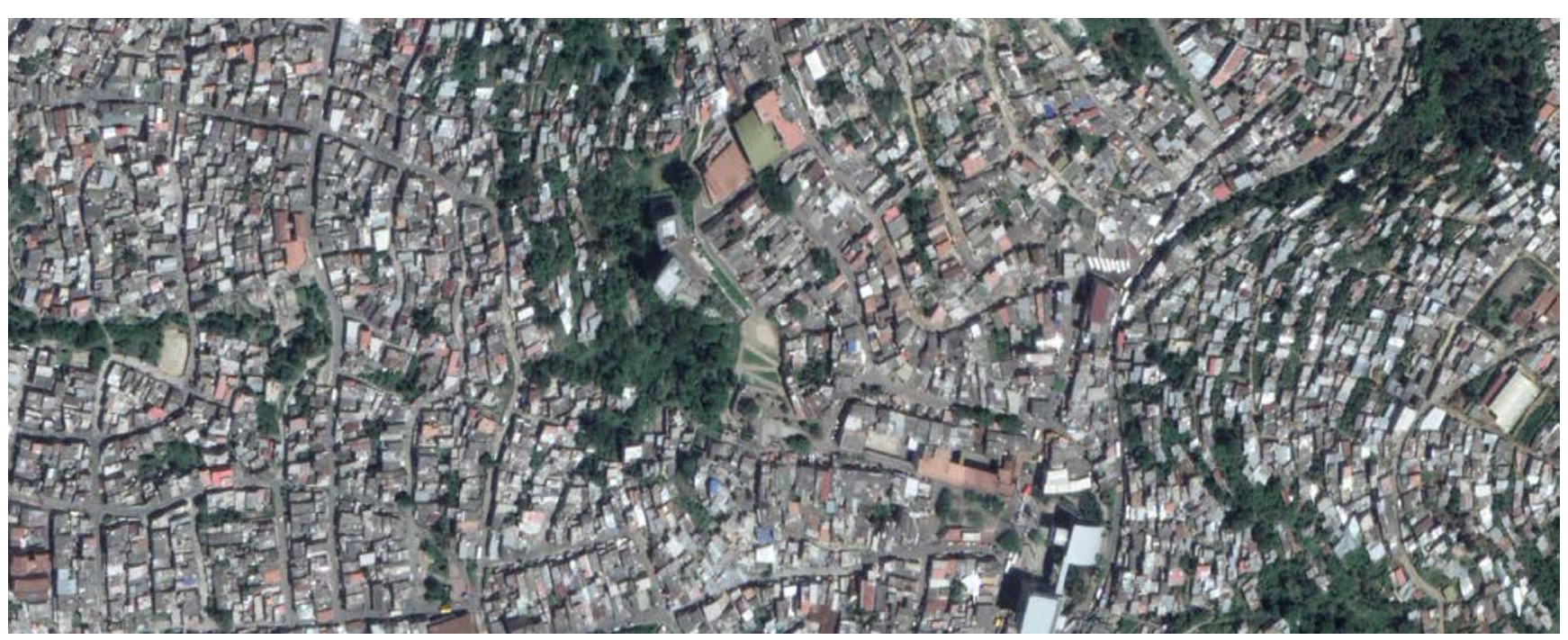

Figura 5.12.6

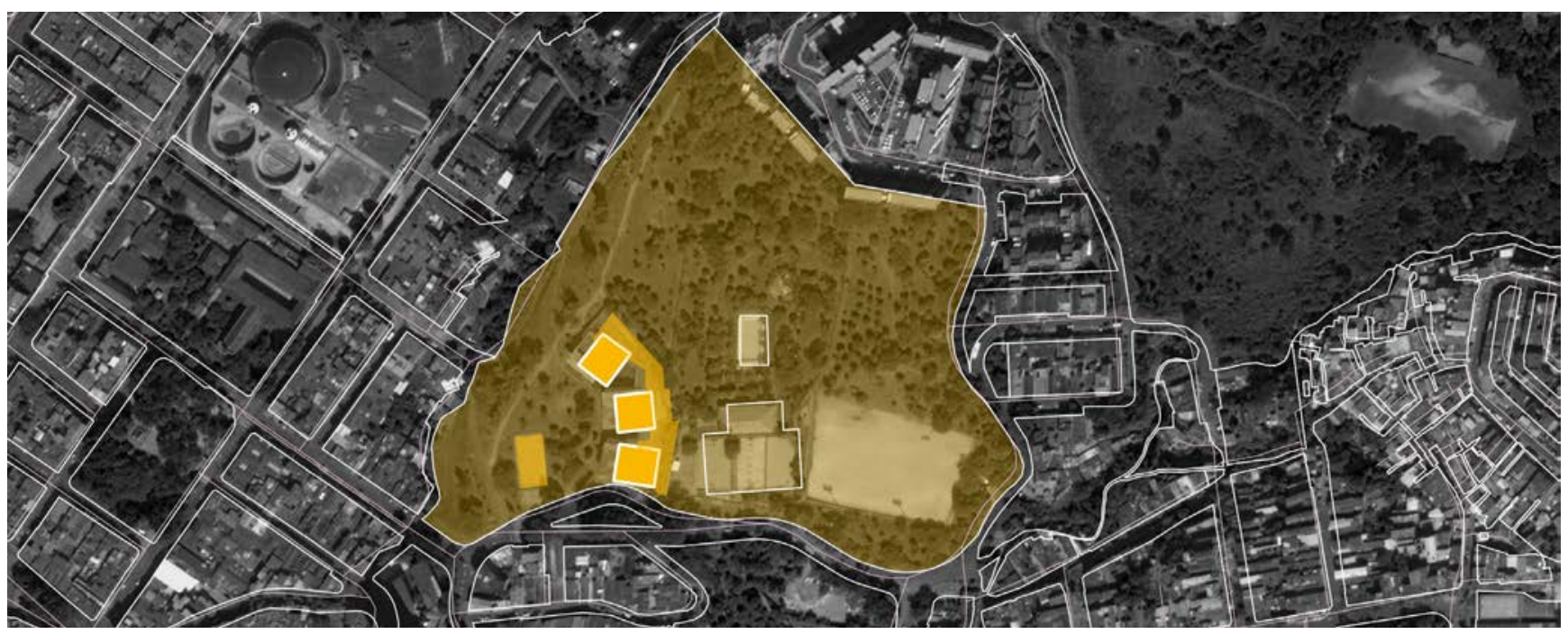

Figura 5.12.7

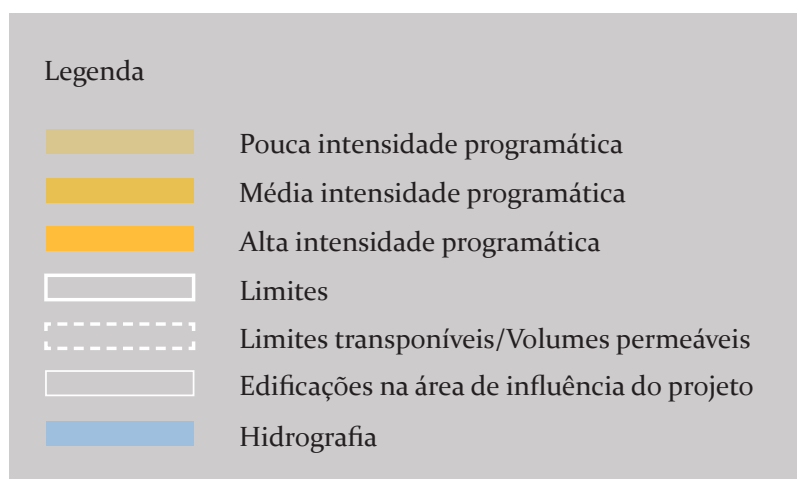

$100 \mathrm{~m}$ 

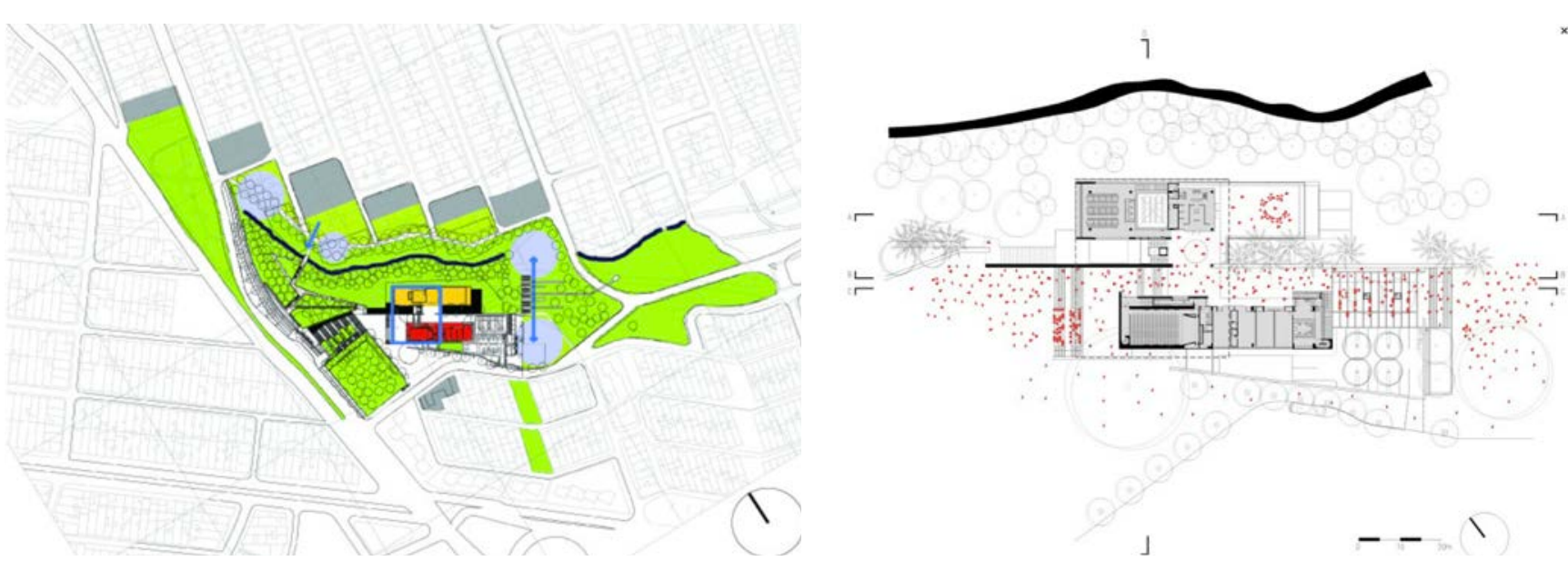

Figura 5.13.1

Localização

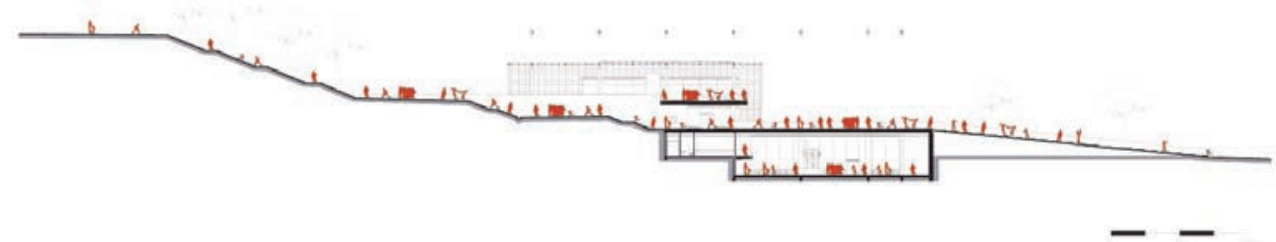

Figura 5.13.2

Nível de acesso

Figura 5.13.3

Corte longitudinal

Figura 5.13.4

Corte AA

Figura 5.13.5

Figura 5.13.6
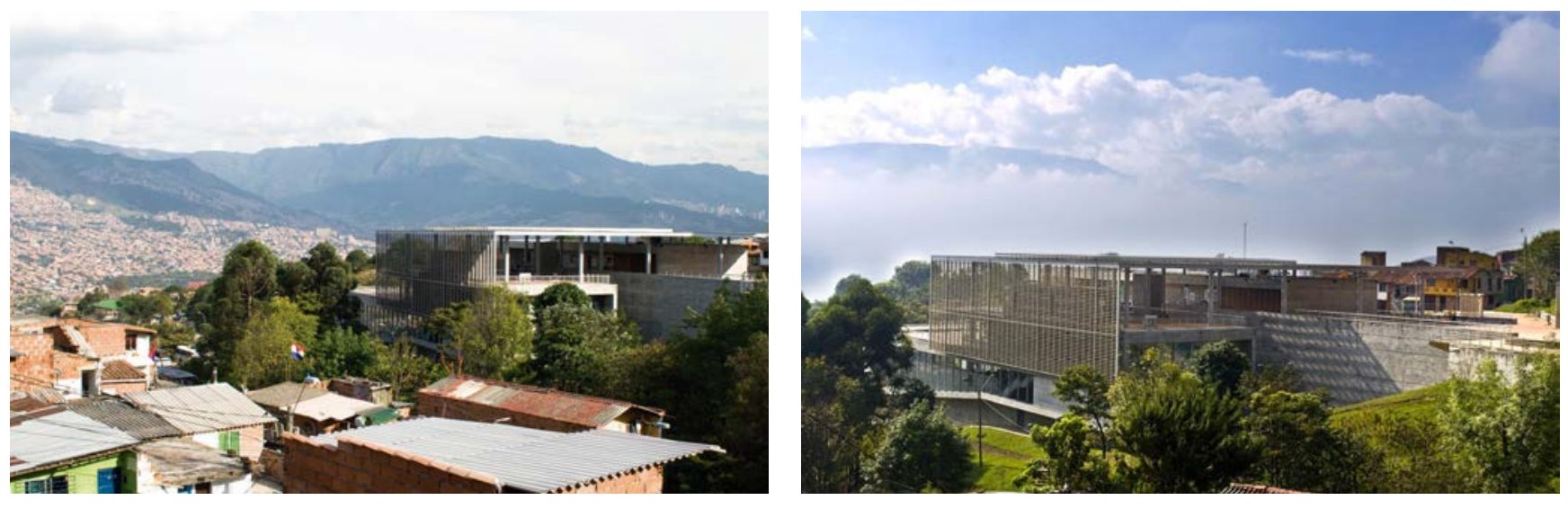


\section{Parque Biblioteca Tomás Carrasquilla}

Autor Ricardo La Rotta Caballero de La Rotta Arquitectos

Equipe Jorge Luis Ovalle, Carlos Guerrero, Manuel Moreno e

Cesar Faustino

Data do projeto 2005

Data da construção 2007
Área construída $12.700 \mathrm{~m}^{2}$

Localização Av. 8o \#\# 82-6o, Medellín, Antioquia, Colômbia

Cliente Concurso Público - Empresa de Desarrollo Urbano - Alcaldía de Medellín

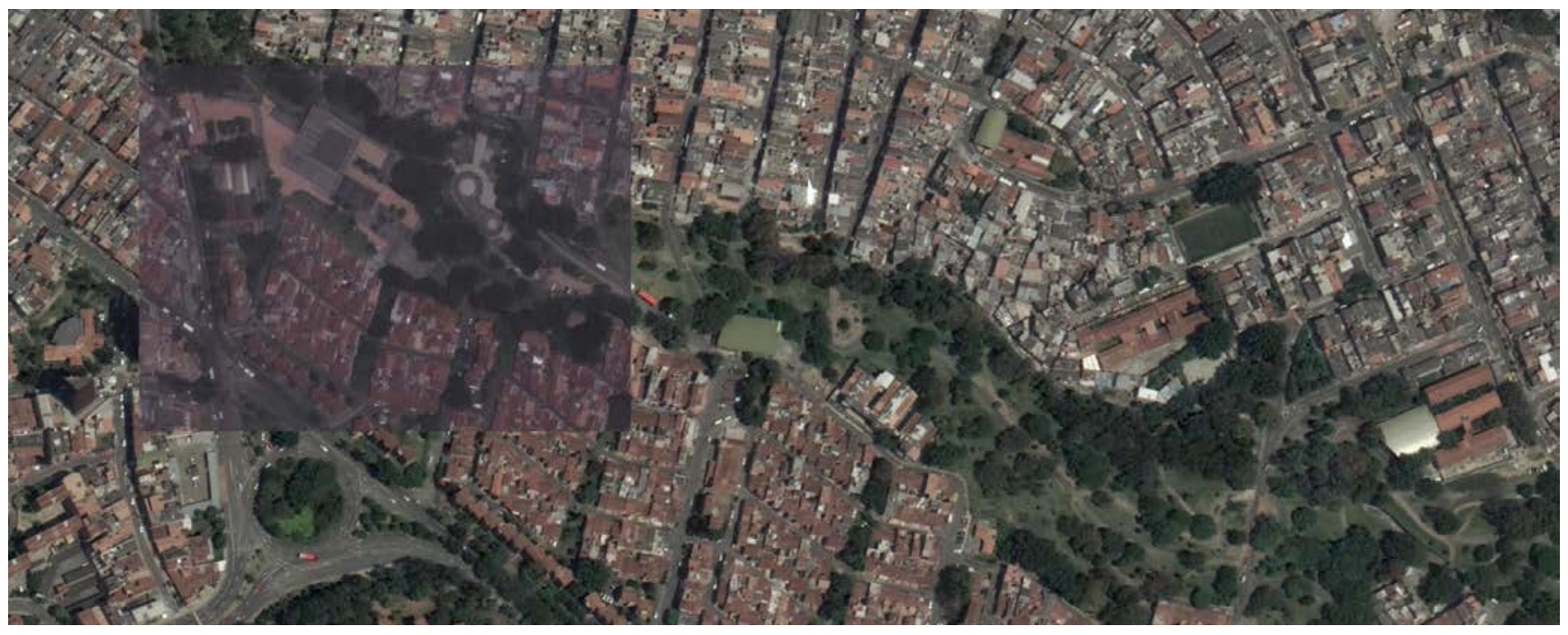

Figura $5 \cdot 13 \cdot 7$

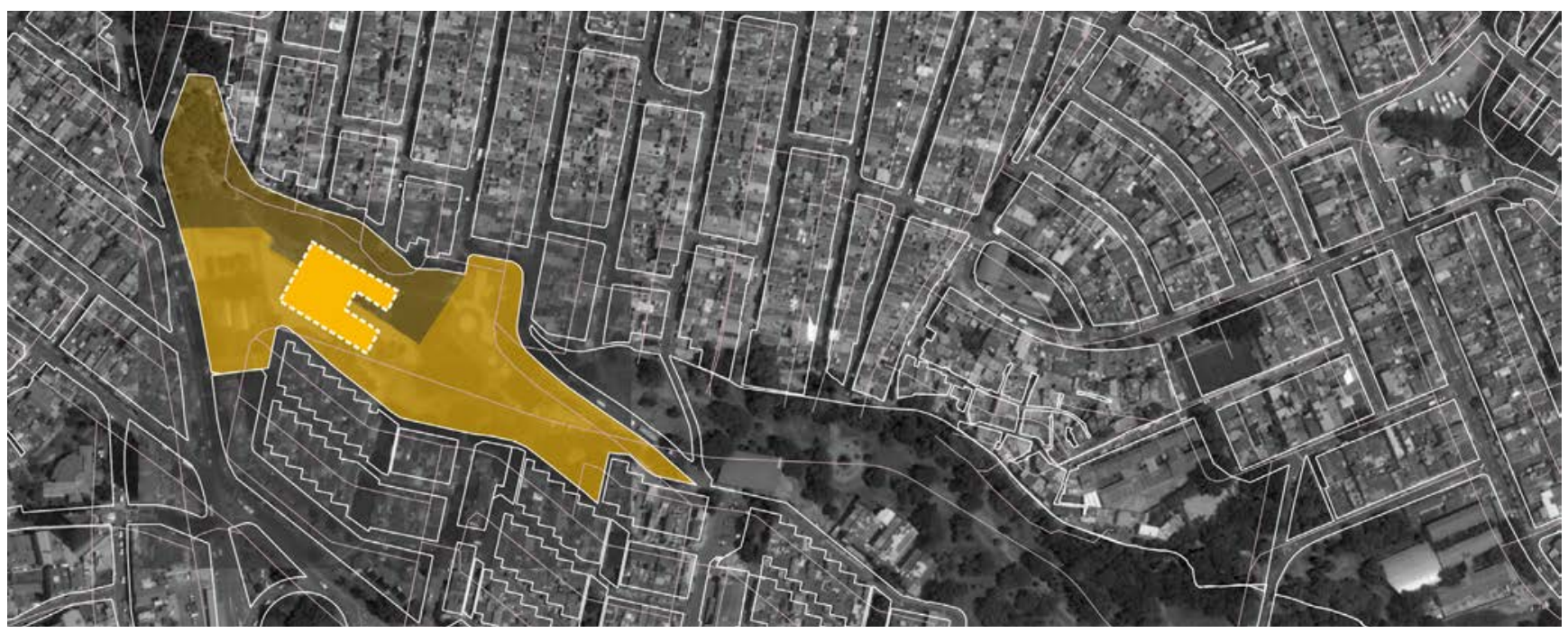

Figura 5.13.8

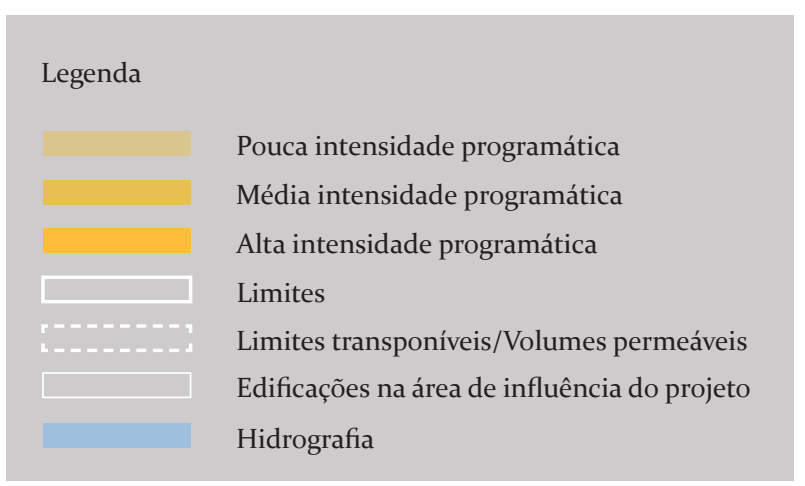




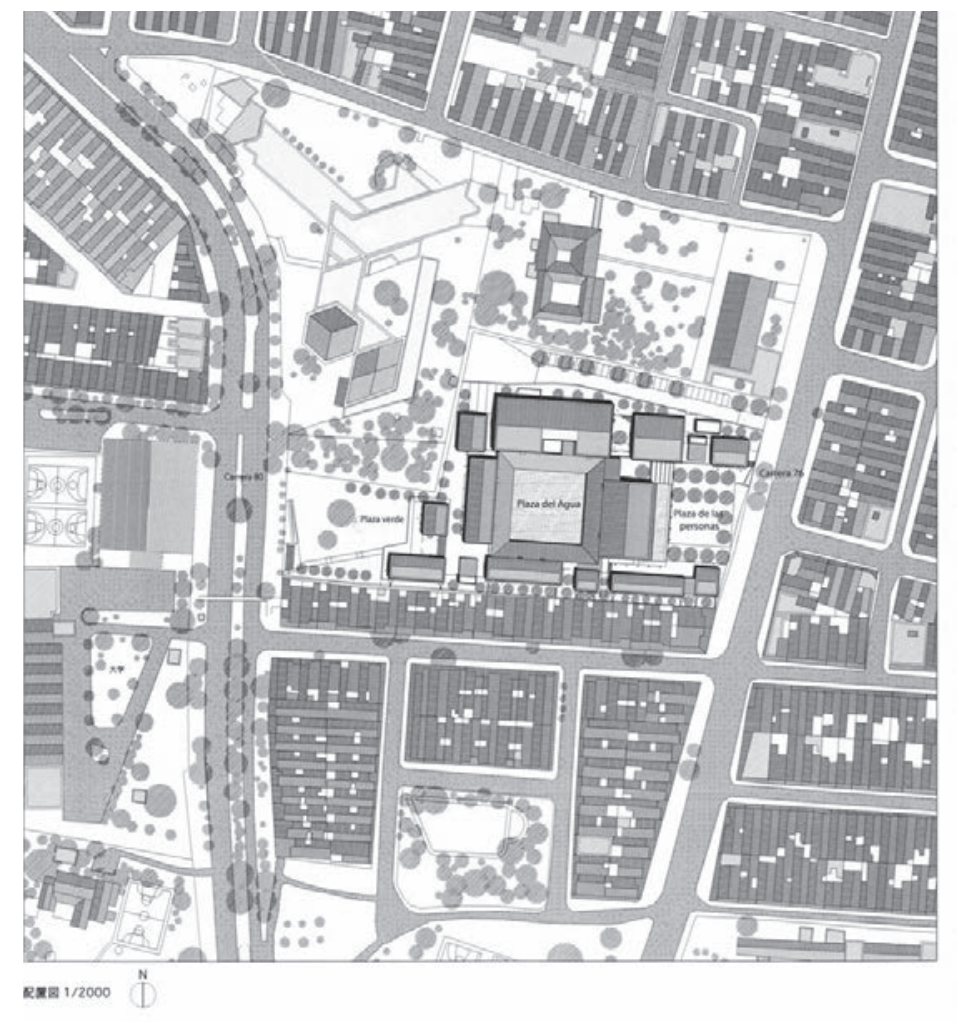

Figura 5.14.1

Implantação

Figura 5.14.2

Corte Transversal

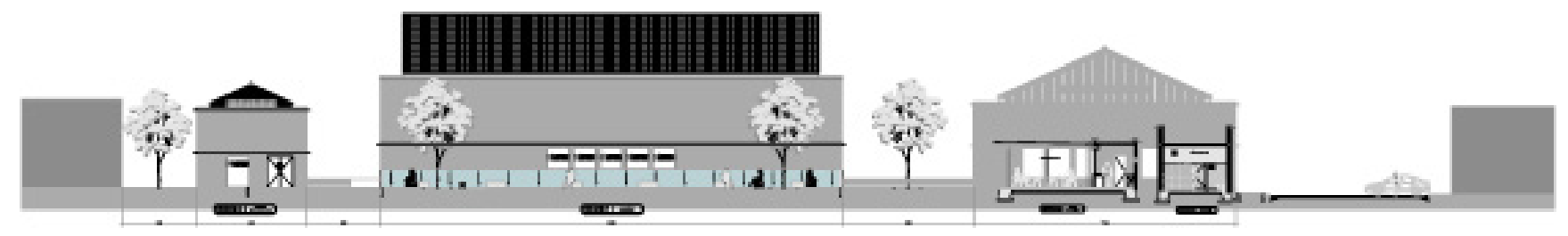

Figura 5.14.3

Figura 5.14.4
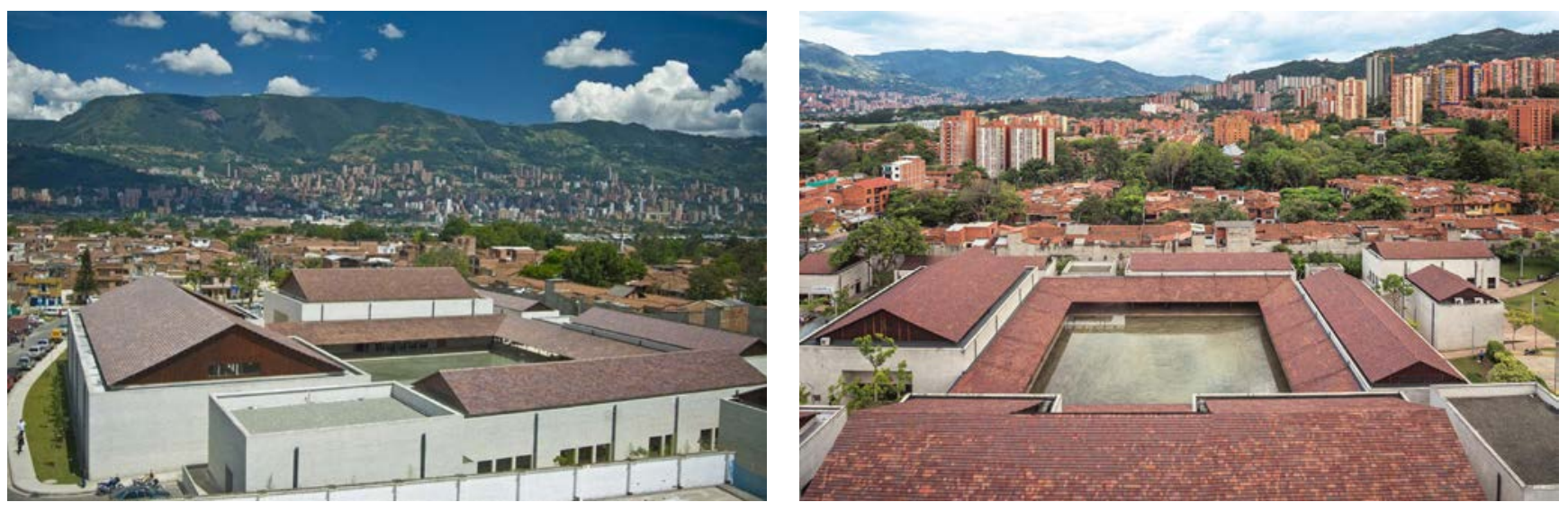


\section{Parque Biblioteca Belén}

Autor Hiroshi Naito

Equipe Japão: Yu Nakai, Yoshiyuki Kawazoe, Satoshi Okamura y Hideyuki Hagiuda. Colômbia - EDU: Carlos Mario Rodríguez Osorio.

Data do projeto 2005

Data da construção 2008
Área construída $14.991 \mathrm{~m}^{2}$

Localização Cra. 76 \#18a 19, Medellín, Antioquia, Colômbia

Cliente Concurso Público - Alcaldía de Medellín y Mauricio Valencia, Secretario de Obras Públicas

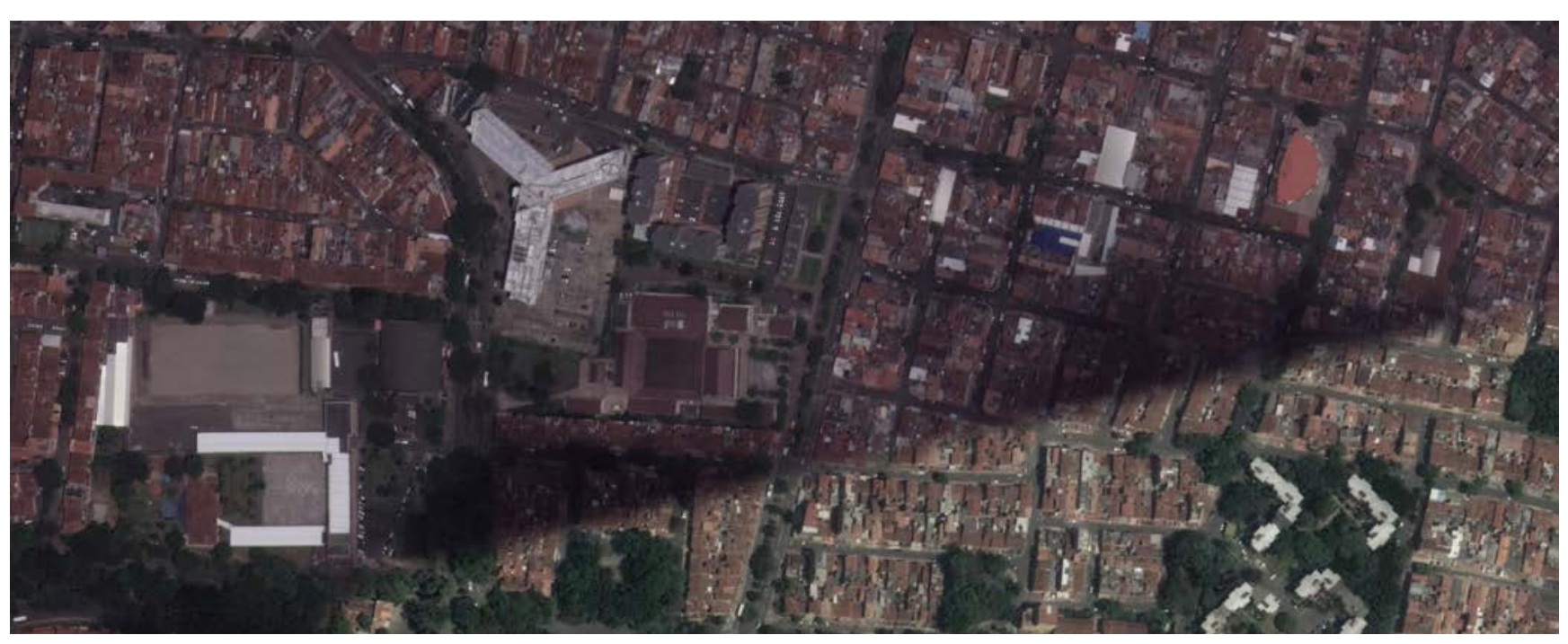

Figura 5.14.5

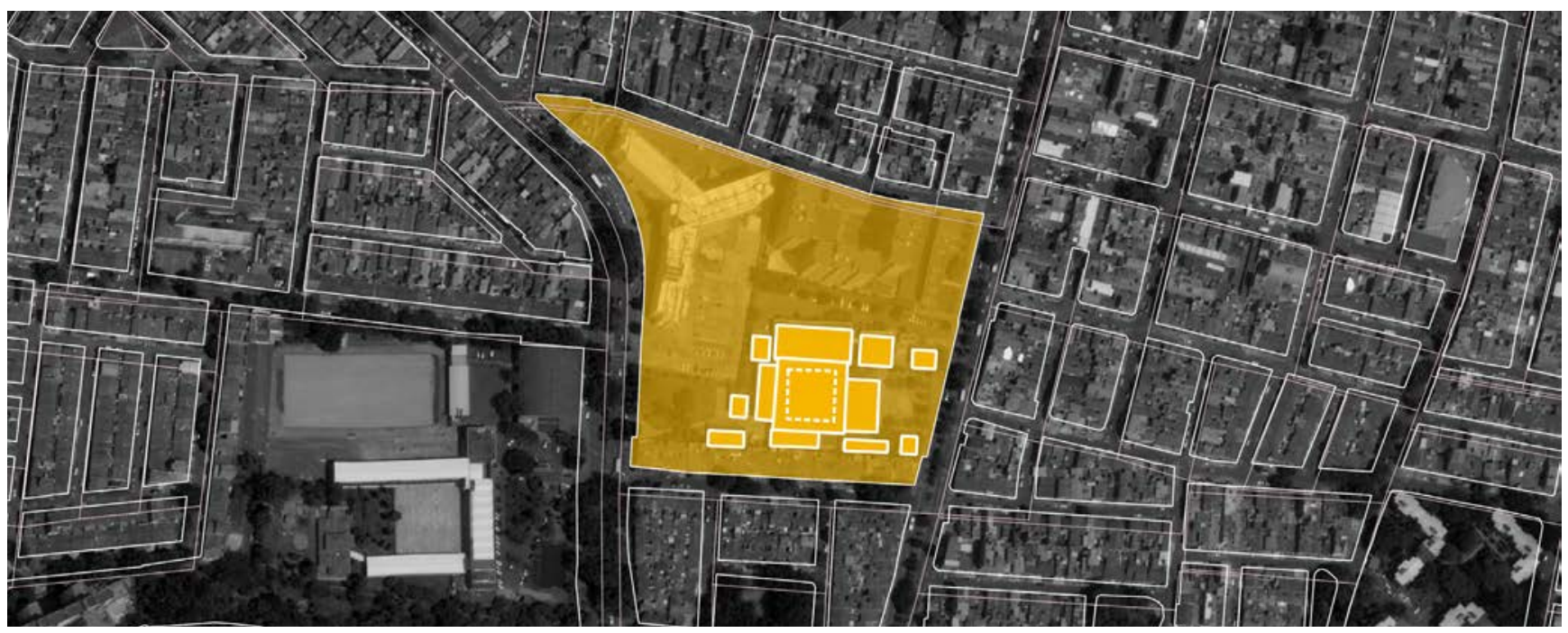

Figura 5.14.6

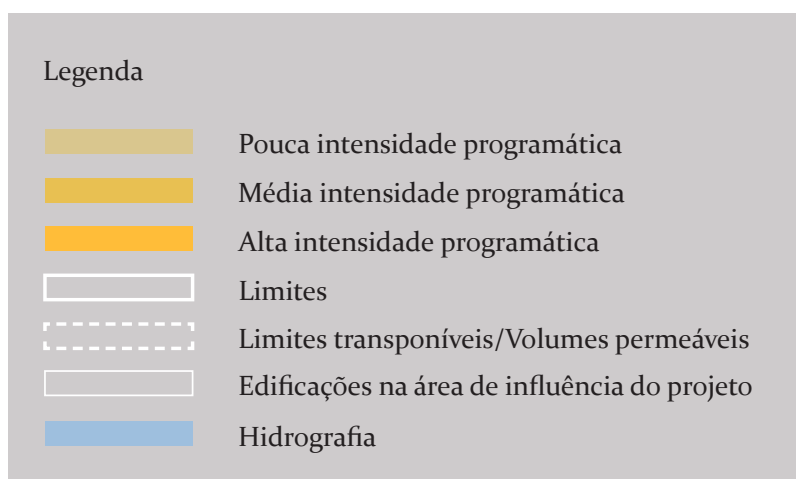

o

$100 \mathrm{~m}$ 


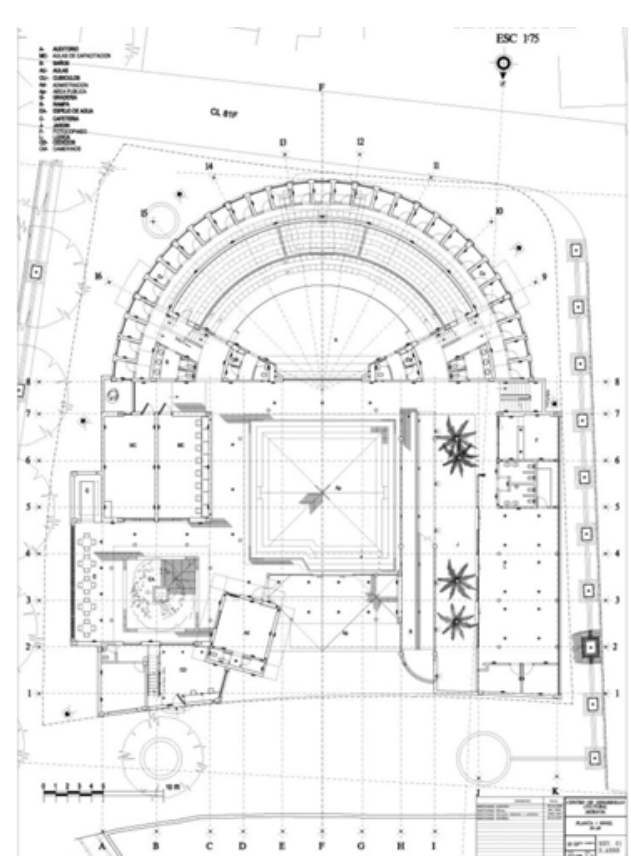

Figura 5.15.1

Planta Nível 1

Figura 5.15.2

Cortes
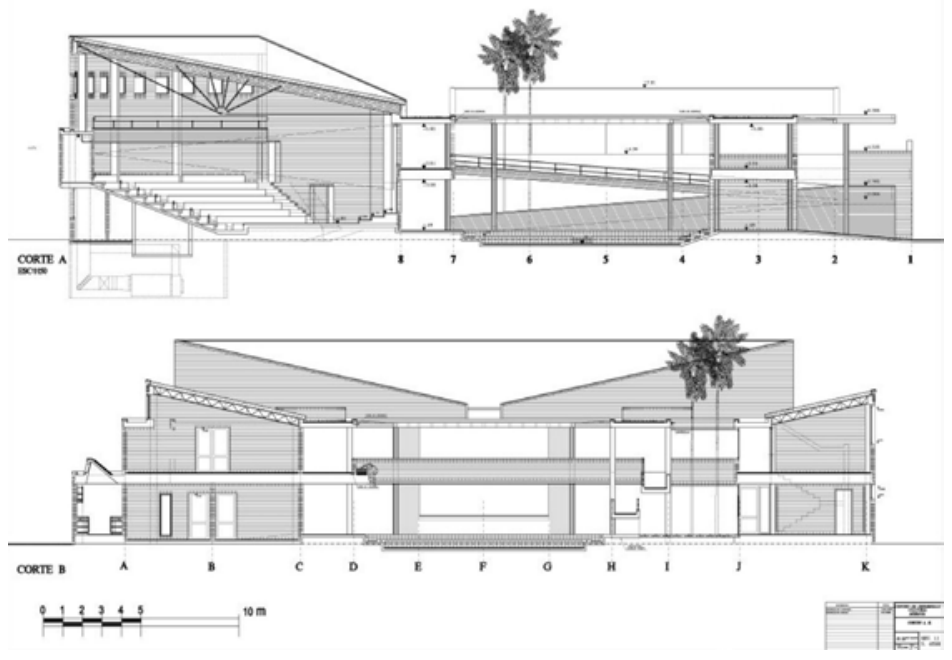

Figura 5.15.3

Figura 5.15.4
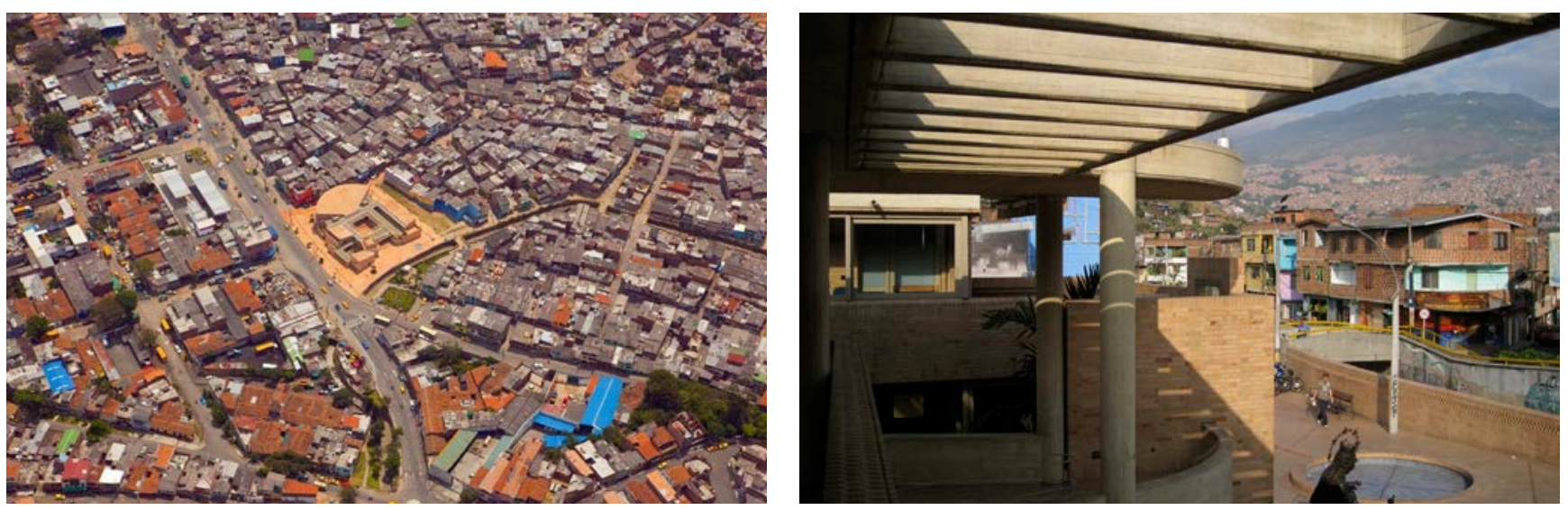


\section{Centro de Desarollo Cultural Moravia}

Autor Rogelio Salmona

Equipe Rogelio Salmona e María Elvira Madriñán

Data do projeto 2006

Data da construção 2008
Área do lote $1.859 \mathrm{~m}^{2}$

Localização Cra. 52, Medellín, Antioquia, Colômbia

Cliente Alcaldía De Medellín

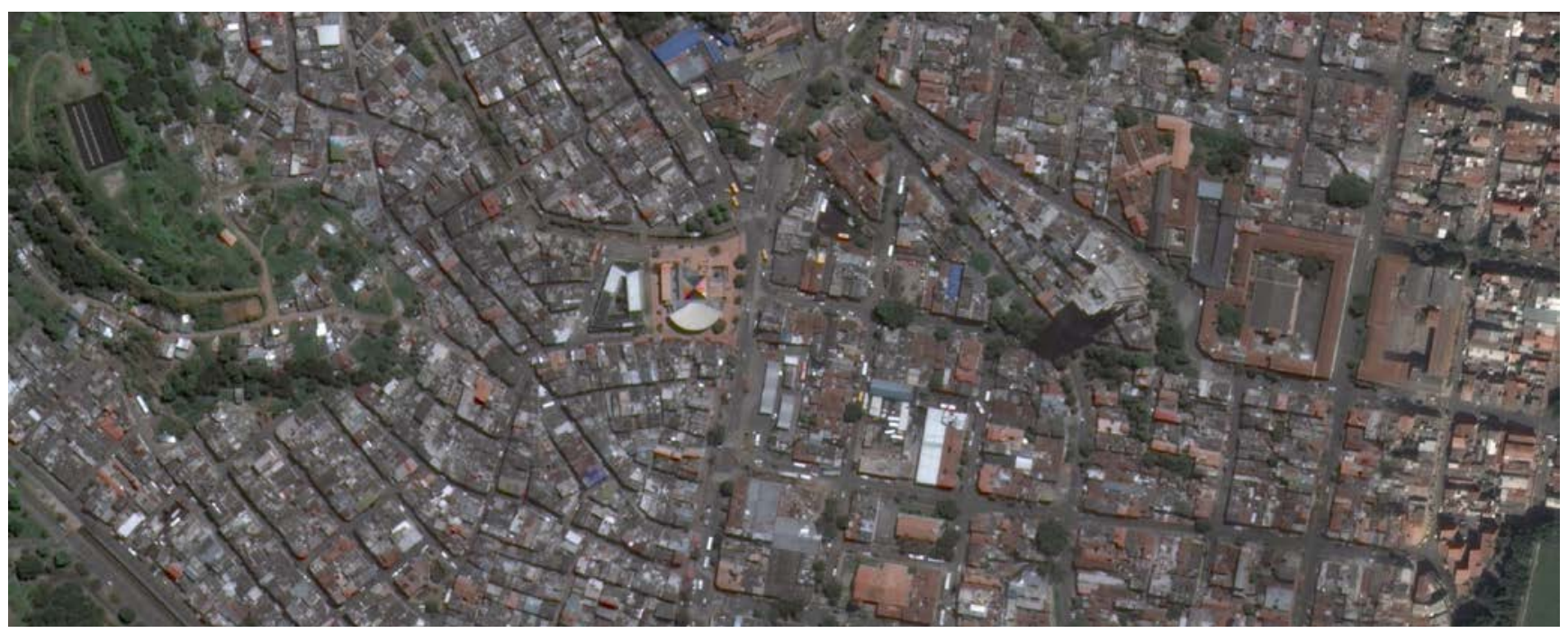

Figura $5 \cdot 15 \cdot 5$

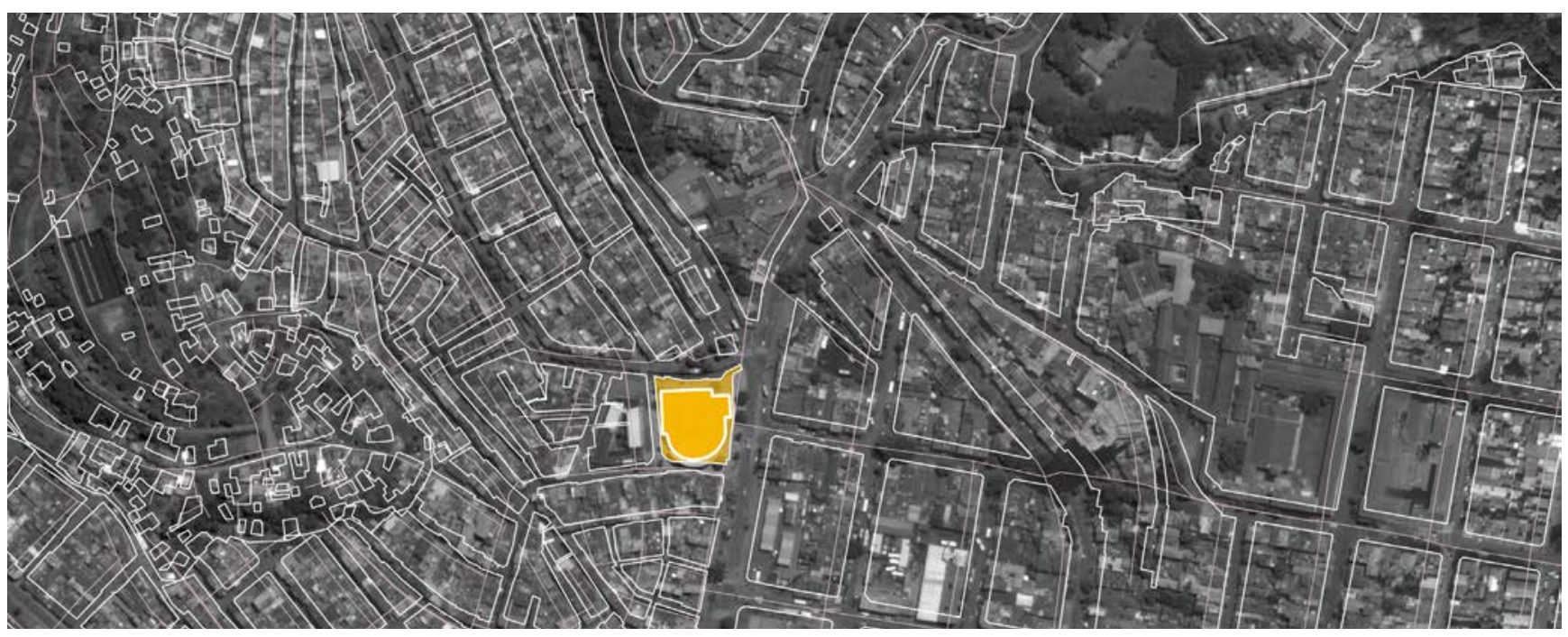

Figura 5.15.6

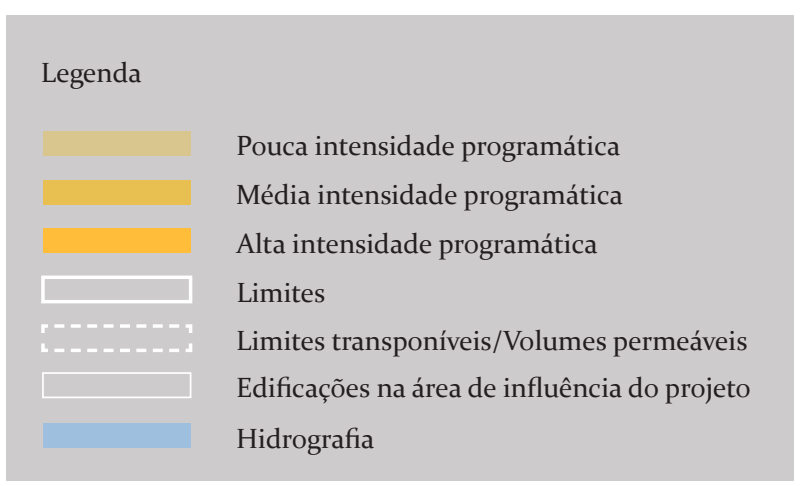




\section{Estrategia Física}

Reubicación

Mejoramiento

Reposición

Densificación

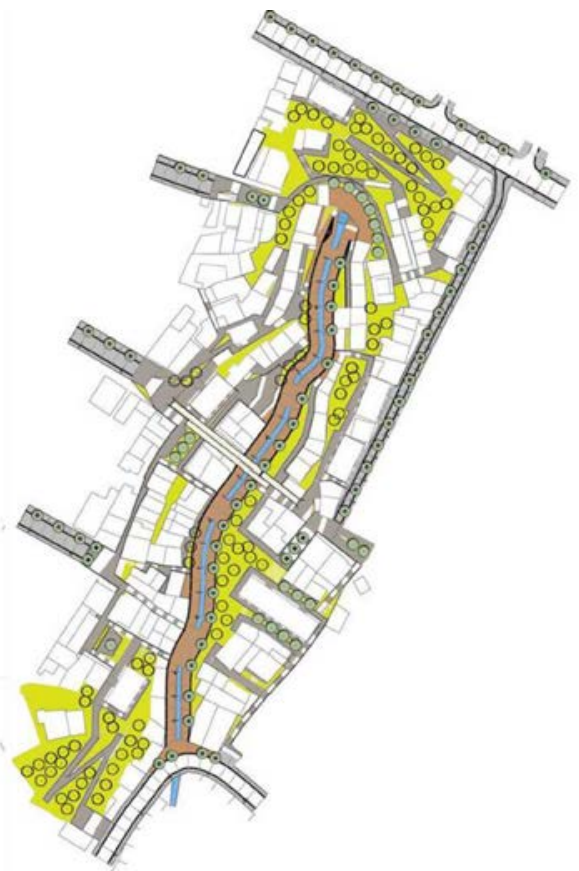

Figura 5.16.1

Estrategia física

Figura 5.16.2

Coordenação

Interinstitucional

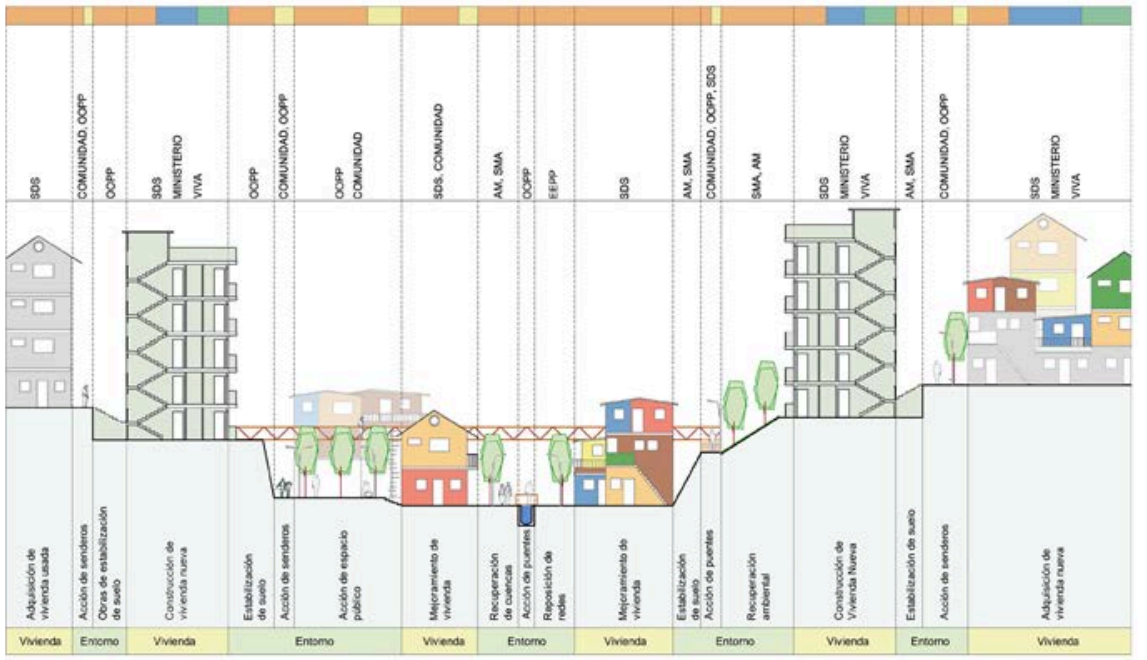

Figura 5.16.3

Figura 5.16.4
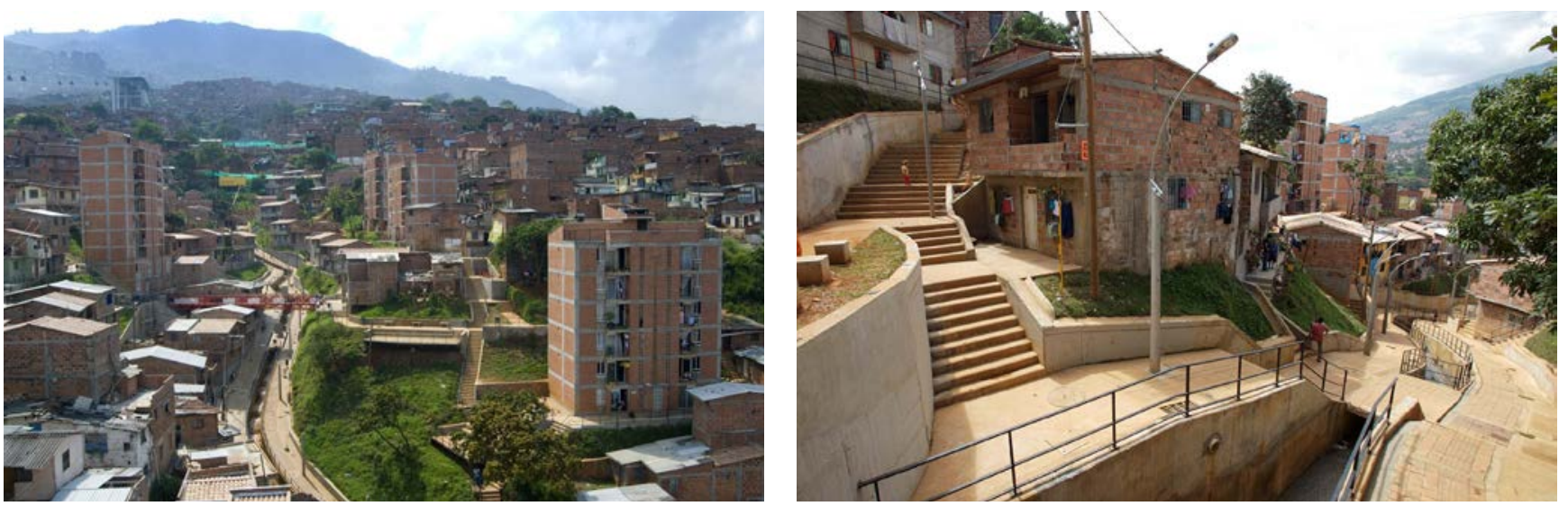


\section{Quebrada Juan Bobo}

Autores Carlos Montoya Correa, Claudia Juliana Portillo Francesco Maria Orsini

\section{Data do projeto 2004}

Data da construção 2007

Área do lote $22.885 \mathrm{~m}^{2}$

Localização Entre carreras ${ }_{51 B} \mathrm{~B}$ e $49 \mathrm{~B}$ e calles ${ }_{105} \mathrm{C}$ e 107

Cliente EDU - Empresa de Desarollo Urbano

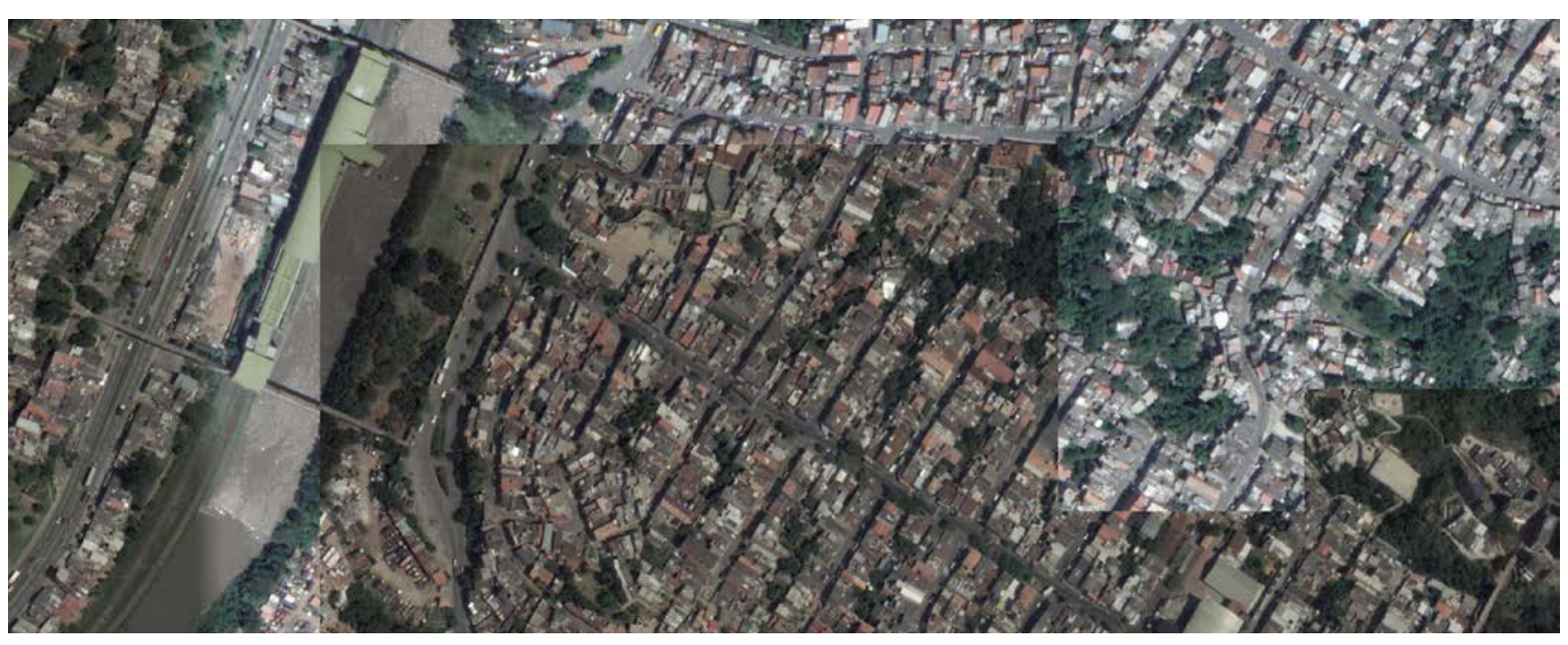

Figura 5.16.5

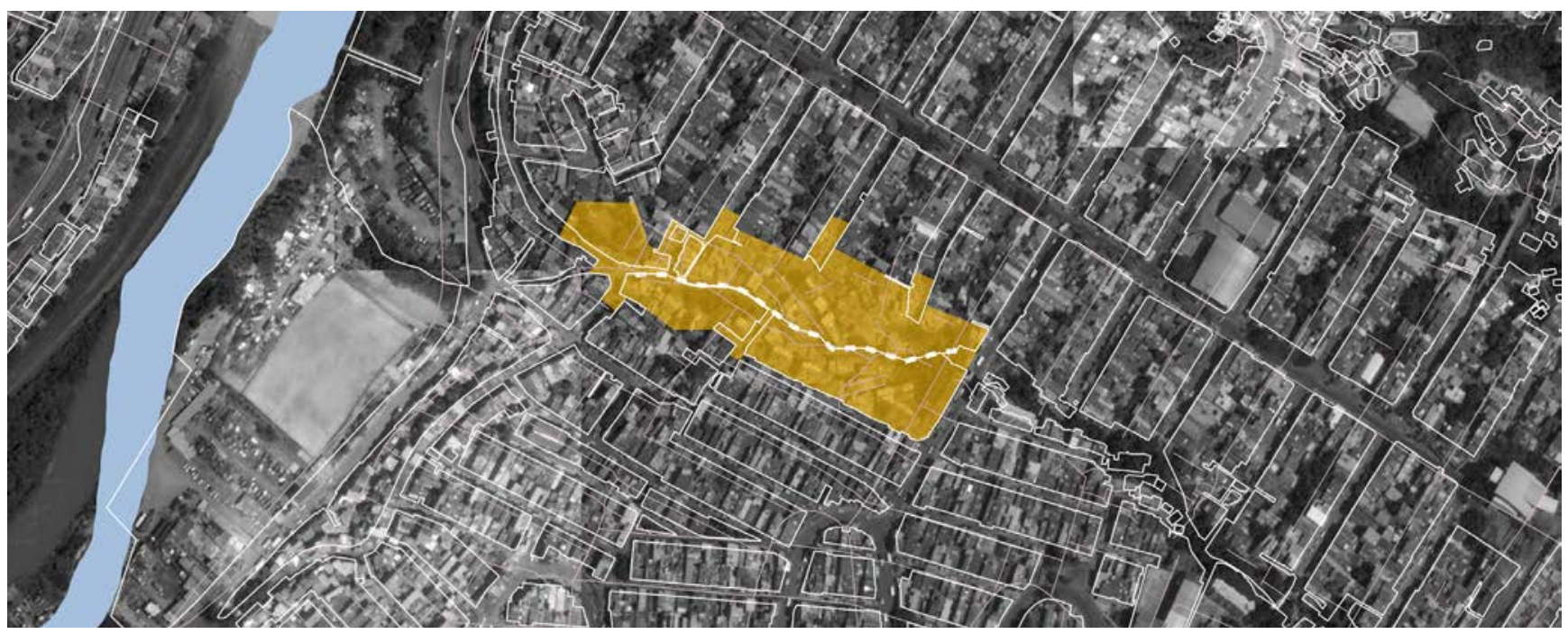

Figura 5.16.6

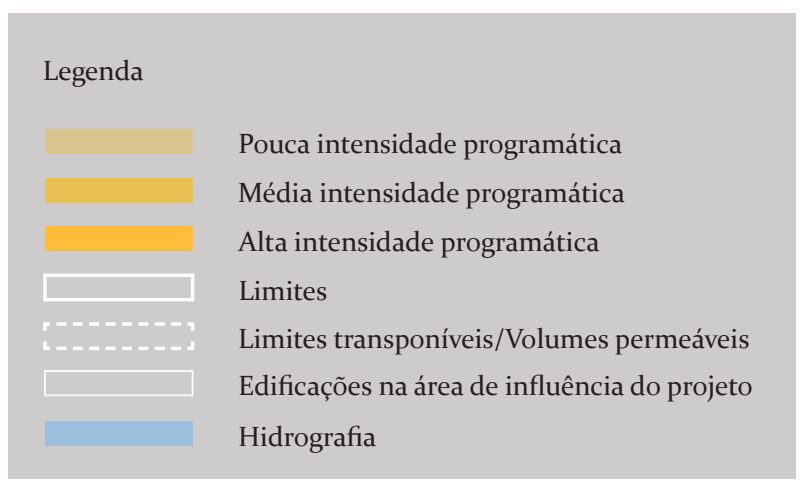

o

$100 \mathrm{~m}$ 


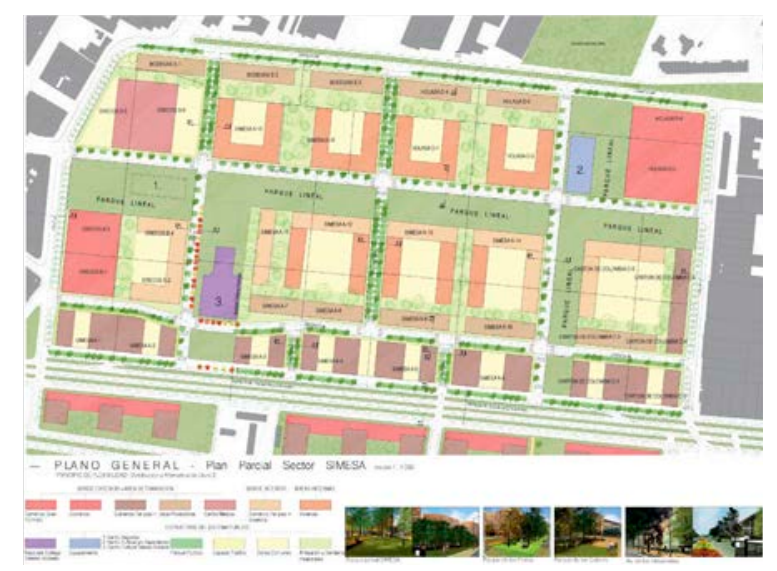

Figura 5.17.1

Planta - Giovanna Spera e Juan Carlos García

Figura 5.17.2

Croquis - Juan Carlos García
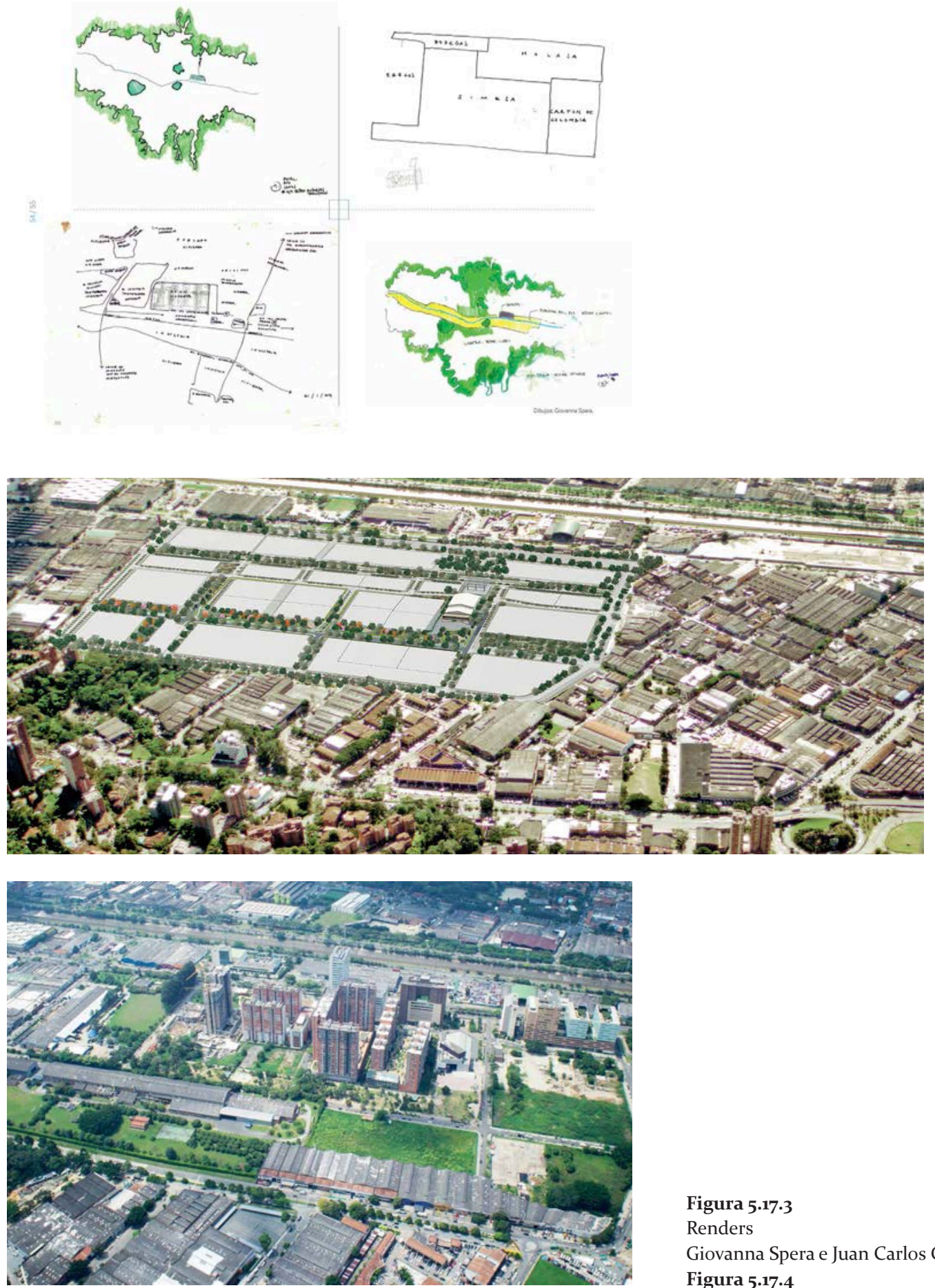

Figura 5.17.3

Renders

Giovanna Spera e Juan Carlos García

Figura 5.17.4 


\section{Parque Lineal Ciudad del Rio}

Autores Giovanna Spera, Juan Esteban Arteaga

Data do projeto 2006

Data da construção 2009
Área do lote $306.000 \mathrm{~m}^{2}$

Localização Cra 43G \#2420, Medellín, Antioquia, Colômbia

Cliente Valores Simesa

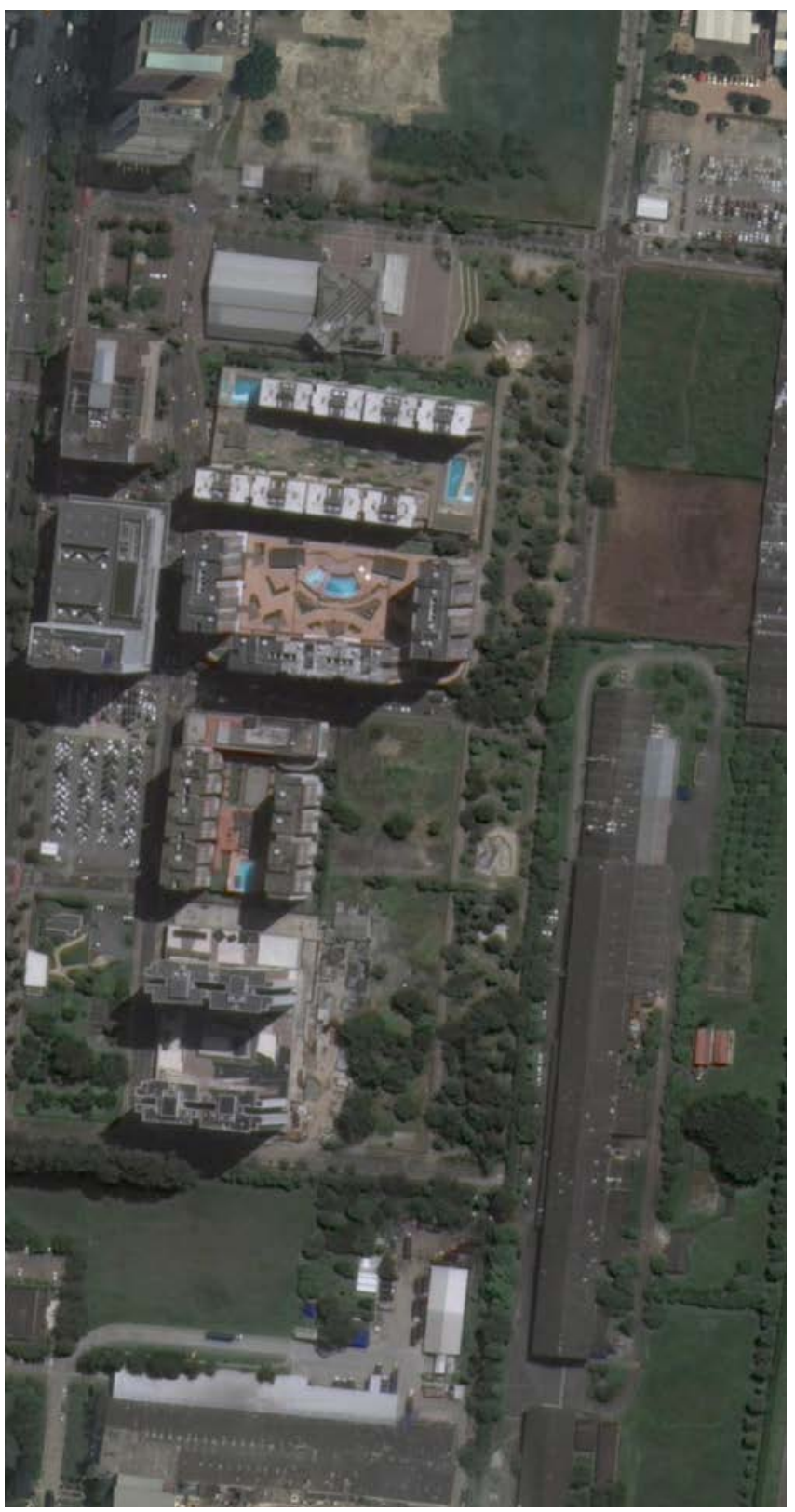

Figura 5.17.5

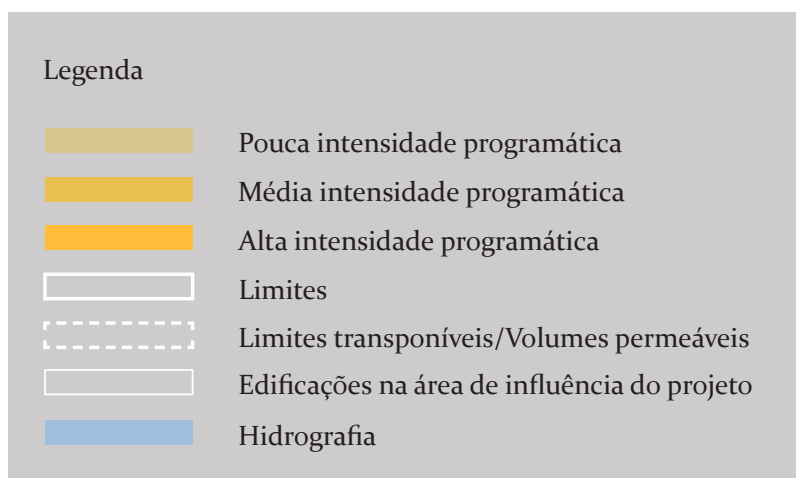

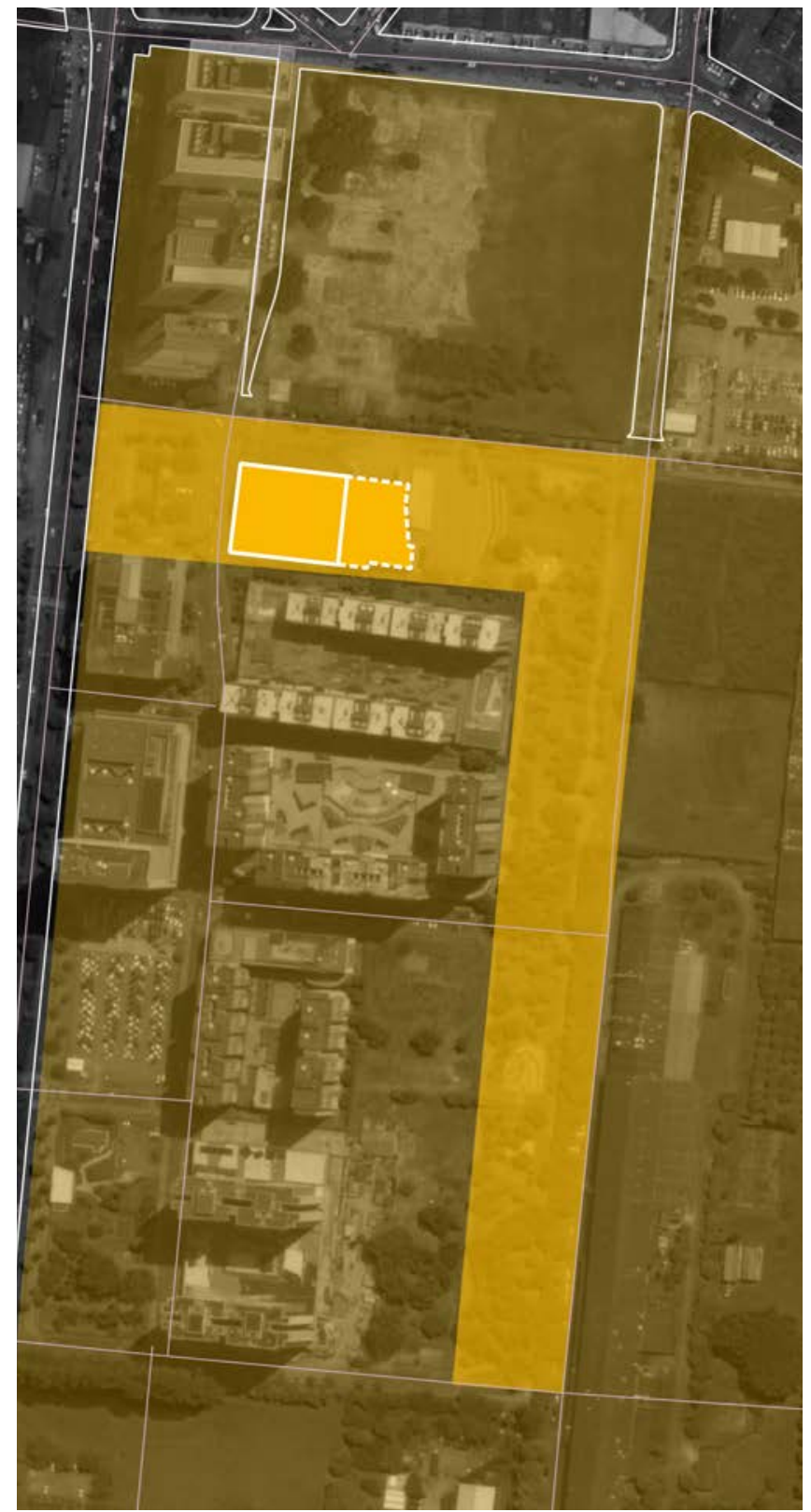

Figura 5.17.6 


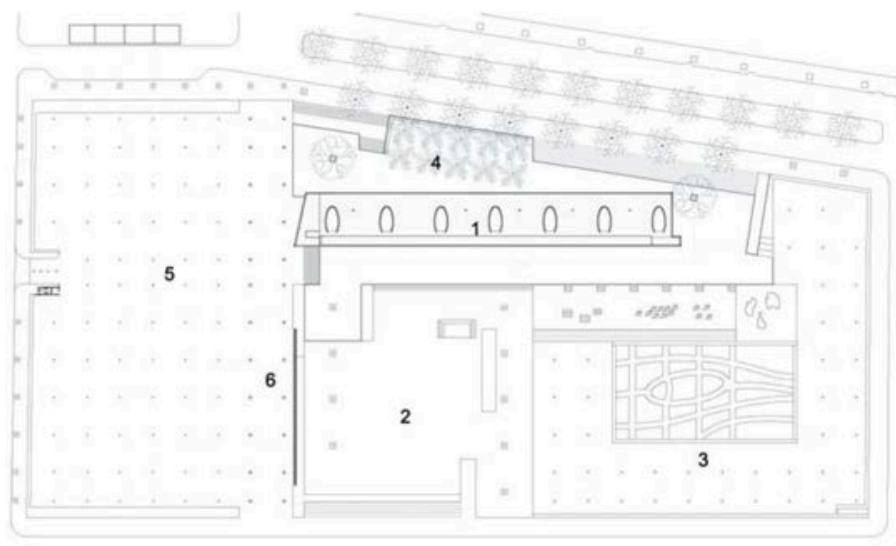

PLANTA DE LOCALIZACION DEL EDIFICIO

1. EDIFICIO CENTRO INTERACTNO

SITE PLAN

2. PLAZA

3. BOSQUE

4. TERPAZA

6. CALLE PEATONAL
1. INTERACTIVE CENTER E.P.M

2. SQUARE

3. FORREST

4. TERRACE

5. PARKING

6. PATHWAY
Figura 5.18.1

Planta de localização do edifício

Figura 5.18.2

Planta do museu
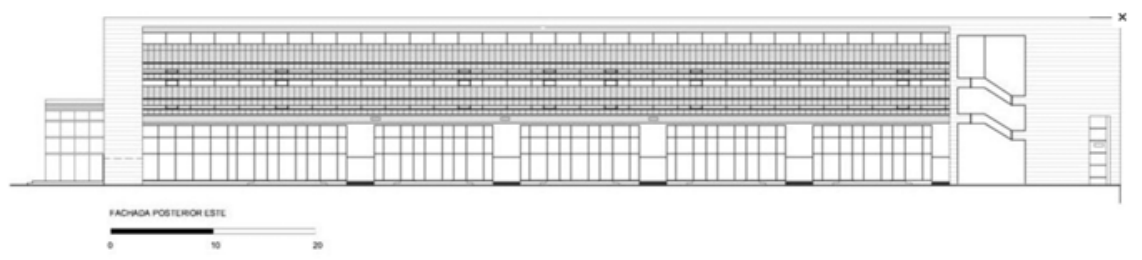

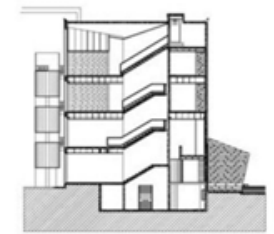

-

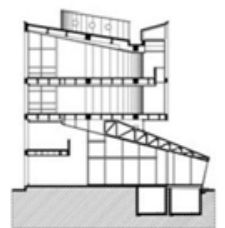

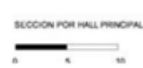

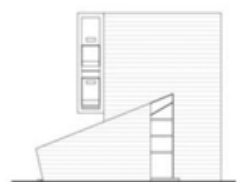

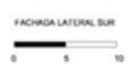

Figura 5.18.3

Figura 5.18.4
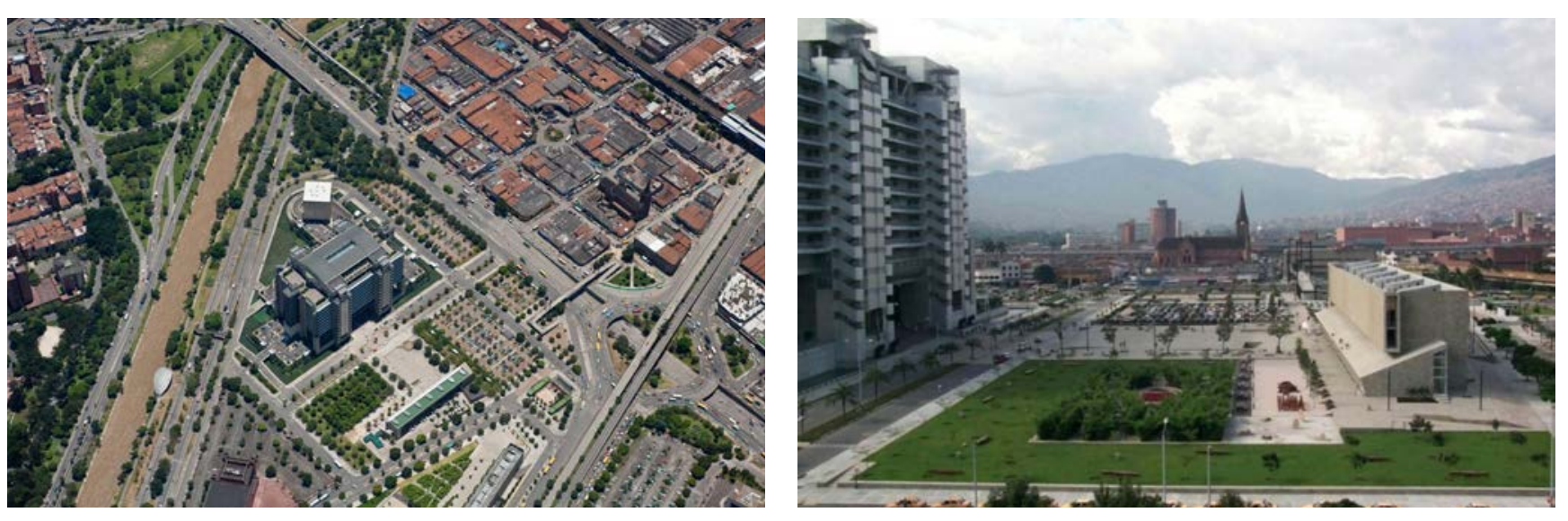


\section{Parque de los Piés Descalzos}

Autor Felipe Uribe de Bedout,

Ana Elvira Vélez, Giovanna Spera, LAUR Facultad de Arquitectura Universidad Pontificia Bolivariana

Equipe Orlando García Mejía, Andrés Montoya, Guillermo Valencia Calle

\section{Data do projeto 1997}

Data da construção 1999

Área do lote $38.550 \mathrm{~m}^{2}$

Localização Cra. 58 \#42-125, Medellín, Antioquia, Colômbia

Cliente Fundación Empresas Públicas de Medellín

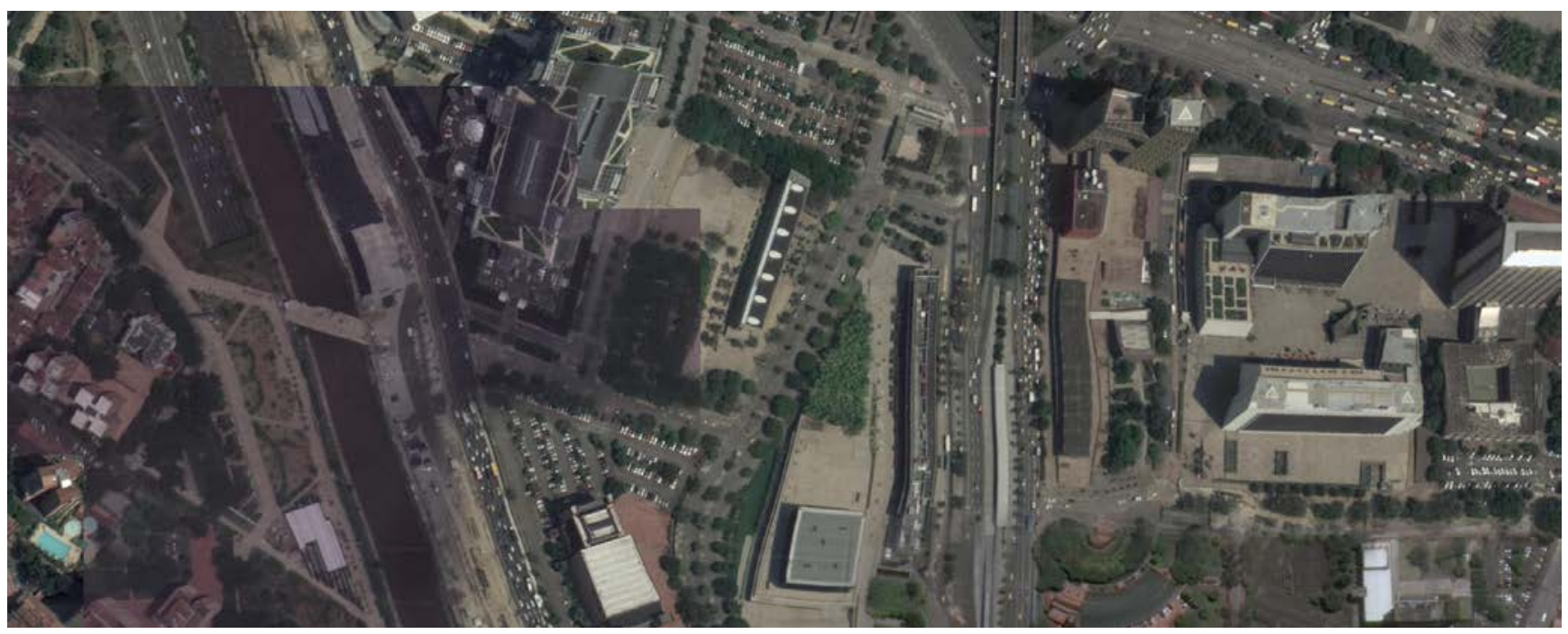

Figura 5.18.5

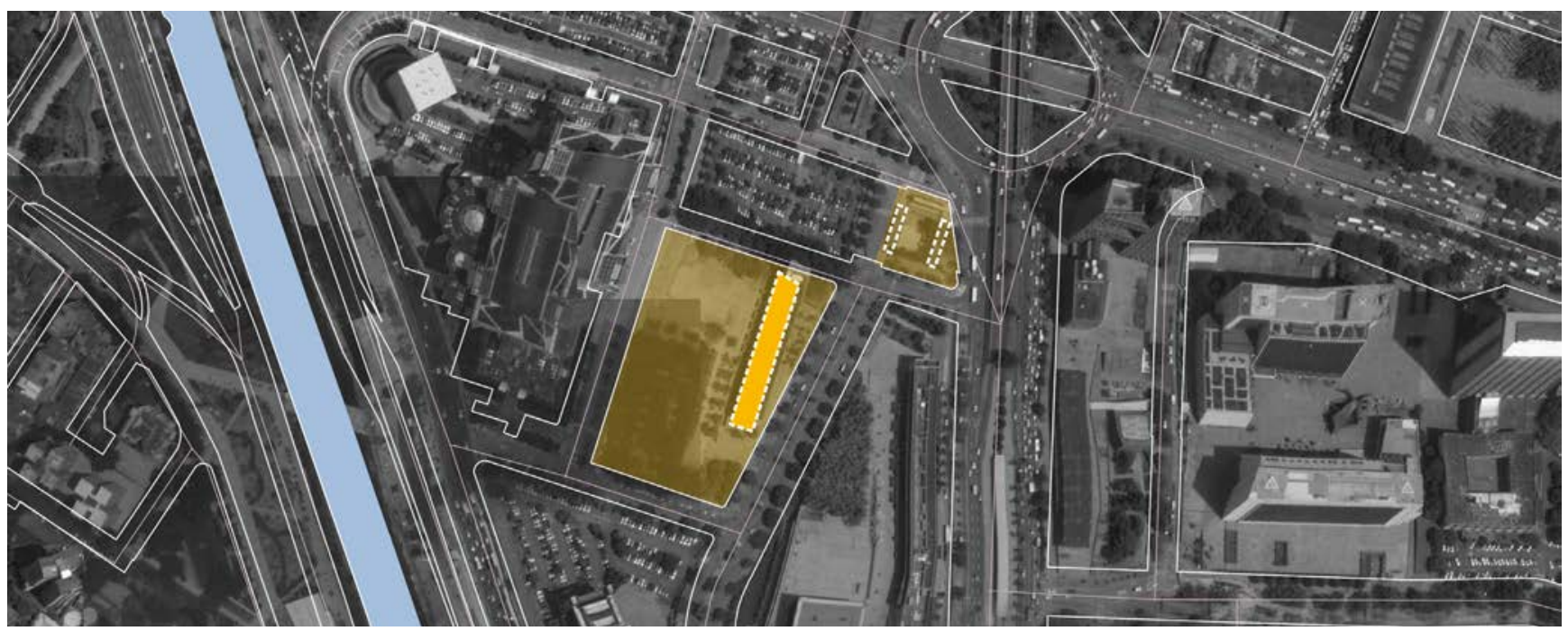

Figura 5.18.6

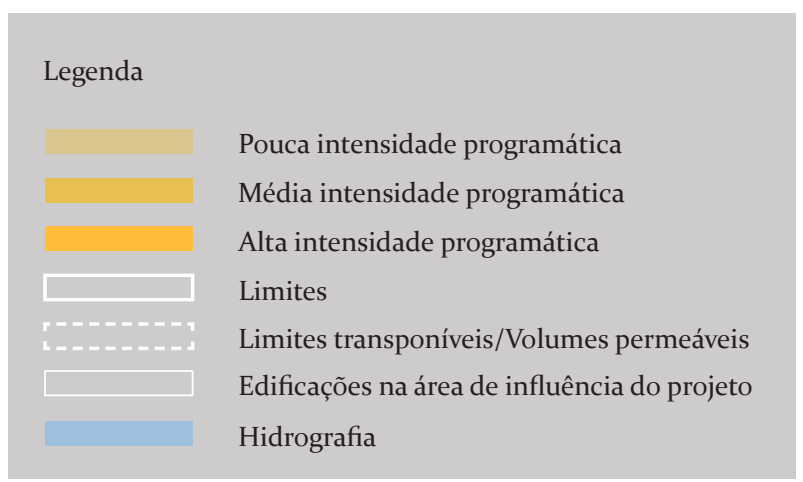

$100 \mathrm{~m}$ 


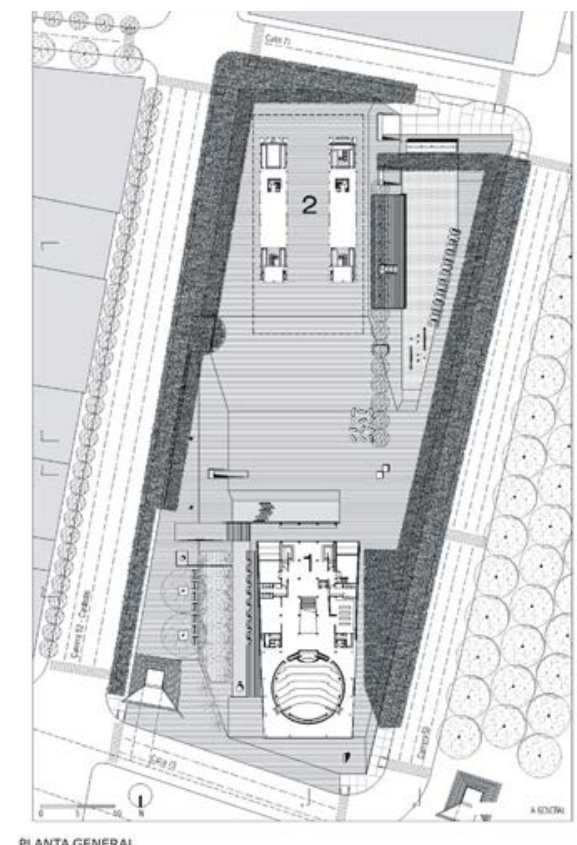

PLANTAGENERAL

1. planetario existente
2. edificio nuevo
Figura 5.19.1

Planta geral

Figura 5.19.2

Corte AA

Figura 5.19.3

Corte FF
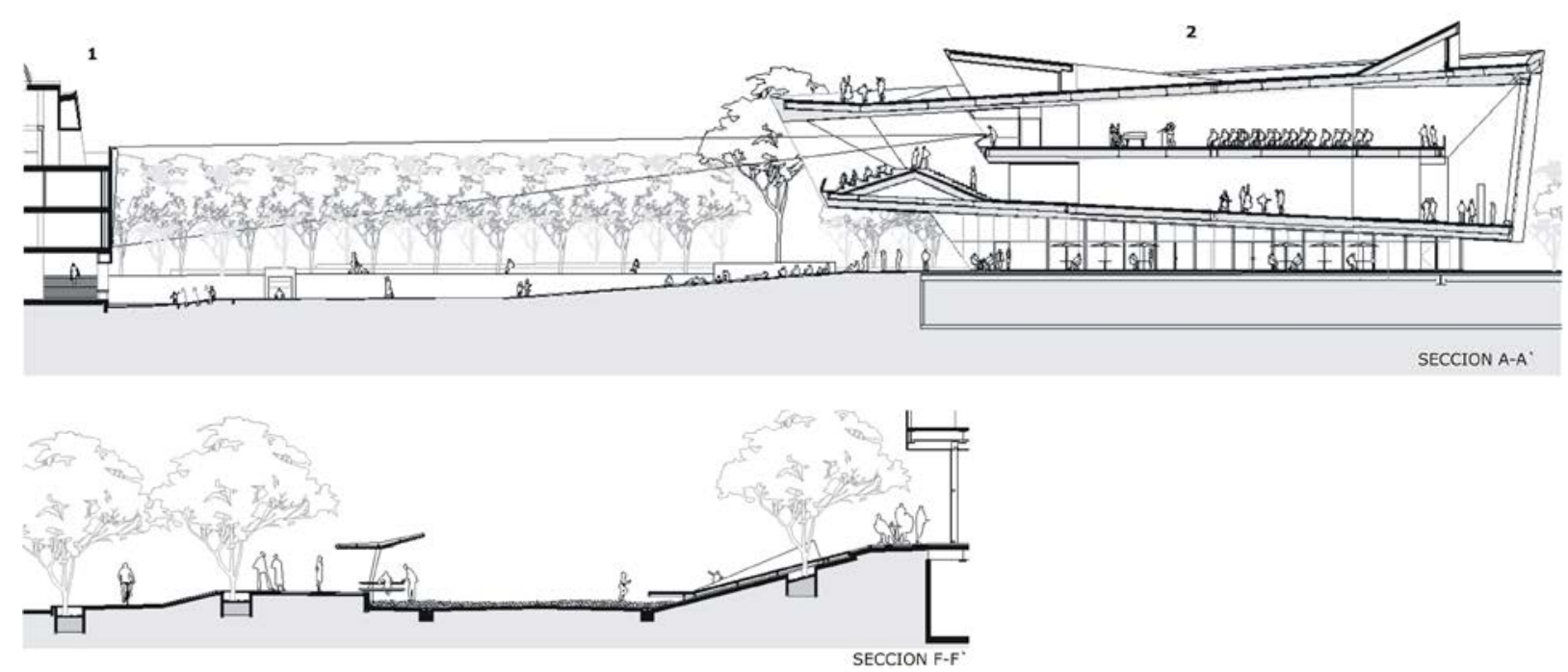

Figura 5.19.4

Figura 5.19.5
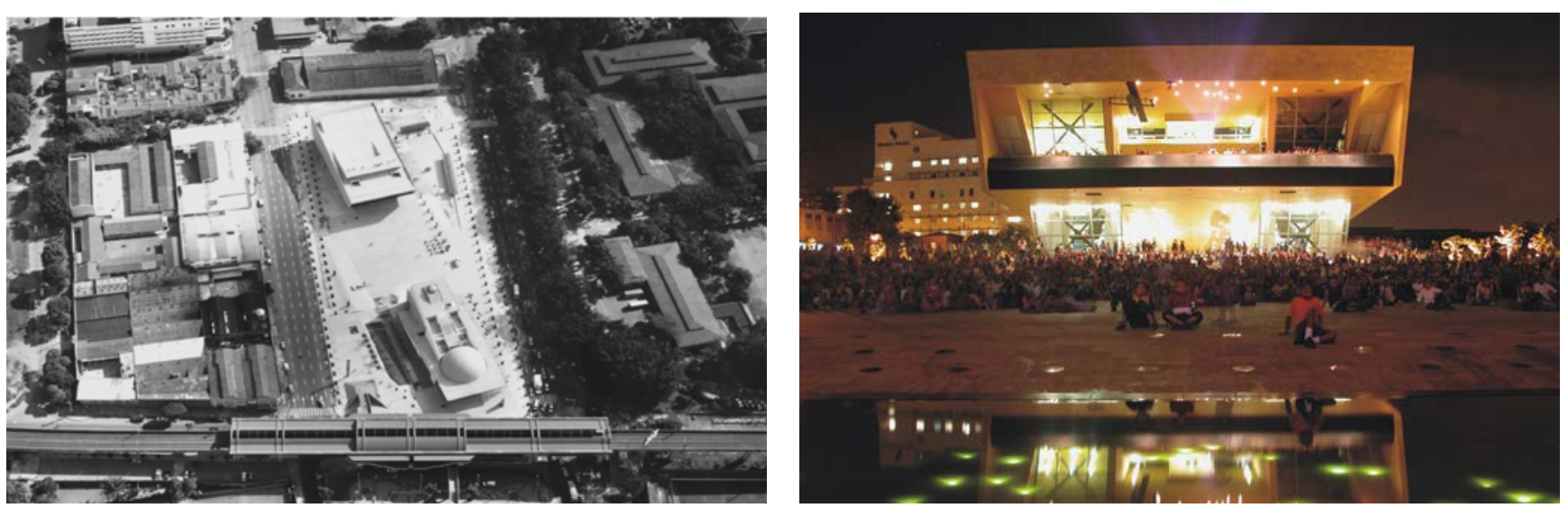


\section{Parque de Los Deseos}

Autor Felipe Uribe de Bedout

Equipe Gerardo Olave Triana, Jheny Nieto Ropero, Alvaro

Criollo López, Manuel Villa Largacha, Andrés Castro Amaya e Néstor Riascos

\section{Data do projeto 2003}

Data da construção 2004

Área do lote $15.250 \mathrm{~m}^{2}$

Localização Cl. 71, Medellín, Antioquia, Colômbia

Cliente Empresas Públicas de Medellín

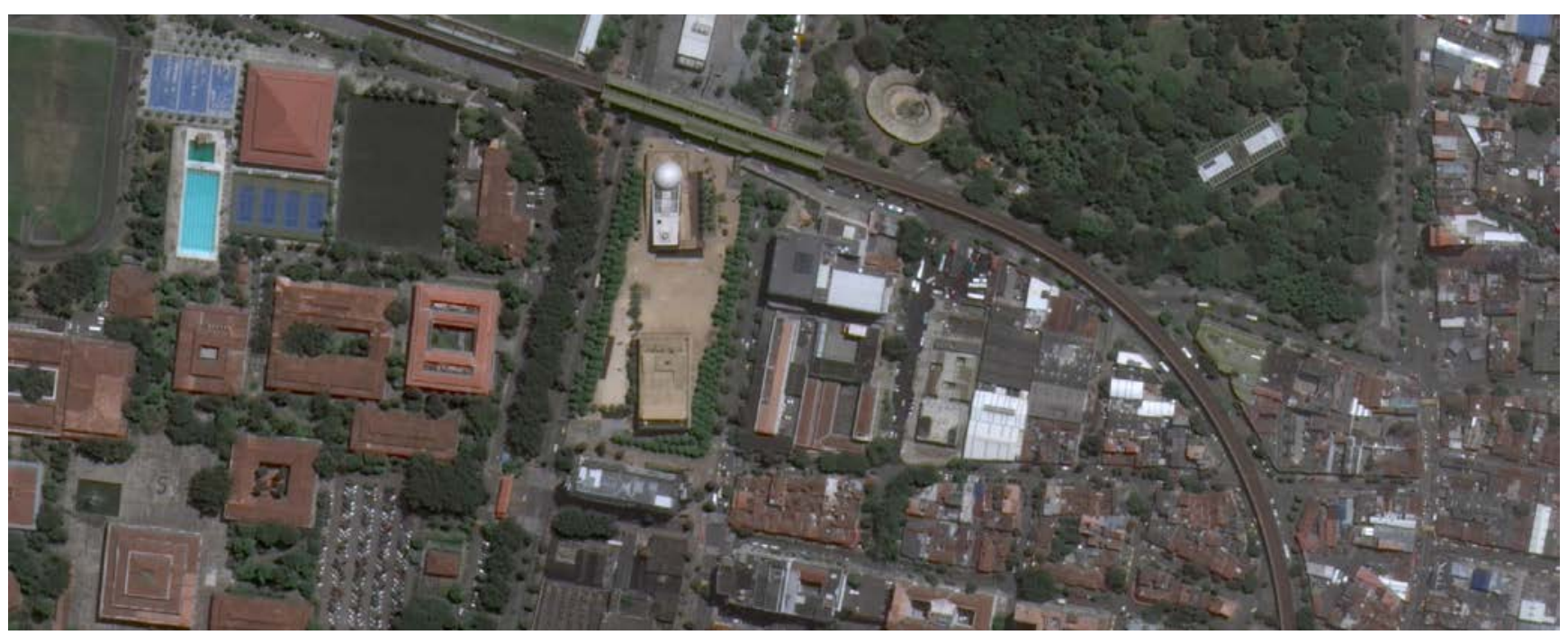

Figura 5.19.6

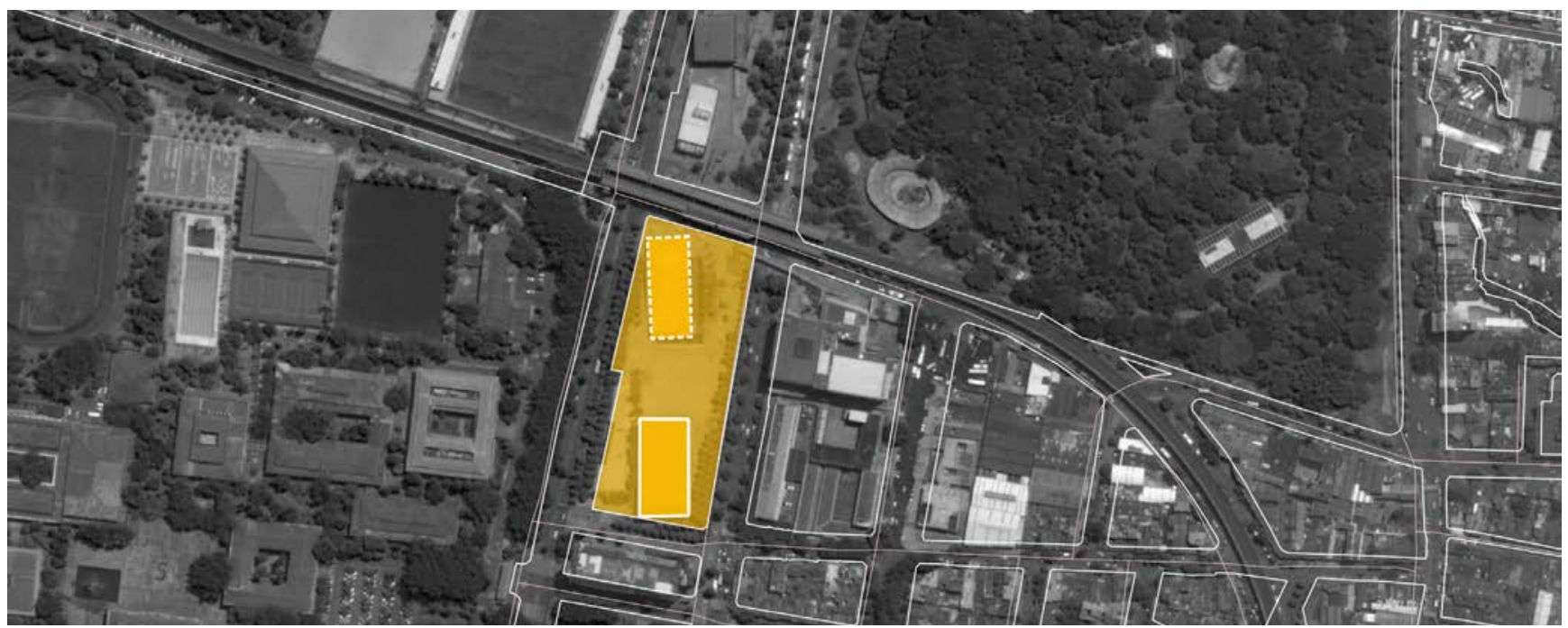

Figura 5.19.7

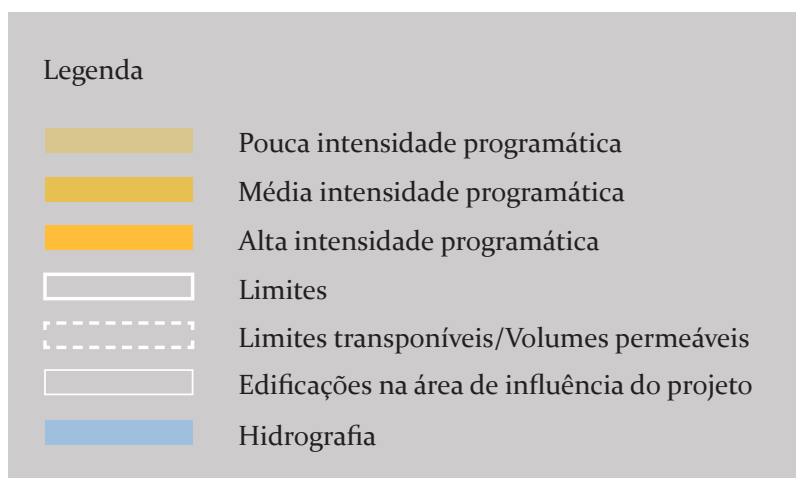

o 


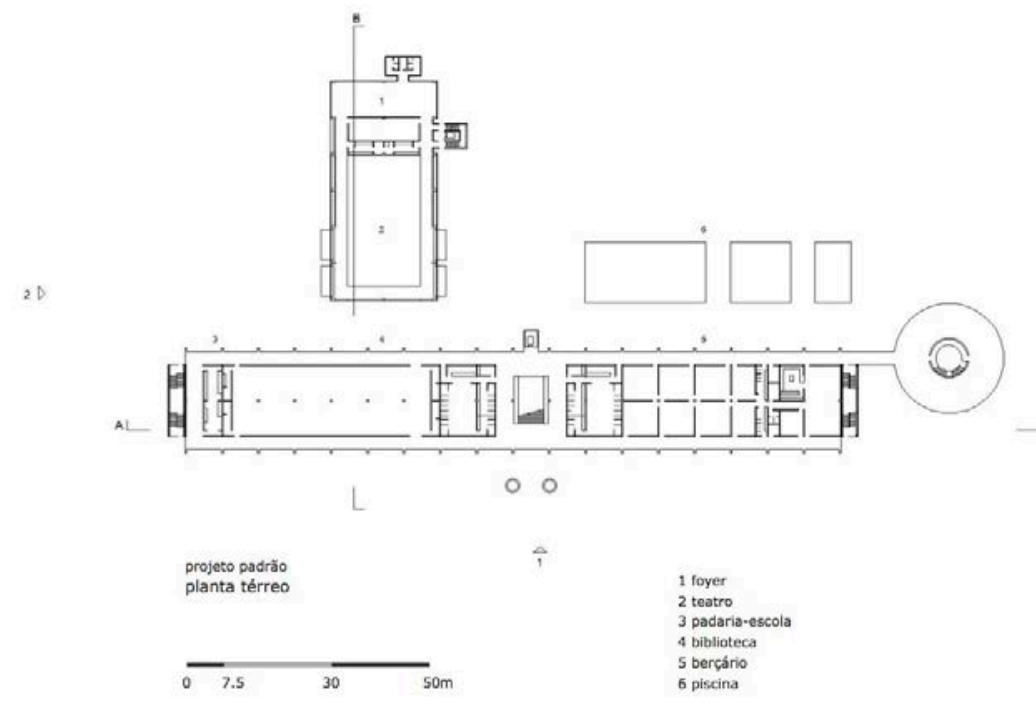

Figura 5.20.1
Projeto padrão

Planta Térreo

Figura 5.20.2

Projeto padrão

Cortes e elevações
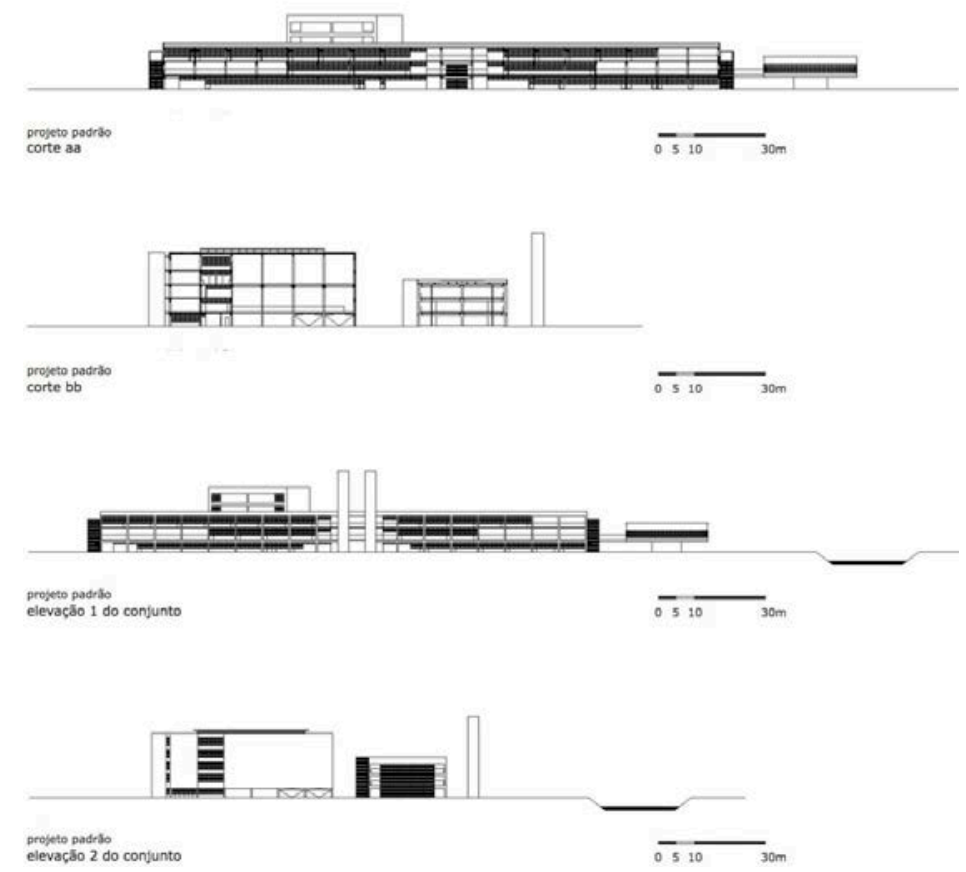

Figura 5.20.3

Figura 5.20.4
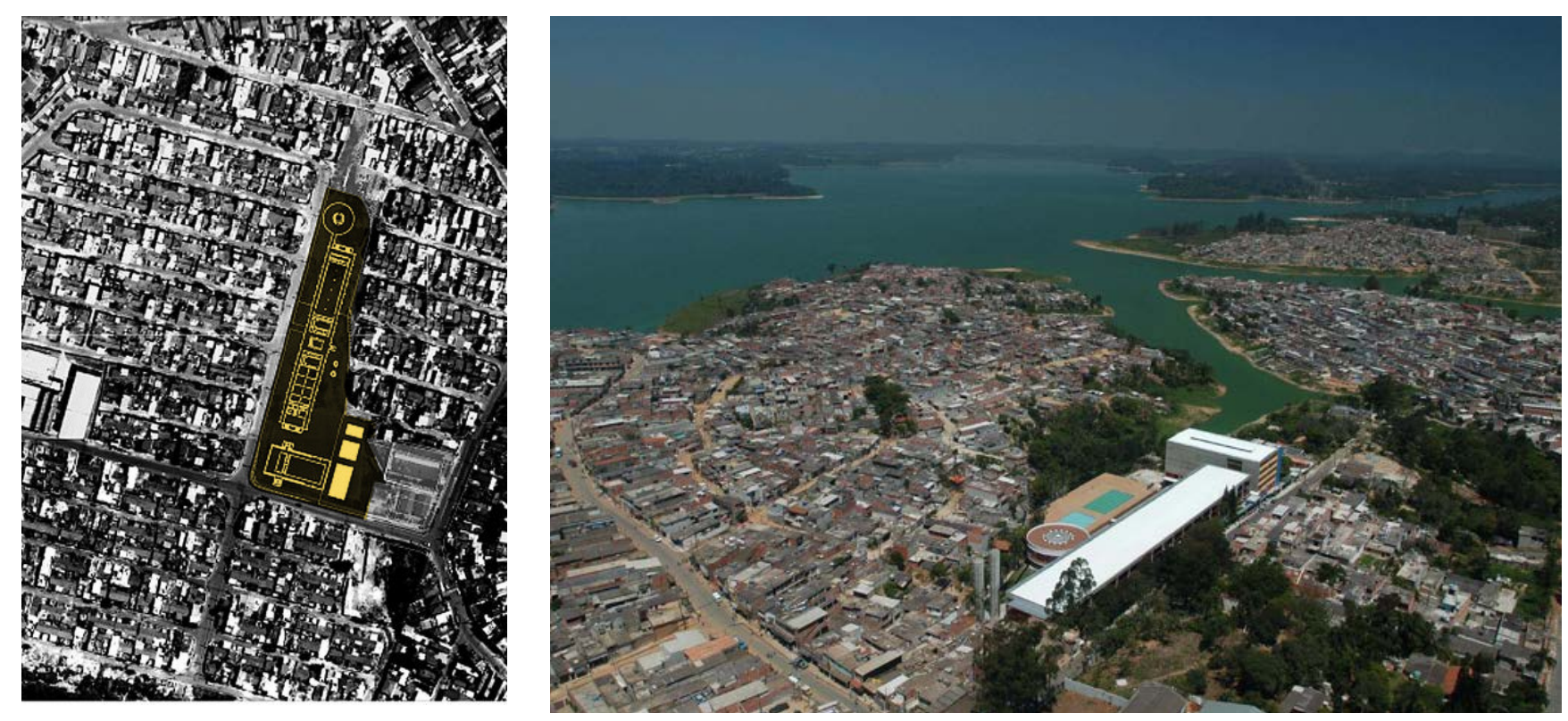


\section{CEU Navegantes}

Autores Alexandre Delijaicov, André Takiya e

Wanderley Ariza

\section{Data do projeto 2001}

Data da construção 2003

Área do lote $14.700 \mathrm{~m}^{2}$

Localização Rua Maria Moassab Barbour, s/n - Parque Residencial Cocaia, São Paulo - SP

Cliente PMSP - Prefeitura Municipal de São Paulo

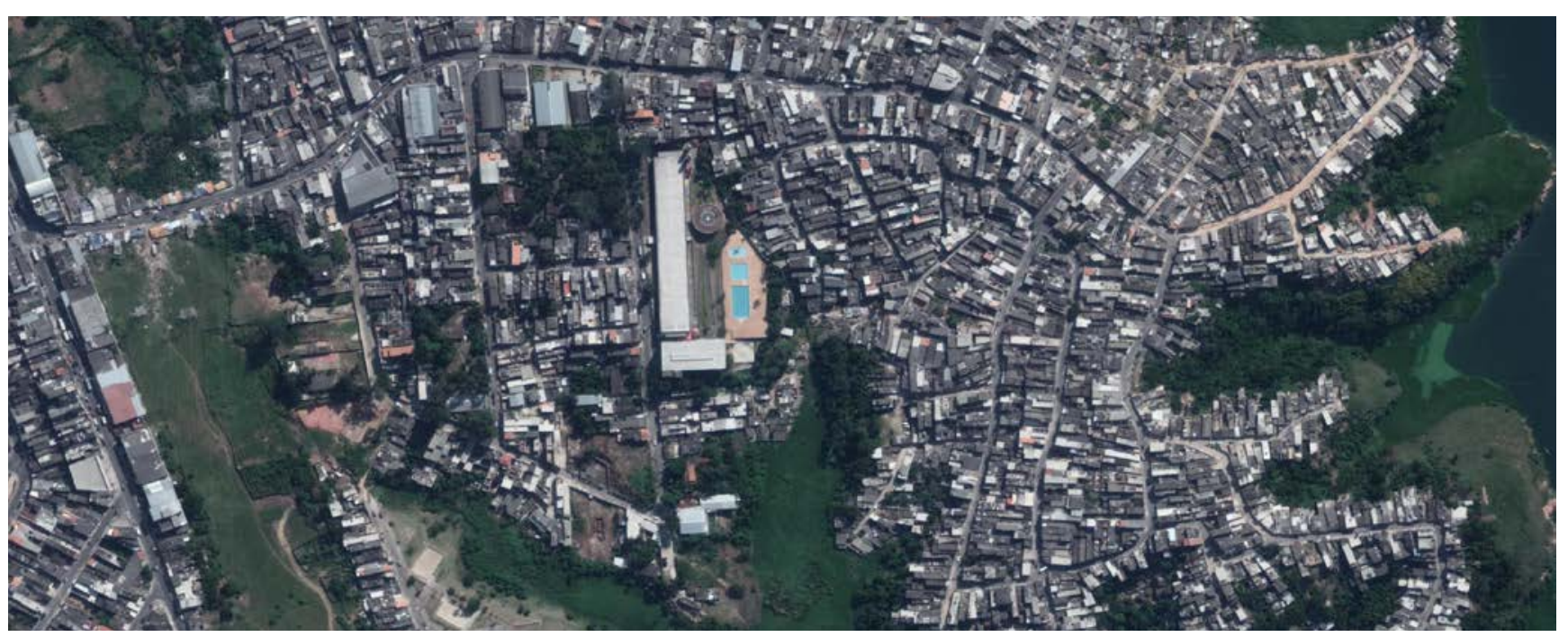

Figura 5.20.5

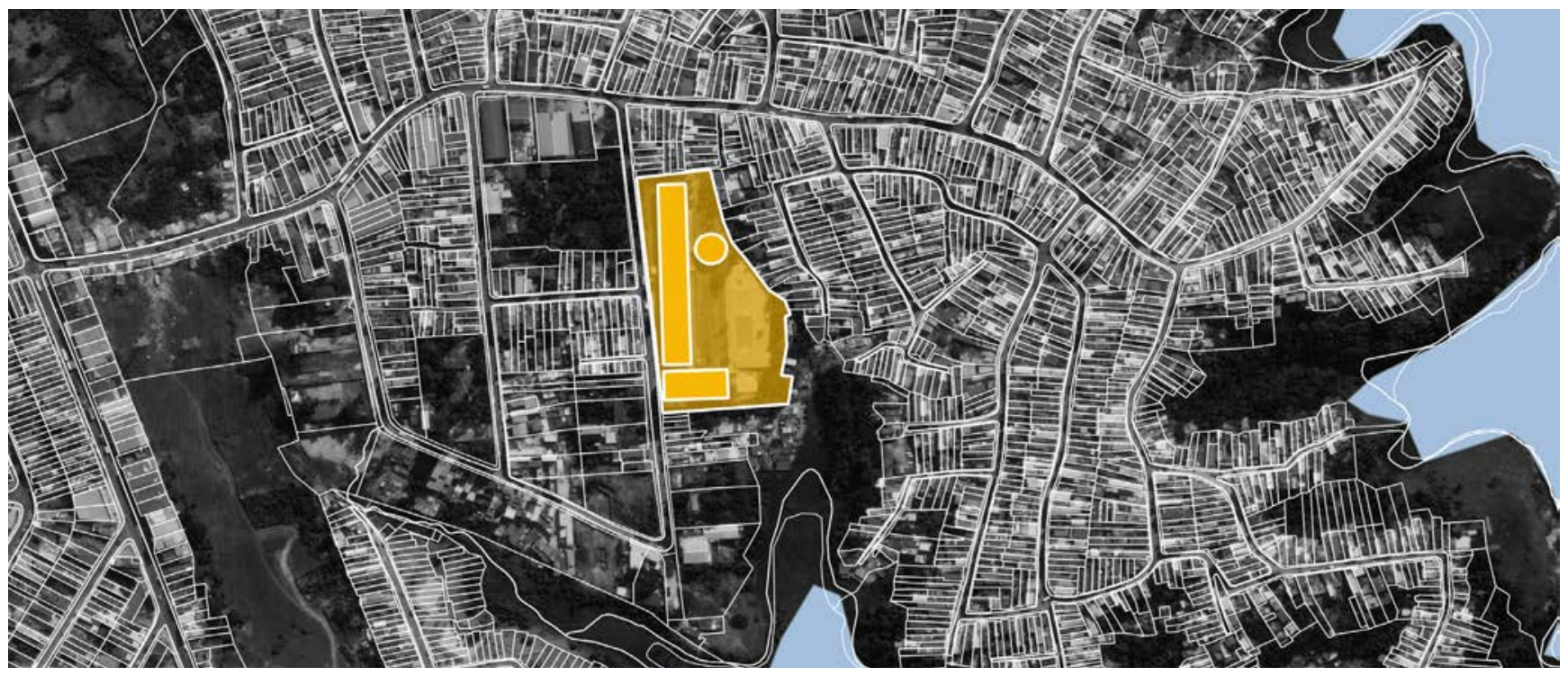

Figura 5.20.6

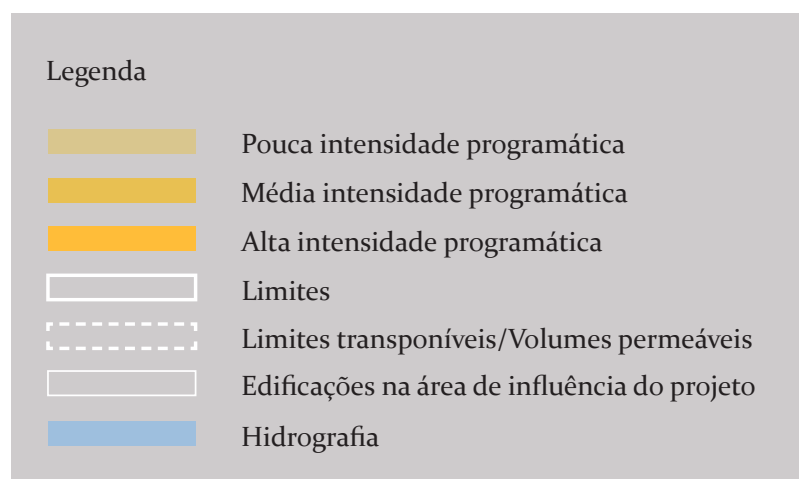



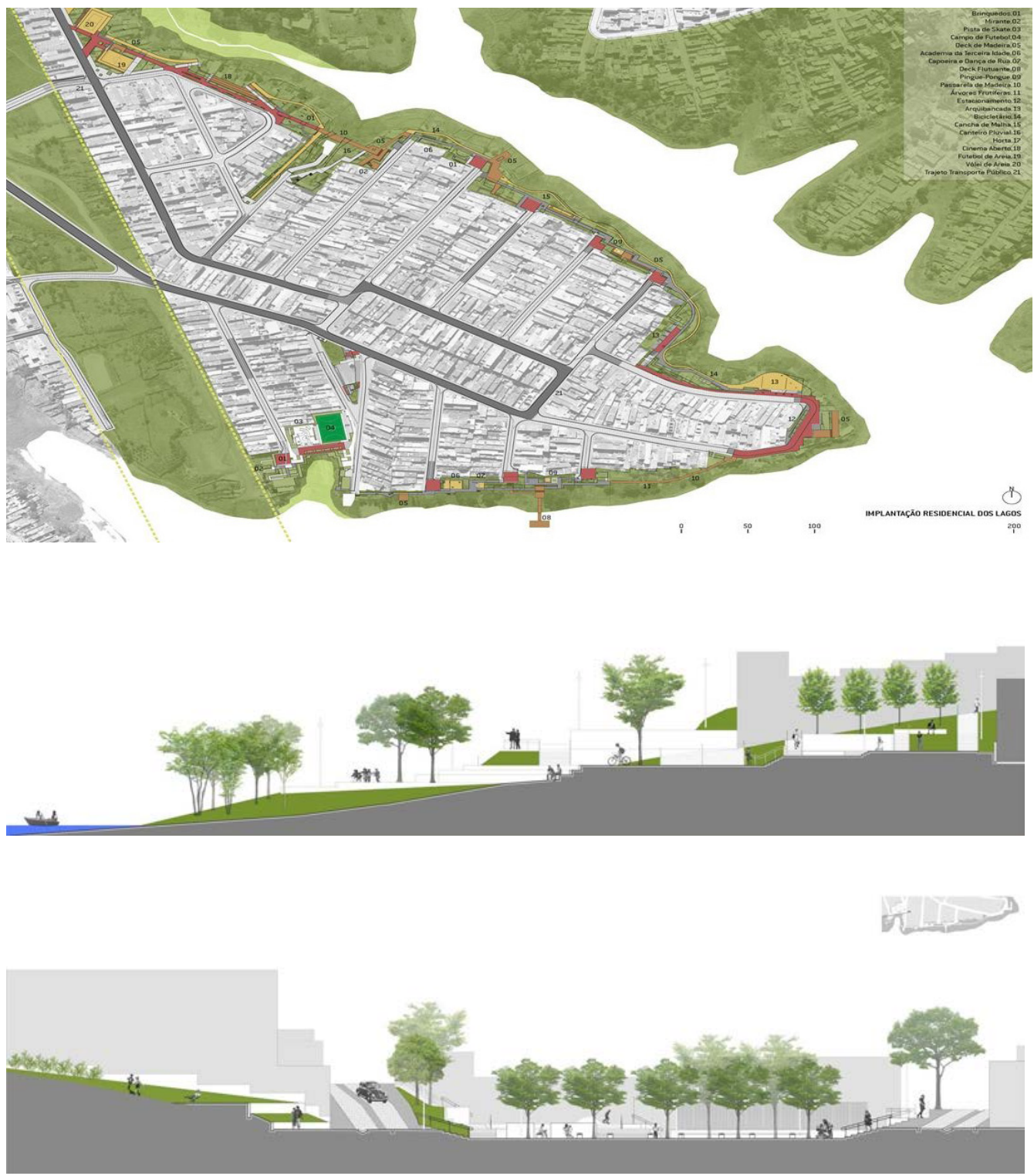

Figura 5.21.1 Implantação

Figura 5.21.2

Corte

Figura 5.21.3

Corte

Figura 5.21.4

Figura 5.21.5
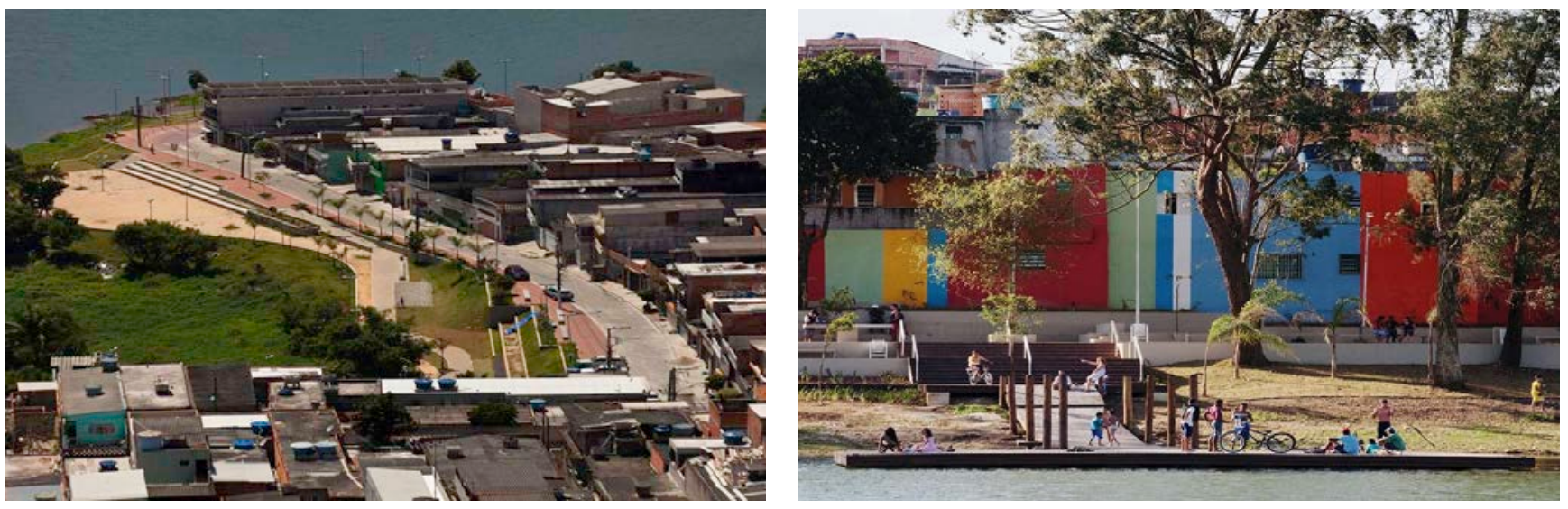


\section{Cantinho do Céu}

Autores Boldarini Arquitetos Associados

Equipe Marcos Boldarini (coordenador), Melissa Matsunaga, Cristiana Salomão, Josiane Viana, Juliana J. Pedroso de Melo, Larissa Reolon dos Santos, Lucas Nobre, Melina Giannoni, Renato Bomfim, Ricardo Falcoski, Sergio Faraulo, Simone Ikeda, (Arquitetos), Maurício Adinolfi (Murais) e consultorias de Suzel Maciel (paisagismo), Wagner Garcia (estruturas de madeira) e George Rotatóri (pista de skate)

\section{Data do projeto 2008}

\section{Data da construção 2011}

Área do lote $1.500 .000 \mathrm{~m}^{2}$

Localização Cantinho do Céu - Grajaú, São Paulo - SP

Cliente PMSP - Prefeitura Municipal de São Paulo

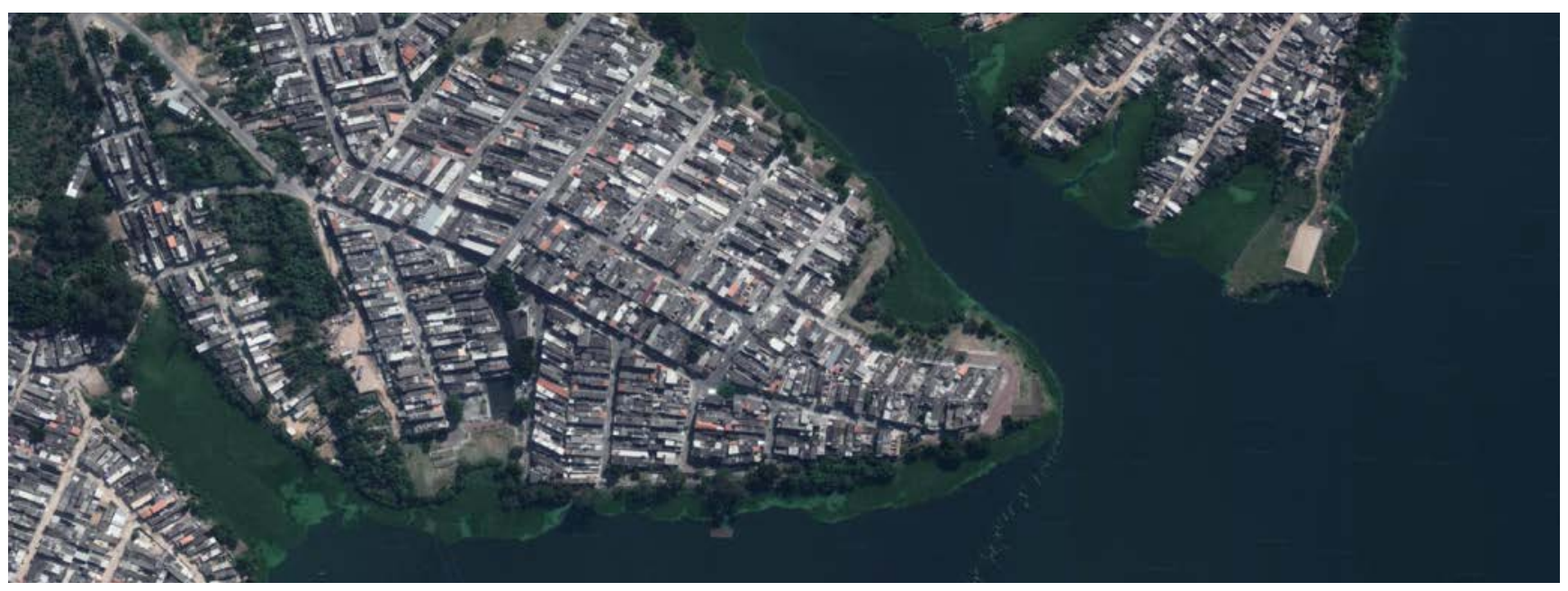

Figura 5.21.6

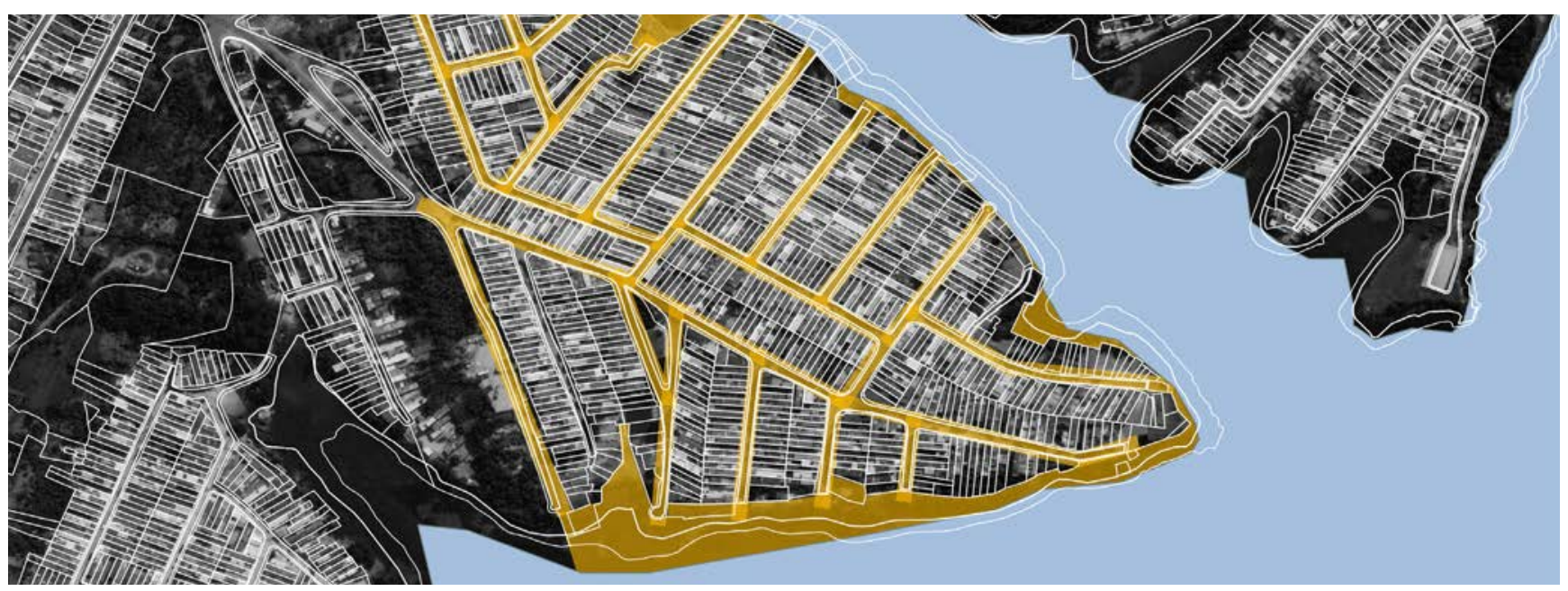

Figura 5.21.7

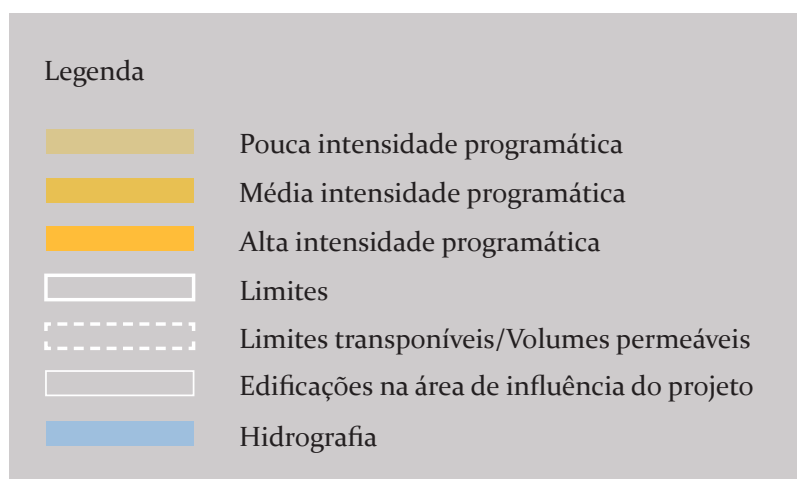




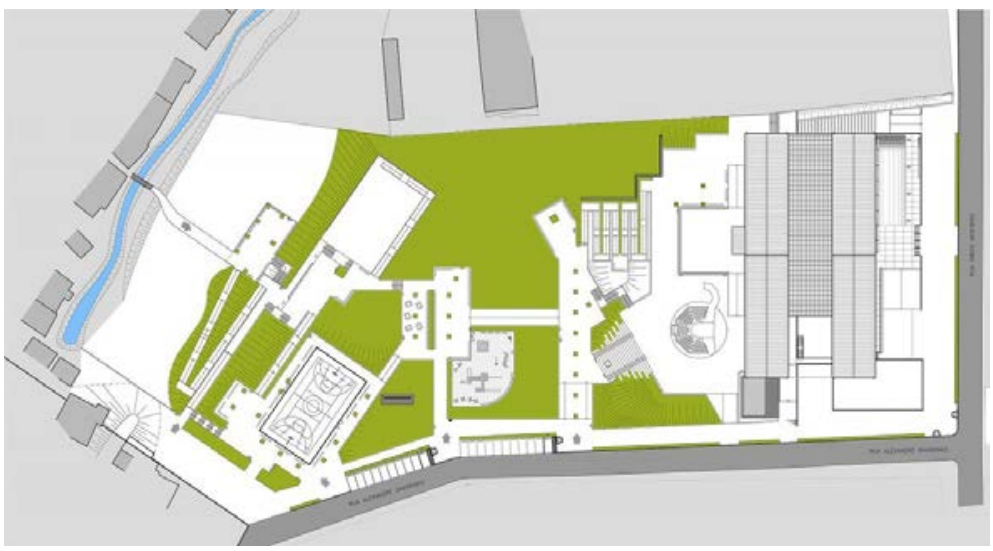

Figura 5.22.1

Implantação

Figura 5.22.2

Corte B

Figura 5.22.3

Corte A
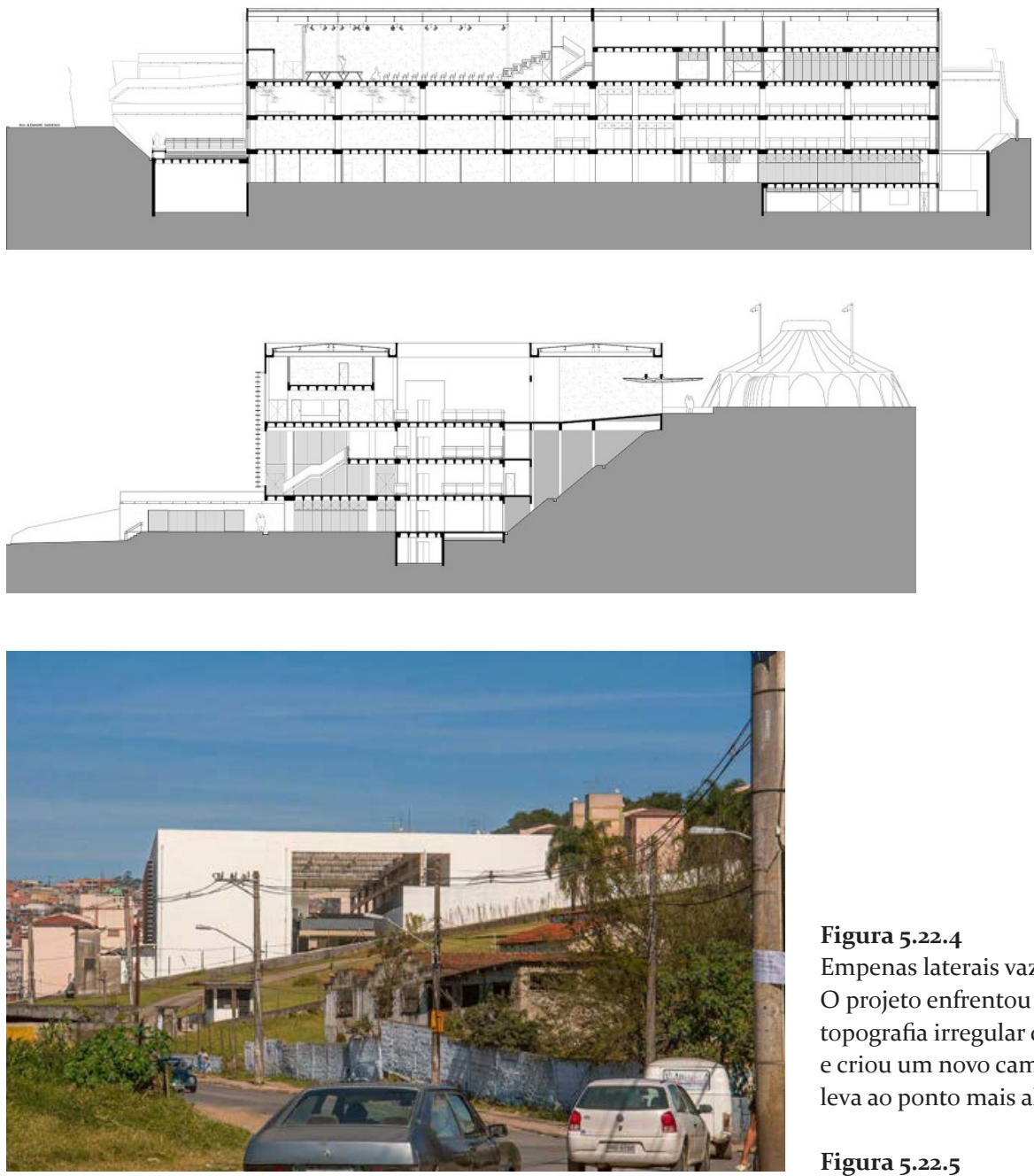

Figura 5.22.4

Empenas laterais vazadas

$O$ projeto enfrentou a

topografia irregular do terreno

e criou um novo caminho que

leva ao ponto mais alto

Figura 5.22.5

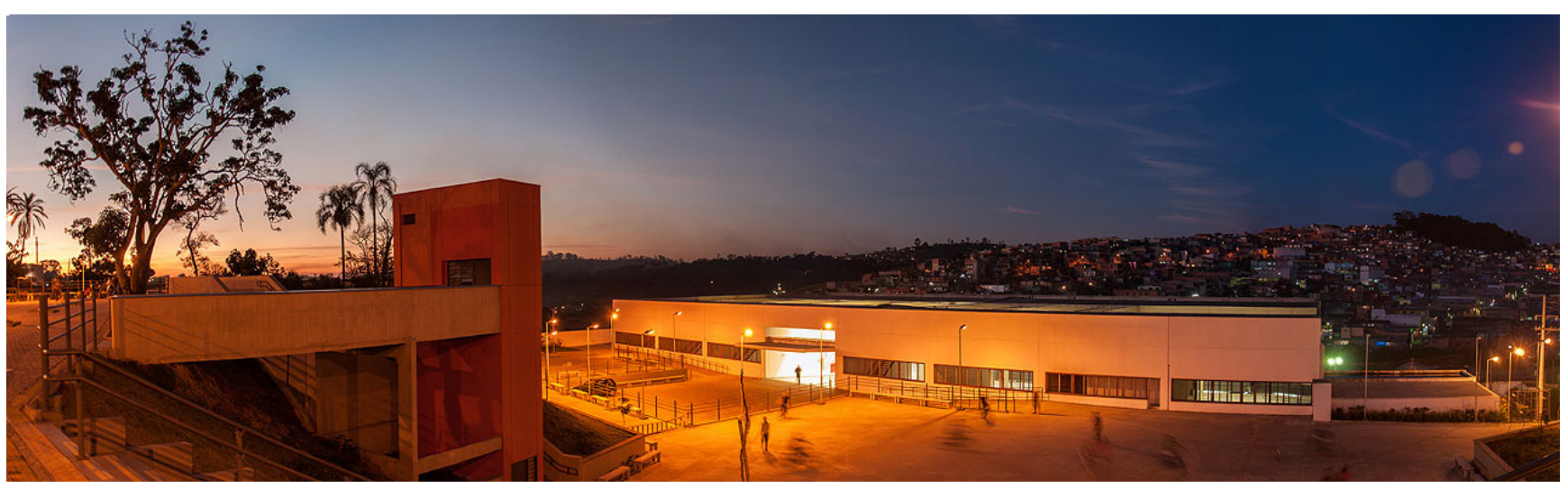




\section{Centro de Formação Cultural Cidade Tiradentes}

Autores José Rollemberg de Mello Filho e Lara Melo Souza

Equipe Hereñu + Ferroni Arquitetos e ODVO Arquitetura e Urbanismo - Omar Dalank
Data do projeto 2005

Data da construção 2012

Área do lote $23.000 \mathrm{~m}^{2}$

Localização Av. Inácio Monteiro, 6900 - Cidade Tiradentes,

São Paulo - SP

Cliente PMSP - Prefeitura Municipal de São Paulo

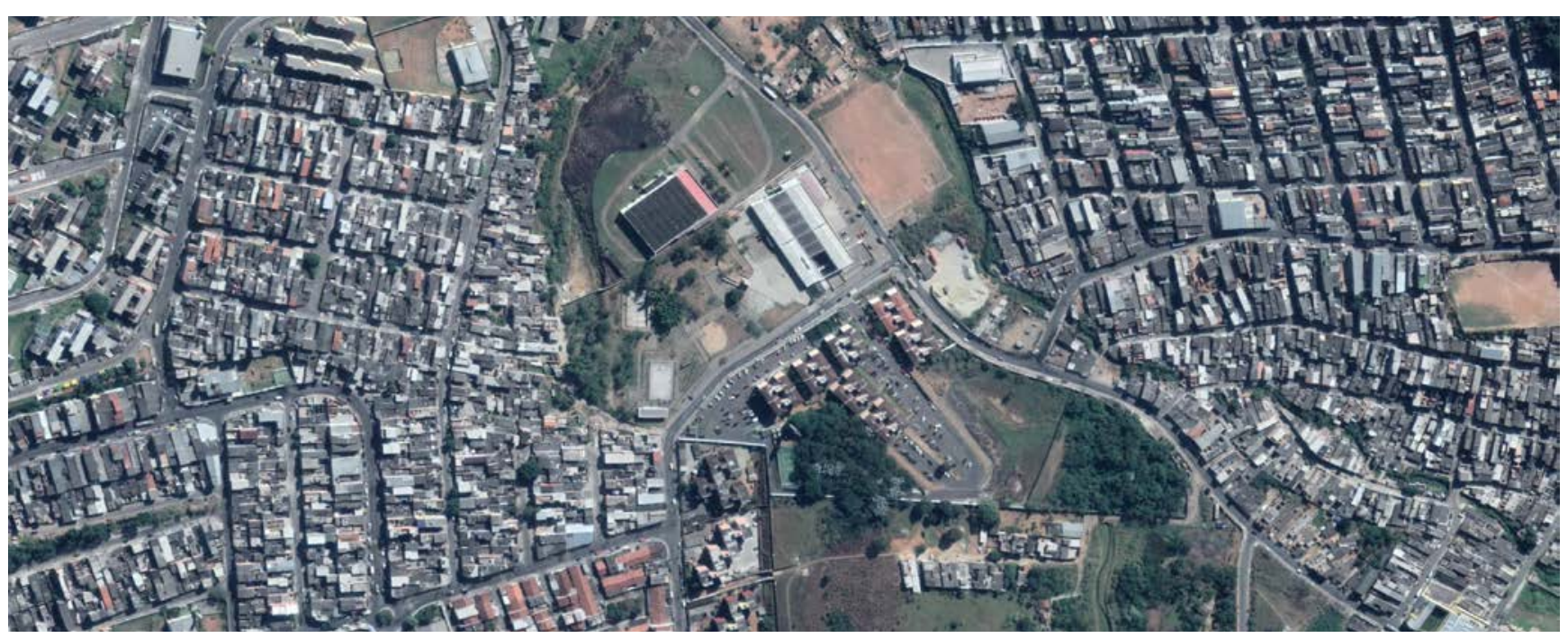

Figura 5.22.6

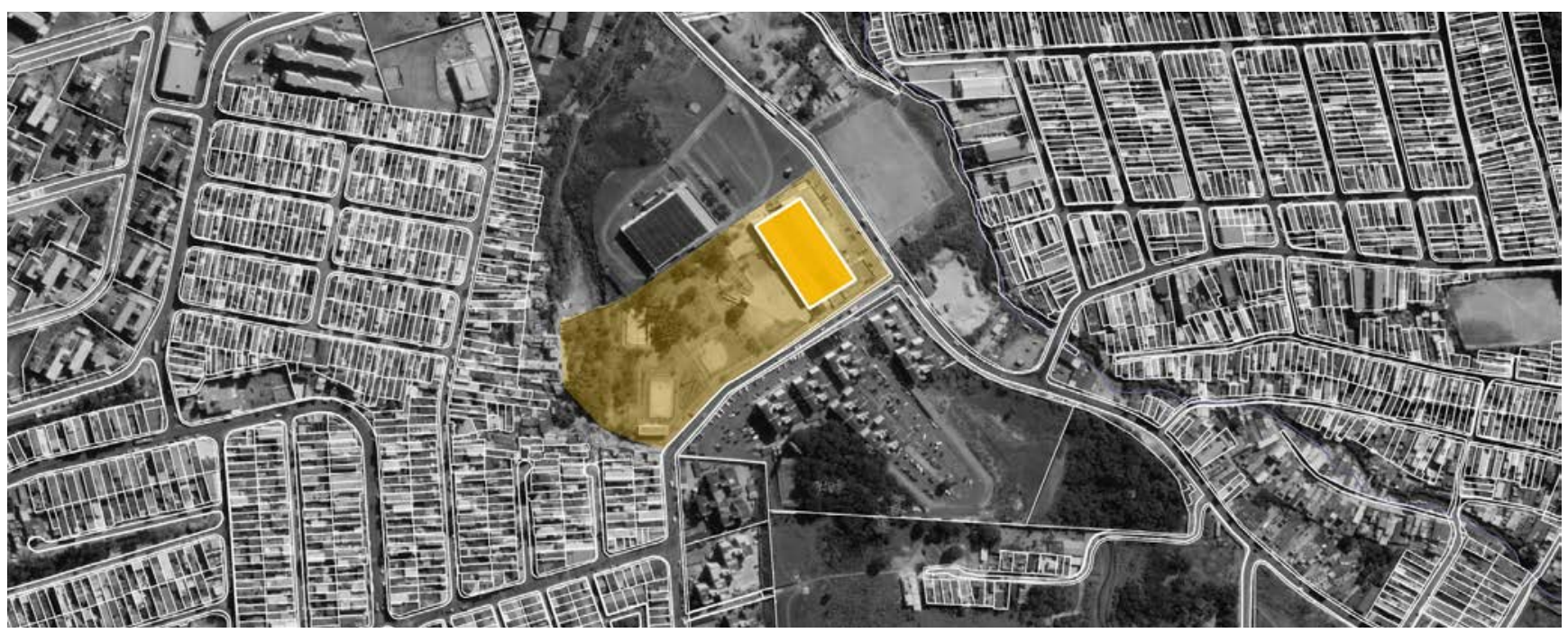

Figura 5.22.7

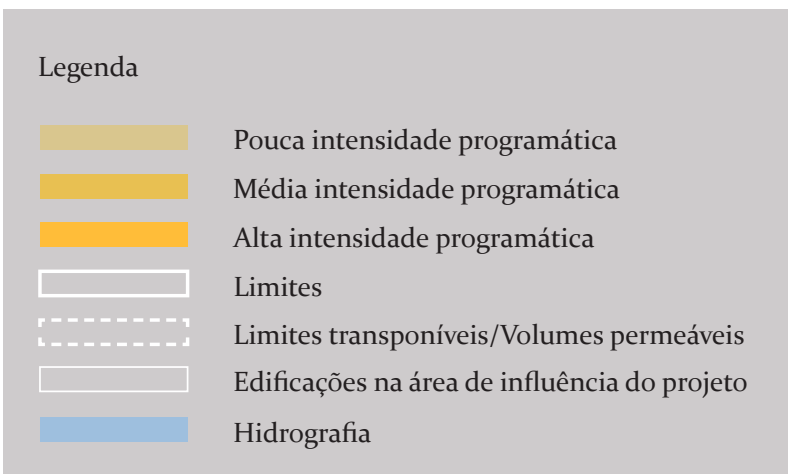

100 


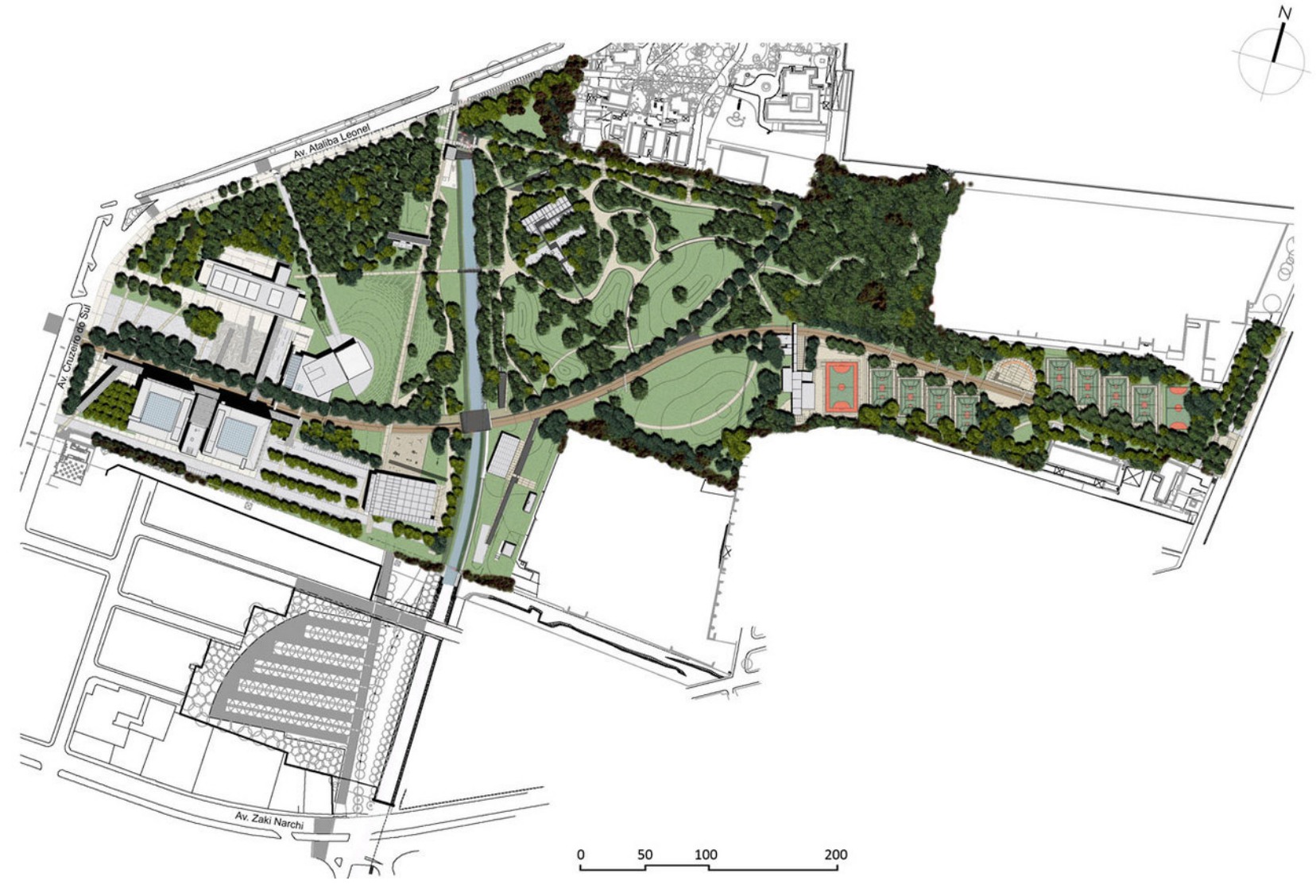

Figura 5.23.1

Figura 5.23.2

Figura 5.23.3
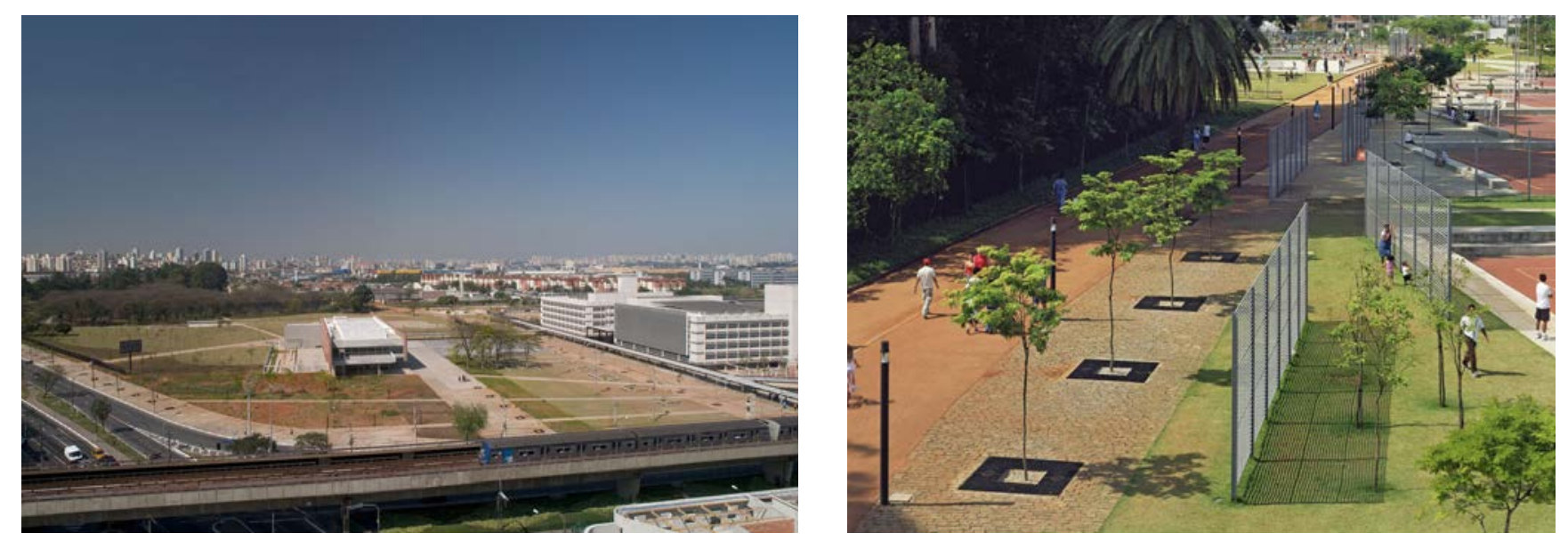


\section{Parque da Juventude}

Autores Aflalo Gasperini Arquitetos

Equipe Gian Carlo Gasperini, Roberto Aflalo Filho e Luiz Felipe Aflalo Herman (autores), Eduardo Martins Ferreira, Takuji Nakashima (coordenadores gerais), Fátima Moreira ( cordenadora Teatro e Exposições), Aquiles Accocella, André becker, André Bezerra de Mello, Ana Raquel Pionti, Aleksander Marcello Braz, Bruno Luchese, Fabiano Sinibaldi, Flavio Garcia, Juliana Garcias, Maria Paula Seixas, Meire Negami, Mirela Rezze, Paulo Katz,
Raquel Valdivia, Rebeca Perrella, Regis Okusako, Robison Keith Yonegura, Rodrigo Sobreiro, Karen (arquitetos), Jonatas Olim, Pamela Sarabia (estagiários)

\section{Data do projeto 1999}

\section{Data da construção 2007}

Área do lote $240.000 \mathrm{~m}^{2}$

Localização Av. Cruzeiro do Sul, 2630 - Carandiru, São Paulo - SP

Cliente Governo do Estado de São Paulo

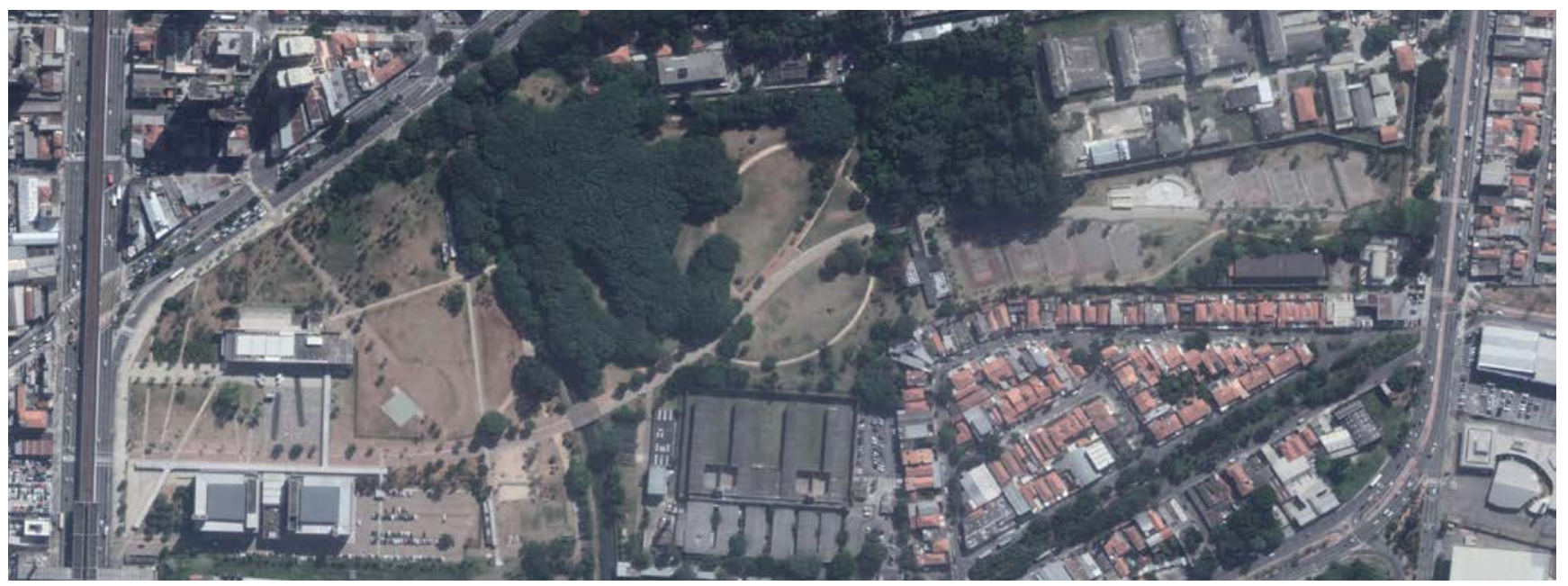

Figura 5.23.4

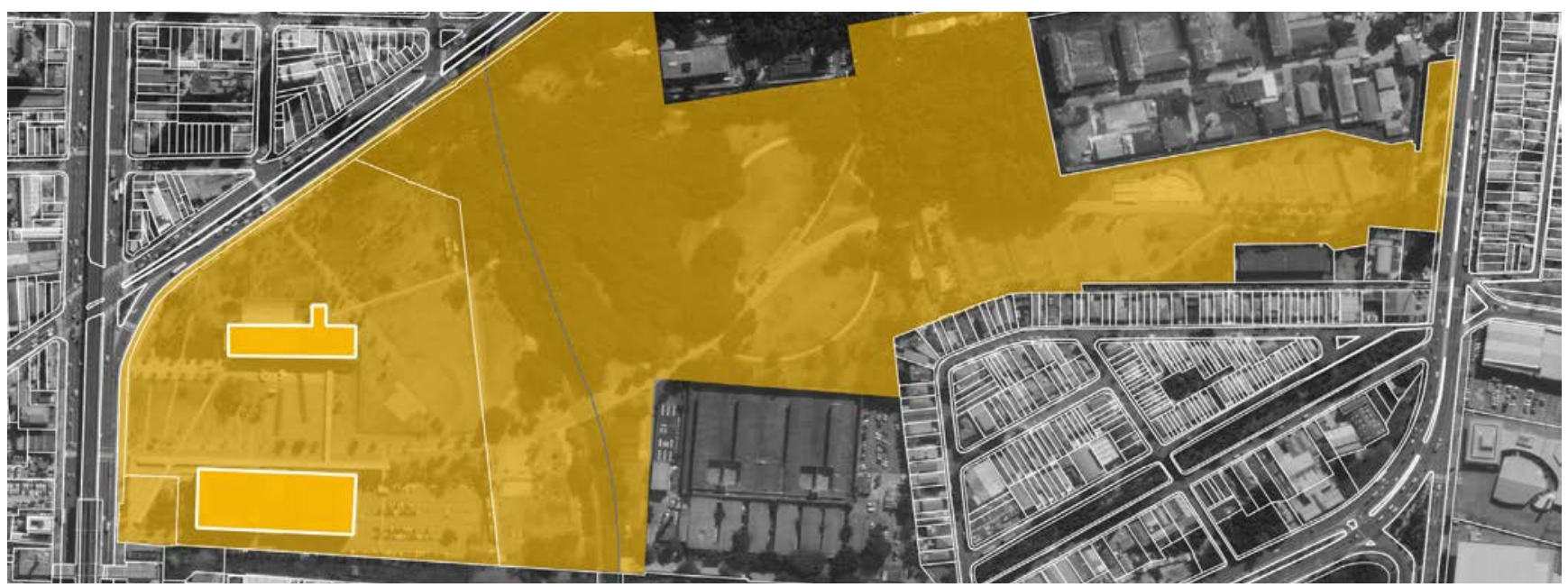

Figura 5.23.5

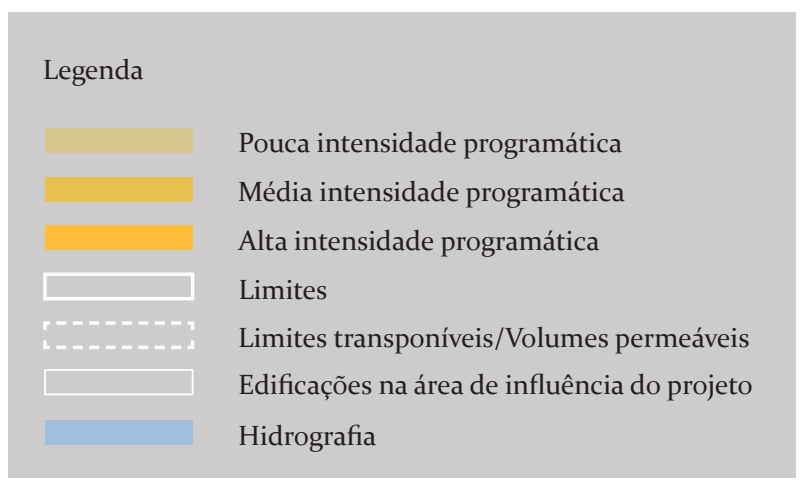




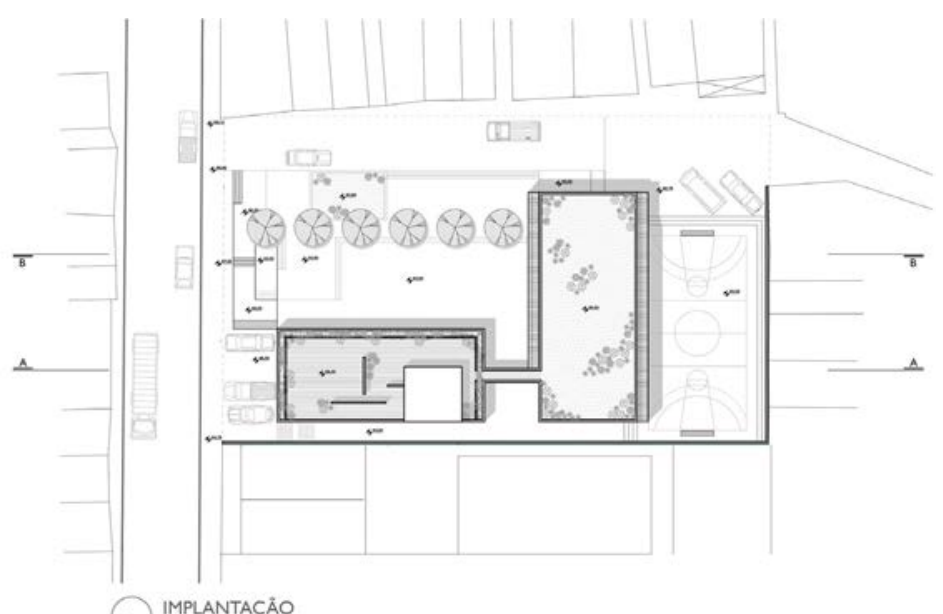

Figura 5.24.1

Implantação

Figura 5.24.2

Cortes longitudinais

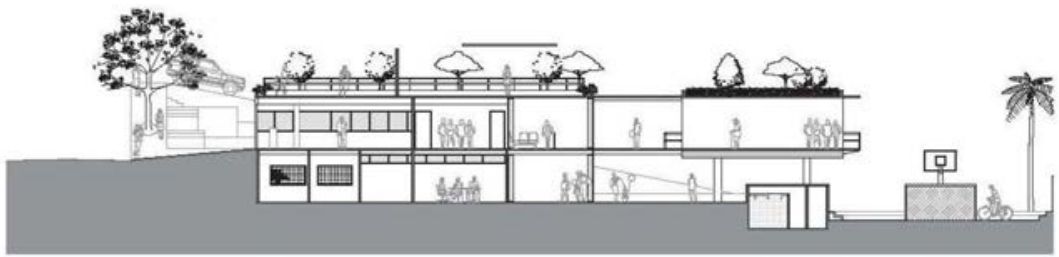

Corte Longitudinal 01

$\overline{0246} 10 \mathrm{~m}$

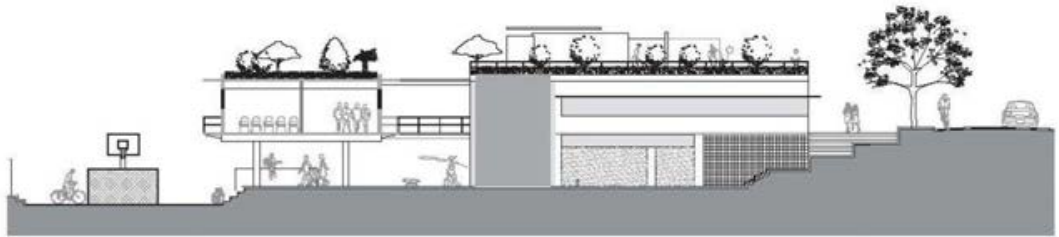

Corte Longitudinal 02

Figura 5.24.3

Figura 5.24.4
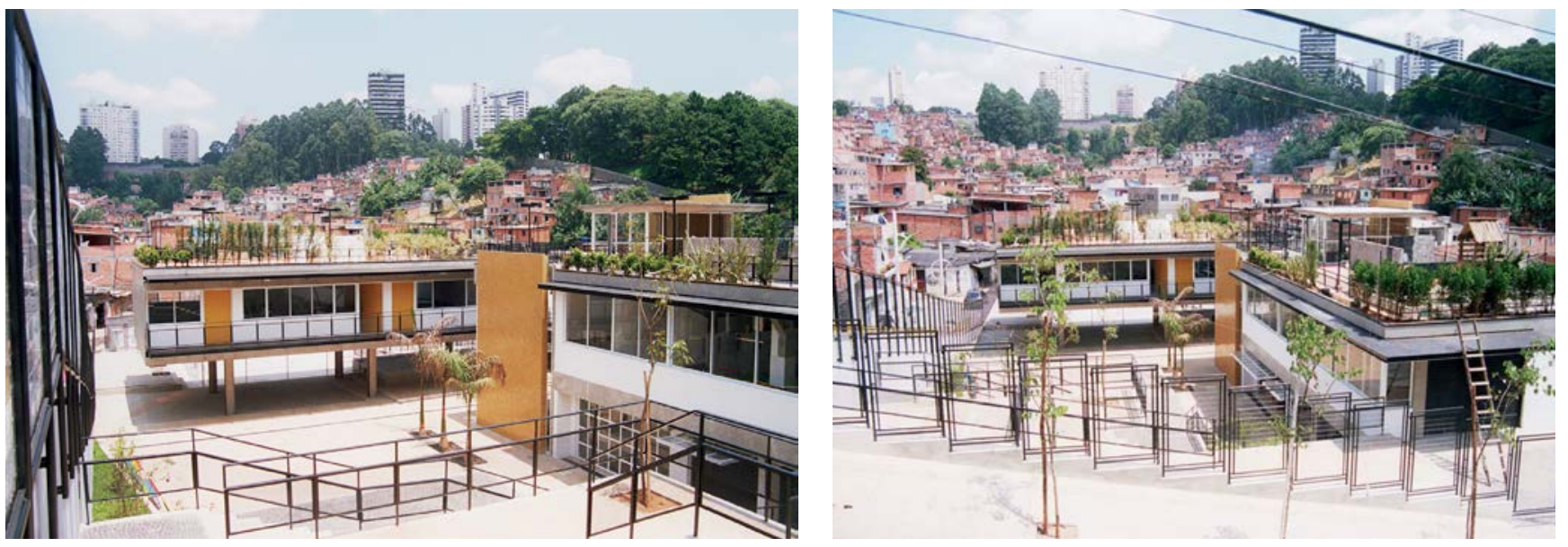


\section{Projeto Viver}

Autores FGMF Arquitetos

Equipe Autores: Fernando Forte, Lourenço Gimenes, Rodrigo

Marcondes Ferraz. Colaboradores: Marília Caetano, Cecília Reichstul

\section{Data do projeto 2003}

Data da construção 2006

Área do lote $1.500 \mathrm{~m}^{2}$

Localização Favela do Jardim Colombo - São Paulo, SPr

Cliente ONG - Associação Viver em Família

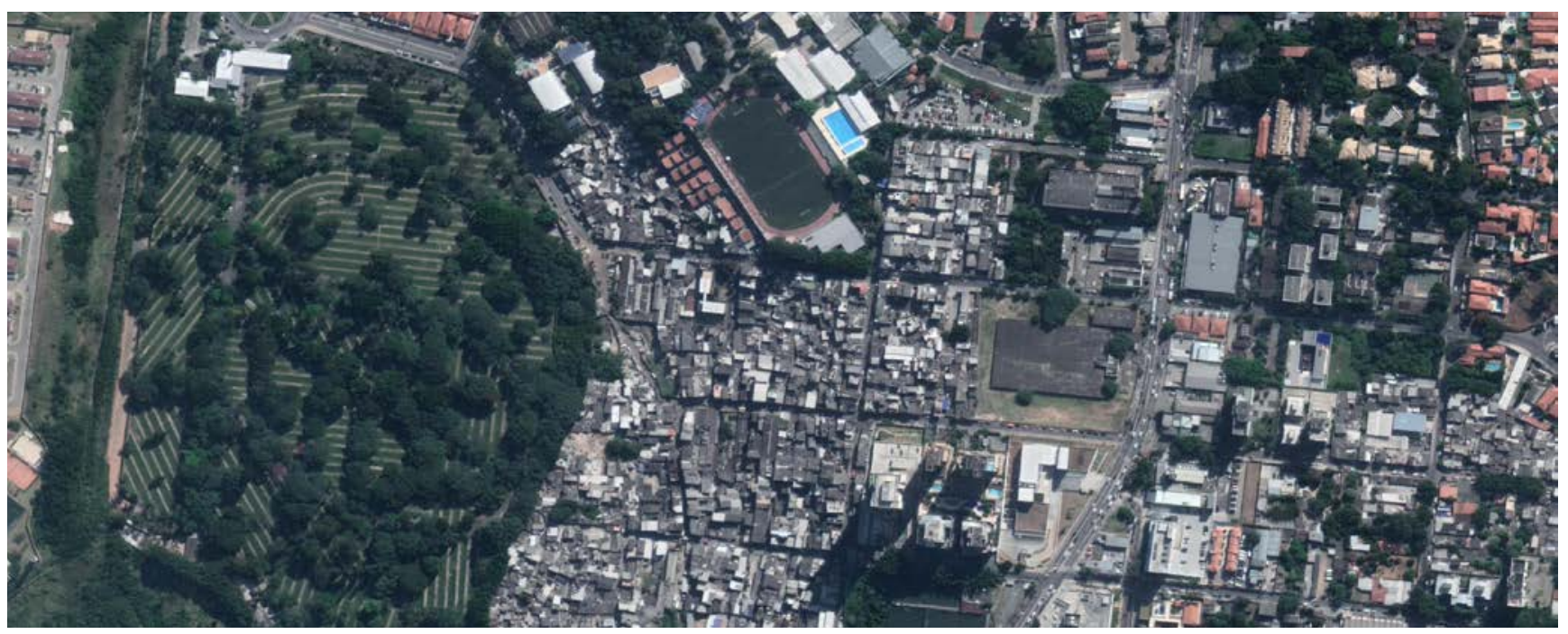

Figura 5.24.5

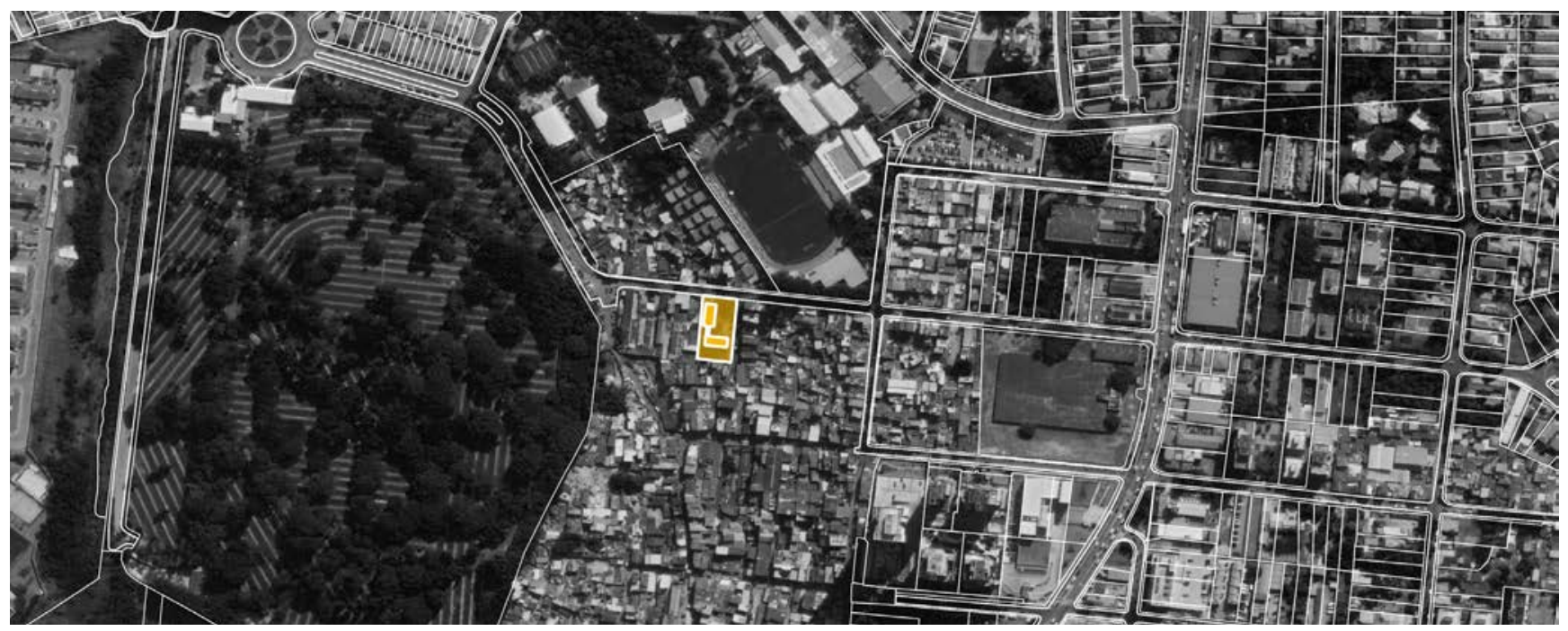

Figura 5.24.6

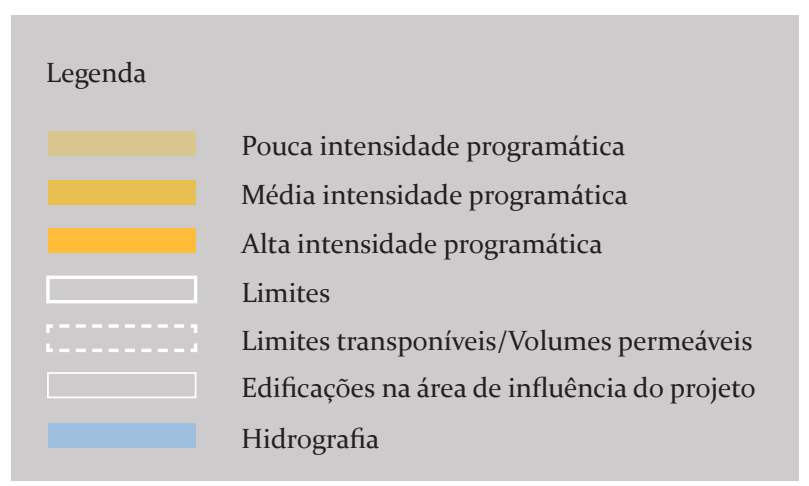

o 

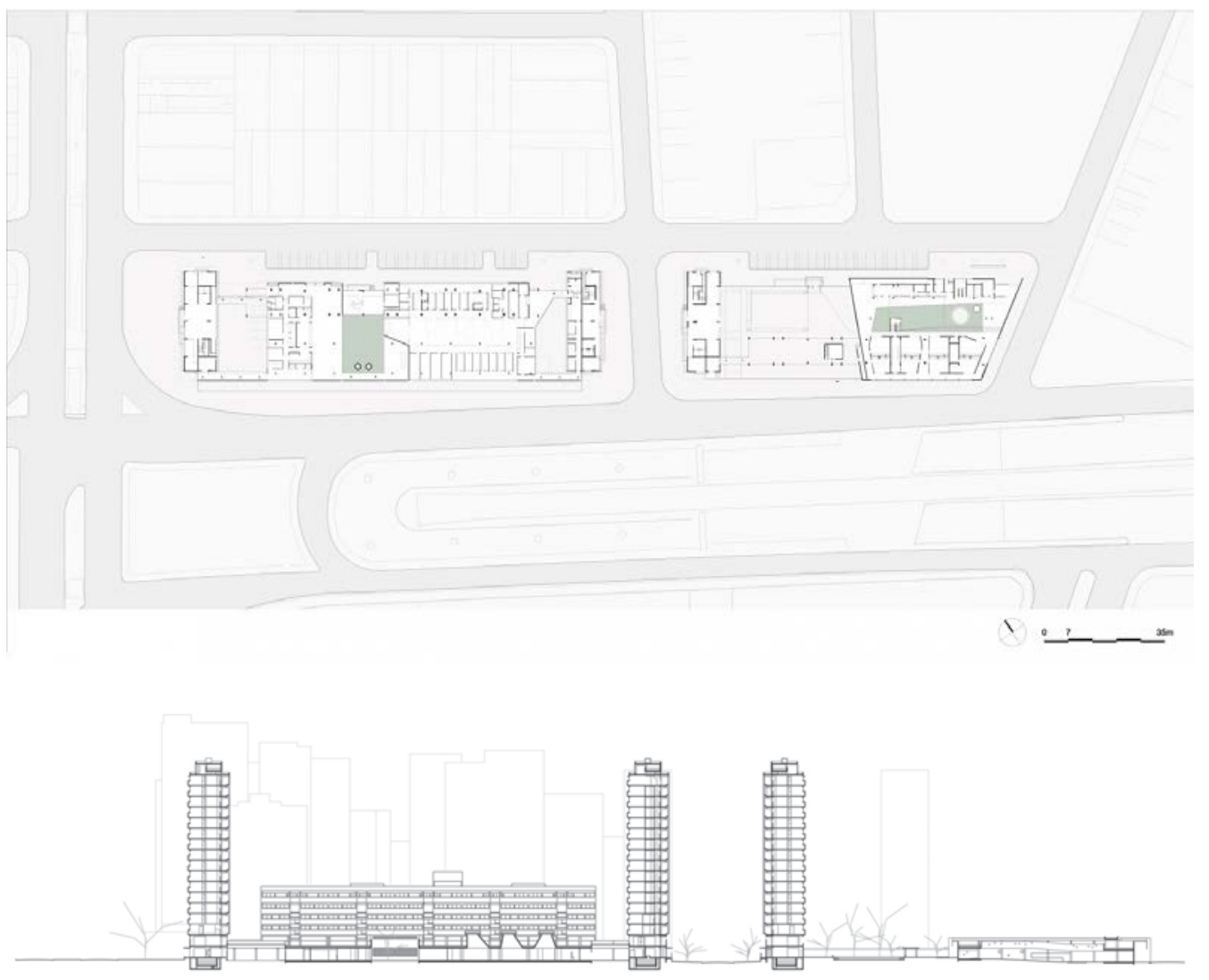

Figura 5.25.1

Térreo

Figura 5.25.2

Corte longitudinal

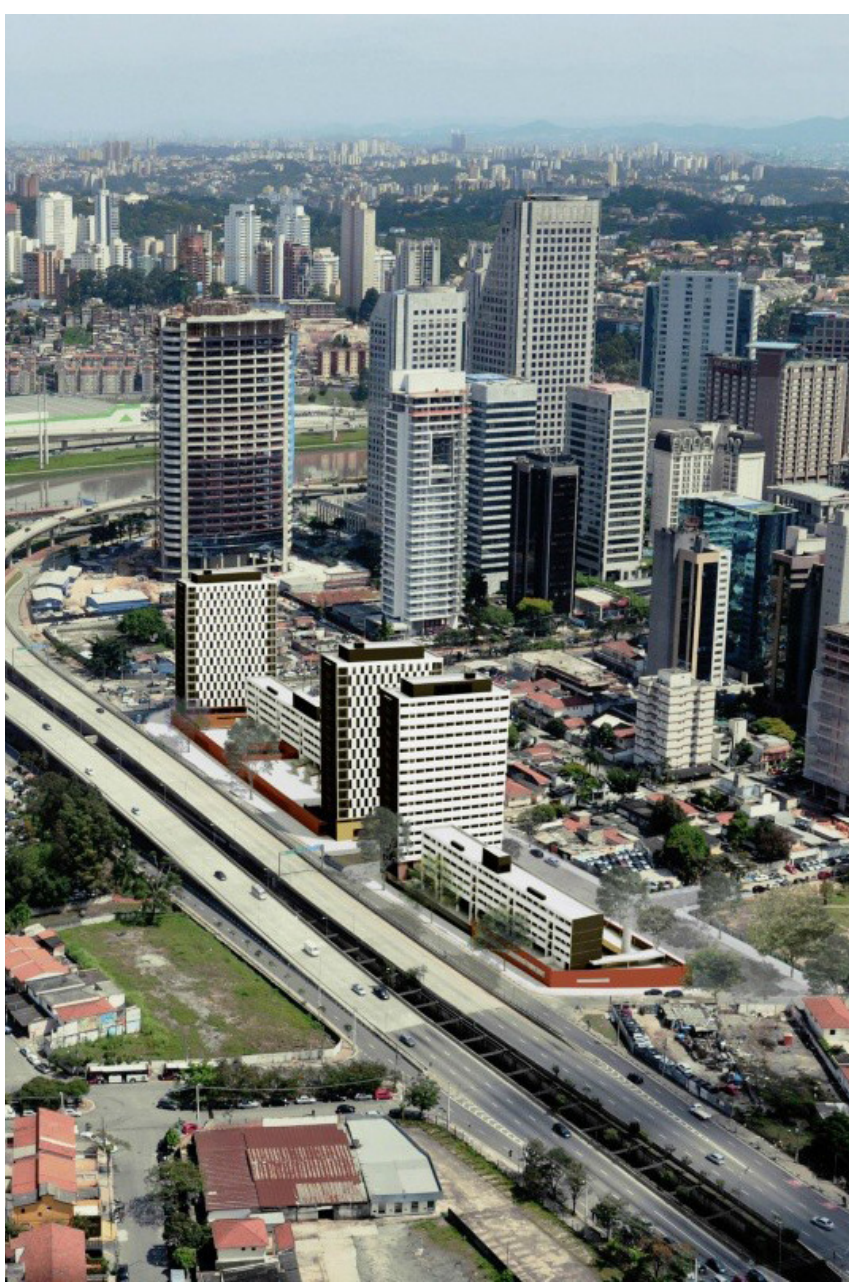

Figura 5.25.3

Figura 5.25.4

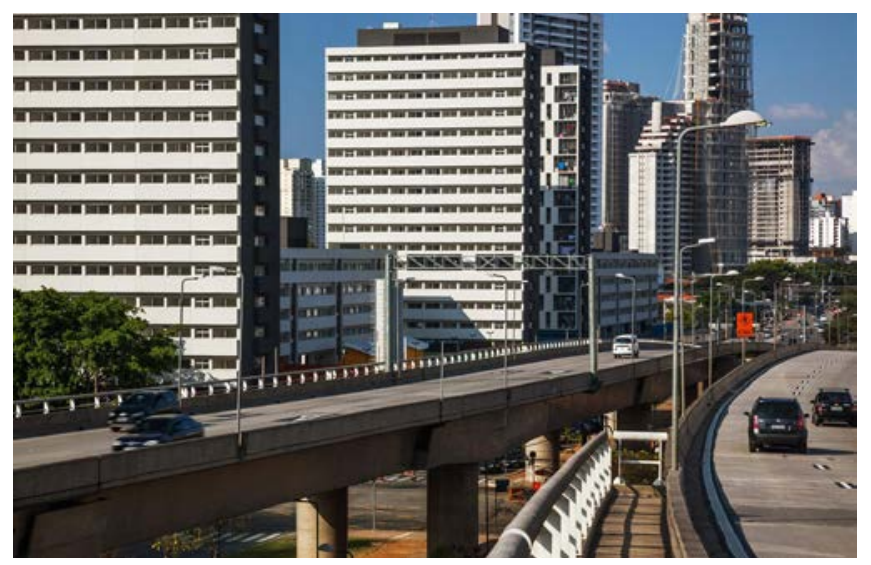




\section{Jardim Edite}

Autores MMBB Arquitetos $+\mathrm{H}+\mathrm{F}$ Arquitetos

Equipe Arquitetos MMBB: Marta Moreira, Milton Braga e

Fernando de Mello Franco. Arquitetos H+F: Eduardo Ferroni e Pablo Hereñú

\section{Data do projeto 2008}

Data da construção 2013

Área construída $25.714 \mathrm{~m}^{2}$

Localização Av. Engenheiro Luís Carlos Berrini - Itaim Bibi, São Paulo - SP

Cliente PMSP - Prefeitura Municipal de São Paulo, SEHAB - Secretaria de Habitação e SMDU - Secretaria de Desenvolvimento Urbano

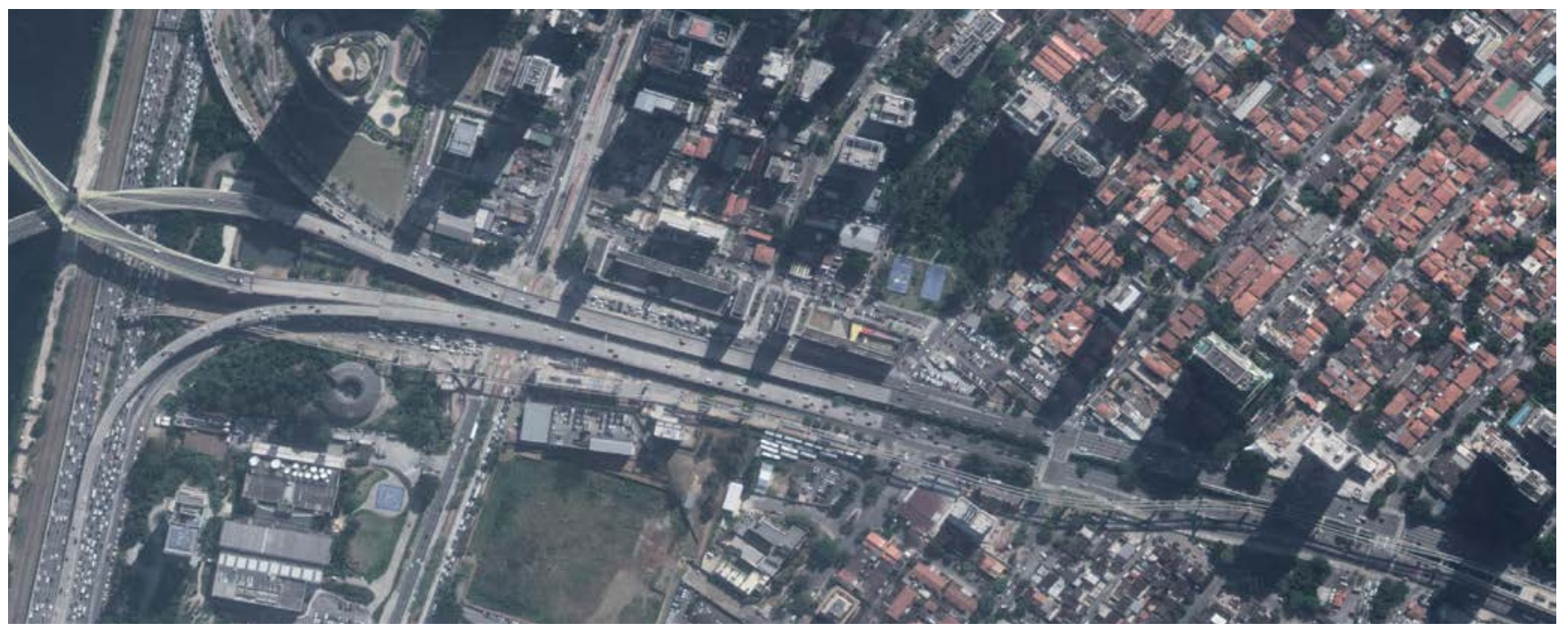

Figura 5.25.5

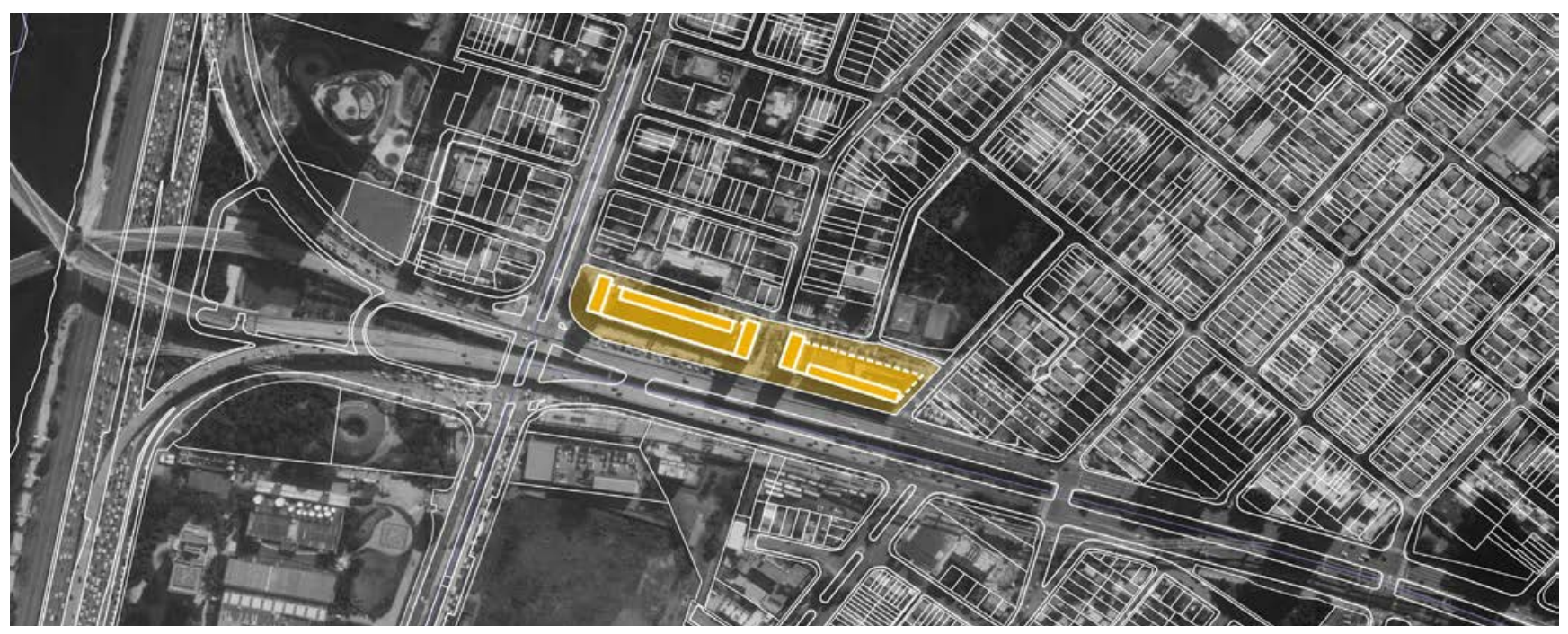

Figura 5.25.6

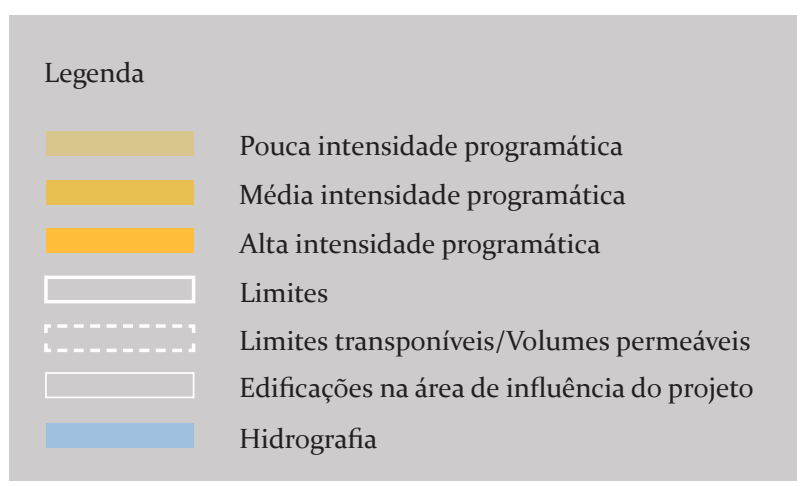



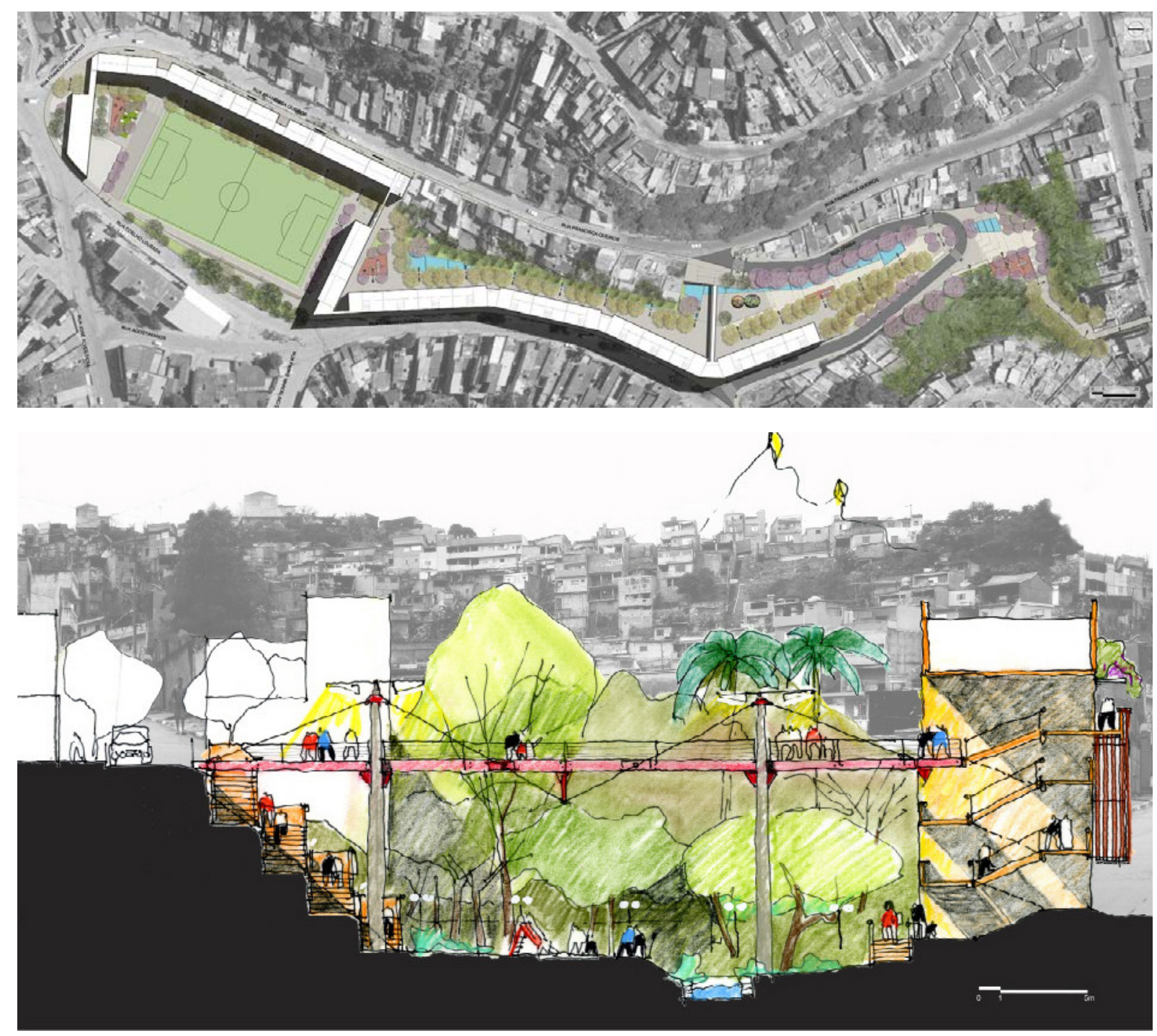

Figura 5.26.1

Implantação

Figura 5.26.2

Croqui

Figura 5.26.3

Figura 5.26.4
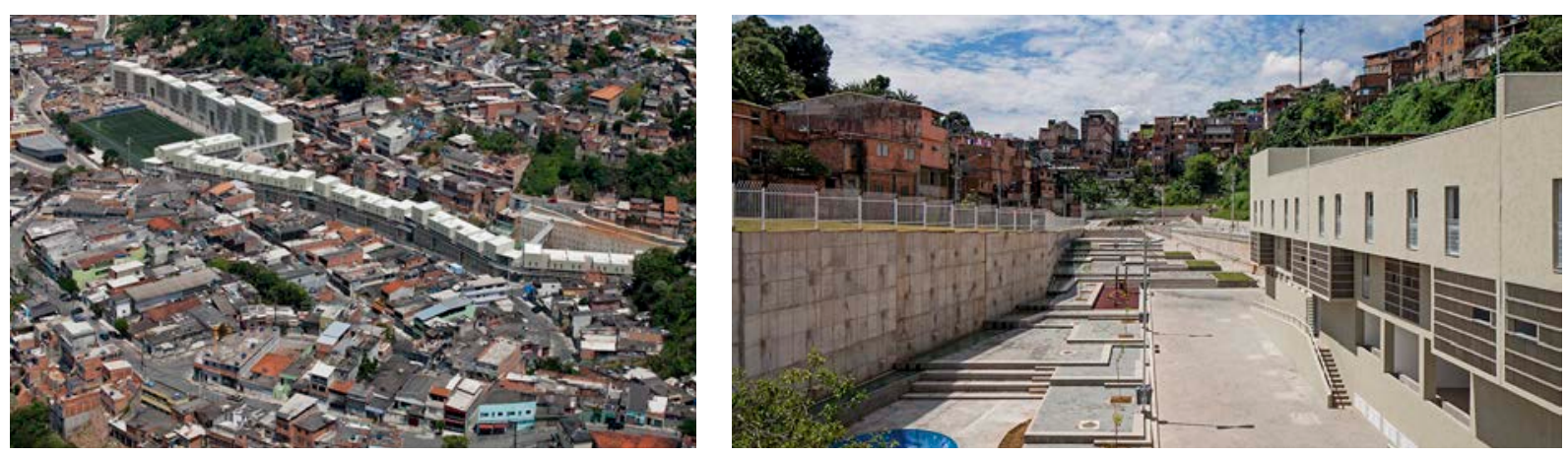


\section{Parque Novo Santo Amaro V}

Autores Viglieca\&Associados

Equipe Héctor Vigliecca, Luciene Quel, Neli Shimizu, Ronald Werner, Caroline Bertoldi, Kelly Bozzato, Pedro Ichimaru, Bianca Riotto, Mayara Rocha Christ, Fábio Pittas, Thaísa Fróes, Aline Ollertz, Sérgio Faraulo, Paulo Serra, Luci Maie

\section{Data do projeto 2009}

Data da construção 2012

Área do lote $21.900 \mathrm{~m}^{2}$

Localização Rua Zâmbia - Parque Independencia, São Paulo - SP, Brasil

Cliente PMSP - Prefeitura Municipal de São Paulo / SEHAB - Secretaria de Habitação de São Paulo

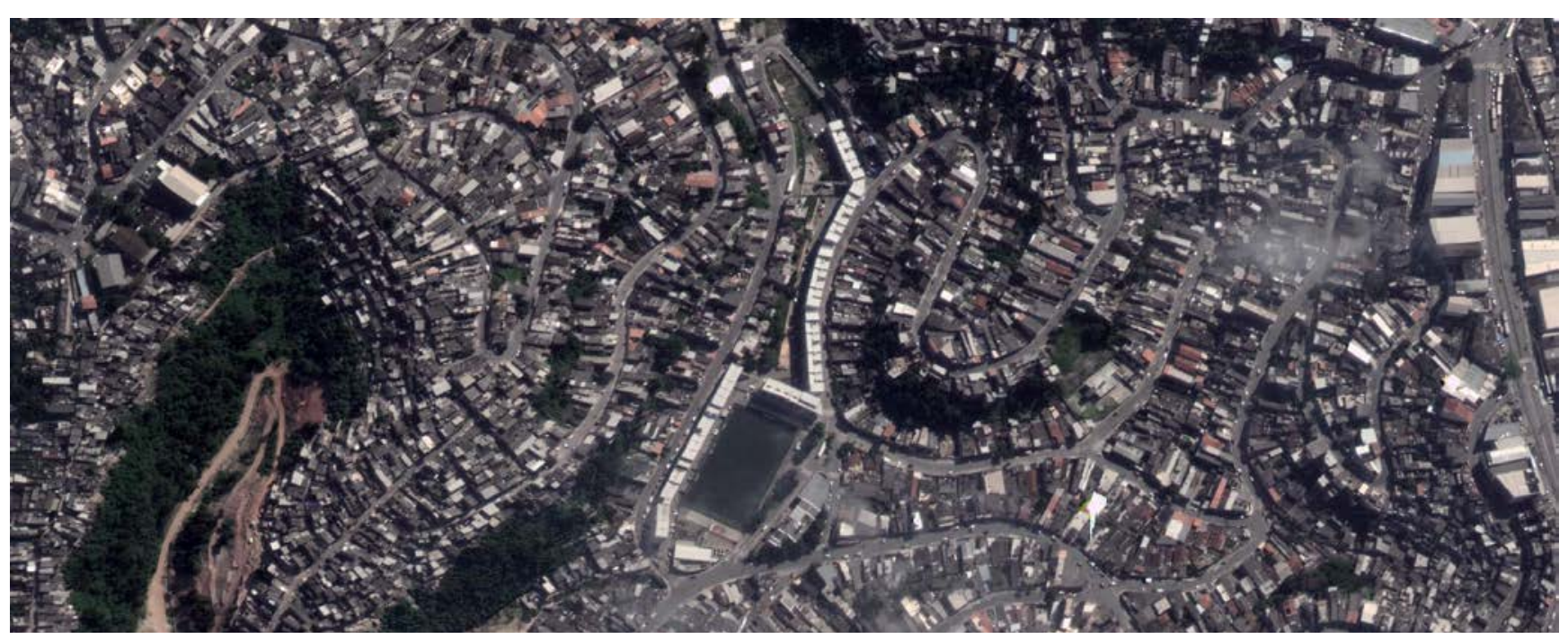

Figura 5.26.5

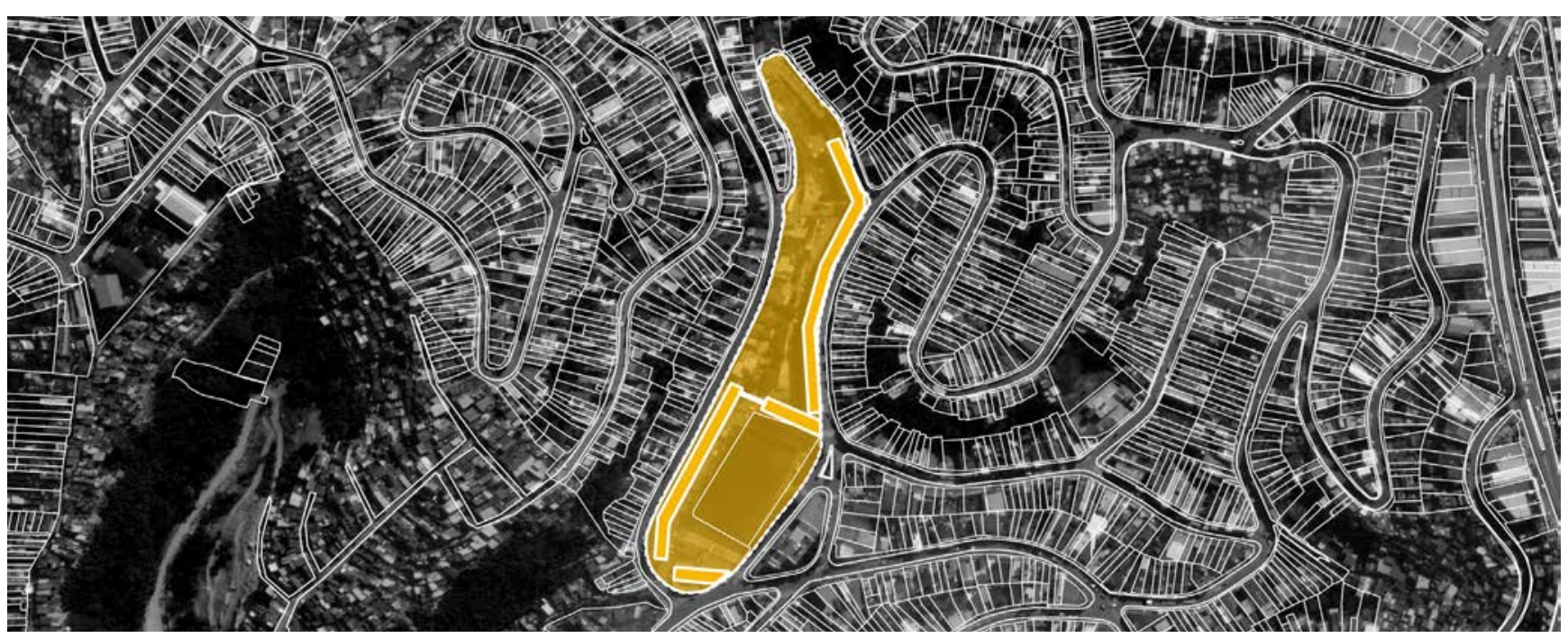

Figura 5.26.6

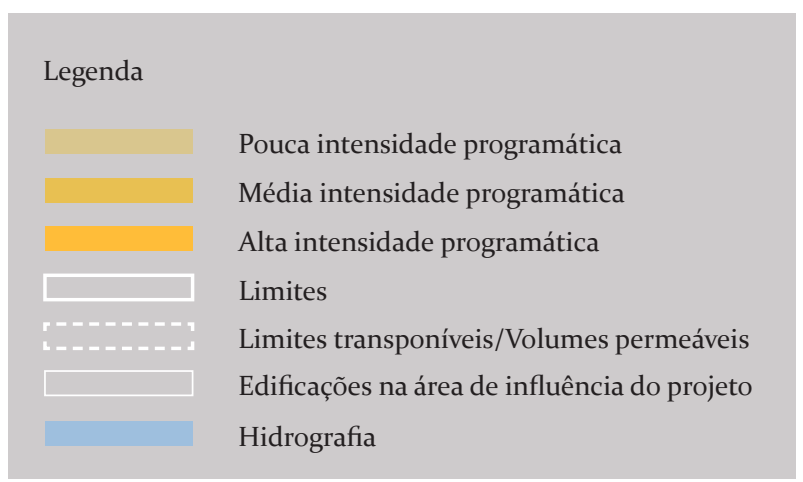

$100 \mathrm{~m}$ 


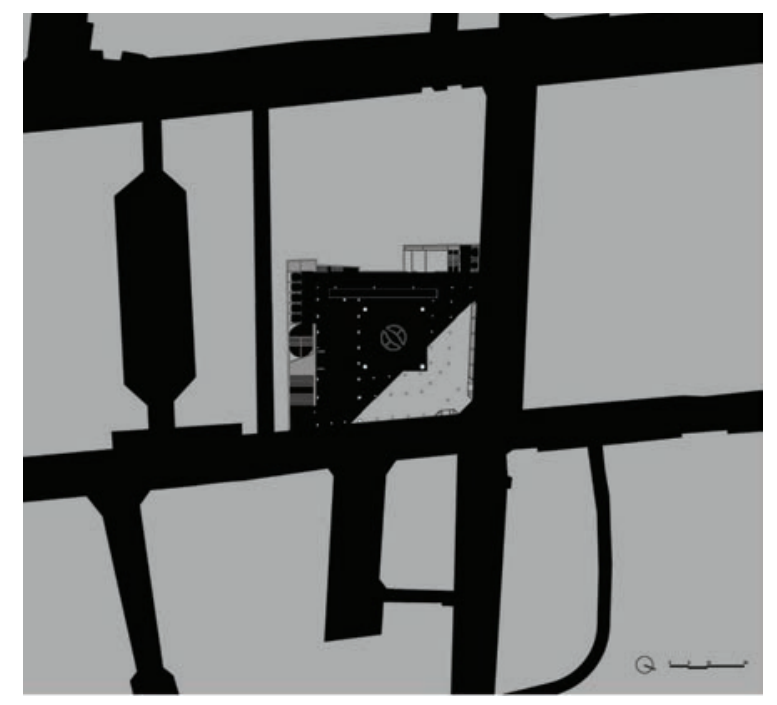

Figura 5.27.1

Situação

Figura 5.27.2

Corte C

Figura 5.27.3

Corte A
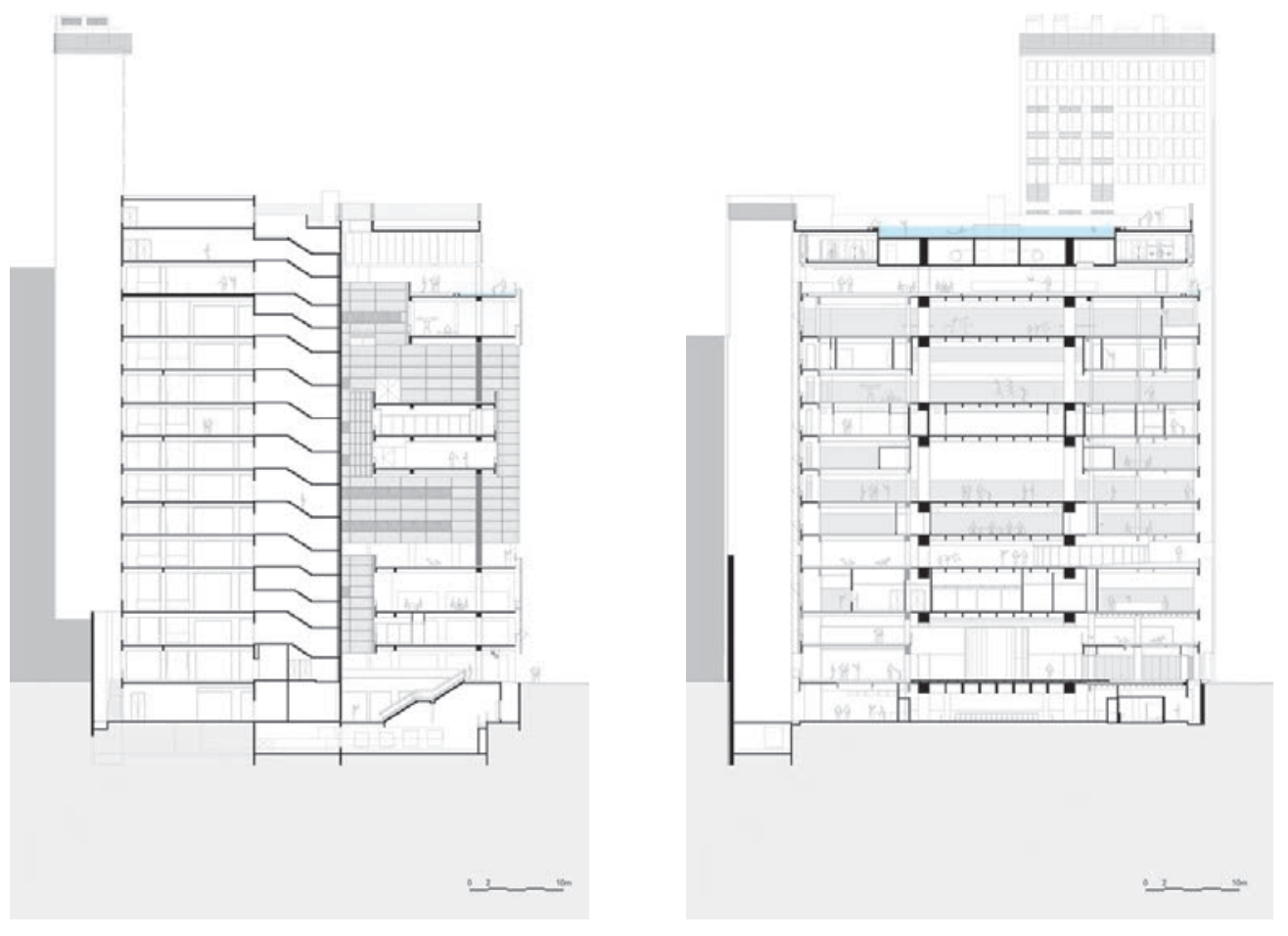

Figura 5.27.4

Figura 5.27.5
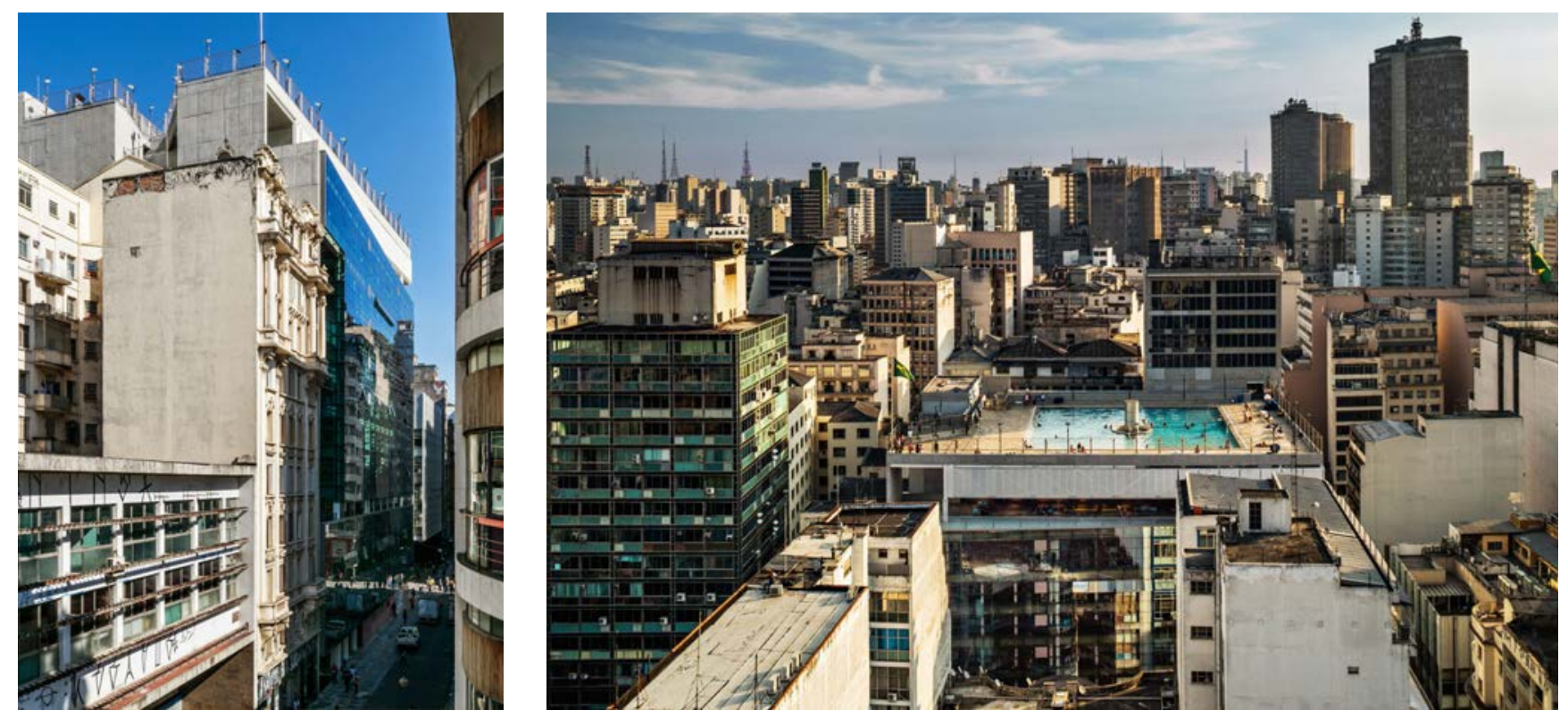


\section{Sesc 24 de Maio}

Autores Paulo Mendes da Rocha + MMBB Arquitetos

Equipe Adriano Bergemann, Ana Carina Costa, Ana Carolina

Mamede, Cecília Góes, Eduardo Ferroni, Giovanni Meirelles, Gleuson Pinheiro, Guilherme Pianca, Jacques Rordorf, Lucas Vieira, Márcia Terazaki, Maria João Figueiredo, Marina Acayaba, Marina Sabino, Martin Benavidez, Vito Macchione, João Yamamoto, Rafael Monteiro, Rodrigo Brancher, Thiago Rolemberg

\section{Data do projeto 2000}

\section{Data da construção 2017}

Área do lote $27.865 \mathrm{~m}^{2}$

Localização Rua 24 de Maio, 109 - República, São Paulo - SP

Cliente Sesc - Serviço Social do Comércio

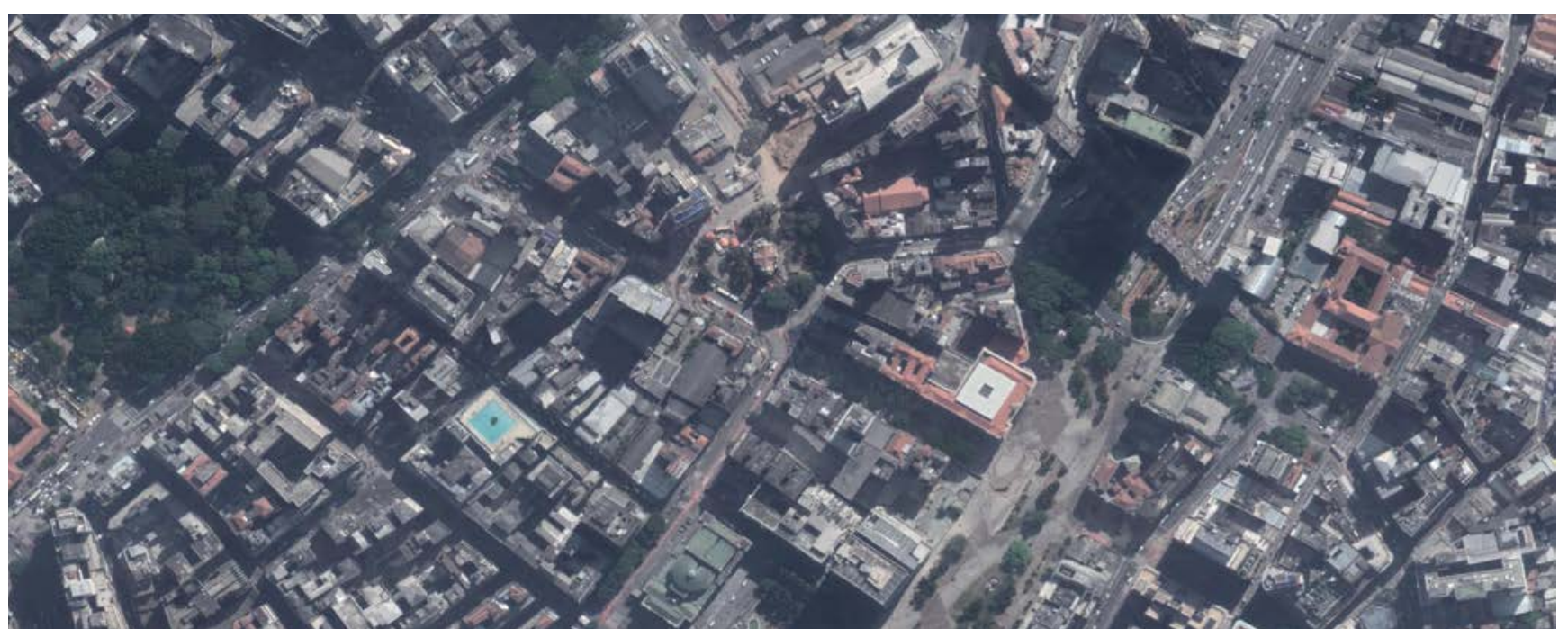

Figura 5.27.6

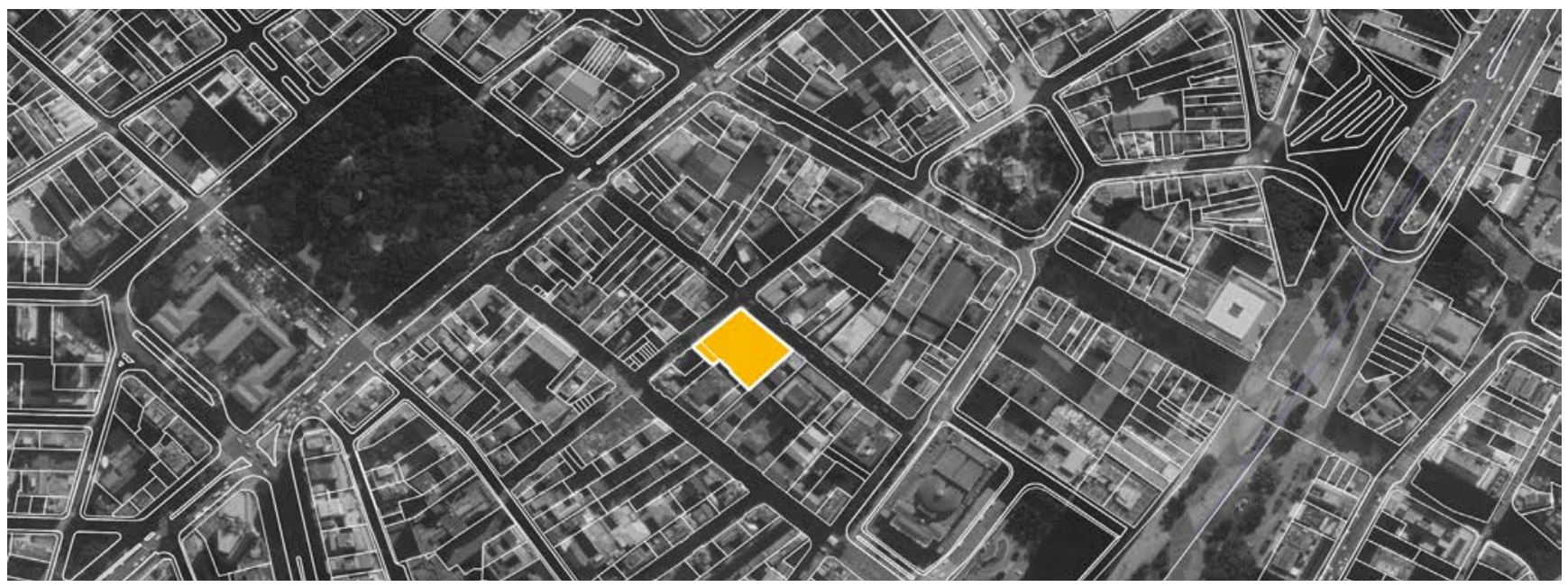

Figura 5.27.7

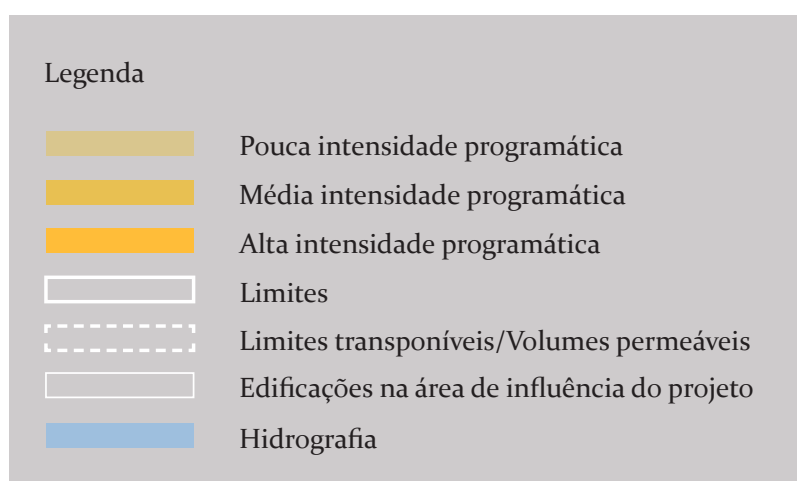



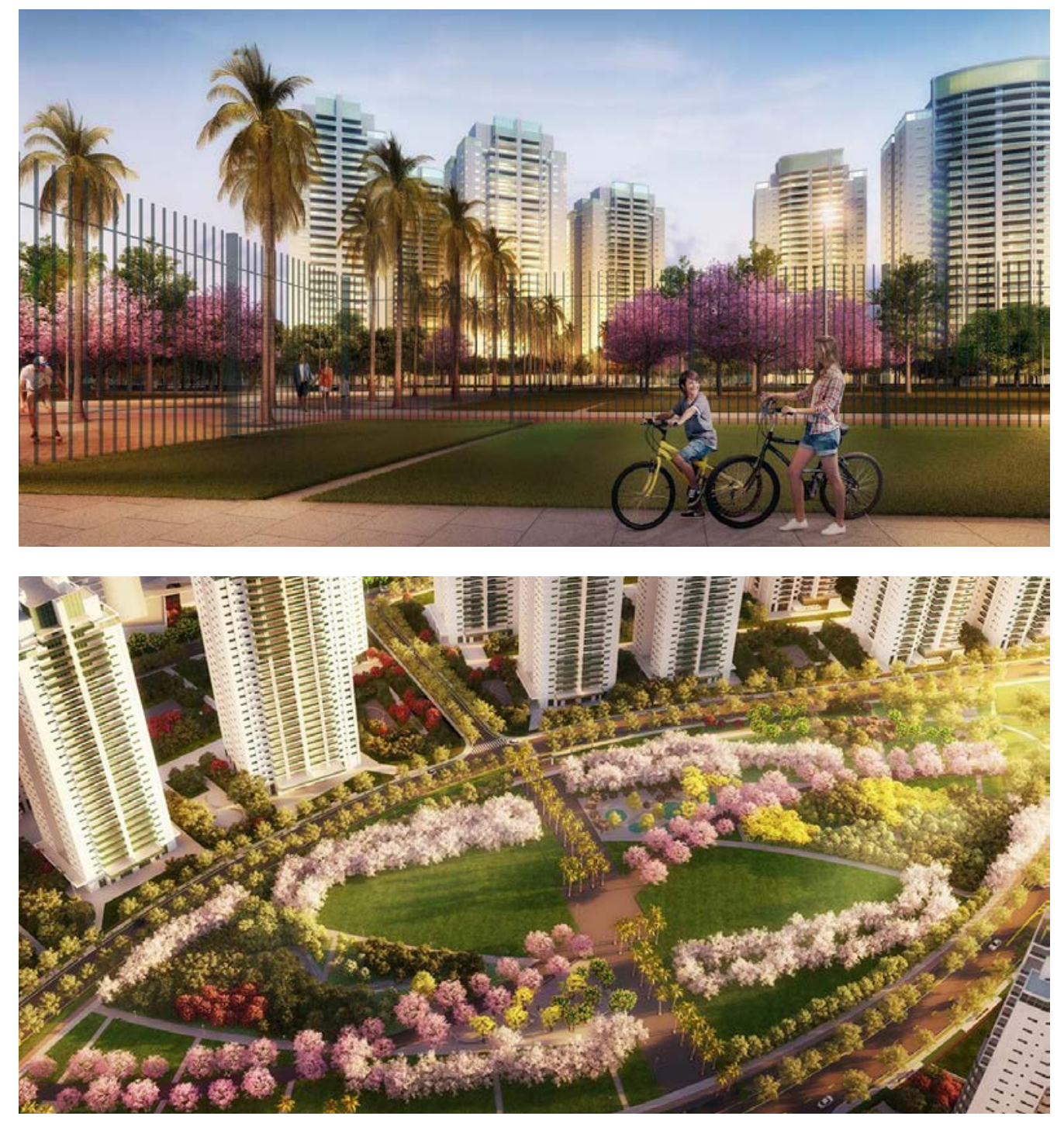

Figura 5.28.1

Figura 5.28.2

Figura 5.28.3

Figura 5.28.4
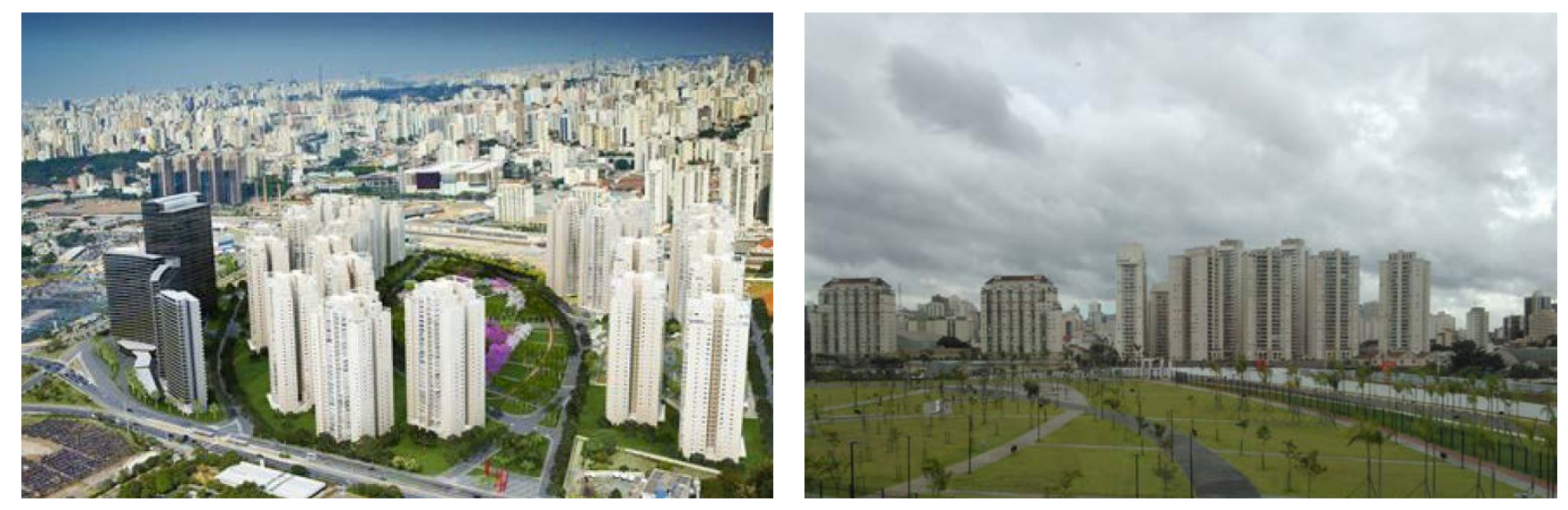
Jardim das Perdizes

Autores Itamar Berezin Arquitetura

Equipe

\section{Data do projeto 2011}

Data da construção 2017

Área do lote $251.280 .81 \mathrm{~m}^{2}$

Localização Jardim das Perdizes, São Paulo - SP

Cliente

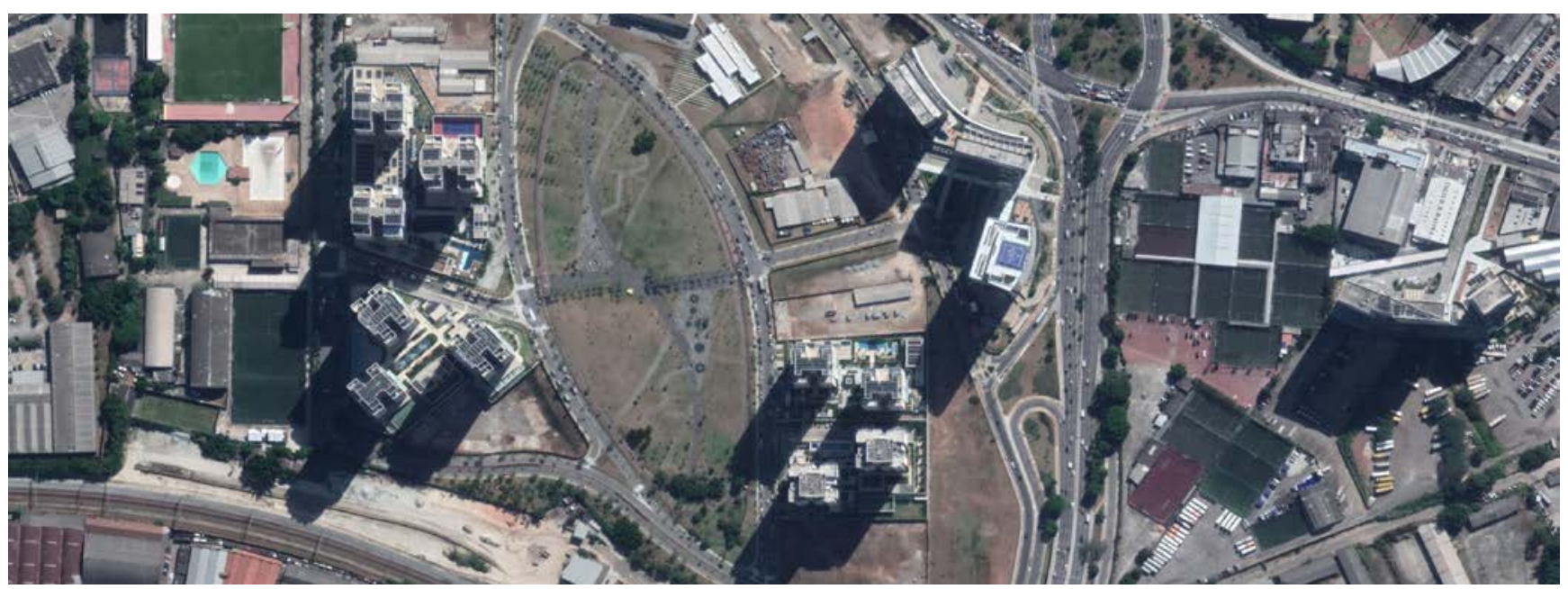

Figura 5.28.5

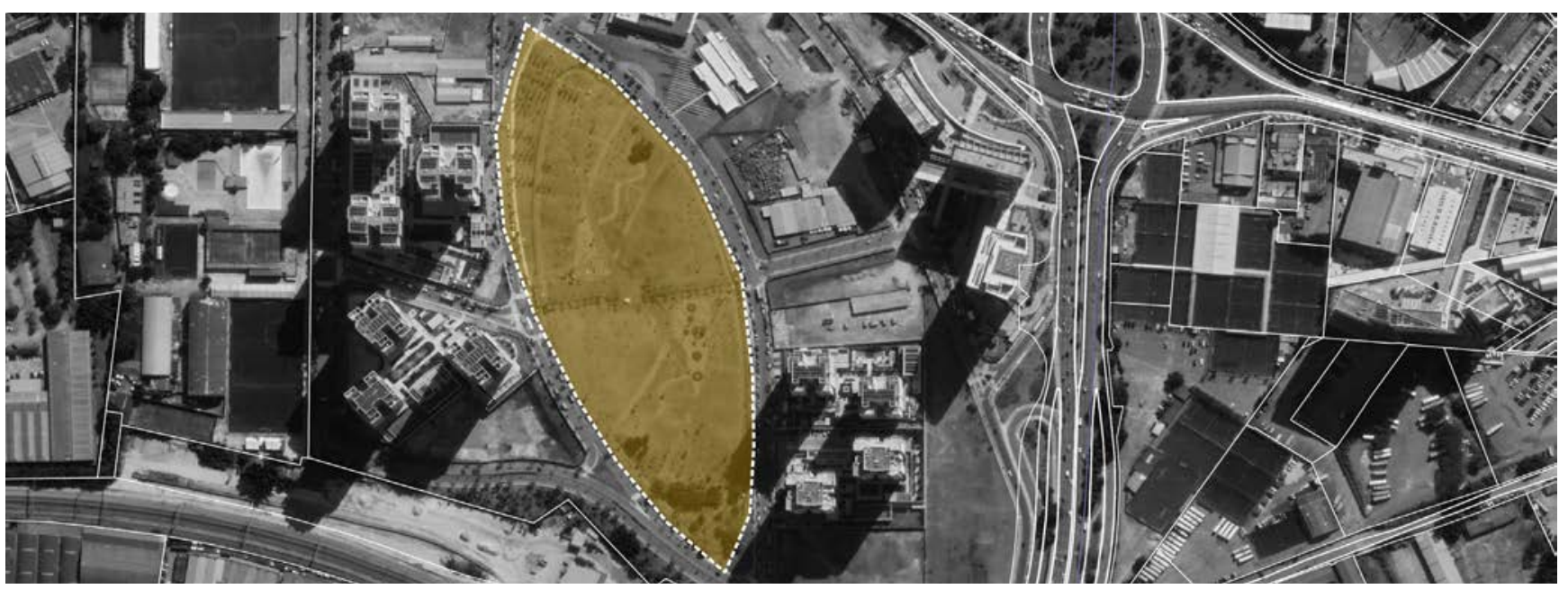

Figura 5.28.6

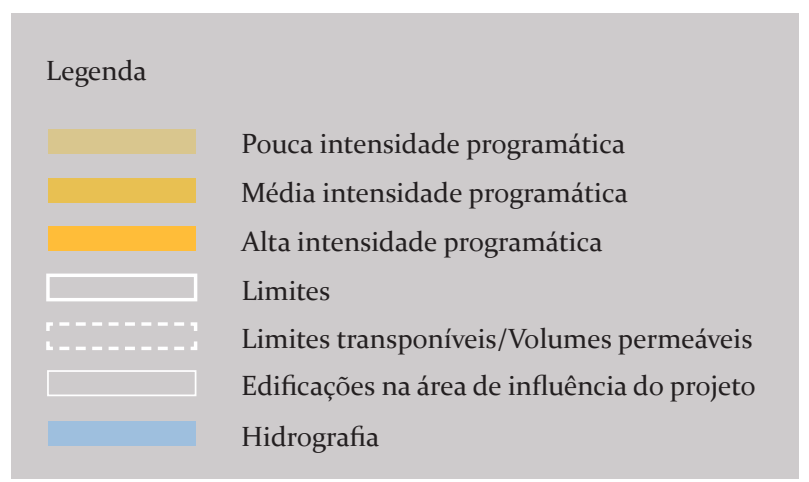

o

$100 \mathrm{~m}$ 


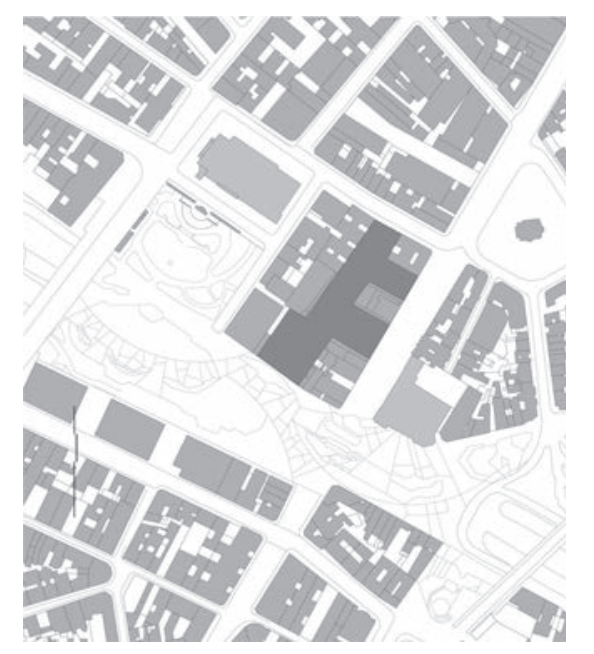

Figura 5.29.1

Implantação

Figura 5.29.2

Corte A

Figura 5.29.3

Corte C
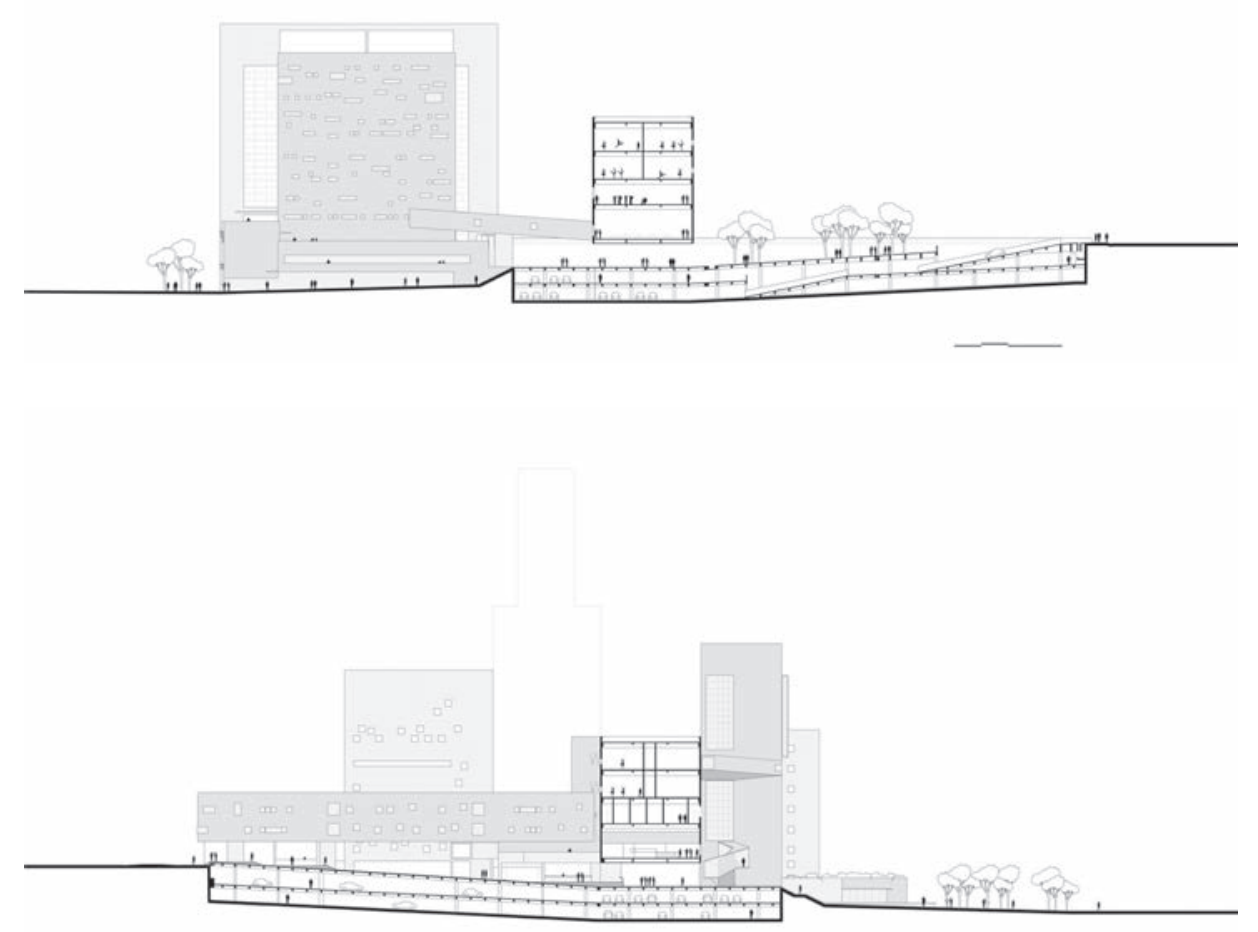

Figura 5.29.4

Figura 5.29.5
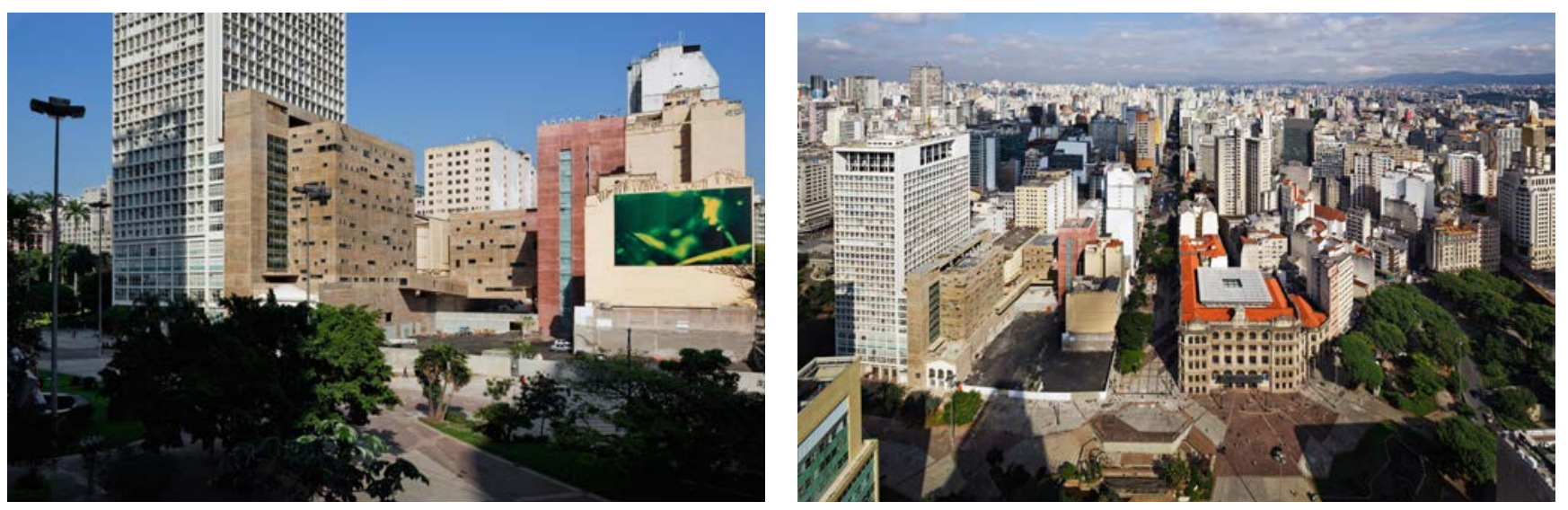


\section{Praça das Artes}

Autores Brasil Arquitetura

Equipe Francisco Fanucci e Marcelo Ferraz + Luciana Dornellas

\section{Data do projeto 2006}

Data da construção 2012

Área do lote $7.210 \mathrm{~m}^{2}$

Localização Av. São João, 281 - Centro, São Paulo - SP

Cliente PMSP - Prefeitura Municipal de São Paulo

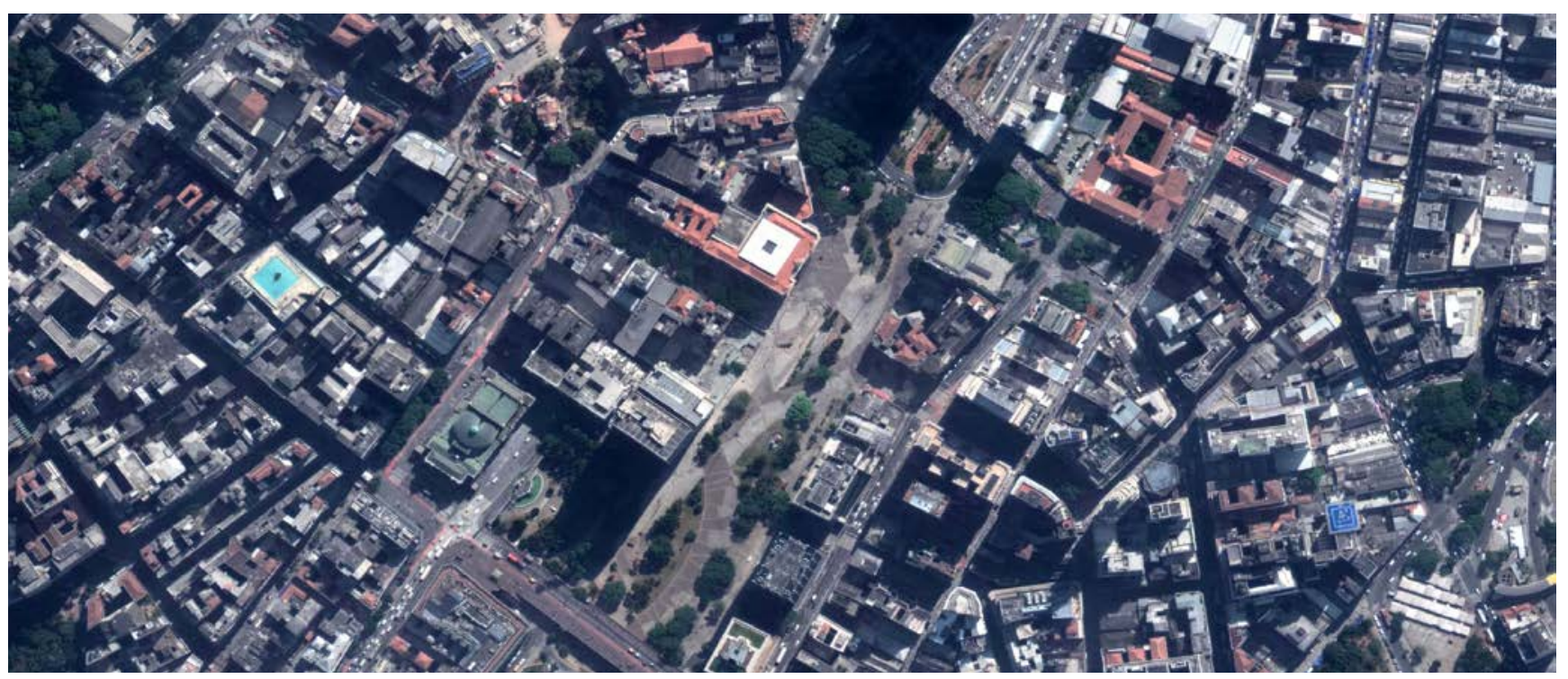

Figura 5.29.6

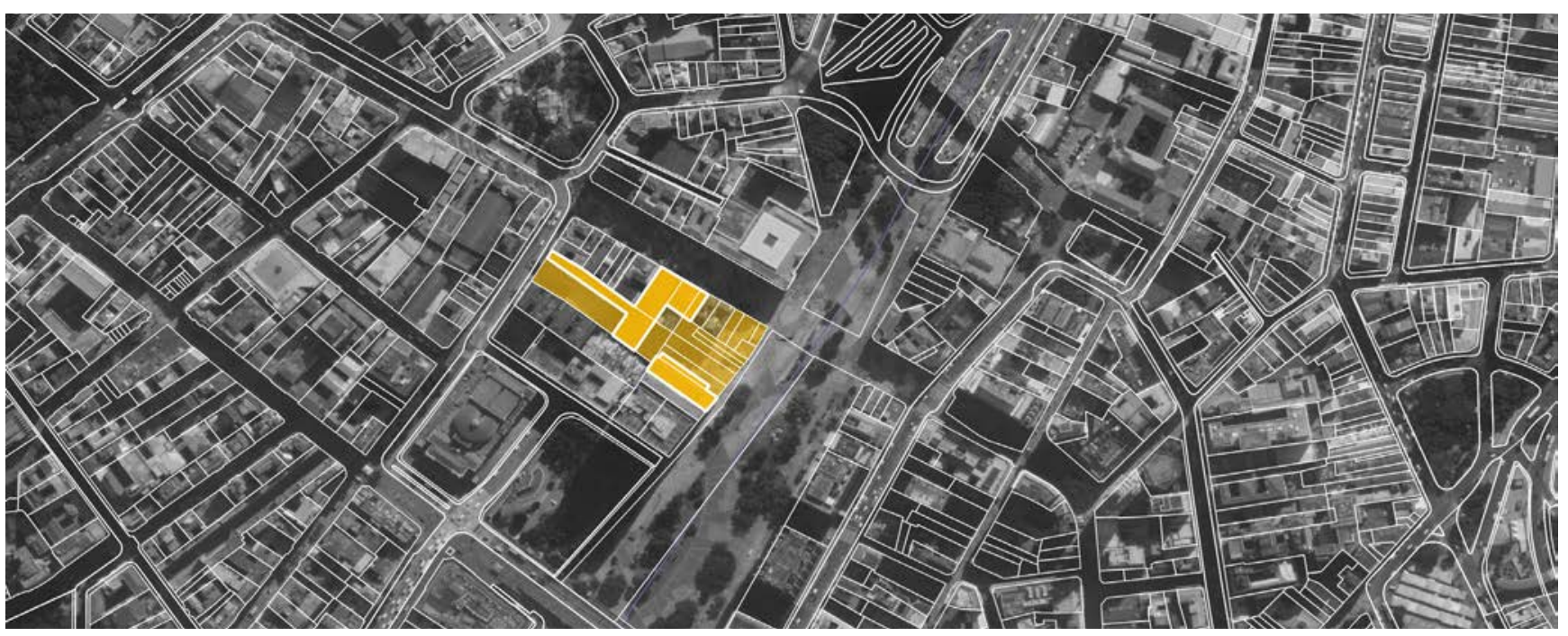

Figura 5.29.7

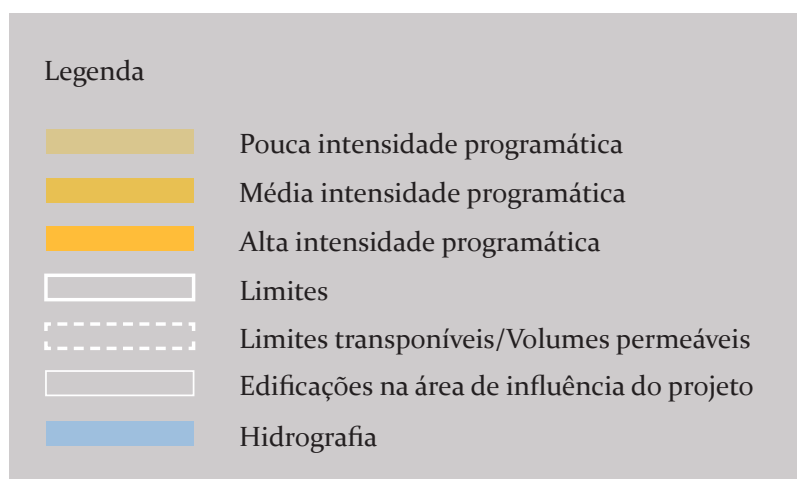

$100 \mathrm{~m}$ 


\section{Lista de imagens do anexo}

Figuras 5.1.1 e 5.1.2 Disponível em <http://arqa.com/gallery-page? $\mathrm{id}=503407>$. Último acesso em 1/3/2019.

Figuras 5.1.3 e 5.1.4 GÓMEZ, Sergio. Disponível em <http://arqa. com/gallery-page?id=503407>. Último acesso em 1/3/2019.

Figura 5.1.5 Google Earth

Figura 5.1.6 Base Open Data Alcadía de Medellín.

Mapa elaborado pela autora.

Figuras 5.2.1 e 5.2.2 Disponível em <https://www.archdaily. com.br/br/804533/uva-sol-de-oriente-edu/579eacece58ece52e70oo182-uva-sol-de-oriente-edu-photo $>$. Último acesso em $1 / 3 / 2019$.

Figuras 5.2.3 5.2.4 ARANGO, Alejandro. Disponível em <https:// www.archdaily.com.br/br/804533/uva-sol-de-oriente-edu/579eacece58ece52e7000182-uva-sol-de-oriente-edu-photo $>$. Último acesso em 1/3/2019.

Figura 5.2.5 Google Earth

Figura 5.2.6 Base Open Data Alcadía de Medellín.

Mapa elaborado pela autora.

Figuras 5.3.1, 5.3.2 e 5.3.3 Disponível em <https://www.archdaily. com.br/br/788974/uva-el-paraiso-edu-empresa-de-desarrollo-urbano-de-medellin/57416o2oe58ece6ec9ooo15e-uva-el-paraiso-edu-empresa-de-desarrollo-urbano-de-medellin-photo $>$. Último acesso em 1/3/2019.

Figuras 5.3.4 e 5.3.5 ARANGO, Alejandro. Disponível em <https:// www.archdaily.com.br/br/788974/uva-el-paraiso-edu-empresa-de-desarrollo-urbano-de-medellin/57416020e58ece6ec9ooor5e-uva-el-paraiso-edu-empresa-de-desarrollo-urbano-de-medellin-photo >. Último acesso em 1/3/2019.

Figura 5.3.6 Google Earth

Figura 5.3.7 Base Open Data Alcadía de Medellín.

Mapa elaborado pela autora.

Figuras 5.4.1 e 5.4.2 Arquitectura Pública e Innovación Social Taller de Diseño, Empresa de Desarrollo Urbano, pág. 44 e 48.

Figuras 5.4.3 e 5.4.4 Disponível em <https://cinturonverde.wordpress.com/2014/02/>. Último acesso em 1/3/2019.

Figura 5.4.5 Google Earth

Figura 5.4.6 Base Open Data Alcadía de Medellín. Mapa elaborado pela autora.

Figuras 5.5.1, 5.5.2 e 5.5.3 Disponível em <https://www. plataformaarquitectura.cl/cl/o2-320551/primer-lugar-concurso-publico-internacional-de-anteproyectos-parque-del-rio-en-la-ciudad-de-medellin/52b846ffe8e44e83afooooo2-primer-lugar-concurso-publico-internacional-de-anteproyectos-parque-del-rio-en-la-ciudad-de-medellin-imagen $>$.

Último acesso em 1/3/2019.

Figuras 5.5.4 e 5.5.5 Disponível em <https://www.plataformaarquitectura.cl/cl/o2-320551/primer-lugar-concurso-publico-internacional-de-anteproyectos-parque-del-rio-en-la-ciudad-de-medellin/52b846ffe8e44e83afooooo2-primer-lugar-concurso-publico-internacional-de-anteproyectos-parque-del-rio-en-la-ciudad-de-medellin-imagen $>$. Último acesso em 1/3/2019.

Figura 5.5.6 Google Earth

Figura 5.5.7 Base Open Data Alcadía de Medellín.

Mapa elaborado pela autora.

Figuras 5.6.1, 5.6.2 e 5.6.3 Disponível em <https://www.archdaily. com.br/br/756192/escola-antonio-derka-obranegra-arquitectos/ 5420dcfdco7a8oode500oo7d-colegio-antonio-derka-santo-domingo-savio-obranegra-arquitectos-photo $>$.

Último acesso em 1/3/2019.

Figuras 5.6.4 e 5.6.5 RAMÍREZ, Luis Adriano. Disponível em <https://www.archdaily.com.br/br/756192/escola-antonio-derka-obranegra-arquitectos/5420dcfdco7a8oode50ooo7d-colegio-antonio-derka-santo-domingo-savio-obranegra-arquitectos-photo $>$. Último acesso em 1/3/2019.

Figura 5.6.6 Google Earth

Figura 5.6.7 Base Open Data Alcadía de Medellín.
Mapa elaborado pela autora.

Figuras 5.7.1-5.7.4 Disponível em <http://www.planbarq.com/ jardn-infantil-sd/>. Último acesso em 1/3/2019.

Figura 5.7.5 Google Earth

Figura 5.7.6 Base Open Data Alcadía de Medellín.

Mapa elaborado pela autora.

Figuras 5.8.1 e 5.8.2 Disponível em <https://www.plataformaarquitectura.cl/cl/o2-111727/jardin-infantil-san-antonio-de-prado-viviana-pena-eliana-beltran-catalina-patino-ctrlg-y-federico-mesa-planb/57410073e58ecee2f8ooooc4-jardin-infantil-san-antonio-de-prado-viviana-pena-eliana-beltran-catalina-patino-ctrlg-y-federico-mesa-planb-planta-nivel-acceso>.

Último acesso em 1/3/2019.

Figuras 5.8.3 e 5.8.4 GÓMEZ, Sergio. Disponível em <http:// www.planbarq.com/jardines-infantiles-sap-pla/>.

Último acesso em 1/3/2019.

Figura 5.8.5 Google Earth

Figura 5.8.6 Base Open Data Alcadía de Medellín.

Mapa elaborado pela autora.

Figuras 5.9.1-5.9.3 Disponível em <https://www.plataformaarquitectura.cl/cl/o2-105858/jardin-infantil-pajarito-la-aurora-ctrl-g-plan-b/512b7a66b3fc4b11a70oba22-jardin-infantil-pajarito-la-aurora-ctrl-g-plan-b-foto>.

Último acesso em 1/3/2019.

Figuras 5.9.4 5.9.5 PALMA, Cristobal. Disponível em <http:// www.planbarq.com/jardines-infantiles-sap-pla/>.

Último acesso em 1/3/2019.

Figura 5.9.6 Google Earth

Figura 5.9.7 Base Open Data Alcadía de Medellín.

Mapa elaborado pela autora.

Figuras 5.10.1 e 5.10.2 Disponível em <http://arqa.com/editorial/medellin-r/biblioteca-presbitero-jorge-luis-arroyave $>$.

Último acesso em 1/3/2019.

Figuras 5.10.3 e 5.10.4 GÓMEZ, Juan Felipe. Disponível em <http://arqa.com/editorial/medellin-r/biblioteca-presbitero-jorge-luis-arroyave $>$.

Último acesso em 1/3/2019.

Figura 5.10.5 Google Earth

Figura 5.10.6 Base Open Data Alcadía de Medellín.

Mapa elaborado pela autora.

Figuras 5.11.1-5.11.3 Disponível em <https://www.plataformaarquitectura.cl/cl/o2-6075/biblioteca-parque-espana-giancarlo-mazzanti/57423e56e58ecee2f80oo2b8-biblioteca-parque-espana-giancarlo-mazzanti-foto $>$.

Último acesso em 1/3/2019.

Figuras 5.11.4 e 5.11.5 TOBON, Carlos. Disponível em <https:// www.plataformaarquitectura.cl/cl/o2-6075/biblioteca-parque-espana-giancarlo-mazzanti/57423e56e58ecee2f8ooo2b8-biblioteca-parque-espana-giancarlo-mazzanti-foto $>$.

Último acesso em 1/3/2019.

Figura 5.11.6 Google Earth

Figura 5.11.7 Base Open Data Alcadía de Medellín.

Mapa elaborado pela autora.

Figuras 5.12.1-5.12.3 Disponível em <https://www.plataformaarquitectura.cl/cl/o2-5937/parque-biblioteca-leon-de-grieff-giancarlo-mazzanti/51270914b3fc4b11a70oogd7-parque-biblioteca-leon-de-grieff-giancarlo-mazzanti-foto $>$.

Último acesso em 1/3/2019.

Figuras 5.12.4 e 5.12.5 GÓMEZ, Sergio. Disponível em <https:// www.plataformaarquitectura.cl/cl/o2-5937/parque-biblioteca-leon-de-grieff-giancarlo-mazzanti/51270914b3fc4b11a70oogd7-parque-biblioteca-leon-de-grieff-giancarlo-mazzanti-foto $>$. Último acesso em 1/3/2019.

Figura 5.12.6 Google Earth

Figura 5.12.7 Base Open Data Alcadía de Medellín.

Mapa elaborado pela autora.

Figuras 5.13.1-5.13.4 Disponível em <http://www.nomads.usp. $\mathrm{br} /$ virus/virus14/?sec=4\&item $=13$ \&lang $=\mathrm{en}>$. 
Último acesso em 1/3/2019.

Figuras 5.13.5 5.13.6 GÓMEZ, Sergio. Disponível em <https:// architizer.com/projects/biblioteca-la-quintana-tomas-carrasquilla/>.

Último acesso em 1/3/2019.

Figura 5.13.7 Google Earth

Figura 5.13.8 Base Open Data Alcadía de Medellín.

Mapa elaborado pela autora.

Figuras 5.14.1 e 5.14.2 Disponível em <http://arqa.com/edito$\mathrm{rial} /$ medellin-r/biblioteca-belen $>$.

Último acesso em 1/3/2019.

Figuras 5.14.3 e 5.14.4 MORENO, Diana. Disponível em <http:// arqa.com/editorial/medellin-r/biblioteca-belen>.

Último acesso em 1/3/2019.

Figura 5.14.5 Google Earth

Figura 5.14.6 Base Open Data Alcadía de Medellín.

Mapa elaborado pela autora.

Figuras 5.15.1 e 5.15.2 Disponível em <http://arqa.com/editorial/medellin-r/centro-de-desarrollo-cultural-moravia>

Último acesso em 1/3/2019.

Figuras 5.15.3 e 5.15.4 TOBÓN, Carlos. Disponível em <http:// arqa.com/editorial/medellin-r/centro-de-desarrollo-cultural-moravia >. Último acesso em 1/3/2019.

Figura 5.15.5 Google Earth

Figura 5.15.6 Base Open Data Alcadía de Medellín.

Mapa elaborado pela autora.

Figuras 5.16.1-5.16.4 Juan Bobo - Consolidación habitacional y recuperación ambiental de la quebrada Juan Bobo. Ing. Francesco Orisini.

Figura 5.16.5 Google Earth

Figura 5.16.6 Base Open Data Alcadía de Medellín.

Mapa elaborado pela autora.

Figuras 5.17.1 e 5.17.2 Ciudad Del Río: Inspiración para una nueva Medellín, pág 30.

Figuras 5.17.3 5.17.4 Disponível em <http://www.funlam.edu. co/azulnaranja/?p=7572>. Último acesso em 1/3/2019.

Figura 5.17.5 Google Earth

Figura 5.17.6 Base Open Data Alcadía de Medellín.

Mapa elaborado pela autora.

Figuras 5.18.1 e 5.18.2 Disponível em <http://vitruvius.com.br/ revistas/read/projetos/12.134/4259

>. Último acesso em 1/3/2019.

Figuras 5.18.3 e 5.18.4 TOBÓN, Carlos. Disponível em <http:// arqa.com/editorial/medellin-r/parque-de-los-pies-descalzos-y-museo-de-ciencia-y-tecnologia-2>. Último acesso em 1/3/2019. Figura 5.18.5 Google Earth

Figura 5.18.6 Base Open Data Alcadía de Medellín.

Mapa elaborado pela autora.

Figuras 5.19.1-5.19.3 Disponível em <http://arqa.com/editorial/ medellin-r/parque-de-los-pies-descalzos-y-museo-de-ciencia-y-tecnologia-2>. Último acesso em 1/3/2019.

Figuras 5.19.4 e 5.19.5 TOBÓN, Carlos. Disponível em <http:// arqa.com/editorial/medellin-r/parque-de-los-pies-descalzos-y-museo-de-ciencia-y-tecnologia-2>. Último acesso em 1/3/2019. Figura 5.19.6 Google Earth

Figura 5.19.7 Base Open Data Alcadía de Medellín.

Mapa elaborado pela autora.

Figuras 5.20.1 e 5.20.4 REATO, Marina Nobrega, Trabalho final de graduação - Universidade de São Paulo, São Paulo, 2011.

Figura 5.20.5 Google Earth

Figura 5.20.6 Base Geosampa. Mapa elaborado pela autora.

Figuras 5.21.1 e 5.21.5 Parque Cantinho do Céu - Soluções para cidades, Associação Brasileira de Cimento Portland.

Figura 5.21.6 Google Earth

Figura 5.21.7 Base Geosampa. Mapa elaborado pela autora.

Figuras 5.22.1-5.22.3 Disponível em <http://www.odvo.com. $\mathrm{br} /$ portfolio/centro-de-formacao-cultural-cidade-tiradentes/>. Último acesso em 1/3/2019.
Figuras 5.22.4 e 5.22.5 ROCHA, Lauro. Disponível em <http:// www.odvo.com.br/portfolio/centro-de-formacao-cultural-cidade-tiradentes/>. Último acesso em 1/3/2019.

Figura 5.22.6 Google Earth

Figura 5.22.7 Base Geosampa. Mapa elaborado pela autora.

Figura 5.23.1 Disponível em <https://www.archdaily.com.br/ br/880975/parque-da-juventude-paisagismo-como-ressignificador-espacial/59d5610cb22e38dacaoooo26-parque-da-juventude-paisagismo-como-ressignificador-espacial-imagem $>$. Último acesso em 1/3/2019.

Figuras 5.23.2 e 5.23.3 KON, Nelson. Disponível em <https:// www.archdaily.com.br/br/880975/parque-da-juventude-paisagismo-como-ressignificador-espacial/59d5610cb22e38dacaoooo26-parque-da-juventude-paisagismo-como-ressignificador-espacial-imagem > Último acesso em 1/3/2019.

Figura 5.23.4 Google Earth

Figura 5.23.5 Base Geosampa. Mapa elaborado pela autora.

Figuras 5.24.1 e 5.24.2 Disponível em <https://www.archdaily. com.br/br/625866/vencedor-do-premio-rogelio-salmona-edificio-projeto-viver-fgmf/53f75ed8co7a80388eooo722>.

Último acesso em 1/3/2019.

Figuras 5.24.3 e 5.24.4 SCANDAROLLI, Maurício. Disponível em <https://www.archdaily.com.br/br/625866/vencedor-do-premio-rogelio-salmona-edificio-projeto-viver-fgmf/53f75ed8co7a80388eooo722>. Último acesso em 1/3/2019.

Figura 5.24.5 Google Earth

Figura 5.24.6 Base Geosampa. Mapa elaborado pela autora.

Figuras 5.25.1 e 5.25.2 Disponível em <https://www.archdaily. com.br/br/o1-134091/conjunto-habitacional-do-jardim-edite-slash-mmbb-arquitetos-plus-h-plus-f-arquitetos?ad_medium=gallery>.

Último acesso em 1/3/2019.

Figuras 5.25.3 e 5.25.4 KON, Nelson. Disponível em <https:// www.archdaily.com.br/br/o1-134091/conjunto-habitacional-do-jardim-edite-slash-mmbb-arquitetos-plus-h-plus-f-arquitetos?ad_medium=gallery>. Último acesso em 1/3/2019.

Figura 5.25.5 Google Earth

Figura 5.25.6 Base Geosampa. Mapa elaborado pela autora.

Figuras 5.26.1 e 5.26.2 Disponível em <https://www.archdaily. com/601717/novo-santo-amaro-v-park-housing-vigliecca-and-associados/53ac2296co7a80644fooooo1-novo-santo-amaro-v-park-housing-vigliecca-and-associados-photo>

Último acesso em 1/3/2019.

Figuras 5.26.3 e 5.26.4 FINOTTI, Leonardo. Disponível em <https://www.archdaily.com/6o1717/novo-santo-amaro-v-park-housing-vigliecca-and-associados/53ac2296co7a8o644fooooo1-novo-santo-amaro-v-park-housing-vigliecca-and-associados-photo $>$. Último acesso em 1/3/2019.

Figura 5.26.5 Google Earth

Figura 5.26.6 Base Geosampa. Mapa elaborado pela autora.

Figuras 5.27.1-5.27.3 Disponível em <https://www.archdaily. com.br/br/889788/sesc-24-de-maio-paulo-mendes-da-rocha-plus-mmbb-arquitetos/5a956383fig7ccc42300007b-sesc-24-de-maio-paulo-mendes-da-rocha-plus-mmbb-arquitetos-situacao $>$. Último acesso em 1/3/2019.

Figuras 5.26.3 e $\mathbf{5 . 2 6 . 4}$ FINOTTI, Leonardo. Disponível em <https://www.archdaily.com.br/br/889788/ sesc-24-de-maio-paulo-mendes-da-rocha-plus-mmbb-arquitetos/5a956383fi97ccc42300oo7b-sesc-24-de-maio-paulo-mendes-da-rocha-plus-mmbb-arquitetos-situacao $>$. Último acesso em 1/3/2019.

Figura 5.27.5 Google Earth

Figura 5.27.6 Base Geosampa. Mapa elaborado pela autora. Figuras 5.28.1-5.28.4 Disponível em <https://www.galeriadaarquitetura.com.br/projeto/itamar-berezin-arquitetura_/jardim-das-perdizes/316>. Último acesso em 1/3/2019.

Figura 5.28.5 Google Earth 
Figura 5.28.6 Base Geosampa. Mapa elaborado pela autora.

Figuras 5.29.1-5.29.3 Disponível em <https://www.archdaily.com.br/br/626025/praca-das-artes-brasil-arquitetura/ 57480c1ee58ece3d4000029d-praca-das-artes-brasil-arquitetura-photo $>$. Último acesso em 1/3/2019.

Figuras 5.29.4 e 5.29.5 KON, Nelson. Disponível em <https:// www.archdaily.com.br/br/626025/praca-das-artes-brasil-arquitetura/57480ciee58ece3d4000029d-praca-das-artes-brasil-arquitetura-photo $>$. Último acesso em 1/3/2019.

Figura 5.29.6 Google Earth

Figura 5.29.7 Base Geosampa. Mapa elaborado pela autora. 
